DOE/OR-1060\&D3

ES/ER-43\&D3

Y/ER/Sub/91-99069/1/R3

\title{
Remedial Investigation Work Plan for Bear Creek Valley Operable Unit 2 (Rust Spoil Area, SY-200 Yard, Spoil Area 1) at the Oak Ridge Y-12 Plant, Oak Ridge, Tennessee
}

\author{
Environmental Restoration Program \\ P.O. Box 2003 \\ Oak Ridge, Tennessee 37831-7298
}

Date Issued-May 1993

\footnotetext{
Prepared by

Science Applications International Corporation

Oak Ridge, Tennessee

under contract 18B-99069C

Prepared for

U.S. Department of Energy

Office of Environmental Restoration and Waste Management

under budget and reporting code EW 20

MARTIN MARIETTA ENERGY SYSTEMS, INC. managing the

Oak Ridge K-25 Site

Oak Ridge Y-12 Plant

Oak Ridge National Laboratory under contract DE-AC05-84OR21400

Paducah Gaseous Diffusion Plant Portsmouth Gaseous Diffusion Plant under contract DE-AC05-760R00001

for the
}

U.S. DEPARTMENT OF ENERGY

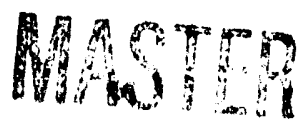




\section{CONTENTS}

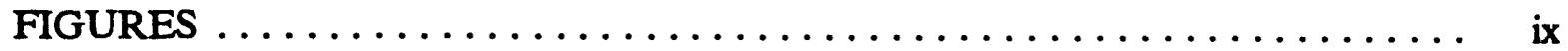

TABLES $\ldots \ldots \ldots \ldots \ldots \ldots \ldots \ldots \ldots \ldots \ldots \ldots \ldots \ldots \ldots \ldots \ldots \ldots \ldots \ldots \ldots \ldots$

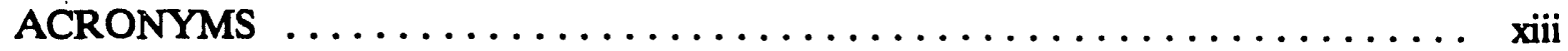

EXECUTTVE SUMMARY $\ldots \ldots \ldots \ldots \ldots \ldots \ldots \ldots \ldots \ldots \ldots \ldots \ldots \ldots \ldots \ldots \ldots$

1. INTRODUCTION $\ldots \ldots \ldots \ldots \ldots \ldots \ldots \ldots \ldots \ldots \ldots \ldots \ldots \ldots \ldots \ldots \ldots \ldots, 1-1$

1.1 REGULATORY INITIATTVE ................... $1-1$

1.2 DOE-OR ENVIRONMENTAL RESTORATION (ER) PROGRAM . 1-3

1.3 Y-12 SITE CORRECTIVE ACTION PROGRAM $\ldots \ldots \ldots \ldots \ldots, 1-3$

1.4 SITE ER PROGRAM $\ldots \ldots \ldots \ldots \ldots \ldots \ldots \ldots \ldots \ldots \ldots, 1-4$

1.5 SPECIAL PROBLEMS $\ldots \ldots \ldots \ldots \ldots \ldots \ldots \ldots \ldots \ldots \ldots, 1-4$

1.6 OBJECTIVES $\ldots \ldots \ldots \ldots \ldots \ldots \ldots \ldots \ldots \ldots \ldots \ldots \ldots \ldots \ldots \ldots \ldots \ldots \ldots, 1-4$

1.7 SCHEDULE $\ldots \ldots \ldots \ldots \ldots \ldots \ldots \ldots \ldots \ldots \ldots \ldots \ldots, 1-5$

2. CHARACTERIZATION OF THE ENVIRONMENTAL SETTING $\ldots \ldots, 2-1$

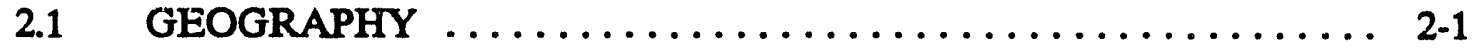

2.2 TOPOGRAPHY, GEOLOGY, AND SOILS $\ldots \ldots \ldots \ldots \ldots \ldots \ldots 2-1$

2.2.1 Topography and General Geology . . . . . . . . . . . . 2-1

2.2.2 General Soil Characteristics $\ldots \ldots \ldots \ldots \ldots \ldots \ldots \ldots \ldots \ldots, 2-7$

2.3 CLIMATE $\ldots \ldots \ldots \ldots \ldots \ldots \ldots \ldots \ldots \ldots \ldots \ldots \ldots \ldots \ldots, 2-9$

2.4 ECOLOGY $\ldots \ldots \ldots \ldots \ldots \ldots \ldots \ldots \ldots \ldots \ldots \ldots \ldots \ldots \ldots \ldots \ldots \ldots \ldots, 2-9$

2.5 DEMOGRAPHY $\ldots \ldots \ldots \ldots \ldots \ldots \ldots \ldots \ldots \ldots \ldots \ldots \ldots \ldots \ldots \ldots \ldots \ldots \ldots, 2-12$

2.5.1 Population Information $\ldots \ldots \ldots \ldots \ldots \ldots \ldots \ldots \ldots, 2-12$

2.5.2 Land Use $\ldots \ldots \ldots \ldots \ldots \ldots \ldots \ldots \ldots \ldots \ldots \ldots \ldots \ldots \ldots \ldots \ldots \ldots, 12$

2.6 SURFACE WATER AND SEDIMENTS $\ldots \ldots \ldots \ldots \ldots \ldots \ldots \ldots \ldots \ldots \ldots$

2.6.1 Surface Water Network $\ldots \ldots \ldots \ldots \ldots \ldots \ldots \ldots \ldots .2-15$

2.6.2 Surface Water Hydrology $\ldots \ldots \ldots \ldots \ldots \ldots \ldots \ldots \ldots \ldots, 2-15$

2.6.3 Bear Creek Hydrograph $\ldots \ldots \ldots \ldots \ldots \ldots \ldots \ldots \ldots \ldots .2-17$

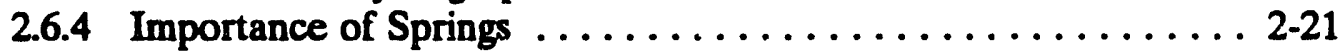

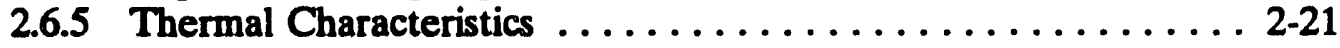

2.6.6 General Sediment Description .................. 2-22

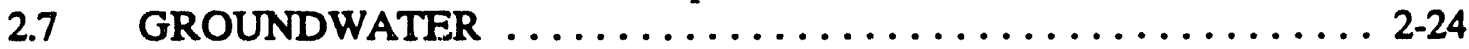

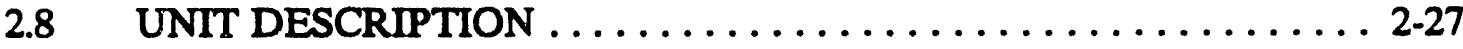

2.8.1 Geographic Information ........................ 2-27

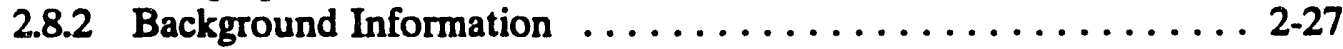

2.8.3 Operational Information $\ldots \ldots \ldots \ldots \ldots \ldots \ldots \ldots \ldots \ldots .2-27$

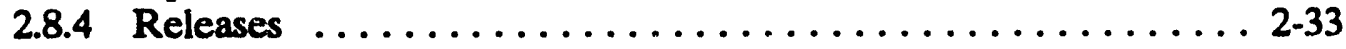

2.9 EXISTING DATA $\ldots \ldots \ldots \ldots \ldots \ldots \ldots \ldots \ldots \ldots \ldots \ldots \ldots \ldots \ldots \ldots \ldots \ldots \ldots \ldots, 2-33$

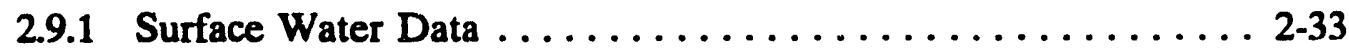

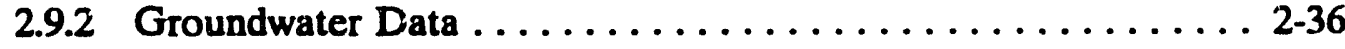

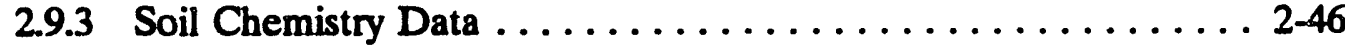

2.9.4 Biomonitoring Data $\ldots \ldots \ldots \ldots \ldots \ldots \ldots \ldots \ldots \ldots \ldots .2-61$

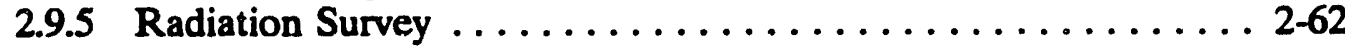


3. DATA QUALTTY OBJECTIVES (DQOs) $\ldots \ldots \ldots \ldots \ldots \ldots \ldots \ldots \ldots$ 3-1

3.1 DQO STAGE 1: IDENTIFICATION OF DECISION TYPES . . . . . 3-1

3.1.1 Identification and Involvement of Data Users . . . . . . . 3-1

3.1.2 Evaluation of Available Information . . . . . . . . . . 3-1

3.1.3 Conceptual Site Model . . . . . . . . . . . . . . 3-1

3.1.4 Remedial Investigation Objectives ............. 3-1

3.2 DQO STAGE 2: IDENTIFY DATA USES/NEEDS $\ldots \ldots \ldots \ldots \ldots . . . . . .$.

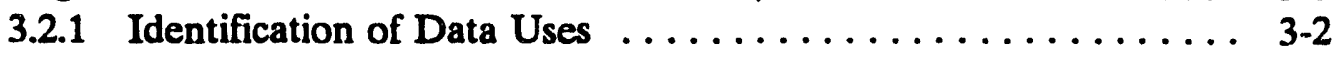

3.2.2 Identification of Data Types $\ldots \ldots \ldots \ldots \ldots \ldots \ldots \ldots \ldots$ 3-2

3.2.3 Identification of Data Quantity Needs ........... 3-2

3.2.4 Identification of Data Quality Needs . . . . . . . . . . . 3-2

3.2.5 Evaluation of Sampling and Analysis Options .......... 3-4

3.2.6 Reviewing and Utilizing Precision, Accuracy,

Representativeness, Completeness, and

Comparability (PARCC) Information ............ 3-4

3.3 DQO STAGE 3: DESIGN DATA COLLECTION PROGRAM .... 3-4

3.3.1 Assemble Data Collection Components ............. 3-4

3.3.2 Develop Data Collection Documentation ............ 3-4

4. CONCEPTUAL SITE MODEL $\ldots \ldots \ldots \ldots \ldots \ldots \ldots \ldots \ldots \ldots \ldots$ 4-1

4.1 POTENTIAL PATHWAYS OF MIGRATION $\ldots \ldots \ldots \ldots \ldots \ldots . . \ldots$ 4-1

4.1.1 Soil ............................ 4-1

4.1.2 Surface Water ....................... 4-1

4.1.3 Groundwater ....................... 4-3

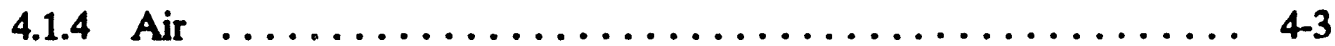

4.1.5 Biological ........................ 4-3

4.2 POTENTIAL RECEPTORS $\ldots \ldots \ldots \ldots \ldots \ldots \ldots \ldots \ldots \ldots$ 4-3

4.2.1 Human Populations ................... 4-3

4.2.2 Ecologicai Populations ................... 4-4

4.3 POTENTIAL EXPOSURE PATHWAYS . . . . . . . . . 4 4-15

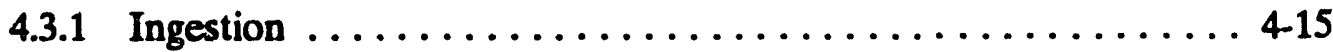

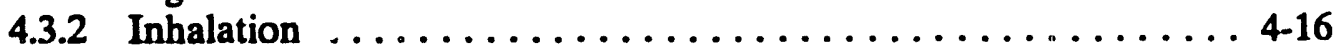

4.3.3 Dermal Contact . . . . . . . . . . . . . . . . 4-16

4.3.4 External Exposure to Radionuclides . . . . . . . . . . . 4-17

4.4 RISK ASSESSMENT METHODOLOGY . . . . . . . . . . . 4-17

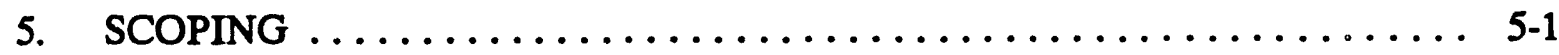

5.1 APPLICABLE OR RELEVANT AND APPROPRIATE
REQUIREMENTS (ARARs) $\ldots \ldots \ldots \ldots \ldots \ldots \ldots \ldots \ldots, 5,1$

5.1 .1 Definitions ........................ 5-2

5.1 .2 Chemical-Specific ARARs ................. 5-3

5.1.3 Radiation Protection Standards .............. 5-5

5.1.4 Location-Specific ARARs .................. 5-9

5.1.5 Action-Specific ARARs . . . . . . . . . . . . . . 5 .10

5.2 IDENTIFICATION OF POTENTIAL TECHNOLOGIES $\ldots \ldots \ldots$. 5-10 
6. SUMMARY OF DATA NEEDS $\ldots \ldots \ldots \ldots \ldots \ldots \ldots \ldots \ldots \ldots \ldots$ 6-1

6.1 ENVIRONMENTAL CHARACTERIZATION . ........... 6-1

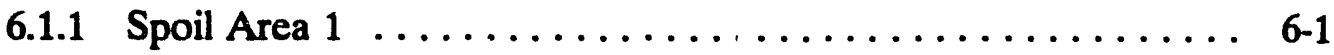

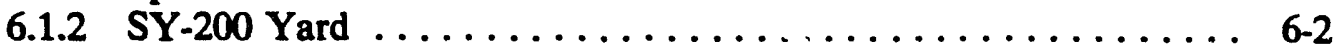

6.1.3 Rust Spoil Area ..................... 6-2

6.2 ENGINEERING TECHNOLOGY SCREENING $\ldots \ldots \ldots \ldots \ldots .6$ 6-3

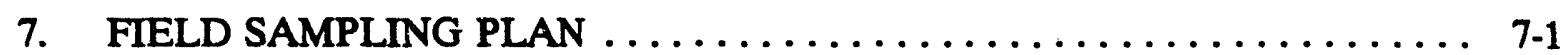

7.1 SAMPLING PLAN SCOPE $\ldots \ldots \ldots \ldots \ldots \ldots \ldots \ldots \ldots \ldots \ldots \ldots$

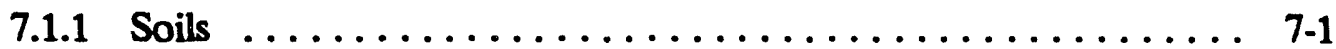

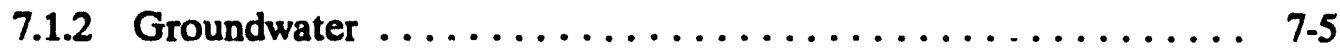

7.1.3 Surface Water/Sediment $\ldots \ldots \ldots \ldots \ldots \ldots \ldots \ldots \ldots$ 7-6

7.2 FIELD SAMPLING AND SAMPLE ANALYSIS $\ldots \ldots \ldots \ldots \ldots 7.6$

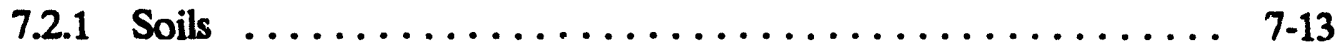

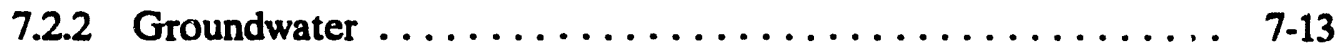

7.2.3 Surface Water/Sediments ................ 7-14

7.3 SAMPLE TRACKING AND RECORDS MANAGEMENT . . . . . . 7-14

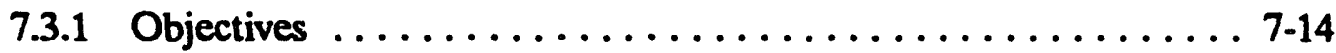

7.3.2 Roles and Responsibilities ................ 7-15

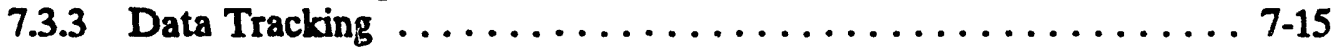

7.3.4 Sample Coding Procedures ................ 7-16

7.3.5 Completion of Field and Laboratory Records . . . . . . . . 7-16

7.3.6 Data Management ..................... 7.18

7.4 PROJECT DESCRIPTION ...................... 7 .19

7.5 PROJECT ORGANIZATION . . . . . . . . . . . . . 7-19

8. FIELD QUALTTY ASSURANCE PROJECT PLAN $\ldots \ldots \ldots \ldots \ldots \ldots \ldots$ 8-1

8.1 QUALTTY ASSURANCE OBJECTIVES FOR DATA

MEASUREMENT ......................... 8-1

8.1.1 Project Objectives and Intended Data Usages ........ 8-1

8.1.2 Level of Analysis . . . . . . . . .

8.1.3 Data Quality Parameters $\ldots \ldots \ldots \ldots \ldots \ldots \ldots \ldots \ldots$ 8-3

8.1.4 Field Activities . . . . . . . . . . . $\ldots \ldots \ldots \ldots \ldots \ldots$

8.1.5 Readiness Review ...................... 8-4

8.2 SAMPLE COLLECTION PROCEDURES $\ldots \ldots \ldots \ldots \ldots \ldots \ldots .8 .4$

8.2.1 Field Procedures . . . . . . . . . . . . . . . . . $8-4$

8.2.2 Sampling Program ................... 8-4

8.2.3 Sample Containers, Preservation, Transport,

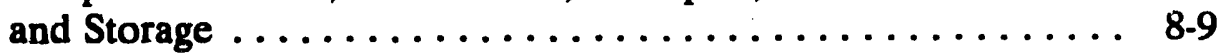

8.2.4 Prevention of Cross Contamination ............. 8-9

8.2.5 Decontamination of Equipment and Supplies . . . . . . . . 8.9

8.2.6 Field Documentation . . . . . . . . . . . . . . . 8.9

8.2 .7 Variance System ...................... 8.9

8.2.8 Sample Identification $\ldots \ldots \ldots \ldots \ldots \ldots \ldots \ldots \ldots \ldots .11$

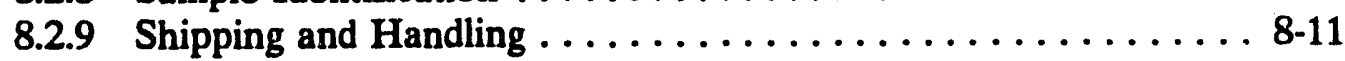

8.2.10 Sample Turnaround Time $\ldots \ldots \ldots \ldots \ldots \ldots \ldots \ldots \ldots \ldots . \ldots \ldots$ 8-11

8.2.11 Field Data Management $\ldots \ldots \ldots \ldots \ldots \ldots \ldots \ldots$ 8-11 
8.3 SAMPLE AND DOCUMENT CUSTODY PROCEDURES . . . . 8 8-11

8.3.1 Field Custody Procedures $\ldots \ldots \ldots \ldots \ldots \ldots \ldots \ldots .8 \ldots \ldots .12$

8.3.2 Sample Labeling $\ldots \ldots \ldots \ldots \ldots \ldots \ldots \ldots \ldots \ldots$ 8-12

8.4 CALIBRATION PROCEDURES AND FREQUENCY $\ldots \ldots \ldots \ldots .8$

8.4.1 Instrument Calibration Procedures and Frequency ........ 8-13

8.4.2 Calibration Failures $\ldots \ldots \ldots \ldots \ldots \ldots \ldots \ldots \ldots \ldots \ldots, 8-14$

8.4.3 Calibration Records ........................ 8-14

8.5 PREVENTIVE MAINTENANCE $\ldots \ldots \ldots \ldots \ldots \ldots \ldots \ldots \ldots .8 \ldots \ldots$

8.5 .1 Field Instruments $\ldots \ldots \ldots \ldots \ldots \ldots \ldots \ldots \ldots \ldots \ldots, 8,14$

8.6 FIELD ANAIYYSES $\ldots \ldots \ldots \ldots \ldots \ldots \ldots \ldots \ldots \ldots \ldots \ldots \ldots \ldots \ldots$

8.7 DATA REDUCTION, VALIDATION, AND REPURTING . . . $\ldots .8$ 8-15

8.7.1 Field Data Reduction and Evaluation $\ldots \ldots \ldots \ldots \ldots \ldots \ldots$ 8-16

8.8 FIELD QUALITY CONTROL SAMPLES $\ldots \ldots \ldots \ldots \ldots \ldots \ldots .8,16$

8.9 FIELD AUDITS AND SURVEILLANCES $\ldots \ldots \ldots \ldots \ldots \ldots \ldots .8-17$

8.9.1 Frequency of Audits $\ldots \ldots \ldots \ldots \ldots \ldots \ldots \ldots \ldots \ldots, 8,17$

8.9.2 Performance Audits $\ldots \ldots \ldots \ldots \ldots \ldots \ldots \ldots \ldots \ldots, 8, \ldots, 18$

8.9.3 Systems Audits $\ldots \ldots \ldots \ldots \ldots \ldots \ldots \ldots \ldots \ldots \ldots, 8,18$

8.9.4 Field Surveillance $\ldots \ldots \ldots \ldots \ldots \ldots \ldots \ldots \ldots \ldots$ 8-18

8.10 DATA MEASUREMENT ASSESSMENT PROCEDURES $\ldots \ldots \ldots .8$ 8-19

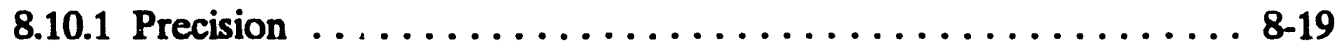

8.10 .2 Accuracy $\ldots \ldots \ldots \ldots \ldots \ldots \ldots \ldots \ldots \ldots \ldots \ldots \ldots .6 .19$

8.11 CORRECTIVE ACTIONS $\ldots \ldots \ldots \ldots \ldots \ldots \ldots \ldots \ldots \ldots .6 .19$

8.11.1 Responsibilities of Project Participants .............. 8-19

8.11.2 Nonconformances and Corrective Action
Procedures ....................... 8-20

8.12 QUALITY ASSURANCE REPORTS TO MANAGEMENT $\ldots \ldots .8$ 8-20

9. LABORATORY QUALITY ASSURANCE PROJECT PLAN $\ldots \ldots \ldots$ 9-1

9.1 QUALITY ASSURANCE OBJECTIVES FOR DATA

MEASUREMENT $\ldots \ldots \ldots \ldots \ldots \ldots \ldots \ldots \ldots \ldots \ldots \ldots, \quad 9.1$

9.1.1 Level of Analysis $\ldots \ldots \ldots \ldots \ldots \ldots \ldots \ldots \ldots \ldots \ldots, 9.1$

9.1.2 Data Quality Parameters $\ldots \ldots \ldots \ldots \ldots \ldots \ldots \ldots \ldots$ 9-2

9.1.3 Laboratory Activities $\ldots \ldots \ldots \ldots \ldots \ldots \ldots \ldots \ldots \ldots, \quad 9.2$

9.2 SAMPLE PREPARATION PROCEDURES $\ldots \ldots \ldots \ldots \ldots \ldots \ldots, \mathbf{9 - 2}$

9.3 ANALYTICAL PROCEDURES $\ldots \ldots \ldots \ldots \ldots \ldots \ldots \ldots \ldots \ldots \ldots$

9.3.1 Laboratory Analyses $\ldots \ldots \ldots \ldots \ldots \ldots \ldots \ldots \ldots \ldots, \quad 9.3$

9.3.2 Analytical Laboratories . . . . . . . .

9.4 SAMPLE AND DOCUMENT CUSTODY PROCEDURES $\ldots \ldots \ldots, 9-3$

9.4.1 Laboratory Receipt and Handling of Samples ........... 9-3

9.5 CALIBRATION PROCEDURES AND FREOUENCY $\ldots \ldots \ldots \ldots .9 .5$

9.5.1 Instrument Calibration Procedures and Frequency ......... 9-5

9.5.2 Calibration Failures $\ldots \ldots \ldots \ldots \ldots \ldots \ldots \ldots \ldots \ldots, 9.5$

9.5.3 Calibration Records $\ldots \ldots \ldots \ldots \ldots \ldots \ldots \ldots \ldots \ldots \ldots, 9 \ldots \ldots$

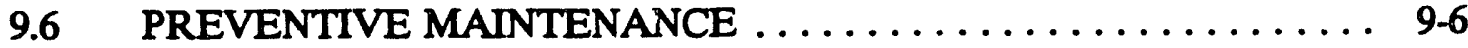

9.6.1 Laboratory Instruments $\ldots \ldots \ldots \ldots \ldots \ldots \ldots \ldots \ldots .9 \ldots \ldots$ 
9.7 DATA REDUCTION, VALIDATION, AND REPORTING . . . . . . . 9-6

9.7.1 Analytical Laboratory Data Reduction and Evaluation ....... 9.7

9.7.2 Data Reporting of Analytical Results ............. 9-7

9.8 INTERNAL QUALITY CONTROL CHECKS . . . . . . . . . . 9.8

9.8.1 Laboratory Quality Control Procedures ............. 9.9

9.9 PERFORMANCE AND SYSTEMS AUDITS . . . . . . . . . 9-11

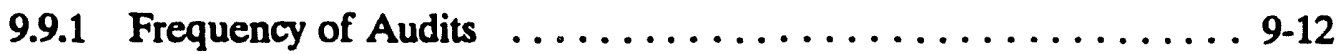

9.9.2 Performance Audits . . . . . . . . . . . . . . .

9.9.3 Systems Audits . . . . . . . . . . . . . . . . 9-12

9.10 DATA MEASUREMENT ASSESSMENT PROCEDURES . . . . . 9-13

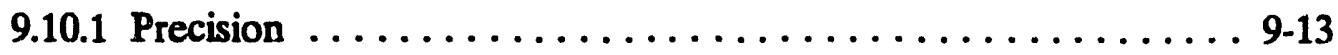

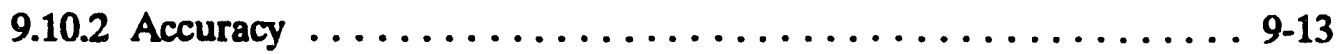

9.11 CORRECTIVE ACTIONS $\ldots \ldots \ldots \ldots \ldots \ldots \ldots \ldots \ldots \ldots \ldots . \ldots \ldots$

9.11.1 Responsibilities of Project Participants ........... . 9-15

9.11.2 Nonconformances and Corrective Action

Procedures ....................... 9-15

9.12 QUALITY ASSURANCE REPORTS TO MANAGEMENT ..... 9-15

10. HEALTH AND SAFETY PLAN $\ldots \ldots \ldots \ldots \ldots \ldots \ldots \ldots \ldots \ldots \ldots$

10.1 SITE HEALTH AND SAFETY PERSONNEL . . . . . . . . 10-1

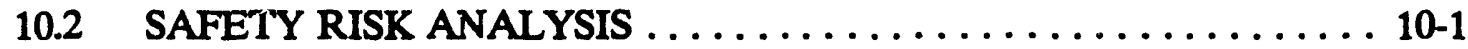

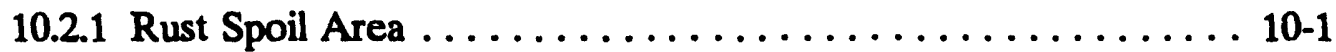

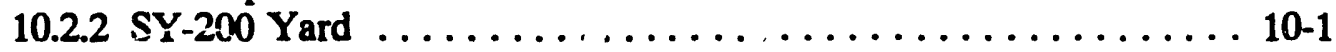

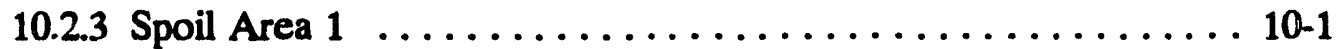

10.2.4 On-site Safety Hazards . . . . . . . . . . . . . . 10-2

10.3 TRAINING REQUIREMENTS $\ldots \ldots \ldots \ldots \ldots \ldots \ldots \ldots \ldots \ldots$ 10-2

10.4 PERSONAL PROTECTIVE EQUIPMENT $\ldots \ldots \ldots \ldots \ldots \ldots \ldots 10.2$

10.5 MEDICAL SURVEILLANCE .................. 10-3

10.6 MONITORING AND SAMPLING $\ldots \ldots \ldots \ldots \ldots \ldots \ldots \ldots \ldots$ 10-4

10.7 SITE CONTROL MEASURES $\ldots \ldots \ldots \ldots \ldots \ldots \ldots \ldots \ldots \ldots \ldots$

10.8 DECONTAMINATION PROCEDURES $\ldots \ldots \ldots \ldots \ldots \ldots \ldots \ldots$ 10-5

10.9 SITE OPERATING PROCEDURES $\ldots \ldots \ldots \ldots \ldots \ldots \ldots \ldots \ldots \ldots$ 10-5

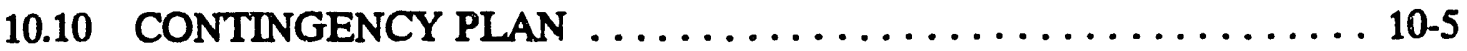

10.11 SPECIAL HAZARD PROCEDURES $\ldots \ldots \ldots \ldots \ldots \ldots \ldots \ldots$ 10-7

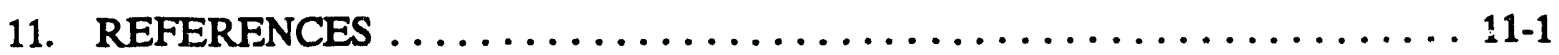

Appendix A. SUPPORTING DOCUMENTS ................. A-1

Appendix B. ANALYTICAL QUANTTTATION LIMITS $\ldots \ldots \ldots \ldots \ldots \ldots \ldots$ B-1

Appendix C. ANALYTICAL DATASOIL BORING LOGS $\ldots \ldots \ldots \ldots \ldots \ldots$. C-1

Appendix D. ENVIRONMENTAL RESTORATION PROGRAM

SITE-SPECIFIC HEALTH AND SAFETY PLAN $\ldots \ldots \ldots \ldots \ldots \ldots$ D-1 
-

-

- 


\section{FIGURES}

1.1 Schedule for the OU 2 RI/FS $\ldots \ldots \ldots \ldots \ldots \ldots \ldots \ldots \ldots \ldots \ldots$

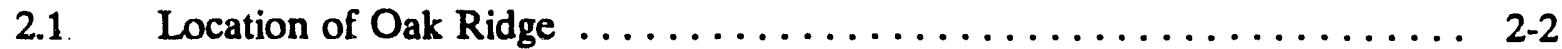

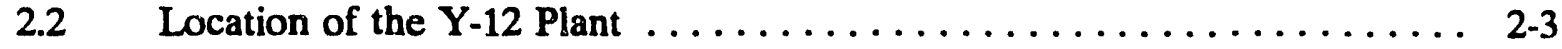

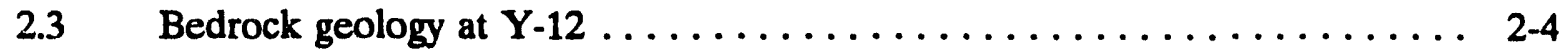

2.4 Annual precipitation in the Oak Ridge area $\ldots \ldots \ldots \ldots \ldots \ldots \ldots \ldots \ldots$

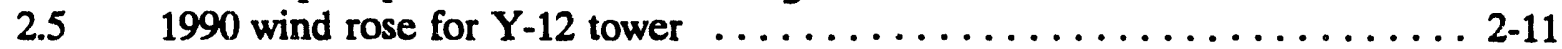

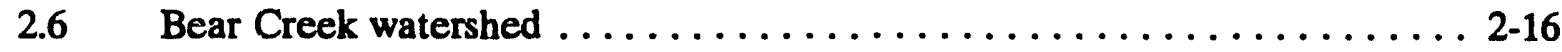

2.7 Upper Bear Creek hydrologic system . . . . . . . . . . . . . . 2-18

2.8 Mean daily stream flow in Bear Creek at USGS gauging station 03538270 at BCK-4.55, March 1985-December $1987 \ldots \ldots \ldots \ldots \ldots .220$

2.9 Particle size distribution of sediment samples collected in Bear Creek for chemical analysis . . . . . . . . . 23

2.10 Water-table surface in the Bear Creek hydrologic regime (April 16-19, 1990) ............................ 2-25

2.11 Generalized cross section of BCV showing inferred groundwater

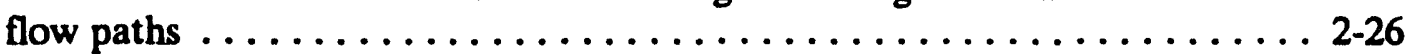

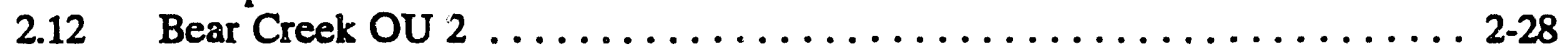

$2.13 \quad$ SY-200 Yard and former ESF construction area $\ldots \ldots \ldots \ldots \ldots \ldots \ldots$

2.14 BCV watershed and location of stream gauging sites $\ldots \ldots \ldots \ldots \ldots \ldots . \ldots \ldots$

2.15 Upper Bear Creek trend chart, 1987-1990 . . . . . . . . . . . . . 2-37

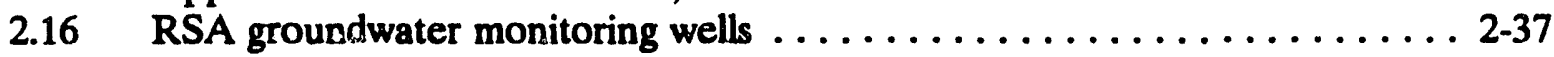

2.17 Location of groundwater monitoring wells and generalized groundwater

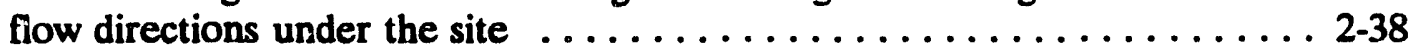

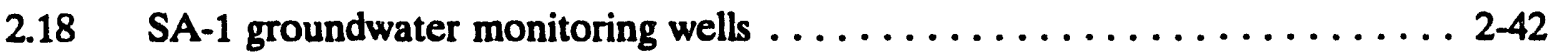

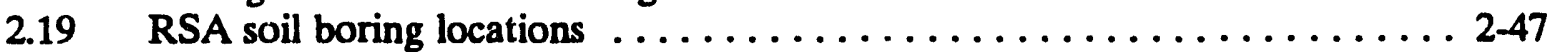

2.20 Previous soil sampling locations in the vicinity of the SY-200 Yard . . . 2-51

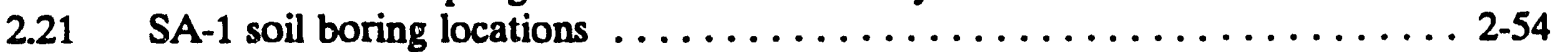

2.22 Locations of existing biological monitoring sites $\ldots \ldots \ldots \ldots \ldots \ldots \ldots$ 2-63

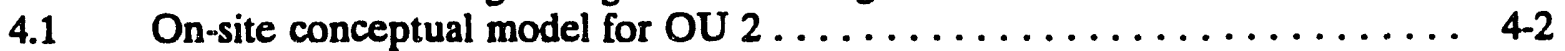

7.1 Proposed locations for piezometers, surface water/sediment and seep sampling, SA-1 ....................... 7-2

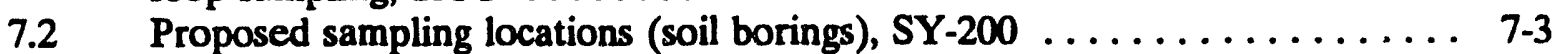

7.3 Proposed surface water/sediment sampling locations, RSA $\ldots \ldots \ldots \ldots \ldots$ 7-4

7.4 Sample label and identification structure $\ldots \ldots \ldots \ldots \ldots \ldots \ldots \ldots \ldots$

7.5 BCV OU 2 RI functional organization chart $\ldots \ldots \ldots \ldots \ldots \ldots \ldots \ldots$

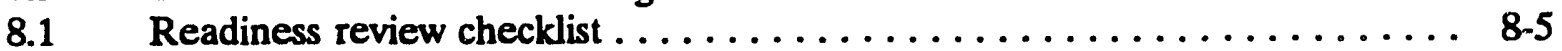

8.2 Field change request form $\ldots \ldots \ldots \ldots \ldots \ldots \ldots \ldots \ldots \ldots \ldots \ldots$

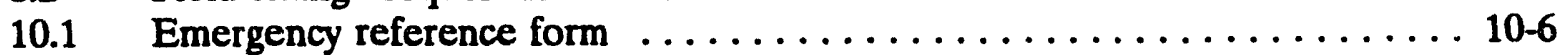




\section{TABLES}

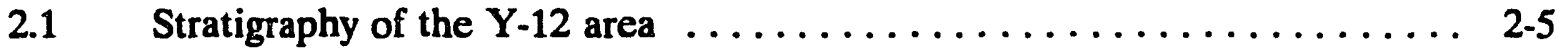

2.2 Land use data for the Eastern Tennessee Development District . . . . . . 2-13

2.3 Urban land use data for the city of Oak Ridge, Tennessee . . . . . . . . 2-13

2.4 Mean, standard deviation, and range of stream flows in Bear

Creek and selected tributaries, $1985-87 \ldots \ldots \ldots \ldots \ldots \ldots \ldots . \ldots \ldots$ 2-17

2.5 Summary of 1986 inventory at the SY-200 Yard . . . . . . . . . . 2-32

2.61990 summary of surface water concentrations from sampling stations

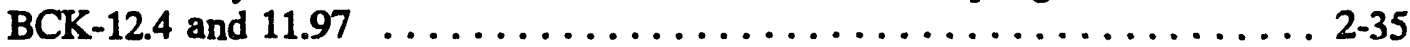

$2.7 \quad$ RSA -1990 average groundwater concentrations $\ldots \ldots \ldots \ldots \ldots \ldots \ldots \ldots .4 \ldots \ldots$

2.8 SA-1 1990 average groundwater concentrations . . . . . . . . . . . . 2-43

2.9 Summary of soil chemical data, RSA soil borings $\ldots \ldots \ldots \ldots \ldots \ldots \ldots . . \ldots 2$

2.10 Summary of detected soil contaminants, RSA $\ldots \ldots \ldots \ldots \ldots \ldots \ldots .2-49$

2.11 SY-200 Yard soil sample analytical results, July $1986 \ldots \ldots \ldots \ldots \ldots \ldots .2-52$

2.12 Summary of SY-200 Yard soil sample analytical results, January $1988 \ldots \ldots$ 2-52

2.13 Summary of soil sample analytical results, January $1989 \ldots \ldots \ldots \ldots \ldots$. . . . . . . .

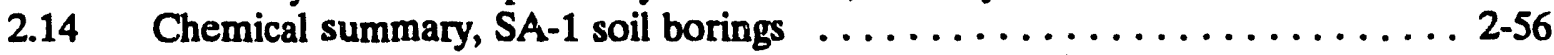

2.15 Comparison of field and background inorganics data for SA-1 soils . . . . 2 2-59

3.1 Data Quality Objectives for OU 2 RI $\ldots \ldots \ldots \ldots \ldots \ldots \ldots \ldots \ldots \ldots$

4.1 Flora and fauna found within the Oak Ridge Reservation .......... 4-6

5.1 Radiation protection standards that may be ARARs for OU $2 \ldots \ldots \ldots \ldots$ 5-6

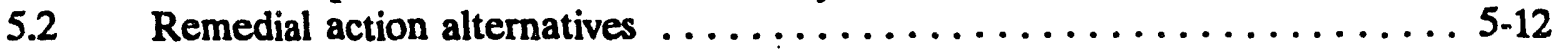

5.3 OU 2 remedial action alternatives $\ldots \ldots \ldots \ldots \ldots \ldots \ldots \ldots \ldots \ldots \ldots \ldots$

7.1 Sample apportionment by medium $\ldots \ldots \ldots \ldots \ldots \ldots \ldots \ldots \ldots \ldots \ldots$

7.2 Numbers of samples and quality control for water samples $\ldots \ldots \ldots \ldots \ldots$ 7-8

7.3 Numbers of samples and quality control for sediment and soil

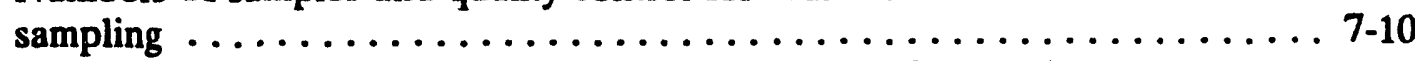

7.4 Proposed analytical parameters for surface water and groundwater and for soil and sediment samples during RI at Bear Creek OU $2 \ldots \ldots$ 7-12

8.1 Cross reference of EPA QAMS 005/80 and ES/ER/TM-4/R1 elements

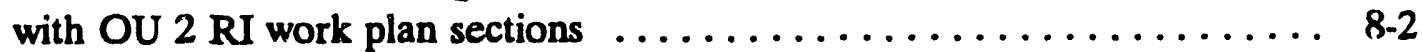

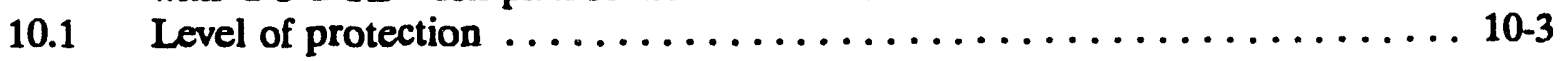

B.1 Contract required detection limits - inorganics $\ldots \ldots \ldots \ldots \ldots \ldots \ldots$ B-3

B.2 Practical quantitation limits - volatile organics $\ldots \ldots \ldots \ldots \ldots \ldots \ldots \ldots$ B-4

B.3 Practical quantitation limits - semivolatile organics $\ldots \ldots \ldots \ldots \ldots \ldots \ldots$ B-5

B.4 Practical quantitation limits - pesticides and PCBs $\ldots \ldots \ldots \ldots \ldots \ldots$ B-7 


\section{ACRONYMS}

\section{1,2-DCE \\ AAS \\ ALARA \\ ANPRM \\ ANSI/ASME}

APR

ARARs

ASC

ATDL

BCK

BCV

CAA

CAR

CDB

CERCLA

CFR

CLP

CMS

CPFs

DCA

DCE

DMC

DOD

DOE

DOE-OR

DQO

I EA

EFPC

Energy Systens

EPA

EP tox

ER

ESD

ESF

FDA

FFA

FID

$F R$

FS

FSP

FTA

FTL trans-1,2-dichloroethene

atomic absorption spectroscopy

as low as reasonably achievable

Advance Notice of Proposed Rulemaking

American National Standards Institute/American Society of Mechanical Engineers

average or mean percent recovery

applicable and relevant or appropriate requirements

Analytical Services Coordinator

Atmospheric Turbulence and Diffusion Laboratory

Bear Creek Kilometer

Bear Creek Valley

Clean Air Act

Corrective Action Report

Consolidated Data Base

Comprehensive Environmental Response, Compensation, and

Liability Act

Code of Federal Regulations

Contract Laboratory Program

Corrective Measures Study

carcinogen potency factors

dichloroethane

dichloroethene

Data Management Coordinator

U. S. Department of Defense

U. S. Department of Energy

DOE Oak Ridge Field Office

Data Quality Objectives

Environmental Assessment

East Fork Poplar Creek

Martin Marietta Energy Systems, Inc.

U.S. Environmental Protection Agency

extraction procedure toxicity

Environmental Restoration

Environmental Sciences Division

Environmental Support Facility

U.S. Food and Drug Administration

Federal Facility Agreement

flame ionization detector

Federal Register

Feasibility Study

field sampling plan

Fire Training Area

Field Team Leader 
HPD

HSWA

IAEA

ICF

IRIS

LCS

LDR

LLW

MCL

MDL

MSL

NAAQS

NCP

NCP.

NEPA

NERP

NESHAP

NOAA

NPDES

NPL

NPRM

NRC

NT

ORNL

ORR

OSWER

OU

PA

PAHs

PARCC

PC

PCBs

PCE

PGDP

PID

PPE

PQL

PSS

QA

QAMS

QAPP

QAS

QC

RCRA

RFA

RfCs
Health Physics Department

Hazardous and Solid Waste Amendments

International Atomic Energy Agency

inductively coupled plasma

Integrated Risk Information System

Laboratory Control Sample

land disposal restrictions

low-level waste

maximum contaminant level

method detection limit

mean sea level

National Ambient Air Quality Standards

National Contingency Plan

Nonconformance Report

National Environmental Policy Act

National Environmental Research Park

National Emission Standards for Hazardous Air Pollutants

National Oceanic and Atmospheric Administration

National Pollutant Discharge Elimination System

National Priorities List

Notice of Proposed Rulemaking

Nuclear Regulatory Commission

North Tributary

Oak Ridge National Laboratory

Oak Ridge Reservation

Office of Solid Waste and Emergency Response

operable unit

Preliminary Assessment

polycyclic aromatic hydrocarbons

Precision, Accuracy, Representativeness, Completeness, and

Comparability Information

personal computer

polychlorinated biphenyls

perchloroethene (or tetrachlorethene)

Paducah Gaseous Diffusion Plant

photoionization detector

Personal Protective Equipment

practical quantitation limits

Plant Shift Superintendent

quality assurance

Quality Assurance Management Staff

quality assurance project plan

quality assurance specialist

quality control

Resource Conservation and Recovery Act

RCRA Facility Assessment

reference concentrations 


RADs
RFI/RI
RI
ROD
RPD
RSA
S\&A
SA-1
SARA
SAS
SD
SDWA
SEG
SHSO
SI
SOW
ST
SWMU
TBC
TCA
TCA
TCE
TCL
TDEC
TDS
TIMS
TSCA
TSD
TSS
TVA
TWRA
UEFPC
USDA
USGS
VOCS
WMA
WOM

reference doses

RCRA Facility Investigation/Remedial Investigation

Remedial Investigation

Record of Decision

relative percent difference

Rust Spoil Area

sampling and analysis

Spoil Area 1

Superfund Amendments and Reauthorization Act

Statistical Analysis System

standard deviation

Safe Drinking Water Act

Scientific Ecology Group

site safety and health officer

Site Investigation

statement of work

South Tributary

solid waste management unit

to be considered

trichloroethane

Tennessee Code Annotated

trichloroethene

target compound list

Tennessee Department of Euvironment and Conservation total dissolved solids

Thermal Ionization Mass Spectrometry

Toxic Substances Control Act

treatment, storage, and disposal

total suspended solids

Tennessee Valley Authority

Tennessee Wildlife Rc:ources Agency

Upper East Fork Poplar Creek

U.S. Department of Agriculture

U.S. Geological Survey

volatile organic compounds

Waste Management Area

White Oak Mountain 


\section{EXECUTIVE SUMMARY}

The enactment of the Resource Conservation and Recovery Act (RCRA) in 1976 and the Hazardous and Solid Waste Amendments (HSWA) to RCRA in 1984 created management requirements for hazardous waste facilities. The facilities within the Oak Ridge Reservation (ORR) were in the process of meeting the RCRA requirements when ORR was placed on the Comprehensive Environmental Response, Compensation, and Liability Act (CERCLA) National Priorities List (NPL) on November 21, 1989. Under RCRA, the actions typicaliy follow the RCRA Facility Assessment (RFA)/RCRA Facility Investigation (RFI)/Corrective Measures Study (CMS)/Corrective Measures Implementation process. Under CERCLA, the actions follow the PASI/Remedial Investigation (RI)/Feasibility Study (FS)/Remedial Design/Remedial Action process. The development of this document will incorporate requirements under woth RCRA and CERCLA into an RI work plan for the characterization of Bear Creek Valley (BCV) Operable Unit (OU) 2.

OU 2 is located within the U.S. Department of Energy (DOE) ORR in Anderson County, Tennessee. The unit is located in BCV, near the headwaters of Bear Creek, just west of the Oak Ridge Y.12 Plant main facilities. OU 2 comprises two construction spoil areas, Rust Spoil Area (RSA) and Spoil Area 1 (SA-1), and an equipment storage yard, SY-200 Yard.

The RSA was used as a disposal area for solid waste (spoil material) generated from various renovation, maintenance, and construction operations at the $\mathrm{Y}-12$ Plant. Although no detailed records are available, the bulk of spoil material disposed at RSA consisted of soil, masonry materials, and metal. Discussions with Y-12 Plant personnel indicated the possibility that small quantities of solvent-contaminated material, and material containing asbestos, mercury, and uranium, may have been disposed in the RSA. However, existing administrative and other established in-plant controls prevented the disposal of significant amounts of chemicals, wastes, or contaminated material a: the RSA. Previous investigations at the site indicate that contaminants of concern at RSA include arsenic, beryllium, lead, mercury, selenium, thorium, uranium, and tetrachloroethene.

SA-1 was used for the disposal of what was considered to be nonhazardous, nonradioactively contaminated construction debris from various renovation, maintenance, and construction operations at the Y-12 Plant. The bulk. of the solid waste known to have been disposed of included asphalt, brick, concrete, roofing materials, brush, metal, rock, and tile. However, the results of soil and groundwater studies in the area confirmed the presence of heavy metals and radiological contamination. Contaminants of concern include arsenic, beryllium, barium, chromium, lead, mercury, fluoranthene, phenanthrene, pyrene, radium, and uranium.

The SY-200 Yard was operated as a "hold for future use" storage area. The yard was an outside graveled area used to store nonradioactively contaminated equipment, electrical transformers, piping, tanks, mercury flasks, and miscellaneous items. All items stored at the site were removed by September 1986 . Based on data obtained through soil sampling, 
contaminants of concern include barium, chromium, lead, mercury, polychlorinated biphenyls (PCBs), and uranium.

This RI work plan contains summaries of geographical, historical, operational, geological, and hydrological information specific to the unit. The potential for release of contamination to receptors through the various media is addressed, and a sampling and analysis plan is presented to determine the extent of release of contamination to the surrounding environment. Proposed activities include walkover radiation surveys at all sites, soil borings at SY-200, piezometer installation and water table sampling at SA-1 and SY-200, and surface water and sediment runoff sampling at all three sites. Data from the site characterization activities will be combined with data from ongoing site-wide monitoring programs (i.e., groundwater, surface water, and biological monitoring) to provide input for a screening-level risk assessment and evaluation of alternative remedial actions. 


\section{INTRODUCTION}

\subsection{REGULATORY INITIATTVE}

The Oak Ridge Reservation (ORR) is composed of three major installations: the Oak Ridge National Laboratory (ORNL), the Oak Ridge Y-12 Plant, and the Oak Ridge K-25 Site (formerly referred to as the Oak Ridge Gaseous Diffusion Plant). These installations were constructed in the early to mid-1940s by the U.S. Department of Energy (DOE) as research, development, and process facilities in support of the Manhattan Project. These installations, along with the Paducah Gaseous Diffusion Plant (PGDP) in Paducah, Kentucky, and the Portsmouth Gaseous Diffusion Plant in Piketon, Ohio, are currently administered by the DOE Oak Ridge Field Office (DOE-OR) in Oak Ridge, Tennessee.

During the construction and operation of these research, development, and process facilities, the associated decontamination, maintenance, and fabrication processes resulted in the generation of various hazardous and radioactive waste by-products. Hazardous waste treatment, storage, and disposal (TSD) facilities were created at each of the DOE-OR facilities to handle such by-products. Some of these facilities continue to receive hazardous wastes while others have been decommissioned. All DOE-OR TSD facilities are currently subject to the requirements of several laws:

- Resource Conservation and Recovery Act (RCRA)-created in 1976 as a management system for hazardous wastes that mandates permitting currently operating TSD facilities. Under RCRA, these TSD facilities are referred to as solid waste management units (SWMUs). RCRA defines a SWMU as any "discernible waste management unit at a RCRA facility from which hazardous waste or hazardous constituents might migrate, irrespective of whether the unit was intended for the management of solid or hazardous waste. Such units include any area at a facility at which hazardous waste or hazardous constituents have been routinely and systematically released.

- Hazardous and Solid Waste Amendments (HSWA)-amendments to RCRA (1984) which provide the U.S. Environmental Protection Agency (EPA) with the authority to enforce corrective actions by broadening the scope of the RCRA Corrective Action Program. In addition to evaluating and correcting releases to the uppermost aquifier from regulated RCRA units, HSWA promotes the cleanup of continuing releases to any media resulting from waste management units and practices at RCRA facilities. Among the most significant provisions of the HSWA are the following.

- Section 3004(u): Corrective Action for Continuing Releases. Section 3004(u) states that for permits issued after November 8, 1984, corrective action is required for releases of hazardous waste or constituents from any SWMU at any TSD facility seeking permit for permanent operation, regardless of when waste was placed in the unit. Thus, corrective actions apply to releases presently occurring as well as past releases. 
- Section 3004(v): Corrective Action Beyond the Facility Boundary. Section 3004(v) authorized EPA to require that corrective action be taken by the facility owner or operator for releases that have migrated beyond the facility boundary (off site). Such action should be taken where necessary in orde: to protect human health and the envircnment unless the owner/operator demonstrates to the satisfaction of the administrator that permission to undertake such action was denied.

- Comprehensive Environmental Response, Compensation, and Liability Act (CERCLA, also referred to as Superfund)-created in 1980 to establich a program to identify sites [operable units (OUs)] from which environmental releases of hazardous substances might occur or have occurred. At such sites, Superfund promotes the evaluation of damage to natural resources, ensures cleanup by the responsible party or the government, and creates a claims procedure for parties involved in site cleanup and natural resource reclamation. Sites identified by CERCLA are evaluated and then placed on the National Priorities List (NPL), if appropriate. The ORR was listed on the NPL in the December 1989 Federal Register (54 FR 48184).

- Superfund Amendments and Reauthorization Act (SARA)-created in 1986 as a 5-year extension of the Superfund/CERCLA program to clean up hazardous releases at uncontrolled or abandoned hazardous waste sites.

- National Environmental Policy Act (NEPA)-created in 1968, directed federal agencies to consider the impacts of their actions (e.g., construction, remediation) on the human environment as a part of all decision-making processes.

In anticipation of the ORR being listed on the NPL, DOE, the Tennessee Department of Environment and Conservation (TDEC), and EPA formulated a Federal Facility Agreement (FFA) for ORR. The FFA was designed to ensure that all necessary steps were undertaken to protect the public health and the environment during the investigation, evaluation, and remediation of all OUs (OUs contain one or more contaminated sites or areas formerly identified at Y-12 as SWMUs). The FFA also outlines all deliverables, review times, and schedules to ensure that activities are undertaken in a timely manner.

DOE and TDEC have formulated an oversight agreement/agreement-in-principle. As stated in this agreement, TDEC is the lead agency for the state of Tennessee. The purposes of this agreement are to (1) ensure compliance with applicable federal, state, and local environmental laws and (2) assure the citizens of Tennessee that their health, safety, and environment are being protected through a program of independent monitoring and oversight by the state.

Each of these agreements provides a measure of oversight for all environmental restoration at the ORR installations. The PGDP and the Portsmouth facility are not listed on the NPL and as such have no FFA. (They do however have agreements-in-principle with heir respective states.) 


\subsection{DOE-OR ENVIRONMENTAL RESTORATION (ER) PROGRAM}

The mission of the DOE-OR ER Program is "to eliminate or reduce to prescribed safe levels the risks to the environment or to human health and safety posed by inactive and surplus OR-managed sites and facilities that have been contaminated by radioactive, hazardous, or mixed wastes" (Energy Systems 1991c). As a result of ORR's placement on the NPL in December 1989, all remedial activities including characterization, alternative selection, and implementation must meet the requirements of RCRA, CERCLA, and NEPA. Therefore, the DOE ER Program decided to address the requirements of all applicable laws in a series of "integrated" documentation for each OU.

To facilitate consistency in the preparation of these integrated documents at all DOE-OR facilities, the managing and operating contractor for DOE-OR facilities established an ER Division. Along with central staff which serve to oversee the main program areas, ER site program managers were appointed at each of the DOE-OR facilities. These site program managers oversee the day-to-day operations of the facility-specific programs and interface with the central ER Division staff.

\subsection{Y-12 SITE CORRECTIVE ACTION PROGRAM}

To meet the requirements of RCRA and the additional requirements of CERCLA, two types of RCRA Facility Investigation/Remedial Investigation (RFI/RI) plans were prepared for the Y-12 site. The RCRA Facility Investigation Plan, General Document, Vols. I, II, and III, (Welch 1989a, Wiggins 1988, and Wiggins et al. 1988) (herein referred to as the General Document ${ }^{*}$ ), contains information applicable to all Y-12 Plant SWMUs (now areas within OUs). The General Document, begun under RCRA, serves as a reference document for the second type of RFI/RI plan, the site-specific RI plan for each OU. RI plans for many of the Y-12 Plant SWMUs/OUs are now under review by EPA Region IV and TDEC.

The Y-12 Plant OUs have been grouped not only by their proximity but also by common physical and hydrogeological parameters. Extensive study of groundwater movement and its relation to contaminant transport at the Y-12 Plant indicates that groundwater can be subdivided into three distinct hydrogeological regimes: Upper East Fork Poplar Creek (UEFPC), Bear Creek, and Chestnut Ridge. This subdivision is based on topography, surface water drainage, and groundwater flow patterns. It offers the advantages of providing a basis for unifying monitoring efforts at the Y-12 Plant and for tailoring monitoring efforts to the hydrogeologic characterization of each regime. The strategy used to delineate boundaries of each regime is included in Comprehensive Groundwater Monitoring Plan for the DOE Y-12 Plant, Oak Ridge, Tennessee (Geraghty and Miller 1990a). The Bear Creek Hydrogeologic regime, in general, and specifically the Bear Creek Valley (BCV) OU 2, is the focus of this RI plan.

The General Document is currently under revision. 


\subsection{SITE ER PROGRAM}

A major objective of CERCLA investigations is to characterize the nature and extent of contamination at uncontrolled hazardous waste sites. HSWA requires assessments to be conducted at all former and current SWMUs at RCRA-permitted facilities. Descriptions of many of the individual SWMUs at the Y-12 Plant are provided in a report titled Solid Waste Management Unit Information for the Y-12 Plant RCRA 3004(u) Facility Assessment and its supplements (Welch et al. 1987, Welch 1987a, Welch and Poore 1987, Wiggins and Welch 1988, Murphy 1989). For SWMUs that are suspected to be the source of contaminant release to the environment, an RFI is required to define the nature and extent of the release.

Under RCRA, actions typically follow the RCRA Facility Assessment (RFA)/ RFI/Corrective Measures Study (CMS) implementation process. The RFA that was conducted for the Y-12 Plant (Welch et al. 1987) resulted in the decision to perform RFIs for the Rust Spoil Area (RSA) (SWMU D-106) and the Spoil Area 1 (SA-1) (SWMU D-107). The decision was based on the likelihood that these units received solid waste containing hazardous or potentially hazardous constituents. The SY-200 Yard was scheduled for further investigation after traces of mercury were observed in fill material excavated during 1988 construction activities (P rkins 1989). Under CERCLA, actions typically follow the Preliminary Assessment (PA)/Site Investigation (SI)/Remedial Investigation (RI)/ Feasibility Study (FS)/remedial design/remedial action process. The development of this document incorporates the requirements under both RCRA and CERCLA into an RI work plan.

\subsection{SPECIAL PROBLEMS}

No special problems have been identified at the site.

\subsection{OBJECTTVES}

The results of previous investigations within OU 2, summarized in this plan, have helped to define the nature and extent of contamination. The general objectives of the OU 2 RI include (1) defining further the nature and extent of contamination in media of concern (i.e., soil), especially at the SY-200 Yard, and (2) gathering information for the specific needs of the risk assessment and FS. Specific objectives are to

- define the nature of soil contamination at SY-200;

- define the extent (vertical and horizontal) of soil contamination at SY-2C0;

- fill any identified data gaps in the extent of soil contamination at RSA and SA-1;

- define the interaction (transfer mechanism), if any, between soil contaminants and shallow groundwater; and 
- define the relative contribution of OU 2 contaminants to BCV groundwater and surface water/sediment contamination.

\subsection{SCHEDULE}

The schedule of the BCV OU 2 RI sampling and analysis activities is provided in Fig. 1.1. 


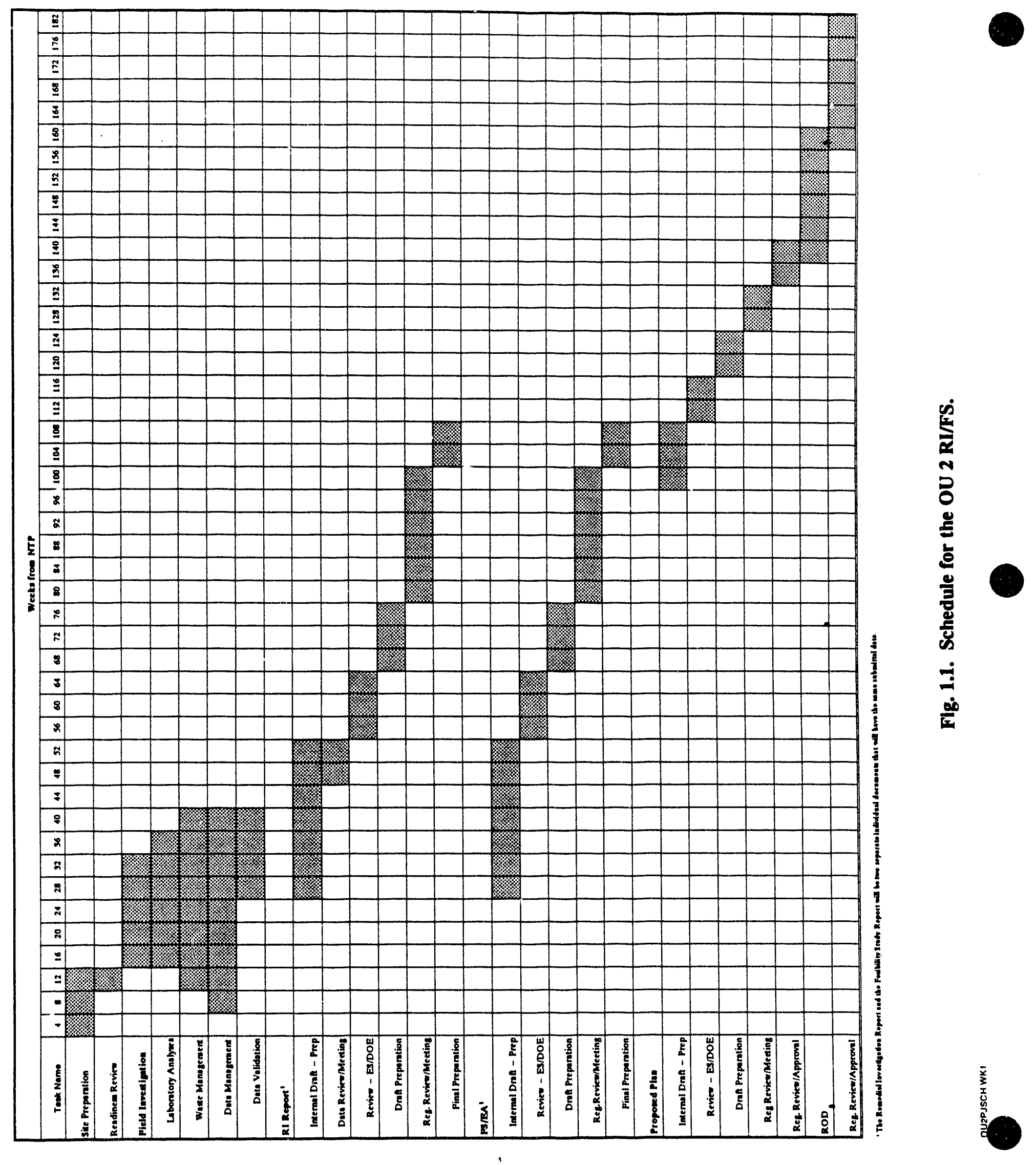




\section{CHARACTERIZATION OF THE ENVIRONMENTAI, SETTING}

\section{GEOGRAPHY}

The DOE ORR is located within the corporate limits of the city of Oak Ridge in eastern Tennessee, $\sim 16 \mathrm{~km}(10 \mathrm{mi})$ southeast of the Cumberland Mountains and $113 \mathrm{~km}(70 \mathrm{mi})$ northwest of the Great Smoky Mountains. Figure 2.1 shows the city's location approximately midway between Nashville, Tennessee, and Asheville, North Carolina, on an east-west line and between Lexington, Kentucky, and Atlanta, Georgia, on a north-south line. The area is serviced by Interstates 40 and 75, which intersect in nearby Knoxville, Tennessee, east of Oak Ridge. The reservation, 14,300 ha (35,300 acres) of federally owned land, houses three facilities (the K-25 Site, ORNL, and the Y-12 Plant) (Fig. 2.2) which are managed by Martin Marietta Energy Systems, Inc. (Energy Systems).

The Y-12 Plant contains $\sim 800$ acres and is located adjacent to the corporate center of the city of Oak Ridge between Chestnut Ridge, located to the south, and Pine Ridge, located north of the plant (Fig. 2.2). The plant complex, built predominately in the mid-1940s, is roughly divided into two portions; the western portion is devoted to DOE ongoing weaponsmanufacturing activities, and the eastern portion is devoted to ORNL research programs.

The Y-12 Plant is located in the Valley and Ridge Physiographic Province, which lies between the Cumberland Mountains to the northwest and the Great Smoky Mountains to the southeast. This province is characterized by roughly parallel, alternating ridges and valleys. The main facilities of the Y-12 Plant lie on the BCV floor, with auxiliary facilities along Pine Ridge and Chestnut Ridge. OU 2 is located on the BCV floor immediately west of the Y-12 main plant facilities.

\section{TOPOGRAPHY, GEOLOGY, AND SOILS}

\section{Topography and General Geology}

OU 2 is located in the Valley and Ridge Physiographic Province, part of the Appalachian fold and thrust belt. The area is characterized by a succession of northeast-trending ridges and valleys, which formed as a result of differential erosion of the clastic and carbonate lithologies that make up the individual thrust sheets.

OU 2 is located in BCV, which is bounded to the north and south by Pine Ridge and Chestnut Ridge, respectively. Maximum relief of the ridges is $-200 \mathrm{ft}$. The elevation of $\mathrm{BCV}$ is $975 \pm 50 \mathrm{ft}$ above mean sea level (MSL), and Pine Ridge and Chestnut Ridges have an approximate elevation of $1200 \pm 50 \mathrm{ft}$ above MSL. These ridges and valley are part of the White Oak Mountain (WOM) thrust sheet, which exposes Lower Cambrian to Ordovician rock units in the immediate area (Fig. 2.3). The stratigraphy of the area, from oldest to youngest (and exposed from grid-north to grid-south), includes the Lower Cambrian Rome Formation (exposed on Pine Ridge), the Cambrian Conasauga Group (exposed in BCV), and the Knox Group (exposed on Chestnut Ridge). 


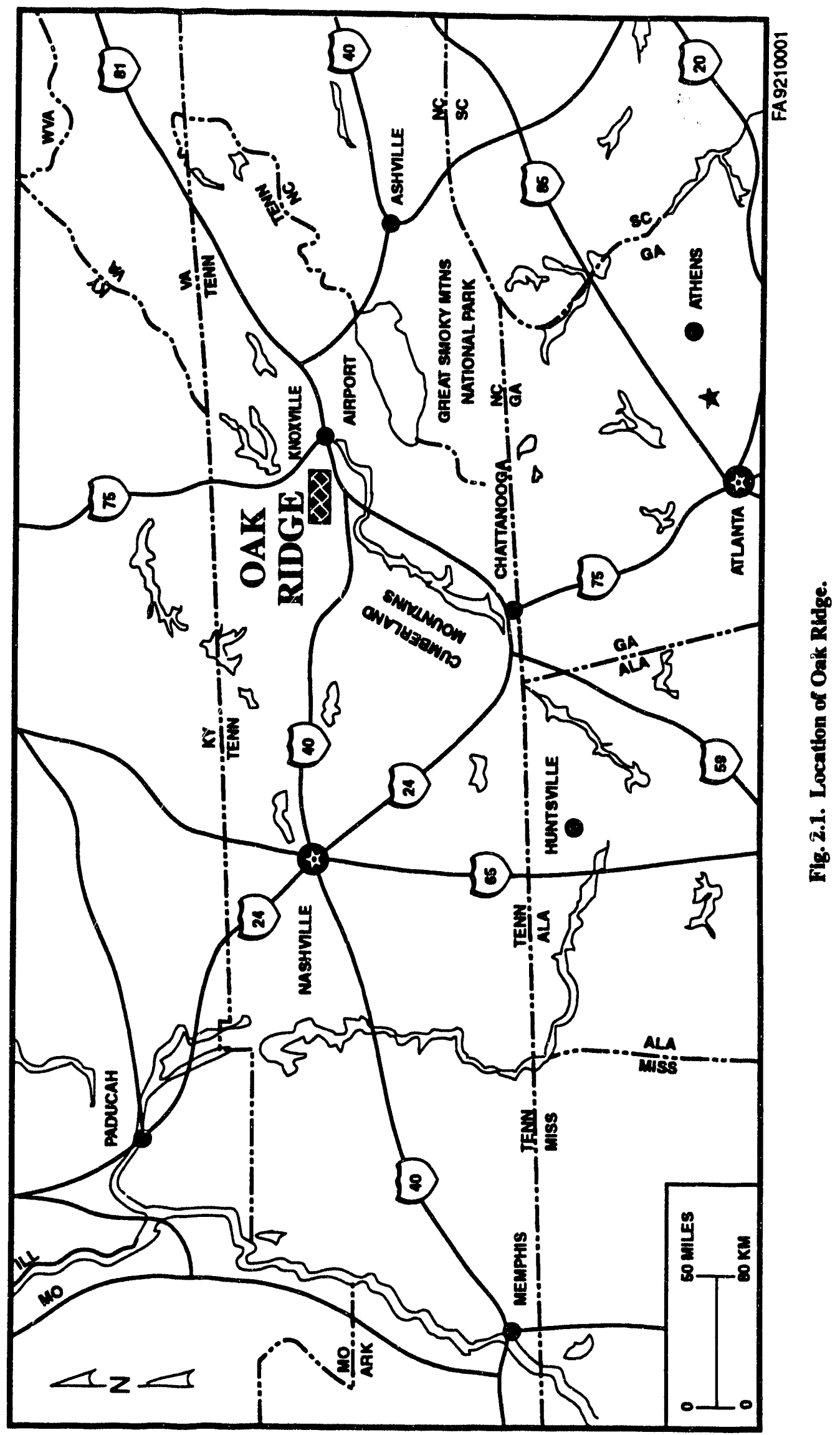




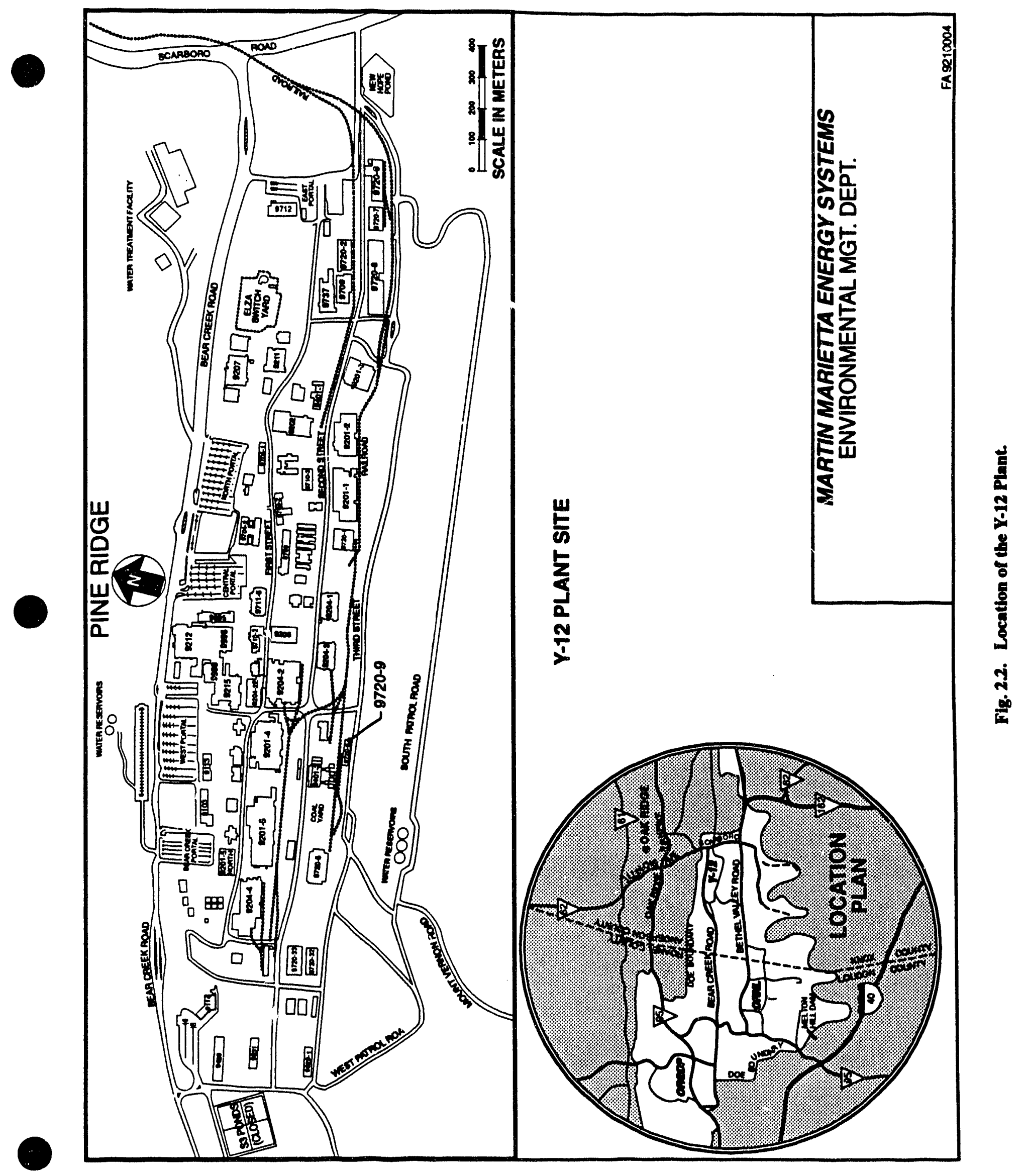




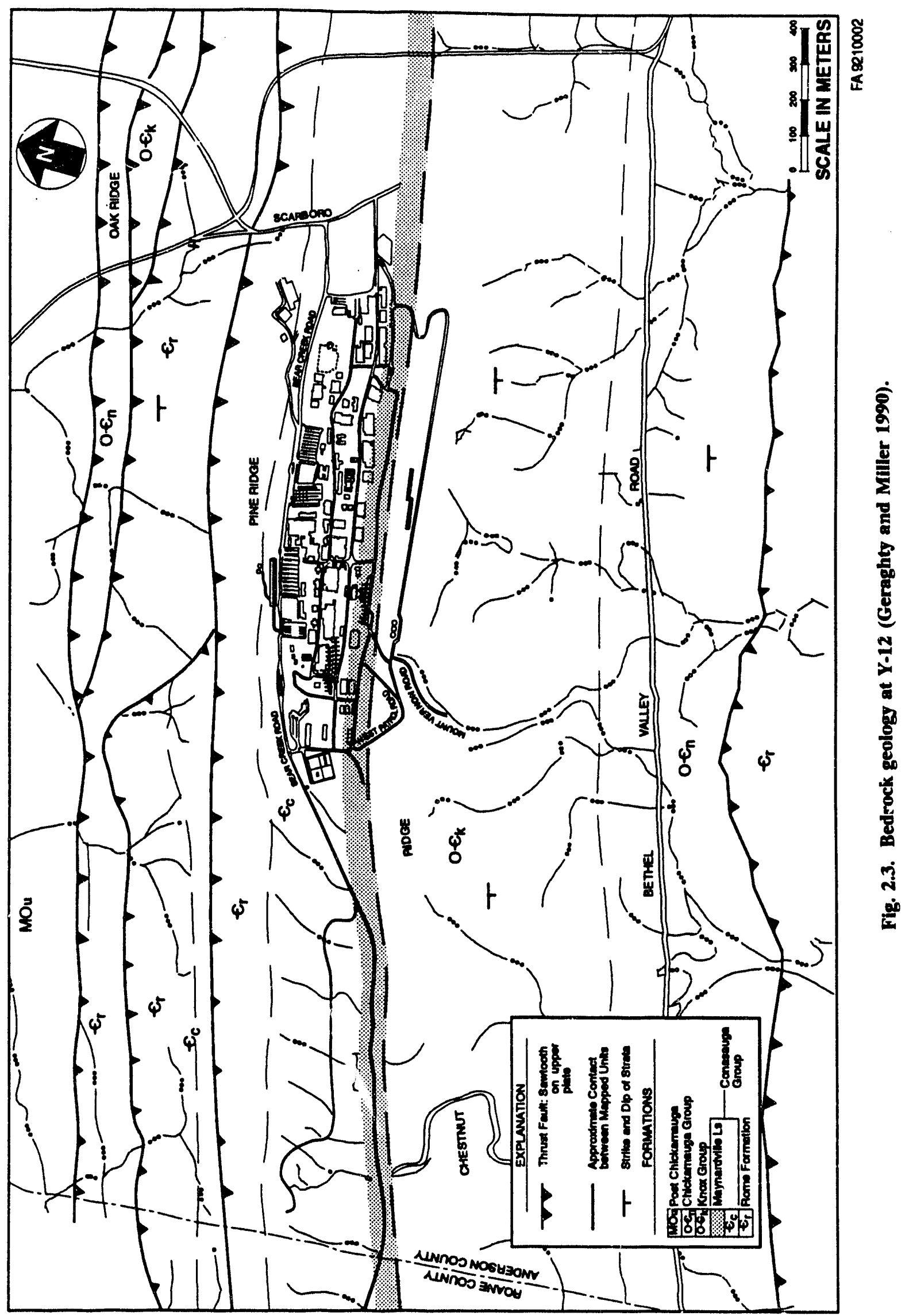


The Conasauga Group, which underlies OU 2, is further divided into six formations of alternating shale and carbonate-rich lithologies. From oldest to youngest these are the Pumpkin Valley Shale, the Rutledge Limestone, the Rogersville Shale, the Maryville Limestone, the Nolichucky Shale, and the Maynardville Limestone (Table 2.1).

Table 2.1. Stratigraphy of the $Y-12$ area

\begin{tabular}{|c|c|c|c|}
\hline Age & Group or formation & $\begin{array}{l}\text { Thickness }^{a} \\
\text { (ft) }\end{array}$ & General comments \\
\hline $\begin{array}{l}\text { Upper Cambrian- } \\
\text { Lower Cambrian }\end{array}$ & Knox Group & & $\begin{array}{l}\text { Only the lowermost formation, } \\
\text { the Copper Ridge Dolomite, } \\
\text { occurs in the Y-12 area on } \\
\text { Chestnut Ridge. This formation } \\
\text { consists mainly of siliceous } \\
\text { dolomites. }\end{array}$ \\
\hline Cambrian & $\begin{array}{l}\text { Conasauga Group } \\
\text { Maynardville Limestone } \\
\text { Nolichucky Shale } \\
\text { Maryville Limestone } \\
\text { Rogersville Shale } \\
\text { Rutledge Limestone } \\
\text { Pumpkin Valley Shale }\end{array}$ & $\begin{array}{l}410-440 \\
490-540 \\
380-400 \\
100-120 \\
100-120 \\
320\end{array}$ & $\begin{array}{l}\text { This group underlies BCV. } \\
\text { UEFPC flows along strike with } \\
\text { the Maynardville Limestone. }\end{array}$ \\
\hline Lower Cambrian & Rome Formation & & $\begin{array}{l}\text { This formation is exposed on } \\
\text { Pine Ridge and consists } \\
\text { predominately of sandstones } \\
\text { and sandy shales. }\end{array}$ \\
\hline
\end{tabular}

${ }^{-}$Only thicknesses of the formations of the Conasauga Group at the Y-12 Plant are given.

Source: Energy Systems (1989).

\subsection{Stratigraphy}

The strata of greatest interest, with respect to contaminant migration in BCV, include the Maynardville and Nolichucky Formations of the Conasauga Group. For general descriptions of the stratigraphy of other units in the ORR, the reader is referred to Haase et al. (1985) (Conasauga Group and Rome Formation), Lee and Ketelle (1987) (Knox Group), and Lee and Ketelle (1988) (Chickamauga Group).

Maynardville Limestone (King and Haase 1987; Rothschild et al. 1984; Geraghty \& Miller 1987). In BCV, the Maynardville Formation varies from 418 to $450 \mathrm{ft}$ in thickness and shows a gradational lower contact with the Nolichucky Shale (King and Haase 1987). The Maynardville Limestone comprises light-gray to tan, massive to thinly bedded limestone with subordinate amounts of dolostone. This formation can be divided into two members on the ORR (Haase et al. 1985). The uppermost Chances Branch member consists of medium to 
thinly bedded buff and light-gray dolostones, ribbon-bedded dolostones/ limestones, and thinly bedded medium-gray limestones. The lower Low Hollow Member is principally wavy to even thinly bedded (o)microsparite, with alternating horizons of dolomite bearing, ribbon-bedded microsparite and calcarenite. The Low Hollow Member and the lower portion of the Chances Branch Member are oolitic, and soft sediment deformation fabrics have been observed (Geraghty \& Miller 1987). Both members are locally stylolitic.

Drilling in the Y-12 Plant area (Rothschild et al. 1984; Army Corps of Engineers 1954a,b) and further west in the Y-12 Plant burial grounds (Bechtel 1984) shows that, in the near subsurface, the Maynardville Limestone is characterized by numerous solution cavities, which generally range in thickness from less than 1 to $3 \mathrm{ft}$, although cavities from 8 to $11 \mathrm{ft}$ thick have been noted (Rothschild et al. 1984). The cavities commonly parallel bedding planes. Where Bear Creek lies in the Maynardville Limestone, the position of the channel is controlled by preferential solution along joints and fractures (Geraghty \& Miller 1987).

Nolichucky Shale (King and Haase 1987; Rothschild et al. 1984). In BCV, the Nolichucky Shale ranges in thickness from 422 to $550 \mathrm{ft}$ (King and Haase 1987). In eastern Tennessee, the Nolichucky Shale can be divided into three members: the Upper Shale, the Bradley Creek, and the Lower Shale Members (Hasson and Haase 15\%8), although identification of these members in BCV is not straightforward. The formation consists of maroon-brown to rare green-gray, massive to very thinly bedded, locally calcareous mudstones and shales interstratified with thinly bedded, medium gray limestones and calcareous siltstones. The maroon-brown color of the shales is characteristic of the Nolichucky Shale. The interbedded limestones typically contain limestone-pebble conglomerates and oolite-rich beds similar to those occurring in the underlying Maryville Limestone. Throughout much of the Nolichucky Shale, mudstone/shale and limestone lithologies alternate on a scale of 1 to $3 \mathrm{ft}$, giving the formation a thickly bedded appearance.

During drilling at the Y-12 Plant, solution cavities, opened fractures, and iron precipitate were commonly observed up to downhole depths of $50 \mathrm{ft}$ (Rothschild et al. 1984). Comparison of Maynardville Limestone and Nolichucky Shale descriptions suggests the solution cavity development is not as extensive in the Nolichucky Shale as it is in the Maynardville Limestone.

\subsection{Structural geology}

Faults. Pine Ridge, BCV, and Chestnut Ridge all are part of the WOM thrust sheet, which is floored by the WOM thrust fault. The WOM fault is a regional thrust fault of the Valley and Ridge, which shows at least several kilometers of displacement. The fault formed during the Permian-Pennsylvanian Alleghanian Orogeny and has not been historically active. At the ORR, the fault trends parallel to regional strike (N55E) and dips steeply $\left(45^{\circ}\right)$ to the southeast (King and Haase 1987). Bedding plane dip values measured in outcrops cluster around $45^{\circ}$ but may steepen to vertical as a result of localized small-scale folding or faulting.

The WOM thrust fault north of Pine Ridge is very complex and is characterized by a sequence of cross-cutting imbricate splay faults that repeatedly stack the Rome Formation. In the vicinity of Bear Creek, this fault superposes the Cambrian Rome Formation over the 
younger Cambrian Copper Ridge Dolomite member of the Knox Group. In addition, north of the WOM thrust fault, in the underlying Kingston Thrust Sheet, Bear Creek flows over slices of the Knox Group and Chickamauga Group that have been complexly stacked and rotated as a result of footwall deformation associated with displacement along the WOM fault. Because of the complex deformation associated with the WCM thrust fault and the immediately underlying Kingston Sheet, it is anticipated that this region contains numerous fault-related fracture zones of enhanced permeability.

BCV is characterized by numerous cross-strike streams with a consistent northwestern trend. Such a consistent orientation suggests that the location of these creek beds is controlled by a geological structural feature, either a minor te $r$ fault or a prominent fracture trend. Both features are possible, and in Melton Valley the White Oak Creek Tear Fault shows a similar north trend. If these structures are faults, they show minor displacement but should have an associated fracture zone.

Fracturea. Because of the large-scale faulting, all geologic units in the ORR are highly fractured. Recent detailed investigzitions of Conasauga Group core by Lutz and Dreier (1988) show that five fracture sets occur conswizntly throughout the core. One set is parallel to bedding, but the other four are generally perpendicular to bedding. The parallel bedding fractures are mainly release joints. Recent studies elsewhere in the Appalachians suggest that release joints can form at depths up to a kilometer (Engelder 1985, Assuming a regional strike of N55E, the strikes of the high angle sets are approximately N55E, N75W, N15E, and N20W.

Fracture density varies throughout the cores. The two variables that have the greatest effect on density are lithology and bedding thickness. Density is inversely proportional to bedding thickness. High fracture densities are found in shales and interbedded limestone and shale, whereas limestones exhibit lower densities. Mineralization is almost entirely confined to limestone beds. All fracture sets exhibit vein development; however, the N55E direction is most commonly mineralized.

\section{General Soil Characteristici}

Bejrock units in BCV are overlain by unconsolidated deposits of varying thicknesses consisting of residuum, which comprises the majority of the unconsolidated materials, manmade fill, alluvium, and colluvium (Petrich et al. 1984). Soils of particular importance to OU 2 are those characteristic of the Conasauga Group. These soils include, but are not limited to, the Armuchee, Fullerton, Greendale, Hamblen, Jefferson, Leadvale, Newark, and Sequoia. Depth to bedrock varies from less than $10 \mathrm{ft}$ to $30 \mathrm{ft}$, with the Montevallo series being the most shallow (Lietzke et al. 1986). In general, these soils are classed as poor for crop growth or pasture. With the exception of a few areas that are suitable for pasture, the general classification of Y-12 Plant soils is for forestry. In BCV the Armuchee and Sequoia soil series are most prevalent. The Armuchee is a shaley, silty clay loam becoming more shaley with depth, and the Sequoiais a yellowish-brown silt loam overlying a residuum of acid shale. Chemical and physical properties of these soils are given in Tables 4.2 and 4.3 in Vol. I of the General Document. 
The presence and extent of virgin soils below the OU 2 sites are not well known due to the extensive filling that took place during its operational lifetime. Lithologic logs from soil borings at SA-1 (Appendix C) provide much of the existing soils information for the site. Based on a comparison of the description of soil types as provided in the Soil Survey of Anderson County, Tennessee (USDA 1981) and these lithologic logs, Fullerton is the most important soil series for area.

The Fullerton series is made up of the Fullerton cherty silt loam which consists of 5 to 45\% slopes. This deep, well drained, sloping soil is on rolling ridgetops and the sides of ridges and hills. The soils formed in a residuum of dolomite.

Typically, the surface layer is brown cherty silt loam 7 in. thick. It overlies a 5 -in. layer of strong brown cherty loam. The subsoil extends to a depth of more than 64 in. It is strong brown cherty silt loam in the upper part and yellowish red cherty silty clay and cherty clay in the lower part.

This soil is low in natural fertility and has a medium available water capacity. It is strongly acid or very strongly acid throughout except where the surface layer is limed. Permeability is moderate. Runoff is medium. On the average the soil contains more chert than other phases of the Fullerton soils.

The physical and chemical properties of this soil follow (USDA 1981):

$\begin{array}{ll}\text { Permeability } & 0.6-2.0 \mathrm{in} . / \mathrm{h} \\ \text { Available water capacity } & 0.1-0.16 \mathrm{in} . / \mathrm{in} . \\ \text { Soil reaction }(\mathrm{pH}) & 4.5-5.5\end{array}$

A soil leaching and contaminant transport model will be developed to help determine the risk for contaminants to move off site. The model can also be used to evaluate the potential for contaminant migration during screening of alternative technologies in the FS. The MultiMedia model (Salhotra et al. 1990) will be used to develop the site-specific model. Data requirements for the model will be satisfied as follows:

- Site physical characteristics. Data already available and summarized in this Work Plan.

- Site hydrologic characteristics. Hydrologic properties of the Conasauga Group and its residuum on the ORR are detailed in Rothschild et al. 1984. Average infiltration and recharge rates for the Bear Creek Valley are given in Solomon et al. 1992. Determination of site-specific physical parameters required by Multimed, such as depth to groundwater, aquifer thickness, and soil layering, is outlined in the Work Plan.

- Soil geochemical properties. The normalized distribution coefficient (Koc) values for volatile and semivolatile contaminants will be taken from standard references (e.g., EPA/540/2-89/057). Hydrolusis rate constants for a wide variety of VOCs are available in. the literature as outlined in Salhotra et al. 1990. 
Distribution coefficients (Kd's) and retardation factors ( $R$ 's) of common radionuclides are available for the Conasauga Group and its residuum on the ORR in Rothschild et al. 1984, Meyer et al. 1987, and Davis et al. 1984. Average Kd's of metals in soils and sand are available in Gilbert and Yu 1989 and Baes and Sharpe 1983. No Kd values for metals are available for the ORR at this time; however, most metals of interest have high average $\mathrm{Kd}$ values for soils $\left(>100 \mathrm{~cm}^{3} / \mathrm{g}\right)$ and moderate to high $\mathrm{Kd}$ values for sand $\left(>10 \mathrm{~cm}^{3} / \mathrm{g}\right)$. A worstcase scenario for these metals can be modeled using $\mathrm{Kd}$ values for sand. For metals with low average $\mathrm{Kd}$ values [As, $\mathrm{Cd}, \mathrm{Cr}(\mathrm{VI}), \mathrm{Cu}$, and $\mathrm{Zn}$ ], a worst-case scenario can be modeled using $\mathrm{Kd}$ 's in sand; if this scenario shows high potential leachability, site-specific $\mathrm{Kd}$ values can be determined for these metals which are present in soils above target cleanup levels.

\section{CLMMATE}

Detailed discussions of climate can be found in Sect. 4.4 of Vol. I of the General Document (Welch 1989a) and in Sect. 3.1 of the Clinch River RCRA Facility Investigation Plan (Energy Systems 1990). The Oak Ridge area has a temperate climate that is moderated by the Blue Ridge Mountains to the east and the Cumberland Plateau to the west.

Weather patterns in Oak Ridge are generally temperate, with warm, humid summers and cool winters. The annual mean temperature is about $15^{\circ} \mathrm{C}\left(58^{\circ} \mathrm{F}\right)$, with a January mean of about $3.5^{\circ} \mathrm{C}\left(38^{\circ} \mathrm{F}\right)$ and a July mean of about $25^{\circ} \mathrm{C}\left(77^{\circ} \mathrm{F}\right)$. Relative humidity in midafternoon averages about 55\%. At night humidity is higher, averaging $85 \%$ at dawn.

The mean annual rainfall is about $136 \mathrm{~cm}$ (Fig. 2.4), but during the drought of 1981-88 yearly precipitation was about $30-35 \mathrm{~cm}$ less than average. Winter months usually have the most rain, with another peak in July, when thunderstorms are common. Autumn is usually the season of lowest rainfall.

Prevailing winds in the area follow the general topography of the surrounding ridges (Fig. 2.5). The down-valley draft, coming from the northeast and identified with gravitational flow down local slopes and the Tennessee Valley, prevails during inversion conditions of late evening through mid-morning. Daytime up-valley flow is from the southwest when regional or synoptic flows aloft become strong enough to dominate the opposing local gravitational winds.

Oak Ridge is one of the country's calmest wind areas. Average wind speed for the Oak Ridge area is $4.4 \mathrm{mph}$. The Cumberland Plateau and the Smoky Mountains divert severe storms; local irregular ridges further minimize the air movement and wind impact.

\section{ECOLOGY}

OU 2 lies outside the main Y-12 complex and as such is in close proximity to areas of potential ecological sensitivity. Bear Creek runs along the northwest edge of the unit, and one spring exists along the northern edge of the RSA. OU 2 is not likely to have a significant detrimental impact on the ecology of Bear Creek in relation to the other 


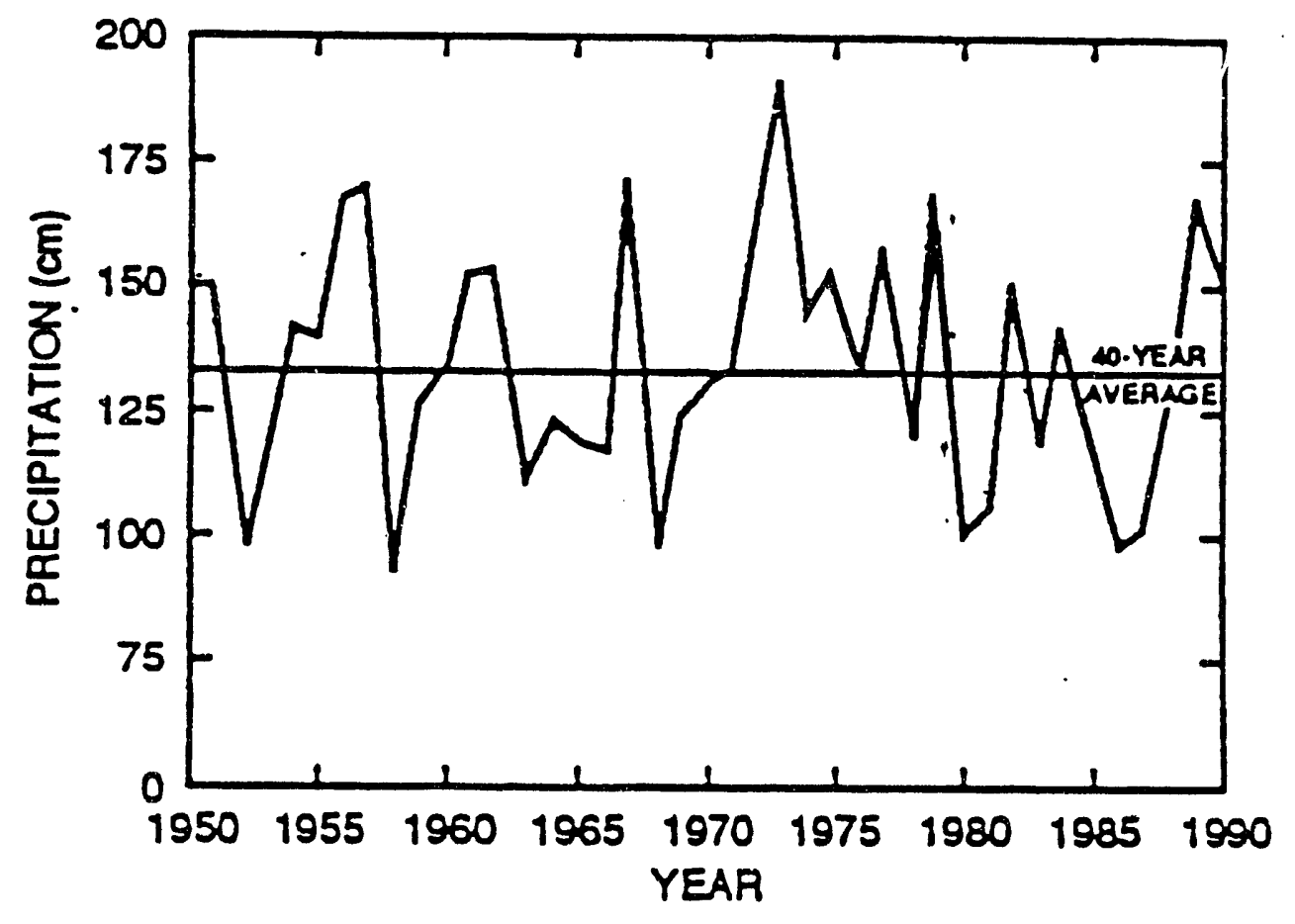

Fig. 2.4. Annual precipitation in the Oak Ridge area. 


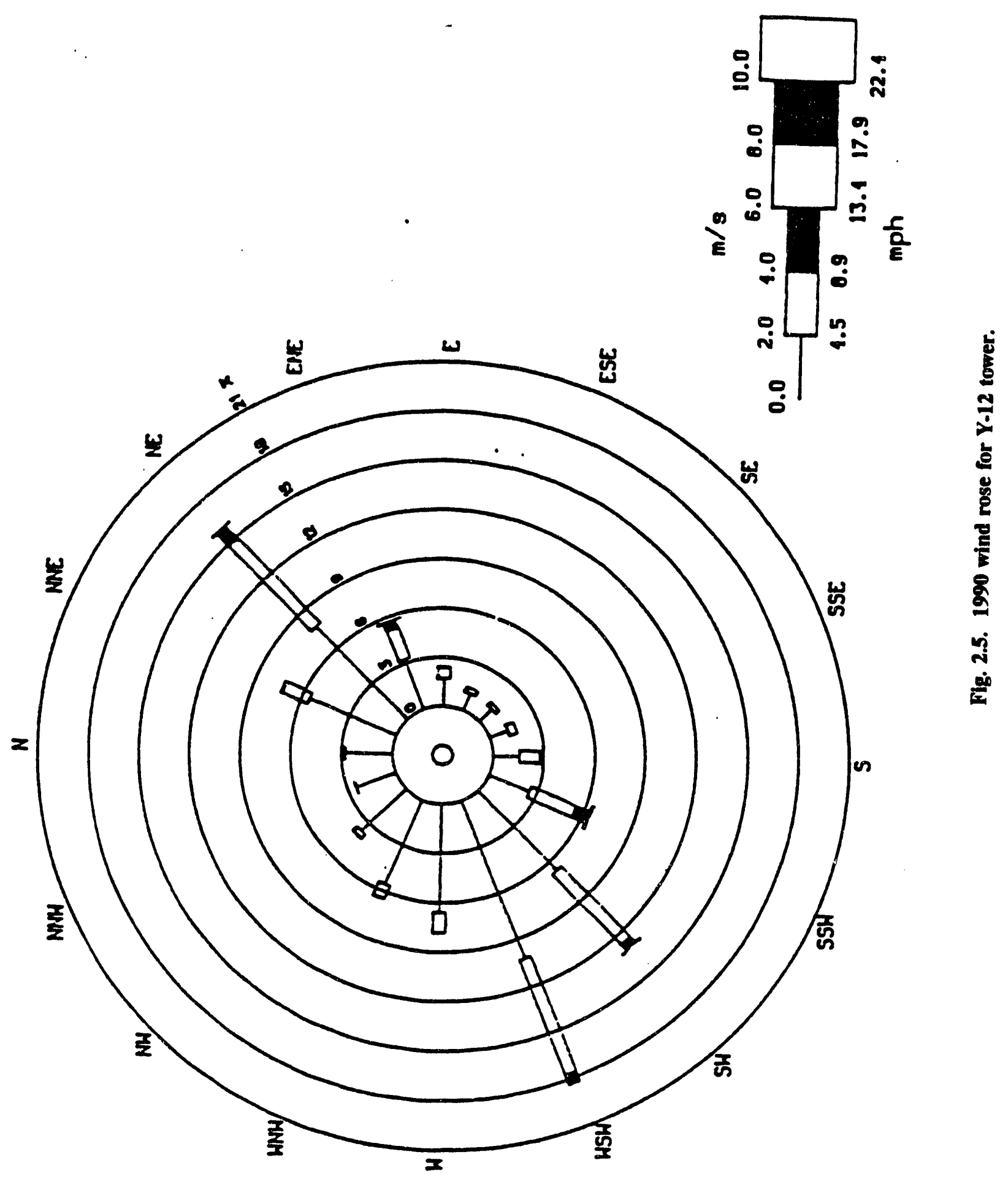


upgradient sources of contamination. Ecological monitoring is ongoing at the Y-12 Plant under separate programs that are beyond the scope of this RI plan.

The environs surrounding OU 2 are typical of the ecological systems of the Appalachian region. The dominant plant community is the old hickory forest, which has extensive stands of mixed yellow pine and hardwoods. Nonforest areas include grasslands, devegetated areas, and developed locations.

The forests of ORR serve as hosts for many forest wildlife species. Recorded wildlife species include $\sim 60$ species of reptiles and amphibians; more than 120 species of terrestrial birds; 32 species of waterfowl, wading birds, and shore birds; and about 40 species of mammals (Nix et al. 1986).

The ecology of OU 2 is discussed in detail in Sect. 4.2.2 of this document. The potential ecological impacts of OU 2 on surrounding environs will be addressed as part of the phased Bear Creek Valley ecological studies proposed in the Remedial Investigation Work Plan for Bear Creek Valley Operable Unit 4 (Shallow Groundwater in Bear Creek Valley) at the Oak Ridge Y-12 Plant, Oak Ridge, Tennessee (DOE 1992).

\section{DEMOGRAPHY}

\subsection{Population Information}

The Y-12 Plant is located at the northeast boundary of ORR adjacent to the commercial center of Oak Ridge, which has a population of 27,310 (U.S. Department of Commerce 1991). The employment at the Y-12 Plant, as of January 1992, consisted of 6934 full-time Energy Systems employees and 1000 on-site employees of M-K Ferguson, DOE, and ORNL. No drinking water supplies are located within the ORR boundary: a pumping station located on the north bank of Melton Hill Lake at Clinch River supplies water to the Y-12 Plant and the Oak Ridge water plant.

\section{Land Use}

The East Tennessee Development District, which includes Oak Ridge, is rural in character. Knoxville is the district's regional center and the only city with a population in excess of 50,000. Oak Ridge and other cities in the district are within the 7500 to 50,000 population range, are incorporated, and have a definite central core that provides major employment and trade opportunities. Of the district's $1,700,010$ ha $(4,200,800$ acres $), \sim 80 \%$ is in agricultural and forest land use (Table 2.2).

In contrast to the district's general land use patterns, the city of Oak Ridge is an urban center with minimal agricultural activities. Land not owned by the federal government consists of 5510 ha $(13,615$ acres) and is divided into more than 9500 parcels. Table 2.3 categorizes urban land use data for the city of Oak Ridge. Most of this land is either residential or vacant, with over 1903 ha (4700 acres) of the vacant land suitable for housing (DOE 1982).

92-043P/050493 
Table 22 Land use data for the Eastern Tennessee Development District

\begin{tabular}{lccc}
\hline \multicolumn{1}{c}{ Land use category } & Hectares & Acres & Percent \\
\hline Residential & 35,074 & 86,670 & 2.1 \\
Commercial & 1,950 & 4,820 & 0.1 \\
Industrial & 20,700 & 51,150 & 1.2 \\
Recreational & 269,129 & 665,030 & 15.8 \\
Agricultural & 685,904 & $1,694,900$ & 40.3 \\
Public and quasi-public & 28,430 & 70,250 & 1.7 \\
Forest & $\underline{658,823}$ & $\underline{1,627,980}$ & $\underline{38.8}$ \\
& $1,700,010$ & $4,200,800$ & 100.0 \\
\hline
\end{tabular}

Source: DOE 1982.

Table 23. Urban land use data for the city of Oak Ridge, Tennessee

\begin{tabular}{lccc}
\hline \multicolumn{1}{c}{ Land use category } & Hectares & Acres & Percent \\
\hline Residential & 1,640 & 4,050 & 28.9 \\
Vacant & 2,247 & 5,550 & 39.6 \\
Recreational & 749 & 1,850 & 13.2 \\
Commercial & 104 & 256 & 1.8 \\
Industrial & 47 & 115 & 0.8 \\
Public transportation, Parking & 480 & 1,185 & 8.5 \\
Private transportation & 33 & 82 & 0.6 \\
Utilities and communications & 52 & 129 & 0.9 \\
Services & 314 & $\underline{775}$ & 5.5 \\
& 5,666 & 13,992 & 99.9 \\
\hline
\end{tabular}

Excludes federally owned lands within the corporate city limits. Source: DOE 1982. 
Several categories of land use are in close proximity to the ORR. The nearest privately owned residential properties are in the Poplar Springs, Sugar Grove Valley, and Oak Ridge communities. Relative to ORR boundaries, Poplar Springs is located 2 miles west across the Clinch River, and Sugar Grove Valley is located 1.5 miles north. Other residential areas include Bradbury, Edgewood, and Lawnville. Bradbury is located across the Clinch River - 5 miles to the south. Edgewood and Lawnville are located immediately west-northwest of the Poplar Springs community (see Fig. 2.2). Agricultural use includes limited-scale private gardening; raising of tobacco, corn, wheat, and soybeans as cash crops; raising of beef cattle; and dairy farming. Some areas are also used for commercial logging.

Industrial land use includes Phyton Technologies, Inc.; Scientific Ecology Group (SEG); and IT Corporation's Bear Creek Radiological Laboratory. SEG, Phyton, and the IT Corporation laboratory are within 2 miles of the Y-12 Plant. Tennessee Valley Authority (TVA) facilities, including the Melton Hill Dam, the Bull Run Steam Plant, and the Kingston Steam Plant, are all greater than 6 miles from the Y-12 Plant.

Recreational areas in close proximity to ORR include the Watts Bar Lake Embayment/Clinch River waterway, which is used as a recreational area by both pleasure boaters and fishermen; a number of small camping areas and boat launching ramps, one of which is located only slightly more than a mile upstream of the K-25 Site; a small dirt-surface racetrack located $\sim 4$ miles south which attracts several thousand spectators during the racing season; and a public swimming area 7 miles southeast at Melton Hill Dam. There are no public recreational facilities, except the previously mentioned boat launching ramp, within 2 miles of ORR. Sport hunting of gamebirds and game animals occurs seasonally in the region, and deer hunting is authorized on some parts of the ORR as a conservation measure.

The ORR lies within the corporate limits of the city of Oak Ridge. A buffer zone surrounds each of these facilities to provide security, space for expansion, and isolation from the general public. Tracts totalling about 5666 ha (14,000 acres) are allocated around operating reactors, waste disposal areas, and streams that receive routine waste releases and burial ground seepages. Acreage used for high-voltage transmission lines, pipelines, transportation corridors, and security fences amounts to about 2023 ha (5000 acres) (DOE 1982).

About $80 \%$ of the ORR is part of a comprehensive forest management program that divides the ORR into 27 compartments. These compartments range in size from 148 to 486 ha (365 to 1200 acres). Vegetational features unique to the area are excluded from timber harvest operations, and 40 individual sites are designated for environmental research.

The Y-12 Plant is situated at the eastern end of the ORR, adjacent to the commercial center of Oak Ridge and contains $\sim 800$ acres. Land uses associated with the Y-12 Plant facility include several waste storage or disposal areas, of which (1) a parcel of $\sim 61$ ha (150 acres) serves as a sanitary waste landfill for solid wastes; (2) $\sim 26$ ha (65 acres) located west of the main plant is used as a rial ground for low-level radioactively contaminated solid wastes generated by the Y-12 Plant; and ( 3 ) $~-1.6$ ha ( 4 acres) is an abandoned quarry formerly used as a disposal and dilution basin for selected nonradioactive chemical wastes, primarily sodium, lithium, and potassium from Y-12 Plant operations. 


\section{SURFACE WATER AND SEDIMENTS}

\subsection{Surface Water Network}

Bear Creek flows southwestward from its headwaters at the S-3 Ponds for $\sim 4.5$ miles, where it then turns northward to flow into EFPC (Fig. 2.6). EFPC ultimately enters Poplar Creek, which discharges to the Clinch River. The drainage area of Bear Creek at its confluence with EFPC is 7.4 miles $^{2}$. Altitudes of the land surface in the entire watershed of Bear Creek range from $755 \mathrm{ft}$ MSL to about $1200 \mathrm{ft}$ MSL on Pine Ridge and Chestnut Ridge.

Bear Creek is fed by small tributaries originating on the slopes of Pine and Chestnut Ridges, which border the valley, and by springs emanating mainly from the base of Chestnut Ridge. The trellis type drainage pattern is strongly influenced by the underlying geologic structure.

The headwaters of Bear Creek are characterized by a relatively steep-banked channel cut to a depth of about $5 \mathrm{ft}$ or more into the silts and clays of the fill and unconsolidated material. Bear Creek tributaries have been numbered, beginning with North Tributary 1 (NT-1) near the S-3 Ponds. The total area of the Bear Creek Watershed above the point where it crosses the Anderson/Roane County line slightly downstream of NT-8 is 1.57 miles ${ }^{2}$. The area of the watershed at the National Pollutant Discharge Elimination System (NPDES) station at Bear Creek Kilometer (BCK) 4.55 is about 4.2 miles ${ }^{2}$. The area of the flood-ofrecord floodplain is 164 acres, with an average width of $169 \mathrm{ft}$.

\subsection{Surface Water Hydrology}

The hydrology of Bear Creek and its tributaries reflects the underlying geology of the watershed. Mainstem Bear Creek above the U.S. Geological Survey (USGS) gauging station at BCK-4.55 is characterized by reaches of stream where flow is lost to the solution-cavity system (McCauley 1985a). A major losing reach is located between the Burial Grounds and oil landfarm near BCK-10.41, and another is located just above BCK-4.70. Periods of zero flow are common in Bear Creek near BCK-10.41 but occur less frequently at BCK-4.70 (Table 2.4). The north tributaries of Bear Creek above the SS-5 spring, especially NT-3, NT-4, NT-5, and NT-6 (Fig. 2.7), drain portions of Pine Ridge; these streams are intermittent and are usually dry during summer and early fall. The south tributaries, on the other hand, originate as springs in the Knox Dolomite of Chestnut Ridge and are perennial streams. There is evidence that springs receive at least some flow from the solution-cavity system, although the precise outlets of the system are unknown (McCauley 1985a).

The characterization of surface water hydrology in Bear Creek Watershed is based on weekly or continuous flow measurements at 10 main-stem stations and 15 tributaries. Continuous USGS records of stream flow are available at BCK-4.55 (the NPDES site on lower Bear Creek) since March 1985 and at BCK-6.24 and BCK-3.88 since September and October 1986, respectively. The USGS has also monitored flows on two north tributaries (NT-14 and NT-15) and an east tributary (ET-1) from October 1986 to December 1989 (Fig. 2.6 with flow monitoring on NT-14 only continuing. Stream flow measurements were conducted weekly between March 19,1984, and October 16,1987, by staff in the ORNL 


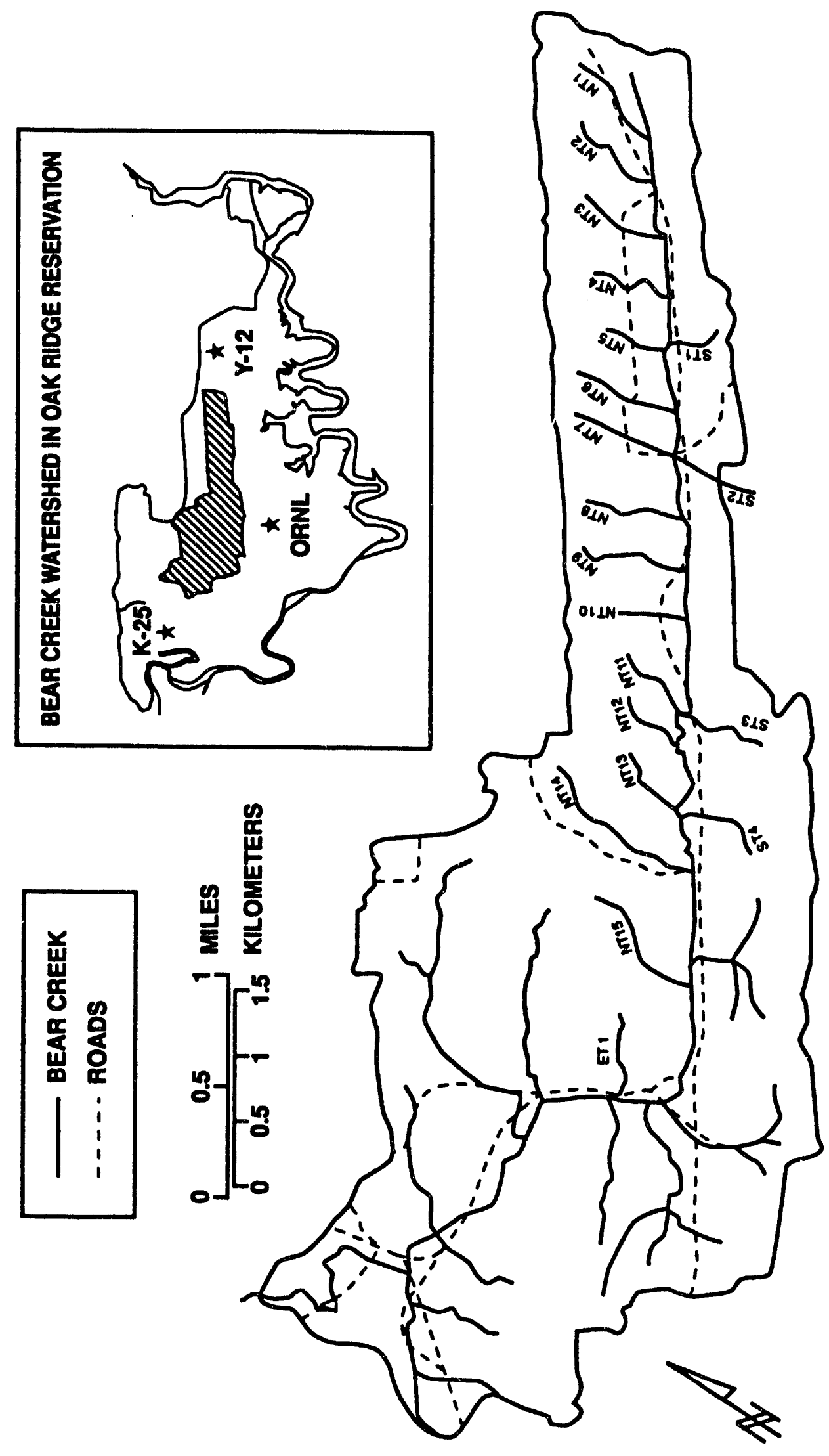

疍 
Table 24. Mean, standard deviation (SD), and range of stream flows in Bear Creek and selected tributaries, 1985-87

\begin{tabular}{|c|c|c|c|c|c|c|c|c|c|c|}
\hline \multirow[b]{2}{*}{ Site . } & \multirow{2}{*}{$\begin{array}{l}\text { Drain- } \\
\text { age area } \\
\left(\mathrm{km}^{2}\right)\end{array}$} & \multicolumn{3}{|c|}{$1985(\mathrm{~L} / \mathrm{s})$} & \multicolumn{3}{|c|}{$1986(\mathrm{~L} / \mathrm{s})$} & \multicolumn{3}{|c|}{$1987(\mathrm{~L} / \mathrm{s})$} \\
\hline & & $\overline{\mathbf{x}}$ & SD & Range & $\overline{\mathbf{x}}$ & SD & Range & $\overline{\mathbf{x}}$ & SD & Range \\
\hline BCK-12.46 & 0.43 & 0.76 & 0.54 & $0.08-2.6$ & 0.71 & 0.85 & $0.06-5.1$ & 1.53 & 3.82 & $0.06-20.7$ \\
\hline BCK-11.64 & 1.57 & 7.4 & 6.8 & $1.13-26.3$ & 7.9 & 12.7 & $0.28-67.7$ & 10.2 & 19.5 & $0.0-118.4$ \\
\hline BCK-11.17 & 1.91 & 9.1 & 9.1 & $0.3-34.0$ & 11.9 & 22.1 & $0.0-124.0$ & 18.4 & 59.8 & $0.0-388.0$ \\
\hline BCK-10.41 & 2.81 & 9.6 & 12.7 & $0.0-51.5$ & 13.3 & 28.3 & $0.0-160.3$ & 20.4 & 70.5 & $0.0-456.0$ \\
\hline BCK-9.53 & 3.92 & 13.6 & 16.4 & $1.1-63.4$ & 16.4 & 36.2 & $0.0-217.5$ & 23.2 & 68.5 & $0.0-436.7$ \\
\hline BCK-9.41 b & $4.07^{c}$ & 28.3 & 24.6 & 5.4-95.7 & 29.2 & 51.8 & $0.8-302.4$ & 37.4 & 88.6 & $0.8-557.3$ \\
\hline BCK-7.87 & 5.96 & 32.3 & 31.7 & $2.8-138.8$ & 38.5 & 71.9 & $1.4-431.9$ & 47.6 & 123.2 & $1.4-791.0$ \\
\hline BCK-6.24d & 8.29 & & $\mathbf{N A}^{\mathbf{}}$ & & & $f$ & & 63.8 & 191.4 & $0.3-2974$ \\
\hline BCK -4.70 & NA & $46.2^{2}$ & 45.3 & $3.7-199.4$ & 74.2 & 160.6 & $0.0-965.4$ & 83.3 & 192.6 & $0.0-1186$ \\
\hline BCK $-4.55^{4}$ & 11.03 & $103.9^{4}$ & 159.8 & $12.2-2237$ & 106.0 & 227.6 & $6.5-2 i-66$ & 110.9 & 232.9 & $5.4-2974$ \\
\hline BCK-3.88 & 12.95 & & NA & & & $i$ & & 119.9 & 351.4 & $6.8-5579$ \\
\hline \multicolumn{11}{|c|}{ Tributaries } \\
\hline $\begin{array}{l}\text { SS1 } \\
(\text { BCK-12.38) }\end{array}$ & 0.10 & 0.45 & 0.31 & $0.03-1.42$ & 0.34 & 0.31 & $0.0-1.70$ & 0.42 & 0.57 & $0.0-3.40$ \\
\hline $\begin{array}{l}\text { SS2 } \\
\text { (BCK-11.68) }\end{array}$ & NA & & NA & & & $l$ & & 1.6 & 1.8 & $0.23-6.8$ \\
\hline $\begin{array}{l}\text { SS3 } \\
\text { (BCK-11.67) }\end{array}$ & 0.23 & 0.76 & 0.68 & $0.17-2.55$ & 0.68 & 0.88 & $0.08-3.40$ & 1.02 & 1.19 & $0.06-5.10$ \\
\hline $\begin{array}{l}\text { SS4 } \\
(B C K-10.14)\end{array}$ & 0.22 & 4.0 & 1.7 & $1.7-9.3$ & 3.7 & 2.8 & $0.6-11.9$ & 3.7 & 2.8 & $0.4-11.0$ \\
\hline $\begin{array}{l}\text { SS5 } \\
\text { (BCK-9.41) }\end{array}$ & 0.12 & 11.9 & 6.8 & $4.0-27.5$ & 9.9 & 12.2 & $0.8-63.2$ & 10.2 & 10.8 & $0.8-45.0$ \\
\hline $\begin{array}{l}\text { NT14 } \\
(B C K-6.24)\end{array}$ & 0.78 & 4.0 & 4.2 & $0.6-18.1$ & 5.1 & 11.6 & $0.03-74.2$ & $\begin{array}{c}7.6 \\
(5.3)^{i, m}\end{array}$ & $\begin{array}{c}19.8 \\
(19.5)^{i, m}\end{array}$ & $\begin{array}{c}0.31-124.6 \\
(0.0-311.5)^{i, m}\end{array}$ \\
\hline $\begin{array}{l}\text { NT15' } \\
\text { (BCK-5.32) }\end{array}$ & 0.36 & & NA & & & $i$ & & 2.7 & 9.2 & $0.0-141.6$ \\
\hline $\begin{array}{l}\text { ET1 }^{d} \\
(B C K-4.07)\end{array}$ & 0.36 & & NA & & & $i$ & & 2.2 & 6.9 & $0.0-102.0$ \\
\hline
\end{tabular}

Flows were measured weekly except at those USGS sites on lower Bear Creek where stream flow is monitored continuously and average daily values are computed. Number of samples $(N)=45$ in 1985, 47 in 1986, and 42 in 1987, except the USGS sites and unless noted otherwise.

Tabular values based on summation of flows at BCK-9.53, NT8, and SS5 (see Fig. 2.7).

BCK-9.42 (McMaster 1967).

USGS station; tabular data are based on average daily values.

NA = no data available.

$N=98$ in 1986 and $N=365$ in 1987.

$w=40$ in 1985 because monitoring was initiated on February 21, 1985

$N=306$ in 1985 because monitoring was initiated on March 1, 1985. $N=365$ in 1986 and $N=360$ in 1987.

$N=92$ in 1986 and $N=360$ in 1987.

Tributaries are named sequentially from the headwaters of Bear Creek; NT and ET denote rain-fed streams and SS denotes spring-fed streams.

"Confluence with Bear Creek is given in parentheses.

$\mathrm{N}=6$ in 1986.

"USGS data in parentheses. 


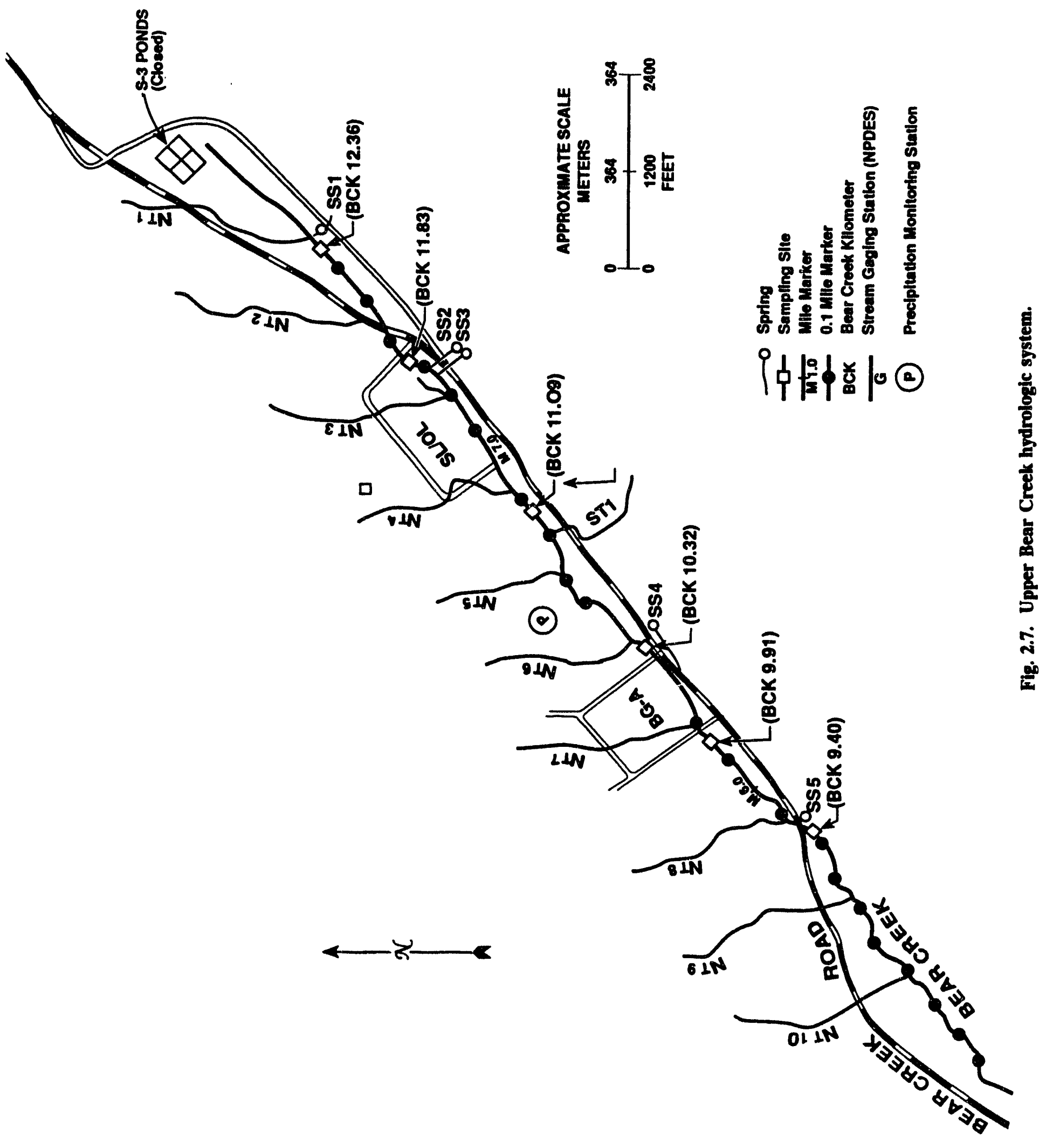


Environmental Sciences Division (ESD) at 19 sites, all but 3 of which were located in Bear Creek Watershed at or above the SS-5 spring. Since November 1987, monitoring has been conducted monthly. The flow measuring techniques utilized in the ESD program are described in McCauley (1985a, Sect. 6.2.1).

Flow data collected on Bear Creek and selected tributaries from 1985 through 1987 by both USGS and ESD personnel are summarized in Table 2.4. Because the ESD program was primarily a hydrologic characterization of Bear Creek during low-flow periods, the increase in the mean annual discharge observed from 1985 to 1987 at all main-stem sites except BCK-12.46 is probably spurious. High flows could not be accurately measured, and peak flows could have been missed by the weekly sampling frequency. Moreover, the maximum flow measured at ESD site BCK-4.70 was only $40 \%$ of that observed at USGS site BCK-4.55 in 1986 and 1987 and <10\% in 1985. Although two large springs (SS-7 and SS-8) enter Bear Creek between these two sites, their contribution to the flow at BCK-4.55 would not significantly increase the annual maximum flow. The decrease in the annual minimum flow observed between 1985 and 1987 was most likely real, reflecting the effects of an extended drought.

\section{Bear Creek Hydrograph}

The 3-year hydrograph for lower Bear Creek at the NPDES monitoring station (BCK-4.55) was dominated by extensive periods of low flow in both 1986 and 1987 (Fig. 2.8). In both years, the mean annual flow at BCK-4.55 (Table 2.4) was $\sim 50 \%$ of that estimated by McMaster (1967) for the period 1936-1960. From late July through October of 1986 and 1987, mean daily flow was consistently below $10 \mathrm{~L} / \mathrm{s}$ and contrasted sharply with 1985 when stream flow never fell below $10 \mathrm{~L} / \mathrm{s}$. Minimum flows were always more than double the $7 \mathrm{Q} 10$ (i.e., the lowest mean discharge for 7 consecutive days with a recurrence interval of 10 years) of $2.8 \mathrm{~L} / \mathrm{s}$, but in 1986 and 1987 flows were less than the estimated 7Q2 of $8.5 \mathrm{~L} / \mathrm{s}$ for this site (McMaster 1967).

The occurrence of minimum flows at BCK -4.55 in excess of the $7 \mathrm{Q} 10$ during a period of severe drought can probably be attributed to the location of the site just below two large springs (SS-7 and SS-8). Upstream at BCK-9.53, which is located just above the SS-5 spring, the minimum flow was zero in both 1986 and 1987 compared with the estimated 7Q10 and 7Q2 for that site of 0.85 and $0.57 \mathrm{~L} / \mathrm{s}$, respectively (McMaster 1967). Because the flow rates of springs are less variable than those of other tributaries, reaches of Bear Creek immediately below these springs are less affected by extended periods of drought than other reaches not in proximity to upstream springs.

Because of below normal precipitation during the study period, especially during the period from November to April, the Bear Creek hydrograph exhibited infrequent periods of high flow. There were eight major storms (i.e., greater than $5 \mathrm{~cm}$ of precipitation in a 24-h period) during $1985-87$, but only one had a recurrence interval greater than 1.5 years. The maximum 24-h rainfall during this period occurred on August 16-17, 1985, when $10.9 \mathrm{~cm}$ of rain was recorded at the Atmospheric Turbulence and Diffusion Laboratory (ATDL) station in Oak Ridge (NOAA 1985, 1986, 1987). A storm of this magnitude has a recurrence interval 


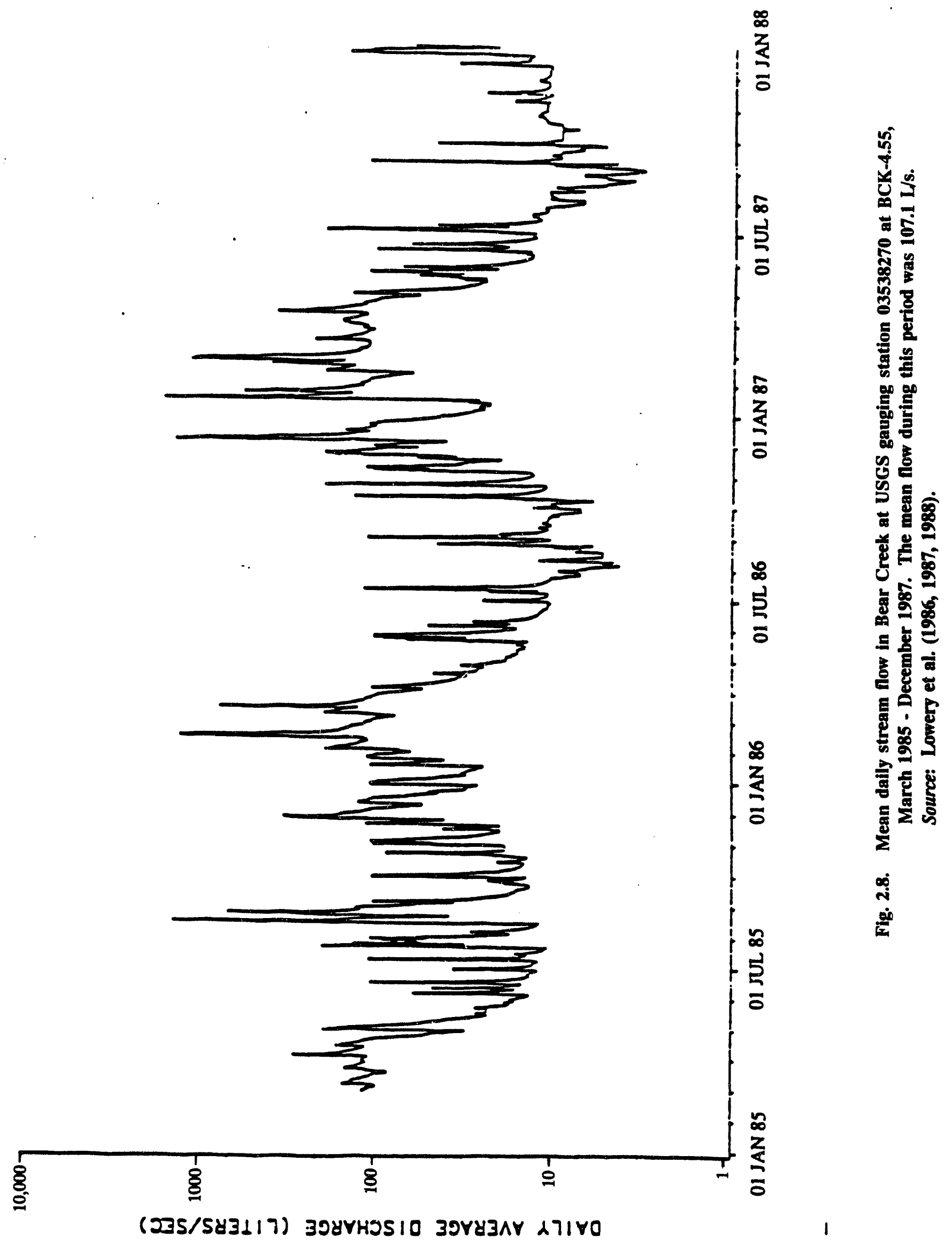


of 3 years (Sheppard 1974). Runoff from the August 1985 storm resulted in a peak flow $(2240 \mathrm{~L} / \mathrm{s})$ in Bear Creek that was similar to those observed in the winter and early spring, when runoff is usually high because of minimal evapotranspiration. This peak in flow was more than an orrer of magnitude greater than the peak flows that occurred during the summer and fall of 1986 and 1987.

\subsection{Importan s of Springs}

The numerous springs that originate on the north slope of Chestnut Rijge are a dominant feature of the hydrograph of upper Bear Creek, especially during drought periods. At such times, most of the flow in the main-stem Bear Creek is contributed by springs. The best example of the importance of these springs occurred in the fall of 1987, a time of low precipitation (e.g., rainfali was $24 \%$ and $47 \%$ of normal in October and November, respectively) that followed a period of extended drought. Four of the five flow-monitoring stations on the main-stem Bear Creek above the SS-5 spring were dry (Fig. 2.7). The only flow in this reach of stream was immediately below the SS-2, SS-3, and SS-4 springs and in the headwa'ers (BCK-12.46) below the S-3 Pondis.

The springs in ypper Bear Creek differ greatly in flow rate. Flow rates are highest in the SS-5 spring at BCK-9.41 and lowest in the SS-1 spring at BCK-12.38, where flow was intermittent between late August and mid-October 1987. Several springs also occur downstream of the SS-5 spring, and two of the largest (SS-7 and SS-8) are located less than $100 \mathrm{~m}$ above the. USGS/NPDES monitoring station at BCK-4.55. Although flow at this site was never zero, a section of stream at BCK-4.70 immediately above the SS-7 and SS-8 springs was periodically dry in both 1986 and 1987. Thus, springs in this limited section of Bear Creek, like those in the 3-km reach above the SS-5 spring, provide a significant portion of the flow in Bear Creek during periods of low rainfall.

\subsection{Thermal Characteristics}

Continuol's monitoring of water temperatures began in September 1985 at the SS-5 spring and three sites in Bear Creek located just above, immediately below, and $1.5 \mathrm{~km}$ below the spring. In April 1987, two additional sites, BCK-11.98 and Grassy Creek, a reference stream, were added to the monitoring program.

Springs are important in stabilizing flows, but they also influence the thermal re $e_{b}$.me of Bear Creek, especially the upper reaches where springs are numerous and flows are intermittent in summer and early fall. The thermal characteristics at a given site depend, in part, on the proximity of springs. Mean temperatures at BCK-9.40 just below the SS-5 spring were $-2-3^{\circ} \mathrm{C}$ warmer in the winter and $4-8^{\circ} \mathrm{C}$ cooler in the summer than BCK-9.91 above the spring (Fig. 2.7). The temperature differential between the two sites was greater in summer than in winter because of the seasonal difference in flow and smaller effect of the spring on main-stem flows in winter. Although BCK-9.91 is $250 \mathrm{~m}$ below the SS -4 spring, the flow rate of this spring is only one-third that of the SS-5 spring. The thermal regime at BCK-9.91 is nearly identical to that at BCK-7.87, $\sim 1.5 \mathrm{~km}$ below the SS-5 spring. These comparisons indicate that the moderating effect of springs on mean temperatures in Bear Creek is highly localized. 
The effect of springs on temperature extremes, however, was more pronounced and extended over greater distances. The maximum temperature at BCK-9.91 was $24.9^{\circ} \mathrm{C}$, which was similar to that at $\mathrm{BCK}-9.40\left(23.4^{\circ} \mathrm{C}\right)$ but $6.7^{\circ} \mathrm{C}$ below the maximum observed at $\mathrm{BCK}-7.87$. Temperatures as high as $38^{\circ} \mathrm{C}$ were recorded at $\mathrm{BCK}-11.98$ during a period of near-zero flow in July and August 1987 . This site is not significantly influenced by springs; the nearest upstream spring is SS-1, which was dry in late August 1987. Minimum winter temperatures were higher at BCK-9.91 than at BCK-7.87 and, like the trend in maximum temperatures, indicate a greater moderating effect on temperature at BCK-9.91, the site nearest a spring.

Springs have their greatest influence on stream temperatures during periods of low rainfall in summer and fall. Both the mean and maximum temperatures in August 1987 exceeded those in June and July at BCK-9.91 and BCK-7.87. At BCK-9.40, however, August temperatures were actually lower than those observed in the two previous months. Rainfall for August 1987 totaled only $3.2 \mathrm{~cm}$ in the Bear Creek Burial Grounds (51\% of normal at the Oak Ridge site), and no precipitation occurred on 22 consecutive days before August 2. Thus, the importance of springs in moderating the effects of elevated stream temperatures caused by decreased stream flow during a drought is directly related to the severity of the drought.

\subsection{General Sediment Description}

The substrate materials of Bear Creek vary considerably among several general types, including rock ledges, sand/gravel bars, indurated cohesive clay, flocculent precipitates/clays, and mixtures of these types. In most areas the creek is stable to degradational with respect to net sediment accumulation. The supply of sediment from upland areas and the floodplain is small with respect to the ability of stream flow to export sediment from the watershed. A high percentage of forest cover and stabilization of bank deposits by riparian vegetation limit significant soil erosion during peak stream flows. Thus the most voluminous sediment deposits tend to be fairly coarse-grained, the finer material having been winnowed and exported out of the watershed. Between high flow events, fine-grained sediment deposits do accumulate in low-energy environments (pools, leeward of obstacies, inside of bends) in the creek. These deposits are typically silty sands or sandy silts, with small and variable amounts of gravel and clay. Figure 2.9 exhibits sediment size distributions for several locations on Bear Creek. These distributions were measured on sampies collected for chemical analysis anc may be biased in favor of fine particles.

Although no mineralogical investigations have been conducted on Bear Creek sediment, such investigations carried out on streams flowing over rocks and soils derived from the Knox, Conasauga, and Rome Groups have reported illite, quartz, and feldspar, with minor amounts of hematite and hydrous manganese oxides. Common clay minerals include kaolinite, mica, vermiculite, hydroxy-interlayered vermiculite, and gibbsite. White to yellowish-white precipitates occur in the upper reaches (above BCK-11.83) and are presumed to be amorphous aluminum hydroxide resulting from the neutralization of acidic groundwater that originates from the plume of the former S-3 Ponds (Turner and Kamp 1984). 


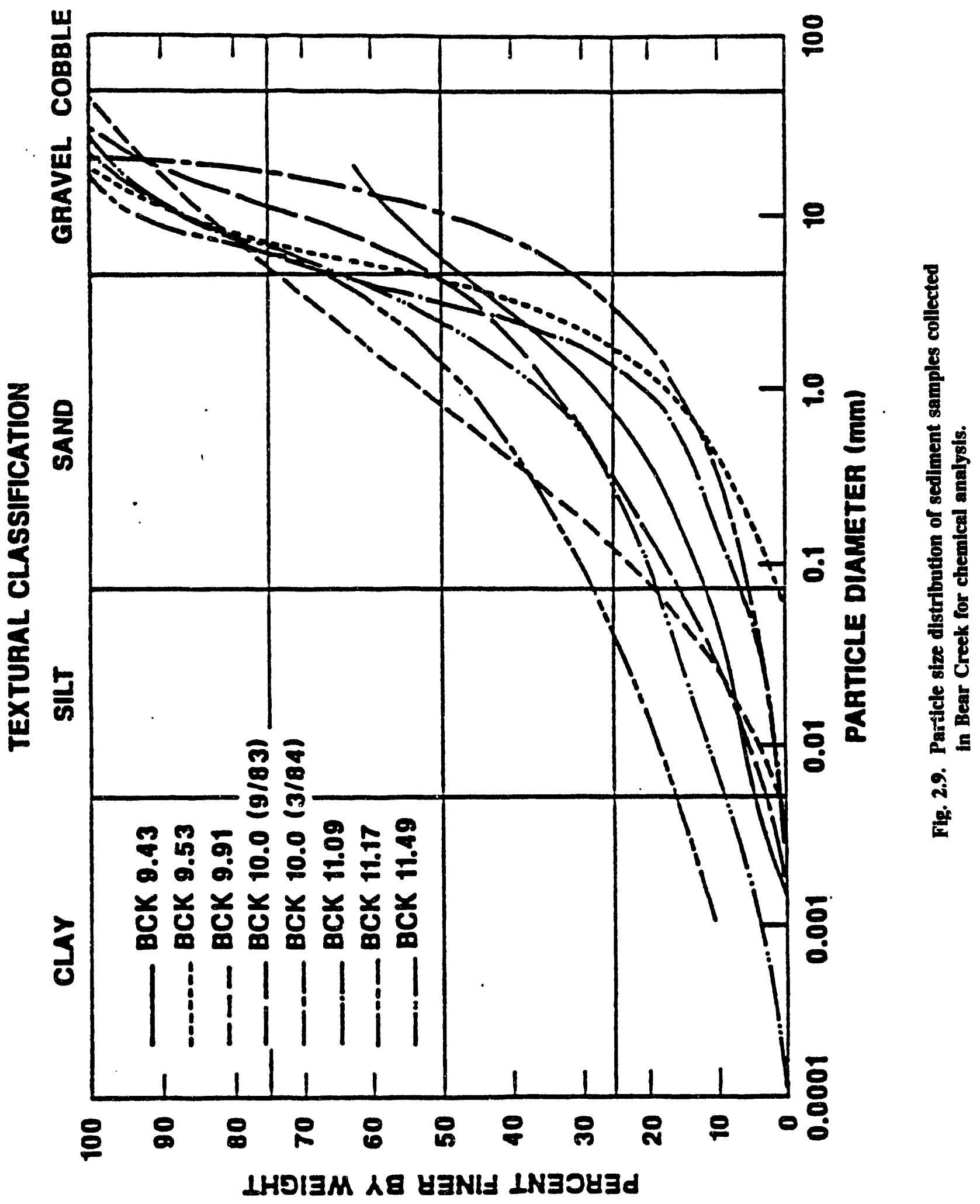




\section{GROUNDWATER}

The hydrologic regime underlying BCV has two major components, regional flow component and local flow component. In general, a groundwater flow component of regional scale is defined by relatively deep circulation that is independent of local topography and small-scale surface water systems. The regional flow system underlying BCV is virtually undefined because of the limited number of deep wells that are available and have been included in past characterization studies. Currently, the only hint to the depth at which regionally controlled groundwater flow may predominate comes from examination of a few scattered chemical analyses that have been obtained in the deep wells. For example, see the partial analyses presented in Geraghty \& Miller (1988a and b) for wells GW-117, -118, -119, -123 , and -125 . These and more extensive, but as yet unpublished, analyses show that below depths of $\sim 500 \mathrm{ft}$ the groundwater appears to become more highly mineralized with sodium, chloride, and sulfate than the relatively dilute, shallow groundwaters typical of this region. The nature of any interaction between the compositionally distinguishable shallow and deep groundwaters beneath BCV is unknown at this time but probably is limited.

The local flow component includes groundwater contained within the unconsolidated weathered residuum and the upper part of the underlying bedrock. Groundwater flow within this hydrologic component is strongly influenced by topography and surface drainage patterns. Hydrologic investigations reported by Geraghty \& Miller (1988a) show that the surfacedrainage divide that separates EFPC from Bear Creek near the S-3 Ponds also is a groundwater divide that defines the eastern boundary of the shallow BCV hydrologic system (Fig. 2.10).

Results of numerous studies (e.g., Geraghty \& Miller 1988b; Bailey and Lee 1991) within $\mathrm{BCV}$ and along its bounding ridges demonstrate that recharge of this flow component occurs along the ridges through infiltration of precipitation. Groundwater flow paths typically are directed away from the bounding ridges and generally follow the topography, converging within the valley in the vicinity of Bear Creek. Figure 2.11 presents a generalized cross-section of BCV that illustrates the idealized subsurface flow of groundwater described above. In the zone underlying Bear Creek, the direction of groundwater flow is southwest along the valley axis. These results are consistent with those obtained in other regions of BCV.

Flow within the shallow groundwater component, while dominated by the topography of the drainage system, is strongly influenced by structural properties of the bedrock. For example, several recent studies have investigated the fractures in bedrock material obtained from coreholes along a transect across BCV near the head of Bear Creek (Lutz and Dreier 1988). These studies demonstrate that several major fracture sets exist, dominated by a strikeparallel set. The results of these studies provide reasonable confirmation for observations from a pumping test performed in this area which showed that hydraulic properties of bedrock are not isotropic (Geraghty \& Miller 1987). Rather, hydraulic conductivity values in the strike-parallel direction are at least several times larger than in any other direction. Anisotropy in hydraulic properties means that the direction of groundwater flow deviates somewhat from that predicted by the potentiometric contours such as those presented in Fig. 2.10. 


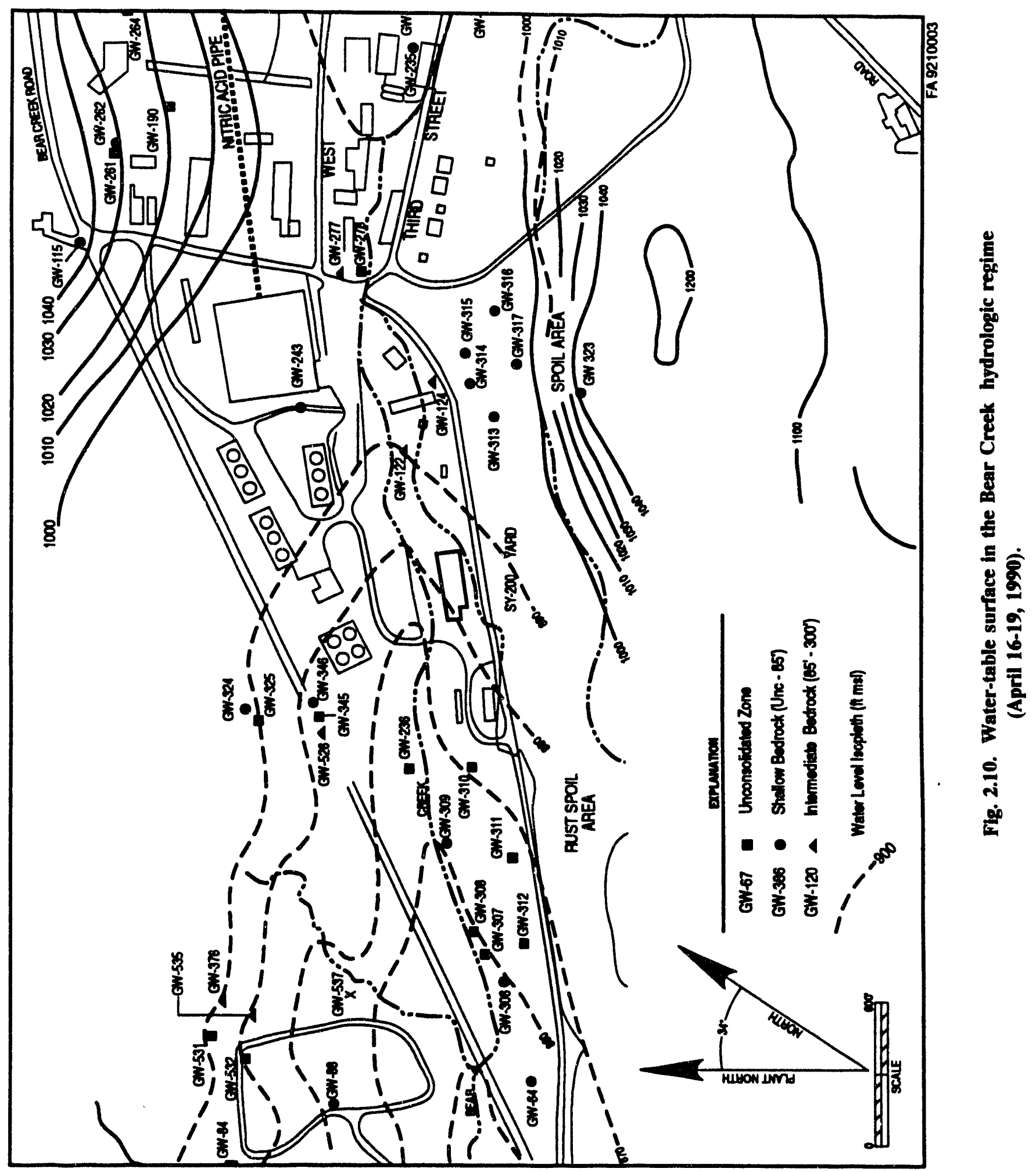




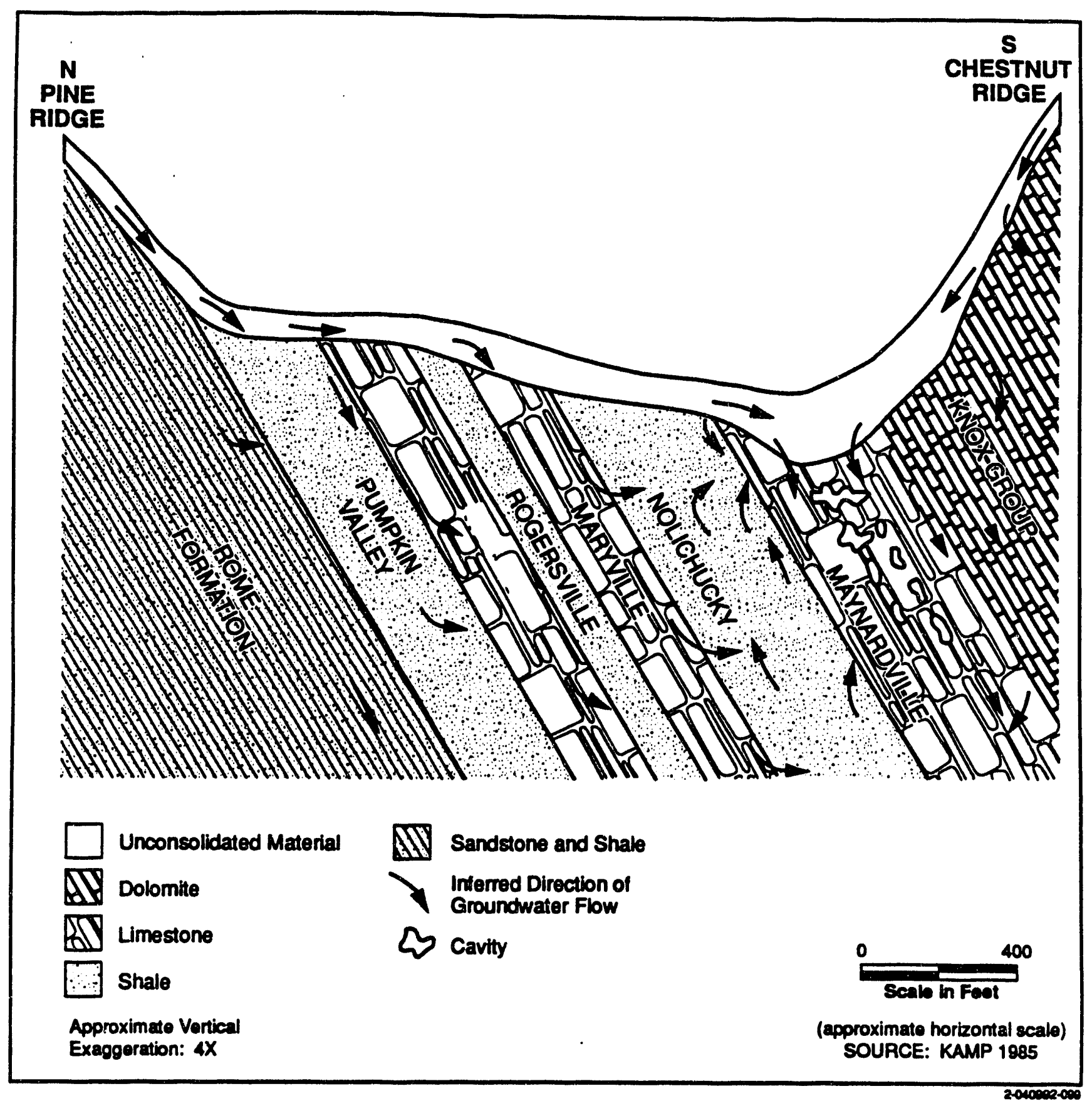

Fig. 2.11. Generalized cross section of BCV showing inferred groundwater flow paths. 
In addition to small-scale deformation features such as the fracture sets discussed above, it is probable that large-scale features, including fracture zones and faults, exist in BCV and influence groundwater flow. The nearly parallel southerly flow of most tributaries draining the southern slope of Pine Ridge is one example of the type of surface expression anticipated from parallel fracture zones. At present, the identity of these structural features and their potential for affecting groundwater flow paths, contaminant migration, and the interaction between shallow and deep hydrologic components are unknown.

In the vicinity of Bear Creek the interartion between the creek and the shallow groundwater component has not been systematically investigated. It is believed that an extensive network of solution channels within the Maynardville Limestone that underlies Bear Creek makes it an efficient drain for the local groundwater component and is the principal cause for the existence of losing reaches along the length of the stream. The results of a recent tracer study (Geraghty \& Miller 1989a) clearly demonstrate that some spring discharge is composed of water that enters the groundwater in an upstream losing reach.

\section{UNIT DESCRIPTION}

\subsection{Geographic Information}

OU 2 is located in BCV in Anderson County $~ 0.4$ miles west of the Y-12 Plant on Old Bear Creek Road (Fig. 2.12).

\subsection{Background Information}

The Oak Ridge Y-12 Plant was built by the U.S. Army Corps of Engineers in 1943 as part of the Manhattan Project. The original mission of the Plant was to separate the fissionable isotope of uranium $\left({ }^{235} \mathrm{U}\right)$ using an electromagnetic separation process. After World War II, this process was discontinued in favor of a more economical gaseone diffusion process conducted at the nearby Oak Ridge K-25 Site (Welch 1989a).

Since the early years, the Y-12 Plant has developed into a highly sophisticated manufacturing and developmental engineering facility. Current manufacturing activities at the Y-12 Plant include chemical processing of lithium and uranium compounds, and precision fabrication of components from lithium compounds, uranium, and many other materials. In support of these activities, areas were needed for disposal of uncontaminated fill and construction debris (RSA and SA-1) and for the temporary storage of equipment (SY-200 Yard).

OU 2 is composed of the RSA, the SA-1, and the SY-200 Yard.

\subsection{Operational Information}

The following subsections contain descriptions of the wastes managed in each OU as well as information about their generation, disposal methods, and any subsequent treatment or cleanup activities at the OU. Where monitoring data have been obtained which are sitespecific to an OU, those results are also included. 


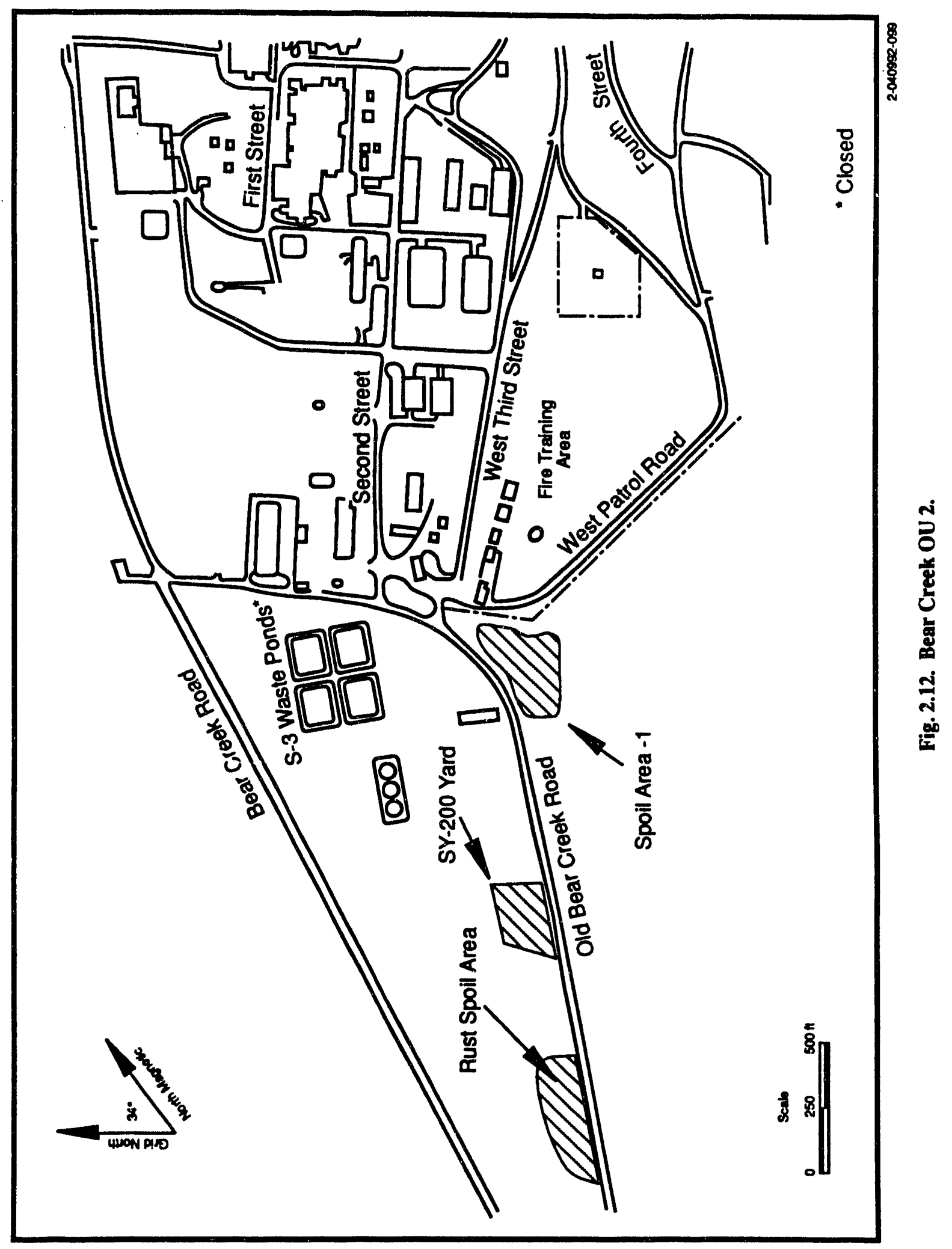




\subsubsection{Rust Spoil Area}

Rust Engineering, formerly a DOE prime contractor, conducted various renovation, maintenance, and construction operations at the Y-12 Plant. Solid waste (spoil material) generated during these operations was disposed of in an area on ORR known as the RSA. The RSA was operated from 1975 to 1983 . The 5.4 -acre site measures -300 by $900 \mathrm{ft}$ in area (Welch 1989c). A walkdown by Energy Systems/SAIC staff showed the RSA to be either vegetated or graveled. Equipment at the site was segregated into lots for storage.

The RSA was operated as a dump with periodic grading (typically once a month) to promote positive drainage. Dumping progressed northward from Old Bear Creek Road. As dumping occurred, the natural topography was elevated and a portion of the Bear Creek Channel was filled. Eventually, the stream channel course was relocated to the north to compensate for the outslope progression. Based on a review of maps depicting the topography before and after the disposal operations, it is estimated that less than $100,000 \mathrm{yd}^{3}$ of construction debris and spoil were disposed of at the site. The spoil material apparently was not covered with soil. Because routine compaction of the soil was not intended but occurred only as grading took place, it is likely that the compaction operations at the site were somewhat deficient.

The RFI plan for this SWMU (Welch 1987b) indicates that no formal design plans were developed for the disposal area and that no detailed disposal records are available for the wastes disposed of there. The bulk of the waste is reported to consist of demolition debris, including soil, masonry materials, and metal (steel rebar in concrete). The RFI plan also indicated the possibility that minor amounts of solvent-contaminated material, and material containing asbestos, mercury, and uranium, may have been disposed of in this area.

Site closure activities began in the fall of 1983 with the preparation of the site's closure plan. The plan called for grading and shaping the existing fill, capping the entire fill area with a minimum of $2 \mathrm{ft}$ of soil, and establishing vegetative growth over all the disturbed areas. The specifications of the capping plan called for a minimum of $1.5 \mathrm{ft}$ of compacted clay and $0.5 \mathrm{ft}$ of topsoil to be placed over the site. The clay layer would be compacted in maximum 8-in. lifts. Closure began in late 1983 and was completed in mid-1984 (Welch 1987b).

\subsection{Spoil Area 1}

SA-1 is located west of the Y-12 Plant on Old Bear Creek Road near the junction with West Patrol Road (Fig. 2.12). Various renovation, maintenance, and construction operations at the Y-12 Plant produced construction debris that included concrete, asphalt, brick, brush, rock, and tile. Solid waste (spoil material) generated during these operations has been disposed of in SA-1 since about 1980, but the RFI plan for this SWMU (Welch 1989b) indicates that no detailed disposal records are available. The site is $\sim 5$ acres. Since 1985, SA1 has had a permit from TDEC as a landfill for rubble and noncombustible, nonputrescible solid waste. It is estimated that roughly $100,000 \mathrm{yd}^{3}$ of nonuranium-contaminated construction debris had been disposed of at the site (Welch 1989b). The waste was determined to be nonradioactively contaminated according to health physics requirements established for the Y-12 Plant, although construction material disposed of in this area may have contained minor 
amounts of asbestos, mercury, beryllium, uranium, thorium, and other contaminants, according to the RFI plan.

Soil borings were completed in September 1990 at various locations within SA-1. Subsurface soil samples were collected and analyzed for metals, organics, and selected radiologicals (see Appendix C).

\subsection{SY-200 Yard}

From the 1950s to 1986, the SY-200 Yard was operated as an aboveground "hold for future usen storage area. The site was surrounded by a 6-ft fence with gate access. During operation there were no underground utilities or piping at the site. The Y-12 Plant operations divisions that used the yard included the Assembly Division, Engineering Technology Division, Metal Preparation Division, and ORNL Fusion Energy Division. Items stored at the site were segregated with respect to ownership by the various operating divisions using the yard.

Fill soil was placed in the SY-200 area in the 1950s, and there are no records of the sources of this soil fill. Similarly, there are no detailed records available on the items that were stored and removed during the early operational period of the SY-200 Yard. All items stored at the site were removed by September 1986 to prepare the area as the future site for an Environmental Support Facility (ESF) to include a maintenance shop, office complex, tanker terminal, and security portal. Before removal, all items stored at the site were surveyed by the Y-12 Plant Health Physics Department (HPD) and flagged for proper disposal and handling. Construction of the ESF was temporarily postponed due to the presence of mercury and asbestos in some of the excavated soils. Table 2.5 summarizes an inventory of items removed from the site before closure in 1986. This inventory is based on available records and discussions with Y-12 Plant personnel.

The SY-200 Yard area remained unused until ESF construction activities were initiated in December 1988. At that time, the fence surrounding the SY-200 Yard was removed and a larger one encompassing all proposed ESF operations was erected. The planned construction of the ESF building and support facilities is shown on Fig. 2.13.

During construction of the ESF building foundation, the top $6 \mathrm{in.} \mathrm{of} \mathrm{gravel} \mathrm{and} \mathrm{soil} \mathrm{were}$ removed and stored in the southwest corner of the site. Excavation for the building foundation progressed until $\sim \mathbf{8} \mathrm{ft}$ of fill material was removed and bermed along the north and east corners of the excavation. Because no natural soils were encountered during the excavation, construction activities ceased for evaluation of engineering designs. Construction activities resumed in September 1989, when the top 6 in. of soil that had been removed in December 1988 was spread and graded over the bottom of the excavation. A silt fence was placed along Bear Creek to intercept runoff and eroded soils. In light of the RFI process, construction of the ESF on the SY-200 Yard site has ceased. In early 1990, the material bermed along the north and east corners of the ESF excavation was placed back in the excavated area and covered with about $5 \mathrm{ft}$ of clean borrow material. The ESF is currently under construction immediately south of Old Bear Creek Road. Old Bear Creek Road is being moved north $\sim 75 \mathrm{ft}$ to make room for the ESF parking area. This will place the new location of the road across the southern part of the SY-200 Yard. 
$2-31$

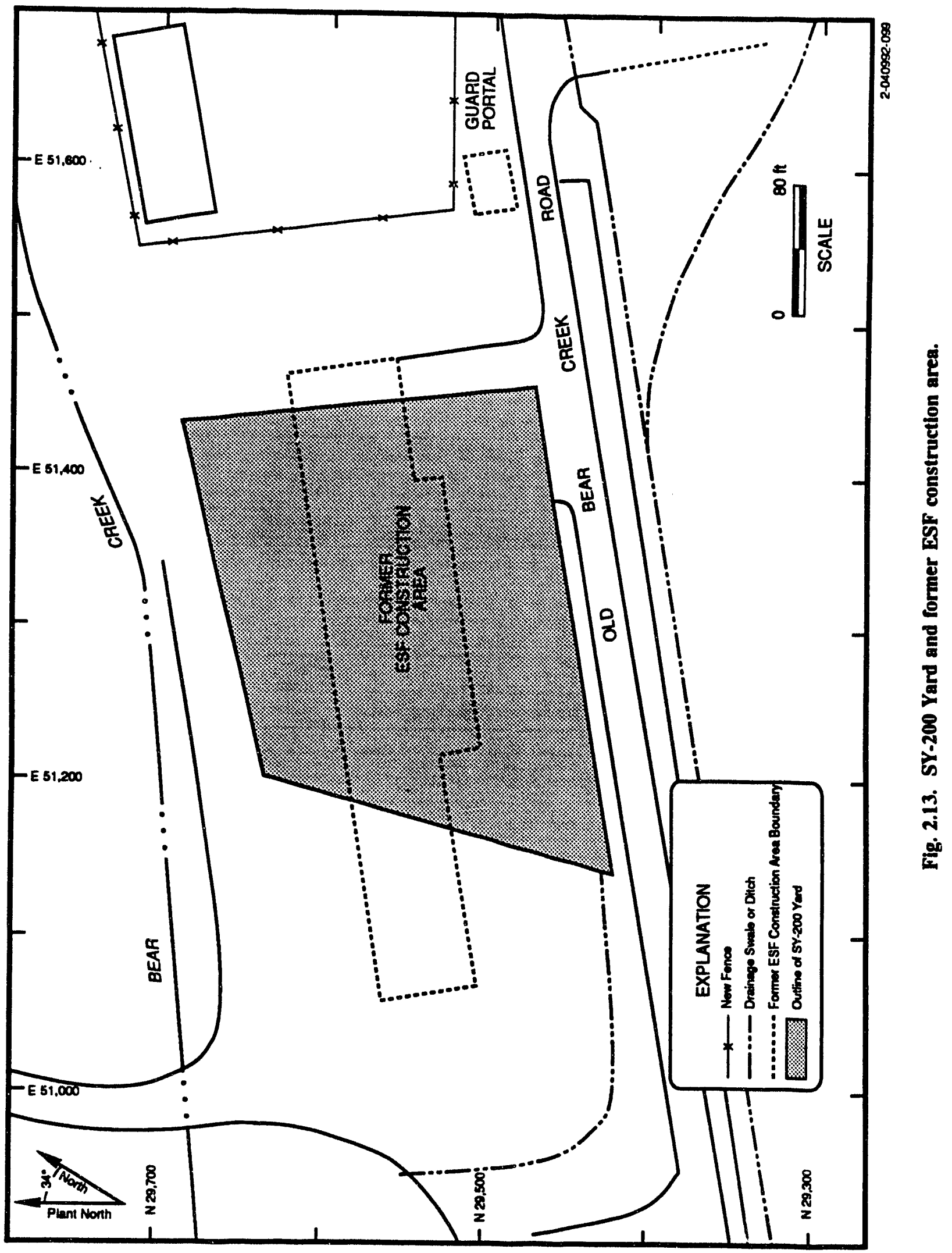


Table 25. Summary of 1986 inventory at the SY-200 Yard

\begin{tabular}{ll}
\hline Rubber-Lined Steel Tank & Pit Furnace Hearth \\
Nickel Plating Tank & Work Roll Bearings \\
Caustic Exhaust Fan & Plate Lifting Arms \\
Plating Tank Liner & Shaft Heat Treat Fixture \\
Head Tank F5000-7 & Drive and Sleeve Set \\
Plating Tanks & Vacuum Tank for DCX2 \\
Waste Storage Tank & Transformers (five) \\
Ni Strip Fix K25 Gas DF & Radiators for Power Supply \\
Handling FXT for Bells & Lead Shielding Plates \\
Tank BRK LND 12 $\times 15 \times 8$ Deep & Aluminum Plate and Buss \\
Tank 13 RK BOTM & Cooling Fins (12 crates) \\
Fiberglass Tank Liner & CRBRP Demineralizer \\
31D1A $\times$ 30 length Exhaust Fan & CRBRP Chemical Feed Equipment \\
Support Tanks & Lube Oil Cooler \\
Duct Ext 48-diam Fiberglass & Bullard Hood \\
E10 Pipe 4 for Lindberg & Converxor Roller \\
Flange Lindberg Furnace & High Rise Rack with Shelving \\
Retort Hold Furnace Cover & Hardware for Shelving \\
E-K Evaporator Parts & Well Cabinets \\
TurbaFilm Evaporator Parts & Well Positioner \\
100-gal. Tank & Table Stand with Racks \\
6-in. Stainless Steel Piping & Braces for Racks \\
B-1 col. Dissolver Parts (13) & Bed Plate \\
DPU Retort & Loading Frames \\
Steam Coil for F6005 & 48 $\times 48 \times 60$ Steel Tank \\
Nitric Acid Still & Railroad Ties \\
Table Roll Parts & Blocks \\
Used Table Roll & Bricks \\
Backup Roll Lift Fixture & Fencing Material \\
Strip Pallets & \\
\hline & \\
\hline
\end{tabular}

Source: Perkins 1989. 


\subsection{Releases}

The RSA and SA-1 were used as disposal areas for solid waste (spoil material) generated from various renovations, maintenance, and construction operations at the Y-12 Plant. Although no detailed records are available, the bulk of disposed spoil material consisted of (1) soil, (2) masonry materials (i.e., brick and concrete), and (3) metal (i.e., steel and rebar). A portion of the demolition debris was packaged and disposed of at RSA in open-top metal containers. These containers were determined to be nonradioactively contaminated, according to health physics requirements established for the Y-12 Plant. Discussions with Y-12 Plant personnel indicated the possibility that small quantities of solvent-contaminated material and material containing asbestos, mercury, and uranium may have been disposed of in these areas. However, existing administrative and other established in-plant controls prevented the disposal of significant amounts of chemicals, wastes, or contaminated material at the sites. Storage of materials at SY-200 may have resulted in minor releases of mercury, lead, and PCBs to the surface soils.

\section{EXISTING DATA}

Existing characterization and monitoring data relevant to OU 2 have been collected in conjunction with sitewide studies of the Bear Creek Hydrogeological Regime (surface water, groundwater, biomonitoring) as well as site-specific sampling programs (groundwater, soil chemistry). In the following discussions, site data are often compared to reference values. Reference values are used in the absence of site-specific background values. Reference values often represent concentrations observed in the media from areas of east Tennessee beyond the influence of the Oak Ridge facilities; however, differences in similar geologic formations and the soils developed on them have not been examined in detail.

\subsection{Surface Water Data}

In April 1984, a program of weekly streamflow measurements was initiated by Energy Systems at 14 sites along Bear Creek and its tributaries. The streamflow network currently consists of 8 stations (Fig. 2.14), with the farthest downstream site located at an NPDES weir (BCK-4.55). The highest flows in Bear Creek generally occur in the spring, the period of greatest precipitation. Low flows occur in the late summer and early fall, when several tributaries go dry and all or part of the main channel is dry as far downstream as station BCK-9.53. After periods of rainfall, the first several hundred feet of the channel may contain water from surface runoff, but at other times the channel remains dry upstream of the SY-200 Yard.

Energy Systems and USGS are operating recording gauges at the NPDES weir (BCK-4.55). The estimated flow at this point on Bear Creek is $\sim 7.3 \mathrm{ft}^{3} / \mathrm{s}$ (McMaster 1967). This value may be taken as an estimate of the total outflow from the Bear Creek Watershed at its exit poini through Pine Ridge.

In addition to streamflow measurements, monitoring of water chemistry was initiated in 1983 and has continued as part of the Y-12 Plant environmental surveillance efforts. The analyses performed have included both inorganic and organic contaminants and have typically been fairly comprehensive, including one sampling and analysis event for hazardous 

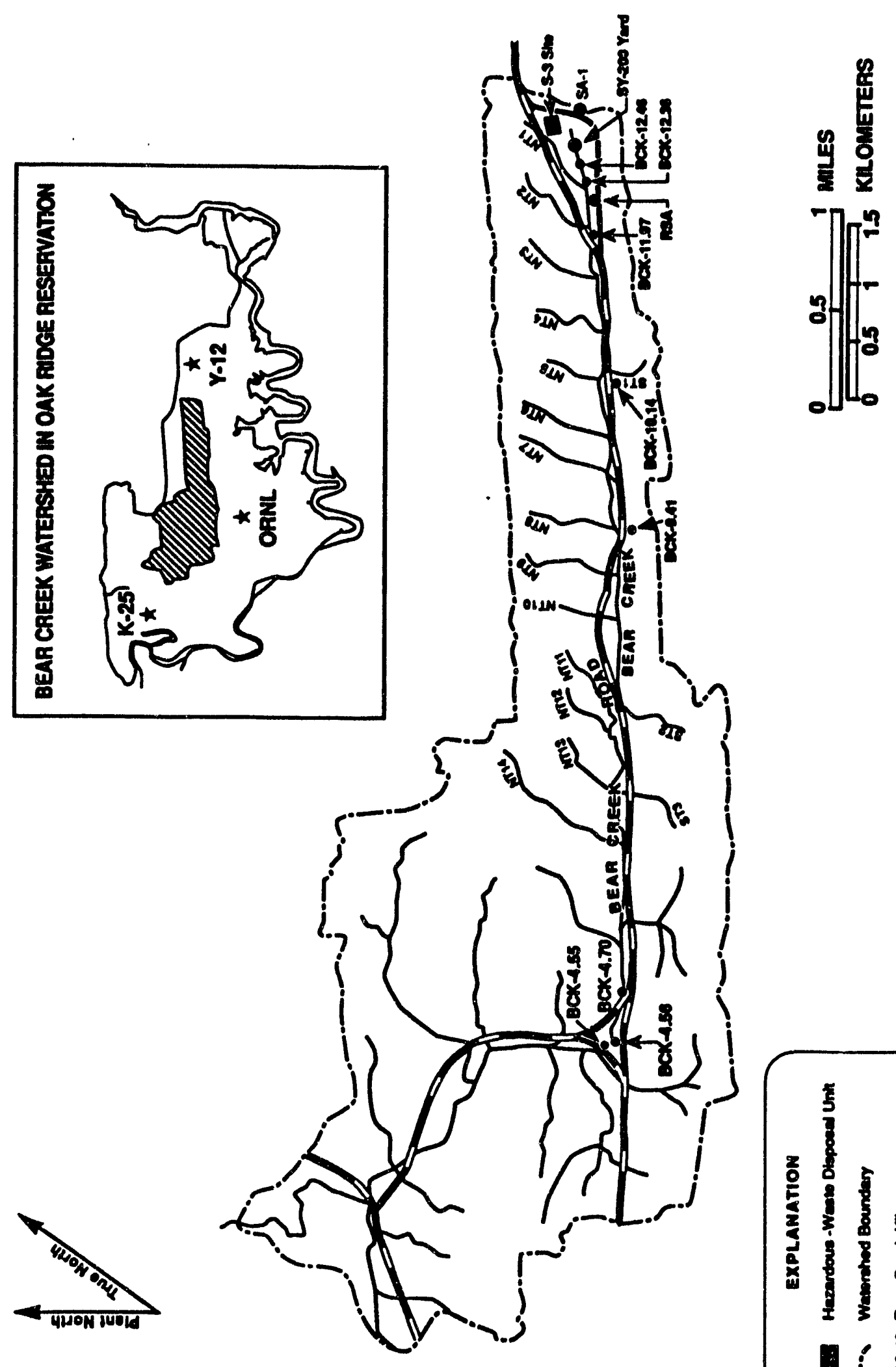

8
8
$\frac{8}{0}$

ช્⿹

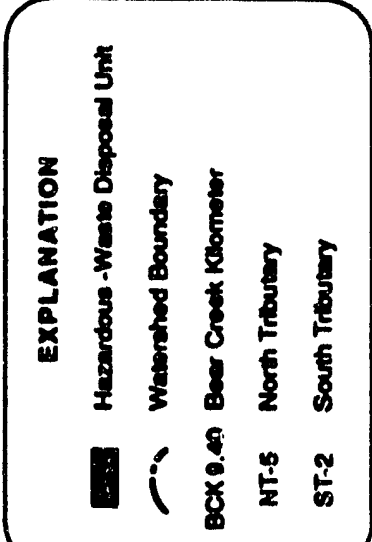


constituents listed in Appendix IX of Code of Federal Regulations, Title 40, Part 264. Results of these analyses suggest that total dissolved solids, nitrate, uranium, aluminum, and cadmium have been the chief contaminants warranting health and ecological concern. The concentrations of all these contaminants tecrease downstream from the headwaters near the S-3 Ponds, suggesting that the primary release to surface water is related to this site. The occurrence of these contaminants in several springs, which seem to sustain flow in parts of Bear Creek during dry periods, appears to result from recharge of shallow groundwater by Bear Creek upstream of these springs and the sirbsequent discharge of this shallow groundwater back into Bear Creek. If this interpretation is correct, corrective measures applied at the S-3 Ponds should continue to reduce both surface water and shallow groundwater contamination in upper Bear Creek.

Stream water quality data have been collected at BCK-12.4 and BCK-11.97 (Fig. 2.14) where, due to decreased flow from the S-3 Ponds, BCK-11.97 has been proposed as the permanent monitoring station to replace BCK-12.4. The 1990 monitoring results for some metals and nitrate that are characteristic of groundwater contamination in OU 2 for the two surface water sites are summarized in Table 2.6.

Table 26. 1993 summary of surfece water concentrations from sampling stations BCK-124 and 11.97

(uell)

\begin{tabular}{lccc}
\hline \multicolumn{1}{c}{ Analyte } & BCK-12.4 & BCK-11.97 & $\begin{array}{c}\text { Maximum } \\
\text { contaminant } \\
\text { level }\end{array}$ \\
\hline Barium & 76.4 & 481 & 1000 \\
Boron & 63 & 50 & 10 \\
Cadmium & $b$ & & 50 \\
Chromium & & & $1300^{\circ}$ \\
Copper & & & 50 \\
Lead & & 44 & 100 \\
Mercury & & 714 & \\
Nickel & & 211 & \\
Strontium & 422 & & $5000^{\circ}$ \\
Uranium & 512 & 150,100 & 10,000 \\
Zinc & & & \\
Nitrate & 31,400 & & \\
\hline
\end{tabular}

Source: Energy Systems 1991.

-Average values for analytes found in OU 2 groundwater samples.

Average corricentration was bel $N$ the detection limit.

Proposed.

Secondary level. 
Elevated concentrations of nitrate are characteristic of the S-3 Pond source area and exceed the Safe Drinking Water Act (SDWA) maximum contaminant level (MCL) at both surface water sampling locations. None of the metals exceeds its MCL. Surface water quality, as measured by nitrate and uranium concentrations, has improved over time (Fig. 2.15) as the S-3 source has diminished.

\subsection{Groundwater Data}

Groundwater monitoring is conducted in the Bear Creek Hydrogeological Regime as part of a Y-12 program of groundwater assessment monitoring. The regional groundwater flow system has been described in Sect. 2.7. Site-specific data on both the groundwater flow system and the groundwater quality are discussed in the following paragraphs.

\subsection{Rust Spoil Area}

Groundwater monitoring wells at RSA are illustrated in Fig. 2.16. Water-level fluctuations in the wells completed in the unconsolidated zone (GW-307, GW-308, GW-310, GW-311, and GW-312) parallel those changes seen in the wells that were completed in the Maynardville Limestone (GW-306 and GW-309). This is consistent with observations made in other monitoring well networks in the valley and supports the concept that the unconsolidated zone and the upper sections of the bedrock can be considered as one interconnected aquifer (Welch 1989c).

The lowest water levels seem to occur in the summer months and possibly continue dropping into the fall, with the highest levels occurring in late winter and spring. These fluctuations are due to the seasonal variations in precipitation and evapotranspiration.

The groundwater flow patterns in BCV have been studied over the past 10 to 15 years (Welch 1989c). The general pattern is one in which water infiltrating into the ground from precipitation ultimately moves toward the lowest elevation, Bear Creek, and is discharged into the creek as springs and seeps or may be discharged to a series of solution cavities in the Maynardville Limestone (Welch 1989c). In the low-lying areas of the valley, heads in deeper wells (50 to $150 \mathrm{ft}$ ) are higher than heads in shallower wells. This supports the concept of an upward flow component in the valley bottom. The resulting discharge of groundwater sustains the flow in lower reaches of Bear Creek and, at times of low or no surface water flow in the upper reaches of Bear Creek, the groundwater moves through the solution cavities under the creek. Some water from the solution cavity system is discharged farther downstream in Bear Creek (Welch 1989c).

A map of the general groundwater flow paths at the RSA (based on 1989 data) is shown in Fig. 2.17. Groundwater elevations from monitoring wells indicate that the direction of flow in the shallow aquifer system parallels the creek and proceeds down the valley to the west. However, these elevations may only indicate the general direction of groundwater flow. The aquifer underlying the RSA is anisotropic, and localized flow paths may oscur because of joints, fractures, and solution cavities in the Maynardville Limestone. 


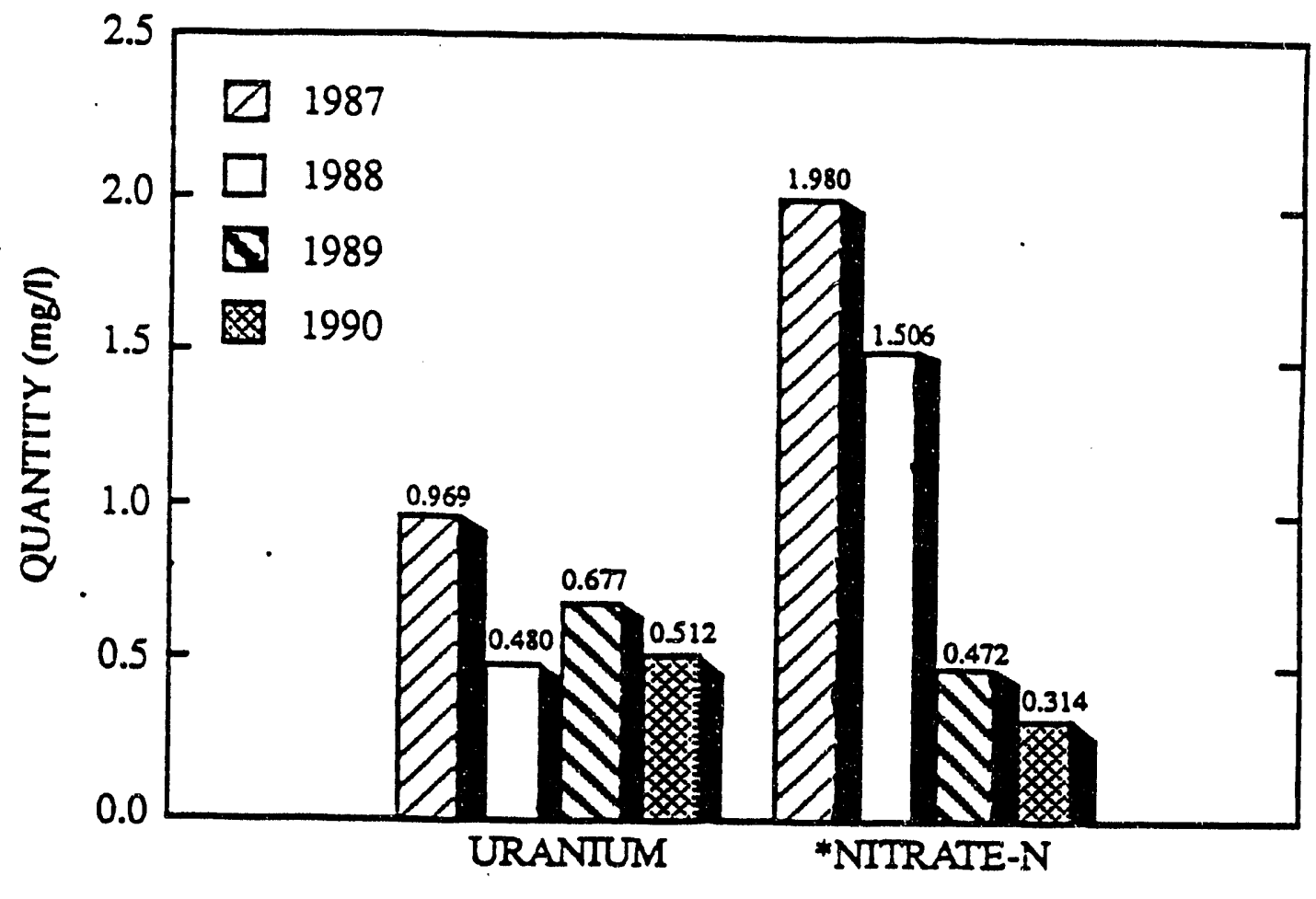

*Acrual Value $=$ Chart Value $\times 100$

Fig. 2.15. Upper Bear Creek trend chart, 1987-1990.

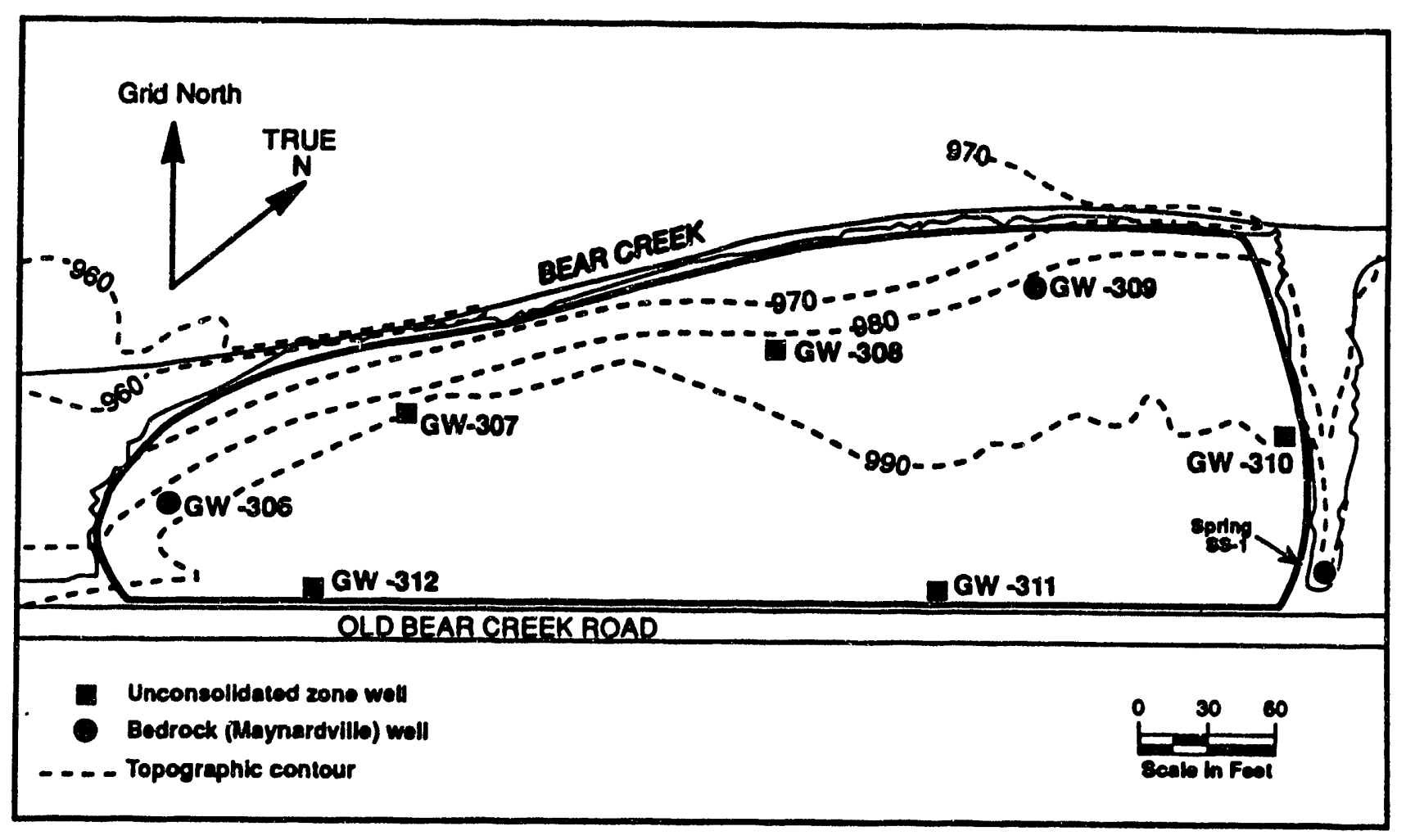

Fig. 2.16. RSA groundwater monitoring wells.

2012700000 
2-38

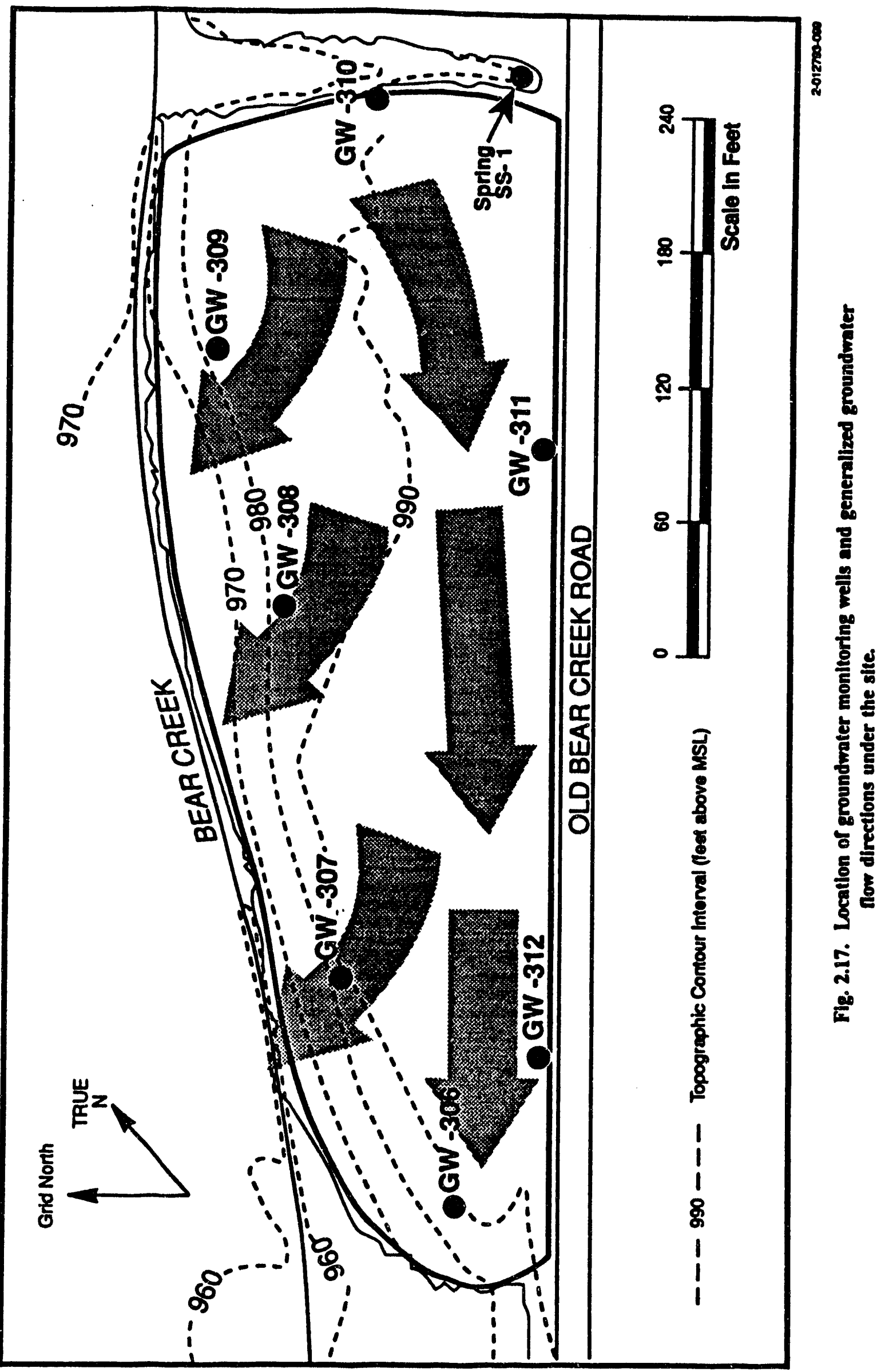


The groundwater flow pattern at the RSA is further complicated by the fact that the area is bordered by Bear Creek and the SS-1 spring. Because of operations at RSA, the original creek channel was filled, and Bear Creek was rerouted to the north. The old channel may still act to influence drainage in the area. Data from stream gauging stations located along Bear Creek indicate that, during times of high surface water discharge, Bear Creek is a gaining (effluent) stream. However, during periods of low water discharge, at least some reaches of Bear Creek act as a losing (influent) stream (Welch 1989c). Analysis of water levels in shallow monitoring wells along Bear Creek indicates that the portion of Bear Creek located adjacent to the RSA is a gaining (effluent) stream (Turner et al. 1988).

The monitoring well network at the RSA has been sampled quarterly since February 1988, and the groundwater quality results for 1990 are summarized in Table 2.7.

The results of the analyses indicated elevated concentrations of radioactivity, nitrate, chloride, sulfate, and volatile organic compounds (VOCs). Heavy metals, polychlorinated biphenyls (PCBs), pesticides, and herbicides did not appear to show elevated concentrations or were below detection limits.

Individual quarterly analyses for alpha activity indicated that wells GW-309 and GW-312 exceeded $15 \mathrm{pCi} / \mathrm{L}$ but that the semiannual average of the analysis was well below the $15 \mathrm{pCi} / \mathrm{L}$ drinking water standard (Welch 1989c).

The results for individual quarters show that the beta activity standard of $50 \mathrm{pCi} / \mathrm{L}$ (Welch 1989c) was exceeded in all wells except GW-308 and that wells GW-309 and GW-312 had high values of 2102 and $403 \mathrm{pCi} / \mathrm{L}$, respectively. The semiannual average indicated that monitoring wells GW-306, GW-309, GW-310, and GW-312 exceeded $50 \mathrm{pCi} / \mathrm{L}$. These results suggest that some contamination from radionuclides has occurred.

Average uranium levels in the wells at the RSA were below $2 \mu \mathrm{g} / \mathrm{L}$. The elevated levels of alpha and beta activity and uranium may be caused by the RSA but may be due to the influence of other sources such as the upgradient S-3 Ponds.

The average concentrations of chloride, nitrate, and sulfate are above reference levels of less than $5 \mathrm{mg} / \mathrm{L}, 0.1 \mathrm{mg} / \mathrm{L}$, and $5 \mathrm{mg} /$, respectively, in all the RSA wells except GW-311 and GW-312, which were only above background for nitrate. All chloride concentrations were below the applicable standard of $250 \mathrm{mg} / \mathrm{L}$ (Rogers et al. 1989). Sulfate concentrations are elevated but still below the applicable standard of $250 \mathrm{mg} / \mathrm{L}$ (Welch 1989c).

Elevated concentrations of nitrate are characteristic of the BCV headwaters. The nitrate applicable standard of $10 \mathrm{mg} / \mathrm{L}$ (Welch $1989 \mathrm{c}$ ) was exceeded in all wells except GW-311 and GW-312. The history of the RSA does not suggest that nitrates in any form were disposed of here. The source of the nitrates is most likely the S-3 Ponds. The findings confirm the presence of a plume emanating from the S-3 Ponds and migrating down the valley which extends at least $2000 \mathrm{ft}$ from the ponds. The nitrates found in the groundwater may be the direct result of groundwater flow or influent surface water/groundwater interaction of contaminated water from Bear Creek. It is probable that both transport mechanisms have contributed to the elevated nitrate concentrations in the wells completed in the unconsolidated and the bedrock zones. 
Table 27. RSA-1990 average groundwater concentrationsa

( $\mu g$, croept where moted)

\begin{tabular}{|c|c|c|c|c|c|c|c|}
\hline Analyte & GW-306 & GW-307 & GW-308 & GW-309 & GW-310 & GW-311 & GW-312 \\
\hline Barium & 46 & 87 & 95 & 46 & 96 & 18 & 41 \\
\hline Boron & 300 & 260 & 38 & 370 & 160 & 260 & 250 \\
\hline Cadmium & c & 2 & & & & & \\
\hline Chromium & & & 62 & & 34 & & 34 \\
\hline Copper & 11 & 30 & 38 & 3.6 & 8.6 & 7.8 & 9.3 \\
\hline Lead & & 30 & 50 & & 22 & & 50 \\
\hline Mercury & & & 0.2 & & 0.2 & & \\
\hline Nickel & 13 & 19 & 16 & & & & 15 \\
\hline Strontium & 180 & 270 & 320 & 420 & 330 & 70 & 580 \\
\hline Uranium & 1 & 1 & 2 & 2 & 0.9 & 0.8 & \\
\hline Zinc & 18 & 40 & 44 & 9 & 12 & 15 & 34 \\
\hline Chloride & 17,800 & 35,500 & 31,200 & 34,000 & 32,500 & 3,750 & 1,000 \\
\hline Nitrate & 11,000 & 17,800 & 15,000 & 17,800 & 23,000 & 750 & 280 \\
\hline Sulfate & 36,000 & 91,500 & 13,100 & 64,700 & 68,000 & 4,250 & 2,750 \\
\hline 1,2-DCE & 12.6 & 20.2 & 16.8 & 16.8 & 19.2 & & \\
\hline PCE & & 1.75 & 1.5 & 1.8 & 2.4 & & \\
\hline TCA & 2.4 & 2.5 & 2.2 & & & & \\
\hline TCE & 75 & 55.5 & 37 & 19.7 & 27.2 & 33.5 & 57.5 \\
\hline $\begin{array}{l}\text { Gross alpha, } \\
\mathrm{pCi} / \mathrm{L}\end{array}$ & 2.64 & 5.33 & 5.57 & 2.38 & 3.50 & 1.25 & 1.36 \\
\hline $\begin{array}{l}\text { Gross beta, } \\
\text { pCi/L }\end{array}$ & 26.7 & 49.0 & 40.5 & 49.9 & 61.9 & 2.36 & 21.4 \\
\hline
\end{tabular}

aAverage values for quarterly samples with a minimum of two analyses above detection limit. Values below detection limit were treated as one-half the detection limit.

${ }^{b}$ Groundwater well designation.

'Analyte not detected above reference more than once during the year.

Source: HSW (1991). 
The results of VOC analyses, summarized in Table 2.7 , indicate that the RSA may be a source area for trichloroethene (TCE), trans-1,2-dichloroethene (1,2-DCE), and to a lesser extent trichloroethane (TCA) and tetrachloroethene (perchloroethene or PCE). TCE concentration exceeded the applicable standard of $5 \mu \mathrm{g} / \mathrm{L}$ in all wells. The downgradient monitoring wells GW-306, GW-307, and GW-312 at the RSA show the highest average concentrations of TCE.

\section{SY-200 Yard}

There are no groundwater monitor wells at the SY-200 Yard. Groundwater east and west of the site has been monitored since 1986 in accordance with RCRA assessment monitoring at TSD units.

The SY-200 Yard is located $\sim 700 \mathrm{ft}$ southwest of the S-3 Site. The RSA and the Oil Landfarm are located about 600 and $2000 \mathrm{ft}$, respectively, west of the SY-200 Yard. Based upon data presented in the 1988 Groundwater Quality Assessment Reports for the S-3 Site and the Oil Landfarm (Geraghty \& Miller, Inc. 1989b and 1989c), groundwater contamination is present in the vicinity of the SY-200 Yard, the RSA, and the Oil Landfarm. Data suggest that a VOC plume beneath the RSA has intermingled with the VOC plume from the Oil Landfarm. In addition, groundwater monitoring data for BCV indicate that a nitrate plume originating at the S-3 Site has migrated into the Maynardville Limestone underlying the SY-200 Yard and extends as far west as the Oil Landfarm. Details on the groundwater quality east and west of the SY-200 Yard are presented in the above-referenced reports.

\subsection{Spoil Area 1}

The monitoring well network at SA-1, which includes wells GW-313 through GW-317 and GW-323 (see Fig. 2.18), has been sampled quarterly since February 1988.

The 1988 groundwater results for SA-1 wells were summarized in the RFI plan for SA-1 (Welch 1989b). Results indicated elevated concentrations of radioactivity, total coliform bacteria, total organic carbon, total organic halides, iron, and nitrate. PCBs, pesticides, and herbicides were below detection limits.

The 1989 results for SA-1 wells were reported in a summary document (Geraghty \& Miller 1990b) that assesses the groundwater quality for the Bear Creek Hydrogeologic Regime. However, this document has limited information on SA-1 wells because only GW-317 was sampled in the 1989 sampling campaign and only for the first two quarters of 1989.

The 1990 groundwater results are summarized in the latest valleywide groundwater quality assessment report (HSW 1991). The discussion in this section is based on those results, which are summarized in Table 2.8 . 


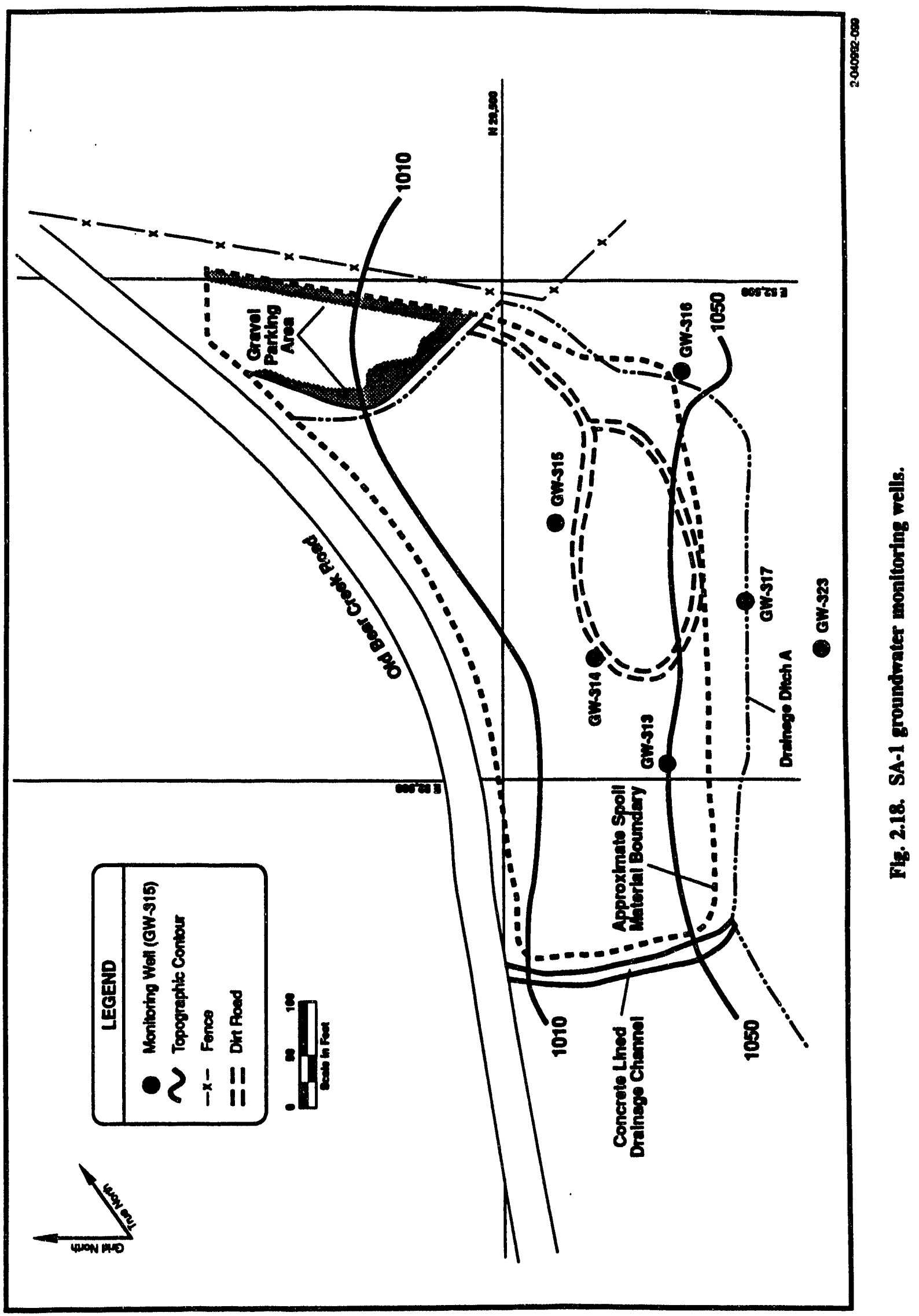


Table 28. SA-1 1990 average groundwater concentrations (ugh, croept where noted)

\begin{tabular}{|c|c|c|c|c|c|c|}
\hline Analyte & GW-313 & GW-314 & GW-315 & GW-316 & GW-317 & GW-323 \\
\hline Barium & 23 & 39 & 47 & 37 & 16 & 34 \\
\hline Boron & 10 & 30 & 22 & 13 & 23 & 16 \\
\hline Cadmium & $c$ & & & & & 3 \\
\hline Copper & 9 & 6 & 5 & 7 & 8 & \\
\hline Lead & 28 & 3 & & 6 & & \\
\hline Strontium & 78 & 93 & 141 & 39 & 45 & 21 \\
\hline Uranium & & & 1 & 0.7 & & \\
\hline Zinc & 8 & 9 & 10 & 32 & 12 & 13 \\
\hline Chloride & 2,000 & 4,600 & 6,800 & 2,000 & 880 & 1,000 \\
\hline Nitrate & 900 & 10,800 & 16,000 & 400 & 180 & \\
\hline Sulfate & 2,600 & 6,200 & 11,200 & 2,600 & 7,000 & 2,000 \\
\hline 1,2-DCE & 7.5 & 11.7 & 26.6 & & & \\
\hline PCE & 8.6 & 13.3 & 33.3 & & & \\
\hline TCE & 4.7 & 5.7 & 13.5 & & & \\
\hline $\begin{array}{l}\text { Gross alpha, } \\
\text { pCi/L }\end{array}$ & 0.30 & 1.00 & 1.30 & 1.01 & 0.38 & 1.14 \\
\hline $\begin{array}{l}\text { Gross beta, } \\
\text { pCi/L }\end{array}$ & 3.12 & 32.3 & 54.9 & 2.54 & 3.01 & 1.80 \\
\hline
\end{tabular}

aAverage values for quarterly samples with a minimum of two analyses above detection limit. Values below detection limit were treated as one-half the detection limit.

${ }^{b}$ Groundwater well designation.

'Analyte not detected above reference more than once during the year.

Source: HSW 1991.

Organic compounds in the SA-1 groundwater. Table 2.8 summarizes the detections of VOCs from the 1990 sampling events from the monitoring wells at SA-1. No semivolatile organic compounds, pesticides, PCBs, or herbicides were detected. Phthalate detections were not considered further because detection of these compounds were determined to be false positives through the use of a screening procedure developed by EPA (EPA 1988b), and these chemicals have not been used at the Y-12 Plant. In addition, concentrations of methylene chloride, acetone, and toluene were not considered further because of similar screening criteria (EPA 1988b).

The upgradient wells for SA-1 are GW-316, GW-317, and GW-323. The other wells, GW-313, GW-314, and GW-315, are positioned down slope near the center of the site. In 
comparing these two groups of upgradient and on-site wells, the on-site wells have all of the detections of organic constituents. This observation suggests a slight degradation of water quality in a direction downgradient across the site.

Of the compounds listed in Table 2.8, promulgated MCLs are available for TCE ( $5 \mu \mathrm{g} / \mathrm{L}$ ); PCE $(5 \mu \mathrm{g} / \mathrm{L})$; and the degradation product $1,2-\mathrm{DCE}(0.07 \mathrm{mg} / \mathrm{L}$ for cis-1,2,dichloroethene and $0.1 \mathrm{mg} / \mathrm{L}$ for trans-1,2, dichloroethene). TCE and PCE exceeded their respective MCLs in the on-site wells GW-314 and GW-315. The PCE concentration in well GW-313 exceeded the MCL. The dichloroethenes did not exceed their MCL in any well.

No available data directly tie the soil to the groundwater as a source for the VOC contaminants found in the groundwater. For example, TCE was found in groundwater samples collected from SA-1 wells, but TCE was not found in any of the soil samples collected from the site and was not nown to be disposed of at SA-1. However, TCE is a component of the VOC groundwater plumes documented in upper BCV (HSW 1991). The primary VOCs found in plumes emanating throughout the Bear Creek Hydrogeologic Regime include TCE, PCE, 1,2-DCE, 1,1,1-trichloroethane (1,1,1-TCA), and 1,1-dichloroethane (1,1-DCA). The extended plumes may be the reason for the slight degradation across the site if these contaminants have reached the on-site wells but not the upgradient wells.

Two potential sources of the VOC groundwater contamination at SA-1 are the former Fire Training Area (FTA) and the S-3 Ponds (see Fig. 2.12). The FTA, located about $450 \mathrm{ft}$ east of SA-1 in the UEFPC Hydrogeologic Regime, has significant (>1 mg/L) VOC contamination detected in samples from on-site wells. The S-3 site, located $\sim 500 \mathrm{ft}$ north of SA-1, is considered to be the primary source of nitrates, metals, and radionuclides in the Bear Creek Hydrogeologic Regime and may also be one of the contributors of VOC contamination found in SA-1 groundwater.

Contaminant plume maps (HSW 1991) indicate that contamination from the S-3 Ponds and other nearby sites within the Y-12 Plant intersect the northern half of the SA-1. The existence of these plumes at SA-1 is supported by valleywide piezometric surface maps, which indicate that groundwater at the S-3 Ponds flows toward the northern edge of SA-1 and then turns westward down BCV (HSW 1991). Site-specific groundwater elevation data collected as part of a recent investigation indicate that flow at SA-1 is generally down Chestnut Ridge toward the center of BCV (see Fig. 2.18). Under these conditions, contamination from the S-3 Ponds and other nearby Y-12 Plant sites is not likely to be migrating onto SA-1. However, the Karstic nature of the Maynardville Limestone, the likely conduit for S-3 Pond contaminants, makes predictions based on potentiometric surfaces tenuous.

This anamoly in flow direction is perhaps the result of short-term fluctuations in groundwater elevations. An additional consideration is that until 1984, the S-3 Ponds served as a local groundwater recharge basin and affected local groundwater gradients (Geraghty \& Miller 1989b). Thus, groundwater flow directions during operation of the S-3 Ponds may have been different from today's directions. Based on this observation and the existence of the documented contaminant plumes, groundwater flow (and associated contamination) from the S-3 Ponds and other nearby Y-12 Plant sites may have reached SA-1 at some time in the past.

92-043P 1072392 
According to HSW (1991), the following supporting evidence links the FTA, rather than the S-3 Ponds, to SA-1 as the principal source of VOC groundwater contamination:

- The types and relative percentages of the VOCs detected in groundwater samples from the FTA are similar to those reported for SA-1 groundwater samples.

- 1,2-DCE was found in both SA-1 and FTA samples but not in samples from wells located in the immediate vicinity of the S-3 Ponds.

- Both SA-1 and the FTA sites overlie the Maynardville Limestone in the water table "saddle" between the Bear Creek and UEFPC Hydrogeologic Regimes. Past variations in the water table may have enabled flow from the FTA to SA-1.

Inorganics in SA-1 groundwater. Principal metal contaminants in the Bear Creek Hydrogeologic Regime are barium, cadmium, chromium, lead, and mercury. The metals contamination is most widespread at the S-3 Waste Management Area (WMA), located north of SA-1.

As noted previously, the upgradient wells for SA-1 are GW-316, GW-317, and GW-323. These wells are used as indicators of the quality of water entering the site and as a basis for comparison with the wells near the center of the site (GW-313, GW-314, and GW-315). Table 2.8 compares average values for the metals detected in the on-site wells with average concentrations of metals found in the upgradient wells.

The highest average on-site concentration of barium $(47 \mu \mathrm{g} / \mathrm{L})$ was found in the on-site well GW-315. Average concentrations in the upgradient wells ranged from 16-37 $\mu \mathrm{g} / \mathrm{L}$. However, the barium results were well below the MCL of $2 \mathrm{mg} / \mathrm{L}$.

The maximum average copper concentration found in the upgradient wells was $8 \mu \mathrm{g} / \mathrm{L}$. This concentration was exceeded by the average concentration of $9 \mu \mathrm{g} / \mathrm{L}$ from the on-site well GW-313. However, all these concentrations are well below the $1.3 \mathrm{mg} / \mathrm{L} \mathrm{MCL}$ for copper.

The highest average lead concentration was $28 \mu \mathrm{g} / \mathrm{L}$ in on-site well GW-313. Lead was below detection limits in most upgradient wells, with the exception of well GW-316 where the average concentration was $6 \mu \mathrm{g} / \mathrm{L}$. All average values are below the $50 \mu \mathrm{g} / \mathrm{L}$ MCL for lead.

The maximum average zinc concentration $(32 \mu \mathrm{g} / \mathrm{L})$ was found in upgradient well GW-316. All concentrations are well below the zinc secondary standard of $5 \mathrm{mg} / \mathrm{L}$.

The highest average strontium concentration was $141 \mu \mathrm{g} / \mathrm{L}$ in on-site well GW-315. Background well average concentrations ranged from 21 to $45 \mu \mathrm{g} / \mathrm{L}$ and were consistently lower than values in on-site wells.

The data suggest that the on-site wells have slightly higher metals concentrations than the upgradient wells for most of the metals discussed. Thus, there appears to be a slight degradation of water quality across the site. However, metals concentrations in the upgradient and on-site wells were less than reference levels for BCV (HSW 1991). 
Total uranium in SA-1 groundwater. Total uranium (via fluorometric analyses) was found at maximum concentrations of $1 \mu \mathrm{g} / \mathrm{L}$ in the upgradient wells and $2 \mu \mathrm{g} / \mathrm{L}$ in the on-site wells. These values are less than or equal to the maximum reference concentration of $2 \mu \mathrm{g} / \mathrm{L}$ specified for BCV (HSW 1991).

In comparison with these data, the 1988 groundwater results for SA-1 wells (Welch 1989b) listed both an on-site weil (GW-313) and an upgradient well (GW-317) as having concentrations above background (12 and $14 \mu \mathrm{g} / \mathrm{L}$, respectively).

Radioactivity in SA-1 groundwater. Table 2.8 summarizes the results for the gross alpha and gross beta analyses performed on the 1990 samples. The mean gross alpha activity ranged from 0.3 to $1.30 \mathrm{pCi} / \mathrm{L}$. However, the statistical errors of each datum overlapped the others, indicating that the results for each well are similar. The mean gross alpha activity of the wells located at SA-1 did not exceed the Primary Drinking Water Standard of $15 \mathrm{pCi} / \mathrm{L}$ during 1990.

The average gross beta results ranged from 2.54 to $54.89 \mathrm{pCi} / \mathrm{L}$. Individual quarterly samples from two wells exceeded the gross beta reporting level of $50 \mathrm{pCi} / \mathrm{L}$ : GW-314 with 51.59 and $57.33 \mathrm{pCi} / \mathrm{L}$, and $\mathrm{GW}-315$ with $54.32,90.2$, and $77.60 \mathrm{pCi} / \mathrm{L}$. Both of these wells are downgradient and are the wells closest to the S-3 WMA. Although the S-3 site is the primary source of radionuclide contamination in the Bear Creek Hydrogeologic Regime, it is not possible to determine with available data whether the source of the radiological contamination is from SA-1 or an extended plume from off site.

Groundwater indicator parameter. The principal indicator parameters for which water quality standards exist are chloride, nitrate (as nitrogen), and sulfate. Table 2.8 presents the average results from the 1990 groundwater monitoring program.

Using wells GW-316, GW-317, and GW-323 as background (upgradient) wells for the site, we found that the chloride, nitrate, and sulfate concentrations in the on-site wells GW-314 and GW-315 exceed background concentrations. However, the chloride and sulfate concentrations are still well below the federal standards of $250 \mathrm{mg} / \mathrm{L}$ for these indicators. The nitrate nitrogen concentrations are $<2$ times their $\mathrm{MCL}$ of $10 \mathrm{mg} / \mathrm{L}$. As previously suggested (HSW 1991), the nitrate plume from the S-3 site has extended southward to the Maynardville Limestone, near its contact with strata of the Knox Group. However, it does not appear from these data that the plume has reached far enough to affect GW-313, GW-316, GW-317, or GW-323.

\section{Soil Chemistry Data}

Site-specific data on soil chemistry, collected as part of recent characterization investigations at SA-1 and RSA are presented in Appendix C and summarized in the following sections.

\subsubsection{Rust Spoil Area soil chemical data}

In order to characterize the nature and extent of soil contamination at RSA, subsurface soil samples were taken from soil borings drilled at seven sampling points around the 
perimeter of the site (Fig. 2.19). Soil samples were collected at each sampling point at 5-ft intervals until refusal was reached. The depth to refusal at the sampling points ranged from a minimum of $5 \mathrm{ft}$ in RSA-6 and RSA-7 up to a maximum of $25 \mathrm{ft}$ in RSA-3 and RSA-4. It is anticipated that the shallow and variable depth to refusal across the site is due to the variable depths to bedrock. Without exception, boring logs indicate that the entire thickness of fill was encountered.

A total of 24 subsurface soil samples were collected at the RSA and analyzed for metals, VOCs, asbestos, cyanide, and radiologicals. Table 2.9 presents a statistical summary of the analytes detected, their frequency of occurrence, the range of detected concentrations, and the BCV background concentration for each analyte. Table 2.10 presents a summary of the nature and extent of the detected contaminants at the RSA.

The results of the current soil characterization at RSA indicate that no significant concentrations of VOCs exist at RSA. PCE was detected in one sample, but at only slightly elevated levels. The majority of the contaminants of concern detected at RSA were metals.

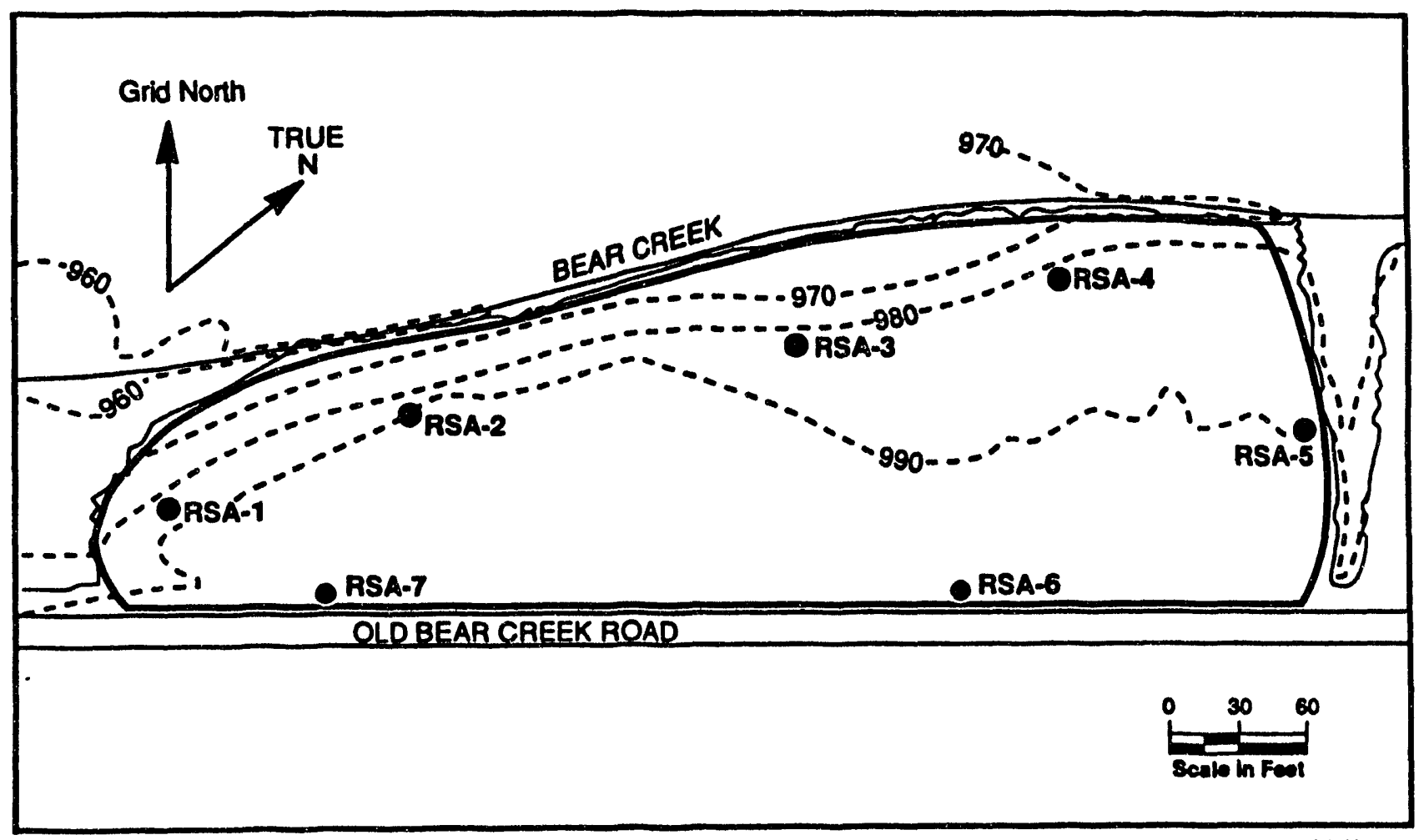

$2-012703000$

Fig 219. RSA soil boring locations. 
Table 29. Summary of soil chemical data, RSA soil borings

\begin{tabular}{|c|c|c|c|c|}
\hline Chemical/element & $\begin{array}{c}\text { Number of } \\
\text { detections/ } \\
\text { analyses }\end{array}$ & $\begin{array}{c}\text { Detected } \\
\text { minimum* } \\
(\mathrm{mg} / \mathrm{kg}) \\
\end{array}$ & $\begin{array}{c}\text { Detected } \\
\text { maximuma } \\
(\mathrm{mg} / \mathrm{kg})\end{array}$ & $\begin{array}{c}\text { BCV soil } \\
\text { background levels } \\
-(\mathrm{ppm})^{6}\end{array}$ \\
\hline \multicolumn{5}{|c|}{ Volatile Organic Compounds } \\
\hline Acetone & 9/24 & 0.16 & 0.49 & \\
\hline $\begin{array}{l}\text { Tetrachloroethene } \\
\text { (PCE) }\end{array}$ & $1 / 24$ & & 0.072 & \\
\hline \multicolumn{5}{|c|}{ Metals } \\
\hline Arsenic & $24 / 24$ & 28 & 26 & 6.758 \\
\hline Barium & $24 / 24$ & 24 & 820 & 149.5 \\
\hline Beryllium & $23 / 24$ & 0.67 & 2.1 & $1.34^{c}$ \\
\hline Cadmium & $23 / 24$ & 2.4 & 7.3 & 0.2453 \\
\hline Chromium & $23 / 24$ & 17 & 41 & 14.70 \\
\hline Cobalt & $23 / 24$ & 9.4 & 66 & 34.81 \\
\hline Copper & $24 / 24$ & 14 & 740 & 21.22 \\
\hline Lead & $24 / 24$ & 13 & 150 & 42.28 \\
\hline Mercury & $5 / 24$ & 1.1 & 7.5 & 0.1639 \\
\hline Nickel & $23 / 24$ & 15 & 55 & $54.86^{c}$ \\
\hline Uranium & $24 / 24$ & 2 & 14.5 & 2.30 \\
\hline Vanadium & $23 / 24$ & 20 & 70 & 49.18 \\
\hline Zinc & $24 / 24$ & 44 & 230 & 46.35 \\
\hline \multicolumn{5}{|c|}{ Radiological } \\
\hline Gross alpha, pCi/g & $24 / 24$ & 1.45 & 4.37 & \\
\hline Gross beta, pCi/g & $24 / 24$ & 1.87 & 5.07 & \\
\hline Uranium-235, wt \% & $3 / 3$ & 0.04 & 1.18 & \\
\hline
\end{tabular}

${ }^{a}$ Concentration units are $\mathrm{mg} / \mathrm{kg}$ unless otherwise indicated.

${ }^{b}$ From Turner et al. 1988.

Represents mean background for East Tennessee based on data in Maker (1973), Bowen (1966), Davis (1990), and Bechtel (1991). 
Table 2.10. Summary of detected soil contaminants, RSA

\begin{tabular}{|c|c|}
\hline Contaminant & Summary \\
\hline \multicolumn{2}{|r|}{ Volatile Organic Compounds } \\
\hline Acetone & $\begin{array}{l}\text { Detected in several samples; however, it was similarly detected in the } \\
\text { correlative laboratory blanks. Consequently, it is believed to be } \\
\text { associated with laboratory processes and is eliminated from concern. }\end{array}$ \\
\hline $\begin{array}{l}\text { Tetrachloroethene } \\
\text { (PCE) }\end{array}$ & $\begin{array}{l}\text { Detected in only one sample from RSA-2 (5 to } 10 \mathrm{ft} \text { ) at slightly elevated } \\
\text { levels. }\end{array}$ \\
\hline \multicolumn{2}{|r|}{ Metals } \\
\hline Arsenic & $\begin{array}{l}\text { Detected concentrations are slightly above background levels. Highest } \\
\text { concentrations are isolated in RSA-6 (5 to } 10 \mathrm{ft} \text { and } 10 \text { to } 15 \mathrm{ft} \text { ). }\end{array}$ \\
\hline Barium & $\begin{array}{l}\text { Detected concentrations are at background levels in all samples except } \\
\text { RSA-4 ( } 20 \text { to } 25 \mathrm{ft} \text { ) where levels are moderately elevated. }\end{array}$ \\
\hline Beryllium & Detected concentrations ars, at background levels. \\
\hline Cadmium & $\begin{array}{l}\text { All samples indicated concentrations significantly above BCV } \\
\text { background levels. Detected concentrations are relatively consistent in } \\
\text { distribution throughout sampled area. Detected concentrations are only } \\
\text { slightly to moderately above the mean background concentrations for } \\
\text { the east Tennessee region. }\end{array}$ \\
\hline Chromium & $\begin{array}{l}\text { Detected concentrations are very slightly elevated in comparison to the } \\
\text { BCV background values and are within the mean background levels for } \\
\text { the east Tennessee region. Consequently, detected concentrations are } \\
\text { possibly background levels. }\end{array}$ \\
\hline Cobalt & Detected concentrations are likely background levels. \\
\hline Copper & $\begin{array}{l}\text { All detected concentrations represent background levels except RSA-3 } \\
\text { ( } 20 \text { to } 25 \mathrm{ft} \text { ) and RSA-5 ( } 10 \text { to } 15 \mathrm{ft}) \text {. RSA-3 ( } 20 \text { to } 25 \mathrm{ft} \text { ) levels are } \\
\text { high, while RSA-6 ( } 10 \text { to } 15 \mathrm{ft} \text { ) concentrations are only slightly elevated. }\end{array}$ \\
\hline Lead & $\begin{array}{l}\text { All detected concentrations represent background levels except RSA-3 } \\
\text { ( } 20 \text { to } 25 \mathrm{ft}) \text { and RSA-6 (10 to } 15 \mathrm{ft}) \text {. RSA-3 ( } 20 \text { to } 25 \mathrm{ft} \text { ) levels are } \\
\text { high, while RSA-6 (10 to } 15 \mathrm{ft} \text { ) concentrations are only slightly elevated. }\end{array}$ \\
\hline Mercury & $\begin{array}{l}\text { All detected concentrations are }<1 \text { mg/kg except RSA-4 ( } 0 \text { to } 5 \mathrm{ft} \text { and } \\
15 \text { to } 20 \mathrm{ft} \text { ) and RSA-3 (0 to } 5 \mathrm{ft}, 5 \text { to } 10 \mathrm{ft} \text {, and } 20 \text { to } 25 \mathrm{ft} \text { ). All } \\
\text { concentrations detected in RSA-3 and RSA-4 are significantly above } \\
\text { BCV iackground levels. The highest concentrations were detected in } \\
\text { RSA-3 (0 to } 5 \mathrm{ft} \text { and } 20 \text { to } 25 \mathrm{ft} \text { ). }\end{array}$ \\
\hline Nickel & All detected concentrations represent background levels. \\
\hline Uranium & $\begin{array}{l}\text { Slightly to moderately elevated concentrations above background were } \\
\text { detected in RSA-2 (5 to } 10 \mathrm{ft}) \text {, RSA-3 (5 to } 10 \mathrm{ft}) \text {, RSA-4 (0 to } 5 \mathrm{ft}) \text {, } \\
\text { and RSA-7 (0 to } 5 \mathrm{ft}) \text {. RSA-3 (5 to } 10 \mathrm{ft} \text { ) and RSA-7 (0 to } 5 \mathrm{ft}) \\
\text { exhibited the highest levels. }\end{array}$ \\
\hline Vanadium & All detected concentrations likely represent background levels. \\
\hline
\end{tabular}


Table 210 (continued)

\begin{tabular}{|c|c|}
\hline Contaminant & Summary \\
\hline Zinc & $\begin{array}{l}\text { Aii detected concentrations appear to be background or very low levels } \\
\text { except RSA-3 ( } 20 \text { to } 25 \mathrm{ft} \text { ) and RSA-6 (5 to } 10 \mathrm{ft} \text { and } 10 \text { to } 15 \mathrm{ft} \text { ). } \\
\text { Concentrations in RSA-3 and RSA-6 are slightly to moderately elevated. }\end{array}$ \\
\hline & Radiological \\
\hline Gross alpha & $\begin{array}{l}\text { All detected concentrations represent very low levels in terms of DOE- } \\
\text { established action limit. }\end{array}$ \\
\hline Gross beta & $\begin{array}{l}\text { All detected concentrations represent very low levels in terms of DOE- } \\
\text { established action limit. }\end{array}$ \\
\hline${ }^{205} \mathrm{U}$ & $\begin{array}{l}\text { Very low levels were detected in RSA-2 ( } 5 \text { to } 10 \mathrm{ft} \text { ), RSA-3 (10 to } \\
15 \mathrm{ft} \text { ), and RSA-7 (0 to } 5 \mathrm{ft} \text { ). }\end{array}$ \\
\hline
\end{tabular}

The results of current soil sampling indicate that there is no widespread occurrence of metals at significantly elevated concentrations at RSA. The occurrence of most metals identified at RSA is sporadic, and the concentrations are slightly to moderately elevated above background levels. The most commonly detected metal contaminants were uranium, cadmium, mercury, arsenic, copper, lead, and zinc. Radiological analyses of the soil samples collected at RSA indicate that very low levels of gross alpha and gross beta radiation exist at the RSA with regard to the DOE established action limits. Three soil samples analyzed for ${ }^{235} U$ similarly indicated that very low levels exist at the RSA.

\section{SY-200 Yand}

Previous soil sampling at the SY-200 Yard has consisted of three sampling events: July 1986, January 1988, and January 1989. The first sampling event was initiated to investigate possible surface contamination from the storage of lead shielding plates and transformers at the SY-200 Yard. The subsequent sampling events were conducted to identify possible contaminants of the soils in the area proposed for construction of the ESF building.

Sampling was first conducted on July 3,1986, during which three surface soil samples (EP-1, EP-2, and EP-3) were collected from the lead shielding storage areas and one composite surface sample and two soil samples from depths of 2 to 4 in. was collected from an oil-stained area where the transformers were stored. A total of six samples was collected in 1986 at locations shown on Fig. 2.20. Samples from the lead shielding storage areas were analyzed for mercury and extraction procedure toxicity (EP tox) metals. All three samples passed the EP tox test. Samples from the transformer storage area were analyzed for mercury and PCBs. PCB concentrations detected in these samples ranged from 2.8 to $32 \mu \mathrm{g} / \mathrm{g}$. All six samples were analyzed for mercury. Mercury concentrations in these samples ranged from $3.8 \mu \mathrm{g} / \mathrm{g}$ in the composite surface sample to $17,000 \mu \mathrm{g} / \mathrm{g}$ in EP-3. Results of these analyses are presented in Table 2.11. 


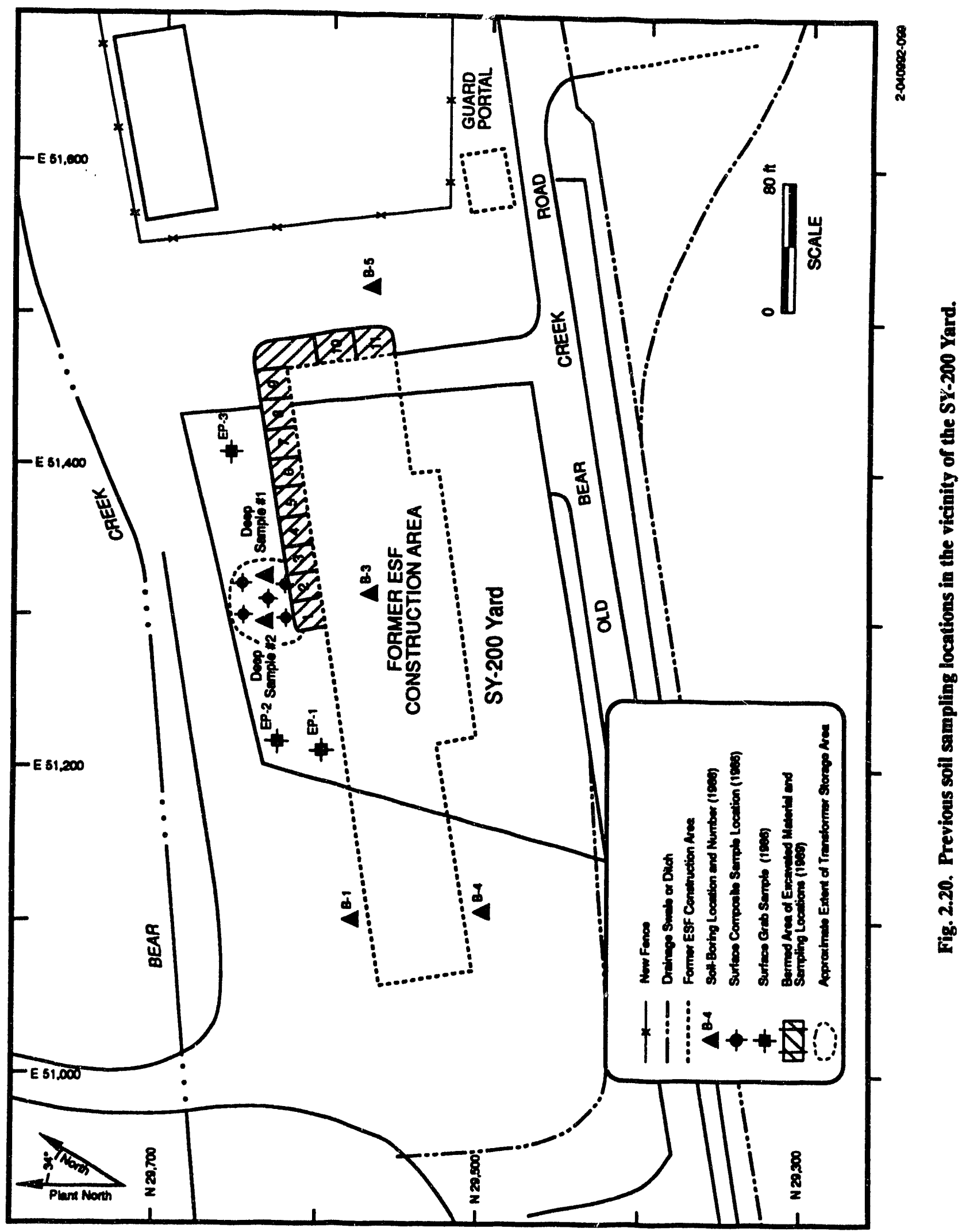




\section{$2-52$}

Table 211. SY-200 Yard soil sample analytical results, July 1986

\begin{tabular}{llccc}
\hline \multicolumn{1}{c}{ Sample name } & Interval & $\begin{array}{c}\text { Mercury } \\
(\mu \mathrm{g} / \mathrm{g})\end{array}$ & $\begin{array}{c}\text { PCB } \\
(\mu \mathrm{g} / \mathrm{g})\end{array}$ & $\begin{array}{c}\text { EP } \\
\text { tox }\end{array}$ \\
\hline EP-1 & Surface & 20 & & Pass \\
EP-2 & Surface & 42 & & Pass \\
EP-3 & Surface & 17,000 & & Pass \\
Surface composite & Surface & 3.80 & 32 & \\
transformer area & & & & \\
Deep sample 1 & $2-4$ in. & 29 & 2.8 & \\
Deep sample 2 & $2-4$ in. & 19 & 7.7 & \\
\hline
\end{tabular}

The next sampling event took place in January 1988 in an effort to identify any contaminated soils on the site where the ESF building was to be located. Fifteen samples were collected from boreholes B-1, B-3, B-4, and B-5 (Fig. 2.20). The samples collected were analyzed for the following parameters: alpha activity, beta activity, gamma activity, PCBs, EPA Primary Drinking-Water metals, and the EP tox metals. The results are summarized in Table 2.12.

Table 2.12. Summary of SY-200 Yard soil sample analytical results, January 1988

\begin{tabular}{|c|c|c|c|c|c|}
\hline \multirow[b]{2}{*}{ Parameter } & \multicolumn{3}{|c|}{ Range } & \multirow[b]{2}{*}{ Average } & \multirow[b]{2}{*}{ Comments } \\
\hline & Units & Upper & Lower & & \\
\hline Alpha activity & $\mathrm{pCi} / \mathrm{g}$ & 170 & 8.6 & 38 & \\
\hline Beta activity & $\mathrm{pCi} / \mathrm{g}$ & 250 & 15 & 71 & \\
\hline Gamma activity & $\mathrm{pCi} / \mathrm{g}$ & 420 & $<300$ & & Detected in 1 of 15 samples \\
\hline Arsenic & $\mathrm{mg} / \mathrm{kg}$ & & $<40$ & & Not detected in any sample \\
\hline Barium & $\mathrm{mg} / \mathrm{kg}$ & 340 & 182 & 239 & \\
\hline Cadmium & $\mathbf{m g} / \mathbf{k g}$ & & & & Not detected in any sample \\
\hline Chromium & $\mathrm{mg} / \mathrm{kg}$ & 80 & 29 & 51 & \\
\hline Lead & $\mathrm{mg} / \mathrm{kg}$ & 370 & $<20$ & 93 & Detected in 11 of 15 samples \\
\hline Mercury & $\mu g / \mathbf{k g}$ & 200 & 0.18 & 28 & Detected in 14 of 15 samples \\
\hline Selenium & $\mathbf{m g} / \mathbf{k g}$ & & $<0.1$ & & Not detected in any samples \\
\hline Silver & $\mathrm{mg} / \mathrm{kg}$ & & $<4$ & & Not detected in any samples \\
\hline PCB & $\mu g / \mathbf{k g}$ & 0.3 & $<0.1$ & & Detected in 3 of 15 samples \\
\hline EP-tox leach test & & & & & All samples passed \\
\hline
\end{tabular}


The analytical results indicate that samples collected in boring B-5 had the highest radiological readings in addition to the highest concentrations of mercury. It should be noted, however, that sample location B-5 is about $60 \mathrm{ft}$ east of the SY-200 Yard boundary. Trace levels of PCBs were detected in the top $4 \mathrm{ft}$ of B-4 and in the top $2 \mathrm{ft}$ of B-3. PCB concentrations were less than or equal to $0.3 \mu \mathrm{g} / \mathrm{g}$. The highest concentrations of lead, barium, and chromium were detected in samples from B-1, B-4, and B-3, respectively. All samples passed the EP tox test. In addition, no measurable amounts of arsenic, cadmium, or silver were detected in any of the samples analyzed.

As discussed in Sect. 2.8.3.3, about $8 \mathrm{ft}$ of fill material in the SY-200 Yard was excavated as part of ESF construction and bermed along the north and east corners of the excavation. The excavated material was $\sim 20 \mathrm{ft}$ high, $20 \mathrm{ft}$ wide, and $180 \mathrm{ft}$ long. In January 1989, 22 composite samples from 1 to $2 \mathrm{ft}$ and 3 to $5 \mathrm{ft}$ in depth were collected from the excavated material. The bermed area was divided into 11 sections, and four hand auger holes were drilled into each section to obtain the samples (Fig. 2.20). Each sample was analyzed for thorium, uranium, percent ${ }^{225} \mathrm{U}$, and mercury. The results for thorium, uranium, and mercury concentrations are summarized in Table 2.13.

Table 213. Summary of soil sample analytical results, January 1989

$(\mu \mathrm{g} / \mathrm{g})$

\begin{tabular}{lccc}
\hline & \multicolumn{3}{c}{ Range } \\
\cline { 2 - 3 } Parameter & Upper & Lower & Average \\
\hline Thorium & 15.3 & 3.71 & 7.34 \\
Uranium & 8.06 & 0.52 & 2.56 \\
Mercury & 2100 & 3.4 & 244 \\
\hline
\end{tabular}

Results of the three soil sampling events at the SY-200 Yard indicate that the fill materials are contaminated with mercury. It is believed that the presence of mercury in these fill materials is not the result of operations at the SY-200 Yard but that mercury was present in the fill materials placed at the site. Lead contamination is indicated in the northwest corner of the site (B-1) where lead shielding plates were stored. PCB contamination of the surface soils was indicated in the north central portion of the site where transformers were stored. In addition, contamination with radiological constituents is also indicated, although the highest levels of radioactivity were detected east of the SY-200 Yard.

\subsection{Spoil Area 1}

The results of soil (fill and residuum) contamination conducted as part of the SA-1 characterization are summarized in the following sections. Samples were collected from six soil borings (Fig. 2.21) and analyzed for VOCs, inorganics (metals and cyanide), radiological 


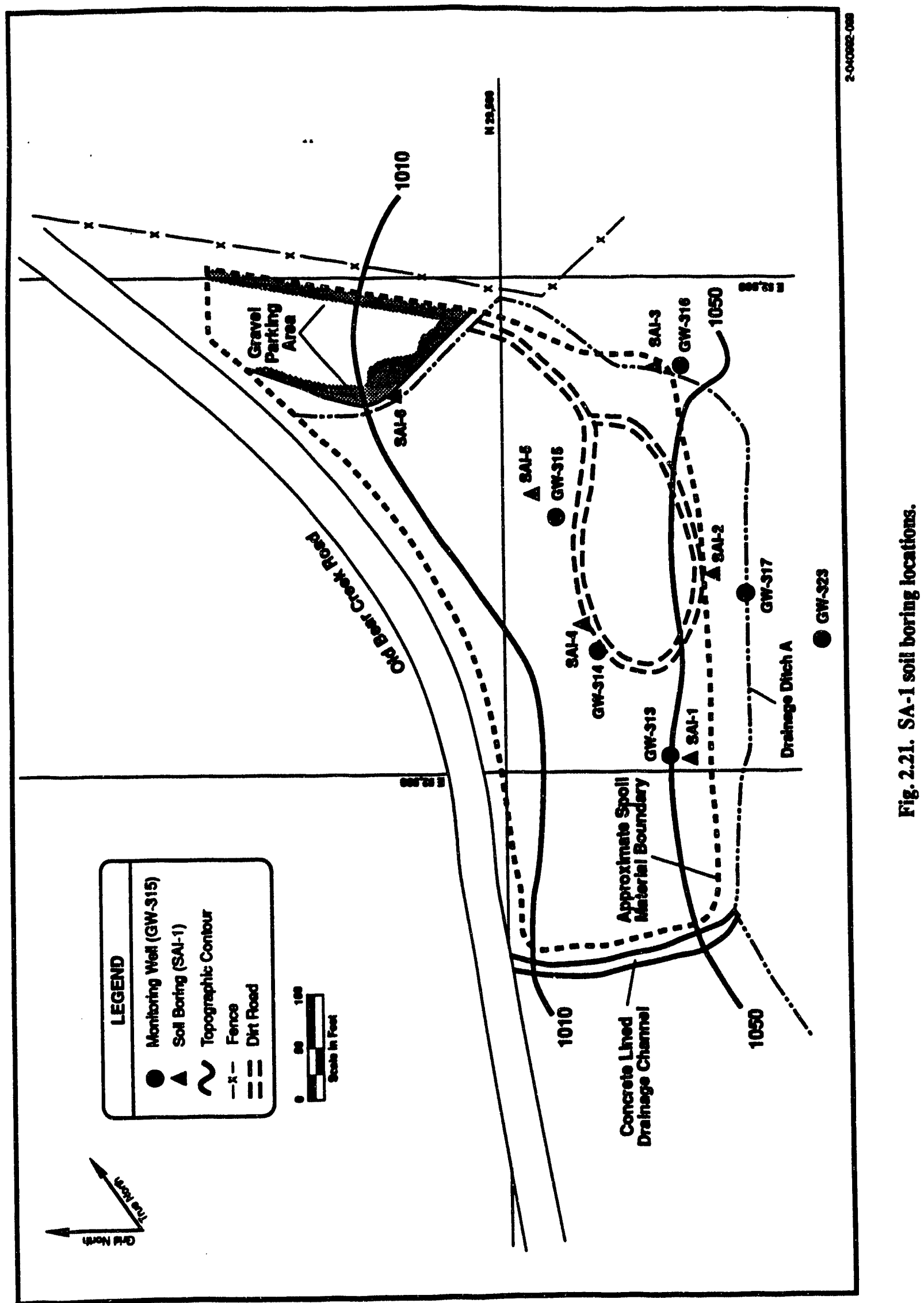


parameters, and semivolatile organics. Three of the borings were placed along the southern edge of SA-1, where the fill and debris were $<15 \mathrm{ft}$ deep. Two of the borings were placed along a diagonal traversing the center of the site. In these locations, the fill material and debris were 35 to $40 \mathrm{ft}$ deep. The sixth boring was in the northeastern corner of the site, where the fill depth had again decreased to $<15 \mathrm{ft}$.

Volatile organic compounds. Disregarding the common laboratory artifacts, the detected VOCs can be grouped as follows:

- gasoline constituents [benzene and xylene (total)];

- chlorinated solvents/potential degradation products [1,1-dichloroethane, 1,2dichloroethene (total), and tetrachloroethene (PCE)]; and

- other solvents and applicants [4-methyl-2-pentanone (also used in extraction processes, including extraction of uranium from fission products), carbon disulfide (also generated in anaerobic biodegradation of organics), and chloroform].

The detection frequency for the VOCs was generally $\leq 5 \%$. Chloroform was the exception, with a detection frequency of $10 \%$. The detected maximum concentrations were at $0.012 \mathrm{mg} / \mathrm{kg}(12 \mathrm{ppb})$ or less.

The infrequent detection and low concentrations of VOCs suggest that no widespread contamination of these constituents exists at SA-1. Indeed, this finding was expected given the disposal restrictions outlined in the site's operating permit.

Semivolatile organic compounds. Table 2.14 presents a summary of the semivolatile organic compounds discovered in the SA-1 soil samples. The semivolatiles most often found were primarily polycyclic aromatic hydrocarbons (PAHs), other polycyclic hydrocarbons, and benzene derivatives. The primary industrial sources of these types of compounds are the high-temperature distillate fractions from coal tar and petroleum Examples include heavy lubricating oils, asphalt or petroleum coke, and wood preservatives. A debris landfill such as SA-1 would be expected to contain some road-building and roofing materials (asphalt), as well as treated lumber, ties, or poles (creosote) from Y-12 Plant demolition activities. Field personnel observed pieces of asphalt at the site.

The detection frequency for the semivolatiles ranged from 1 to $25 \%$. The maximum detected concentrations ranged from 0.055 to $4.1 \mathrm{mg} / \mathrm{kg}(\mathrm{ppm})$, with the highest levels associated with fluoranthene, phenanthrene, and pyrene. As expected, the semivolatile contamination is greater than the volatile contamination primarily due to the types of materials disposed of at the landfill, but also partially due to the tendency for volatiles to escape during debris transport, dumping, and grading. However, the detection frequency and maximum detected concentrations suggest that the semivolatile contamination in the soil is not widespread.

All of the semivolatile contaminants detected were located in the fill/debris material or along the interface between the fill and residuum. Detection of the compounds at or above the fill/residuum interface suggests that downward leaching of these compounds is minimal and that the semivolatiles have been retained in the fill or debris material. 


\section{2-56}

Table 214. Chemical summary, SA-1 soil borings

\begin{tabular}{|c|c|c|c|}
\hline Chemical/element & $\begin{array}{c}\text { Number of } \\
\text { detects/analyses }\end{array}$ & $\begin{array}{c}\text { Detected } \\
\text { minimum }^{a} \\
(\mathrm{mg} / \mathrm{kg})\end{array}$ & $\begin{array}{l}\text { Detected } \\
\text { maximum } \\
(\mathrm{mg} / \mathrm{kg})\end{array}$ \\
\hline \multicolumn{4}{|c|}{ Semivolatile organic compounds } \\
\hline Acenaphthene & $4 / 53$ & 0.079 & 0.41 \\
\hline Acenaphthylene & $1 / 53$ & 0.11 & 0.11 \\
\hline Anthracene & $7 / 53$ & 0.14 & 0.85 \\
\hline Benzo(a)anthracene & $12 / 53$ & 0.14 & 1.7 \\
\hline Benzo(a)pyrene & $11 / 53$ & 0.12 & 1.3 \\
\hline Benzo(a)fluoranthene & $10 / 53$ & 0.11 & 1.4 \\
\hline Benzo(ghi)perylene & $9 / 53$ & 0.085 & 0.8 \\
\hline Benzo(k)fluoranthene & $11 / 53$ & 0.15 & 1.4 \\
\hline Chrysene & $12 / 53$ & 0.16 & 1.7 \\
\hline Dibenzofuran & $3 / 53$ & 0.17 & 0.25 \\
\hline Fluoranthene & $13 / 53$ & 0.07 & 4.1 \\
\hline Fluorene & $6 / 53$ & 0.18 & 0.45 \\
\hline Indeno $(1,2,3-\infty d)$ pyrene & $8 / 53$ & 0.099 & 0.77 \\
\hline Naphthalene & $3 / 53$ & 0.12 & 0.21 \\
\hline Phenanthrene & $13 / 53$ & 0.059 & 3.6 \\
\hline Pyrene & $13 / 53$ & 0.055 & 3.1 \\
\hline \multicolumn{4}{|c|}{ Metals } \\
\hline Arsenic & $44 / 51$ & 1.9 & 45.7 \\
\hline Barium & $51 / 51$ & 15.3 & 385 \\
\hline Beryllium & $50 / 51$ & 0.27 & 11 \\
\hline Cadmium & $50 / 51$ & 1.1 & 10.9 \\
\hline Chromium & $50 / 51$ & 6.4 & 54.2 \\
\hline Cobalt & $50 / 51$ & 1.7 & 110 \\
\hline Copper & $50 / 51$ & 13.3 & 109 \\
\hline Lead & $51 / 51$ & 6.5 & 670 \\
\hline Mercury & $38 / 51$ & 0.05 & 31.5 \\
\hline Nickel & $51 / 51$ & 4.7 & 173 \\
\hline Uranium & $51 / 51$ & 2 & 80 \\
\hline Vanadium & 50/51 & 6.8 & 128 \\
\hline Zinc & $51 / 51$ & 26.4 & 591 \\
\hline \multicolumn{4}{|c|}{ Radiological } \\
\hline Gross alpha, pCi/g & $50 / 51$ & 0.03 & 12 \\
\hline Gross beta, pCi/g & 48/51 & 1.56 & 37.4 \\
\hline Total radium, pCi/g & $51 / 51$ & 0.973 & 7.568 \\
\hline Uranium-235, wt\% & 21/57 & 0.29 & 1 \\
\hline
\end{tabular}

${ }^{9}$ Concentration units are $\mathrm{mg} / \mathrm{kg}$ unless otherwise noted. 
Most of the concentration maxima were located in boring SAI-5. Boring SAI-5 is located near the center of the landfill and penetrated the greatest depth $(39.5 \mathrm{ft})$ of fill/debris of the six borings. Within boring SAI-5, the highest concentrations were located in the fill approximately midway between the surface and fill/residuum interface.

Samples collected from boring SAI-4 contained the second greatest amount of semivolatile compounds, some of which were detected at their maximum concentrations.

Boring SAI-2 had no semivolatile detections. Borings SAI-1 and SAI-6 contained only a few semivolatile compounds, and these were found in the uppermost samples within the fill material. Thus, most of the semivolatile contamination is found near the center of the landfill where the debris/fill has the greatest depth.

Metal contaminants. Background soil samples for metals were not collected as part of the investigation of SA-1. Therefore, background data from a published literature source were used. The published values are for two sampling locations near Blountville and Bristol in northeastern Tennessee (Maher 1973). The samples were taken from residuum overlying Knox Dolomite. These published concentrations are generally lower than concentrations found in soil samples collected at SA-1. They were used as a screening tool to indicate which analytes found at SA-1 may require further evaluation.

Bedrock underneath SA-1 is Maynardville Limestone of the Conasauga Group. The bedrock upslope of SA-1 (e.g., the location of GW-323) is the Copper Ridge Dolomite formation of the Knox Group. In addition, the lithologic log for monitoring well GW-317, located at the southern (upgradient) edge of the site, shows a gradational contact between the Knox Group and the Maynardville Limestone at a depth of 60 to $70 \mathrm{ft}$ (Welch 1989b). The soils present at SA-1 and on the adjacent, upslope part of Chestnut Ridge are classified as belonging to the Fullerton cherty silt loam (USDA 1981), and the soil classification does not change with a change in underlying bedrock. Because the soils developed over both the Maynardville and Knox bedrock units exhibit similar physical characteristics and are classified alike, there is enough similarity in the residual soils to justify using the published chemical data from the Knox Group soils as indicative of background concentrations of metals at SA-1 even though the soils are underlain by the Maynardville Limestone.

One on-site boring, SAI-2 (Fig. 2.21), may be representative of background conditions for the following reasons:

- The boring did not penetrate any debris material; it penetrated only residuum.

- The boring is located on the edge of SA-1 in an upslope direction from the known debris area.

- No organic constituents were identified in soil samples collected from the borehole.

- Concentrations of some metals, such as mercury, barium, and lead, are consistently lower in samples from SAI-2 than in samples from other borings.

Note, however, that the concentrations of inorganics (and radiation parameters) are highly variable in the SAI-2 samples and in some cases exceed concentrations in other

92-043P/072392 
borings. The use of SAI-2 as a background reference is questionable because of its relatively high concentrations and variability of some inorganics.

Metals data comparison. Table 2.14 presents a summary of the metals detected in the SA-1 samples. The detection frequency for the metals was usually $>75 \%$. The exceptions were phosphorus at $51 \%$ and niobium at $8 \%$. Table 2.15 shows, for comparison purposes, the maximum and minimum inorganic concentrations for all soil sampled in SA-1 and relevant soil samples from borings in Tennessee (published values).

In comparing the published maximum concentrations with those from the borings, the SA-1 concentrations were higher for almost every element. The only two exceptions were niobium and potassium. Chromium maxima were about the same-the SA-1 maximum is only $10 \%$ higher than the published maximum.

In summary, all of the detected metals concentrations appear to be higher than background, except for niobium, potassium, and possibly chromium. The high detection frequencies suggest that the contamination is widespread throughout the site.

To facilitate discussion of the extent of metals contamination detected in soil samples at SA-1, this section focuses on only 11 of the 19 metals: arsenic, cadmium, lead, vanadium, barium, chromium, mercury, zinc, beryllium, copper, and nickel.

These metals were selected as indicators for, or representative of, the group of 19 metals. The physical and chemical properties of these 11 metals are believed to be representative of the range of properties for the 19 metals identified as contaminants. Additionally, the list of indicator metals includes those believed to be most potentially dangerous to human health. In contrast with the semivolatiles, which were located almost entirely in the debris, many of the metal maxima appear to be concentrated in the residuum.

Of the metals listed, only barium and mercury have their three uppermost concentrations limited to the fill or debris region. Chromium has relatively high concentrations in both the fill and the residuum. However, soils such as those found at SA-1 may be characterized by high levels of native chromium.

Except for nickel, all of the metal maxima for the fill and debris layer are from borings SAI-4 and SAI-5. These are the same borings that contained the semivolatile maxima. For the residuum layer, the maxima are primarily from borings SAI-1 and SAI-4. The only metals with maximum concentrations in samples from boring SAI-2 were chromium and vanadium. Boring SAI-2 did not penetrate any fill material or debris.

It is useful to compare the fill/debris and residuum maximum concentrations with the literature background concentrations. Most of the fill/debris and residuum maximum concentrations are elevated above background. The exceptions are the barium concentrations in the residuum and chromium concentrations in the fill. The chromium concentration in the residuum is only $\sim 10 \%$ above background. 
Table 215. Comparison of field and background inorganics data for SA-1 soils

\begin{tabular}{|c|c|c|c|c|}
\hline \multirow[b]{2}{*}{ Element } & \multicolumn{2}{|c|}{$\begin{array}{l}\text { Concentrations from soil borings } \\
(\mathbf{m g} / \mathbf{k g})\end{array}$} & \multicolumn{2}{|c|}{$\begin{array}{c}\text { Background concentrations from } \\
\text { literature } \\
(\mathrm{mg} / \mathbf{k g})\end{array}$} \\
\hline & Minimum & Maximum & Minimum & Maximum \\
\hline Aluminum & 3,370 & 61,800 & 13,000 & 19,500 \\
\hline Arsenic & 1.9 & 45.7 & 10 & 10 \\
\hline Barium & 15.3 & 385 & 150 & 150 \\
\hline Beryllium & 0.27 & 11 & 0.10 & $b$ \\
\hline Cadmium & 1.1 & 10.9 & $<0.2$ & $<0.2$ \\
\hline Calcium & 42.9 & 102,000 & 300 & 2,000 \\
\hline Chromium & 6.4 & 54.2 & 30 & 50 \\
\hline Cobalt & 1.7 & 110 & 8 & 30 \\
\hline Copper & 13.3 & 109 & 10 & 20 \\
\hline Iron & 6,360 & 88,700 & 15,000 & 42,000 \\
\hline Lead & 6.5 & 670 & 10 & 30 \\
\hline Magnesium & 532 & 25,200 & 1,500 & 5,000 \\
\hline Manganese & 88.6 & 6,930 & 2 & 2 \\
\hline Mercury & 0.05 & 31.5 & No detect & 0.015 \\
\hline Nickel & 4.7 & 173 & 20 & 50 \\
\hline Niobium & 1.8 & 3.3 & 0.5 & 5 \\
\hline Phosphorus & 48.8 & 720 & 80 & 100 \\
\hline Potassium & 411 & 5,430 & 3,500 & 10,000 \\
\hline Sodium & 61.8 & 458 & 9 & 20 \\
\hline Vanadium & 6.8 & 128 & 20 & 20 \\
\hline Zinc & 26.4 & 591 & 30 & 70 \\
\hline
\end{tabular}

This information corresponds to analyses of residual clay overtying a Knox Dolomite at two locations near Blountville and Bristol in northeastern Tennessee; reference is Table 3 of Mahler (1973) for map locations 10 and 12.

bMaher (1973) reported that the concentration was anomalous; the average concentration of Be is $\leq 2$ ppm.

Note: Data summarized from $\mathrm{CH}_{2} \mathrm{M}$ HILL investigation data, Appendix $\mathrm{C}$. 
Statistically significant differences in the fill vs residuum were observed for arsenic, barium, cadmium, copper, lead, vanadium, and zinc. Barium is characterized by higher concentrations in the fill than the residuum; the others have higher concentrations in the residuum. Chromium appears to have roughly equal distributions in the fill and residuum. Beryllium and nickel show a tendency toward higher concentrations in the residuum, but the difference between the fill and residuum profiles is not statistically significant. Mercury shows a tendency toward higher concentrations in the fill than in the residuum, but this difference also is not statistically significant.

Total uranium. Uranium has an average concentration in the crust of the earth of $\sim 4 \mathrm{mg} / \mathrm{kg}$ (3.0 pCi/g). Literature values for uranium in $\mathrm{Knox}$ residuum range from 0.2 to $1 \mathrm{mg} / \mathrm{kg}$ (Maher 1973). These relatively low concentrations suggest that naturally occurring uranium is probably not very prevalent in the soils at SA-1.

In contrast to the literature values, a review of Table 2.14 shows that uranium was detected in every boring and in every sample (detection frequency of $100 \%$ ). For most of the borings, the detected concentrations ranged from 2 to $10 \mathrm{mg} / \mathrm{kg}$ and thus exceeded published values for Knox residuum (Maher 1973). This upper limit of $10 \mathrm{mg} / \mathrm{kg}$ is low, but it typically corresponds more to a mineral-rich soil than to Knox residuum. Samples from two of the borings produced uranium concentrations $>10 \mathrm{mg} / \mathrm{kg}$ : boring SAI-5 had a maximum of $42 \mathrm{mg} / \mathrm{kg}$, and SAI-6 had a maximum of $80 \mathrm{mg} / \mathrm{kg}$.

The Y-12 Plant is a probable source of the uranium. The Y-12 Plant now has $\sim 85$ exhaust stacks serving operations that have the potential for generating airborne radioactive uranium. Stacks exist for both depleted and enriched uranium operations. Those stacks that did not meet National Emission Standards for Hazardous Air Pollutants (NESHAP) standards were equipped with emission-control systems. In addition, wind rose patterns for the Y-12 Plant indicate that predominant wind directions are to the southwest and the northeast (Energy Systems 1991). Because SA-1 is located in the southwest corner of the Y-12 Plant, some deposition of uranium particles could occur at the site. Assuming deposition occurred before, during, and after operation or buildup of SA-1, the uranium would be distributed at all depths throughout the landfill.

Three of the four highest concentrations of uranium $(80,68.9$, and $18 \mathrm{mg} / \mathrm{kg}$ ) were found in boring SAI-6. One sample in boring SAI-5 residuum had a uranium concentration of $42 \mathrm{mg} / \mathrm{kg}$. All of the other concentrations are $\leq 10 \mathrm{mg} / \mathrm{kg}$. The distribution of uranium concentrations in residuum does appear to be displaced toward higher concentrations than the fill/debris distribution.

Radiological contaminants. Table 2.14 summarizes the radiological constituents detected in soil samples. The analyses performed were for gross alpha, gross beta, total radium, and ${ }^{235} U$. The first three analyses were reported in units of picocuries per gram, whereas the ${ }^{235} U$ analysis was in weight percent of total uranium.

Gross alpha. Gross alpha was detected on all the samples except one. This finding corresponds to a detection frequency of $98 \%$. The maximum specific activity detected was $12 \mathrm{pCi} / \mathrm{g}$. Background levels of gross alpha for SA-1 are unknown. More importantly, the SA-1 results are less than the adopted reporting level of $15 \mathrm{pCi} / \mathrm{g}$. Although gross alpha was 
detected in almost all the SA-1 samples and appears to be widespread, the gross alpha results are not high enough to warrant a significant concern for alpha-emitting contamination.

Groes beta. The detection frequency for gross beta was $94 \%$. The maximum specific activity detected was $37.4 \mathrm{pCi} / \mathrm{g}$. Background levels of gross beta for SA-1 are unknown. However, the maximum concentration is below the adopted reporting level of $50 \mathrm{pCi} / \mathrm{g}$. Thus, although beta-emitting contamination appears to be widespread, the gross beta results do not appear to be high enough to warrant significant concern.

Total radium. The detection frequency for radium was $100 \%$. The maximum concentration detected was $7.6 \mathrm{pCi} / \mathrm{g}$. Background concentrations of radium at the site are unknown. It has been estimated that radium concentrations in soils located in the United States have a general range of 0.8 to $2.81 \mathrm{pCi} / \mathrm{g}$ (IAEA 1990). Some of the concentrations detected at SA-1 are higher than the upper bound of this estimated range.

In summary, radium appears to be prevalent over the site and exists at slightly elevated levels, but it is still below the adopted reporting level of $15 \mathrm{pCi} / \mathrm{g}$. Thus, total radium does not appear to warrant significant concern.

Uranium-235. One of the isotopes of uranium is ${ }^{235} \mathrm{U}$. All soil samples collected were to have been analyzed for total uranium using fluorometric uranium analysis. When a result from the total uranium analysis was $>5 \mathrm{mg} / \mathrm{kg}$, that sample was analyzed for ${ }^{235} \mathrm{U}$ using Thermal Ionization Mass Spectrometry (TIMS). TIMS provided a value for the ${ }^{235} U /{ }^{238} U$ ratio in units of weight percent of total uranium. If the total uranium result was $<5 \mathrm{mg} / \mathrm{kg}$, the value obtained was reported, and no ${ }^{235} U$ analysis was performed. Weight percent results were reported for 21 samples.

The detected minimum, average, and maximum values for ${ }^{235} \mathrm{U}$ in soil were $0.29,0.627$, and $1.0 \mathrm{wt} \%$, respectively. The natural abundance of ${ }^{235} \mathrm{U}$ is $0.72 \mathrm{wt} \%$. This value can vary by as much as 0.1 wt $\%$, depending on the source. However, the detected range at SA-1 ( 0.29 to $1.0 \%$ ) is wider than the expected range $(0.62$ to $0.82 \%)$ for naturally occurring uranium. This finding suggests that the elevated levels of uranium at the site contain enriched and depleted fractions of uranium. This finding was not unexpected given that stack emissions occur at the Y-12 Plant from both enriched and depleted uranium operations.

\subsection{Biomonitoring Data}

Ecological studies of the Bear Creek Watershed were initiated by staff in the ORNL ESD in May 1984 and are continuing at present. The study plan consisted of an initial, detailed characterization of the benthic invertebrate and fish communities in Bear Creek in the first year followed by a subsequent reduction in sampling intensity during the monitoring phase of the study.

The objectives of the ecological studies on Bear Creek have initially been to characterize the ecological condition of Bear Creek and then to monitor any ecological recovery associated with various remedial actions to be taken in the watershed. To accomplish the first objective the existing environment in Bear Creek was characterized using two approaches: (1) instream sampling of the benthic invertebrate and fish communities to identify spatial and temporal patterns in distribution and abundance and (2) laboratory bioassays on water samples from 
Bear Creek and selected tributaries to identify potential sources of toxicity to biota. Periodic monitoring has continued following completion of the initial characterization studies in July 1985.

Because of the existence of an established biological monitoring program that is highly directed toward monitoring recovery of Bear Creek and the location of a biological monitoring site adjacent to OU 2 (Fig. 2.22), biological monitoring is not addressed in this RI Plan.

\subsection{Radiation Survey}

There are no indications that radiation surveys have been conducted at any of the sites in OU 2. 

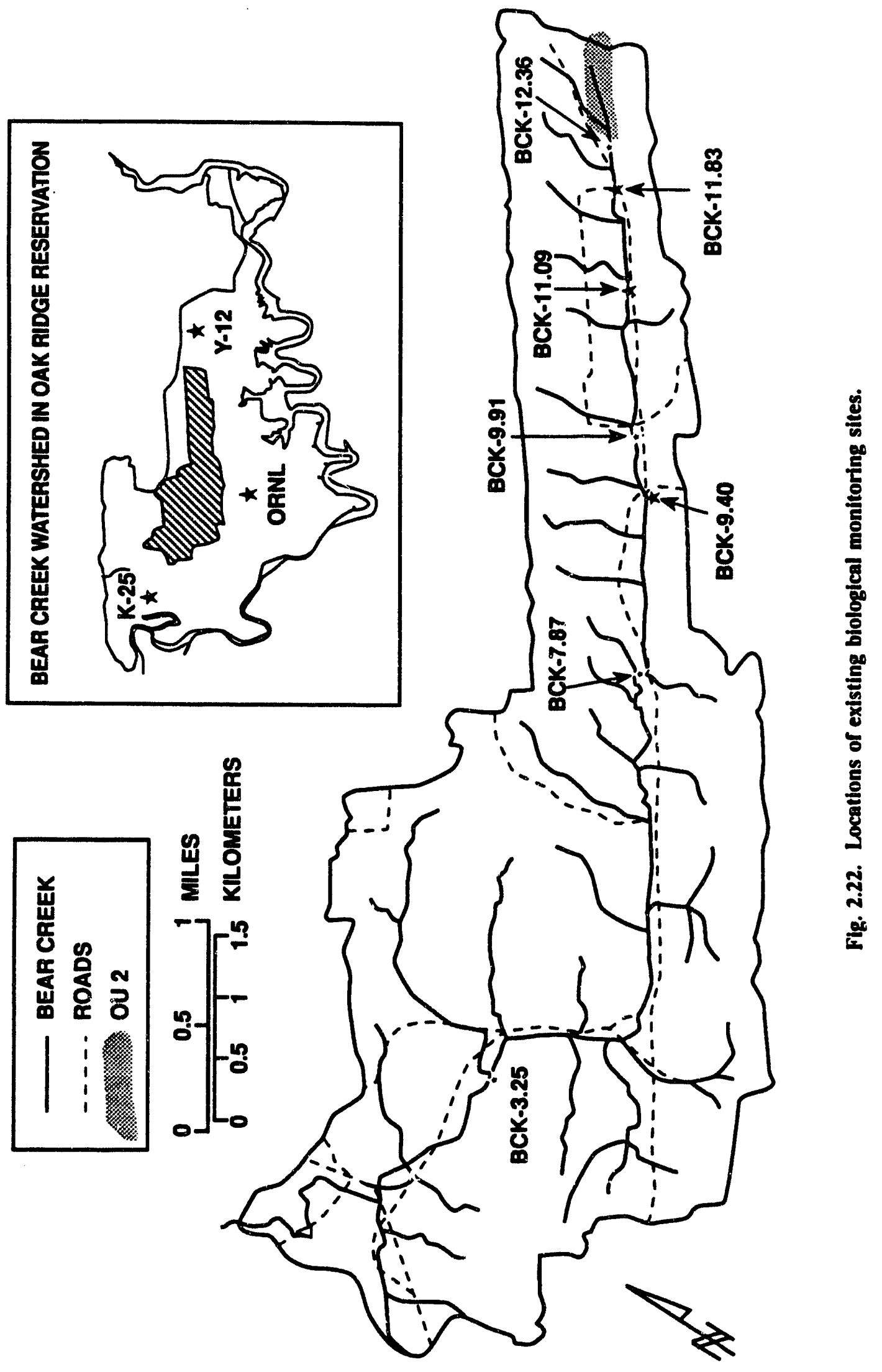
-

-

- 


\section{DATA QUALITY OBJECTIVES (DQOs)}

\subsection{DQO STAGE 1: IDENTIFICATION OF DECISION TYPES}

\subsubsection{Identification and Involvement of Data Users}

In addition to characterization of the nature and extent of contamination, data collected as part of the RI will be used in risk assessment and alternative evaluation for the OU. The immediate decisions resulting from analysis of the OU 2 RI results will be based on the level of risk associated with the site and the need to conduct an immediate corrective action, further investigations, or no further investigation. At the same time, decisions about the types of remedial actions, whether to reduce imminent dangers or to address long-term solutions, will be considered. A primary objective of the RI is to provide the data necessary for evaluation of risk and remedial alternative evaluations. To ensure adequate quality and quantity of data, experts in risk assessment and remedial alternative development have been involved in development of the work plan.

\subsection{Evaluation of Available Information}

Available information for the site (e.g., operational information, historical monitoring data) have been summarized Sect. 2. Evaluation of the available data proceeds from a determination of the data quality (based on protocols and procedures used in sampling and analysis) to an analysis of the data, in conjunction with the site conceptual model, to identifying any site-characterization data gaps.

Characterization data collected as part of previous RI investigations at the RSA and SA-1 were subject to strict quality measures (EPA Leve! III, see Appendix C) as are all groundwater quality data collected as part of the sitewide groundwater quality assessment program. As a result, these data are acceptable in terms of data quality. Characterization data from the SY-200 site appear to be of acceptable quality, but incomplete with the extent of the contaminants unknown because of site activities (i.e., filling and subsequent disturbances).

\subsubsection{Conceptual Site Model}

A conceptual site model has been developed for the site and is discussed in detail in Sect. 4. In summary, the conceptual site model focuses on the soil medium, the transformations within that medium, and the pathways to receptors. The groundwater and surface water/sediment media are being characterized as parts of the sitewide assessment monitoring programs.

\subsubsection{Remedial Investigation Objectives}

The results of previous investigations within OU 2 have helped to define the nature and extent of contamination. The general objectives of the OU 2 RI include (1) further definition of the nature and extent of contamination in media of concern (i.e., soil), especially at the 
SY-200 Yard, and (2) gathering information for the specific needs of the risk assessment and FS. Specific objectives include:

- defining the nature of soil contamination at SY-200;

- defining the extent (vertical and horizontal) of soil contamination at SY-200;

- filling any identified data gaps in the extent of soil contamination at RSA and SA-1;

- defining the interaction (transfer mechanism) between soil contaminants and shallow groundwater; and

- defining the relative contribution of OU 2 contaminants to BCV groundwater and surface water contamination.

\section{DQO STAGE 2: IDENTIFY DATA USES/NEEDS}

\section{Identification of Dała Uses}

Data collected during the OU 2 RI (described in Sect. 7) will be used for site characterization (e.g., nature and extent of contamination, transfer paths), an evaluation of risks to receptors from contaminants at the site, and the evaluation of possible site remedial actions.

\section{Identification of Data Types}

Table 3.1 summarizes the DQOs of the OU 2 RI by listing sampling plan objectives, required sample media and analytical parameters, and the ultimate use of the data.

\section{Identification of Data Quantity Needs}

Based on the results of previous investigations at the RSA and SA-1, data quantity needs are limited. The history of SY-200 suggests that characterization of distributed contamination will require more data from an extensive, systematic sampling program (see Sect. 7).

\section{Identification of Data Quality Needs}

With the exception of health and safety monitoring data and physical measurements collerted during site operations (EPA Level I), all data collected as part of the OU 2 RI will be accompanied by an EPA Data (Quality Level IV deliverable (see Sects. 6 and 7). All data will be validated at Level IV. 


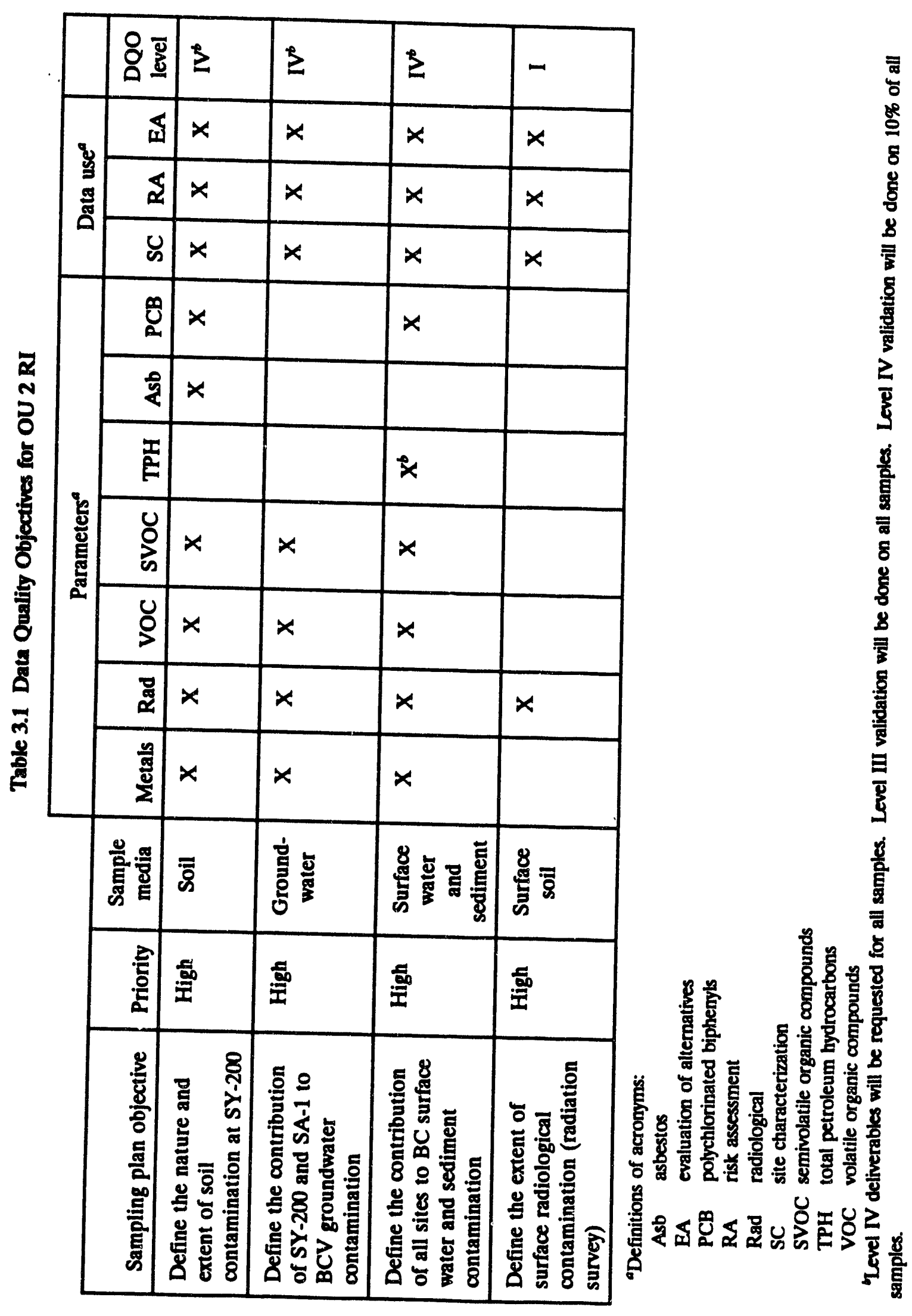




\subsection{Evaluation of Sampling and Analysis Options}

All sampling activities at the sites will be preceded by walkover radiation surveys. The results of those surveys will be evaluated to verify that the proposed level of field health and safety is adequate and to identify any previously unidentified areas warranting investigation.

After incorporating the walkover results into the sampling plan, the field team will implement the field sampling plan (FSP). Implementation of the FSP entails collecting samples from targeted locations and depths. Throughout the sampling events, the field team will use direct reading instruments (e.g., radiation meters, mercury vapor analyzers, photoionization detectors) and visual examination to identify additional or preferable sample intervals.

\subsection{Reviewing and Utilizing Precision, Accuracy, Representativeness, Completeness, and Comparability (PARCC) Information}

The PARCC parameters have been reviewed and incorporated in the planning for the field sampling and analyses. Incorporation of field duplicates into the sampling plan (Sect. 7) will provide some measure of precision (a combination of sampling and analytical factors). Requirements for a minimum of Level III analytical data with accompanying analyses of QC samples will provide an adequate measure of accuracy.

Representativeness and comparability are addressed by use of standard sampling and analysis procedures (Kimbrough et al. 1990). Completeness is a goal (e.g., 85-90\%) for the amount of acceptable data sufficient to support the decisions at a site. Critical samples (e.g., shallow groundwater samples at SA-1 and SY-200) have been identified and plans made to achieve valid data from them (e.g., duplicates or resampling).

\subsection{DQO STAGE 3: DESIGN DATA COLLECTION PROGRAM}

\subsubsection{Assemble Data Collection Components}

A detailed summary of all proposed samples and corresponding quality assurance/quality control (QA/QC) samples is presented in the FSP (Sect. 7).

\subsubsection{Develop Data Collection Documentation}

The data collection documentation (e.g., specific sampling and analysis procedures, forms, data tracking procedures) are discussed in the FSP (Sect. 7) and in the field and laboratory QA plans (Sects. 8 and 9). 


\section{CONCEPTUAL SITE MODEL}

A conceptual site model has been developed (Fig. 4.1) to guide RI sampling design. The components of that model are discussed in the following sections.

\subsection{POTENTIAL PATHWAYS OF MIGRATION}

\subsubsection{Soil}

Leachate produced by water moving through the soil may provide aqueous transport for dissolved chemicals within the unsaturated soil sequence. In a porous, homogeneous soil, contaminants tend to move primarily downward within the unsaturated zone through diffusion and mass flow mechanisms until they reach the water table or an impermeable horizon. However, contaminants also move laterally through dispersion and diffusion caused by changes in the soil structure or composition, or fractures, of seasonally water-saturated soil. In addition, debris buried in spoil areas can affect contaminant migration. Buried debris can create impermeable layers that laterally divert leachate or that enhance vertical movement of leachate because of density or compaction differences. Therefore, contaminant migration in the soil media within spoil areas may be enhanced both vertically and horizontally. Soil or clay caps have been placed over both spoil areas (RSA and SA-1) to reduce water infiltration into the soil matrix and, consequently, to reduce contaminant migration resulting from leachate movement.

Existing evidence indicates that the majority of the metal contaminants of concern at SA-1 are migrating from the fill material present at the sites and are being absorbed in the underlying native soil residuum. This process of absorption of contaminants into the soil matrix is believed to inhibit the transport of certain contaminants of concern into the groundwater media especially if the soil matrix possesses a neutral or elevated $\mathrm{pH}$. A few of the metals, in particular mercury, barium, and chromium, appear to be relatively immobile in the soil and are expected to be retained in the fill and debris of the landfill. In addition, the semivolatile organic compounds detected at RSA are characterized by relatively low volatility and low solubility in water. The semivolatiles are expected to be relatively immobile in the soil and to remain partitioned in the fill and debris of the landfill.

\subsubsection{Surface Water}

Surface water transport of contaminants from sites within OU 2 is possible. The flow of surface water over and through areas of contaminated soil provides a potential for transportation and redeposition of contamination. The potential for surface water transport of contaminants at the spoil areas has been greatly reduced by capping these sites with compacted clay and top soil followed by the establishment of a vegetative cover. However, no such activity has taken place at the SY-200 site, leaving it more susceptible to the potential effects of surface water on contaminant migration. In addition, surface water will eventually erode and penetrate the clay/top soil cap at SA-1, thereby increasing the potential for surface water transport of contaminants at this site. 


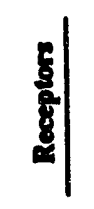

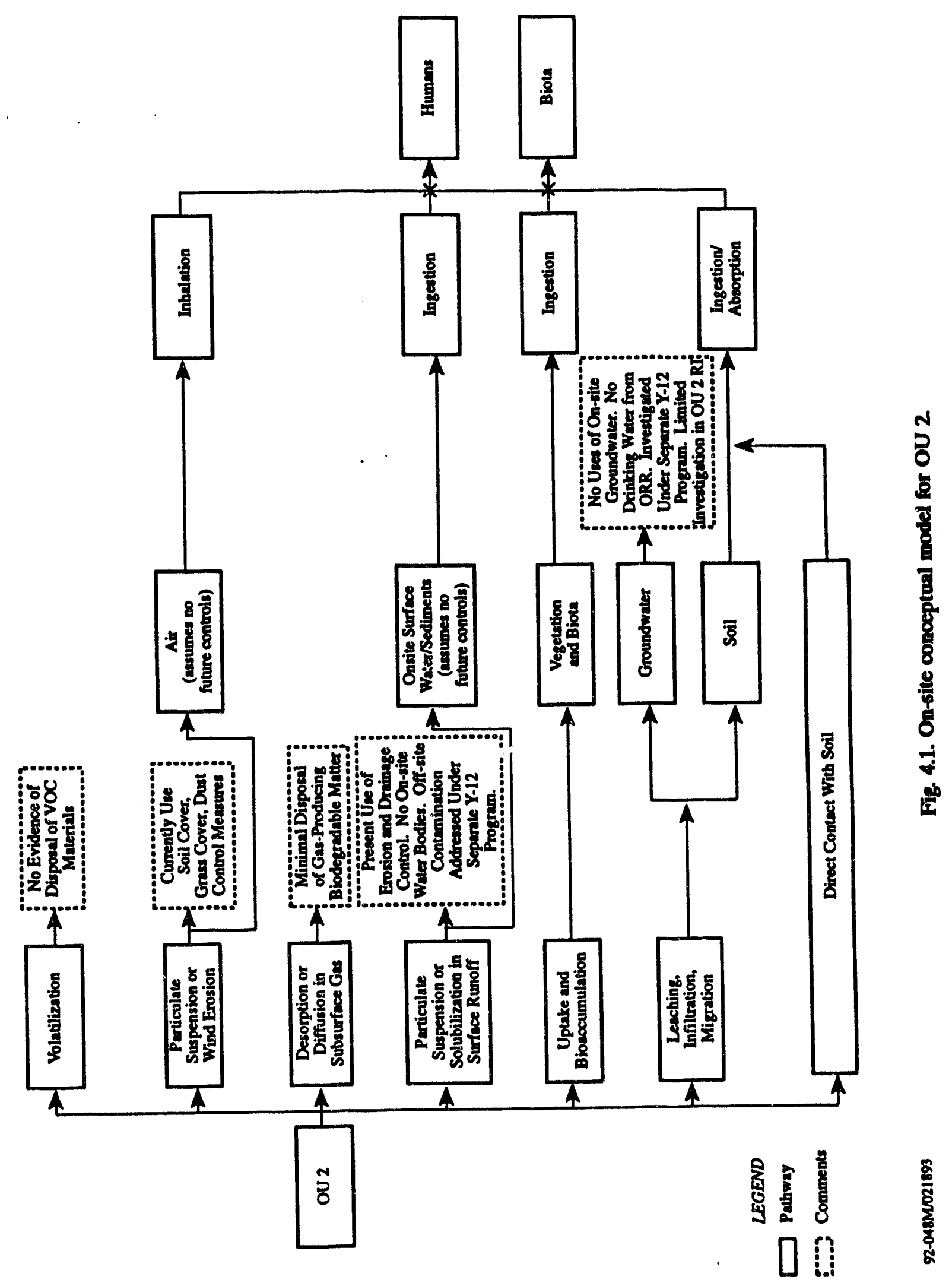

!l 


\subsubsection{Groundwater}

The most likely mechanism for contaminant transport is precipitation infiltration resulting in contaminant leaching into the groundwater system. As previously mentioned in the discussion of SA-1, the potential for contaminant movement into the groundwater system is reduced because the sorptive properties of the soils and contaminants restrict the mobility of the contaminants. These conditions are aiso expected to occur in the SY-200 area. In addition, clay/top soil caps installed at the spoil areas reduce the leaching potential by reducing surface water infiltration. Nevertheless, groundwater is believed to present the greatest potential for contaminant migration at each site, particularly at SY-200, which does not currently have a surface cap tn reduce surface water infiltration.

The potential for groundwater transport of contaminants from OU 2 will be appraised by evaluating existing groundwater analytical data from monitoring wells located hydraulically downgradient of the sites. In general, contaminant transport parallels the direction of groundwater movement. The large number of potential contaminant sources located hydraulically upgradient and cross-gradient of OU 2 makes it necessary to evaluate existing groundwater analytical data in the area to accurately determine the groundwater migration of contaminants from OU 2.

\subsubsection{Air}

Airborne contamination from OU 2 is believed to be minimal. The greatest potential for airborne transport of contaminants would be resuspension of contaminated particles into the atmosphere caused by excavation of soils at the sites. The potential for airborne transport of contamination has been reduced at the spoil areas by installing the compacted clay/top soil caps and the vegetative covers.

\subsubsection{Biological}

The possibility of uptake of contaminants by biota is expected to be minimal. No surface vegetation is present at the SY-200 site, and the compacted clay cap overlying the spoil areas is believed to reduce the potential for biota uptake at these sites.

\section{POTENTIAL RECEPTORS}

\subsubsection{Human Populations}

The Y-12 Plant is a part of the DOE ORR, which covers $\sim 35,000$ acres. The Y-12 Plant is located along the northeastern boundary of the ORR adjacent to the city of Oak Ridge. Although adjacent to Oak Ridge, the Y-12 Plant is situated in a rural area, and no residences or drinking water sources are located on the plant site. In addition, because of security precautions, the presence of persons at the facility is controlled. Consequently, the potential for human exposure to contamination is minimized. The operational period of the plant is projected to be 30 years. 


\subsubsection{On-site potential human receptors}

Employment at the Y-12 Plant, as of January 1992, consisted of 7934 full-time on-site personnel, the majority of which work in the main Y-12 Plant complex in the northeast part of the ORR. OU 2 is situated to the southwest of the main Y-12 Plant complex in an area that the majority of employees do not frequent. Therefore, the exposure potential for the majority of facility employees is minimal.

On-site workers have the greatest risk of exposure to contaminants from OU 2. Because the spoil areas have been closed and no activity now takes place at the SY-200 site, exposure to on-site personnel is limited to a small group of maintenance-type workers. The exposure to on-site workers will increase slightly with implementation of this work plan and possible future remedial actions at each site. However, occupational exposure will be negligible because of health and safety measures that will be employed.

A hypothetical future use scenario, involving a resident on the site, will be included to address the potential for land-use change.

\subsection{Off-site potential human receptors}

It is anticipated that no off-site human receptors will be exposed to contamination resulting from OU 2 because of the rural and unpopulated nature of the Y-12 Plant. The off-site exposure potential is further minimized by access to the facility being restricted to authorized personnel and the remote nature of OU 2. In addition, there are no drinking water sources on the ORR. The greatest potential for off-site human exposure is believed to be from surface water runoff into the adjacent Bear Creek. The potential for exposure to off-site populations is again considered to be minimal.

Regional demography. The regional demography is discussed in detail in Sect. 2.5 of this document.

Sensitive subpopulations. Because of the remote location of OU 2 , no sensitive subpopulations are believed to be potentially at risk.

\subsection{Ecological Populations}

\subsubsection{Flora}

Vegetation in the Bear Creek Watersheil is predominantly oak, oak-hickory associations on the upper slopes and ridgetops, and planted pine along the creek and floodplain area. Pine Ridge is generally an oak, oak-hickory association with chestnut oak, red oak, tulip poplar, white oak, and hickory as the dominant species. The lower areas along Bear Creek and Bear Creek Road are mainly planted loblolly pine with some scattered areas of planted shortleaf, natural pine, and oak-hickory communities. Also of interest is a large area of big bluestem grass that grows along Bear Creek Road. Large stands of this species are uncommon in east Tennessee. This site is being considered as a I'ational Environmental Research Park (NERP) Reference Area. More detailed information is available for portions 
of the Bear Creek Watershed area in forest compartment maps and various documents (Bradburn and Rosenbalm 1984; Parr and Pounds 1987). Table 4.1 contains a listing of flora and fauna found within the ORR.

\subsection{Terrestrial fauna}

OU 2 contains elements of the majority of wildlife habitat types found on the ORR (Table 4.1), and, therefore, the expected terrestrial fauna is that described for the entire reservation (Welch 1989a).

Hardwood and mixed hardwood/conifer habitats compose the most abundant habitat type in Bear Creek Watershed, followed by pine plantation and grassland habitats, with considerable riparian habitat along the length of Bear Creek. Species commonly found in these habitats are listed below.

Old-field and grassland habitat. In the grassland/forb stage of vegetation, the principal species of small mammals are the southeastern shrew, least shrew, short-tailed shrew, eastern harvest mouse, hispid cotton rat, pine mouse, and the eastern cottontail rabbit. The eastern mole occurs in areas of loose soil. Closely mowed or grazed areas and dense kudzu growth is good habitat for the groundhog. Also found there are the striped skunk, coyote, red fox, and white-tailed deer. In more brushy vegetation, the white-footed mouse, golden mouse, and opossum may be found. Bird species found in this habitat include bobwhite, red-tailed hawk, field sparrow, towhee, blue grosbeak, meadowlark, and red-winged blackbird. The eastern bluebird population has increased with the establishment of bluebird nesting boxes. The yellow-breasted chat is found in old fields. Numerous frog, toad, lizard, and snake species are found in the old-field areas.

Hardwood and mixed hardwood/conifer habitats. In wooded areas the eastern gray and southern flying squirrels, southeastern shrew, eastern mole, short-tailed shrew, white-footed mouse, white-tailed deer, and eastern chipmunk may be found. Predators such as the bobcat and weasel occur here. Birds commonly found in forest areas (Kroodsma 1991) include the yellow-shafted flicker, red-bellied woodpecker, hairy woodpecker, downy woodpecker, blue jay, Kentucky warbler, pine warbler, ovenbird, Carolina chickadee, tufted titmouse, and scarlet tanager. Hawks (red-shouldered, red-tailed, and broad-winged) are commonly found on the ORR, as are wild turkeys, which have been reintroduced to the area in recent years. Amphibians and reptiles found in the forest habitat include the dusky salamander, American toad, eastern box turtle, ground skunk, worm snake, black racer, rat snake, black king snake, milk snake, and copperhead.

Pine plantation habitat. Very early stages of planted pine areas contain species similar to those in old-field habitats, and the small mammals present are much the same as in the late stages of old fields. The populations tend to be smaller, though, because of less tree diversity. Pine plantations with a dense canopy and no understory are essentially barren of both small and large mammals except around the edges. As plantations are thinned and canopies opened, undergrowth develops and provides habitat for species similar to those found in earlyto mid-stage hardwood-mixed hardwood/conifer forests. Avian species have a low preference 
Table 4.1. Flora and fauma found within the Oak Ridge Reservation

\begin{tabular}{|c|c|}
\hline Common name & Scientific name \\
\hline & \\
\hline American chestnut & Castanea dentata \\
\hline Northern red oak & Quercus borealis \\
\hline Chestnut oak & Q. prinus \\
\hline Yellow poplar & Liriodendron tulipifera \\
\hline Shortleaf pine & Pinus echinata \\
\hline Virginia pine & P. virginiana \\
\hline Beech & Fagus grandifolia \\
\hline Sugar maple & Acer saccharum \\
\hline Magnolia & Magnolia acuminata and $M$. tripetala \\
\hline Buckeye & Aesculus glabra \\
\hline Willow & Salix sp. \\
\hline Sycamore & Platanus occidentalis \\
\hline Boxelder & Acer negundo \\
\hline Loblolly pine & Pinus taeda \\
\hline Hickory & Carya sp. \\
\hline Hemlock & Tsuga canadensis \\
\hline White pine & Pinus strobus \\
\hline Eastern red cedar & Juniperus virginianus \\
\hline Redbud & Cercis canadensis \\
\hline Sassafras & Sassafras albidum \\
\hline Cottonwood & Populus deltoides \\
\hline Elm & Ulmus sp. \\
\hline Ash & Fraxinus sp. \\
\hline Silver maple & Acer saccharinum \\
\hline River birch & Betula nigra \\
\hline White oak & Quercus alba \\
\hline Blaikk oak & Q. velutina \\
\hline Scarlet oak & Q. coccinea \\
\hline
\end{tabular}


Table 4.1 (continued)

\begin{tabular}{|c|c|}
\hline Common name & Scientific name \\
\hline Post oak & Q. stellata \\
\hline Black gum & Nyssa sylvatica \\
\hline Dogwood & Comus florida \\
\hline Basswood & Tilia americana \\
\hline Bluestem & Andropogon sp. \\
\hline Bluegrass & Poa sp. \\
\hline Orchard grass & Dactylis glomerata \\
\hline Ragweed & Ambrosia artemisifolia \\
\hline Crabgrass & Digitaria sp. \\
\hline Horse week & Conyza canadensis \\
\hline Primrose & Oenothera sp. \\
\hline Honeysuckle & Lonicera japonica \\
\hline Broomsedge & Andropogon virginicus \\
\hline Trumpet creeper & Campsis radicans \\
\hline Sumac & Rhus typhina and $R$ copallina \\
\hline Persimmon & Diospyros vinginiana \\
\hline White poplar & Populus alba \\
\hline Watercress & Nasturtium sp. \\
\hline Cattail & Typha sp. \\
\hline \multicolumn{2}{|c|}{ Manmals } \\
\hline Little brown bat & Myotis lucifugus \\
\hline Keen's bat & Myotis keenii \\
\hline Silver-haired bat & Lasionycteris noctivagans \\
\hline Eastern pipistrelle & Pipistrellus subflavus \\
\hline Big brown bat & Eptesicus fuscus \\
\hline Red bat & Lasiunus borealis \\
\hline Hoary bat & Lasiurus cinereus \\
\hline Virginia oppossum & Didelphis virginiana \\
\hline Least shrew & Cyptotis parva \\
\hline
\end{tabular}


Table 4.1 (continued)

\begin{tabular}{|c|c|}
\hline Common name & Scientific name \\
\hline Southeastern shrew & Sorex longirostis \\
\hline Short-tailed shrew & Blarina breyicauda \\
\hline Southern short-tailed shrew & B. carolinensis \\
\hline Gray myotis & Myotis grisescens \\
\hline Indiana myotis & M. sodalis \\
\hline Eastern cottontain & Sylvilagus floridanus \\
\hline Eastern chipmunk & Tamias striatus \\
\hline Gray squirrel & Sciurus carolinensis \\
\hline Fox squirrel & S. niger \\
\hline Southern flying squirrel & Glaucomys Volans \\
\hline Marsh rice rat & Oryzomys palustris \\
\hline Cotton rat & Sigmodon hispidus \\
\hline Norway rat & Rattus norvegicos \\
\hline White-footed mouse & Peromyscus leucopus \\
\hline House mouse & Mus muscolus \\
\hline Cotton mouse & P. gossypinus \\
\hline Golden mouse & Ochrotomys nuttali \\
\hline Eastern harvest mouse & Reithrodontomy shumulis \\
\hline Woodland (Pine) vole & Microfus pinetorum \\
\hline Eastern mole & Scalopos aquaticos \\
\hline Muskrat & Ondatra zibethica \\
\hline Red fox & Vulpes vulpes \\
\hline Gray fox & Urocyon cinereoargenteus \\
\hline Coyote & Canis latrans \\
\hline Black bear & Ursus americanus \\
\hline Ground hog & Marmota monax \\
\hline Racoon & Procyon lotor \\
\hline Striped skunk & Mephitis mephitis \\
\hline Eastern spotted skunk & Spilogale putorius \\
\hline Long-tailed weasel & Mustela frenata \\
\hline
\end{tabular}


Table 4.1 (continued)

\begin{tabular}{ll}
\hline \multicolumn{1}{c}{ Common name } & \multicolumn{1}{c}{ Scientific name } \\
\hline Mink & Mustela vison \\
Beaver & Castor canadensis \\
Mountain lion (eastern cougar) & Felis concolor \\
Bobcat & Lynx rufus \\
White-tailed deer & Odocoileus virginianus
\end{tabular}

Binds

Sharp-shinned hawk

Cooper's hawk

Red-shouldered hawk

Broad-winged hawk

Southern bald eagle

Marsh hawk

Osprey

Peregrine falcon

Ruffed grouse

Bobwhite

Turkey

Mourning dove

Common (yellow-shafted) flicker

Red-bellied woodpecker

Hairy woodpecker

Downy woodpecker

Red-cockaded woodpecker

Blue jay

Common crow

Carolina chickadee

Tuffed titmouse

Bewick's wren

Wood thrush
Acciptier striatus

A. cooperii

Buteo lineatus

B. playtpterus

Haliaeetus L leucocephalus

Circus cyaneus

Pandion haliaetus

Falco peregrinus

Bonasa umbellus

Colinus vinginianus

Meleagris gallopavo

Zenaida macroura

Colaptes auratus

Melanerpes carolinus

Picoides villosus

$P$. pubescens

$P$. borealis

Cyanocitta cristata

Corvus brachyrhynchos

Parus carolinensis

P. bicolor

Thryomanes bewickii

Hylocichla mustelina 
Table 4.1 (continued)

\begin{tabular}{|c|c|}
\hline Common name & Scientific name \\
\hline Red-eyed vireo & Vireo olivaceus \\
\hline Pine warbler & Dendrocia pinus \\
\hline Ovenbird & Seiurus aurocapillus \\
\hline Kentucky warbler & Oporomis formosus \\
\hline Yellow-breasted chat & Icteria virens \\
\hline Scarlet tanager & Piranga olivacea \\
\hline Summer tanager & P. rubra \\
\hline Cardinal & Cardinalis cardinalis \\
\hline Rufous-sided towhee & Pipilo enthrophthalmus \\
\hline Grasshopper sparrow & Ammodramus savannarum \\
\hline Bachman's sparrow & Aimophila aestivalis \\
\hline White-throated sparrow & Zonotrichia albicollis \\
\hline \multicolumn{2}{|c|}{ Reptiles and amphibians } \\
\hline Eastern narrowmouth toad & Gastrophryne carolinensis \\
\hline Northern cricket frog & Acris creptians \\
\hline Spring peeper & Hyla crucifer \\
\hline Gray treefrog & Hyla versicolor \\
\hline Upland chorus frog & Pseudacris triseriata \\
\hline Bullfrog & Rana catesbeiana \\
\hline Green frog & Rana clamitans \\
\hline Pickerel frog & Rana palustris \\
\hline Southern leopard frog & Rana sphenocephala \\
\hline American toad & Bufo americanus \\
\hline Fowler's toad & B. woodhousei \\
\hline Hellbender & Cryptobranchus alleganiesis \\
\hline Northern dusky salamander & Desmognathus fuscus \\
\hline Red-spotted newt & Notophthalmus viridescens \\
\hline Tennessee cave salamander & Gyrinophilus palleucus \\
\hline Mudpuppy & Necturus malulosus \\
\hline
\end{tabular}


Table 4.1 (continued)

\begin{tabular}{|c|c|}
\hline Common name & Scientific name \\
\hline Red-backed salamander & Plethodon cinereus \\
\hline Slimy salamander & P. glutinosus \\
\hline Northern red salamander & Pseudotriton r. Tuber \\
\hline Spotted salamander & Ambystoma maculatum \\
\hline Marbled salamander & Ambystoma opacum \\
\hline Two-lined salamander & Eurycea bislineata \\
\hline Spring salamander & Gyrinophilus porphyriticus \\
\hline Murt salamander & Pseudotriton montanus \\
\hline Snapping turtle & Chelydra serpentia \\
\hline Map turtle & Graptemys geographica \\
\hline Eastern must turtle & Sternotherus odoratus \\
\hline Stripe-necked musk turtle & Sternotherus minor \\
\hline Spiny softshell turtle & Apalone spinifera \\
\hline Yellow-bellied turtle & Chrysemys scripta \\
\hline Eastern box turtle & Terrapene carolina \\
\hline Northern copperhesis & Agkistrodon contortrix mokasen \\
\hline Six-lined racerunner & Cnemidophorus sexlineatus \\
\hline Northern black racer & Coluber constrictor \\
\hline Timber rattlesnake & Crothalus h. horridus \\
\hline Black rat snake & Elaphe obsoleta \\
\hline Ground skink & Scincella lateralis \\
\hline Five-lined skink & Eumeces fasciatus \\
\hline Broodhead skink & Eumeces laticeps \\
\hline Eastern hognose snake & Heterodon platyrhinos \\
\hline Northern water snake & Natrix s. sipedon \\
\hline Fence lizard & Sceloporus undulatus \\
\hline Northern brown snake & Storeria d. dekayi \\
\hline Eastern garter snake & Thamnophis s. sirtalis \\
\hline Worm snake & Carphophis amoenus \\
\hline Scarlet snake & Cemophera coccinea \\
\hline
\end{tabular}


4-12

Table 4.1 (continued)

\begin{tabular}{|c|c|}
\hline Common name & Scientific name \\
\hline Ringneck snake & Diadophis punctatus \\
\hline Corn snake & Elaphe guttata \\
\hline Mole snake & Lampropeltis calligaster \\
\hline Milk snake & Lampropeltis tringulum \\
\hline Common king snake & Lampropeltis getula \\
\hline Pine snake & Pituophis melanoleucus \\
\hline Common water snake & Nerodia sipedon \\
\hline Rough green snaike & Ophedodrys aestivus \\
\hline Queen snake & Regina septemvittata \\
\hline Brown snake & Storeria dekayi \\
\hline Redbelly snake & Storeria occipitomaculata \\
\hline Smooth earth snake & Vüginia valeriae \\
\hline \multicolumn{2}{|c|}{ Fish } \\
\hline Rock bass & Ambloplites rupestris \\
\hline Common shiner & Notropis cornutus \\
\hline White sucker & Catostomus commersoni \\
\hline Blacknose dace & Rhinichthysctratolos \\
\hline Mountain red belly dace & Phoxinos oreas \\
\hline Stoneroller & Campostoma anomalum \\
\hline Creek chob & Semotilus atromaculatus \\
\hline Northern hogsucker & Hypentelium nigricans \\
\hline
\end{tabular}


for the pure pine areas bordering the transmission line corridors. Pine warblers and whitethroated sparrows are common, but few other species are evident. These habitats are little used by reptiles or amphibians (Johnson 1964).

Aquatic and riparian habitats. Many reptiles and amphibians occur in the various aquatic and wetland areas, including turtles, queen snake, water snake, salamanders, and frogs. The muskrat and beaver are bound closely to aquatic habitats. Rice rats, mink, and raccoons are also found in these areas. Many large mammals come frequently to this habitat to drink, and various small species are present at the water's edge. The American bald eagle occurs occasionally as a transient. The Canada goose, great blue herons, and green-backed herons nest on the ORR.

Rare and endangered species. Three mammal species on the federal list as endangered may occur on the ORR but have not been verified. These are the gray bat (Myotis grisescens), Indiana bat (Myotis sodalis) and eastern cougar (Felis concolor). Only one mammal species listed by the Tennessee Wildlife Resources Agency (TWRA) as in need of management, the southeastern shrew (Sorex longirostris), is known to occur on the reservation (Kroodsma 1987). The pine snake, Pituophis melanoleucas, is listed as tisreatened by the TWRA, and its presence in the Bear Creek Watershed has been verified. The Cooper's hawk (Accipiter striatus) occurs in forests throughout the ORR and is listed by the state as threatened (Kroodsma 1987).

\subsection{Aquatic fauna}

Nineteen species of fish have been found in Bear Creek in recent quantitative monitoring efforts conducted at seven sites along virtually the entire length of Bear Creek. Minnows (blacknose dace, $R$ hinichthys atratulus; mountain redbelly dace, Phoxinus oreas; stoneroller, Campostoma anomalum; and creek chub, Semotilus atromaculatus) were the predominant constituents of the fish fauna upstream from the weir at BCK-4.55. Below the weir, larger species (northern hogsucker, Hypentelium nigricans; white sucker, Catastomus commersoni; and rockbass, Ambloplites rupestris) were more common, the diversity of minnow species increased, and darters were found. Conclusions of the recent fish-monitoring studies were that much of Bear Creek had a limited fish fauna (low species richness) characterized by robust population parameters (high densities and biomass). The uppermost site (BCK-12.36) did not have a stable, resident fish population. Water from this site was commonly toxic to fathead minnow larvae in toxicity testing and contained high levels of dissolved salts as a result of input of contaminated groundwater from the S-3 Pond site. The next two monitoring sites downstream, BCK-11.83 and BCK-11.09, had low fish density and biomass in 1984-85 but showed recovery in later sampling. No impacts on the fish fauna of Bear Creek were evident in the vicinity of inputs from the burial grounds (BCK-9.91 and BCK9.40) despite the fact that qualitative surveys of tributaries (NT-6-8) draining that site found no fish to be present.

No endangered or threatened fish species have been found in Bear Creek. However, the mountain redbelly dace, a major constituent of the fish population above the weir at BCK-4.55, is listed as a species in need of management. Its habitat is protected by the state 
of Tennessee (Starnes and Etnier 1980). In Bear Creek, it occurs at every site above the weir and in at least four tributaries (NT-13, NT-14, NT-18, and ST-7).

Quantitative sampling of benthic invertebrates was conducted monthly at nine sites from BCK-12.36 to BCK-3.25 from June 1984 through May 1985 as part of Phase I of the ecological monitoring program for Bear Creek and at quarterly intervals thereafter. A total of 126 distinguishable taxa was collected in Bear Creek, including crustaceans (Isopoda, Amphipoda, and Decapoda), aquatic worms (Oligochaeta), snails (Gastropoda), mussels (Pelecypoda) and insects (Insecta). Eleven orders of insects were collected in Bear Creek, including springtails (Collembola), mayflies (Ephemeroptera), dragonflies and damselflies (Odonata), crickets and grasshoppers (Orthoptera), stoneflies (Plecoptera), true bugs (Hemiptera), alderflies and fishflies (Megaloptera), caddisflies (Tricoptera), butterflies and moths (Lepidoptera), beetles (Coleoptera), and true flies (Diptera).

The invertebrate fauna of Bear Creek showed a pattern of increasing density, biomass, and taxonomic diversity and richness with increasing distance downstream from the uppermost sampling site (BCK-12.36). The paucity of benthic invertebrates found in the upper reaches of Bear Creek contrasted sharply with reference sites (unimpacted streams of similar size), which had relatively diverse and abundant assemblages of macroinvertebrates. Water from BCK-12.36 and BCK-11.83 was toxic to Ceriodaphnia, an invertebrate test species, but not to fathead minnow larvae, in toxicity tests run in March 1988. At the time of these tests, streamflow in Bear Creek was higher than normal, and contaminants from the S-3 Pond groundwater plume were diluted more than would be the case under baseflow conditions. Under low-flow conditions, it is likely that Bear Creek water would be toxic to Ceriodaphnia as far downstream as BCK-9.4. While evidence of adverse effects on the fish communities of Bear Creek was not noted at sites downstream from BCK-11.83, the benthic fauna appeared to be more sensitive, with clear differences in faunal composition from unimpacted reference sites at all sites except BCK-3.25, where complete recovery appears to have occurred. Species intolerant of pollution (mayflies, stoneflies, and caddisflies) were absent in the upper reaches and became more common downstream. Mayflies, which are particularly sensitive to toxic metals, were virtually absent at all sites except BCK-3.25. Unlike the fish data, which provide evidence of ecological recovery in Bear Creek since 1984, the benthic macroinvertebrate fauna do not appear to have changed in a manner indicative of either improving or degrading water quality since 1984.

No threatened or endangered species of aquatic macroinvertebrates have been collected in Bear Creek.

A limited amount of data have been collected on the bioaccumulation of contaminants by aquatic biota in Bear Creek. Fish collected from lower Bear Creek contained elevated levels of mercury (0.2-0.5 $\mu \mathrm{g} / \mathrm{g}$, wet weight) in 1982 (Van Winkle et al. 1984), and 1984 (TVA 1985). While well below the U.S. Food and Drug Administration action level, these data do indicate the presence of biologically available mercury in the Bear Creek system. Fish from lower Bear Creek were also analyzed for cadmium, chromium, silver, arsenic, and nickel in 1984 (TVA 1985), and levels were found to be typical of fish from uncontaminated environments. 
PCB contamination in fish from Bear Creek was evident in 1982, when rockbass collected from the lower reaches of the creek were found to contain $0.65 \pm 0.29 \mathrm{ppm}$ (wet wt) PCBs. TVA analyzed fish from lower Bear Creek for organic priority pollutants, including PCBs in 1984; levels of all substances were below detection limits. Fish were collected from lower Bear Creek in 1987 as part of an effort to evaluate the importance (relative to other sources) of the EFPC discharge at New Hope Pond as a source of PCB contamination to lower Poplar Creek and the Clinch River. In this colleciion, PCBs in rockbass averaged $0.28 \pm 0.12 \mathrm{ppm}$ $(n=8)$, a value comparable to the level of contamination found in sunfish in the lower third of EFPC and well above the level typical of fish from uncontaminated sites $(0.02 \pm$ $0.01 \mathrm{ppm})$. Clams held in Bear Creek (BCK-4.55) for 1 month as part of the same study accumulated $1.01 \mathrm{ppm}$ PCBs (vs $0.05 \mathrm{ppm}$ in controls), indicating that Bear Creek now contains a source of biologically available PCBs.

PCB contamination has been observed in fish in EFPC, Poplar Creek, and the Clinch River/Watts Bar Reservoir downstream from Bear Creek (TVA 1985). It is unlikely that a substantial fraction of this contamination is attributable to Bear Creek because sources of PCBs and similar levels of contamination are found in fish from these systems far upstream from the mouth of Bear Creek (TVA 1985). A similar situation exists for mercury (TVA 1985).

\subsection{POTENTIAL EXPOSURE PATHWAYS}

A potential exposure pathway is the means by which a contamirant moves from a source to a receptor. Generally, a complete exposure pathway has five elements:

- a contaminant source,

- a mechanism for contaminant release,

- an environmental transport medium,

- a point of potential human contact with the contaminated medium referred to as the exposure point, and

- a feasible route of exposure.

Exposure could occur if soil contaminants migrate from the site to an exposure point or when a receptor comes into direct contact with waste or contaminated media at the site. An exposure pathway is complete if there is a way for the receptor to take in contaminants through ingestion, inhalation, or dermal absorption of contaminated media or waste. The following subsections discuss the potential exposure pathways in terms of OU 2.

\subsubsection{Ingestion}

The potential exists for ingestion of contaminants released as a result of activities at OU 2. Ingestion of contaminants could occur from exposure to groundwater, soil, and surface 
water that may function as transport mediums for contaminants released at OU 2. The soil medium is believed to pose the greatest risk of contaminant exposure through ingestion and inhalation.

The soil medium presents the potential risk for ingestion of contaminants through incidental contact with on-site workers during site sharacterization and potential remedial actions. The potential for ingestion is greatly lessened during these activities because workers are safety-trained and a site-specific health and safety plan is implemented. Because of the limited population potentially exposed to the soil medium and the health and safety planning, the potential for exposure to contaminants through soil ingestion is very limited.

Exposure to contaminants through ingestion of groundwater could occur if the groundwater has become contaminated by soil leachate and if the groundwater is used as a drinking water source. The potential exists for contaminants leaching into the groundwater at OU 2; however, the groundwater on the ORR is not used as a drinking water source. Furthermore, many of the contaminants of concern are suspected to be immobilized in the soil and thus are not likely to leach into the groundwater in high concentrations. Because of the documented groundwater contamination at the Y-12 Plant, which is being addressed under a separate RI, it is believed that OU 2 will likely have an insignificant impact on groundwater. Consequently, the potential for exposure to populations by ingestion of contaminants that may result from OU 2 is considered minimal or nonexistent.

Exposure to contaminants through the ingestion of surface water could occur if the surface water is used as a drinking water source and it has been contaminated by groundwater recharge or surface water erosion and transport of contaminated soil. Surface water is not used as a drinking water source, and there are no downgradient residential uses on the ORR. The potential for surface water contamination due to soil erosion and transport is lessened by the compacted-clay and top-soil caps installed at OU 2 spoil areas. The potential exposure of populations to contaminants through surface water ingestion is considered minimal or nonexistent.

\subsubsection{Inhalation}

The potential exists for inhalation of contaminants at OU 2. Inhalation of potentially contaminated particulates will likely only occur in situations where the subsurface soil is disturbed. The presence of compacted clay and top soil caps and vegetative covers at the spoil areas significantly reduces the potential for inhalation exposure at undisturbed sites. The potential for inhalation exposure is likely to be greatest for on-site workers participating in site characterization and remedial actions in which subsurface soils are disturbed. Because of the limited population potentially exposed in this scenario and the implementation of site-specific health and safety plans during these activities, the potential for inhalation of contaminants is very low.

\subsubsection{Dermal Contact}

Dermal contact is a potential exposure pathway at OU 2. Potential exposure through dermal contact will be limited to on-site workers participating in site characterization and 
remedial actions. The potential for exposure through dermal contact is very low due to the implementation of site-specific health and safety plans during these activities and the limited population potentially exposed.

\subsubsection{External Exposure to Radionuclides}

The potential for external exposure to radionuclides exists at OU 2. Potential radiological exposure could occur from being directly exposed to external gamma from contaminated soil. Under current conditions, exposure is limited to on-site patrol guards and maintenance workers. Future exposure could occur to on-site workers participating in site characterization or remedial activities. The exposure potential for on-site workers is lessened by the implementation of on-site health and safety plans. The risk of external radiological exposure is considered to be low because of the limited population potentially affected.

\subsection{RISK ASSESSMENT METHODOLOGY}

A screening risk assessment will be prepared for OU 2 from existing data and data collected during the RI. The methodology employed to conduct the risk assessment will follow the guidelines established in the risk assessment guidance document for Superfund (EPA 1989). In addition, recommendations from the ER Central Risk Assessment Co incil and other supporting documentation will be followed. Data collected as part of this RI will support development of an ecological risk assessment as part of an integrated Bear Creek Valley RI. 


\section{SCOPING}

\subsection{APPLICABLE OR RELEVANT AND APPROPRIATE REQUIREMENTS (ARARs)}

CERCLA was passed by Congress and signed into law on December 11, 1980 (Public Law 96-510). This act was intended to provide for "liability, compensation, cleanup, and emergency response for hazardous substances released into the environment and the cleanup of inactive waste disposal sites." SARA, adopted on October 17, 1986 (Public Law 99-499), did not substantially alier the original structure of CERCLA but provided extensive amendments to it.

In particular, Sect. 121 of CERCLA specifies that remedial actions for cleanup of hazardous substances must comply with requirements or standards under federal or more stringent state environmental laws that are applicable or relevant and appropriate to the hazardous substances or particular circumstances at a site. Inherent in the interpretation of ARARs is the assumption that protection of human health and the environment is ensured.

The purpose of this section is to supply a preliminary list of available federal and state chemical- and location-specific ARARs that might be considered for OU 2. This list of ARARs represents a compilation of potential ARARs of which subsets will be used or additional ARARs added as site-specific contamination at OU 2 is characterized. No actionspecific ARARs are presented here; they will be developed as remedial alternatives are identified during the RI/FS.

RSA is located 0.4 miles west of the Y-12 Plant on Old Bear Creek Road. It served as a solid waste disposal area for nonuranium contaminated construction debris generated by Rust Engineering, a DOE prime contractor, during various renovation, maintenance, and construction operations from 1975 to 1983 . The site was closed in 1984 under the TDEC Division of Solid Waste Management regulations by capping the fill area with $2 \mathrm{ft}$ of clean soil and planting vegetation. Although Bear Creek borders the northern edge of the area and the eastern edge is bordered by a spring-fed tributary of Bear Creek which discharges into Bear Creek, there are no surface waters directly on the Spoil Area. Storm runoff flows directly into Bear Creek or indirectly via the tributary on the eastern border. Direct soil exposure and surface runoff of contaminants is unlikely because the site was closed and capped with the 2-ft layer of clean soil (Welch 1989c). Contaminants identified in the soil at the RSA include heavy metals, VOCs, and radionuclides. The identified contaminants are arsenic, beryllium, lead, mercury, tetrachloroethene, uranium, vanadium, selenium, and thorium (see Record of Conversation, Appendix A, page A-3).

SA-1 is a 5-acre site located west of the Y-12 Plant on Old Bear Creek Road. It began operation in 1980, and TDEC permitted it in 1985 as a landfill for solid waste (Registration Number DML-10-103-0012). In addition, it is listed in the RCRA Facility Investigation Plan General Document for the Y-12 Plant (Welch 1989a) as a RCRA Sect. 3004(u) SWMU under the HSWA general permit for the ORR. Wastes deposited at the site include asphalt, 
masonry and roofing materials, brush, metal, rock, and tile from renovation, maintenance, and construction activities (Welch 1989b). Preliminary assessment has revealed the presence of the following contaminants at the site: aluminum, arsenic, barium, beryllium, chromium, cobalt, copper, iron, lead, mercury, nickel, vanadium, zinc, total uranium, total radium, benzo( $a$ )anthracene, benzo( $a)$ pyrene, benzo $(a, k)$ fluoranthene, chrysene, dibenzofuran, fluoranthene, phenanthrene, pyrcne, and bis(2-ethylhexl)phthalate (see Record of Conversation, Appendix A, page A-3).

The SY-200 Yard lies in BCV between the RSA and SA-1. The site lies just south of the headwaters of Bear Creek near the base of the northern slope of Chestnut Ridge. Surface runoff from the area drains to the northwest into Bear Creek, which flows along the northern perimeter of the area. No detailed records are available that list all items that have been stored at the SY-200 Yard. Known or suspected contaminants are uranium, thorium, PCBs, lead, mercury, asbestos, and alpha activity (see Record of Conversation, Appendix A, page A-3).

Some site-specific characterization of the nature and extent of groundwater contamination will be conducted at the individual sites. Groundwater for the RSA and SA-1 will be characterized as part of the Y-12 Comprehensive Groundwater Monitoring Program. ARARs for groundwater remediation for all three sites in OU 2 will be addressed under that program. Any contamination of Bear Creek will be addressed and remediated under the program for Bear Creek, and ARARs for surface water remediation for Bear Creek will be discussed in that report. This document will address ARARs for the remaining media of concern, soil.

\subsubsection{Definitions}

Applicable requirements are "those cleanup standards, standards of control, and other substantive environmental protection requirements, criteria, or limitations promulgated under Federal or state law that specifically address a hazardous substance, pollutant, contaminant, remedial action, location, or other circumstance at a CERCLA site" (52 FR 32496, August 27, 1987).

Relevant and appropriate requirements are "those cleanup standards, standards of control, and other substantive environmental protection requirements, criteria, or limitations promulgated under Federal or state law that, while not applicable to a hazardous substance, pollutant, contaminant, remedial action, location, or other circumstance at a CERCLA site, address problems or situations sufficiently similar to those encountered at the CERCLA site that their use is well-suited to the particular site" (52 FR 32496).

CERCLA on-site remedial response actions must only comply with the substantive requirements of a regulation and not the administrative requirements to obtain federal, state, or local permits [CERCLA \$121(e) and FFA \$XXI]]. To ensure that CERCLA response actions proceed as rapidly as possible, EPA has reaffirmed this position in the final National Contingency Plan (NCP) (55 FR 8756, March 8, 1990). Substantive requirements pertain directly to the actions or conditions at a site, while administrative requirements facilitate their implementation. EPA recognizes that certain of the administrative requirements such as 
consultation with state agencies, reporting, etc., are accomplished through the state involvement and public participation requirements of the NCP. These administrative requirements should be observed if they are useful in determining cleanup standards at the site (55 FR 8757).

In the absence of federal- or state-promulgated regulations, there are many criteria, advisories, guidance values, and proposed standards that are not legally binding but may serve as useful guidance for setting protective cleanup levels. These are not potential ARARs but are "to-be-considered" (TBC) guidance.

\subsubsection{Chemical-Specific ARARs}

"Chemical-specific requirements set health or risk-based concentration limits or discharge limitations in various environmental media for specific hazardous substances, pollutants, or contaminants" (52 FR 32496). These requirements generally set protective cleanup levels for the chemicals of concern in the designated media or else indicate a safe level of discharge that may be incorporated when considering a specific remedial activity.

\subsubsection{Soil}

Very little legislation or guidance is available governing cleanup criteria for contaminated soils at CERCLA sites. Because SA-1, RSA, and SY-200 Yard are listed as RCRA Sect. 3004(u) SWMUs, any remedial actions at OU 2 are subject to RCRA corrective action regulations if toxicity testing of soils reveals the presence of RCRA characteristic hazardous waste as defined in 40 CFR 261. Requirements for corrective action for SWMUs have been proposed (55 FR 30798, July 27, 1990). A final rule is expected to appear in January 1993. EPA proposes a risk-based approach to establish media cleanup standards for surface water, groundwater, soil, and air. These standards are to be established at concentrations that ensure protection of human health and the environment and are to be set for each media of concern during the remedy selection process. Target cleanup levels may initially be set at the proposed RCRA action levels and modified as appropriate to reflect site-specific exposure assumptions (55 FR 30826).

SA-1 is registered with TDEC as a solid waste landfill, making it subject to Tennessee state regulations [Tennessee Code Annotated (TCA) 68-31-101-107] governing solid waste disposal facilities. One of the conditions listed in the registered permit for SA-1 states that a final cover of at least $2 \mathrm{ft}$ of compacted soil shall be applied within 1 week following completion of the demolition site. In addition, Rules of the TDEC, Chapter 1200-1-7-.03, require the subrnittal of a closure/postclosure plan for solid waste disposal facilities. TDEC has already contacted the Y-12 Plant Manager requesting submittal of a closure/postclosure plan for SA-1 by November 1992 (see TDEC correspondence, Appendix A, pages A-4 and A-5). Negotiation with state officials may be necessary to coordinate closure under the state solid waste disposal regulations with closure under CERCLA.

EPA has promulgated a final rule establishing a new 40 CFR Part 258, which sets forth revised minimum federal criteria for municipal solid waste landfills ( $56 F R$ 50978, October 9 , 1991). These include closure and postclosure care requirements ( 40 CFR 258.60 and 258.61),

92-043P/072392 
including a final cover consisting of a 6-in. erosion layei underlain by an 18-in. infiltration layer and 30-year postclosure maintenance and groundwater monitoring. Although not legally applicable to remedial action sites found at $\mathrm{OU} 2$, they may prove relevant and appropriate for closure of landfills. These regulations will be analyzed further as action-specific ARARs are addressed.

RCRA has addressed land disposal of treated hazardous wastes in its land disposal restrictions (LDRs) (40 CFR Part 268). The LDRs are triggered by movement of RCRA hazardous waste from one unit (SWMU) and placement into another unit. However, EPA has determined that current best demonstrated achievable technologies listed in the LDR regulations are generally inappropriate or unachievable for soil and debris from CERCLA response actions (55 FR 8760). Therefore, EPA is proposing separate rulemakings to establish treatment standards for disposal of such contaminated soil and debris. The Advance Notice of Proposed Rulemaking (ANPRM) for debris appeared in 56 FR 24444, May 30, 1991; the Notice of Proposed Rulemaking (NPRM) January 9, 1992 (57 FR 958); and the final ruie, June 1992. The proposed rule requires contaminated debris to be treated prior to land disposai using extraction, destruction, or immobilization technologies. Six different categories of debris and ten different categories of contaminants are specified in the rule. As with mixed waste, debris contaminated with both hazardous and radioactive waste must comply with the treatability standards for contaminated debris as well as those under the Atomic Energy Act. Disposal of treated debris and resultant wastes are discussed in the proposed rule.

The ANPRM for soil appeared October 24, 199i (56 FR 55160), the NPRM is scheduled for May 1992, and the final rulemaking for May 1993. These will be analyzed as ARARs or TBC when available. EPA has developed guidance for obtaining and complying with a treatability variance for soil and debris that are contaminated with RCRA hazardous wastes for which treatment standards have already been set (Office of Solid Waste and Emergency Response Directive 9347.3-06FS, July 1989). Alternate treatment levels are presented for structural functional groups of organics and for ten inorganics based on actual treatment of soil and best management practices for debris. These will Le considered as TBC guidance when renedial alternatives are selected and more information becomes available on waste types.

Several sections of RCRA require promulgation of corrective action regulations; when finalized, these requirements will most likely be ARARs for CERCLA remedial actions. Currently, only the 40 CFR 264 Subpart F regulations on groundwater protection at units regulated by RCRA are potential ARARs to CERCLA corrective actions within facility boundaries, and these include groundwater protection standards (40 CFR 264.92 and 264.94) and groundwater monitoring requirements ( 40 CFR 264.97). The corrective action standards developed under RCRA Sect. 3004(u) will be applicable to any CERCLA cleanup site that is also an active or a formerly active RCRA facility with an active SWMU; thus, the standards will also be applicable to a CERCLA site where disposal is currently occurring. In addition, RCRA Sect. 3004(v) authorizes cleanup beyond facility boundaries.

The regulations found in the Toxic Substances Control Act (TSCA) contain storage, disposal, and cleanup requirements for materiali contaminated with PCBs. These regulations

92-043P/072392 


\section{$5-5$}

limit concentrations of $\mathrm{PCBs}$ disposed of in soil to $50 \mathrm{ppm}$ and require that any soils containing concentrations of PCBs greater than $50 \mathrm{mg} / \mathrm{kg}$ (ppm) (40 CFR 761.60) be incinerated ( 40 CFR 761.70) or stored in a chemical waste landfill (40 CFF 761.75). TSCA also specifies requirements that must be achieved for PCBs disposed of by incineration (40 $C F R$ 761.70), in a chemical waste landfill ( $40 C F R$ 761.75), or by other disposal methods [40 CFR 761.60(a)(5)(iii)].

\subsection{Other TBC guidance}

EPA has suggested cleanup values for lead in soils based on studies of blood lead levels in exposed children. The EPA OSWER Directive 9355.4-02 (dated September 7, 1989) recommends a cleanup level for soils of 500 to $1000 \mathrm{ppm}$ lead.

In the absence of federal- or state-promulgated ARARs, or in the case where ARARs are not adequately protective, EPA states a preference for reference doses (RIDs) and refernnce concentrations (RfCs) for systemic toxicants and slope factors or carcinogen potency factors (CPFs) for carcinogens (EPA 1989). RfDs, RfCs, and CPFs are available through the EPA Integrated Risk Information System (IRIS) (EPA 1990b) and EPA Health Effects Assessment Summary Tables (EPA 1992). The information found in IRIS is frequently in flux, as it is constantly undergoing EPA review and verification. Therefore, chemicalspecific values are not included here.

Although not an ARAR, EPA has published a TSCA PCB spill cleanup policy (52 FR 10688 ) which recommends cleanup standards for $\mathrm{PCBs}$ of $25-50 \mathrm{ppm}$ for sites with restricted access; a 10-ppm cleanup level is recommended for residential and unrestricted access rural areas. In this latter case, a 10-in. cap of clean soil must cover the site. In the EPA guidance report for remedial actions at Superfund sites containing PCBs, preliminary remediation goals are set at $1 \mathrm{ppm}$ for residential land use (a risk of $10^{-5}$ ) and between 10 and $25 \mathrm{ppm}$ for industrial and/or remote areas (a risk of $10^{-4}$ ) (EPA 1990a). Alternatives should reduce concentrations to these levels or limit exposures. EPA also presents an approach to deriving cleanup levels of PCBs in sediments (EPA 1990). This approach results in "sediment quality criteria" as a function of organic carbon concentrations and is meant to protect wildlife consumers of freshwater benthic species. These values are considered TBC guidance, not ARARs.

\subsubsection{Radiation Prótection Standards}

There are presently no EPA regulations appropriate for consideration of cleanup of radioactively contaminated soils. DOE is authorized to control all types of nuclear materials at sites under its jurisdiction and is exempt from the U.S. Nuclear Regulatory Commission (NRC) licensing and regulatory requirements. Therefore, NRC regulations are not considered to be ARARs for CERCLA cleanup at DOE facilities. However, all or parts of individual NRC regulations may be considered relevant and appropriate, depending on the particular conditions at each OU. DOE regulations for handling and cleanup of radioactive materials are outlined in a series of DOE orders that are legally binding to DOE contractors but are not considered by EPA to be ARARs. Therefore, for the purposes of development 
of ARARs, DOE orders will be treated, along with the NRC regulations, as TBC guidance. Table 5.1 summarizes dose limits that appear in the various regulations and DOE orders.

Table 5.1. Radiation protection standards that anay be $A^{\mathbb{V}}$ ARs for OU 2

\begin{tabular}{|c|c|c|c|}
\hline Regulation & Applicability & Exposure conditions & Standard \\
\hline \multirow[t]{2}{*}{10 CFR 20} & $\begin{array}{l}\text { Radiation from facilities } \\
\text { licensed by NRC }\end{array}$ & $\begin{array}{l}\text { Worker exposure } \\
\text { limits in unrestricted } \\
\text { areas }\end{array}$ & 5 rem/year ${ }^{b}$ \\
\hline & & $\begin{array}{l}\text { Public exposure, } \\
\text { unrestricted areas }\end{array}$ & 100 mrem/year \\
\hline 10 CFR 61 & $\begin{array}{l}\text { Licensing requirements } \\
\text { for land disposal of radio- } \\
\text { active waste }\end{array}$ & $\begin{array}{l}\text { Public exposure, all } \\
\text { sources }\end{array}$ & $\begin{array}{l}25 \text { mrem/year } \\
\text { (total body) } \\
75 \text { mrem/year } \\
\text { (thyroid) }\end{array}$ \\
\hline \multirow[t]{3}{*}{ DOE Order 5400.5} & $\begin{array}{l}\text { Radiation Protection of } \\
\text { the Public and the Envi- } \\
\text { ronment }\end{array}$ & $\begin{array}{l}\text { Public exposure, all } \\
\text { sources }\end{array}$ & 100 mrem/year \\
\hline & & $\begin{array}{l}\text { Temporary exemption } \\
\text { maximum limit }\end{array}$ & $500 \mathrm{mrem} /$ year \\
\hline & & $\begin{array}{l}\text { Aquatic organism } \\
\text { exposure, absorbed } \\
\text { dose }\end{array}$ & $1 \mathrm{rad} / \mathrm{d}$ \\
\hline \multirow[t]{2}{*}{ DOE Order $5820.2 \mathrm{~A}$} & $\begin{array}{l}\text { Radioactive Waste } \\
\text { Management }\end{array}$ & $\begin{array}{l}\text { Public exposure, all } \\
\text { sources, excluding air }\end{array}$ & 25 mrem/year \\
\hline & & $\begin{array}{l}\text { Public exposure, } \\
\text { atmospheric releases }\end{array}$ & 10 mrem/year \\
\hline \multirow[t]{3}{*}{ DOE Order 5480.11} & $\begin{array}{l}\text { Radiation Protection for } \\
\text { Occupational Workers }\end{array}$ & $\begin{array}{l}\text { Worker exposure } \\
\text { limits, continuous } \\
\text { exposure }\end{array}$ & $\begin{array}{l}5 \text { mrem/year, } \\
\text { cancer effects }^{c}\end{array}$ \\
\hline & & & $\begin{array}{l}50 \text { mrem/year, } \\
\text { noncancer } \\
\text { effects }\end{array}$ \\
\hline & & $\begin{array}{l}\text { Public exposures, } \\
\text { controlled areas }\end{array}$ & 100 mrem/year \\
\hline
\end{tabular}

"ARARs = applicable or relevant and appropriate requirements.

Final rule of May 22, 1991 (56 FR 23360), effective June 21, 1991. Implementation of this regulation by NRC licensees may be deferred until January 1, 1993. This rule deleted the quarterly limits for occupational exposures and lowered the limit for public exposure from 500 mrem/year to 100 mrem/year.

Proposed as 10 CFR 835 (56 FR 64334, December 9, 1991). 
In addition to hazardous wast $\mathrm{s}$, OU 2 shows evidence of possible radiological contamination of soils with uranium, radium, and thorium. The proper definition of "mixed low-level radioactive and hazardous waste" has caused considerable debate with regard to dual jurisdiction by EPA and NRC. However, EPA has published a clarification of the problem (53 FR 37045, September 23, 1988), as did DOE previously [52 FR 15937, May 1, 1987, and DOE Order 5400.3 ("Hazardous and Radioactive Mixed Waste Program," dated February 22, 1989)]. In effect, mixed wastes are those containing a RCRA hazardous waste as defined in 40 CFR 261 as well as radioactive waste subject to the AEA RCRA regulations apply to the hazardous component of the waste, and AEA regulations apply to the radioactive component.

When the application of both standards is conflicting or inconsistent, RCRA yields to the Atomic Energy Agency. Tennessee received final authorization to regulate radioactive mixed waste on July 3, 1986 (53 FR 37045, September 23, 1988); however, the state has not implemented any regulations or guidance related to the handling of mixed waste (see Memorandum of Conversation, Appendix A, page A-6). On October 24, 1991, the U.S. Senate approved legislation granting DOE an extension through 1993 for storage of mixed waste without penalty (DPW 1991). After that date, DOE would have to seek EPA capacity variances yearly through June 30,1997 , accompanied with annual reports on the availability of technology to meet the RCRA storage requirements. Final passage of the bill is undetermined at this time.

\subsubsection{EPA regulations}

Subpart H of 40 CFR 61 addresses atmospheric radionuclide emissions from DOE facilities and may be applicable to airborne emissions during cleanup of OU 2. EPA has issued a final NESHAP rule (54 FR 51654, December 15, 1989) that limits emissions of radionuclides to the ambient air from DOE facilities to amounts that would not cause any member of the public to receive an effective dose equivalent of 10 mrem/year ( $40 \mathrm{CFR}$ 61.92).

EPA intends to develop environmental radiation protection standards for the disposal of low-level waste (LLW) under 40 CFR 193 and 764. The intent of these standards will be to protect the public health and general environment from potential adverse effects from LLW disposal. These proposed regulations may provide TBC guidance for cleanup of OU 2 and, when promulgated, will be considered as ARARs. This proposed rule, however, is currently on hold pending resolution of the issue with the NRC (Houlberg et al. 1992).

In addition, EPA is developing public health and environmental radiation protection criteria for cleanup of residual radioactive materials at decommissioned DOE, Department of Defense, and NRC-licensed sites, as well as others. These criteria may provide useful TBC guidance for remedial response at OU 2. This rulemaking initiative is presently on hold; however, EPA plans to reactivate it in May 1992 (Houlberg et al. 1992).

\subsubsection{NRC regulations}

As mentioned previously, DOE is not regulated by NRC; however, NRC regulations may be relevant and appropriate and may provide some TBC guidance for cleanup of radioactive 
waste at OU 2. Thus the regulations are summarized here. The standards for protection against radiation (10 CFR 20) were revised recently (56 FR 23360, May 21, 1991). They are designed to limit radiation exposures from NRC-licensed activities. They provide permissible worker exposure limits for restricted areas of 5 rem/year (10 CFR 20.1201) and lowered radiation exposure limits to the general public in unrestricted areas from $500 \mathrm{mrem} / \mathrm{year}$ to $100 \mathrm{mrem} /$ year (10 CFR 20.1301) (Table 5.1).

Appendix B of 10 CFR 20.1001-20.2401 sets annual average concentration limits for radionuclides in airborne and liquid effluents. These represent the radionuclide concentrations which, if inhaled or ingested, would produce a total annual effective dose equivalent of 50 mrem.

NRC has promulgated licensing requirements for land disposal of radioactive waste (10 CFR 61). Part 61 contains procedural requirements and performance standards applicatile to any method of land disposal, with specific technical requirements for near-surface disposal of radioactive waste. Although not legally applicable, the substantive requirements found in this regulation may be relevant and appropriate or provide TBC guidance for remedial options selected at Bear Creek OU 2 and will be addressed when remedial alternatives are selected. 10 CFR 61.41 states that concentrations of radioactive materials released to the environment in all media must not result in an annual dose to an individual that exceeds $75 \mathrm{mrem}$ to the thyroid and $25 \mathrm{mrem}$ to the total body or all other organs (Table 5.1). In addition, reasonable effort must be made to maintain releases of radioactive materials to levels that are "as low as reasonably achievable" (ALARA).

\subsubsection{DOE orders}

As mentioned previously, DOE orders are not promulgated regulations and thus are not considered to be ARARs by EPA. They are, however, legally binding between DOE and Energy Systems because of contractual agreements. The radiation exposure limits defined in DOE Order 5400.5 ("Radiation Protection of the Public and the Environment," February 8, 1990) are an effective dose equivalent of 100 mrem/year from all exposure pathways and all DOE sources of radiation and a dose of less than 500 mrem/year for a single acute exposure. In addition, effluent releases to surface water must not result in exposures to aquatic organisms which exceed an absorbed dose of $1 \mathrm{rad} / \mathrm{d}$. The overriding principle of the DOE order is that all releases of radioactive material shall be ALARA.

DOE Order 5820.2A ("Radioactive Waste Management," September 9, 1988) states that the management of LLW must ensure that external exposure to the waste and concentrations of radioactive material that may be released into surface water and soil does not exceed $25 \mathrm{mrem} / \mathrm{year}$ to any member of the public. Releases to the atmosphere shall not exceed $10 \mathrm{mrem} / \mathrm{year}$. Reasonable effort should be made to maintain releases to the environment to ALARA levels. The order pertains to the management of radioactive waste that is not mixed with RCRA hazardous waste.

DOE Order 5480.11 contains guidelines for worker protection which are similar to those of 10 CFR 20 [i.e., 5 rem/year and 50 rem/year annual effective dose equivalent for stochastic (cancer) and nonstochastic (systemic) effects, respectively, from both internal and external 
sources for continuous exposures]. Also included in the order are standards for the general public when entering a controlled area. Exposures to the public are limited to an effective dose equivalent of $100 \mathrm{mr}$ m/year. As with the other DOE orders, the ALARA principle prevails. Remediation of radionuclide-contaminated soils must be handled so that exposures to on-site workers or public intruders do not exceed these standards. DOE hav proposed for codification in 10 CFR 835 the primary standards for radiation protection of occupational workers from normal operation of DOE facilities ( 56 FR 64334, December 9, 1991). No date for a final rule has been established; however, when promulgated, these standards will then be legally applicable for CERCLA cleanup at DOE sites.

\subsubsection{TBC guidance for radiological risk assessment}

The EPA Office of Radiation Programs has derived slope and unit risk factors for radionuclides of concern at remedial sites for each of three major exposure pathways (inhalation, ingestion, and external exposure to contaminated soil). These are available in the EPA Health Effects Assessment Summary Tables (EPA 1992).

\subsubsection{Location-Specific ARARs}

Location-specific requirements "set restrictions upon the concentration of hazardous substances or the conduct of activities solely because they are in special locations" (53 FR 51394).

\subsubsection{Caves, salt-dome formations, salt-bed formations, and underground mines}

There are no indications of salt-dome formations, salt-bed formations, or underground mines on or near any of the three sites (Lee 1991). However, there apparently are limestone structures under OU 2 which may be subject to cave formation, sinkhole development, and trends of groundwater movement that could cause problems for site modifications (Welch 1989b; Murphy 1988). If any caves are located in areas where remedial activities may occur, the regulations found in RCRA [40 CFR 264.18(c)] which prohibit the placement of noncontainerized or bulk liquid hazardous waste in caves might be ARARs.

\subsubsection{Faults}

Two regionally extensive thrust faults transect $O R R$, the WOM and Copper Creek thrust faults (Ketelle 1991). Although no faults occur directly in the BCV near the Y-12 Plant, the WOM fault has induced some minor folding and major jointing and fracturing of the bedrock near the site (Ketelle 1991). The faults on the ORR are ancient (pre-Holocene) and are stable (Ketelle 1991). The possibility of fault movement is considered extremely unlikely (Chance 1986).

\subsubsection{Wilderness areas, wildlife refuges, wildlife resources, and scenic rivers}

There are no known designated wilderness areas, wildlife refuges, or scenic rivers at OU 2 or within range of the area such that remedial action would likely impact these resources. However, if any remedial action is taken that will impact Bear Creek,which 
borders OU 2 on the north, the Fish and Wildlife Coordination Act and the Tennessee Water Quality Control Act of 1977 [TCA Sect. 69-3-101 et seq. (1987)] may be ARARs.

\subsubsection{Wetlands and floodplains}

The northern portions of the RSA and the SY-200 Yard are within the 100-year flood plain of Bear Creek (Welch 1989c). There is no evidence of wetlands located at, or in the immediate vicinity of OU 2 (Cunningham and Pounds 1991). The Cunningham and Pounds 1991 survey does not purport to be complete however. Therefore the presence or absence of wetlands at the area should be confirmed by on-site inspection. If any remedial actions are chosen that would impact floodplains or wetlands, consideration should be given to Executive Order 11990, 40 CFR 6.302(a), 40 CFR Appendix A, 10 CFR 1022, the Clean Water Act Sect. 404, 40 CFR 230, and 33 CFR 320-330 for applicable requirements.

\subsubsection{Historic sites and archaeoloyical findings}

A number of studies have indicated the presence of abundant archaeological and historic resources on the reservation (Sanders 1984). These surveys are summarized in Volume 3 of the Resource Management Plan for the U.S. Department of Energy Oak Ridge Reservation (Sandars 1984). Although the surveys are not exhaustive of the entire reservation, there appears to be no known archaeological or historic resources at OU 2 (Sanders 1984).

\subsubsection{Rare, threatened, or endangered species}

Many of the animal or plant species known to occur on ORR are listed in the Resource Management Plan for the Oal Ridge Reservation, Vols. 4 and 24 (Parr 1984, Kroodsma 1987). In addition, more recent information on rare plants at the ORR is being compiled (Parr 1992). Although there are a number of state- and federal-listed species on ORR, there are at present no known rare, theatened, or endangered species at OU 2 (Parr 1984, Kroodsma 1987).

\subsubsection{Action-Specific ARARs}

Performance, design, or other action-specific requirements set controls or restrictions on particular kinds of activities related to the management of hazardous waste (52 FR 32496). Selection of a particular remedial action at a site will invoke the appropriate action-specific ARARs that may specify particular performance standards or technologies, as well as specific environmental levels for discharged or residual chemicals. Action-specific ARARs are derived primarily from RCRA, the Clear Air Act, and the Clean Water Act; the action-specific ARARs for OU 2 will be developed during selection of remedial action alternatives.

\subsection{IDENTIFICATION OF POTENTIAL TECHNOIOGIES}

Ine purpose of this section is to identify potential treatment technologies that may apply to OU 2. Based on existing data, each potentially contaminated medium identified is 
evaluated so that additional data may be collected as a part of the RI to identify and develop the most effective remedial action plan.

The media that are potentially contaminated from OU 2 are soil and debris, groundwater, and surface water. Because the potential remediations of groundwater and surface water are being addressed as part of separate assessment programs covering Bear Creek Valley, they are not considered in this RI. Consequently, the treatment alternatives for the soil media are solely addressed in the RI.

Based on the information gathered during previous studies, objectives for the remediation of the site will be formulated and an assessment of the alternatives will be completed. The goal of the alternatives assessment will be to develop cost-effective alternatives that can meet the remediation objectives. To accomplish this goal, remediation technologies and process options will be identified, evaluated for technical feasiblity, and screened to eliminate those that are obviously unsuited to site conditions or contaminants. The retained technology process options will then be assembled into alternatives. These alternatives will be evaluated based on implementability, effectiveness, and cost to reduce the number of alternatives and yet retain a reasonable range of alternatives. The process will be completed in the FS report, in which the alternatives will be defined in detail and evaluated relative to each other.

The remedial action alternatives considered for OU 2 are listed in Table 5.2. The remedial technologies are presented in association with the applicable general response action. General response actions have been developed for contaminated soil and debris suspected at OU 2. The response action categories are designed to address the environmental and public health effects of the contaminants, possible migration pathways, and exposure routes of the contaminated media.

The remedial technologies have undergone preliminary screening to identify those that potentially apply to OU 2 . Table 5.3 presents the results of the screening process along with the options available for each technology and comments on the potential effectiveness, implementability, and cost of each technology. 


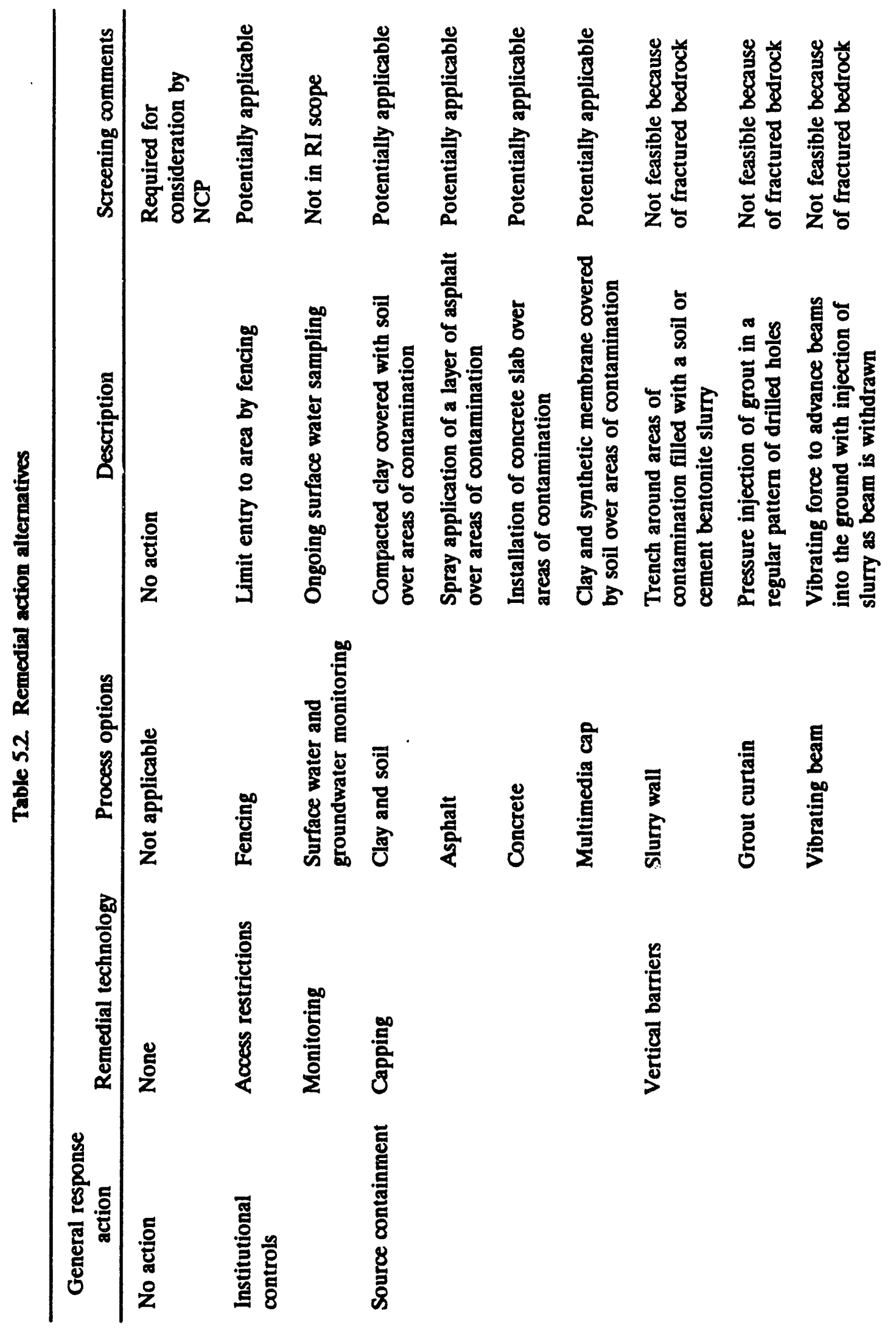




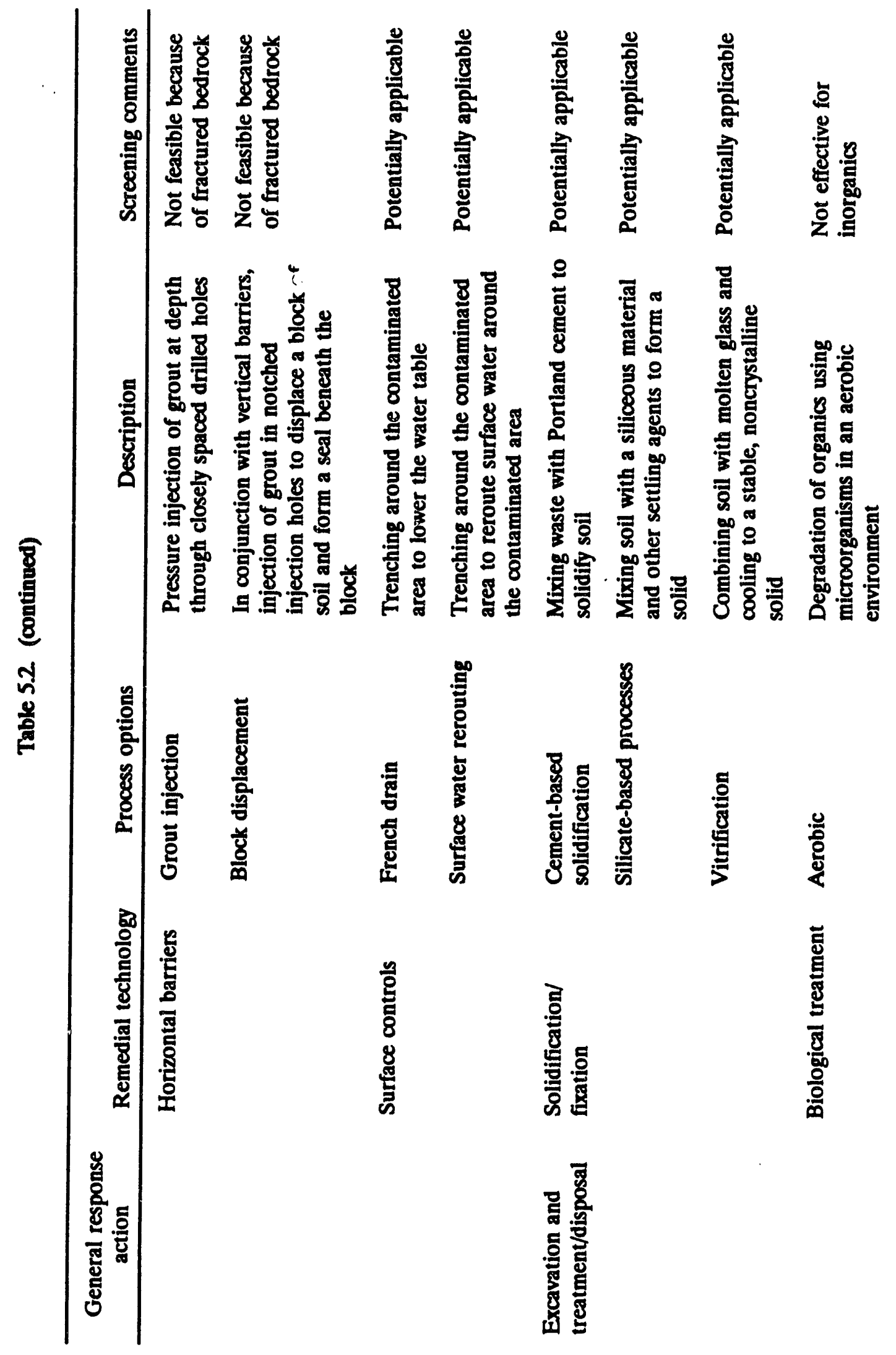




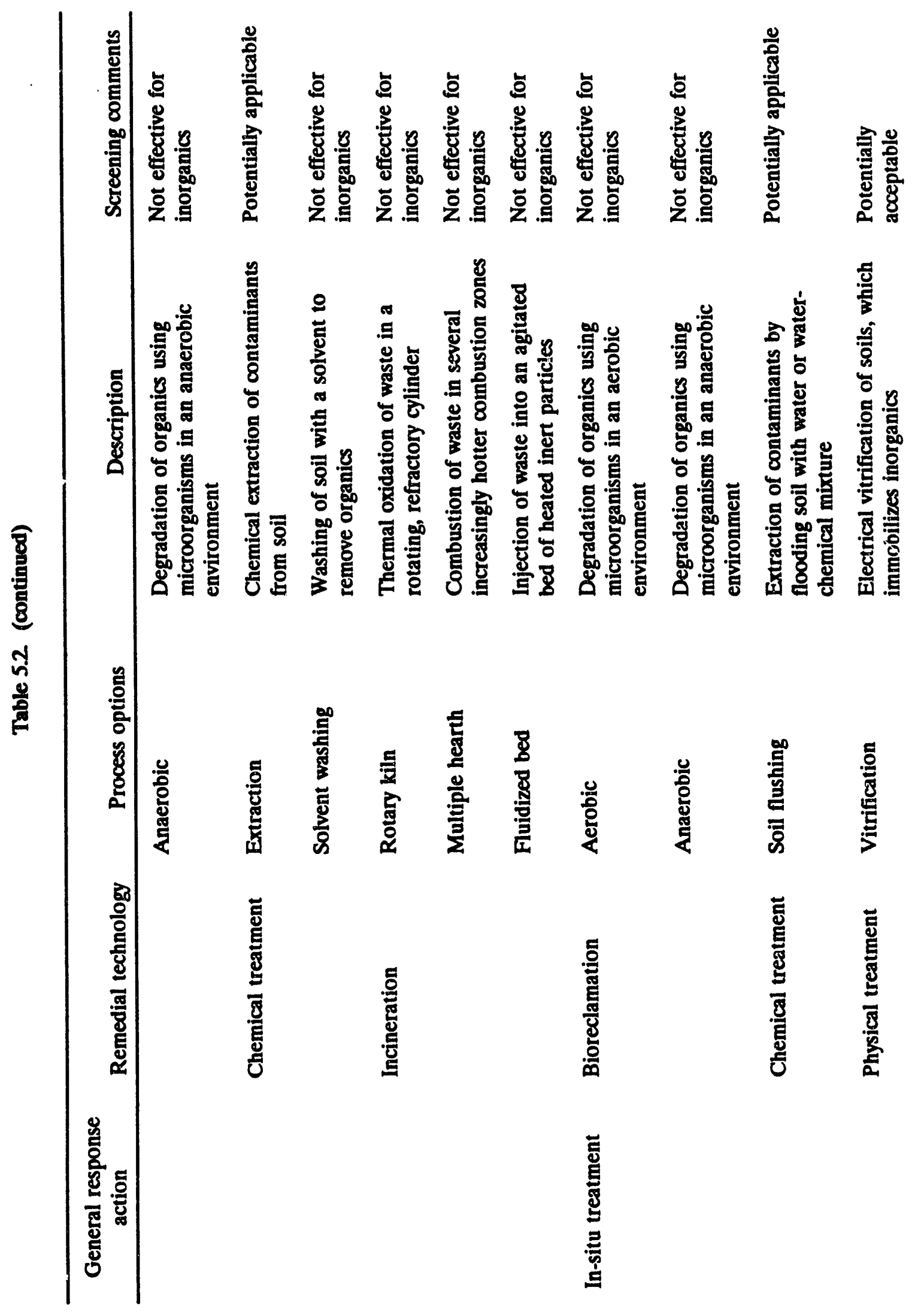




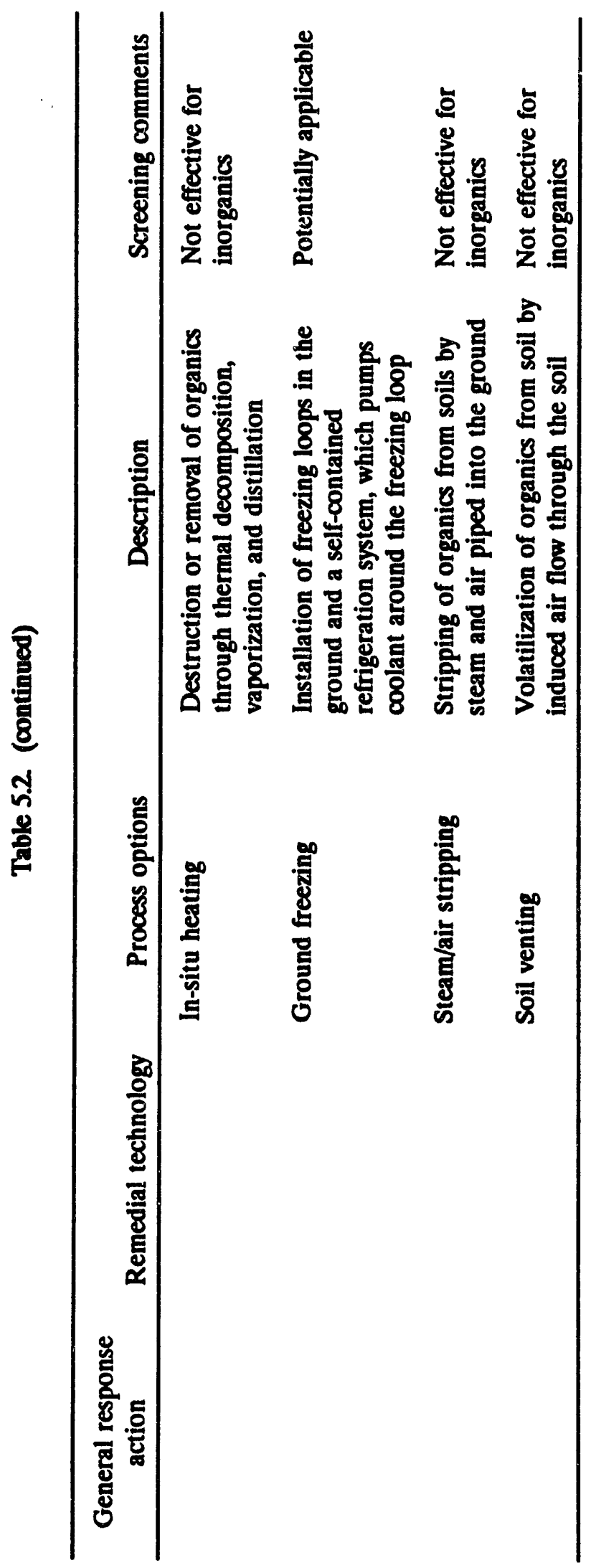




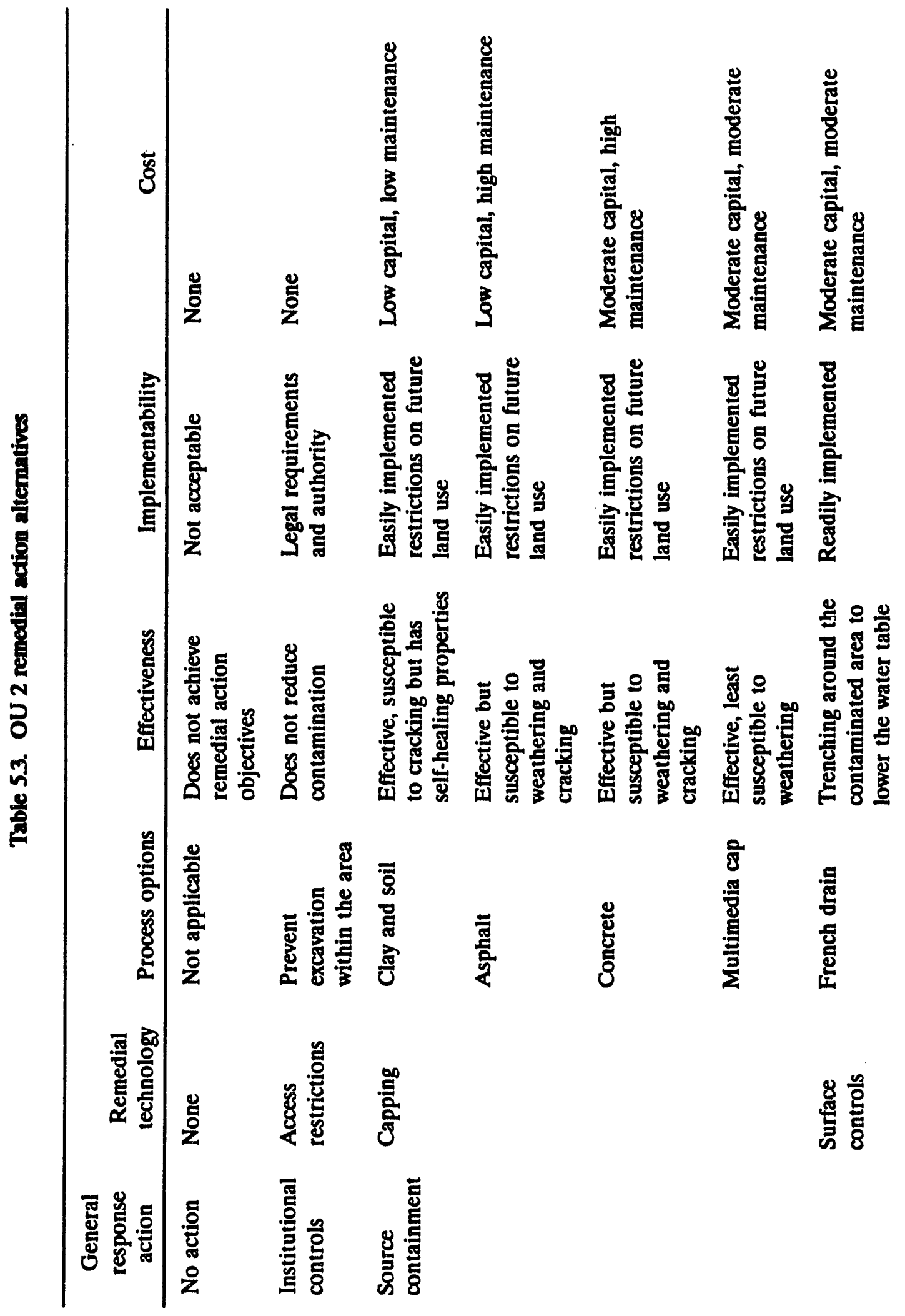




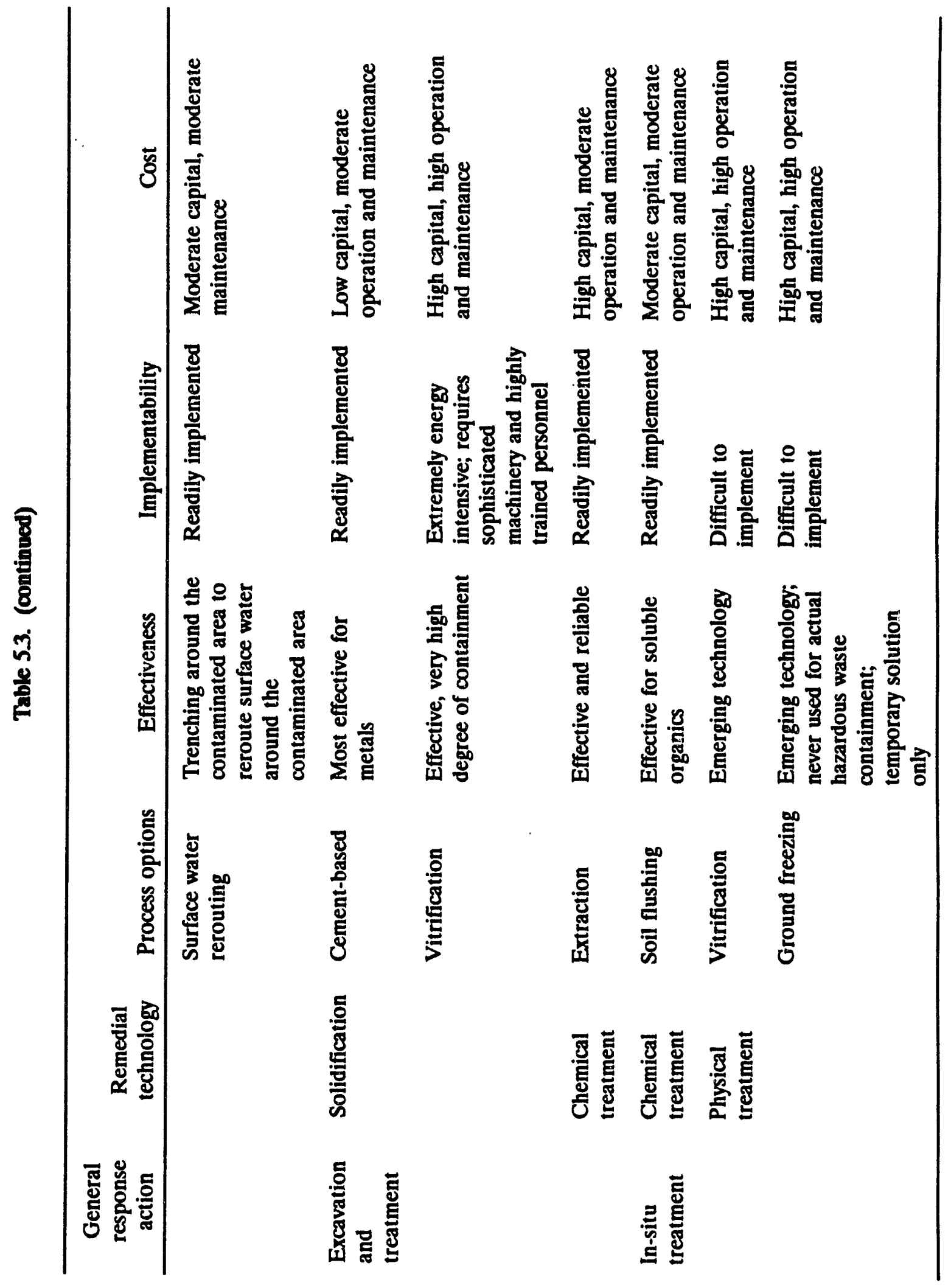

శ్స్్․ 


\section{SUMMARY OF DATA NEEDS}

Based on the presentation and discussion of the existing monitorirg and characterization data available for OU 2, several data needs have been identified. Specifically, data are needed to fully characterize several possible contaminant migration pathways and to evaluate the relative contribution of the OU 2 sites to contaminants in BCV groundwater, surface water, and sediments.

\section{(5.) ENVIRONMENTAL CHARACTERIZATION}

\subsubsection{Spoil Area 1}

\subsubsection{Soils}

Subsurface soils (fill and residuum) have been adequately characterized by previous investigations.

\subsubsection{Groundwater}

Groundwater contamination at SA-1 is characterized by elevated concentrations of nitrate and uranium, characteristic of the S-3 plume, and VOCs which may originate at another source (e.g., FTA). However, the available groundwater characterization data may not be indicative of contaminants from SA-1. Groundwater wells at the site are screened in the bedrock, whereas most of the identified soil contamination is located either in the fill material or concentrated at the fill/residuum contact. At several locations within SA-1 the water table intersects the zone of concentrated soil contamination. Groundwater samples from the water table in contact with SA-1 soil contaminants are needed to evaluate the contribution of SA-1 to $\mathrm{BCV}$ groundwater contaminant plumes.

Anecdotal accounts of seepage outbreaks on the downslope face of SA-1 shovid be investigated, and samples of affected soil and liquid should be collected and analyzed. The location of the seeps relative to the water table may indicate the presence of perched water within SA-1.

\subsubsection{Surface water/sediment}

The incomplete soil cap and evidence for erosion of the cap in places suggest that surface water runoff may be transporting contaminants to the headwaters of Bear Creek. Stormwater and sediment runoff are channelled around the periphery of SA-1 and should be sampled to assess this transport pathway. 


\subsubsection{SY-200 Yard}

\subsubsection{Soils}

Site history suggests that contaminants in the subsurface were the result of disposal of contaminated soils from several sources. With the exception of near-surface contamination associated with known storage of lead shielding and transformers, the vertical and horizontal distribution of contaminants may be nearly random. The nature and extent of soil contamination at SY-200 are essentially unknown.

\subsubsection{Groundwater}

No groundwater assessment program monitoring wells exist in the immediate vicinity of SY-200. Given the preceding discussion on the distribution of subsurface contamination and the likelihood that contaminated soils are in direct contact with the water table, shallow groundwater samples are required to assess the relative contribution of SY-200 to BCV groundwater plumes.

\subsection{Surface water/sediment}

Observations at the site suggest that surface water runoff (and entrained sediments) may be discharging directly into Bear Creek. Runoff from an adjacent waste oil/PCB facility merges with that runoff from the west end of SY-200 before entering Bear Creek. Stormwater runoff samples, with separate analyses for water and sediment, should be collected to assess the relative contribution of SY-200 to Bear Creek contamination.

\subsubsection{Rust Spoil Area}

\subsubsection{Soils}

The nature and extent of sril contamination at RSA will be verified with additional sampling.

\subsubsection{Groundwater}

The groundwater monitoring wells at RSA include a mix of unconsolidated and bedrockzone screen intervals. As a result, data from these wells should be adequate to characterize the nature and extent of any groundwater contamination at the site.

\subsubsection{Surface water/sediment}

Observations at the site suggest that surface water runoff (and entrained sediments) may be discharging directly into Bear Creek, especially along the east side of the site where an intermittent spring (SS-1) discharges into a steep tributary channel. Runoff from an adjacent waste oil/PCB facility enters the same channel (through a discharge pipe) near its headwaters and before entering Bear Creek. Stormwater runoff samples, with separate analyses for water 
6-3

and sediment, should be collected to assess the relative contribution of RSA to Bear Creek contamination.

\section{ENGINEERING TECHNOLOGY SCREENING}

Data needs for continued screening of engineering technologies should be satisfied by the data collected for site characterization with the addition of geotechnical data (e.g., permeability, grain size) on subsurface soils at SY-200. 


\section{FIELD SAMPLING PLAN}

\subsection{SAMPLNG PLAN SCOPE}

The scope of sampling activities at OU 2 includes soil borings and soil sampling (at SY-200), groundwater piezometer installation for water table sampling at SA-1 and SY-200, seep sampling (soil and/or water) at SA-1, and storm event surface water and sediment sampling at all sites. Proposed sampling rationales and locations are discussed in the following sections and illustrated in Figs. 7.1 through 7.3. Prior to any invasive sampling, a walkover radiation survey will be conducted by Energy Systems personnel. The result of the surveys may indicate affitional locations for soil sampling.

\subsubsection{Soils}

Based on the results of previous soil sampling, contaminants of concern in soil at OU 2 include metals and PCBs at SY-200, metals and radiological contaminants at RSA, and metals and VOCs at SA-1.

Soil characterization at SA-1 has covered the readily available portions of the site. Because of relatively steep slopes near the western end of the site (Fig. 7.1), no soil borings are proposed.

The history of the SY-200 site suggests that contaminated soils were brought to the site and used as fill. Subsequent construction activities have redistributed those soils such that the horizontal and vertical distribution of contamination is unpredictable. Observations at the site during earlier construction activities suggest there are areas of particular concern which warrant focused sampling. The proposed sampling plan for SY-200 was generated by overlaying a 100-ft triangular grid over the site and systematically selecting grid nodes as locations for soil borings (Fig. 7.2). Within historical areas of concern, the sampling grid has been reduced to a 25 -ft triangular grid.

Fifty-six soil borings will be installed within and outside the SY-200 Yard boundary. Each boring will be drilled to the water table, and continuous samples will be collected with a split barrel device. Where possible, the final soil sample in each boring will be collected from just beneath the water table surface. Twenty-two of the borings will be submitted for a complete suite of analyses. A random selection of 34 borings from the $25-\mathrm{ft}$ grid will be analyzed for a more limited suite of analytes.

Extensive cutting and filling in the area during plant construction has resulted in a mixture of soils making up the fill materials; thus it is unlikely that background soil characteristics can be identified. However, upgradient soil conditions will be determined from borings located east of the site and downgradient conditions from borings located west of the site.

Soil characterization at RSA will be completed by locating five borings along two transects through the center of the site (Fig. 7.3). 
7-2

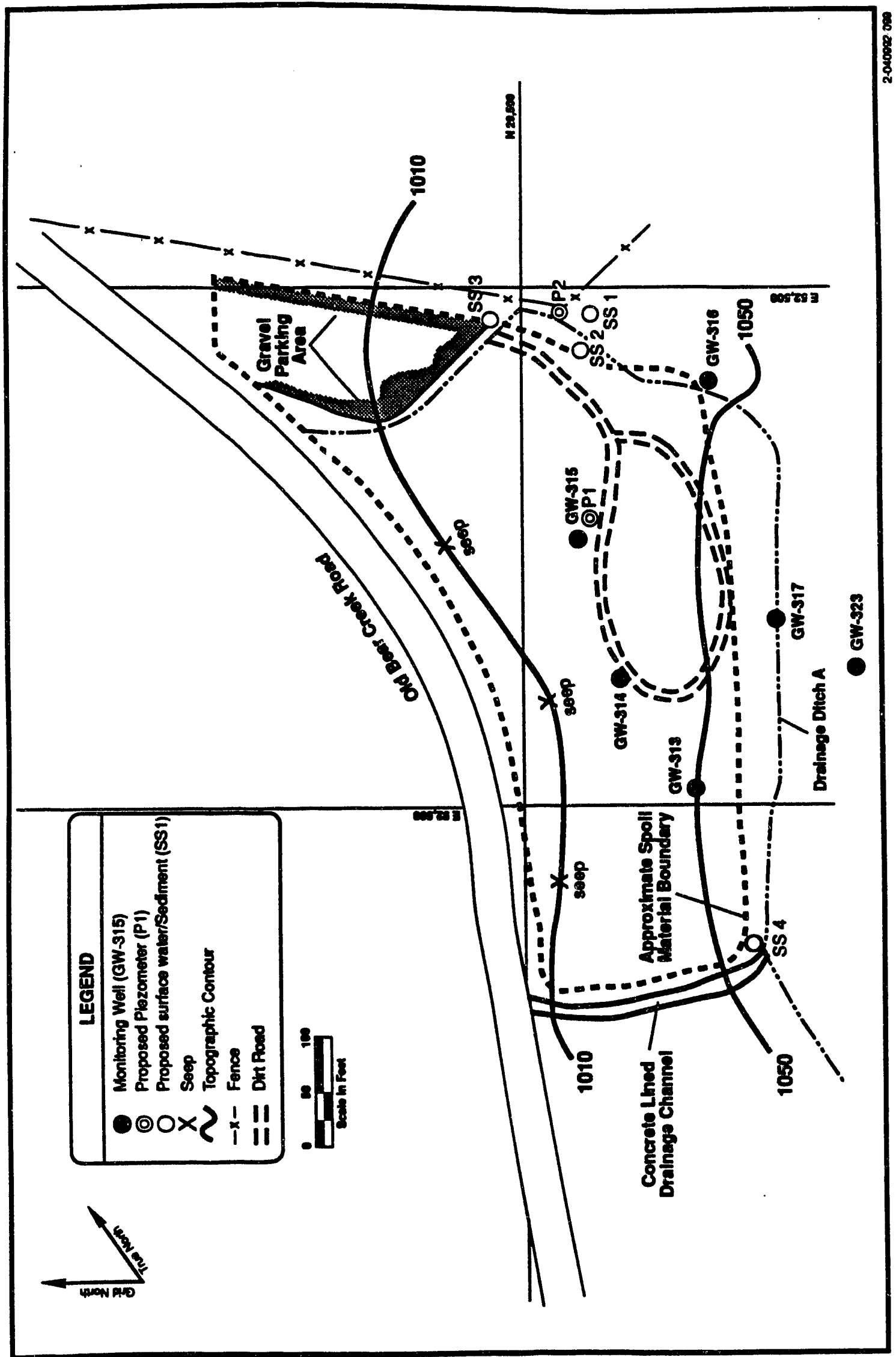

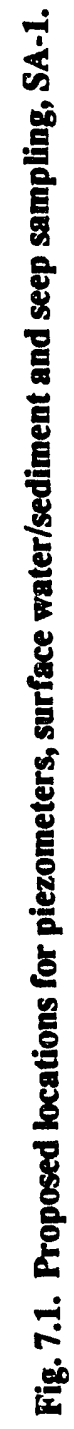


7-3

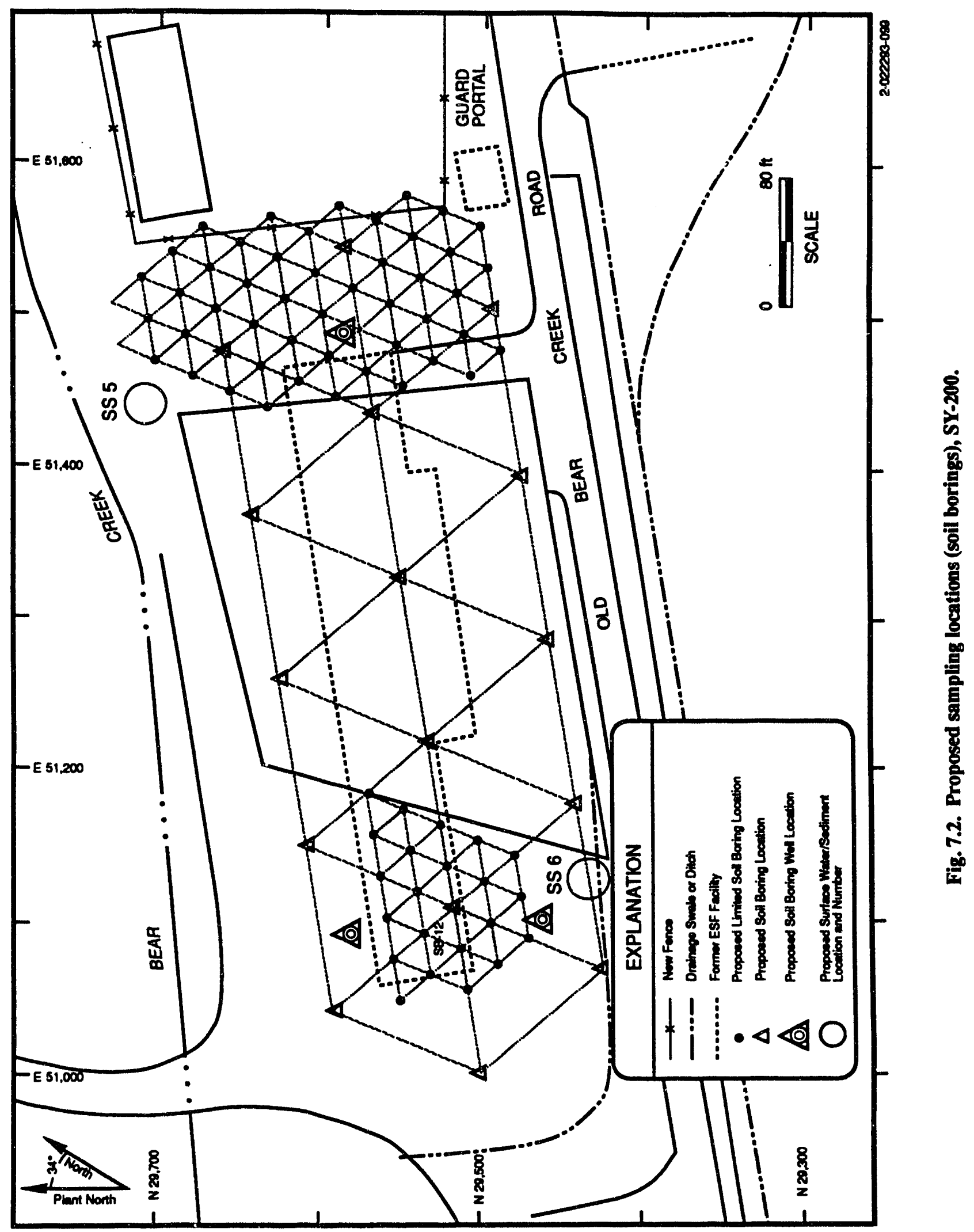




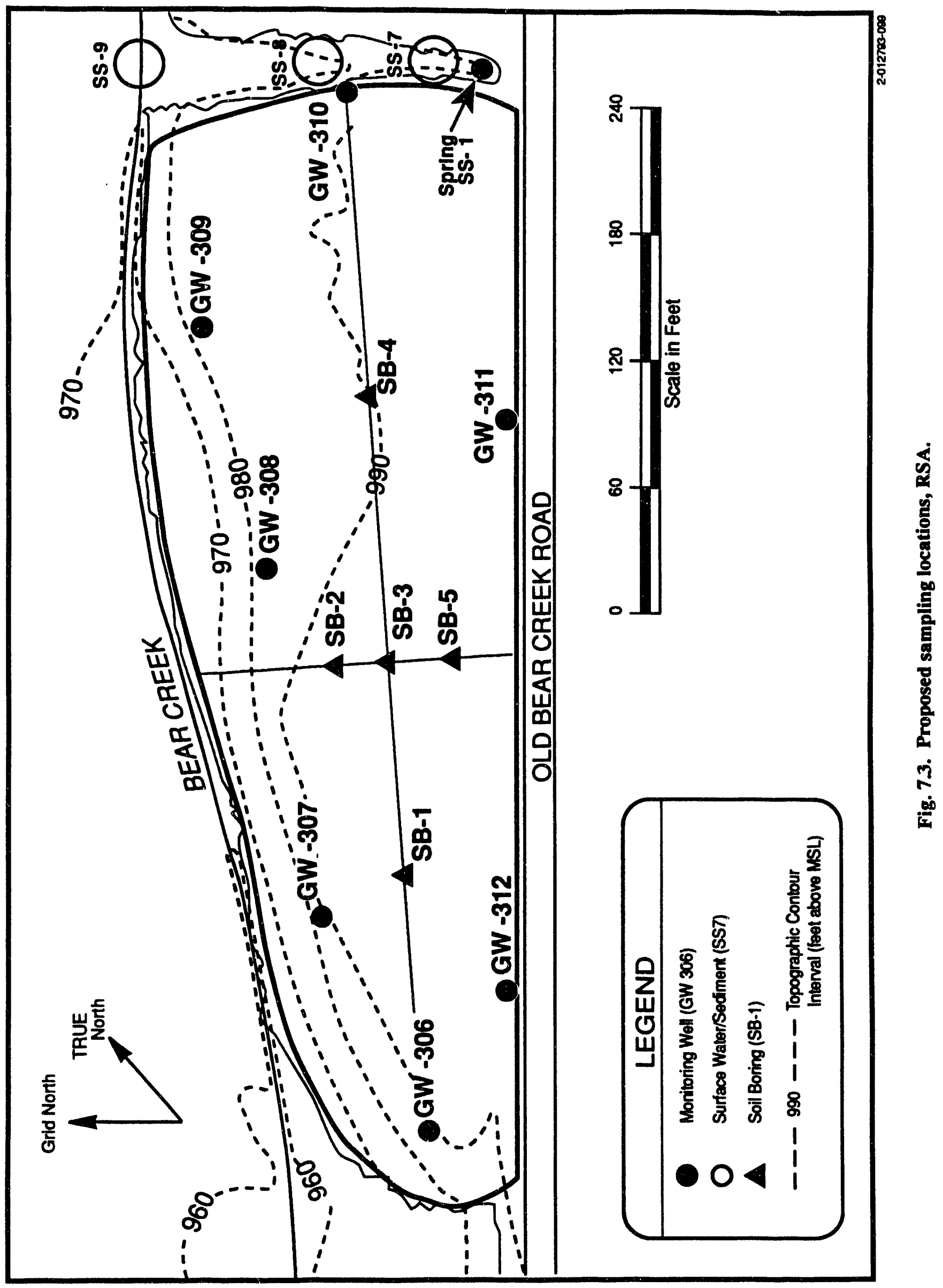


All soil borings will be advanced using an auger drill rig. Split-spoon soil samples will be collected every $5 \mathrm{ft}$ following the procedures outlined in Method 303-4 (Kimbrough et al. 1990). The standard split-spoon sample length is $2 \mathrm{ft}$. Soil samples will be screened for the presence of contar uinants to determine selection of samples for laboratory analysis. Screening procedures will include field observations for oil staining and mercury and instrumental measurements for VOC content and radionuclides. Once the dimensions of the fill material are more fully defined, three subsequent sampling intervals will be selected for collection of geotechnical samples with a Shelby tube (ESP-303-5).

Three to five feet of clean borrow material caps the SY-200 area; continuous samples will be collected in this area beginning at a depth of $3 \mathrm{ft}$. Based upon water table elevations, the average boring depth is expected to be about $18 \mathrm{ft}$. It is estimated that four samples will be collected from each boring totaling 224 samples. The average boring depth at RSA is expected to be about $20 \mathrm{ft}$. It is estimated that a maximum of five samples will be collected from each boring for a total of 25 samples. Composite samples will include, at most, two contiguous 2-ft split spoon samples. The required excavation permits will be obtained, ensuring clearance from underground utilities, and all soil boring locations will be surveyed using the National Geodetic Vertical Datum for Vertical Control.

\subsection{Groundwater}

Several well and piezometer installations are proposed for the OU $2 \mathrm{RI}$, specifically for the SA-1 and SY-200 sites.

The results of previous investigations at SA-1 demonstrate that contaminants of concern within the fill at SA-1 have migrated to the fill/residuum boundary. Furthermore, this boundary is often intersected by the water table in the center of the site. A piezometer installation is proposed at location P1 (Fig. 7.1) for the collection of a water table sample from an area with associated contaminant concentration in the fill/residuum.

Another piezometer installation proposed for SA-1 (P2, Fig. 7.1) is located upgradient of the site but downgradient of the FTA; this location is a possible source for VOC contamination at the site. Data from this sampling point will be used to resolve the shallow groundwater flow directions in this area (on or near the groundwater divide) and help to identify the source of VOC contamination observed in SA-1 groundwater. Both piezometers will be sampled once, however, multiple groundwater level measurement events will occur.

Three soil borings at SY-200 will be converted to stainless steel monitoring well installations (Fig. 7.2). The proposed locations will provide local groundwater quality samples both upgradient and downgradient of the site.

Data from the new wells and piezometers will be evaluated with the data from existing groundwater assessment monitoring wells to determine which, if any, of the piezometer locations should be retained as potential future locations for permanent groundwater monitoring wells. 
A field reconnaisance survey will be conducted to identify areas of visible seepage on the downslope face of SA-1. If seeps are located (Fig. 7.1 and Tables 7.2 and 7.3 assume identification of three seeps), they will be sampled (soil and water) once during a period of wet weather flow.

\subsubsection{Surface Water/Sediment}

Surface water and sediment samples will be collected from several locations throughout OU 2 during or immediately after major runoff events. The rationale for this effort is to determine, especially in the cases of SA-1 and SY-200, whether the lack of sufficient capping of the site leads to significant contaminant transport. A secondary objective of the sampling will be, if possible, to isolate the contribution to runoff from the study sites from that of other facilities in the area (e.g., the waste oil and PCB facility between RSA and SY-200).

Surface water and sediment sampling locations SS1 through SS4 (Fig. 7.1) are located in drainage channels surrounding SA-1. Drainage on the east side of SA-1 is complicated, and several sampling points (SS-1, SS-2, SS-3) have been proposed to separate the component of runoff associated with SA-1 from that associated with facilities farther up the ridge.

Surface water and sediment samples will be collected at two locations in Bear Creek adjacent to SY-200 (Fig. 7.2). Sampling location SS5 is proposed to sample runoff from the east end of SY-200. Sampling location SS6 is proposed for comparison with data from SS5 and to evaluate the runoff from the west end of the site.

Proposed surface water and sediment sampling locations at RSA are concentrated on the upstream (east) side of the site (Fig. 7.3). Sampling location SS7 is proposed to collect surface water and sediment from a point upstream of runoff input from the adjacent waste oil and PCB facility and as close as feasible to the discharge point of the SS-1 spring. Sampling location SS8 is located immediately downstream of the surface water runoff input from that facility. Sampling location SS-9 is upstream of all influences of the RSA. Data from the sitewide Bear Creek monitoring station at BCK-11.97 will be used to assess the downstream effects of runoff from RSA.

\subsection{FIEID SAMPLING AND SAMPLE ANALYSIS}

The following sections discuss the technical procedures that will be used as guidelines to implement the sampling activities at OU 2. All sampling activities, where applicable, will follow the technical procedures established in the Environmental Surveillance Procedures, Quality Control Program (Kimbrough et al. 1990). All technical methods referenced in the subsequent sections, except where otherwise noted, are contained within the above-referenced document. Sample apportionments by medium are summarized in Table 7.1. Detailed summaries of maximum numbers of samples, quality assurance samples, and analytical methods are presented in Tables 7.2 through 7.4. 


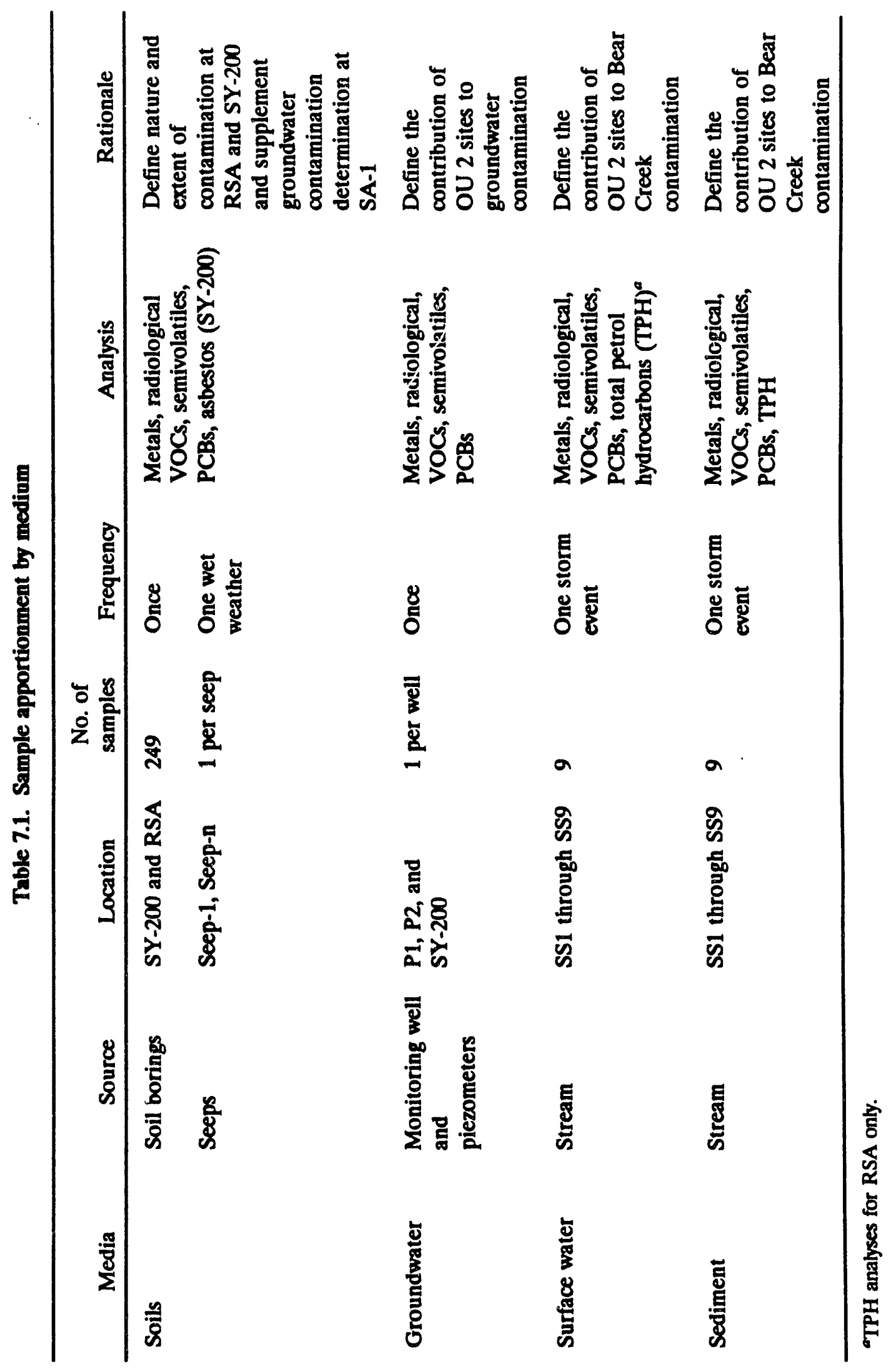




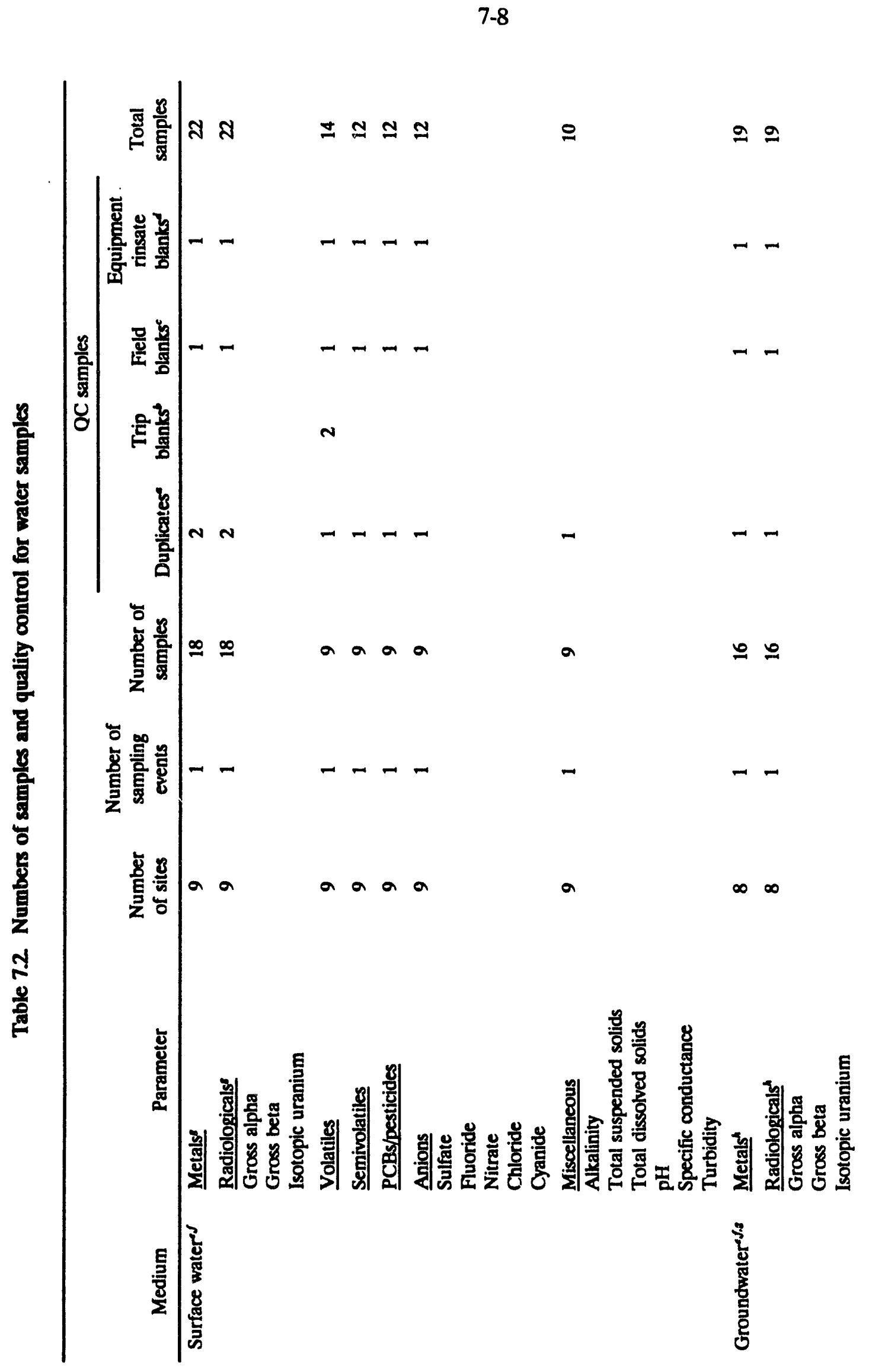




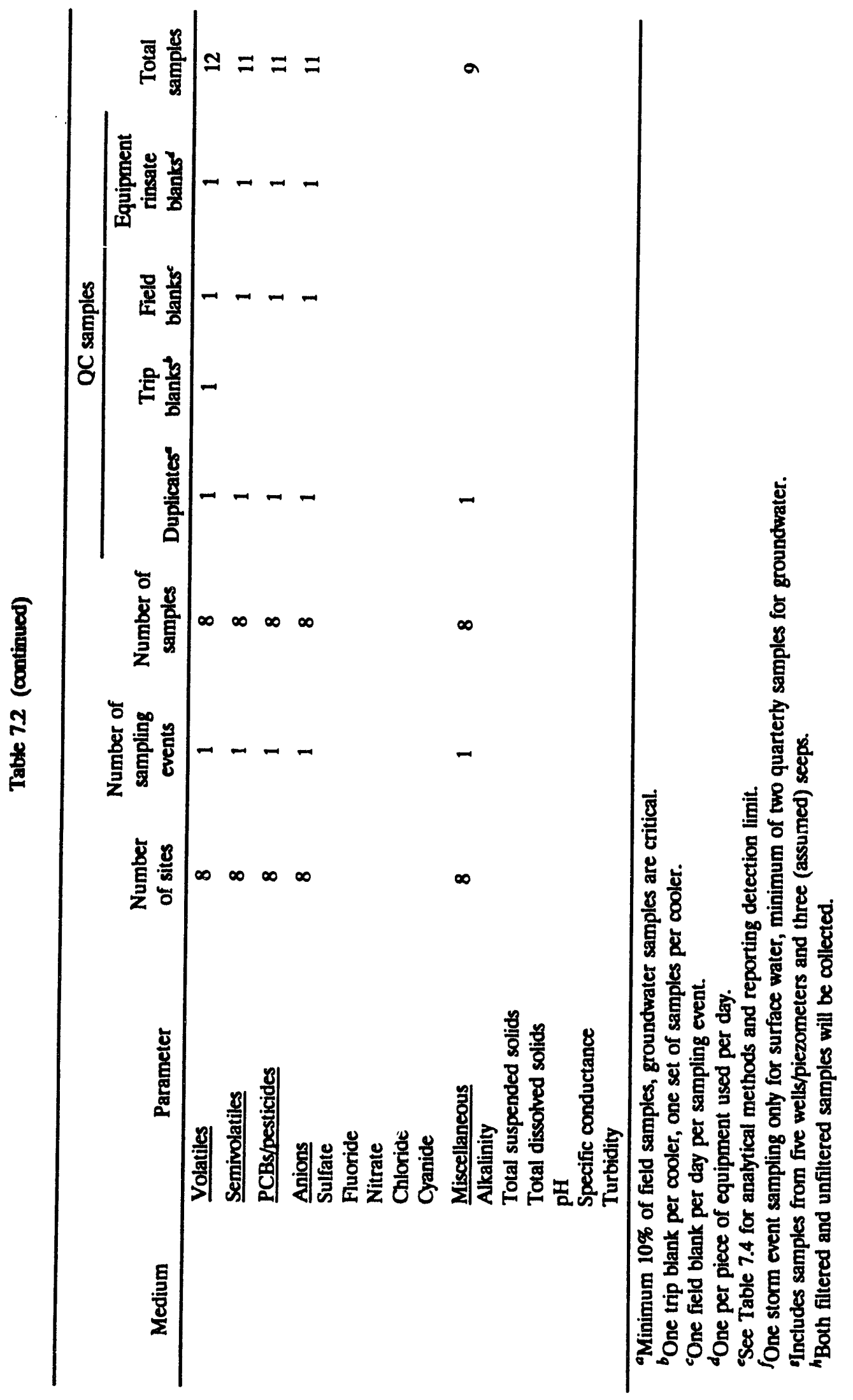




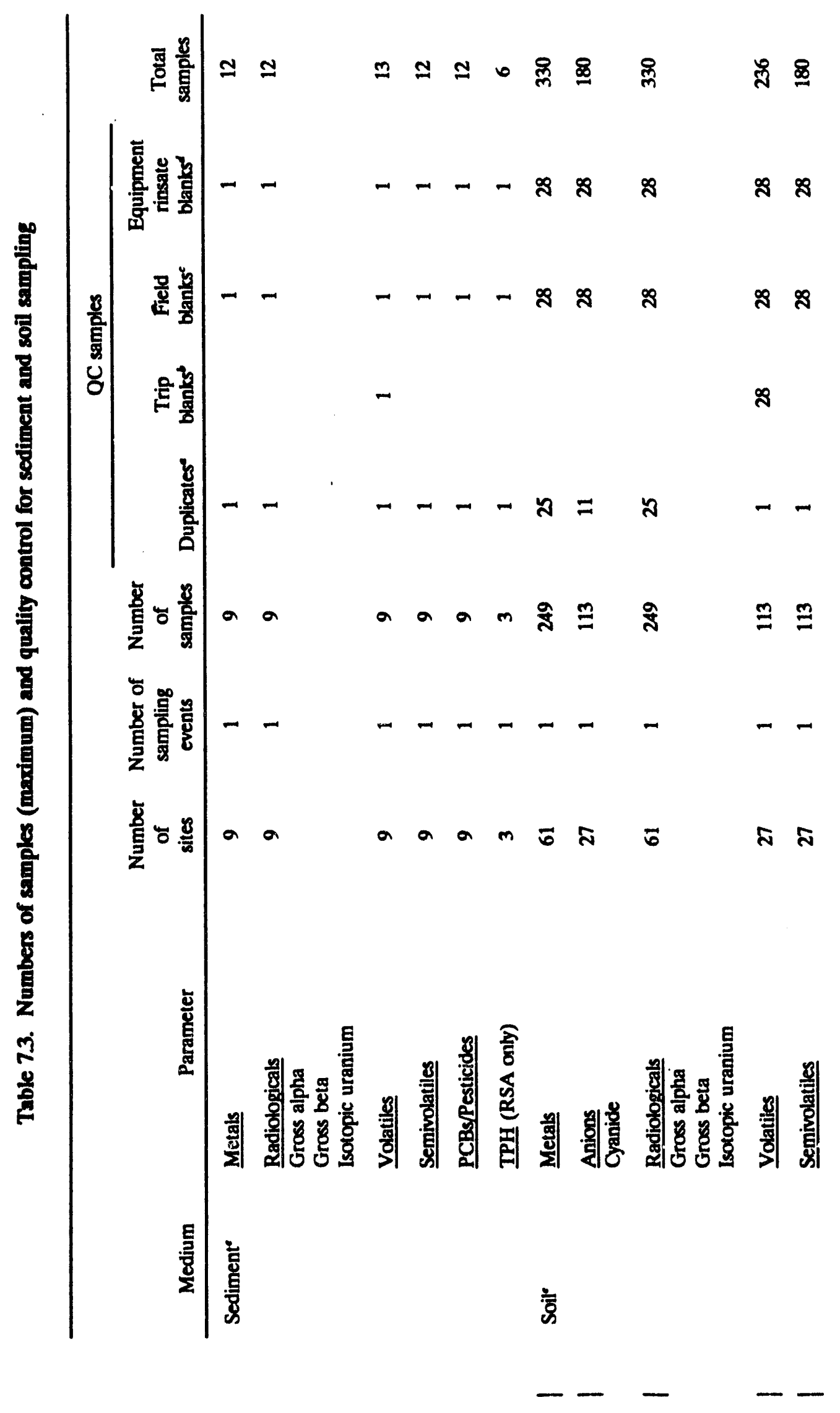




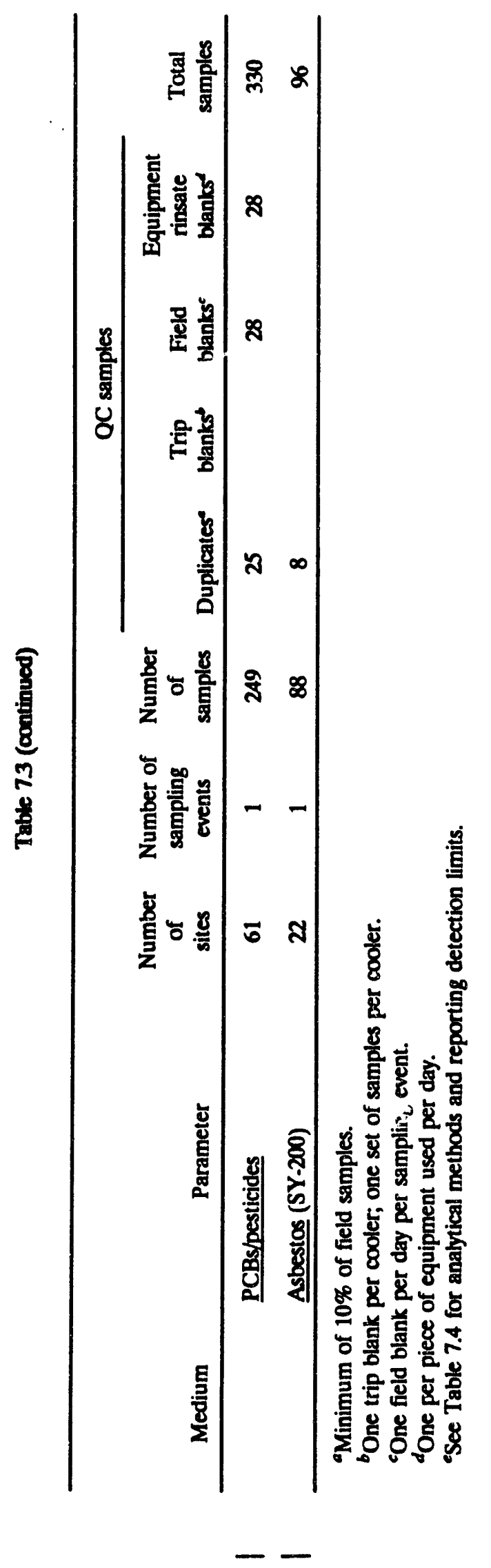


Table 7.4. Proposed analytical parameters for surface water and groundwater and for soil and sediment samples during RI at Bear Creek OU 2

\begin{tabular}{|c|c|}
\hline Parameter & Method $^{a, b}$ \\
\hline \multicolumn{2}{|c|}{ Surface water and groundwater } \\
\hline $\begin{array}{l}\text { CLP metals } \\
\text { Total } \\
\text { Dissolved }\end{array}$ & sow $3 / 90$ \\
\hline $\begin{array}{l}\text { Atomic absorption spectroscopy (AAS) metals } \\
\text { Chromium } \\
\text { Cadmium } \\
\text { Lead } \\
\text { Mercury }\end{array}$ & sow 3/90 \\
\hline CLP volatile organics & sow $3 / 90$ \\
\hline CLP sernivolatile organics & sow 3/90 \\
\hline CLP polychlorinatei biphenyls (PCBs)/pesticides & sow 3/90 \\
\hline $\begin{array}{l}\text { Anions } \\
\text { Chloride } \\
\text { Cyanide } \\
\text { Nitrate } \\
\text { Sulfate } \\
\text { Fuoride }\end{array}$ & $\begin{array}{l}300.0^{c} \\
\text { SOW } 3 / 90 \\
300.0^{\circ} \\
300.0^{c} \\
340.2^{c}\end{array}$ \\
\hline $\begin{array}{l}\text { Radiologicals } \\
\text { Gross alpha } \\
\text { Gross beta } \\
\text { Isotopic uranium }\end{array}$ & $\begin{array}{l}9310 \\
9310 \\
\text { TP183708 }\end{array}$ \\
\hline $\begin{array}{l}\text { Miscellaneous } \\
\text { pH } \\
\text { Specifis conductance } \\
\text { Total suspended solids (TSS) } \\
\text { Total dissolved solids (TSD) } \\
\text { Alkalinity } \\
\text { Turbidity } \\
\text { Total petroleum hydrocarbons (TPH) }\end{array}$ & $\begin{array}{l}9040 \\
9050 \\
160.2^{c} \\
160.1^{c} \\
310.1^{c} \\
180.1^{c} \\
418.1^{c}\end{array}$ \\
\hline \multicolumn{2}{|l|}{ Soil and sediment } \\
\hline CLP metals & sow 3/90 \\
\hline $\begin{array}{l}\text { AAS metals } \\
\text { Chromium } \\
\text { Cadmium } \\
\text { Lead } \\
\text { Mercury }\end{array}$ & sow $3 / 90$ \\
\hline CLP volatile organics & sow 3/90 \\
\hline
\end{tabular}


Table 7.4 (continued)

\begin{tabular}{|c|c|}
\hline Parameter & Methoda,b \\
\hline CLP semivolatile organics & sow 3/90 \\
\hline CLP PCBs/pesticides & sow 3/90 \\
\hline CLP cyanide & sow 3/90 \\
\hline $\begin{array}{l}\text { Radiologicals } \\
\text { Gross alpha } \\
\text { Gross beta } \\
\text { Isctopic uranium }\end{array}$ & $\begin{array}{l}9310 \\
9310 \\
\text { TP183708 }\end{array}$ \\
\hline Asbestos & Y/P65-8540 \\
\hline $\begin{array}{l}\text { The methods cited, unless otherwis } \\
\text { Onganic/Inorganic Analysis, Multi-Media, } \\
\text { and Test Methods for Evaluating Solid } \\
\text { oThe detection limits presented for C } \\
\text { laboratory for the analytical method indi } \\
\text { 'EPA 1979b. } \\
\text { Total uranium analyses will be com } \\
\text { whether additional isotopic analyses shou } \\
\text { 'Asbestos in Bulk Material Samples b } \\
\text { Method No. } 9002 \text { (NIOSH 1989). }\end{array}$ & $\begin{array}{l}\text { tatement of Work for } \\
\text { W 3/90) (EPA 1990d), } \\
\text { lethods (EPA 1986). } \\
\text { ose established by the } \\
\text { r CLP detection limits. } \\
\text { analyses to determine } \\
\text { Opy, based on NIOSH }\end{array}$ \\
\hline
\end{tabular}

\subsection{Soik}

The soil-sampling activities include the installation of soil borings and the collection of composite soil samples from discrete intervals using split-spoon samplers. The composite soil samples will be collected in accordance with the guidelines specified in methods ESP-303-4, ESP-303-5, and ESP-308-1. Soil samples will be put in containers, preserved, and handled in accordance with methods ESP-400, ESP-701, and ESP-800. During the sampling event all soils will be screened for potential organic and radiological contamination following the guidelines established in methods ESP-307-6 and ESP-307-7. After each sample-cillecting derice is used during the sampling event, it will be decontaminated in accordance with method ESP-900 prior to its next use to prevent the potential for cross-contamination of samples.

All sampling and drilling equipment will be decontaminated according to the procedures detailed in method ESP-901.

\section{Groundwater}

The field sampling plan includes the installation of wells and piezometers to further evaluate the water table level at OU 2, and the collection of water table samples for characterization purposes. The piezometers will be installed and modified for groundwater sampling in accordance with method ESP-600. Prior to the installation of each piezometer and the initiation of each groundwater sampling event, all equipment, piezometer materials, 
and sampling devices will be decontaminated in compliance with ESP-900 and ESP-901. The piezometers will be developed, purged, and sampled in compliance with the guidelines specified in ESP-302-2 and ESP-302-3. All groundwater samples collected will be put into containers, preserved, and handled in accordance with ESP-400, ESP-701, and ESP-800. Water level measurements recorded from the piezometers will follow the guidance specified in ESP-302-1.

\section{Surface Water/Sediments}

Surface water and sediment samples will be collected at several locations at OU 2 . It is anticipated that several surface water samples will have to be collected in association with a storm event because of the intermittent flow nature at some sampling locations. Surface water samples taken during storm events will be collected, as applicable, in accordance with ESP-301-1.

Surface sediment samples will be collected, as applicable, using the guidelines detailed in methods ESP-303-2 and ESP-304-1. These methods provide guidance for surface sediment/ soil samples collected at dry locations and sediment samples collected from stream beds respectively. It is anticipated that the sediment samples collected will be composited in accordance with method ESP-308-1.

Prior to each surface water and sampling event, all sampling equipment will be decontaminated following the guidelines established in methods ESP-900 and ESP-901. All samples collected will be put into containers, preserved, and handled in accordance with methods ESP-400, ESP-701, and ESP-800.

\section{SAMPLE TRACKING AND RECORDS MANAGEMENT}

The proper sample tracking and records management of technical data are critical to the overall success of this RI because (1) the data are important in determining potential environmental and human health effects, (2) the data must be legally defensible, and (3) the data collection and analysis costs are high. The key to ensuring that these activities are properly carried out is to use proper records and data management procedures that will allow complete auditability and traceability of the data.

\subsubsection{Objectives}

The objective of an effective sample tracking and records management program is to ensure auditable and accurate transmission of information from the RI field sampling activities through the analytical laboratory analyses to its end use in the analysis, risk assessment, and production of the RI reports. This objective will be met by using existing records management plans, information management procedures, and data base management systems. 


\subsubsection{Roles and Responsibilities}

A Data Management Coordinator (DMC) will be designated by the RI project manager. The DMC responsibilities will be to acquire, store, validate, analyze, and report all field and analytical data collected in the performance of the RI. In addition, the DMC will acquire, store, analyze and report validated data from the appropriate Y-12 environmental data bases (e.g., groundwater, surface water, sediment). DMC will be supported by a computer programmer, records manager, and data entry clerk.

The RI Field Team Leader (FIL) will be responsible for the delivery to DMC of paper copies of all field information (e.g., field results, copies of field logbooks, and field notes). The RI project manager will be responsible for laboratory information (e.g., analytical results, blanks, surrogates, and detection limits) required for inclusion in the RI report or as supporting documentation. If electronic versions of this information are also available, FTI. will work with DMC to facilitate the electronic transfer of the data.

\subsection{Data Tracking}

Before mobilizing the field sample collection personnel, all technical information contained in this RI plan (i.e., sample location, sample identification codes, chemical parameters to be collected, field measurements to be taken, and chain-of-custody details) will be entered by a data entry clerk into a presampling data base. DMC will then use this data base to preprint sample labels, sample tags, and field sampling logbook pages. The data base will also be used to track the sample and sample results as they are returned by the field teams and analytical laboratories.

The field data collected by the field team will include field sample information, details on field conditions, field instrument measurements, and any deviations from prescribed plans or procedures. FTL will send to DMC all required data packages (consisting of copies of field results, field logbooks, and field notes) on the schedule specified in the RI plan.

The data received from the analytical laboratory will include the results from routine field samples, field QAVC samples, laboratory QAVC samples, and any data flags placed on the results by the laboratory analysts to explain any deviations from prescribed procedures or methods. FTL will send to DMC all required data packages (consisting of copies of analytical data results, QC documentation, and lab notes) on the schedule specified in the plan.

DMC will track and reconcile both the field data packages and analytical data packages received from FTL against the presampling data base to ensure that all planned sample collection activities were performed and documented. At the beginning of each week, DMC will review for content and completeness all data packages received from FTL the previous sampling period. If the individual data packages are complete and arrive on schedule, DMC will enter the final receipt date into the presampling data base and enter a " $\mathrm{C}$ " into the acceptance field for "complete." If, on review, DMC determines that the data package was incomplete, DMC will enter the initial receipt date into the presampling data base and enter an " $I$ " into the acceptance field for "incomplete." If the expected data package was not 
delivered on schedule (as detailed in the RFI plan), DMC will leave the initial receipt date, final receipt date, and acceptance field blank.

For both incomplete data packages and missing data packages, DMC will contact the FTL verbally (with a backup written record of communication) to determine the status of the missing information. After the missing data have been located and transferred to DMC, or the issue has been resolved to the satisfaction of FTL and DMC, a Memorandum to File will be filed explaining the problem, the process taken to resolve the problem, and the final resolution by DMC. After the entire data package has been received, reviewed, and approved, DMC will enter the final receipt date into the presampling data base and enter a " $\mathrm{C}$ " into the acceptance field for "complete."

\subsubsection{Sample Coding Procedures}

A common sample coding and data structure format (Figure 7.4) has been developed for the storage and retrieval of the field sampling and laboratory analysis data. The sample coding format used will be compatible with Energy Systems' Consolidated Data Base (CDB) for environmental compliance and restoration data.

\subsubsection{Completion of Field and Laboratory Records}

The field sampling data to be included in CDB will consist of (1) details on field conditions; (2) field instrument measurements; and (3) task team activity logs, including chainof-custody information, deviations from plan, QA concerns, and any noteworthy observations. The data collected by the field sampling team will be entered into a personal computer (PC) by a data entry operator using the verified field forms following Energy Systems procedures for data entry. All chain-of-custody documentation will be filled out in accordance with Enengy Systems Chain-of-Custody Procedure ESP-500 (January 31, 1990, Rev. 1) (Kimbrough et al. 1990). All data will be entered twice, and the resulting files will be compared. Changes will be iterated until the final correct file is produced. The actual field measurements, field observations, deviations from the sampling plan, and task team activity logs will be included in the data bases. All field information will then be transferred from the PC to a Statistical Analysis System (SAS) data base for the ER Division, which resides on a VAX computer. Paper copies of all field data will be indexed, cataloged, and placed in the project file following appropriate Energy Systems Records Management Procedures.

The analytical laboratory data collected for this study will include (1) sample management and tracking data; (2) sample custody documentation; (3) analytical results from the field samples; (4) analytical results from the field QAVQC samples (duplicates, trip, equipment, and field blanks); (5) analytical results from the laboratory QAVC samples (e.g., spikes, duplicates, surrogates, and calibrations). Data from the analytical laboratories will be transferred electronically from a PC floppy disk prepared by the analytical laboratory to an SAS ER Division data base on the VAX computer. The analytical laboratory will have the responsibility for verifying the electronic data before release. Paper copies of all analytical data including QA forms will be indexed, cataloged, and placed in the project file. 
Sample No.:

Project No:

Location:

Station:

Sample Media:

Sample Type:

Analysis:

Preservative:

Volume:

Rad Screen:

Units:

Sample Date/Time

Comments:

Collector's Initials:

Position 1: Site Location

A-SA-1

B-SY-200

C-RSA

Position 2: Sample Type

1-Soil

2-Sediment

3-Groundwater

4-Surface water
Position 3 to 4: Sample Location Numbers 01-99

Position 5 to 6: Sample Interval 00-Groundwater 01-Surface water 02-Sediment

05 to 20-Soil (depth in $\mathrm{ft}$ )

EXAMPLE: B30500

A groundwater sample would be taken from location 5 in the SY-200 area.

Fig. 7.4. Sample label and identification structure. 


\subsubsection{Data Management}

Data backup activities are the responsibility of DMC. All data files that have been updated during the day will be copied to backup files on floppy disk or tape the same evening following Energy Systems procedures for data backup. On a weekly basis, all data files will be copied to backup files on floppy disk or tape and stored on site in a fireproof safe. Each month, all data files will be copied to backup files on floppy disks or tape and will be stored in a secure, off-site location. All data bases will be archived yearly in tape format.

The data received from the field activities and the analytical laboratory will initially be stored in an unvalidated data base. After the data have passed through validation procedures, they will be updated and stored in the validated data base. All subsequent summaries, statistical analyses, and reports will be generated from the data contained in the validated data base. All validation activities will follow Energy Systems procedures for data validation and correction.

After the data have been stored in the appropriate consolidated data base files, DMC will perform an internal data consistency check. This check will involve the use of data validation programs designed for sorting the data and comparing the data identifiers with one another to determine whether data are missing, mislabeled, or duplicated because of data transcription or data transmittal errors.

Manual data checks will then be performed to verify data entry accuracy, compare data values with field notes, and compare questionable data values with data previously collected at or near the same sampling or measurement location. Data flags that qualify data values will be set as required. The accuracy and precision of the data will be determined by evaluating the trip blanks, field blanks, equipment blanks, and replicate field and laboratory samples.

All data determined to be incorrect using the previously described procedures will be reconciled. DMC will perform all data reconciliation activities with accompanying error correction logs, document control, and data base update methods following Energy Systems data validation and correction procedures. Any changes to the data base from its receipt from the analytical laboratory or the field to its final form will be documented. All verified data inconsistencies will be corrected by recording information into an error correction log and updating the data base with the correct value. A log of program changes will be kept in an SAS program audit file. All changes will be annotated in the program audit file with reasons stating why changes were made. This log will specify the sample identification number, the field to be corrected, the incorrect value, the correct value, the reason for the change, and the last name of the responsible person.

After the data have passed through the verification and validation procedures, they will be updated and stored in a "validated" data base. All subsequent summaries, analyses, and reports will be generated from the data contained in the validated data base. 


\subsection{PROJECT DESCRIPTION}

BCV OU 2 comprises two construction spoil areas (RSA and SA-1) and an equipment storage yard (SY-200) located just beyond the west end of the Y-12 Plant facilities. Previous investigations at the individual sites have identified contaminants (e.g., metals, VOCs, semivolatile organics, radionuclides) in the soils and groundwater. This project is designed to more fully characterize the nature and extent of contaminants associated with the OU and, in doing so, provide data for the subsequent risk assessment and remedial alternatives evaluation.

\subsection{PROJECT ORGANIZATION}

The BCV OU 2 RI project organization is illustrated in Fig. 7.5. 


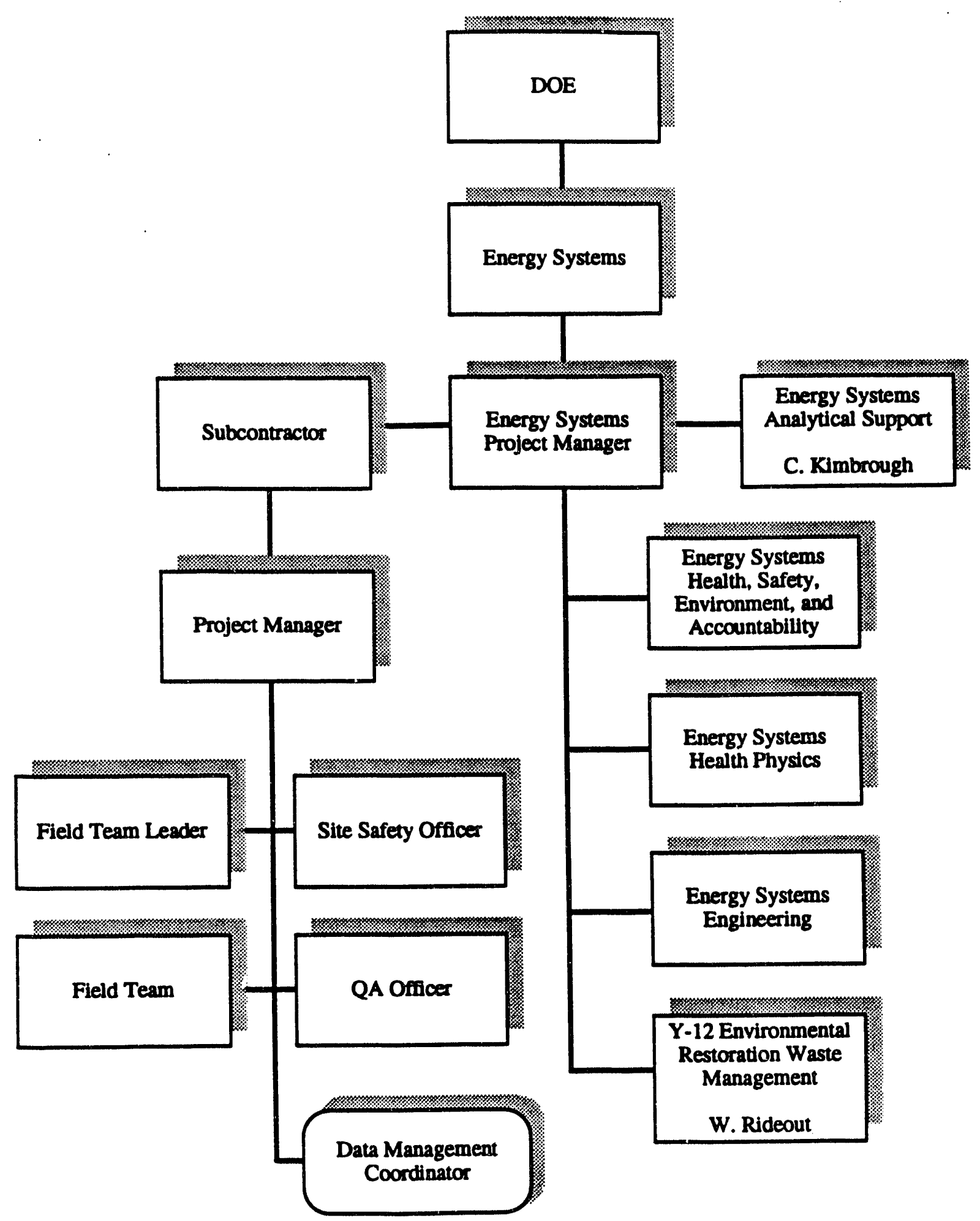

Fig. 7.5. BCV OU 2 RI functional organization chart. 
Environmental Restoration Program

Field Quality Assurance Project Plan (QAP.P)

for

Bear Creek Valley Operable Unit 2

Revision 2

February 1993
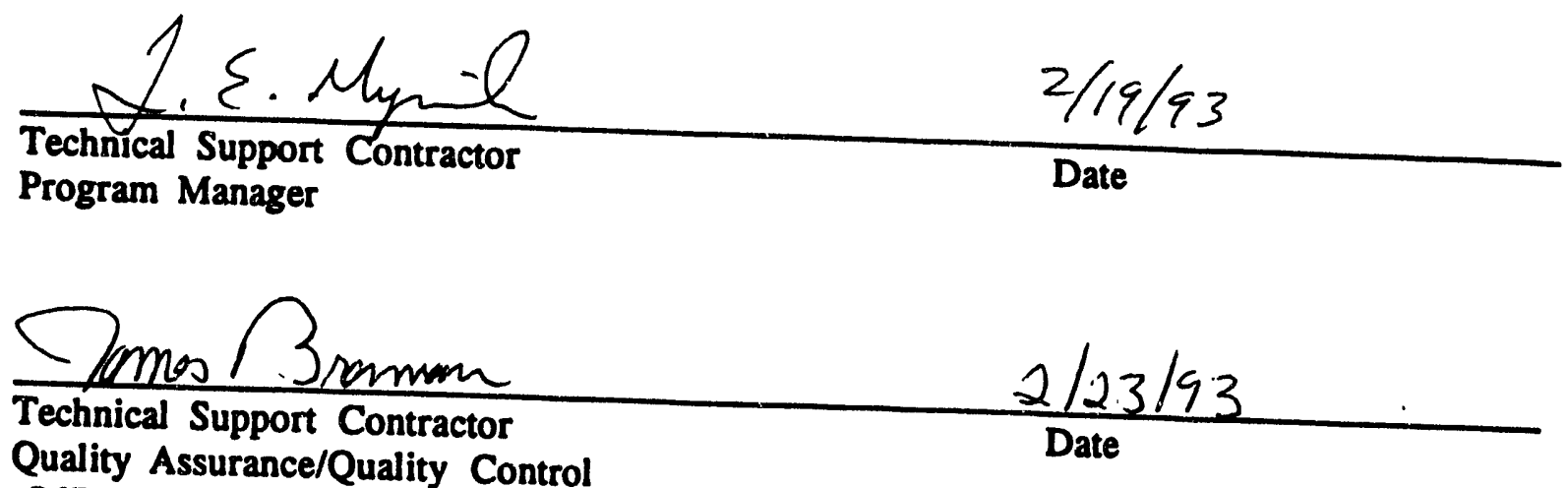

Quality Assurance/Quality Control

Officer Concurrence
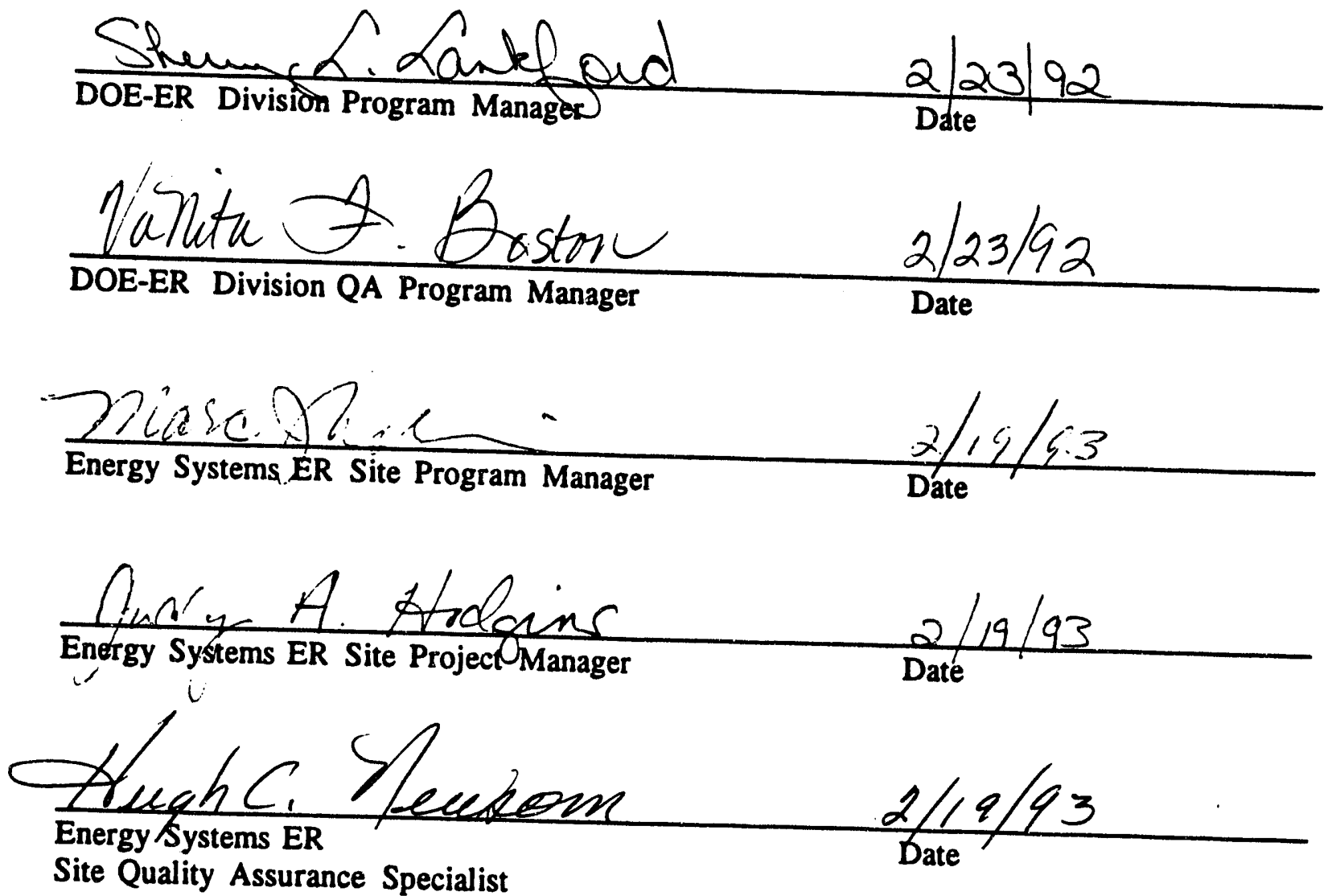

Site Quality Assurance Specialist 


\section{FIELD QUALITY ASSURANCE PROJECT PLAN}

This Quality Assurance Project Plan (QAPP) has been developed for use in the site preparation and sample collection activities during the $\mathrm{RI}$ for OU 2 to ensure that appropriate levels of QA and QC are achieved. This QAPP defines procedures that will be followed in the collection, custody, and handling of data used in the RI for OU 2. These procedures are intended to define the methods applied to achieve the DQOs established for the OU 2 project.

This QAPP establishes QA requirements and responsibilities applicable to project participants and establishes methods through which project participants implement the requirements of the project. Where no appropriate procedure exists, this QAPP requires that one be developed by one or more cognizant individuals or organizations. At this time, the details of roles and responsibilities have not been assigned to specific individuals or organizations. When assignments are made, the QAPP will be revised.

This QAPP is designed to comply with both the EPA Quality Assurance Management Staff (QAMS) Interim Guidelines and Specifications for Preparing Quality Assurance Project Plans (EPA 1980) and the American National Standards Institute/American Society of Mechanical Engineers (ANSI/ASME) NQA-1 guidelines and the Environmental Restoration Division Quality Assurance Program Plan (Energy Systems 1991).

Table 8.1 provides a guide to the location of all relevant QA elements in this work plan.

\subsection{QUALITY ASSURANCE OBJECTIVES FOR DATA MEASUREMENT}

\subsubsection{Project Objectives and Intended Data Usages}

The objectives for OU 2 are detailed in Sect. 1.6 of this work plan.

Soil and water samples will be collected and analyzed for the constituents shown in Tables 7.4 and 7.5 in Sect. 7.2. Data collected from the OU 2 stations will be evaluated to determine the need for additional long-term monitoring and will be reviewed for concentrations of contaminants greater than health and environmental criteria given by regulatory agencies. Specific sampling locations, including maps, and sample collection methodology are discussed in more detail in the FSP.

The purpose of this section is to implement applicable regulatory requirements and to provide internal control and review so the data are scientifically sound and legally defensible.

QA objectives for data are as follows:

- scientific data generated will withstand scientific scrutiny; 
Table 8.1. Cross re:erence of EPA QAMS 005/80 and ES/ER/TM-4/R1 elements with OU 2 RI work plan sections

\begin{tabular}{|c|c|c|}
\hline EPA QAMS 005/80 & $\begin{array}{c}\text { ES/ER/TM-4/R1 } \\
\text { element }\end{array}$ & $\begin{array}{l}\text { Location in RI } \\
\text { work plan }\end{array}$ \\
\hline 1. Title Page & 6. Document Control & Title Page, Sects. 8, 9 \\
\hline 2. Table of Contents & 6. Document Control & Table of Contents \\
\hline 3. Project Description & $\begin{array}{l}\text { 2. QA Program } \\
\text { 6. Document Control }\end{array}$ & Executive Summary \\
\hline $\begin{array}{l}\text { 4. Project Organization and } \\
\text { Responsibility }\end{array}$ & 1. Organization & Sect. 7.5 \\
\hline 5. QA Objectives & 3. Design Control & Sects. 8.1, 9.1 \\
\hline 6. Sampling Procedures & $\begin{array}{l}\text { 3. Design Control } \\
\text { 6. Document Control } \\
\text { 9. Control of Processes }\end{array}$ & Sects. 8.2, 9.2, 8.6 \\
\hline 7. Sample Custody & $\begin{array}{l}\text { 6. Document Control } \\
\text { 13. Handling, Storage, and } \\
\text { Shipping }\end{array}$ & Sects. 8.3, 9.4 \\
\hline $\begin{array}{l}\text { 8. Calibration Procedures and } \\
\text { Frequency }\end{array}$ & $\begin{array}{l}\text { 8. Identification and Control } \\
\text { of Items } \\
\text { 12. Control of Measuring and } \\
\text { Test Equipment }\end{array}$ & Sects. $8.4,9.5$ \\
\hline 9. Anayltical Procedures & 9. Control of Processes & Sect. 9.3 \\
\hline $\begin{array}{l}\text { 10. Data Reduction, Validation, and } \\
\text { Reporting }\end{array}$ & 9. Control of Processes & Sects. $8.7,9.7$ \\
\hline 11. Internal QC Checks & 3. Design Control & Sects. $8.8,9.8$ \\
\hline 12. Performance and System Audits & 18. Audits and Surveillance & Sects. 8.9, 9.9 \\
\hline 13. Preventive Maintenance & $\begin{array}{l}\text { 12. Control of Measuring and } \\
\text { Test Equipment }\end{array}$ & Sects. 8.5, 9.6 \\
\hline $\begin{array}{l}\text { 14. Specific Routine Procedures Used } \\
\text { to Assess Data Precision, } \\
\text { Accuracy, Representativeness, } \\
\text { Completeness, and Comparability }\end{array}$ & 3. Design Control & Sects. $8.10,9.10$ \\
\hline 15. Corrective Actions & $\begin{array}{l}\text { 15. Control of Nonconforming } \\
\text { Items }\end{array}$ & Sects. 8.11, 9.11 \\
\hline 16. QA Reports to Management & $\begin{array}{l}\text { 2. QA Program } \\
\text { 16. Corrective Action }\end{array}$ & Sects. $8.12,9.12$ \\
\hline
\end{tabular}


- data will be gathered using appropriate procedures for field sampling, chain of custody, laboratory analyses, and data reporting; and

- data will be of known precision and accuracy.

The procedures to be used for assessing the quality of field data are described in Sect. 8.8.

\subsubsection{Level of Analysis}

The specific QA objectives for all data are to obtain reproducible, precise, and accurate measurements consistent with the intended use of the data and the limitations of the sampling procedures used. These objectives are accomplished through the assignment of measurement tasks to the appropriate analytical level (I through IV) as defined in Data Quality Objectives for Remedial Response Activities (EPA 1987). Field data, such as those collected during organic vapor and radiation monitoring, will meet the requirements for Level I data quality. Laboratory data will meet the requirements for Level III data quality.

\subsubsection{Data Quality Parameters}

Typical quantitative limits applicable to this project are presented in the EPA Contract Laboratory Program (CLP) statements of work (SOW) (EPA 1990d) as applicable, as are sample precision, accuracy, and completeness objectives. The QA objectives for QC data are designed to (1) screen out data of unacceptable precision or accuracy and (2) provide data that will meet the data quality goals for this project.

This project will follow the definitions for precision, accuracy, completeness, comparability, and sensitivity given in the Handbook for Analytical Quality Control in Water and Wastewater Laboratories (EPA 1979a).

\subsection{Field Activities}

Precision between monitoring instruments is determined by comparison of readings during calibration to a standard. Precision in sampling is measured through the use of field duplicates.

Accuracy is addressed by the use of standard criteria for container and equipment cleaning, sample collection, personnel training and performance criteria, uniform sample handling techniques, and blanks to detect contamination.

Representativeness of samples collected is controlled through adherence to the sampling plan and to detailed descriptions of sampling procedures, which will be included in the final OU 2 Field Sampling and Analysis (S\&A) Plan.

The QA completeness objective for this project is to obtain valid analytical results for at least $85 \%$ of the samples collected during the project. This means that completeness of sample collection (number planned vs number collected for which valid data can be obtained) 
must be essentially $100 \%$ to allow for some laboratory wastage. Accountability of samples collected, from field to final disposal, must be $100 \%$ complete.

Objectives for comparability between samples collected for this and other RIs are met by the following: (1) narrowly defined sampling methodologies; (2) site surveillance, use of standard sampling devices, and monitoring devices; (3) training of personnel; (4) documentation of sampling point; (5) stringent control limits for the daily QC checks; (6) reporting results in appropriate, comparable units; and (7) standard analytical methods.

Staff responsible for particular instruments must maintain a log of calibration procedures and results to remain with the instrument as a means of establishing a record of calibration. The Sampling Team Leaders will inspect such logs, which will become part of the project records. Each operator must be trained in the proper use of the instrument, be familiar with the instrument's use, and be able to interpret data from the instrument properly.

\subsubsection{Readiness Review}

Before mobilizing for the field effort, a readiness review is led by the QA Officer and is attended, at a minimum, by the Project Manager, key field team members, Contracts Manager, and Health and Safety Officer. The readiness review follows a checklist (Fig. 8.1) that ensures that all proper work plans and standard operating procedures are approved and controlled; all assigned personnel are trained; the drilling subcontractor is available to begin with qualified personnel, materials, and equipment; the site logistics have been handled; the laboratory is ready to accept samples; and the QA system is implemented on the field activity.

\section{SAMPLE COLLECTION PROCEDURES}

\section{Field Procedures}

Field procedures for the collection of samples are discussed in the S\&A Plan. The equipment and the techniques that will be employed to obtain representative samples will be in accordance with approved Environmental Surveillance Procedures ESP-300 series, (Kimbrough et al. 1990).

\subsection{Sampling Program}

Soil and water samples will be collected at OU 2 for the RI investigation. Table 7.1 summarizes the sampling/monitoring locations and media. Tables 7.2 and 7.3 show the numbers of samples to be collected, the number of analyses estimated to be conducted, and the field quality control samples to be collected and sent to the analytical laboratory. 
Project:

Site:

1. DOCUMENTATION

A. Are all the appropriate documents for the Project in their final, approved form? i(Work Plan, Field Sampling and Analysis Plan, QA Project Plan, Health and Safety Plan, Others (specify)]: Yes_ No__ N/A__ Comments:

B. Are copies of the approved documents (above) in the hands of the Subcontractors Project Management, assigned field personnel, and Analytical Laboratory personnel? Yes__ No__ N/A__ Comments:

C. Are applicable forms available and current with contract specifications? (Well Construction Log, Groundwater/Surface Wa er/Sediment Sampling Form. Field Change Request Form, etc.) Yes__ No__ NiA___ Comments:

\section{STANDARD OPERATING PTOCEDURES}

A. Have Standard Operating Procedures (SOPs) been prepared and approved for all field activities identified in the Field Sampling and Analysis Plan, QA Project Plan, and the Health and Safety Plan?

Yes__ No__ N/A___ Comments:

B. Do the Subcontractor's assigned fieid personnel and the selected analytical laboratory personnel have copies of, and have they been trained on, the SOPs that govern their work assignments? (Attech documestation of dates and subjects of training and rames of personnel attending.) Yes__ No__ N/A_ Comments:

C. Are the appropriate documents (See I.A) on-site and avallable to the field personnel? Yes__ No__ N/A__ Comments:

D. Are required site and field logbooks and field personnel information available? Yes No N/A_Comments:

E. Are the site and fit'd logbooks of the appropriate type and construction? Yes__ No._ N/A___ Comments:

F. Are chain-of-custody forms required and have the field personnel been fully trained in the proper documentation for using and completing these forms? Yes_No No_ N/A Comments:

Fig. 8.1. Readiness review checklist. 


\section{PERSONNEL AND TRAINING}

A. Have an appropriate number of personnel with the appropriate speciality training been assigned to this project to ensure appropriate and consistent results? (Attach roster of personnel and brief description of qualifications.)

Yes__ No_ N/A__ Comments:

B. Is there documented evidence that the assigned field personnel have been adequately trained in the specifics of this project, such as field sampling methods, to accomplish their tasks? Yes__ No__ N/A__ Comments:

C. Is there documented evidence and or training certificates that the field personnel have been adequately trained in the Health and Safety requirements? (OSHA 40-hour training, medical records, site-specific H\&S training, CPR, and first aid)

Yes__ No__ N/A__ Comments:

D. Has chain of command from field operations to management been defined and communicated to all personnei?

Yes__ No__ N/A___ Comments:

E. Is there backup personnel properly trained and available?

Yes No_ N/A__ Comments:

F. Have personnel been trained in DOE Order 5000.3A?

Yes__ No__ N/A__ Comments:

\section{MATERIALS AND EQUIPMENT}

A. Is the drilling company ready to begin work with the appropriate equipment and personnel for this project? Are there backup pleces of key equipment available? (Attach list of equipment and personnel assigned to this project.)

Yes__ No__ N/A__ Comments:

B. Have the qualifications of the drilling company personnel been verified? (Attach verification documentation.)

Yes_ No__ N/A___ Comments:

C. Have the materials for well construction been verified to meet the specifications of the Statement of Work (SOW) and the Field Sampling and Analysis Plan?

Yes No N/A Comments:

D. Have well materials (such as bentonite, gel and sand packs) been analyzed and certified analyte free? If not analyte free, has material background been analyzed and documented? (Attach certification or analysis documentation.)

Yes_ No _ N/A_ Comments:

E. Have the necessary instruments/measurement equipment and associated calibration devices been assembled on-site to conduct the specified tests and analyses for this job? Is all the equipment currently in calibration? Please attach list of all equipment used on the project with measurement and calibration documentation for each piece. Ensure initial calibration logs for each piece of equipment are in the approperate $10 \mathrm{~g}$ books.

Yes_ No N N _ _ Comments:

Fig. 8.1 (continued)

92-04591073092 
F. Have all necessary materials and equipment been assembled to correctly collect, identify, preserve, and transport the types and number of samples to be taken for this job? (Attach a list of the type and quantity of materials/equipment available for this project.)

Yes__ No__ N/A__ Comments:

G. Have all the necessary types of personnel protection and decontamination equipment (clothing, breathing apparatus, respirators, face masks, gloves, plastic sheeting, plastic baggies, spare compressed air bottles, boots, decontamination gear, etc.) been assembled and made ready for this job? (Attach a list of the types and quantities of equipment available for this project.)

Yes_ No N N/A Comments:

H. Has the Health and Safety Officer been identified? Have all site personnel received H\&S training? Has H\&S Officer verified that all health and safety precautions can be implemented? (Attach documentation of dates and subjects of training and names of personnel attending.) Yes__ No__ N/A__ Comments:

I. Have all materials and pieces of equipment (communication devices, drinking water, first aid lits, etc.) been assembled to meet the requirements of the Health and Safety Plan?

Yes__ No__ N/A__ Comments:

J. Have all required interfacing arrangements (telephone numbers, site contacts, emergency signals, medical response team, etc.) been made and tested satisfactorily?

Yes__ No__ N/A__ Comments:

\section{SITE LOGISTICS}

A. Have clearances been obtained for all job-site personnel? Is the site security organization aware of the project, the scope of activities to be accomplished, and the estimated duration of the project?

Yes_ No__ N/A___ Comments:

B. Have all drilling permits/clearances been granted or a schedule established for obtaining them? Have permits/clearances been obtained for any radioactive materials to be taken on-site? (Attach permits or schedules as appropriate.)

Yes__ No__ N/A__ Comments:

C. Have the appropriate site commands/facilities/functions been informed of the activities and potential interfaces in their work areas?

Yes_ No_ N/A__ Comments:

D. Have arrangements been made for the disposal of drill cuttings, refuse, contaminated materials, rinsate, etc.?

Yes_ No__ N/A___ Comments:

E. Have arrangements been made for the location of field laboratories (phone, electricity, etc.) and storage facilities for bottles, samples, solvents, and sampling equipment?
Yes
No
N/A
Comments:

Fig.8.1 (continued) 


\section{LABORATORY LOGISTICS}

A. Has a contract-approved laboratory been selected and been made aware of the data quality objectives and the anticipated schedule of project activities? Have laboratory personnel been advised of any unusual requirements or circumstances? (Indicate name and address of primary laboratory.)

Yes N/A Comments:

B. Has the selected laboratory been notified when sampling will begin, the projected volume of samples, the types of samples, and when samples should start arriving for analysis? Yes_ No N/A_ Comments:

C. Has a secondary, backup laboratory been selected and approved in case of emergency situations? (Indicate name and address of backup laboratory.) Yes_ No_ N/A Comments:

D. Has notification been made to the selected sample transportation company? Have arrangements been made to ensure that appropriate chain-of-custody and quality control requirements can be achieved? (Indicate name and address of transportation company.) Yes No N/A Comments:

E. Are an appropriate number of the correct type(s) of sample containers available for the anticipated work? (Attach a list of the types and numbers of containers available for this project.)

Yes.

No

$\mathbf{N} / \mathbf{A}$

Comments:

\section{vil. QUALITY ASSURANCE}

A. Is a Quality Assurance Program being implemented? Yes_ No__ N/A__ Comments:

B. Have arrangements been made to have QA audits and survelliances? Yes_ No_ N/A__ Comments:

C. Do the various plans and manuals require a document control program? If yes, is this being implemented? (Supply the Document Control Coordinator name and address.)

Yes_No No N/A__ Comments:

D. Is there a system in place to identify, refort, and evaluate any conditions adverse to quality? Yes No N/A Comments:

\section{ATTESTATION}

By my signature, I do hereby attest, to the best of my knowledge and professional ability, that this Readiness Review Checklist accurately reflects the status of our Company to complete the authorized task(s) at per Task Order
scheduled to begin on (Base name or site) (Date). (Contract Task Order Number) scheduled to begin on

Fig.8.1 (continued) 
823 Sample Containers, Preservation, Transport, and Storage

Sample preservation, holding times, storage conditions, and container materials shall be in accordance with ESP-701 (Kimbrough et al. 1990). The procedures required to properly package containers of environmental samples for transportation are described in ESP-800 (Kimbrough et al. 1990).

\subsection{Prevention of Cross Contamination}

Sampling equipment will be decontaminated before use and between collection of each sample per ESP-900 (Kimıbrough et al. 1990). Each decontamination activity will be recorded in the field logbook.

\section{Decontamination of Equipment and Supplies}

Decontamination of sample containers and sampling devices given in ESP-900 (Kimbrough et al. 1990) will be followed. Equipment used in field investigations-including well drilling equipment, soil sampling equipment, and field test equipment-will be decontaminated as described in ESP-901 (Kimbrough et al. 1990).

\subsubsection{Field Documentation}

An integral part of the QAVQC Plan for the field activities will be to maintain accurate and complete field records, including logbooks and appropriate field data forms. Field logbooks shall be hardcover with stitcheci bindings and water-resistant pages. Information identified in these records will be obtained from the site exploration and sampling activities and will be reviewed by the Sampling Team Leader. All information pertinent to field activities will be recorded. Entries in the logbooks or on the data forms will be made in water-resistant ink and will include the information given in ESP-500 Sect. VII, Part D (Kimbrough et al. 1990).

Appropriate field-generated data forms will be prepared based on the requirements in the QC Manual (Kimbrough et al. 1990).

\section{Variance System}

Procedures that properly anticipate all conditions encountered during a field sampling program cannot be prepared. Variances from approved operating procedures in the OU 2 RI Plan, S\&A Plan, the QAPP, or the Health and Safety Plan will be documented in a field change request form (Fig. 8.2) and in the logbooks.

The Sampling Team Leader will initiate and chronologically maintain a variance or field change request log. A variance requires the approval of the OU 2 Project Manager and the QA specialist (QAS) before work proceeds. As appropriate, regulatory agencies will be notified of any variances that significantly affect project scope or objectives and approval will be obtained if needed. Any variances from the Health and Safety Plan must be approved by the Health and Safety Coordinator. Approval by the OU 2 Project Manager and QAS can 
Revision Date: January 1989

FIEID CHALIGE REQUEST FORM

Field Change No.

Page

of

Project

Project No.

Applicable Document:

Description:

\section{Reason for change:}

\section{Recommended disposition:}

Impact on present and completed work:

Final Disposition:

Requested by:

Field/Project Manager:

Approvals:

Project Manager:

Fig. 8.2. Field change request form. 
be initiated verbally via the telephone or radio with follow-up sign-off. In no case will non-OU 2 project personnel initiate a variance. Copies of the field change request form will be maintained by sampling teams until the field work is complete and will then be forwarded to the OU 2 Project Manager and sent to the Document Management Center.

\section{Sample Identification}

The identification of samples will be established and maintained as specified by the chain-of-custody procedures described in ESP-500 (Kimbrough et al. 1990) and will be specifically described in the final S\&A Plan (Sect. 7).

\section{Shipping and Handling}

Handling, shipping, and storage of samples and data resulting from field activities will adhere to custody (Sect. 8.3) and will ensure that sample integrity for analytical purpose is maintained. Specific shipping and handling procedures are described in ESP-800 (Kimbrough et al. 1990).

\section{Sample Turnaround Time}

Sample analyses will be scheduled according to site investigation needs and consistent with the sample holding times. The S\&A Plan will specify the turnaround times that will meet the project schedule and objectives. These requirements shall be included in any contractual agreement between the OU 2 project and contract laboratories.

\section{Field Data Management}

Field records will be recorded legibly in permanent ink and will be sufficiently complete to permit reconstruction of data-gathering activities by a qualified individual (other than the originator) when data are reduced. Field notebook entries should be factual, detailed, and objective. The field records will be the basis for later written reports and all entries must be free of inappropriate terminology. The Sampling Team Leaders will collect and review fieldgenerated data sheets daily for accuracy and completeness before being transferred to the Analytical Services Coordinator (ASC). Manual entry of field data will be coordinated by the ASC. Data entry clerks will enter field data into specified computer systems to facilitate retrieval by OU 2 personnel. Quality will be checked by double entry and verification of entered data. The OU 2 Project Manager will forward field notebooks to the Document Management Center at the conclusion of field activities.

\subsection{SAMPLE AND DOCUMENT CUSTODY PROCEDURES}

Chain-of-custody procedures require documented sample possession from the time of collection to disposal. Chain of custody shall be maintained in accordance with ESP-500 (Kimbrough et al. 1990). Additional details of document control are included in the RCRA Facility Investigation Plan, General Document, Volume III: Data Management Plan (Wiggins et al. 1988). 
Sample custody will be initiated at the time of sample collection. Sample tags or other appropriate labels will be used to identify field samples with the following information: unique sample identification code, date and time of sampling, sampling location or station, preservation, analysis, and any additional comments that are applicable. Descriptions of sampling activities and sample identification data will also be recorded in a field notebook. Field chain-of-custody forms containing the same information will be completed for each set of samples. A line item on the sample chain-of-custody form will be completed for each sample, and the sampling technician will confirm (by signature) the completeness of the information on the form. Each individual who assumes responsibility for the samples will sign the chain-of-custody form.

Sample custody will be maintained by OU 2 staff until custody is transferred to an overnight express company. The overnight express company delivers samples and transfers custody to particular analytical laboratories, where their intralaboratory chain-of-custody procedures will be in effect. On completion of analyses, sample custody will be returned to OU 2 staff. Remaining samples may be archived for 1 year and disposed of as prescribed in ESP-1000 (Kimbrough et al. 1990). The chain-of-custody form terminates upon final disposal of the sample. The OU 2 Project Manager will be responsible for ensuring that the original chain-of-custody form is submitted to the Document Management Center.

\subsubsection{Field Custody Procedures}

Field custody procedures include the following steps:

- Before sampling begins, the QAS will instruct sampling personnel on the chain-of-custody and sample-labeling procedures, as necessary.

- A chain-of-custody record will be initiated in the field for each sample and will correspond to the sample identification label.

- Each time sample custody is transferred, the person relinquishing the sample and the new custodian will sign the record and note the date and time.

- The analyses to be performed for each sample will be recorded on a request-for-analysis form or on the chain-of-custody record.

- The Sampling Team Leader will confirm that proper custody procedures were used during the field work and that results were documented in the field logbook.

- Samples transferred to analytical laboratories are recorded in the field logbook at the end of the collection period.

\section{Sample Labeling}

Sample labels or tags will contain sufficient information to identify the sample in the absence of other documentation. The label or tag will be directly affixed to the sample 
container, will be completed with black indelible ink, and will include the following as a minimum:

- project name,

- unique sample number,

- sample location,

- sampling date and time,

- signature of individual collecting the sample, and

- preservation method employed.

In the event that samples arrive damaged or with custody seals broken, a Nonconformance Report (NCR) (Sect. 8.11) will be initiated. The Project Manager will be advised and will make a decision as to the fate of the nonconforming sample. The OU 2 Project Manager and the QAS will sign the NCR, noting the reason for sample dispositionand will initiate corrective actions if necessary.

Once samples are in the possession of the laboratory, their internal chain-of-custody and sample-handling procedures will be in effect (Sect. 9.4).

\subsection{CALIBRATION PROCEDURES AND FREQUENCY}

\subsubsection{Instrument Calibration Procedures and Frequency}

A list of all measuring and test equipment to be used, along with a schedule for calibration, will be prepared prior to initiating field work. In general, field calibration methods will be those recommended by the manufacturer. Instrument logbooks will be established.

Calibrated equipment will be uniquely identified by using either the manufacturer's serial number or other means. All equipment shall be categorized as one of the following:

- Category A-Casual devices and systems (rulers, tape measures, graduated cylinders, pipettes, etc.) that are not to be calibrated in service (i.e., not calibrated other than by the manufacturer).

- Category B-Routine devices and systems (balances, spectrophotometers, etc.) that are to be included in a calibration recall program on a regular cycle.

- Category $\mathrm{C}$-Experimental devices and systems ( $\mathrm{pH}$ meters, turbidimeters, etc.) that are to be calibrated by, or at the direction of, the user as deemed necessary. All pH 
meters are calibrated in the field, at a minimum each morning and whenever the instrument is turned off. Calibration is also checked at the end of each day.

The appropriate category decal with the identification number and the due date of the next calibration will be attached to the equipment. If this identification is not possible, records traceable to the equipment will be readily available for reference.

\subsection{Calibration Failures}

Scheduled periodic calibration of equipment will not relieve field personnel of the responsibility to employ properly functioning equipment. If an individual suspects an equipment malfunction, he/she should remove the device from service, tag it so it is not inadvertently used, and notify project management. If equipment is found to be out of calibration, the Sampling Team Leader will evaluate and document (in the instrument logbook) the validity of previous inspection or test results and the acceptability of similar equipment previously inspected or tested. The responsible supervisor will ensure that the devices that are out of calibration are (1) tagged or segregated from other equipment and (2) disposed of or not used until they are calibrated. Any equipment that is consistently found to be out of calibration will be repaired or replaced. Any repair or replacement should be recorded in the instrument logbook.

All standards used for equipment calibration will be traceable to the EPA, the National Institute of Standards and Technology, or a commercially available certified standard. The source of the standard used must be documented in a calibration logbook.

\subsection{Calibration Records}

Calibration data will be recorded in the instrument logbook. Records will be prepared and maintained for each piece of calibrated equipment to indicate that established calibration procedures have been followed. The Sampling Team Leader will ensure that records of calibration data are kept current. Records for field equipment used will be maintained by the Sampling Team Leader and kept in the project files.

\section{PREVENTIVE MAINTENANCE}

Periodic preventive maintenance is required for all measuring and test equipment. Instrument manuals will be kept on file for reference purposes if equipment needs repair. Maintenance frequency will be based on manufacturer's recommendations, intended use, and experience. The troubleshooting section of factory manuals may be used to assist personnel in performing maintenance tasks. Routine maintenance will be performed on instruments to reduce the incidence of extensive repairs immediately prior to sampling and analysis.

\subsubsection{Field Instruments}

The frequency of preventive maintenance for field equipment is usually indicated in each operating instruction manual. Maintenance will be documented and maintained in permanent 
records by the individual responsible for each instrument. Critical spare parts will be identified and stocked to minimize equipment downtime and lost field sampling effort.

\subsection{FIEID ANALYSES}

All field measurements will follow the ESP-307 Series (Kimbrough et al. 1990) and will be recorded in the field logbooks or on specially designated data forms. All data will be directly entered in the field, signed, and dated. If entry changes are made, one line will be drawn through the error, and the change and explanation will be signed and dated in the notebook or on the data form. Changes made to original notes should not obliterate the original information. All field data records will be organized into standard format when possible. Team leaders are responsible for review of daily entries in the field logbooks.

\section{DATA REDUCTION, VALIDATION, AND REPORTING}

Data validation is a systematic process for reviewing a body of data against a set of criteria to provide assurance that the data are adequate for their intended use. Data validation consists of data editing, screening, checking, auditing, verifying, certifying, and reviewing.

All data for this project will be evaluated by QAVQC methods and internal peer review. Data reduction, verification, and reporting will be in accordance with the Data Management Plan (Wiggins et al. 1988). Data will be entered into common standardized formats. In addition to following field sampling documentation and QAVC procedures, data are verified using a variety of computerized checks. These procedures will ensure that data are entered, encoded, and manipulated in a consistent way and are available to OU 2 investigators in a usatle format.

\subsubsection{Field Data Reduction and Evaluation}

Data collected during field activities will be evaluated by checking the procedures used and comparing the data with previous measurements. The QA/QC Coordinator and Sampling Team Leaders will be responsible for checking field QC sample results to ensure that field measurement and sampling protocols have been observed. These reviews will check the following:

- date and time sampled,

- preservation,

- standard operating procedures,

- calibration method and frequency, and

- chain-of-custody documentation. 
Reviewers are responsible for ensuring that data reduction calculations are documented and checked by qualified personnel.

Written reports that include reduced and summarized data will include the raw data in appendixes. Specific calculations used for data reduction will also be included.

\subsection{FIELD QUALTYY CONTROL SAMPLES}

Field QC samples will be established to check sampling. Field QC samples will include blanks and replicates as follows:

Trip Blank-A trip blank, consisting of a sealed container of organic-free water, will travel from the field to the laboratory with the samples to be analyzed for the contaminant of concern. The trip blank identifies contamination that may have been contributed to the field samples during the transport (receives same treatment as sample containers). As a minimum, one trip blank will be prepared and transported with every packed cooler containing VOC samples.

Equipment Rinsate Blanks-An equipment rinsate blank consists of final rinse water from the decontamination of field sampling equipment. Analysis of the field rinsate determines if the decontamination procedure is adequate to avoid carryover of contamination from one sampling location to another and to ensure that samples are not being biased in any way by the equipment used to collect the sample. One equipment rinsate blank will be taken from each type of equipment used per sampling event or one blank for every 20 field samples collected.

Field Blank-Field blanks are samples of the source water, ASTM Type II, used in the decontamination and cleaning of equipment used in smaple collection. A field blank is a sample container filled with distilled, deionized water that is exposed during sampling and then analyzed to detect accidental or incidental contamination.

Duplicate Samples-Duplicate samples, which consist of a duplicate sample from one sampling location, indicate whether the field sampling technique is reproducible. A minimum of $10 \%$ of the samples taken per sampling event and per sample matrix (soil, surface water, etc.) will be duplicates. Duplicate samples will have discrete sample numbers and will be submitted as "blind" to the laboratories.

The quantities and collection procedures for each field QC sample type are specified in the Field Sampling Plan. Results of these samples will be included in the añalytical data report. Results for QC samples will not be used to adjust the results obtained for original samples. If contaminants are found in blanks, attempts will be made to identify the source of contamination, and corrective action will be initiated in accordance with Sect. 8.11. 


\subsection{FIELD AUDITS AND SURVEILLANCES}

Audits are performed to review and evaluate the adequacy of field performance and to ascertain whether the QAVC Plan is being completely and uniformly implemented. The following requirements are adapted from basic requirement 18, "Audits," of ANSI/ASME NQA-1 (ANSI/ASME 1986), and Environmental Restoration Division Quality Assurance Program Plan (Energy Systems 1991b). Planned and scheduled audits will be performed to verify compliance with all aspects of the QA program and to determine the program's effectiveness. These audits will be conducted in accordance with written procedures and checklists and will be performed by personnel who do not have direct responsibility for performing the activities being audited. Audit results will be documented and will be reported to and reviewed by responsible management. Follow-up action will be taken by the responsible line organization when necessary.

The objectives of performance and systems audits are to (1) ensure that the QA program developed for this project is being implemented according to the specified requirements, (2) assess the effectiveness of the QA program, (3) identify nonconformances, and (4) verify that identified deficiencies are corrected. Upon discovery of any significant deviation from the QA program, the Project Manager will be informed of the nature, extent, and corrective action taken to remedy the deviation.

An individual audit plan will be developed to provide a basis for each audit. This plan will identify the audit scope, the activities to be audited, the audit personnel, any applicable documents, and the schedule. Records of audits will be maintained in the project files. Audit files will include-as a minimum-the Surveillance Report, the reply to audit, and any supporting documents. The OU 2 Project Manager is responsible for conforming to audit procedures, particularly as to timely replies to audit reports and implementation of such corrective action indicated.

\subsubsection{Frequency of Audits}

The QAS is responsible for internal audits and will perform them according to a schedule that coincides with appropriate activities on the project schedule and sampling plans. Such scheduled audits may be supplemented by additional audits for one or more of the following reasons:

- when significant changes are made in the QAVQC Plan,

- when it is necessary to verify that corrective action has been taken on a nonconformance reported in a previous audit, or

- when requested by the Project Manager.

In addition to these internal audits, surveillance of selected activities may be performed on a periodic basis. 


\subsubsection{Performance Audits}

A performance audit can be defined as a review of the existing project and QC data to determine the accuracy of a total measurement system(s) or a component part of the system. The QAS or his designee will check the logging of samples, proper chain of custody, and related documentation. Any irregularities in $\mathrm{QA}$ procedures that are not immediately corrected will be brought to the attention of the OU 2 Project Manager.

\subsection{Systems Audits}

A systems audit consists of an evaluation to determine if the components of a measurement system were properly selected and are being used correctly. A systems audit includes a careful evaluation of field QC procedures to ensure that the QA/QC procedures are being adhered to. Systems audits are conducted as deemed necessary by the QAS, normally either before or shortly after systems are operational. The systems audit is reported in formal audit reports.

\subsubsection{Field Surveillance}

An individual surveillance plan will be developed to provide a basis for each field surveillance. This plan will identify the scope, activities, and personnel to be involved, any applicable documents, and the schedule for each field surveillance. Checklists may be prepared and used to conduct all surveillances. These checklists will be developed to accomplish the review of necessary items and to document the results of the surveillance.

Field surveillance will involve an on-site visit by the QAS or appropriate surveillance personnel. Items to be examined may include, but are not limited to, the availability and implementation of approved work procedures; calibration and operation of equipment; packaging, storage, and shipping of samples; documentation procedures and instructions; and documentation of nonconformances.

The records of field operations will be reviewed to verify that field-related activities were performed in accordance with standard procedures. Items reviewed may include, but are not limited to, calibration records of field equipment, daily field activity logbooks, chain-of-custody records, and data resulting from field operations.

During a surveillance and upon its completion, the surveillance personnel and the individuals surveyed will discuss the observations of deviations and will agree on corrective actions to be initiated. A surveillance report will be completed for each surveillance activity.

Minor administrative findings that can be resolved to the satisfaction of the surveillance personnel during a surveillance are not required to be cited as items requiring corrective action. Findings that are not resolved during the course of the surveillance and findings affecting the overall quality of the project will be noted on the checklists and included in the surveillance report. 


\subsection{DATA MEASUREMENT ASSESSMENT PROCEDURES}

A statistical evaluation of livuratory analytical results will be performed to apply precision and accuracy criteria for each parameter analyzed. When the analysis of a sample set is completed, the QC data gencrated will be reviewed and evaluated by an organization other than the analytical laboratory to validate the data set. All QC data will be reported to the OU 2 Project Manager, along with the sample analysis results. The QC data will be reviewed for precision and accuracy.

\subsection{Precision}

Precis.un will be assessed by conducting separate analyses of duplicate samples. The level of precision is determined by calculating the relative percent difference (RPD) between the two measurements; thus,

$$
R P D=\frac{\left(D_{1}-D_{2}\right) \times 100}{\left(D_{1}+D_{2}\right) / 2},
$$

where $D_{1}=$ value of first measurement,

$D_{2}=$ value of second measurement.

\subsection{0 .2 Accuracy}

Accuracy is achieved by the use of standard criteria for container and equipment cleaning, sample collection, personnel training and performance criteria, uniform sample handling techniques, and blanks to detect contamination.

\subsection{CORRECTIVE ACTIONS}

This section identifies mcthods and policies for the documentation, evaluation, corrective action, and verification activities necessary when a deviation from established procedure occurs. Requirements for the documentation and implementation of corrective actions are also included.

Any deviation or nonconformance will be evaluated with respect to its possible impact on reportable data. All deviations from standard operating procedures, equipment calibrations, or any aspect $o_{\text {, the }}$ QA plan will be evaluated and documented. Significant deviations identified using the statistical assessment of quality data will also be used in Nonconformance and Corrective Action Procedures.

\subsubsection{Responsibilities of Project Participants}

OU 2 personnel will ensure the prompt identification, control, and disposition of nonconforming items. Each laboratory participant is responsible for submitting records of all nonconformance events to the appropriate Sampling Team Leader and/or the QAS within a 
reasonable period of time following the initial identification and documentation of the nonconformance. The nonconformance will then be evaluated by Team Leaders, QAS, Project Manager, and others as is deemed relevant. This evaluation will determine the disposition of the nonconformance.

\subsection{Nonconformances and Corrective Action Procedures}

Nonconforming equipment, items, activities, conditions, and unusual incidents that could affect compliance with project requirements will be identified, controlled, and reported in a timely manner. A nonconformance is defined as a malfunction, failure, deficiency, or deviation from specified requirements. The originator of an NCR will describe the finding on the form provided for this purpose and will notify the OU 2 project management and the QAS. Each nonconformance will be reviewed and a disposition given for the item, activity, or condition. Evaluations also will determine if the event justifies the issuance of a Corrective Action Report (CAR). The CAR will document the event, the findings of the evaluation, and the required corrective actions. The disposition of a nonconformance will be documented and approved by the OU 2 Project Manager. The QAS will concur with the disposition of the nonconformance.

The QA/QC Coordinator for a particular laboratory is responsible for the assessment of laboratory quality control sample information. If data fall outside accepted limits, established laboratory procedures for identifying the problem and taking appropriate corrective actions will be employed. Completion of corrective action should be evident when deviations return to prescribed acceptable limits.

The modification, repair, rework, or replacement of nonconforming equipment, items, or activities will require the reverification of acceptability. In certain instances, as determined by project management, these activities may require that corrective action be completed and verified before site work continues.

If, in the opinion of project management and the QAS, the nonconformance does not significantly affect the technical quality or use of the work, then the work may continue, pending resolution of the nonconformance. The basis for such a decision will be documented on the NCR and submitted to the QAS for review and approval. The documentation will include the statement that the decision was made before continuing with the work. The records of nonconformance and their dispositions will be maintained by the OU 2 Project Manager and forwarded to the Document Management Center.

\section{QUALTTY ASSURANCE REPORTS TO MANAGEMENT}

The active participation of management in the OU 2 Project is fundamental to the success of this QAVC Plan. Management will be aware of project activities and will participate in development, review, and operation of the project. Management will be informed of QA status and activities through the receipt, review, and/or approval of the following: 
- regular quality status reports,

- laboratory and project-specific QAVC plans and procedures,

- postaudit reports and audit closures,

- surveillance reports,

- corrective action overdue notices, and

- NCRs.

Copies of these reports will be distributed to appropriate management and regulatory agencies. In addition, periodic assessment of QAVC activities and data precision, accuracy, representativeness, completeness, and comparability will be conducted and reported by the analytical laboratories.

As appropriate, project management will inform the QAS of the QA status of the project, especially any significant quality accomplishments. OU 2 personnel are required to inform the Project Manager or project support staff of all nonconformances or quality failures. The Project Manager will document and immediately report any nonconformance or quality failure to the QAS. 
Environmental Restoration Program

Laboratory Quality Assurance Project Plan (QAP) for

Bear Creek Valley Operable Unit 2

Revision 2

February 1993
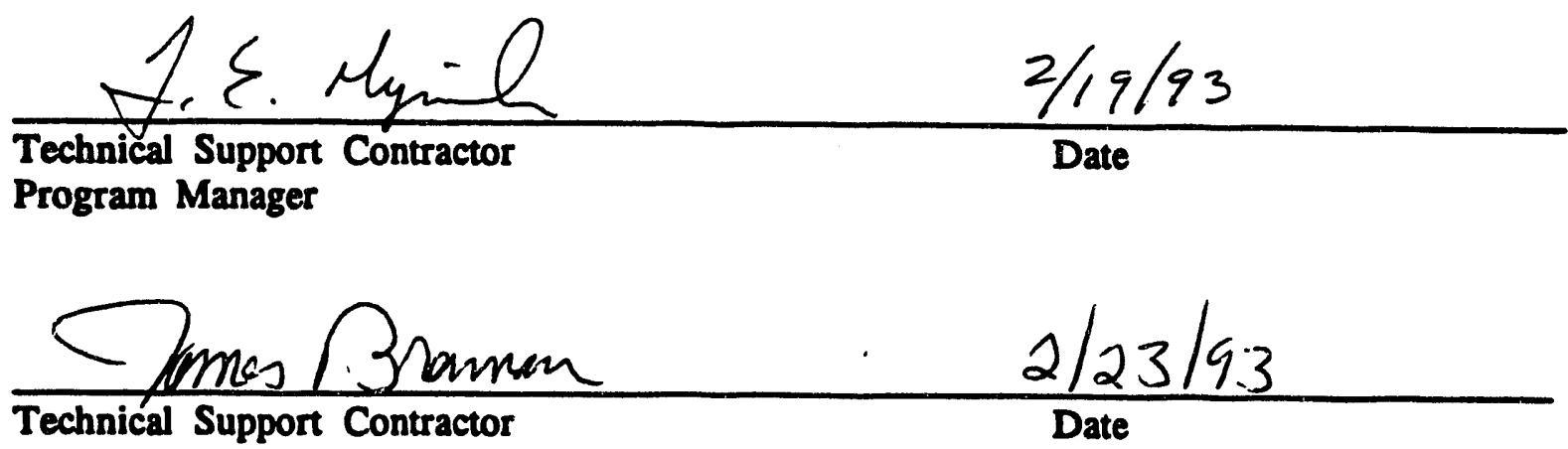

Quality Assurance/Quality Control Officer Concurrence
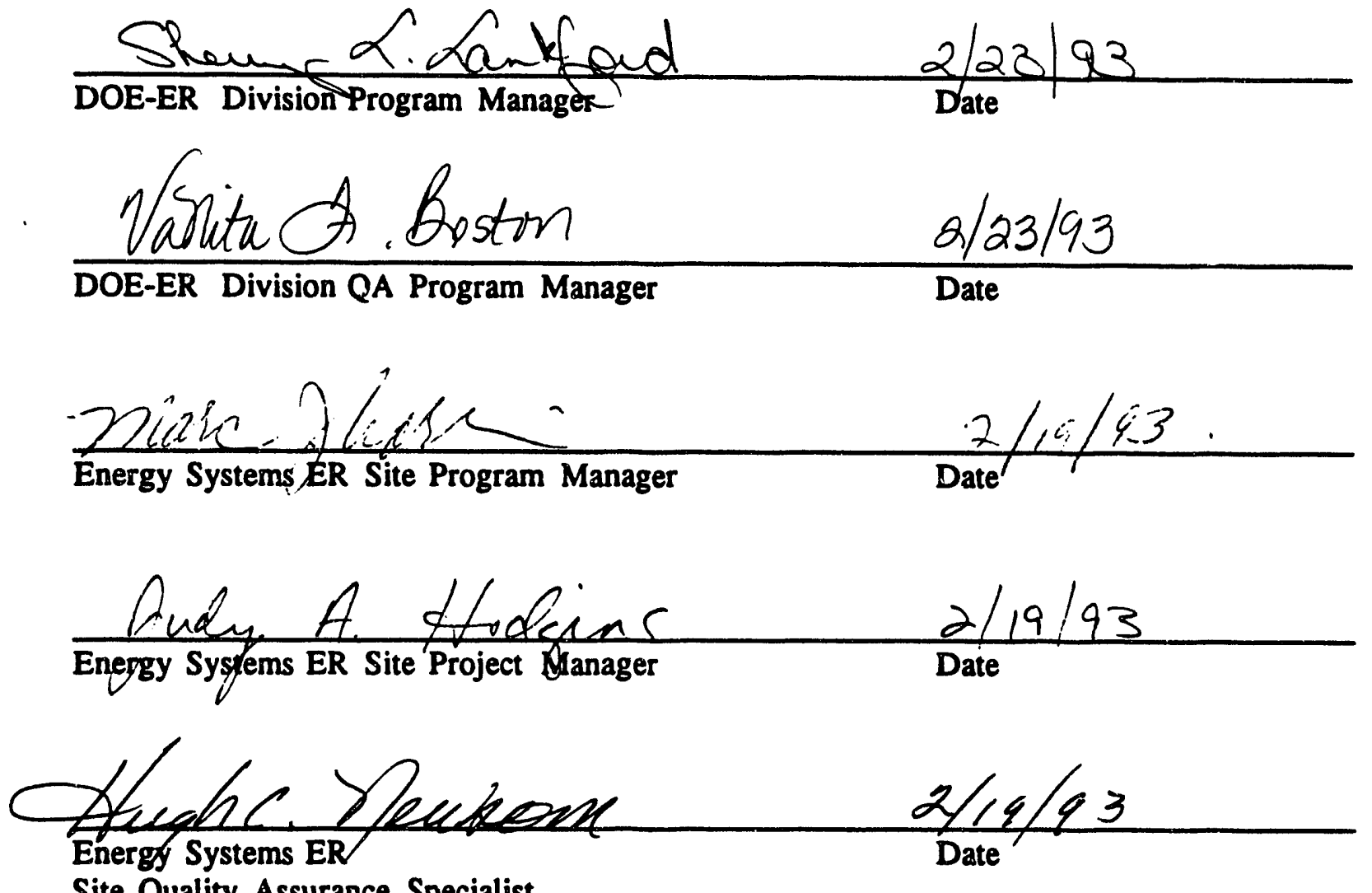

Site Quality Assurance Specialist 


\section{LABORATORY QUALTTY ASSURANCE PROJECT PLAN}

This QAPP has been developed for use in the sample analysis activities during the RI for OU 2 to ensure that appropriate levels of QA and QC are achieved. This QAPP defines procedures that will be followed in the custody, analysis, and handling of data used in the RI for OU 2. These procedures are intended to define the methods applied to achieve the DQOs established for the OU 2 project.

This QAPP establishes QA requirements and responsibilities applicable to laboratory project participants and establishes methods through which project participants implement the requirements of the project. Where no appropriate procedure exists, this QAPP requires that one be developed by one or more cognizant individuals or organizations. At this time, the details of roles and responsibilities have not been assigned to specific individuals or organizations. When assignments are made, the QAPP will be revised.

This QAPP is designed to comply with both the EPA QAMS Interim Guidelines and Specifications for Preparing Quality Assurance Project Plans (QAMS-005/80) and the ANSI/ASME NQA-1 guidelines.

\subsection{QUALITY ASSURANCE OBJECTIVES FOR DATA MEASUREMENT}

The purpose of this section is to implement applicable regulatory requirements and to provide internal control and review so that the data are scientifically sound and legally defensible. QA objectives for data are as follows:

- scientific data generated will withstand scientific scrutiny;

- data will be gathered using appropriate chain-of-custody procedures, laboratory analyses, and data reporting; and

- data will be of known precision and accuracy.

The QA requirements for the OU $2 \mathrm{RI}$ are defined previously in this report. The procedures to be used for assessing the quality of analytical laboratory data are described in Sect. 9.8. Analytical laboratories selected for this project must meet criteria for laboratory certification and adherence to regulatory QA requirements.

\subsubsection{Level of Analysis}

The specific QA objectives for all data are to obtain reproducible, precise, and accurate measurements consistent with the intended use of the data and the limitations of the sampling and analytical procedures used. This is accomplished through the assignment of measurement tasks to the appropriate analytical level (I through IV) as defined in Data Quality Objectives for Remedial Response Activities (EPA 1987). Analytical laboratory data generated from the 
analysis of surface water, groundwater, sediment, and soil samples will meet the requirements for Level III data quality.

\subsection{Data Quality Parameters}

Typical quantitation limits applicable to this project are presented in the EPA CLP SOW (EPA 1990d) as applicable, as are sample precision, accuracy, and completeness objectives. The QA objectives for QC data are designed to (1) screen out data of unacceptable precision or accuracy and (2) provide data that will meet the data quality goals for this project.

This project will follow the definitions for precision, accuracy, completeness, comparability, and sensitivity given in the Handbook for Analytical Quality Control in Water and Wastewater Laboratories (EPA 1979a).

\subsubsection{Laboratory Activities}

The QA objectives for precision and accuracy in the laboratory are defined by con:rol limits established by the EPA CLP (EPA 1990d). The laboratory will be required to submit the results of all control sample analyses to ensure conformance with established control limits and other QA requirements.

The QA completeness objective for this project is to obtain valid analytical results for at least $85 \%$ of the samples collected. Laboratory completeness will be determined by the extent to which data are substantiated by hard-copy documentation, which includes chain-ofcustody request for services and instrument calibration forms. Comparability and sensitivity criteria are established by either CLP (EPA 1990d) or standard operating procedures for particular analytical laboratories.

\section{SAMPLE PREPARATION PROCEDURES}

The sampling program and sample preparation procedures are discussed in Sect. 8.2. Tables 7.2 and 7.3 show the numbers of samples to be collected, the number of analyses estimated to be conducted, and the field quality control samples to be collected and sent to the analytical laboratory.

Sample analyses will be scheduled according to site investigation needs and consistent with the sample holding times. The S\&A Plan will specify the turnaround times that will meet the project schedule and objectives. These requirements will be included in any contractual agreement between the OU 2 project and contract laboratories. 


\section{ANALYTICAL PROCEDURES}

\subsubsection{Laboratory Analyses}

OU 2 samples will be analyzed for potential contaminants of concern using methods in EPA CLP SOW 3/90 (EPA 1990d) for parameters specified by EPA CLP. Non-CLP parameters may be analyzed by using Test Methods for Evaluating Solid Waste (EPA 1986), Methods for Chemical Analysis of Waters and Wastes (EPA 1979b), Guidelines Establishing Test Procedures for the Analysis of Pollutants under the Clean Water Act (EPA 40 CFR Part 136), and Martin Marietta Energy Systems Environmental and Effluent Analysis Manual (Energy Systems 1986). A listing of the recommended methods and detection limits to be used for samples collected at OU 2 is provided in Table 7.4 of this plan.

\subsection{Anałytical Laboratories}

Contracts will be established with analytical laboratories to analyze samples collected during the sampling phase of the OU 2 project.

Each contractor laboratory that analyzes samples will provide quantification limits for each constituent analyzed. The method detecion limit (MDL) is defined as the minimum concentration of a substance that can be measured and reported with $99 \%$ confidence that the value is $>0$. The MDL actually achieved in a given analysis will vary depending on instrument sensitivity and interferences. The objectives for precision and accuracy for each chemical are based mainly on the capabilities of the approved EPA analytical method with respect to laboratory $\mathbf{Q C}$.

In addition to evaluating each set of data for accuracy and precision, an assessment will also be made of the completeness of the data. This assessment will involve computing the fraction of the reported values that remain valid after the sampling procedures have been reviewed and the results have been assessed for precision and acruracy.

\subsection{SAMPLE AND DOCUMENT CUSTODY PROCEDURES}

Chain-of-custody procedures require documented sample possession from the time of collection to disposal. Sample custody will be maintained by OU 2 project staff until custody is transferred to an overnight express company. The overnight express company delivers samples and transfers custody to particular analytical laboratories, where their intralaboratory chain-of-custody procedures will be in effect. On completion of analyses, sample custody will be returned to OU 2 project staff. The chain-of-custody form terminates on final disposal of the sample. The OU 2 Project Manager will be responsible for ensuring that the original chain-of-custody form is submitted to the Document Management Center.

\subsubsection{Laboratory Receipt and Handling of Samples}

When each sample identification is received at the laboratory, it is compared to the information contained on the included chain-of-custody documents. If discrepancies exist, 
appropriate note (signed and dated) will be made on the chain-of-custody document, and the Project Manager or designated person will be notified.

After receipt and initial inspection of samples and accompanying forms, the following items are checked and recorded:

- seals and tapes on the transportation container are unbroken and uncut,

- sample containers in the transportation container are intact and at correct temperature,

- check is made with survey instruments to determine external activity and smear surfaces for removal of contamination,

- $\quad$ pH of preserved samples (except VOCs) is checked and documented, pH of preserved VOCs is checked upon analysis and documented,

- identification on the sample bottles corresponds to the entire description on accompanying forms, and

- number of sample containers received is equal to the number of samples listed on the chain-of-custody forms.

In the event that samples arrive damaged or with custody seals broken, an NCR (Sect. 9.11) will be initiated. The Project Manager will be advised and will make a decision as to the fate of the nonconforming sample. The OU 2 Project Manager and the QAS will sign the NCR-noting the reason for sample disposition-and will initiate corrective actions if necessary.

Once samples are in the possession of the laboratory, their internal chain-of-custody and sample-handling procedures will be in effect. If samples are to be shipped from one laboratory to another, proper chain-of-custody and packaging procedures will be maintained, as specified in ESP-800 (Kimbrough et al. 1990). Preanalysis sample storage procedures used are described in the CLP SOW (EPA 1990d). Anticipation of reanalysis requires proper environmental control of samples following analysis. Samples requiring refrigeration will remain refrigerated for 3 months unless prior arrangements have been made by the OU 2 Project Manager. Unused sample portions will be archived. If re-analysis is not anticipated, then environmental conditions will be observed, and the samples will be stored at room temperature. Sample residues will be disposed of by contractor laboratories in accordance with ESP-1000 (Kimbrough et al. 1990), or other EPA-approved procedures. 


\subsection{CALIBRATION PROCEDURES AND FREQUENCY}

\subsubsection{Instrument Calibration Procedures and Frequency}

A list of all measuring and test equipment to be used, along with a schedule for calibration, will be prepared prior to initiating field work. In general, calibration methods will be those recommended by the manufacturer. Instrument logbooks will be established and maintained.

Laboratory equipment will be calibrated in accordance with the CLP (EPA 1990d) or other contractor laboratory QA manual when CLP protocol is not established. Calibration frequency will be based on the analytical methods employed, type of equipment, inherent stability, manufacturer's recommendations, values given in national standards, intended use, and experience.

Calibrated equipment will be uniquely identified by using either the manufacturer's serial number or other means. All equipment shall be categorized as one of the following:

- Category A-Casual devices and systems (rulers, tape measures, graduated cylinders, pipettes, etc.) that are not to be calibrated in service (i.e., not calibrated other than by the manufacturer).

- Category B-Routine devices and systems (balances, spectrophotometers, etc.) that are to be included in a calibration recall program on a regular cycle.

- Category C-Experimental devices and systems (pH meters, turbidimeters, etc.) that are to be calibrated by-or at the direction of-the user, as deemed necessary.

The appropriate category decal with the identification number and the due date of the next calibration will be attached to the equipment. If this identification is not possible, records traceable to the equipment will be readily available for reference.

Volumetric glassware will be used to prepare calibration standards, bench standards, samples for analysis, etc.; thus the glassware used for these preparations must be of known accuracy. Glassware may be purchased with known accuracy per federal and American Society for Testing and Materials specifications.

\subsection{Calibration Failures}

Scheduled periodic calibration of equipment will not relieve laboratory personnel of the responsibility to employ properly functioning equipment. If an individual suspects an equipment malfunction, he/she should remove the device from service, tag it so it is not inadvertently used, and notify project management. If equipment is found to be out of calibration, the laboratory supervisor will evaluate and document (in the instrument logbook) the validity of previous inspection or test results and the acceptability of similar equipment previously inspected or tested. The responsible supervisor will ensure that the devices that are out of calibration are (1) tagged or segregated from other equipment and (2) disposed 
of or not used until they are recalibrated. Any equipment that is consistently found to be out of calibration will be repaired or replaced. Any repair or replacement should be recorded in the instrument logbook.

All standards used for equipment calibration will be traceable to the EPA, the National Institute of Standards and Technology, or a commercially available certified standard. The source of the standard used must be documented in a calibration logbook.

\subsubsection{Calibration Records}

Calibration data will be recorded in the instrument logbook. Records will be prepared and maintained for each piece of calibrated equipment to indicate that established calibration procedures have been followed. The laboratory supervisor will ensure that records of calibration data are kept current. Records for laboratory equipment used will be maintained by the laboratory supervisor and kept in the project files.

\subsection{PREVENTIVE MAINTENANCE}

Periodic preventive maintenance is required for all measuring and test equipment. Instrument manuals will be kept on file for reference purposes if equipment needs repair. Maintenance frequency will be based on manufacturer's recommendations, intended use, and experience. The troubleshooting section of factory manuals may be used to assist personnel in performing maintenance tasks. Routine maintenance will be performed on instruments to reduce the incidence of extensive repairs immediately prior to analysis.

\subsubsection{Laboratory Instruments}

Laboratory equipment requiring routine maintenance will have a control system indicating the date of required maintenance, person maintaining the equipment, and the next maintenance date. Information pertaining to life histories of equipment maintenance will be kept in an individual log for each instrument. Preventive maintenance for laboratory equipment will follow established procedures and will be documented.

\subsection{DATA REDUCTION, VALIDATION, AND REPORTING}

Data validation is a systematic process for reviewing a body of data against a set of criteria to provide assurance that the data are adequate for their intended use. Data validation consists of data editing, screening, checking, auditing, verifying, certifying, and reviewing.

All data for this project will be evaluated by QA/QC methods and internal peer review. Data reduction, verification, and reporting will be in accordance with the Data Management Plan (Wiggins et al. 1988). Data will be entered into common standardized formats. In addition to following field sampling documentation and QAVC procedures, data are verified using a variety of computerized checks. These procedures will ensure that data are entered, 
encoded, and manipulated in a consistent way and are available to OU 2 investigators in a usable format.

\subsubsection{Analytical Laboratory Data Reduction and Evaluation}

Analytical data generated during the OU 2 project will be evaluated for completeness. This will include-but will not be limited to-review of completed custody logs, photocopied pages of laboratory notebooks, and data forms completed by the technical staff, including sample weights, dilutions, concentrations, data reduction, instrument logs, and all raw data. In the data review process, the data are compared with information such as the sample history, sample preparation, and QC sample data to evaluate the validity of the results. Data validation includes-but is not limited to-the following:

- dated and signed entries by technical staff and supervisors on the work sheets and logbooks used for samples;

- use of sample tracking and numbering systems to track the progress of samples through the laboratory;

- use of QC criteria to reject or accept specific data in accordance with EPA CLP laboratory data validation functional guidelines for evaluating organic and inorganic data (EPA 1988b, EPA 1988a);

- examination of all data for a sample and site by evaluating ion balance, checking for consistency among replicate samples, sending split samples to other laboratories for analysis, and using frequency distribution and range checks to evaluate outliers; and

- determination of compliance with holding time requirements.

\subsection{Data Reporting of Analytical Results}

The format and content of hardcopy and electronic data reports will adhere to project needs. These needs include contract requirements of DOE and reporting formats of regulatory agencies. The laboratory supervisors are responsible for the preparation of each technical report including the process of data validation. The preferred hardcopy report format is the complete CLP data package, including case narrative. Final data presentation will be checked in accordance with data validation requirements and approved by the appropriate laboratory manager. Each page of data will be identified with the project number or project name, sample delivery group number, and date of issue. Electronic copies of the data must match the hardcopy reports. Electronic data contents in the report will include the following:

- sample identification number used by the laboratory and/or sample identification provided to the laboratory, if different from that used in the laboratory;

- sample delivery group number; 


\section{9-8}

- chemical parameters analyzed, reported values, laboratory data qualifiers, and units of measure;

- quantification limit of the analytical procedure;

- results of quality control sample analysis;

- achieved accuracy, precision, and completeness of data;

- references to specific data, if required, to explain reported values, and

- analytical methods used.

These methods will be specifically referenced on all laboratory reports. Any method modification will be included in the case narrative. Data for field and laboratory QC samples will be reported in the same format as actual samples.

\subsection{INTERNAL QUALTYY CONTROL CHECKS}

The basic elements of QC are listed below, proceeding from general to specific:

- technical competence of staff,

- appropriate equipment and instruments,

- good sampling practices,

- good measurement practices,

- project procedures,

- field implementation procedures,

- inspection,

- documentation, and

- training.

The staff must have the necessary competence (defined as education, skill, technical judgment, experience, and professional attitude) to reduce variability in executing procedures, taking measurements, and obtaining data in the field. 
The QC procedures presented in this section are designed to accomplish the following:

- achieve the QA objectives for precision, accuracy, completeness, representativeness, comparability, and sensitivity;

- document data quality and provide accountability information about data received from each laboratory;

- provide criteria to ensure that analytical results are statistically valid; and

- provide sufficient documentation of analytical procedures to establish that the resulting parameter estimates are defensible and the comparability of estimates from each laboratory is quantifiable.

Internal QC procedures involve reviewing the documentation of maintenance and operational procedures and inspecting the instruments and equipment by personnel other than instrument users. Inspection entails the spot inspections conducted by the QAS in combination with the continuous process of inspection conducted by the laboratory supervisors as part of normal procedures.

Achieving the highest level of documentation quality is imperative to QC. Bound notebooks with numbered pages will be used to record all events and activities. Data forms will be used to record selected laboratory measurements. All notebooks and data forms will be subject to custody requirements, including limited distribution, secure storage, and long-term retention.

\subsubsection{Laboratory Quality Control Procedures}

A number of laboratory $\mathrm{QC}$ samples will be used to check sample preparation and analysis and to monitor laboratory performance. The control samples listed in this section are defined in general terms. Analysis-specific control samples may be required as indicated by EPA CLP procedures. QC samples will consist of blanks, duplicates, and spikes. Laboratory standards will also function as QC components. QA procedures for laboratory processing include laboratory duplicates of all field samples to determine the precision of laboratory results. Laboratory QC samples will include the following:

Method Blank-A method blank is a blank sample made up of a pure, noncontaminated substance of the matrix of interest (usually distilled/deionized water or silica sand) that is subjected to all of the sample preparation (e.g., digestion, distillation, extraction) and analytical methodology applied to the samples. The purpose of the method blunk is to check for contamination from within the laboratory that might be introduced during sample analysis.

Calibration/Continuing Calibration Blank-A calibration blank is the substance that is used to "zero" the instrument. The calibration blank is composed of the solvent used for the preparation of the calibration standards and samples. The calibration blank accounts for any interference from the solvent matrix. 
Sample Container Cleaning Blanks-If sample containers are cleaned in the laboratory, "sample container cleaning blanks" are taken for each batch of containers that goes through the cleaning process. If contamination is detected, the containers associated with the contaminated blank will be cleaned again and another blank taken and analyzed.

Laboratory Duplicates-Laboratory duplicates are prepared by the laboratory analyst for each sample and are obtained by homogenizing a sample as thoroughly as possible and taking two separate aliquots of that sample for analysis. The duplicate sample, however, should never be a method blank, trip blank, or field blank. The purpose of laboratory duplicates is to check the precision of the analyst, the sample preparation methodology, and the analytical methodology.

Matrix Spikes-A matrix spike is a sampic to which a known concentration of the compounds of interest has been added. The matrix spike is subjected to the same sample preparation and analytical methodology applied to the samples. The sample to be spiked is selected prior to sample submittal; however, the spiked sample cannot be a method blank, trip blank, or field blank. The purpose of the matrix spike is to check for interferences or false readings caused by the sample matrix. The sample matrix effect is measured by calculating the percent recovery (\%R, Sect. 9.10.2) of the compounds added to the sample.

Blank Spike/Laboratory Control Sample (LCS)-The blank spike, or LCS, is a blank sample (usually distilled/deionized water or silica sand) to which a known concentration of the compounds of interest has been added. The blank spike is subjected to the same sample preparation and analytical method applied to the samples. The purpose of the blank spike is to check the accuracy of the analyst, the sample preparation methodology, and the analytical methodology. The level of accuracy is measured by calculating the \%R.

The Laboratory QAVQC Coordinator is responsible for having QC standards prepared and for sending QC samples to the laboratory for analysis. Statistical analyses will then be performed utilizing the results of QC sample analyses. Each laboratory will apply precision and accuracy criteria to each parameter that is analyzed. When analysis of a sample set is completed, the QC data are reviewed and evaluated using control charts to validate the data set. Laboratory QC standards will include the following:

Calibration Standards-Calibration standards are standards made up of the compounds of interest at known concentrations. Calibration standards are prepared from EPA reference material or from commercially available, certified reference materials traceable to the National Institute of Standards and Technology. Calibration standards for each analyte are prepared for at least three concentration levels throughout the calibration range required for the analysis. Calibration standards are not subjected to all of the preparation (e.g., extraction, distillation, digestion) that is applied to the sample. Calibration standards are used initially to calibrate the instrument by providing reference points throughout the calibration range and to establish linearity throughout the calibration range and working range of the instrument. The instrument is then checked throughout the analysis with the calibration standards to check for any instrument drift. 
Performance Evaluation Samples-Performance evaluation samples consist of known concentrations of the analytes submitted to the laboratory being audited. These samples are obtained through various EPA-sponsored programs and private vendors to provide an objective evaluation of laboratory performance and comparison with other participating laboratories.

Control charts are statistical representations of the laboratory's performance and are used to monitor laboratory performance and to establish control limits or the acceptance criteria for all compounds of interest. For each analyte, a separate control chart is required for each type of control sample that measures precision or accuracy and for each matrix type and concentration level. A minimum of ten measurements of precision and accuracy is required before control limits can be established. Control limits of three standard deviations shall be utilized for all samples. Each control chart must consist of a centerline, two warning limits, and two control limits. Control charts must be updated daily.

Once established, control limits are updated as additional precision and accuracy data become available. Any control sample data point that falls beyond the control limits or any data trend will require an investigation and corrective action. For all identified contaminants of concern, control limits and corrective actions will be in accordance with EPA protocol. Additional statistics for organics work will be done in accordance with SW-846 (EPA 1986) or the CLP SOW (EPA 1990d), as applicable.

\subsection{PERFORMANCE AND SYSTEMS AUDTIS}

Audits are performed to review and evaluate the adequacy of laboratory performance and to ascertain whether the QAVQC Plan is being completely and uniformly implemented. The following requirements are adapted from basic requirement 18, "Audits," of ANSI/ASME NQA-1 (ANSI/ASME 1986), and Environmental Restoration Division Quality Assurance Program Plan (Energy Systems 1991b). Planned and scheduled audits will be performed to verify compliance with all aspects of the QA program and to determine the program's effectiveness. These audits will be conducted in accordance with written procedure $i$ ind cherklists and will be performed by personnel who do not have direct responsibility for performing the activities being audited. Audit results will be documented, reported to, and reviewed by responsible management. When necessary, follow-up action will be taken by the responsible line organization.

The objectives of performance and systems audits are to (1) ensure that the QA program developed for this project is being implemented according to the specified requirements, (2) assess the effectiveness of the QA program, (3) identify nonconformances, and (4) verify that identified deficiencies are corrected. Upon discovery of any significant deviation from the QA program, the Project Manager wil: be informed of the nature and extent of any deviation and corrective action taken to repiedy the deviation.

An individual audit plan will be developed to provide a basis for each : dit. This plan will identify the sudit scope, the activities to be audited, the audit personnel, any applicable documents, and the schedule. Records of audits will be maintained in the project files. Audit 
files will include, as a minimum, the audit report, the reply to audit, and any supporting documents. The OU 2 Project Manager is responsible for conforming to audit procedures, particularly as to timely replies to audit reports and implementation of such corrective action indicated.

\subsubsection{Frequency of Audits}

The QAS is responsible for internal audits and will perform them according to a schedule that coincides with appropriate activities on the project schedule and sampling plans. Such scheduled audits may be supplemented by additional audits for one or more of the following reasons:

- when significant changes are made in the QAVC Plan,

- when it is necessary to verify that corrective action has been taken on a nonconformance reported in a previous audit, or

- when requested by the Project Manager.

In addition to these internal audits, surveillance of selected activities may be preformed on a periodic basis.

\subsection{Performance Audits}

A performance audit can be defined as a review of the existing project and QC data to determine the accuracy of a total measurement system(s) or a component part of the system. The analysis of laboratory performance evaluation samples and the participation in scheduled interlaboratory studies ay be included as part of the performance audit. Laboratory audits are further described in $\mathrm{QA} / \mathrm{QC}$ procedures for particular analytical laboratories.

A surveillance of the laboratory activities will also be made during the first sampling phase. The QAS or his designee will check on the logging of the samples, proper chain of custody, and relat d documentation. Any irregularities in QA procedures that are not immediately corrected will be brought to the attention of the OU 2 Project Manager.

\subsection{Systems Audits}

A systems audit consists of an evaluation to determine if the components of a measurement system were properly selected and are being used correctly. A systems audit includes a careful evaluation of laboratory $\mathrm{QC}$ procedures to ens'ure that the QAVC procedures are being adhered to. Systems audits are conducted as dfemed necessary by the QAS, normally either before or shortly after systems are operational. The systems audit is reported in formal audit reports. 


\subsection{DATA MEASUREMENT ASSESSMENT PROCEDURES}

A statistical evaluation of laboratory analytical results will be performed to apply precision and accuracy cxiteria for each parameter analyzed. When the analysis of a sample set is completed, the $\mathrm{QC}$ data generated will be reviewed and evaluated to validate the data set. All QC data will be reported to the OU 2 Project Manager, along with the sample analysis results. The QC data will be reviewed for precision and accuracy.

The evaluation criteria of the QC sample data for the target compound list have been established for the EPA CLP (EPA 1990d). The control limits for other compounds are derived from laboratory control charts. These criteria provide a means of categorizing a data set as being quantitative, semiquantitative, or qualitative. Where applicable, contract laboratories will use data qualifiers to clearly identify results as qualitative and semiquantitative. Otherwise, reported data are to be considered quantitative. These results provide information on the relative quality of sampling and analytical procedures. Deviations suggested by these assessments will be utilized in nonconformance and corrective action procedures (Sect. 9.11).

\subsubsection{Precision}

Precision will be assessed by conducting separate analyses of duplicate samples. The level of precision is determined by calculating the RPD between the two measurements, using the following formula:

$$
R P D=\frac{\left(D_{1}-D_{2}\right) \times 100}{\left(D_{1}+D_{2}\right) / 2}
$$

where

$D_{1}=$ value of first measurement,

$D_{2}=$ value of second measurement.

\subsection{Awcuracy}

Accuracy will be assessed by splitting a sample into two portions, spiking (i.e., adding known quantity of the constituents of interest to one of the portions), and then analyzing both portions for these parameters. The difference in the concentration levels of the constituents of interest should be equal to the quantity of the spike added to one of the two portions. The \% $\mathrm{R}$ is calculated as follows:

$$
\% R=\frac{O_{i}-O_{i}}{T_{i}} \times 100,
$$


where

$O_{i}=$ observed spiked sample concentration,

$\mathrm{O}_{\mathrm{s}}=$ observed sample concentration,

$T_{i}=$ true or actual concentration of the spike.

Recovery of $100 \%$ is equivalent to $100 \%$ accuracy. Values $<100 \%$ may indicate a sample matrix effect and a false reading. A periodic program of sample spiking is required, for example, one matrix spike and one matrix spike duplicate per 20 samples.

Blank spikes or laboratory control samples check the accuracy of the analyst, the sample preparatio n, and the analytical methodology free of sample matrix effects. Blank samples are spiked with known concentrations of the compounds of interest and then prepared and analyzed as samples. The level of accuracy is measured by calculating the $\% \mathrm{R}$ as follows:

$$
\% R=(O / T) \times 100
$$

where

$\% \mathrm{R}=$ percent recovery,

$\mathrm{O}=$ observed or measured concentration,

$T=$ true or known concentration.

The coefficient of variation $\left(C_{v}\right)$ of the percent recovery values is calculated as follows:

$$
\mathrm{C}_{\mathrm{v}}=(\mathrm{SD} / \mathrm{APR}) \times 100 \text {, }
$$

where SD is the standard deviation of the percent recoveries for the various spiked constituents and APR is the average or mean percent recovery.

\subsection{CORRECTIVE ACTIONS}

This section identifies methods and policies for the documentation, evaluation, corrective action, and verification activities necessary when a deviation from established procedure occurs. Requirements for the documentation and implementation of corrective actions are also included.

Any deviation or nonconformance will be evaluated with respect to its possible impact on reportable data. All deviatirsns from standard operating procedures, equipment calibrations, or any aspect of the $2 \mathrm{~A}$ plan will be evaluated and documented. Significant deviations identified using the statistical assessment of quality data will also be used in Nonconformapce and Corrective Action Procedures. 


\subsubsection{Responsibilities of Project Participants}

OU 2 personnel will ensure the prompt identification, control, and disposition of nonconforming items. Each laboratory participant is responsible for submitting records of all nonconformance events to the QAS within a reasonable period of time following the initial identification and documentation of the nonconformance. The nonconformance will then be evaluated by Team Leaders, QAS, Project Manager, and others as is deemed relevant. This evaluation will determine the disposition of the nonconformance.

\subsubsection{Nonconformances and Corrective Action Procedures}

Nonconforming equipment, items, activities, conditions, and unusual incidents that could affect compliance with project requirements will be identified, controlled, and reported on an NCR in a timely manner. A nonconformance is defined as a malfunction, failure, deficiency, or deviation from specified requirements. The originator of an NCR will describe the finding on the form provided for this purpose and will notify the OU 2 project management and the QAS. Each nonconformance will be reviewed and a disposition given for the item, activity, or condition. Evaluations also will determine if the event justifies the issuance of a CAR. The CAR will document the event, the findings of the evaluation, and the required corrective actions. The disposition of a nonconformance will be documented and approved by the OU 2 Project Manager. The QAS will concur with the disposition of the nonconformance.

The QA/QC Coordinator for a particular laboratory is responsible for the assessment of laboratory quality control sample information. If data fall outside accepted limits, established laboratory procedures for identifying the problem and taking appropriate corrective actions will be employed. Completion of corrective action should be evident when deviations return to prescribed acceptable limits.

The modification, repair, rework, or replacement of nonconforming equipment, items, or activities will require the reverification of acceptability. In certain instances, as determined by project management, these activities may require that corrective action be completed and verified before site work continues.

If, in the opinion of project management and the QAS, the nonconformance does not significantly affect the technical quality or use of the work, then the work may continue, pending resolution of the nonconformance. The basis for such a decision will be documented on the NCR and submitted to the QAS for review and approval. The documentation will include the statement that the decision was made before continuing with the work. The records of nonconformance and their dispositions will be maintained by the OU 2 Project Manager and forwarcied to the Document Management Center.

\subsection{QUALITY ASSURANCE REPORTS TO MANAGEMENT}

The active participation of management in the OU 2 Project is fundamental to the success of this QAVC Plan. Management will be aware of project activities and will participate in development, review, and operation of the project. Management will be 


\section{9-16}

informed of QA status and activities through the receipt, review, and/or approval of the following:

- regular quality status reports,

- laboratory and project-specific QA/QC plans and procedures,

- postaudit reports and audit closures,

- surveillance reports,

- corrective action overdue notices, and

- NCRs.

Copies of these reports will be distributed to appropriate management and regulatory agencies. In addition, periodic assessment of QAVQC activities and data precision, accuracy, representativeness, completeness, and comparability will be conducted and reported by the analytical laboratories.

As appropriate, project management will inform the QAS of the QA status of the project, especially any significant quality accomplishments. OU 2 personnel are required to inform the Project Manager or project support staff of all nonconformances or quality failures. The Project Manager will document and immediately report any nonconformance or quality failure to the QAS. 
Environmental Restoration Program

Health and Safety Plan

for

Bear Creek Valley Operable Unit 2

Revision 2

February 1993

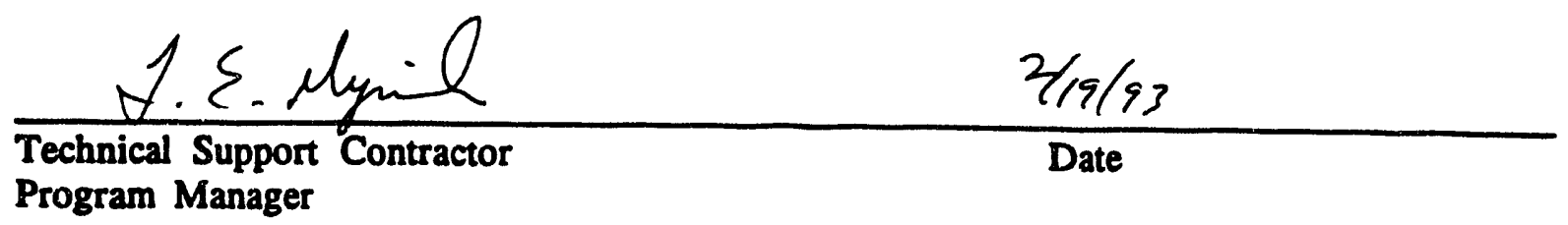

Q.2. Armet

Technical Support Contractor

Field Team Leader

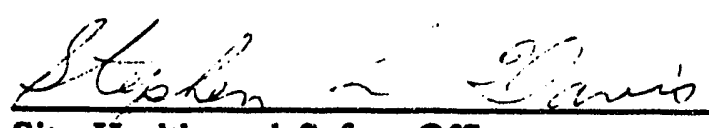

Site Health and Safety Officer
$2 / 19 / 93$

Date

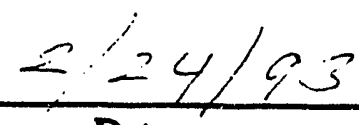

Date
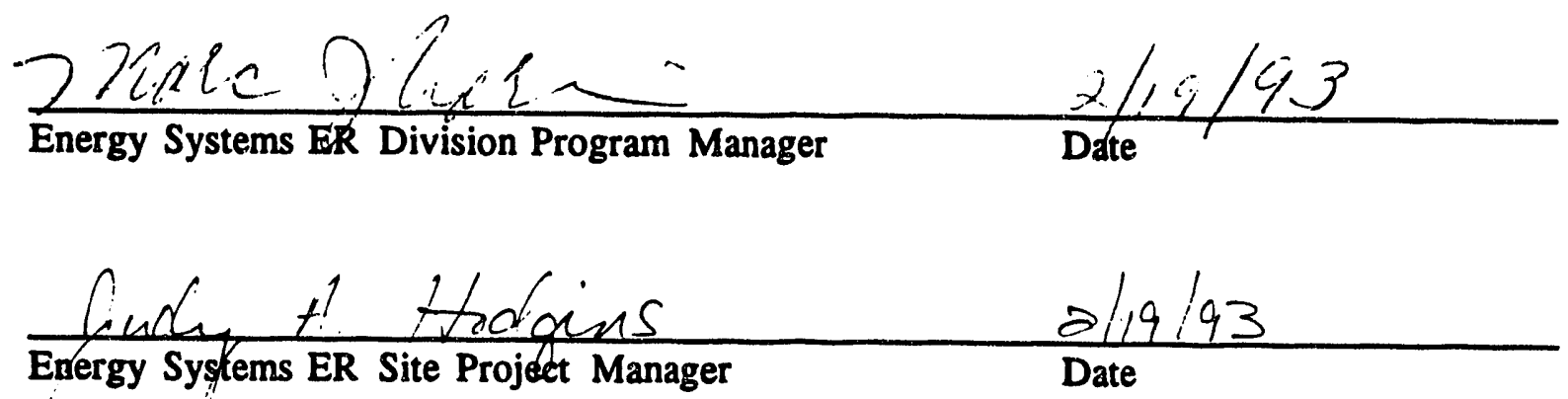


\section{HEALTH AND SAFETY PLAN}

\subsection{SITE HEALTH AND SAFETY PERSONNEL}

A site health and safety officer (SHSO) will be designated by the subcontractor to ensure that the site-specific health and safety plan (Appendix D) remains in compliance with $29 C F R$ 1910 as amended by 29 CFR 1910.120 . The SHSO will be designated no less than 2 weeks before starting field work and will be identified in the site Health and Safety Plan. The SHSO or an alternate will implement, monitor, and assist the site manager in enforcing the site Health and Safety Plan. The subcontractor SHSO may coordinate between the Y-12 Plant Industrial Hygiene and Health Physics Departments on matters of employee health and safety, such as personal monitoring, on-site monitoring, and incident reporting.

\subsection{SAFETY RISK ANALYSIS}

\subsection{Rust Spoil Area}

The RSA was used as a disposal area for solid waste (spoil material) generated from various renovation, maintenance, and construction operations at the Y-12 Plant. Although no detailed records are available, the bulk of spoil material disposed at RSA consisted of (1) soil, (2) masonry materials (i.e., brick and concrete), and (3) metal (i.e., steel and rebar). A portion of the demolition debris was packaged and disposed of in open-top metal containers. These containers were determined to be nonradioactively contaminated, according to health physics requirements established for the Y-12 Plant. Discussions with Y-12 Plant personnel indicated the possibility that small quantities of solvent-contaminated material and material containing asbestos, mercury, and uranium may have been disposed in this area. However, existing administrative and other established in-plant controls prevented the disposal of significant amounts of chemicals, wastes, or contaminated material at RSA. Contaminants of concern in RSA include arsenic, beryllium, lead, mercury, selenium, thorium, uranium, and tetrachloroethane.

\subsection{SY-200 Yard}

The SY-200 Yard was operated from the 1950s to 1986 as a "hold-for-future-use" storage area. The SY-200 Yard, an outside graveled area about $200 \mathrm{ft}$ by $300 \mathrm{ft}$, was used to store nonradioactively contaminated equipment, electrical transformers, piping, tanks, mercury flasks, and miscellaneous items. All items stored at the site were removed by September 1986. Based on data obtained through soil sampling, potential hazards associated with SY-200 include barium, chromium, lead, mercury, PCBs, and ${ }^{235} \mathrm{U}$.

\section{Spoil Area 1}

SA-1 was used for the disposal of what was considered to be nonhazardous, nonradioactively contaminated constructiou debris from various renovation, maintenance, and 
construction operations at the Y-12 Plant. However, recordkeeping regarding waste disposal was inadequate. In addition, the results of soil and groundwater studies of the area confirmed the presence of heavy metals and radiological contamination (see Appendix C). The bulk of the solid waste known to have been disposed of included asphalt, brick, concrete, roofing materials, brush, metal, rock, and tile. Contaminants of concern include arsenic, beryllium, barium, chromium, lead, mercury, fluoranthene, phenanthrene, pyrene, total radium, total uranium, and ${ }^{235} \mathrm{U}$.

\subsection{On-Site Safety Hazards}

The primary hazards associated with the sampling activities at this site are the mechanical risks posed by the use of a hollow-stem auger and the health hazards associated with drilling activities. The SHSO will implement and enforce all safety procedures associated with the use of a hollow-stem auger. These procedures will be followed strictly to avoid accidents. Split spoon sampling will be performed under the close supervision of the project hydrogeologist, with all members of the drilling crew observing all safety precautions specified in the plan while operating the auger. The electrical hazards from overhead power lines will be minimized by following Y-12 procedures for locating the auger. The location of underground utilities will be determined during the Y-12 Plant Excavation and Penetration Permit procedure. This procedure will be followed during all augering operations. Personnel working with or in the immediate vicinity of moving equipment will be prohibited from wearing loose clothing, jewelry, or long hair. Only authorized personnel will be allowed in the immediate vicinity of the auger while it is operating.

\subsection{TRAINING REQUIREMIENTS}

Occupational Safety and Health Administration 40-hour health and safety training, as specified in 29 CFR 1910.120, will be required for all employees engaged in hazardous waste operations. Personnel will be required to have annual 8-hour refresher training courses. Managers and supervisors will receive an additional 8 hours of instruction. All classroom training will be supplemented with 24-hour on-site orientation and instruction under an experienced and qualified individual.

\subsection{PERSONAL PROTECTIVE EQUIPMENT}

The level of personal protection required for $\mathrm{RI}$ sampling activities at $\mathrm{OU} 2$ will be dictated by the location and type of sampling to be conducted. The planned activities consist of split spoon sampling, surface soil, groundwater, and surface water/sediment sampling. Sampling activities will penetrate some of the source areas. Because contaminants such as beryllium, mercury, PCBs, and radionuclides could potentially be encountered at concentrations that constitute a health hazard, the initial personal protection level recommended during intrusive sampling at SY-200 is Level C (see Table 10.1), which is defined in 29 CFR 1910.120 Appendix B. All other sampling activities will be conducted at Level D. 
During sampling activities, mercury vapor, organic vapors, and radioactivity will be monitored continuously. Based on site monitoring, and if deemed appropriate by the SHSO, the personal protection level at SY-200 may be downgraded to Level D. If increased protection is needed, the protection level can be upgraded at the discretion of either the SHSO, the subcontracting project manager, or the Energy Systems project manager.

The SHSO (or the health and safety officer provided by the subcontractor or project manager) will select the type of equipment needed and determine whether additional Personal Protective Equipment (PPE) is needed. All sampling activities will be performed under the close supervision of the project hydrogeologist, with all members of the drilling crew observing the PPE requirements specified in the plan while near the operating auger. Workers will be required to wear appropriate PPE, including steel-toed boots for foot protection, hearing protection, and approved safety glasses for eye protection. Hard hats will be required when workers are in the vicinity of the drilling rig. Only authorized and properly protected personnel will be allowed in the immediate vicinity of the auger while it is in operation.

Table 10.1. Level of protection

\begin{tabular}{|c|c|c|}
\hline $\begin{array}{c}\text { Level } \\
\text { designation }\end{array}$ & Monitoring $\mathrm{p}$ & \\
\hline A & Airborne pollutants ${ }^{a}$ & $\mathbf{X}$ \\
\hline B & Explosion potential & $\mathbf{x}$ \\
\hline$c^{b} \mathrm{x}$ & Radiation & $\mathbf{x}$ \\
\hline D & Total particulates & $\mathbf{x}$ \\
\hline
\end{tabular}

\subsection{MEDICAL SURVEILLANCE}

As required by 29 CFR 1910.120, medical surveillance of all personnel involved in hazardous waste site operations shall be conducted. Baseline and annual physical examinations will be performed by the $:-12$ Plant Medical Center or a qualified occupational physician. Subcontractors will be responsible for ensuring that their employees receive the required examinations. Persons who have not received the necessary physical examinations or who are not medically approved to perform their duties at a hazardous waste site will be excluded from all areas of the site.

In the unlikely event of radioactive contamination, whole body counts of workers from the affected site will be performed by the Y-12 Plant medical itaff. Work at OU 2 will be 
suspended until the conditions abate or PPE is upgraded. When operations are continued, a personal dosimetry program will be instituted by the Y-12 Plant HPD.

\subsection{MONITORING AND SAMPLING}

During sampling activities, the work areas will be monitored for airborne pollutants (organics, mercury), radiation, and total particulates. All monitoring will be conducted in accordance with procedures described in the Environmental Surveillance Procedures, Quality Control Program (Kimbrough et al. 1990).

If any of the following conditions occur, the SHSO may either remove all personnel from the affected area until the conditions abate or upgrade the protection level as described in the Y-12 RCRA Facility Investigation Plan as developed by Welch (1989a):

- organic vapor levels in the breathing zone exceed background conditions for $>1 \mathrm{~min}$ as determined by a photoionization detector (PID) or flame ionization detector (FID);

- mercury vapor levels in the breathing zone exceed $0.01 \mathrm{mg} / \mathrm{m}^{3}$ as measured by a Jerome Mercury Analyzer;

- significant dusting ( $>10 \mathrm{mg} / \mathrm{m}^{3}$, which is the threshold limit value for total nuisance dust) occurs anywhere in the immediate sampling area;

- the release of airborne particulates of asbestos- or beryllium-containing wastes exceeds the American Conference of Governmental Industrial Hygienists Threshold Limit Values, or the permissible exposure levels as described by 29 CFR 1910, Subpart $\mathbf{Z}$ upgraded, whichever is more protective (as determined by personal air monitoring).

The SHSO is responsible for ensuring that vapor and particulate monitoring are performed at the site. These parameters should be monitored continuously while drilling activities are in progress.

Unusual conditions at the site, such as the detection of peculiar odors, will be investigated by the SHSO. In cases of extremely high organic vapor readings (>50 ppm), the SHSO will stop work activities and determine whether any other immediate actions may be needed to mitigate health and safety concerns.

Radiation monitoring will be performed for the OU 2. The SHSO will be responsible for ensuring that this monitoring is scheduled through HPD and completed. HPD will perform all radiation surveys at the site and will recommend actions to the contractor to be taken to protect personnel working in the area based on the interpretation of these surveys. The frequency of monitoring will be deternined by the potential for exposure to radiation at the site and for all samples collected. Exposure will be maintained at a level that is ALARA. 


\subsection{SITE CONTROL MEASURES}

Access to the site will be controlled to reduce the potential exposure of personnel to any contaminants that may be present and to prevent the dispersal of contaminants by personnel or equipment leaving the site. Site control efforts will be the responsibility of the SHSO in coordination with the Y-12 Plant Industrial Safety and Security departments. Measures such as signs, fencing, and ropes will be used as controls.

\subsection{DECONTAMINATION PROCEDURES}

Specific decontamination procedures are required for Level C protection. Decontamination procedures are thoroughly discussed in the Environmental Surveillance Procedures, Quality Control Program (Kimbrough et al. 1990). Workers will be required to follow the standard safety practice of washing hands and faces on leaving the work area and before eating, drinking, smoking, or engaging in any other activity that could cause the ingestion of unwanted materials.

\subsection{STIE OPERATING PROCEDURES}

A work area zone will be established around the drilling rig to keep out unauthorized personnel.

Because contamination may be encountered, Level $\mathbf{C}$ protection has been established. Three work area zones will be established (exclusion, contamination reduction, and support) in accordance with the methodology described in Welch (1989a). Based on site monitoring, and if deemed appropriate by the SHSO, site operating procedures may be upgraded or downgraded as necessary.

\subsection{CONTINGENCY PLAN}

A written contingency plan is required by 29 CFR 1910 . Before operations begin on the site, requirements $120(e)(1)$ and (2) must be completed. In the event of an emergency at OU 2, the SHSO or the site manager must immediately contact the Plant Shift Superintendent (PSS) and ensure that the plan is followed exactly. The PSS on duty is responsible for initiating and coordinating all emergency response operations at the Y-12 Plant. This plan will include a form providing all essential emergency information and contacts and will be made available to the field team. The SHSO will be responsible for maintaining current information on the form and for informing the field team of the form location and the means of contacting emergency aid. A map highlighting the most direct route to the nearest hospital must be included in the contingency and health and safety plans. Figure 10.1 is the emergency reference form. 
SITE:

PROJECT NO.

Emerrency information:

Local resources:

Ambulance (name):

Hospital (name):

Police (local or state):

Fire department (name):

Radio channel:

Nearest telephone:

Project manager:

SHSO:

Emereency contact (medical and health):

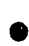

- Poison Information Center:

- National Response Center (FOR ENVIRONMENTAL EMERGENCY ONLY): 1-800-424-8802

- Office:

Directions to hospital:

Fig 10.1. Emergency reference form. 


\subsection{SPECIAL HAZARD PROCEDURES}

No requirements exist to enter a confined space while conducting field activities at OU 2. If confined work spaces are encountered and must be entered, an Occupational Safety Work Permit for confined space entry as required by Y-12 Plant procedure 70-750 will be issued and followed exactly. 


\section{REFERENCES}

ANSI/ASME (American National Standards Institute/American Society of Mechanical Engineers). 1986. Quality Assurance Program Requirements for Nuclear Facilities, NQA-1, New York, New York.

Army Corps of Engineers. 1954a. Geologic Investigation-Alpha 5 Area, Y-12 Plant, Ohio River Division Laboratory

Army Corps of Engineers. 1954b. Foundation Investigation and Analysis-New Steam Plant, Alpha 5 Area, Y-12 Plant, Ohio River Division Laboratory

Baes, C. F., and R. D. Sharpe. 1983. "A Propossl for Estimation of Soil Leaching and Leaching Constants for Use in Assessment Models." J. Environmental Quality, 12(1), 17-28.

Bailey, Z. C., and R. W. Lee. 1991. Hydrogeology and Geochemistry in Bear Creek and Union Valleys, Near Oak Ridge, Tennessee. U.S. Geological Survey Water-Resources Investigations Report 90-4008, Nashville, Tennessee.

Bechtel National, Inc. 1984. Geologic and Hydrogeologic Data for Bear Creek Valley Burial Grounds $A$ and B, Y/Sub/8447974C/2, Oak Ridge Y-12 Plant, Oak Ridge, Tennessee.

Bechtel National, Inc. 1991. Characterization Report for the Elza Gate Site, Oak Ridge, Tennessee, DOE/OR-20722-278, Oak Ridge, Tennessee, April.

Bowen, H. J. M. 1966. Trace Elements in Biochemistry, Academic Press, New York.

Bradburn, D. M., and E. H. Rosenbalm. 1984. Resource Management Plan for the U.S. Department of Energy Oak Ridge Reservation, Appendix 6: Forest Management, ORNL 6026/V6, Oak Ridge National Laboratory, Oak Ridge, Tennessee.

Chance, W. W. 1986. Resource Management Plan for the Oak Ridge Reservation: Resource Information and Site Analysis (V. 22), ORNL/ESH-1/N22, Oak Ridge National Laboratory, Martin Marietta Energy Systems, Inc.

Cunningham, M., and Pounds, L. 1991. Resounce Management Plan for the Oak Ridge Reservation: Wetlands on the Oak Ridge Reservation (V.28), ORNLANERP-51/N28, Oak Ridge National Laboratory, Martin Marietta Energy Systems, Inc.

Davis, B. E. 1990. Applied Soil Trace Elements, John Wiley and Sons, New York. 
Davis, E. C., W. J. Boegly, E. R. Rothschild, B. P. Spalcing, N. D. Vaughan, C. S. Haase, D. E. Huff, S. Y. Lee, E. C. Walls, J. D. Newbold, and E. D. Smith. 1984. Site Characterization Techniques Used at a Low-Level Waste Shallow Land Burial Field Demonstration Facility: Oak Ridge National Laboratory, ORNL/TM-9146, Oak Ridge National Laboratory, Oak Ridge, Tennessee.

DOE (Department of Energy). 1982. Environmental Assessment, Y-12 Plant Site, Oak Ridge, Tennessee, DOE/EA-0182.

DOE (Department of Energy). 1992. Remedial Investigation Work Plan for Bear Creek Valley Operable Unit 4 (Shallow Groundwater in Bear Creek Valley) at the Oak Ridge Y-12 Plant, Oak Ridge, Tennessee, DOE/OR/01-1115\&D1 (Y/ER-56\&D1), prepared by Science Applications International Corporation for the Y-12 Environmental Restoration Program, Oak Ridge Y-12 Plant, Martin Marietta Energy Systems, Inc., December.

DPW (Defense Plant Wastes). 1991. Report on Defense Plant Wastes (newsletter), Vol. 3, No. 22, October 25.

Energy Systems (Martin Marietta Energy Systems, Inc.). 1986. Martin Marietta Energy Systems Environmental and Effluent Analysis Manual, Oak Ridge, Y-12 Plant, Oak Ridge, Tennessee.

Energy Systems (Martin Marietta Energy Systems, Inc.). 1987. Environmental Surveillance of the U.S. Department of Energy Oak Ridge Reservation and Surrounding Envinons During 1986, ES/ESH-1/V1 \& V2. Oak Ridge Y-12 Plant, Oak Ridge, Tennessee.

Energy Systems (Martin Marietta Energy Systems, Inc.). 1989. RCRA Facility Investigation Plan, Upper East Fork Poplar Creek, Oak Ridge Y-12 Plant, Y/TS-579, Oak Ridge Y-12 Plant, Martin Marietta Energy Systems, Inc., December.

Energy Systems (Martin Marietta Energy Systems, Inc.). 1990. Clinch River RCRA Facility Investigation Plan, ES/ER-1/D1, Environmental Restoration Division, Martin Marietta Energy Systems, Inc., March.

Energy Systems (Martin Marietta Energy Systems, Inc). 1991a. Oak Ridge Reservation Environmental Report for 1990, ES/ESH-18/V1 and V2, Martin Marietta Energy Systems, Inc., September.

Energy Systems (Martin Marietta Energy Systems, Inc). 1991b. Environmental Restoration Division Quality Assurance Program Plan, ES/ER/TM-4/R1, Martin Marietta Energy Systems, Inc., September.

Energy Systems (Martin Marietta Energy Systems, Inc.). 1991c. Management Plan for the Oak Ridge Operations Environmental Restoration Program, DOE/OR 931, U.S. Department of Energy, Oak Ridge, Tennessee, March, p. 2-1.

92-043P/063092 
Engelder, T. 1985. "Loading Paths to Joint Propagation During a Tectonic Cycle: An Example from the Appalachian Plateau, U.S.A." J. Structural Geol. 7(3/4):459-476.

EPA (Environmental Protection Agency). 1979a. Handbook for Analytical Quality Control in Water and Wastewater Laboratories, Environmental Monitoring Systems Laboratory, Office of Research and Development, Cincinnati, Ohio.

EPA (Environmental Protection Agency). 1979b. Methods for Chemical Analysis of Water and Wastes, EPA-600-4-79-020.

EPA (Environmental Protection Agency). 1980. Interim Guidelines and Specifications for Preparing Quality fis urance Project Plans, QAMS-005/80, Washington, D.C.

EPA (Environmental Protection Agency). 1986. Test Methods for Evaluating Solid Waste, Physical/Chemical Methods, 3rd Ed., EPA SW-846.

EPA (Environmental Protection Agency). 1987. Data Quality Objectives for Remedial Response Activities, EPA 540/G-87-003.

EPA (Environmental Protection Agency). 1988a. Laboratory Data Validation Functional Guidelines for Evaluating Inorganics Analyses.

EPA (Environmental Protection Agency). 1988b. Laboratory Data Validation Functional Guidelines for Evaluating Onganics Analyses.

EPA (Environmental Protection Agency). 1989. Interim Final Risk Assessment Guidance for Superfund. Vol. I, Human Health Evaluation Manual (Part A) Interim Final, EPA/540/189/002, Office of Emergency and Remedial Response, Washington, D.C., December.

EPA (Environmental Protection Agency). 1989. Determining Soil Response Action Levels Based on Potential Contaminant Migration to Ground Water: A Compendium of Examples, EPA/540/2-89/057, Office of Emergency and Remedial Response, Washington, D.C., October.

EPA (Environmental Protection Agency). 1990a. Guidance on Remedial Actions for Superfund Sites with PCB Contamination, EPA/540/G-90/007, Office of Emergency Remedial Response, Washington, D.C., August.

EPA (Environmental Protection Agency). 1990b. Integrated Risk Information System (IRIS), EPA $600 / 8-86 / 032 a$ (current as of July 1, 1991), Office of Health and Environmental Assessment, Cincinnati, Ohio.

EPA (Environmental Protection Agency). 1990c. Health Effects Assessment Summary Tables. Fourth Quarter, FY 1990, OERR 9200.6-303-(90-4), Office of Emergency and Remedial Response, Washington, D.C.

EPA (Environmental Protection Agency). 1990d. Statement of Work for Organics/Inonganics Analysis, Multi-Media, Multi-Concentration.

92-043P/063092 
EPA (Environmental Protection Agency). 1992. Health Effects Assessment Summary Tables. FY 1992. OERR 9200.6-303-(92), Office of Emergency and Remedial Response, Washington, D.C.

Geraghty \& Miller. 1987. Hydrogeologic Investigation of the S-3 Pond Area at the Y-12 Plant. Y/Sub/87-00206C/18. Oak Ridge Y-12 Plant, Martin Marietta Energy Systems, Inc.

Geraghty \& Miller. 1988a. Groundwater Quality Assessment for the S-3 Ponds Hazardous Waste Disposal Unit at the Y-12 Plant, 1987, Y/Sub/88-00206C/1, Oak Ridge Y-12 Plant, Martin Marietta Energy Systems, Inc.

Geraghty \& Miller. 1988b. Groundwater Quality Assessment for the Burial Grounds Hazardous Waste Disposal Unit at the Y-12 Plant, 1987, Y/Sub/88-00206C/3, Oak Ridge Y-12 Plant, Martin Marietta Energy Systems, Inc.

Geraghty \& Miller. 1989a. Tracer Study of the Hydrologic System of Upper Bear Creek, Y-12 Plant, Oak Ridge, Tennessee, Y/Sub/89-00206C/4, Oak Ridge Y-12 Plant, Martin Marietta Energy Systems, Inc.

Geraghty \& Miller. 1989b. Groundwater Quality Assessment for the S-3 Ponds WasteManagement Area at the Y-12 Plant, 1988, Y/Sub/89-00206C/7, Oak Ridge Y-12 Plant, Martin Marietta Energy Systems, Inc.

Geraghty \& Miller. 1989c. Groundwater Quality Assessment for the Oil Landform WasteManagement Area at the Y-12 Plant, 1988, Y/Sub/89-00206C/8, Oak Ridge Y-12 Plant, Martin Marietta Energy Systems, Inc.

Geraghty \& Miller. 1990a. Comprehensive Groundwater Monitoring Plan for the Department of Energy Y-12 Plant, Oak Ridge, Tennessee, Y/Sub/90-00206C/5, Oak Ridge Y-12 Plant, Martin Marietta Energy System, Inc., September.

Geraghty \& Miller. 1990b. Groundwater Quality Assessment for the Bear Creek Hydrogeologic Regime at the Y-12 Plant, 1989, Y/Sub/90-00206C/1 Part1, Oak Ridge Y-12 Plant, Martin Marietta Energy Systems, Inc., February.

Gilbert, T. L., and C. Yu. 1989. A Manual for Implementing Residual Radioactive Material Guidelines, ANL/ES-160/DOE/CH/8901, Argonne National Laboratory, Argonne, Illinois, June.

Haase, C. S., E. C. Walls, and C. D. Farmer. 1985. Structural and Stratigraphic Data for the Conasauga Group and Rome Formation on the Copper Creek Thrust Sheet Near Oak Ridge Tennessee: Preliminary Data from Test Borehole ORNL-Joy No. 2, ORNL/TM-9159, Oak Ridge National Laboratory, Martin Marietta Energy Systems, Inc.

Hasson, K. O., and C. S. Haase. 1988. "Lithofacies and Paleogeography of the Conasauga Group (Middle and Late Cambrian) in the Valley and Ridge Province of East Tennessee," Geol. Soc. of Am. Bull. 100(2):234-246.

92-043P/063092 
Houlberg, L. M., G. T. Hawkins, and M. S. Salk. 1992. Environmental Regulatory Update Table, January/February, ORNLM-1929, Oak Ridge National Laboratory, Martin Marietta Energy Systems, Inc.

HSW Environmental Consultants, Inc. 1991. Groundwater Quality Assessment for the Upper Bear Creek Hydrogeologic Regime at the Y-12 Plant: Groundwater Quality Data and Calculated Rate of Contaminant Migration, Y/Sub/91-YP507C/1 Part 1, Oak Ridge Y-12 Plant, Martin Marietta Energy Systems, Inc., June.

IAEA (International Atomic Energy Agency). 1990. The Environmental Behavior of Radium, Vol. 1, Technical Report Series No. 310, Vienna, Austria.

Johnson, R. M. 1964. Herpetofauna of the Oak Ridge Area, ORNL-3653, Oak Ridge National Laboratory, Oak Ridge, Tennessee.

Ketelle, R. August 20, 1991. Oak Ridge National Laboratory, Energy Division, personal communication to E. P. McDonald.

Kimbrough, C. W., L. W. Long, and L. W. McMahon. 1990. Environmental Surveillance Procedures, Quality Control Program, ESH/Sub/87-21706/1, Martin Marietta Energy Systems, Inc.

King, H. L., and C. S. Haase. 1987. Subsurface-Controlled Geological Maps for the Y-12 Plant and Adjacent Areas of Bear Creek Valley, ORNL/TM-10112, Oak Ridge National Laboratory, Martin Marietta Energy Systems, Inc.

Kroodsma, R. L. January 1987. Resource Management Mlan for the Oak Ridge Reservation, Volume 24: Threatened and Endangered Animal Species, ORNL/ESH-1/N24, Oak Ridge National Laboratory, Martin Marietta Energy Systems, Inc.

Kroodsma, R. L 1991. Oak Ridge National Laborator, Environmental Sciences Division, personal communication to E. P. McDonald, July 29.

Lee, R. R. 1991. Oak Ridge National Laboratory, Environmental Sciences Division, personal communication to E. P. McDonald, August 16.

Lee, R. R., and R. H. Ketelle. 1987. Stratigraphic Influence on Deep Groundwater Flow in the Knax Group Copper Ridge Dolomite on the West Chestnut Ridge Site, ORNL/TM-10479, Oak Ridge National Laboratory, Martin Marietta Energy Systems, Inc.

Lee, R. R., and R. H. Ketelle. 1988. Subsurface Geology of the Chickamauga Group at Oak Ridge National Laboratory, ORNL/TM-10749, Oak Ridge National Laboratory, Martin Marietta Energy Systems, Inc.

Lietzke, D. A., S. Y. Lee, and R. E. Lambert. 1928. Soils, Surficial Geology, and Geomorphology of the Bear Creek Valley Low-Level Waste Disposal Development and 
Demonstration Program Site, ORNL/TM-10543, Oak Ridge National Laboratory, Martin Marietta Energy Systems, Inc.

Lowery, J. F., P. H. Counts, H. L. Edmiston, and F. D. Edwards. 1986. Water Resources Data for Tennessee, Water Year 1985, Report USGS/WRG/HD-86/216, U.S. Geological Survey, Nashville, Tennessee.

Lowery, J. F., P. H. Counts, H. L. Edmiston, and F. D. Edwards. 1987. Water Resources Data for Tennessee, Water Year 1986, Report USGS/WRG/HD-86/216, U.S. Geological Survey, Nashville, Tennessee.

Lowery, J. F., P. H. Counts, F. D. Edwards, and J. W. Garrett. 1988. Water Resources Data Tennessee Water Year 1988. Water Data Report TN-88-1, U.S. Geological Survey, Nashville, Tennessee.

Lutz, C. T., and R. B. Dreier. 1988. "Differences in Local Deformation History as Indicated by Fracture Orientations in Two Foreland Thrust Sheets," Geol. Soc. Am. Abstracts with Program. 20(7).

Maher, S. W. 1973. Analyses of Geologic Materials, Boone Lake Area, Tennessee, Tennessee Division of Geology, Report of Investigations No. 35, Nashville, Tennessee.

McCauley, L. L. 1984. Sediment Assessment and Inventory of Existing Contamination and Biological Data for Two Oil Retention Ponds in the Y-12 Plant, Bear Creek Valley Waste Disposal Area, Y/LA-165, Oak Ridge Y-12 Plant, Oak Ridge, Tennessee.

McCauley, L. L. 1985a. Remedial Alternatives for the Bear Creek Valley Waste Disposal Area, Y/Sub/85-00206C/3, Oak Ridge Y-12 Plant, Oak Ridge, Tennessee.

McCauley, L. L. 1985b. Analytical Quality Assurance/Quality Control Data for 1983-1984 Bear Creek Valley Sampling and Analysis Program, Y/TS-111, Oak Ridge Y-12 Plant, Oak Ridge, Tennessee.

McCauley, L L. 1985c. Analytical Results for Water, Sediment, and Soil Samples Collected in the Y-12 Plant Bear Creek Valley Waste Disposal Areas, Y/TS-112, Oak Ridge Y-12 Plant, Oak Ridge, Tennessee.

McCauley, L. L. 1985d. Field Sampling and Laboratory Analytical Methods Used for 19831984 Characterization of Water, Soih, and Sediment in Bear Creek Valley Waste Disposal Areas, Y/TS-113, Oak Ridge Y-12 Plant, Oak Ridge, Tennessee.

McMaster, W. M. 1967. "Hydrologic Data for the Oak Ridge Area, Tennessee," U.S. Geological Survey-Water Supply Paper No. 1838-N, U.S. Government Printing Office, Washington, D.C. 
Meyer, R. E., W. D. Arnold, P. C. Ho, F. I. Case, and G. D. O'Kelley. 1987. Geochemical Behavior of $C s, S r, T c, N p$, and $U$ in Saline Groundwaters: Sorption Experiments on Shales and their Clay Mineral Components, ORNL/TM-10634, Oak Ridge National Laboratory, Oak Ridge, Tennessee.

Murphy, J. L. 1988. RCRA Facility Investigation Plan Filled Coal Ash Pond (D-112) Oak Ridge Y-12 Plant, Oak Ridge, Tennessee, Y/TS-411, Oak Ridge Y-12 Plant, Martin Marietta Energy Systems, Inc., November.

Murphy, J. L. 1989. Supplement to Solid Waste Management Unit Information for Y-12 Plant RCRA 3004(u) Facility Assessment, Y/TS-273, Suppl. 4, Oak Ridge Y-12 Plant, Martin Marietta Energy Systems, Inc., February.

NIOSH (National Institute for Occupational Safety and Health). 1989. NIOSH Manual of Analytical Methods. Washington D.C., May.

NOAA (National Oceanic and Atmospheric Administration). 1985. Local Climatological Data: Monthly Summaries for 1985, Oak Ridge, Tennessee, National Climatic Data Center, Asheville, North Carolina.

NOAA (National Oceanic and Atmospheric Administration). 1986. Local Climatological Data: Monthly Summaries for 1986, Oak Ridge, Tennessee, National Climatic Data Center, Asheville, North Carolina.

NOAA (National Oceanic and Atmospheric Administration). 1987. Local Climatological Data: Monthly Summaries for 1987, Oak Ridge, Tennessee, National Climatic Data Center, Asheville, North Carolina.

NOAA (National Oceanic and Atmospheric Administration). 1988. Local Climatologicai Duta: Monthly Summaries for 1988, Oak Ridge, Tennessee. National Climatic Data Center, Asheville, North Carolina.

NOAA (National Oceanic and Atmospheric Administration). 1989. Local Climatologicui Data: Monthly Summaries for 1988, Oak Ridge, Tennessee. National Climat ic Data Center, Asheville, North Carolina.

NOAA (National Oceanic and Atmospheric Administration). 1990. Local Climatological Data: Monthly Summaries for 1988, Oak Ridge, Tennessee. National Climatic Data Center, Asheville, North Carolina.

Nix, C. E., F. K. Edwards, T. E. Myrick, J. R. Trabalka, and J. B. Cannon. 1986. CERCLA Phase 1 Report: Identification and Preliminary Assessment of Inactive Hazardous Waste Disposal Sites and Other Contaminated Areas at ORNL, ORNL/TM-9989, Oak Ridge National Laboratory, Martin Marietta Energy Systems, Inc. 
Parr, P. D., 1984, Resource Management Plan for the Oak Ridge Reservation, Volume 4, Appendix D: Endangered and Threatened Plant Species, GRNL/6026/V4, Oak Ridge National Laboratory, Martin Marietta Energy Systems, Inc.

Parr, P. D., and L. R. Pounds. 1987. Resource Management Plan for the Oak Ridge Reservation, Volume 23: Oak Ridge National Environmenta' Research Park, Research Sites, and State Natural Areas, ORNL/ESH-1/V23, Oak Ridge National Laboratory, Martin Marietta Energy Systems, inc.

Parr, P. D. 1992. Environmental Sciences Division, Oak Ridge National Laboratory, Oak Ridge, Tennessee, personal communication to E. P. McDonald, March 19.

Perkins, A. B. 1989. RCRA Facility Investigation Plan, SY-200 Yard, Oak Ridge Y-12 Plant, Oak Ridge, Tennessee, Y/TS-598, Oak Ridge Y-12 Plant, Martin Marietta Energy Systems, Inc., December.

Petrich, C. H., W. E. Manrod, W. D. Barton, R. C. Durfee, J. F. Hiene, and E. P. Tinnel. 1984. Resource Management Plan for the U. S. Department of Enengy Oak Ridge Reservation. Appendix G: Geography, Demography, Topography, and Soils, ORNL-6020/V7, Oak Ridge National Laboratory, Martin Marietta Energy Systems, Inc.

Rogers, J. G., K. L. Daniels, S. T. Goodpasture, C. W. Kimbrough, and N. L. Prince. 1989. Oak Ridge Reservation Environmental Report for 1988, Volume 1: Narrative, Summary, and Conclusions, ES/ESH-8/V1, Martin Marietta Energy Systems, Inc., May.

Rothschild, E. R., D. D. Huff, C. S. Haase, R. B. Clapp, B. P. Spalding, C. D. Farmer, and N. D. Farrow. 1984. Geohydrologic Characterization of Proposed Solid Waste Storage Area (SWSA) 7, ORNLTM-9314, Oak Ridge National Laboratory, Oak Ridge, Tennessee.

Rothschild, E. R., R. R. Turner, S. H. Stow, M. A. Bogle, L. K. Hyder, O. M. Sealand, and J. Wyrick. 1984. Investigation of Subsurface Mercury at the Oak Ridge Y-12 Plant. ORNL/TM-9092, Oak Ridge National Laboratory, Martin Marietta Energy Systems, Inc.

Sanders, M. 1984. Resource Management Plan for the U.S. Department of Energy Oak Ridge Reservation, Volume 3, Appendix B: Archaeological Conservations, ORNL-6026/V4, Oak Ridge National Laboratory, Martin Marietta Energy Systems, Inc., July.

Sheppard, J.D. 1974. Storm Runoff in the Viciniuy of Oak Ridge, Tennessee, ORNL/TM-4662, Oak Ridge National Laboratory, Oak Ridge, Tennessee.

Sohatra, A. M., P. Mineart, S. Sharp-Hansen, and T. Allison. 1990. Multimedia Exposure Assessment Model (MULTIMED) for Evaluating the Land Disposal of Wastes-Model Theory, Office of Research and Development, U.S. Environmental Protection Agency, Athens, Georgia. 
Solomon, D. K., G. K. Mcore, L. E. Toran, R. B. Dreier, and W. M. McMaster. 1992. Status Report-A Hydrologic Framework for the Oak Ridge Reservation, ORNL/TM-12026, Oak Ridge National Laboratory, Oak Ridge, Tennessee.

Starnes, W. C., and D. Etnier. 1980 (date not indicated on publication). "Fishes," Tennessee's Rare Wildlife. D. C. Eager and R. M. Hatcher, eds. Tennessee Department of Conservation, Nashville, Tennessee.

TVA (Tennessee Valley Authority). 1985. Instream Con:aminant Study, Task 4: Fish Sampling and Analysis, Draft Report to U.S. Department of Energy, Oak Ridge Operations Office. Tennessee Valley Authority, Office of Natural Resources and Economic Development, Kno:ville, Tennessee.

TVA (Tennessee Valley Authority). 1986. Instream Contaminant Study, Task 5: Summary Report, Prepared for U.S. Department of Energy, Oak Ridge, Tennessee, under Interagency Agreement No. DE-AI05-84OR21444.

Turner, R. R., and G. E. Kamp. 1984. Characterization and Remedial Alternatives for Sediments in Upper Bear Creek, Y/TS-56, Oak Ridge Y-12 Plant, Oak Ridge, Tennessee.

Turner, R.R., M. A. Bogle, R. B. Clapp, K. Dearstone, R. B. Dreier, T. O. Early, S. E. Herbes, J. M. Loar, P. D. Parr, G. R. Southworth, and T. M. Mercier. 1988. RCRA Facility Investigation Plan, Bear Creek, Oak Ridge Y-12 Plant, Oak Ridge, Tennessee, Y/TS-417, Oak Ridge Y-12 Plant, Martin Marietta Energy Systems, Inc., December.

USDA (U.S.Department of Agriculture). 1981. Soil Survey of Anderson County, Tennessee. Soil Conservation Service. U.S. Department of Agriculture, Washington, D.C.

U.S. Department of Commerce. 1991. 1990 Census of population and housing: Census tracts (Knarville). Bureau of the Census. U. S. Department of Commerce, Washington, D.C.

Van Winkle, W., R. W., Counts, J. G. Dorsey, J. W., Elwood, V. W., Lowe, Jr., R. McElhaney, S. D., Schlotzhauer, F. G., Taylor, Jr., and R. R., Turner, 1984. Mercury Contamination in East Fork Poplar Creek and Bear Creek, ORNL/TM-8894, Oak Ridge National Laboratory, Martin Marietta Energy Systems, Inc.

Welch, S. H. 1987a. Supplement to Solid Waste Management Unit Information for Y-12 Plant RCRA 3004(u) Facility Assessment, Y/TS-273, Suppl. 1, Oak Ridge Y-12 Plant, Martin Marietta Energy Systems, Inc., August.

Welch, S. H. 1987b. RCRA Facility Investigation Plan Rust Spoil Area (D-107), Y/TS-363, Oak Ridge Y-12 Plant, Martin Marietta Energy Systems, Inc.

Welch, S. H. 1989a. RCRA Facility Investigation Plan General Document Y-12 Plant, Oak Ridge, Tennessee, Y/TS-352, Vol. 1 (Rev. 1), Martin Marietta Energy Systems, Inc., Oak Ridge Y-12 Plant, April. 
Welch, S. H. 1989b. RCRA Facility Investigation Plan Spoil Area I (D-107) Oak Ridge Y-12 Plant, Oak Ridge, Tennessee, Y/TS-363, Rev.1, Oak Ridge Y-12 Plant, Martin Marietta Energy Systems, Inc., June.

Welch, S. H. 1989c. RCRA Facility Investigation Plan, Rust Spoil Area (D-106), Y/TS354/RI, Oak Ridge Y-12 Plant, Martin Marietta Energy Systems, Inc., May.

Welch, S. H., C. S. Haase, C. W. Kimbrough, and T. M. Mercier. 1987. Solid Waste Management Unit Information for Y-12 Plant RCRA 3004(u) Facility Assessment, Y/TS-273, Vol. 1, Oak Ridge Y-12 Plant, Martin Marietta Energy Systems, Inc.

Welch, S. H., and M. A. Poore. 1987. Solid Waste Management Unit Information for the Y-12 Plant RCRA 3004(u) Facility Assessment - Container Accumulation Areas. Y/TS-273, Supplement 2. Oak Ridge Y-12 Plant, Oak Ridge, Tennessee.

Wiggins, K. D. 1988. RCRA Facility Investigation Plan, General Document, Volume II: Quality Assurance Project Plan, U.S. DOE Y-12 Plant, Oak Ridge, Tennessee. Y/TS-352, Vol. II. Oak Ridge Y-12 Plant, Oak Ridge, Tennessee.

Wiggins, K. D., and S. H. Welch. 1988. Supplement to Solid Waste Management Unit Information for Y-12 Plant RCRA 3004(u) Facility Assessment, Container Accumulation Areas. Y/TS-273, Supplement 3, Oak Ridge Y-12 Plant, Oak Ridge, Tennessee.

Wiggins, K. D., R. A. Evans, and J. L. Leslie. 1988. RCRA Facility Investigation Plan, General Document, Volume III: Data Management Plan. Y/TS-352, Vol. III. Oak Ridge Y-12 Plant, Oak Ridge, Tennessee. 
Appendix A

SUPPORTING DOCUMENTS 


\section{Record of Conservation}

This is to document the telephone conversation between Steve Walker, Environmental Restoration Program, ORNL, and Linda Houlberg, BEIA, ORNL, April 1, 1992.

$$
y-12_{s w}
$$

Houlberg: Can you give me a list of contaminants of concern for Rust Spoil Area, Spoil Area I, and SY-200 Yard at Y-12 which I can use to develop ARARs for Bear Creek Operable Unit 2?

Walker: Yes. Characterization work done up to this point has so far identified the following contaminants at the Bear Creek Operable Unit 2 sites:

$\begin{array}{ll}\text { Rust Spoil Area - soil and groundwater } \\ \text { arsenic } & \text { beryllium } \\ \text { lead } & \text { mercury } \\ \text { uranium } & \text { tetrachloroethene } \\ \text { vanadium } & \text { selenium } \\ \text { thorium } & \end{array}$

\begin{tabular}{ll} 
Spoil Area I - soil and groundwater \\
\hline aluminum & arsenic \\
barium & beryllium \\
chromium & cobalt \\
copper & iron \\
lead & mercury \\
nickel & vanadium \\
zinc & total uranium \\
total radium & benzo(a)anthracene \\
benzo(a)pyrene & benzo (a,k)fluoranthene \\
chrysene & dibenzofuran \\
fluoranthene & phenanthrene \\
pyrene & bis(2-ethylhexl)phthalate
\end{tabular}

SY-200 Yard - soil, possibly groundwater and surface water

\begin{tabular}{ll}
\hline uranium & thorium \\
alpha activity & PCBs \\
lead & asbestos
\end{tabular}

mercury
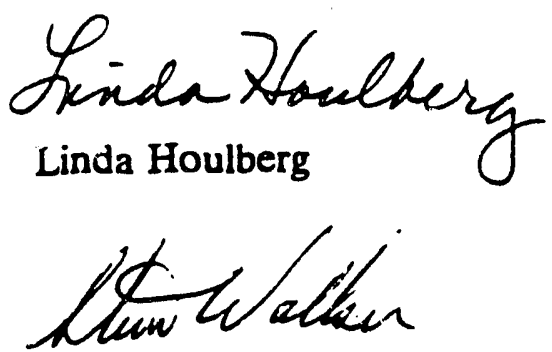

Steve Walker 


\section{TENNESSEE DEPARTMENT OF CONSERVATION}

Customs House

701 Brodiway

Nachville, TN 37247-3530

May 20, 1991

CERTIFIEO MAIL P 465288580 RETURN RECEIPT REQUESTEO

U.S. DOS

U.S. DOS $\gamma-12$

P.O. BOX E

Oak Rldge, II

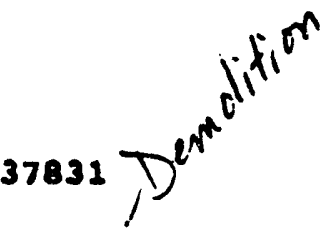

RE: U.S. DOE Y-12, DYL 01-103-0012

Dear sis:

The purpose of this letter is to sormally roguest a closure/post-elosure plan for your Eacldlty as required by Rule 1200-1-7-.03 (REQUIREMENTs FOR EINANCIAL Assurance) of the Regulations Governing solid wente procensing and Dleposal racilities in Tennessee.

The closure/post-elosure plan shall be stibaitred to the appropritet regional office no more than 180 daye from the date postmarked on this letter.

Upon submittal of the closure/post-closure plan the comblesloner will review the plan and will thon notify the applicant whothar the plan is eentatively approved or tentatively disapproved. After the plan has been tentatively approved the applicant must tlle and maintain flnancial ascurar - $\ldots$ th the Commissioner as set forth in paragraph $3(a)$ of the rerementione. $x$. The Commissioner shall establish the amount of the Elnaneial assuranee required of the oporator based upon the estimated cont of operating the facility lor a enirty. (30) day perlod plus the estimeted elosure and post-closure care cont: included in the epproved closure/post-closure care plar.

Attached to this letter is a general outline whleh should provide some guidance for preparation of the requested closure/post-closure plan. If further questions arise ploase contact either tho appropriate regional office or our central office.

sincerely,

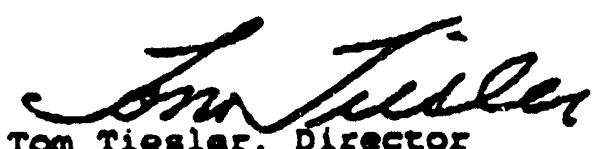

Tom riesier. Director

Division of Solid waste Management

JTT/JH/F1031237

Y.12 SIMY OFICH

Attachment

IOG NO. 911643

FII: CODE 
St: :E a! Tennessee

Department of Health and Environment

Division of Solid Waste Management
Solid Waste Management Program 4 th Floor, 701 Broadway

Nashville, Tennessee $372 i \bar{y}-540 \hat{3}$

$(6 / 5) 741-3424$

\section{REGISTAATION AUTYCR!ZING SOL!D WASTE \\ DISFOSAL ACTIVITIES IN \\ TENNESSEE}

Registration Number: DMLOU1.0300.9

Date issted: JAN 151986

Issued to The United States Department of Energy for a iacility located adjasani to the Y-12 Plant on the U.S. D.O.E. Reservation, near Oak Ridge, Tennus:an, in Ancierson County.

Activities Authorized: Landfil! disposal of demolition wastes generated irom various construction activities at the $Y-12$ Plant.

By my signature, this registration is issued in compliance with the provisions of the Tennessee Solid Waste Disposal Act (Tennessee Code Annotared, Section 68-31101 , et seq.j, and applicabie regulations dereloped persusn: to this !3w and in effect; and in accordance with the conditions and other terms set forth in this registration document and the attached Registration Conditions.

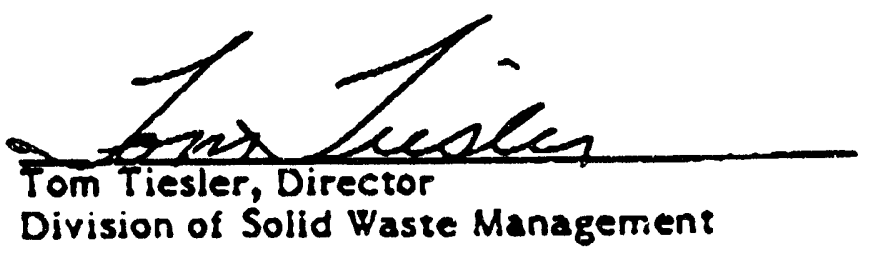

EC/bec $\quad S W / 18$ 
A- 0
MEMORANDUM OF CONFERENCE OR CONVERSATION

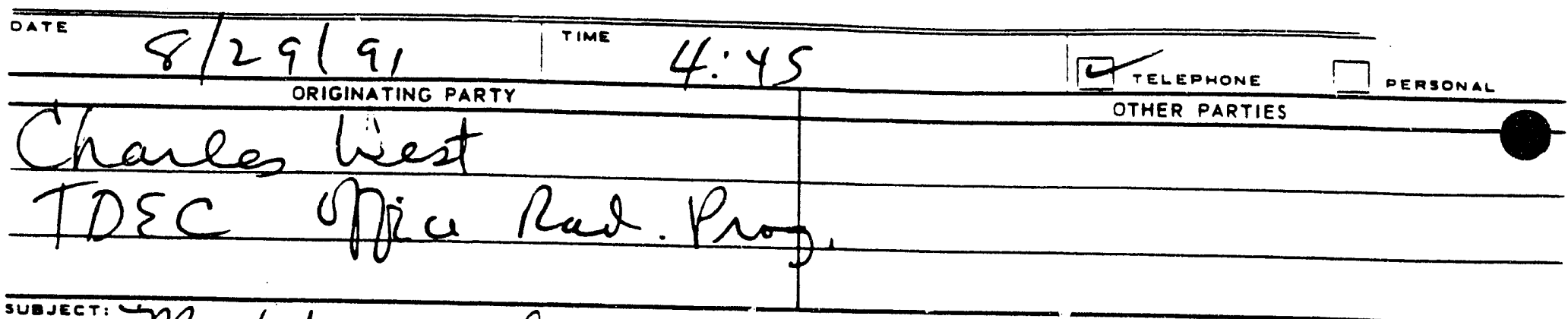

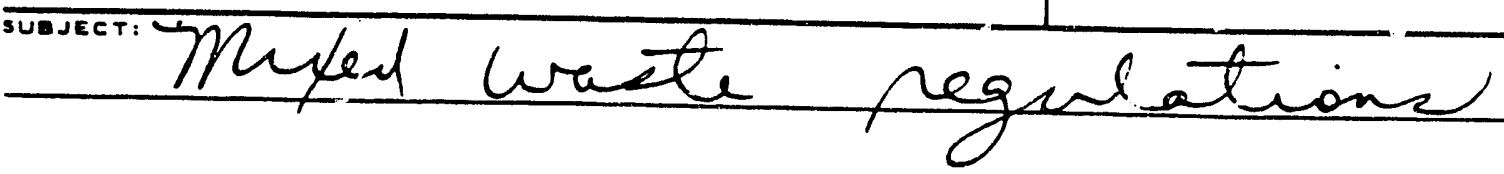

DISCUSSION:

There are tips regulations in place ot this time fo mixed waste

however,

lebrun Schuly - solid wast group may know mon about any thoughts or up coming reaps.

wire be in 9/3/91

CONCLUSION OR AGREEMENTS

DISTRIBUTION:

SIGNED

Ar. Even 
Appendix B

CLP PARAMETERS AND ANALYTICAL QUANTITATION LIMITS 


\section{B-3}

Table B.1. Contract required detection limits - inorganics

\begin{tabular}{lcc}
\hline Element & Water $(\mu \mathrm{g} / \mathrm{L})$ & Soil/Sediment $(\mathrm{mg} / \mathrm{kg})$ \\
\hline Aluminum (Al) & 80 & 20 \\
Antimony (Sb) & 2 & 6 \\
Arsenic (As) & 2 & 1 \\
Barium (Ba) & 5 & 20 \\
Beryllium (Be) & 1 & 0.5 \\
Cadmium (Cd) & 2 & 0.5 \\
Calcium (Ca) & 500 & 500 \\
Chromium (Cr) & 8 & 1 \\
Cobalt (Co) & 6 & 5 \\
Copper (Cu) & 6 & 2.5 \\
Iron (Fe) & 80 & 10 \\
Lead (Pb) & 2 & 0.5 \\
Magnesium (Mg) & 100 & 500 \\
Manganese (Mn) & 5 & 1.5 \\
Mercury (Hg) & 0.1 & 0.1 \\
Nickel (Ni) & 15 & 4 \\
Potassium (K) & 2,000 & 500 \\
Selenium (Se) & 2 & 0.5 \\
Silver (Ag) & 3 & 1 \\
Sodium (N) & 1,000 & 500 \\
Thallium (Tl) & 2 & 1 \\
Vanadium (V) & 5 & 5 \\
Zinc (Zn) & 20 & 2 \\
\hline
\end{tabular}


Table B.2. Practical quantitation limits - volatile organics

\begin{tabular}{|c|c|c|}
\hline Compound & $\begin{array}{l}\text { Groundwater } \\
(\mu g / L)\end{array}$ & $\begin{array}{c}\text { Low soil/sediment } \\
(\mu \mathrm{g} / \mathrm{kg})\end{array}$ \\
\hline Chloromethane & 5 & 5 \\
\hline Bromomethane & 5 & 5 \\
\hline Vinyl chloride & 5 & 5 \\
\hline Chloroethane & 5 & 5 \\
\hline Methylene chloride & 5 & 5 \\
\hline Acetone & 5 & 5 \\
\hline Carbon disulfide & 5 & 5 \\
\hline 1,1-Dichloroethene & 5 & 5 \\
\hline 1,1-Dichloroethane & 5 & 5 \\
\hline 1,2-Dichloroethene (total) & 5 & 5 \\
\hline Chloroform & 5 & 5 \\
\hline 1,2-Dichloroethane & 5 & 5 \\
\hline 2-Butanone (MEK) & 5 & 5 \\
\hline 1,1,1-Trichloroethane & 5 & 5 \\
\hline Carbon tetrachloride & 5 & 5 \\
\hline Bromodichloromethane & 5 & 5 \\
\hline 1,1,2,2-Tetrachloroethane & 5 & 5 \\
\hline 1,2-Dichloropropane & 5 & 5 \\
\hline cis-1,3-Dichloropropene & 5 & 5 \\
\hline Trichloroethene & 5 & 5 \\
\hline 1,1,2-Trichloroethane & 5 & 5 \\
\hline Dibromochloromethane & 5 & 5 \\
\hline Benzene & 5 & 5 \\
\hline trans-1,3-Dichloropropene & 5 & 5 \\
\hline Bromoform & 5 & 5 \\
\hline 2-Hexanone & 5 & 5 \\
\hline 4-Methyl-2-pentanone (MIBK) & 5 & 5 \\
\hline Tetrachloroethene & 5 & 5 \\
\hline Toluene & 5 & 5 \\
\hline Chlorobenzene & 5 & 5 \\
\hline Ethylbenzene & 5 & 5 \\
\hline Styrene & 5 & 5 \\
\hline Xylenes, total & 5 & 5 \\
\hline
\end{tabular}


B-5

Table B.3. Practical quantitation limits - semivolatile organics

\begin{tabular}{|c|c|c|}
\hline Compound & Groundwater $(\mu \mathrm{g} / \mathrm{L})$ & Low soil/sediment $(\mu \mathrm{g} / \mathrm{kg})$ \\
\hline Phenol & 2.0 & 330 \\
\hline bis(2-Chloroethyl)ether & 1.5 & 330 \\
\hline 2-Chlorophenol & 2.0 & 330 \\
\hline 1,3-Dichlorobenzene & 2.0 & 330 \\
\hline 1,4-Dichlorobenzene & 2.0 & 330 \\
\hline 1,2-Dichlorobenzene & 2.5 & 330 \\
\hline 2-Methylphenol & 1.0 & 330 \\
\hline bis(2-Chloroisopropyl)ether & 2.5 & 330 \\
\hline 4-Methylphenol & 1.0 & 330 \\
\hline N-nitroso-di-n-propylamine & 1.5 & 330 \\
\hline Hexachloroethane & 2.0 & 330 \\
\hline Nitrobenzene & 2.5 & 330 \\
\hline Isophorone & 2.5 & 330 \\
\hline 2-Nitrophenol & 2.0 & 330 \\
\hline 2,4-Dimethylphenol & 2.0 & 330 \\
\hline bis(2-Chloroethoxy)methane & 2.0 & 330 \\
\hline 2,4-Dichlorophenol & 2.0 & 330 \\
\hline 1,2,4-Trichlorobenzene & 2.0 & 330 \\
\hline Naphthalene & 2.0 & 330 \\
\hline 2-Chloroaniline & 2.0 & 330 \\
\hline Hexachlorobutadiene & 2.0 & 330 \\
\hline 4-Chloro-3-methylphenol & 1.5 & 330 \\
\hline 2-Methylnaphthalene & 1.5 & 330 \\
\hline Hexachlorocyclopentadiene & 1.5 & 330 \\
\hline 2,4,6-Trichlorophenol & 2.5 & 330 \\
\hline 2,4,5-Trichlorophenol & 1.5 & 1600 \\
\hline 2-Chloronaphthalene & 1.5 & 330 \\
\hline 2-Nitroaniline & 2.5 & 1600 \\
\hline Dimethyl phthalate & 1.5 & 330 \\
\hline Acenaphthylene & 1.5 & 330 \\
\hline 2,6-Dinitrotoluene & 1.5 & 330 \\
\hline 3-Nitroaniline & 2.5 & 1600 \\
\hline Acenaphthene & 1.5 & 330 \\
\hline 2,4-Dinitrophenol & 1.5 & 1600 \\
\hline 4-Nitrophenol & 1.5 & 1600 \\
\hline Dibenzofuran & 1.0 & 330 \\
\hline 2,4-Dinitrotoluene & 1.0 & 330 \\
\hline Diethyl phthalate & 1.0 & 330 \\
\hline 4-Chlorophenyl phenyl ether & 1.0 & 330 \\
\hline Fluorene & 1.0 & 330 \\
\hline 4-Nitroaniline & 3.0 & 1600 \\
\hline 4,6-Dinitro-2-methylphenol & 15. & 1600 \\
\hline N-Nitrosodiphenylamine & 3.0 & 330 \\
\hline
\end{tabular}


B-6

Table B.3 (continued)

\begin{tabular}{lcc}
\hline Compound & Groundwater $(\mu \mathrm{g} / \mathrm{L})$ & Low soil/sediment $(\mu \mathrm{g} / \mathrm{kg})$ \\
\hline Phenol & 2.0 & 330 \\
& & \\
4-Bromophenyl phenyl ether & 1.5 & 330 \\
Hexachlorobenzene & 1.5 & 330 \\
Pentachlorophenol & 2.0 & 1600 \\
Phenanthrene & 1.0 & 330 \\
Anthracene & 2.5 & 330 \\
Carbazole & 10 & 10 \\
Fluoranthene & 1.5 & 330 \\
Pyrene & 1.5 & 330 \\
Butyl benzyl phthalate & 3.5 & 330 \\
3,3'-Dichlorobenzidine & 7.0 & 660 \\
Benz(a)anthracene & 1.5 & 330 \\
bis(2-Ethylhexyl)phthalate & 1.0 & 330 \\
Chrysene & 1.5 & 330 \\
Di-n-octyl phthalate & 1.5 & 330 \\
Benzo(b)fluoranthene & 1.5 & 330 \\
Benzo(k)fluoranthene & 1.5 & 330 \\
Benzo(a)pyrene & 2.0 & 330 \\
Indeno(1,2,3-cd)pyrcne & 2.5 & 330 \\
Dibenzo(a,h)anthracene & 2.5 & 330 \\
Benzo(g,h,i)perylene & 4.0 & 330 \\
\hline
\end{tabular}


Table B.4. Practical quantitation limiıs - pesticides and PCBs

\begin{tabular}{lcc}
\hline Compound & Groundwater $(\mu \mathrm{g} / \mathrm{L})$ & Low soil/sediment $(\mu \mathrm{g} / \mathrm{kg})$ \\
& & \\
\hline Aldrin & 0.04 & 2.68 \\
a-BHC & 0.03 & 2.01 \\
$\beta$-BHC & 0.06 & 4.02 \\
8-BHC & 0.09 & 6.03 \\
$\gamma-$ BHC (Lindane) & 0.04 & 2.68 \\
Chlordane (technical) & 0.14 & 9.38 \\
4,4'-DDD & 0.11 & 7.37 \\
4,4'-DDE & 0.04 & 2.68 \\
4,4'-DDT & 0.12 & 8.04 \\
Dieldrin & 0.02 & 1.34 \\
Endosulfan I & 0.14 & 9.38 \\
Endosulfan II & 0.04 & 2.68 \\
Endosulfan sulfate & 0.66 & 44.2 \\
Endrin & 0.06 & 4.02 \\
Endrin aldehyde & 0.23 & 15.4 \\
Heptachlor & 0.03 & 2.01 \\
Heptachlor epoxide & 0.83 & 55.6 \\
Methoxychlor & 1.76 & 117 \\
Toxaphene & 2.4 & 161 \\
PCB-1016 & nd & nd \\
PCB-1221 & nd & nd \\
PCB-1232 & nd & nd \\
PCB-1242 & 0.65 & 43.5 \\
PCB-1248 & nd & nd \\
PCB-1254 & nd & nd \\
PCB-1260 & nd & nd \\
& & \\
\hline & & \\
\hline & & \\
\hline
\end{tabular}

${ }^{\circledR}$ Not determined. 
Appendix C

ANALYTICAL DATA/SOIL BORING LOGS 
SPOIL AREA 1 SOIL BORING LOGS 


\begin{tabular}{|c|c|c|c|c|c|c|}
\hline & \\
\hline & & & & $\begin{array}{l}\text { PROSECT NUMBER } \\
\text { SED } 30490 . S C \\
\end{array}$ & $\begin{array}{l}\text { UMBER } \\
\text { 90.SC }\end{array}$ & $\begin{array}{l}\text { BORING NUMBER } \\
\text { SAI-1 } \quad \text { Sheet } 1 \text { of } 5 \\
\end{array}$ \\
\hline & & & & \multicolumn{3}{|c|}{ SOIL BORING LOG } \\
\hline \multirow{2}{*}{\multicolumn{4}{|c|}{ Spoll Area 1, Y-12 Group 3 RF }} & & LOCATION & Sal-1, Spoll Area 1 \\
\hline & & & & \multicolumn{3}{|c|}{ DRIUUNG CONTRACTOR } \\
\hline \multicolumn{4}{|c|}{ DPUUNO METHOO AND EQUIPMENT } & \multicolumn{3}{|c|}{ G-1MP LD. HSA, CME Model 75 Rotary Drlll Ro } \\
\hline \multicolumn{4}{|c|}{ WATERLEVES } & START Q-14 & FNISH $\quad 0-15-\infty$ & P. Van Noon \\
\hline \multirow{2}{*}{ 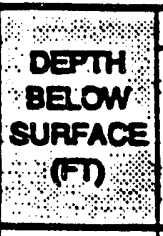 } & \multirow{2}{*}{ 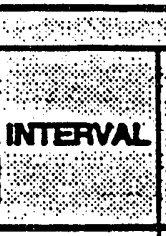 } & SMAPLE: & \%०\%: & \multirow{2}{*}{ 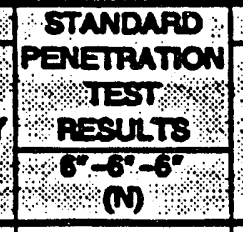 } & \multirow{2}{*}{ 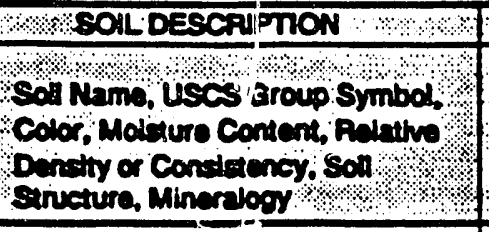 } & \multirow{2}{*}{ 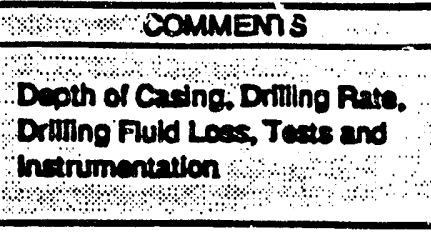 } \\
\hline & & $\begin{array}{l}\text { NUMBER } \\
\text { TMNPE }\end{array}$ & $\begin{array}{l}. \\
\text { RECOVETY } \\
\text { (F) }\end{array}$ & & & \\
\hline $1-$ & 1.5 & 1-S & 1.5 & $\stackrel{4-3-6}{(\theta)}$ & 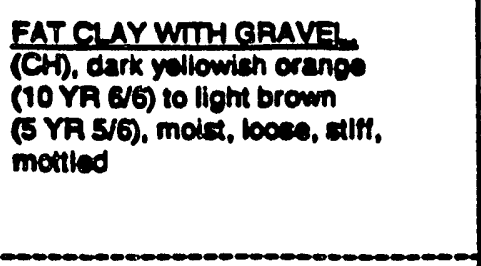 & $\begin{array}{l}\text { Ueing } 4 \text { " eplth spoon with sain- } \\
\text { leas aced liners }\end{array}$ \\
\hline $2-$ & 3.0 & 2-8 & 1.5 & $4-6$ & 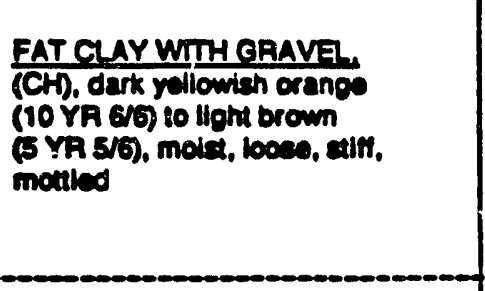 & \\
\hline $4-$ & 4.5 & $3-5$ & 1.5 & $\begin{array}{l}2-20-27 \\
(47)\end{array}$ & 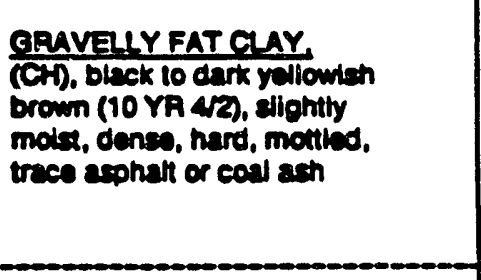 & \\
\hline- & 6.0 & $4-5$ & 1.5 & $\begin{array}{l}12-20-25 \\
(45)\end{array}$ & 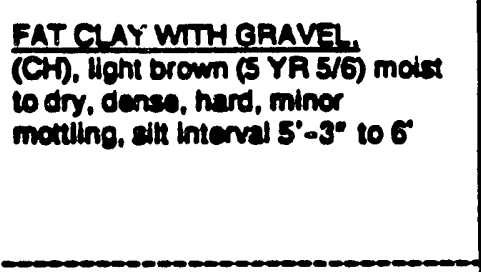 & $\begin{array}{l}\text { Samples SAS1001 VOA, } 1002 \\
\text { samplo sulhe, and 1003 samplo } \\
\text { sulte, at 10:54 }\end{array}$ \\
\hline $7-$ & 7.5 & s-5 & 1.5 & $\begin{array}{c}17-17-13 \\
(50)\end{array}$ & 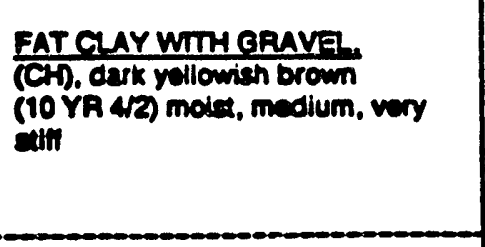 & \\
\hline $\begin{array}{l}8- \\
-\end{array}$ & 9.0 & 6-S & 0.4 & $\begin{array}{l}17-36-24 \\
(60)\end{array}$ & 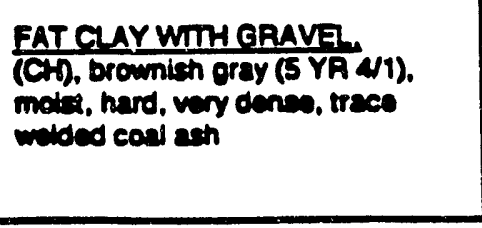 & \\
\hline
\end{tabular}




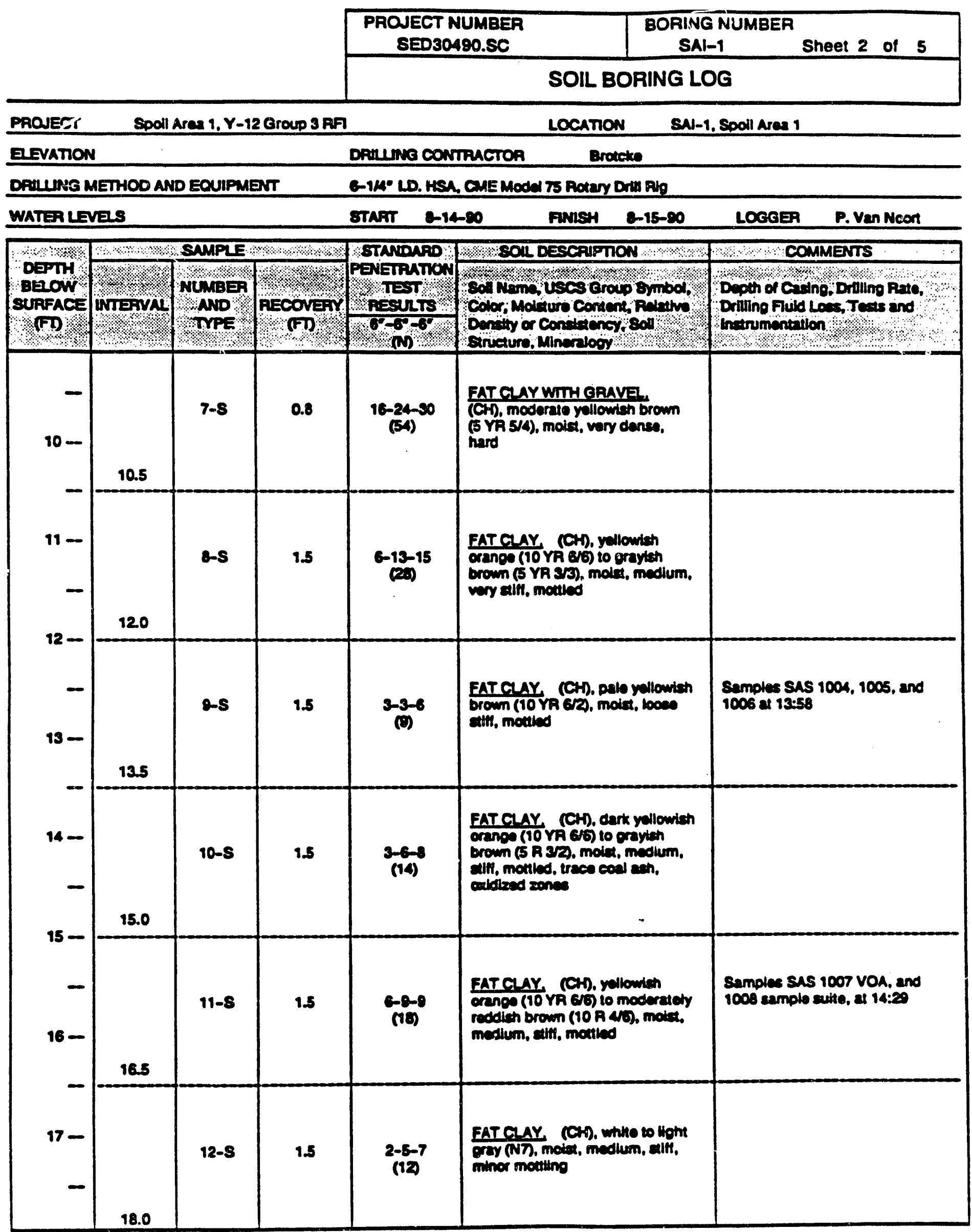


C-7

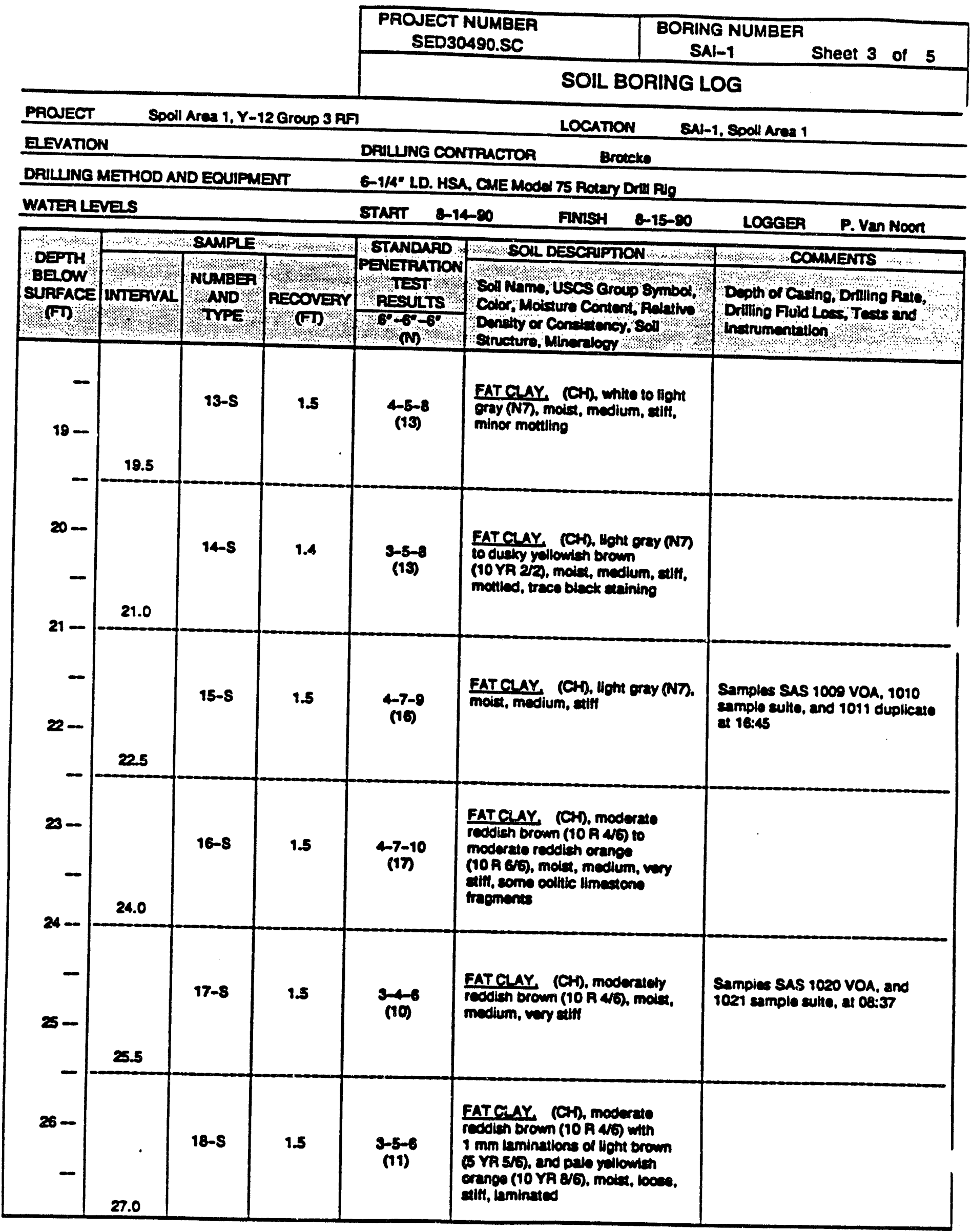


C.8

PROSECT NUMBER SED30490.SC
BOAING NUMBER

SAL-1

Sheet 4 of 5

SOIL BORING LOG

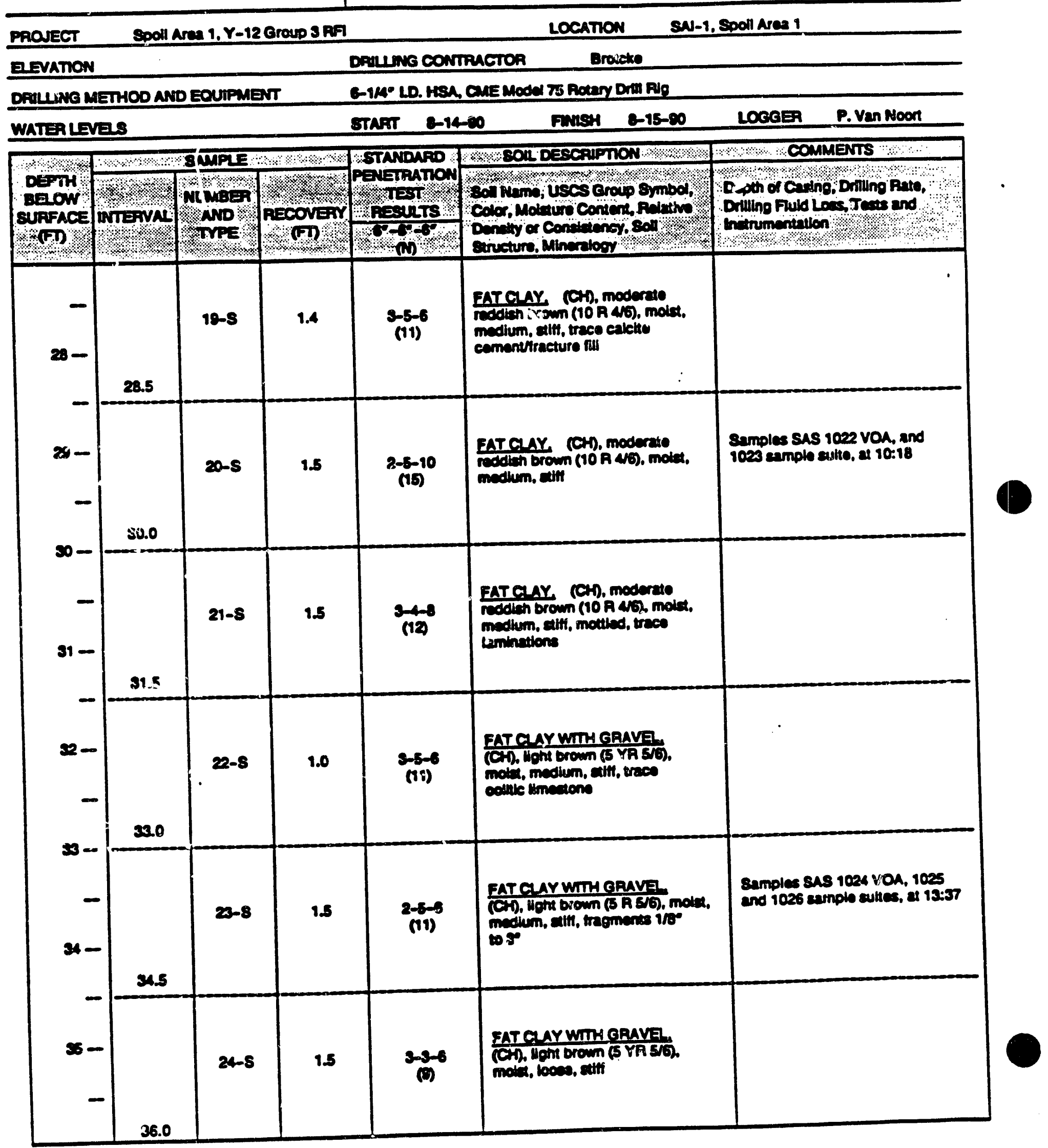


C-9

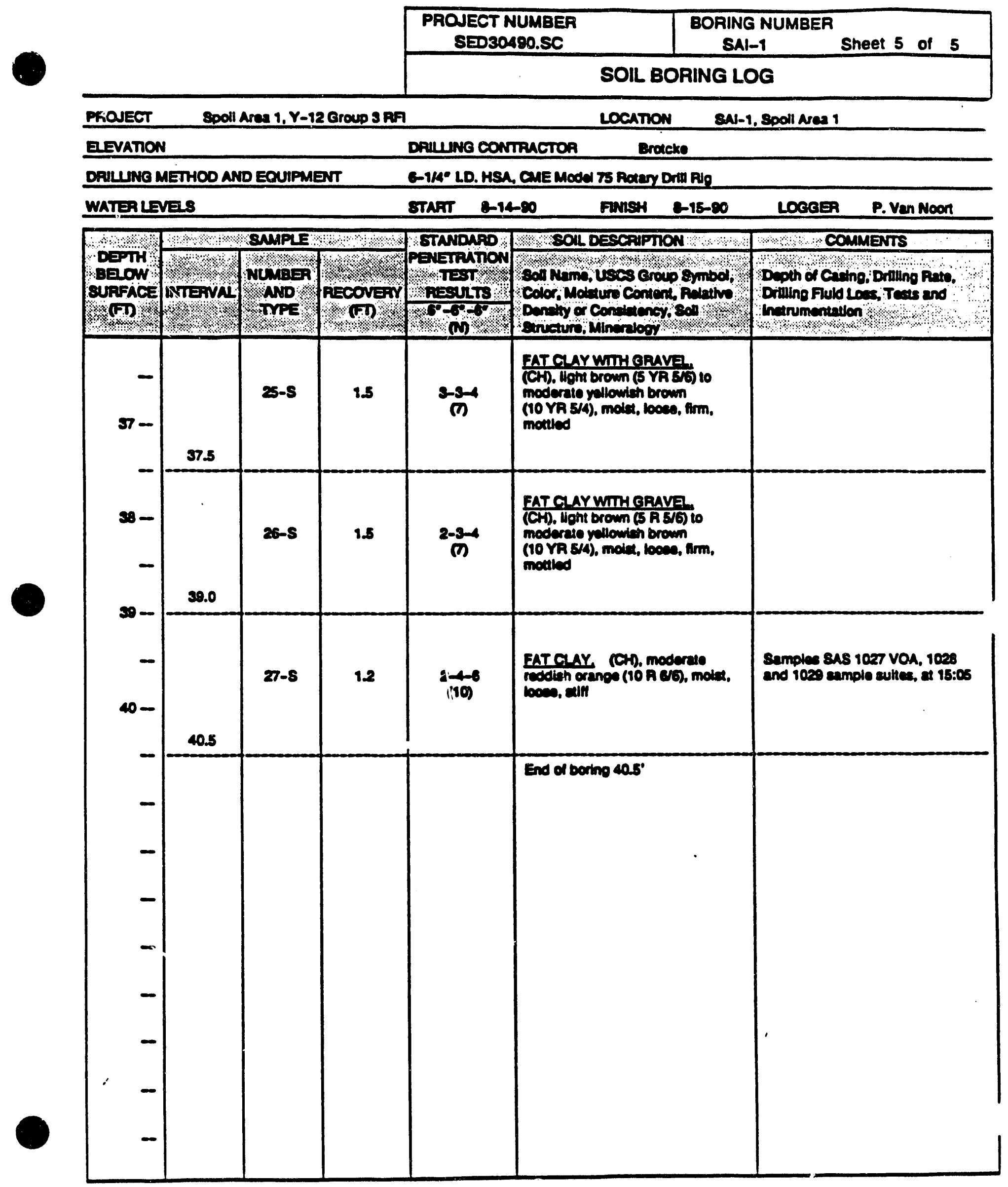


C-10

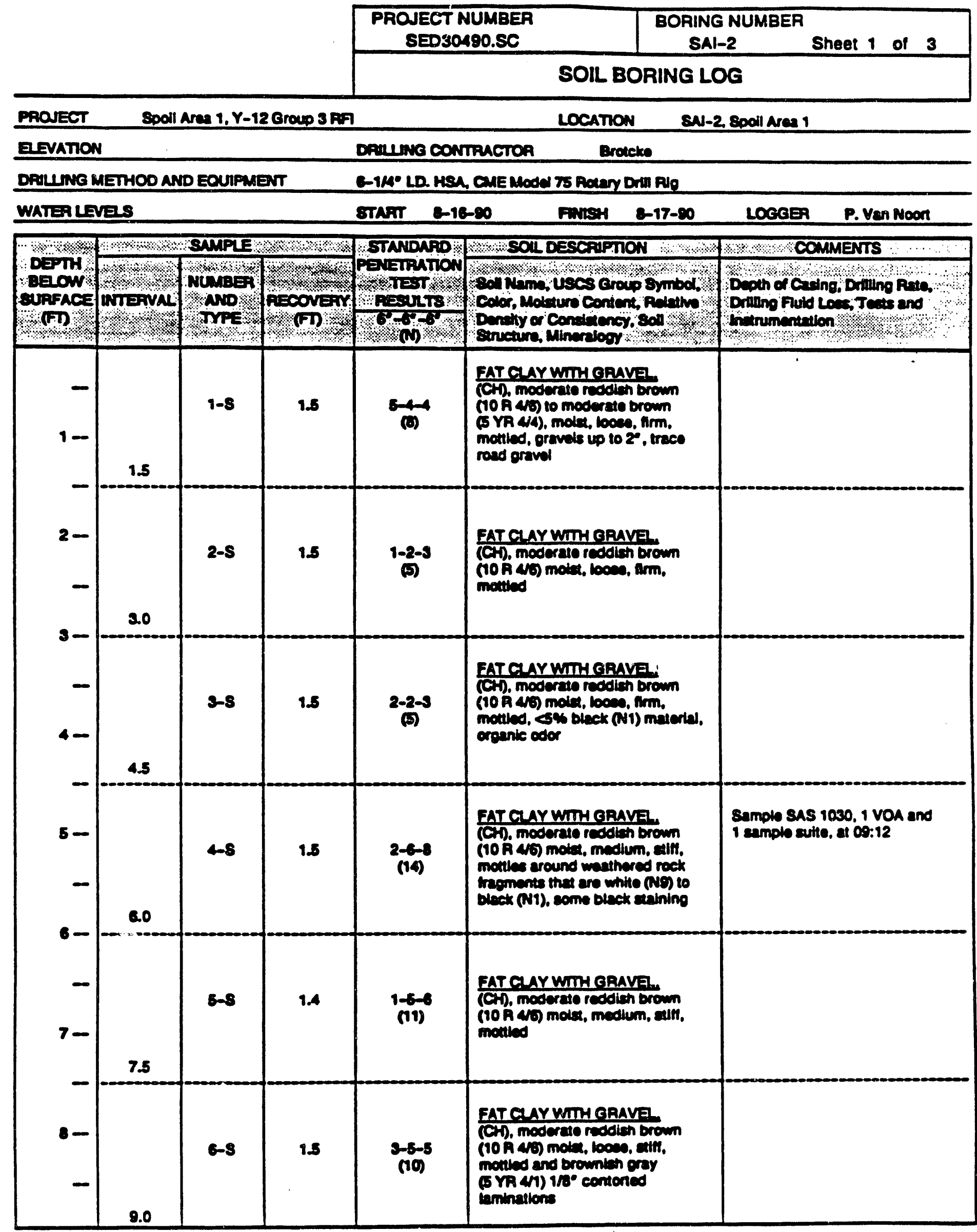




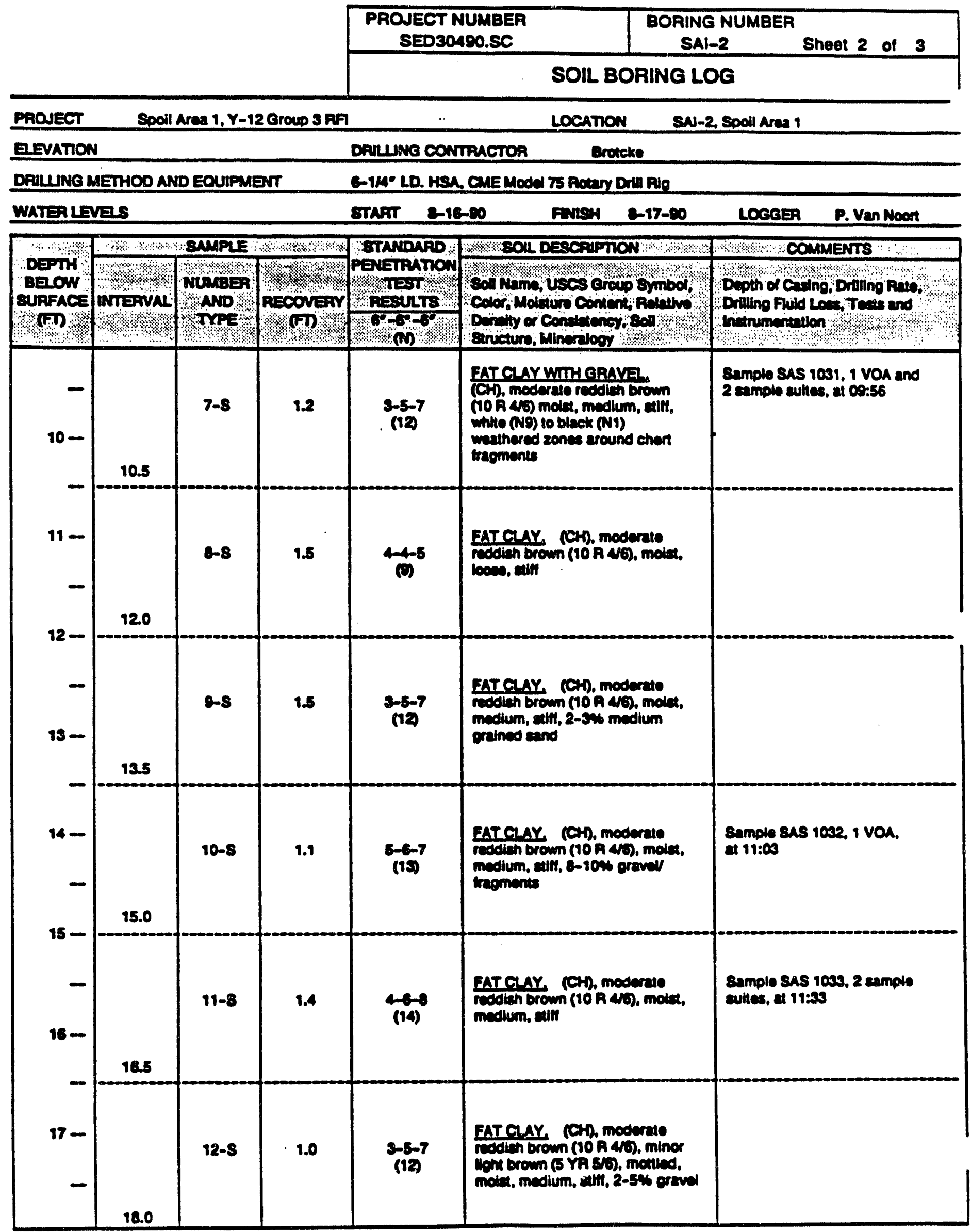


C- 12

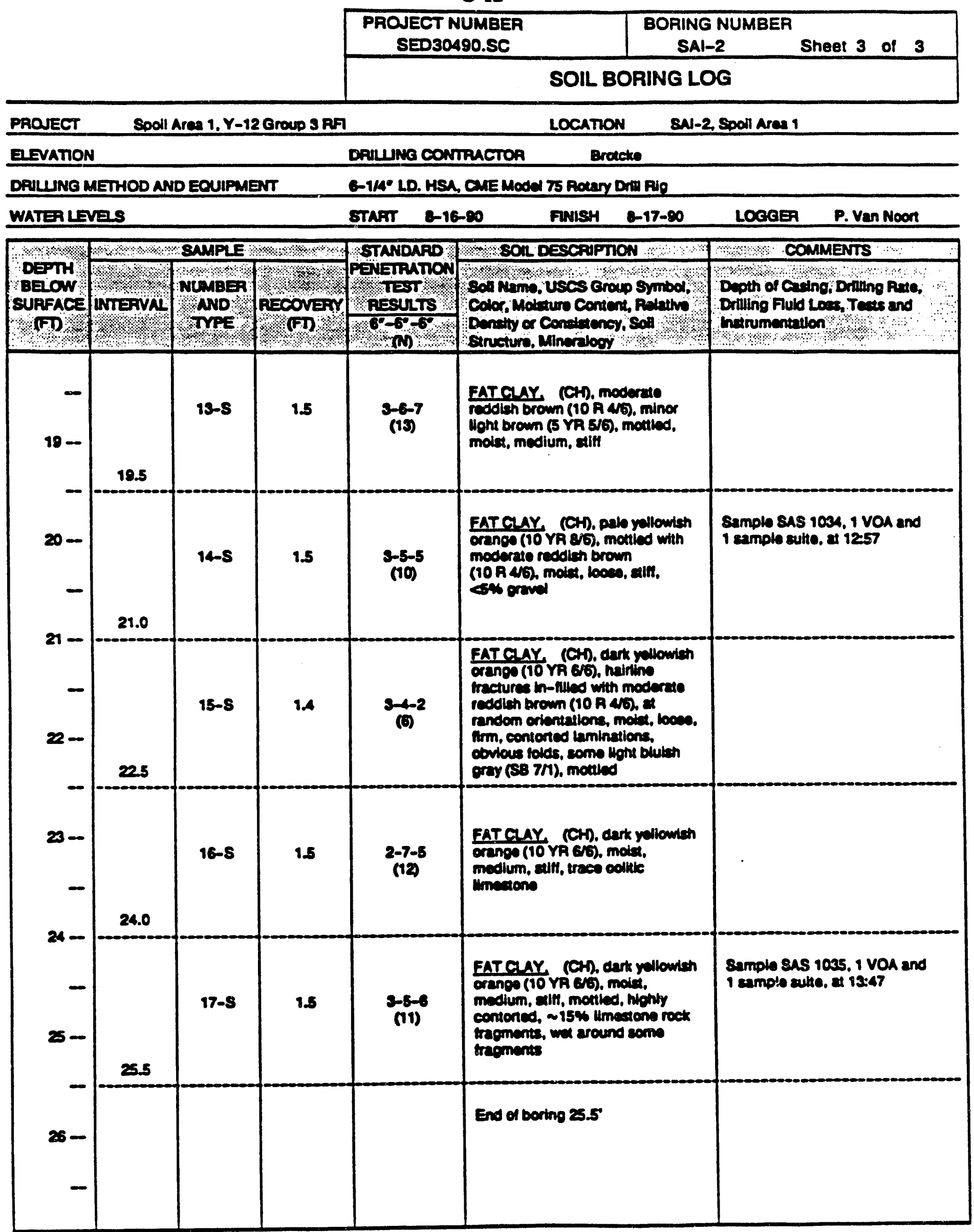


C- 13

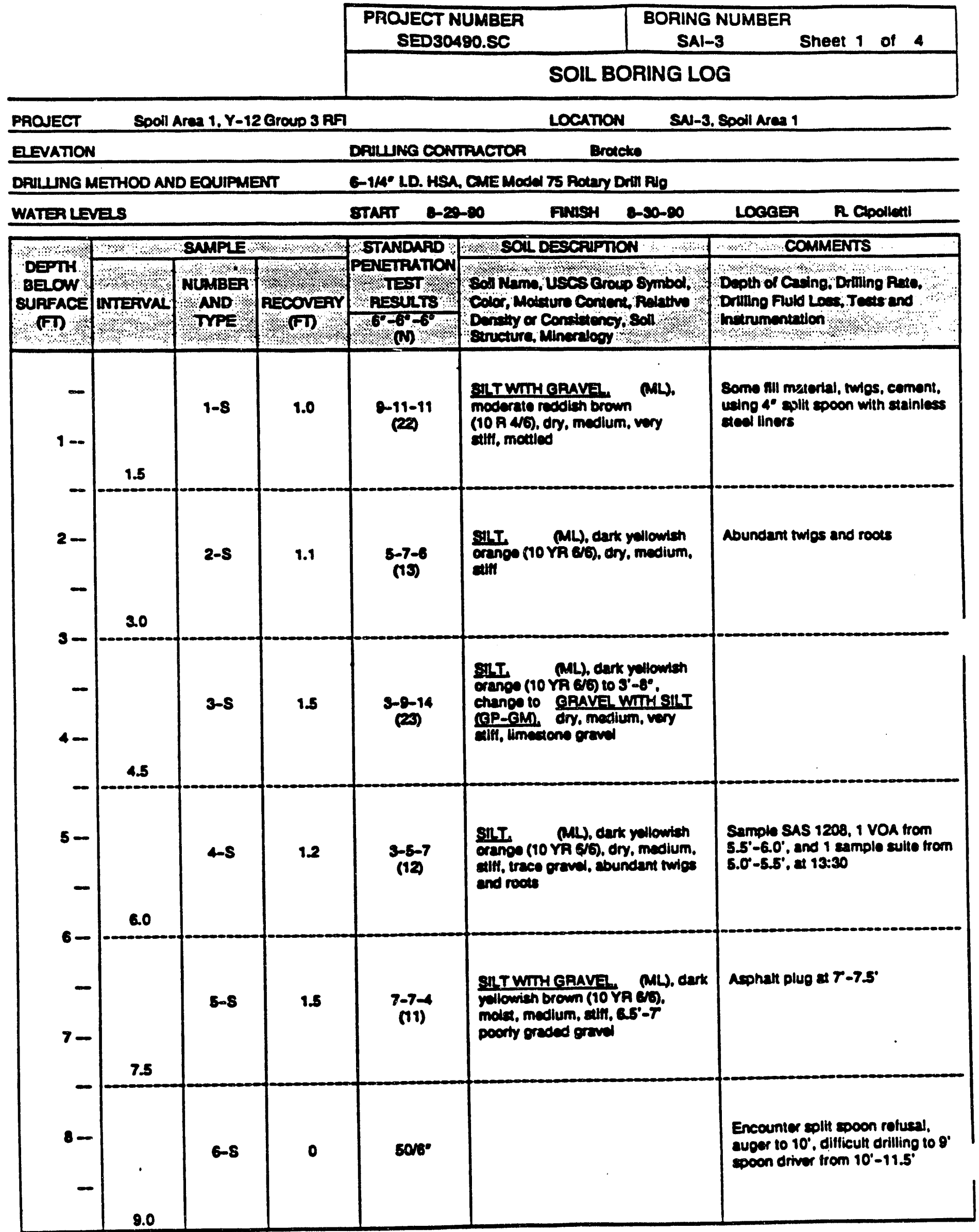


C-14

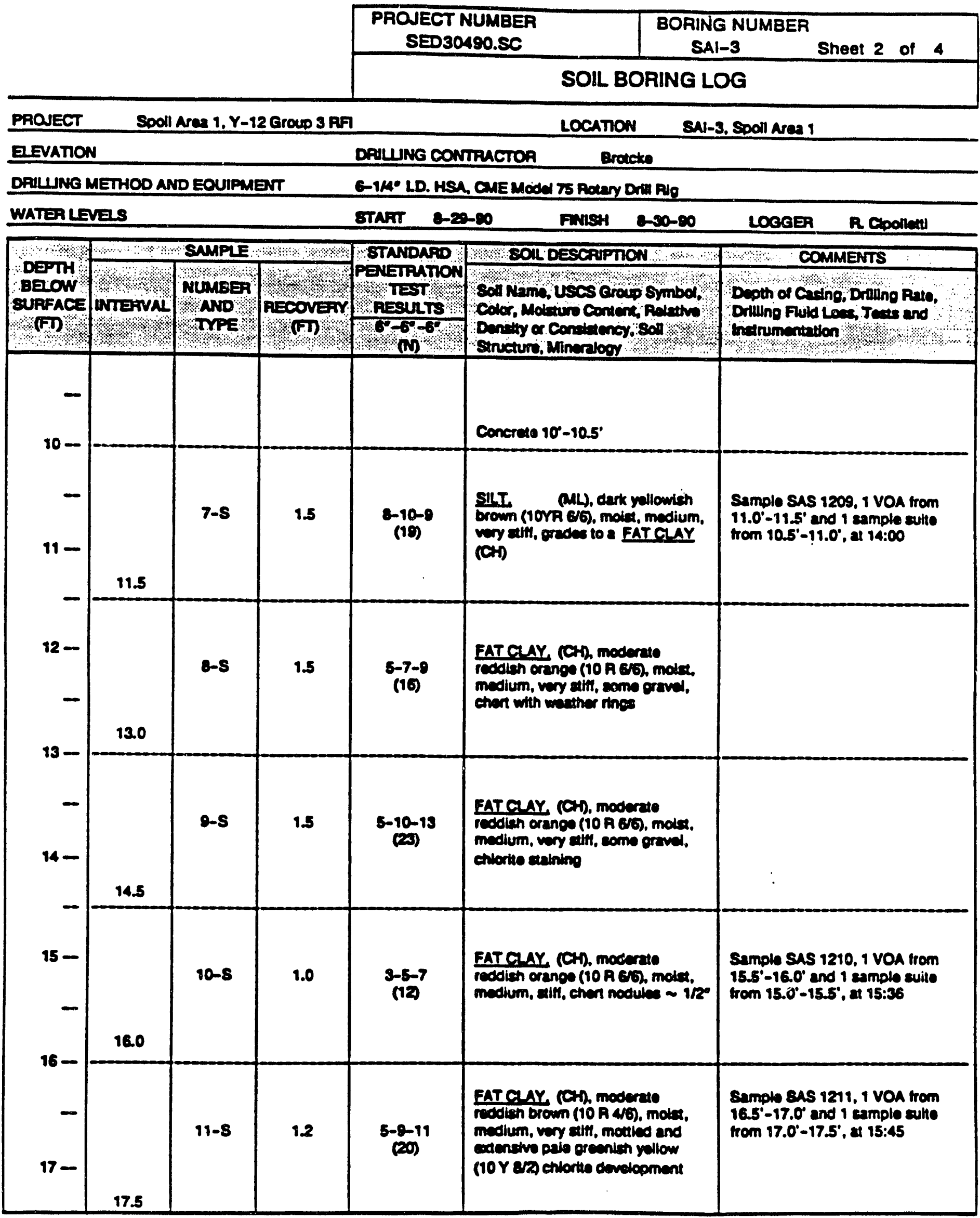




\section{C- 15}

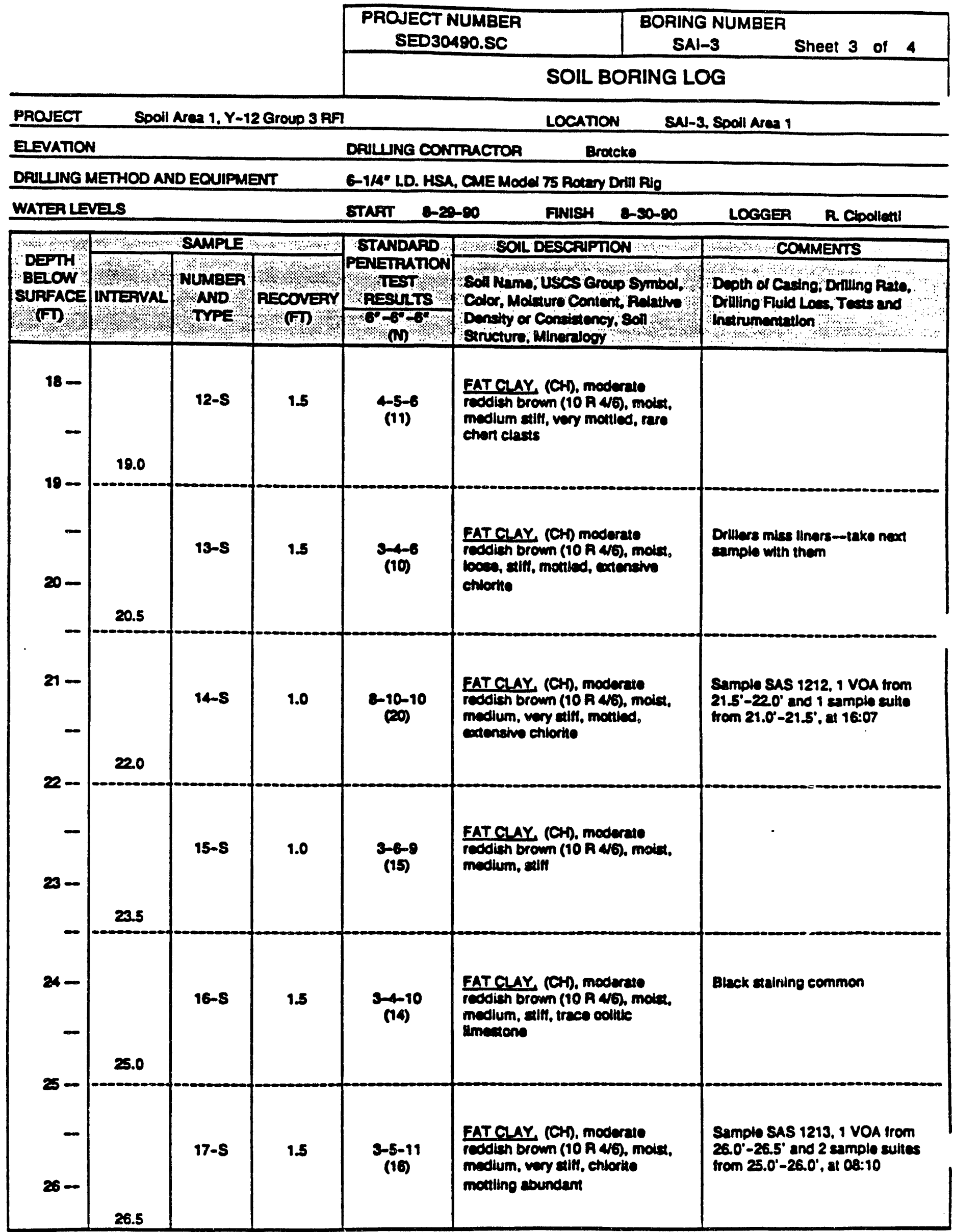


C-16

\begin{tabular}{|l|c|}
\hline $\begin{array}{c}\text { PRONECT NUMBER } \\
\text { SED30490.SC }\end{array}$ & $\begin{array}{c}\text { BORING NUMBER } \\
\text { SAI-3 }\end{array}$ Sheet 4 of 4 \\
\hline \multicolumn{3}{|l}{ SOIL BORING LOG } \\
\hline
\end{tabular}

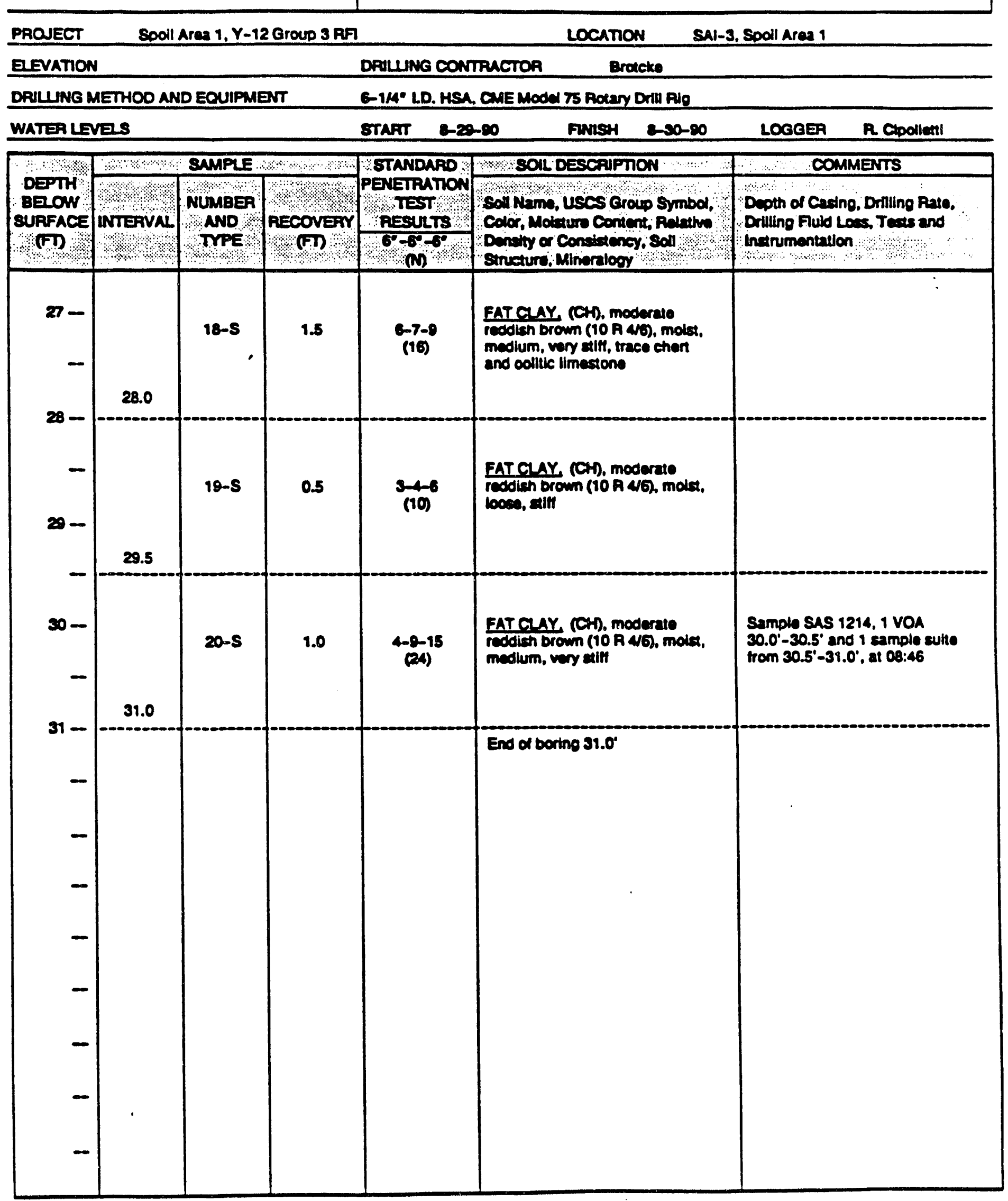


C-17

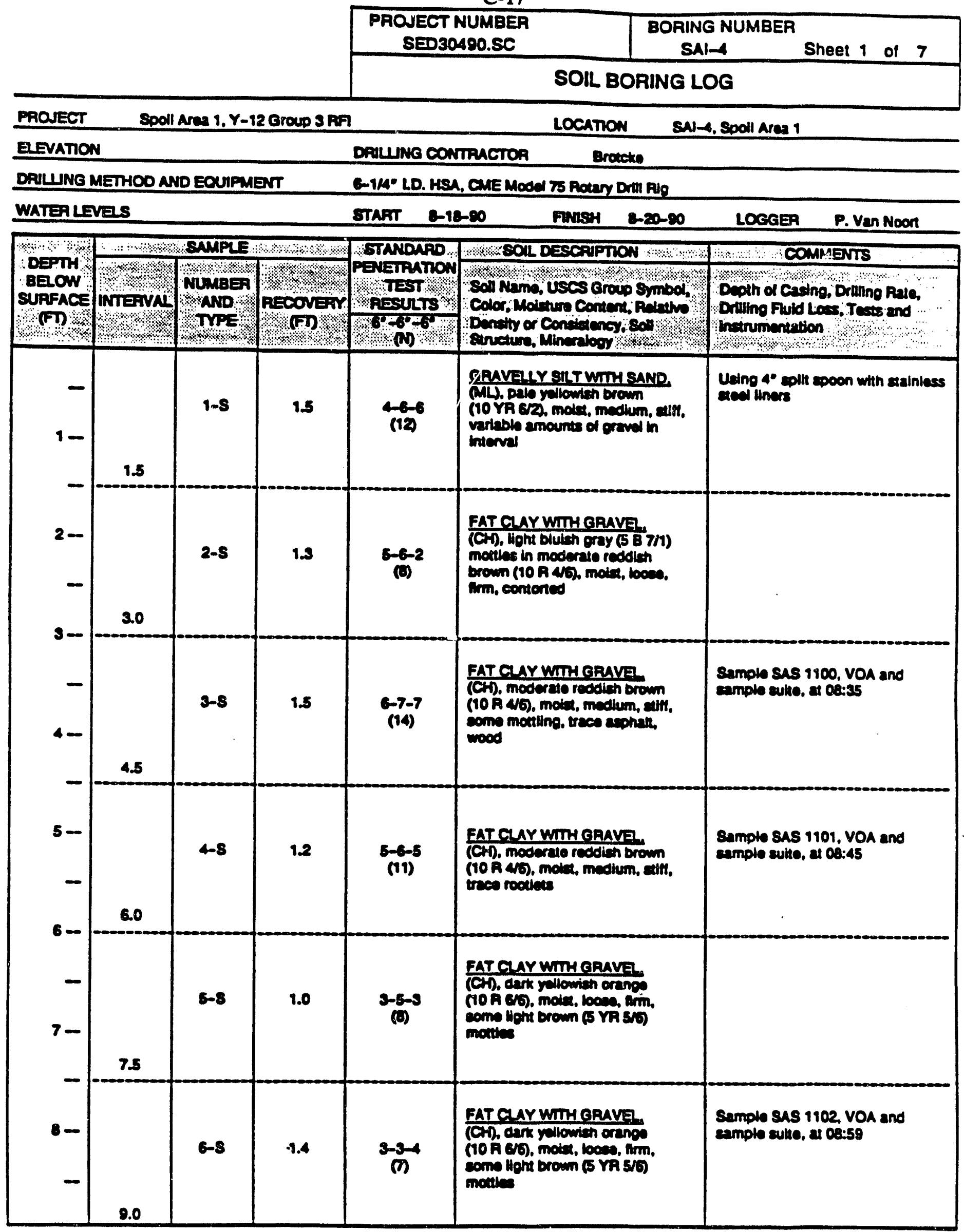


C- 18

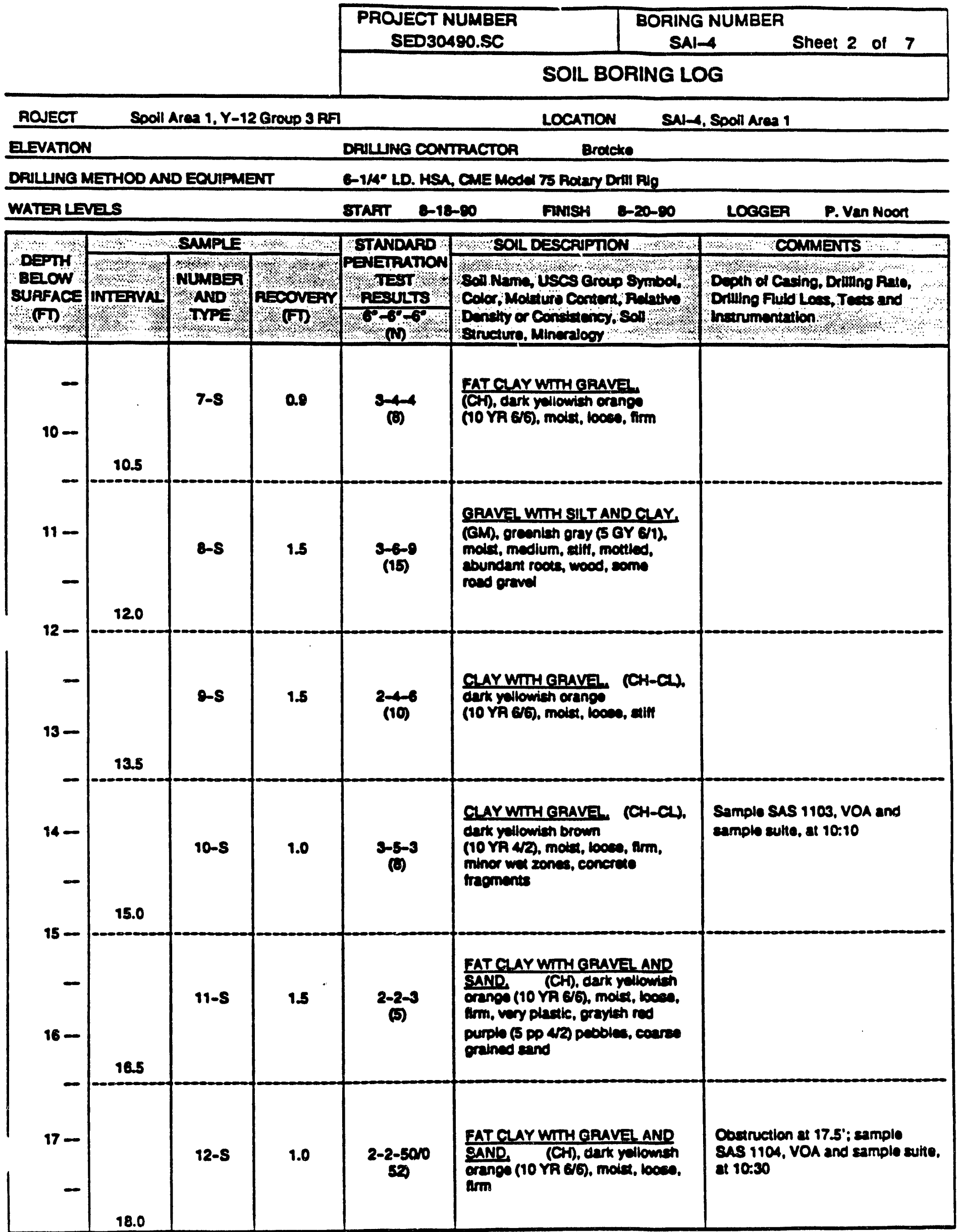


C-19

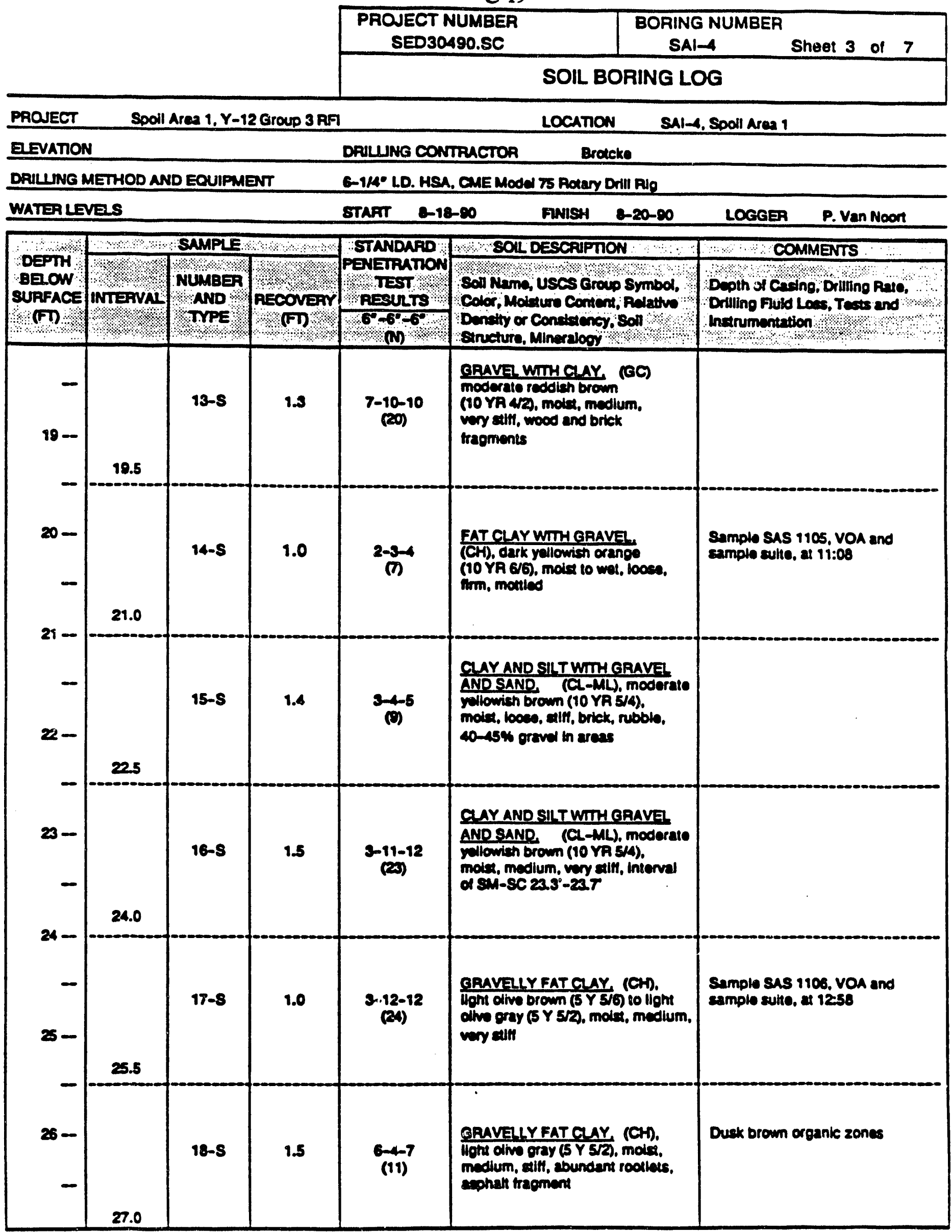




\section{C-20}

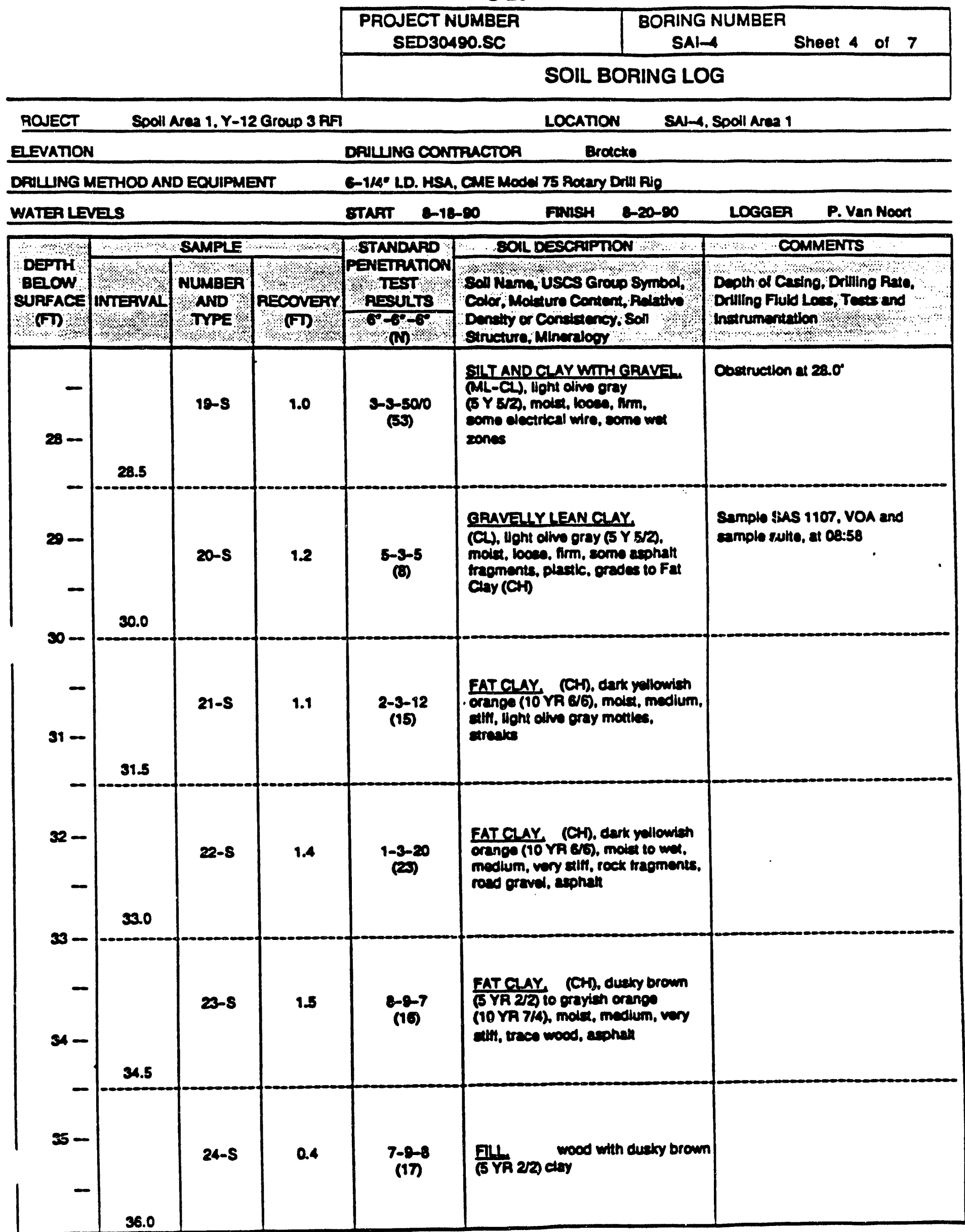


C:21

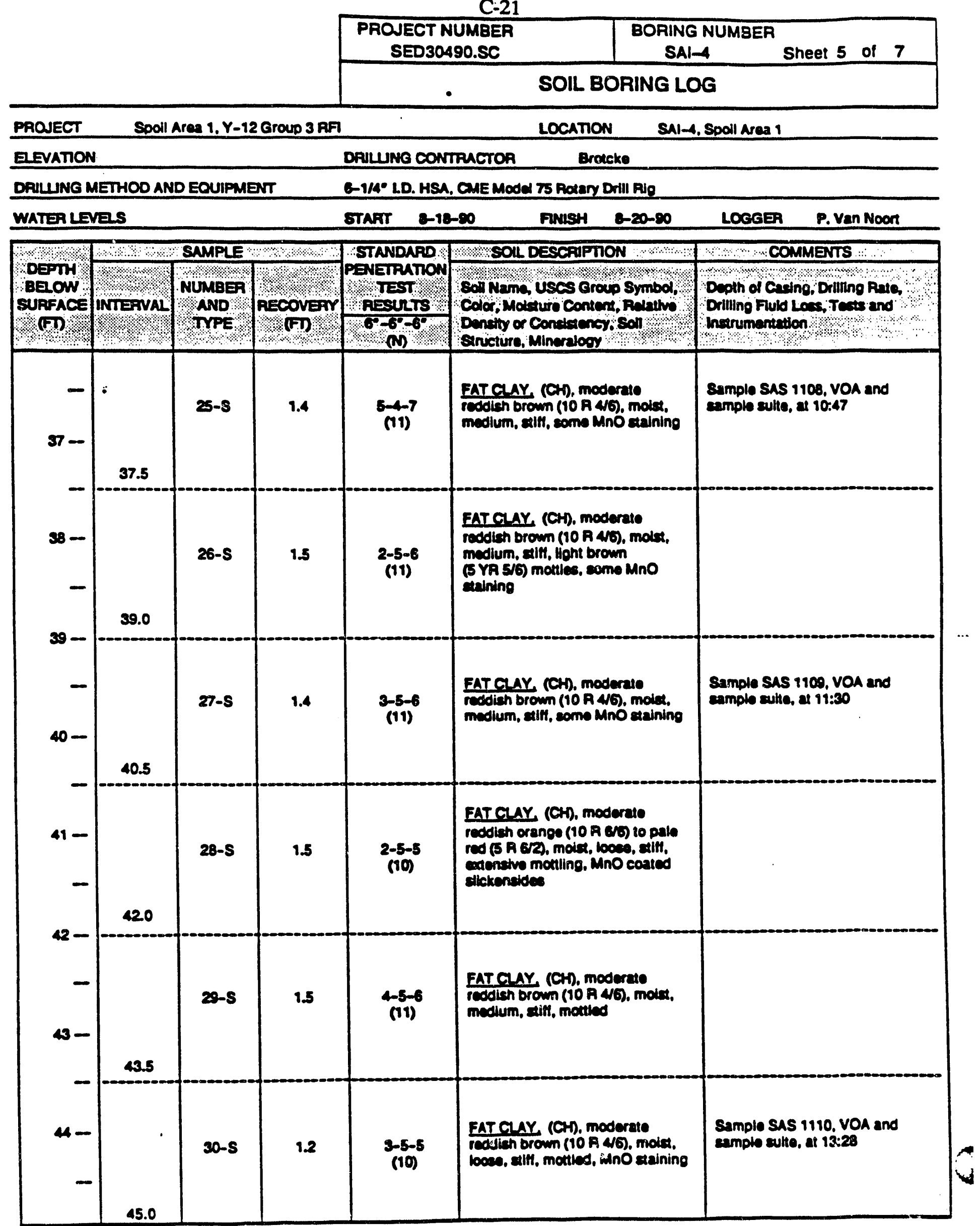


C-22

PROJECT NUMBER

SED30480.SC

BORING NUMBER

SAI-A

Sheet 6 of 7

SOIL BORING LOG

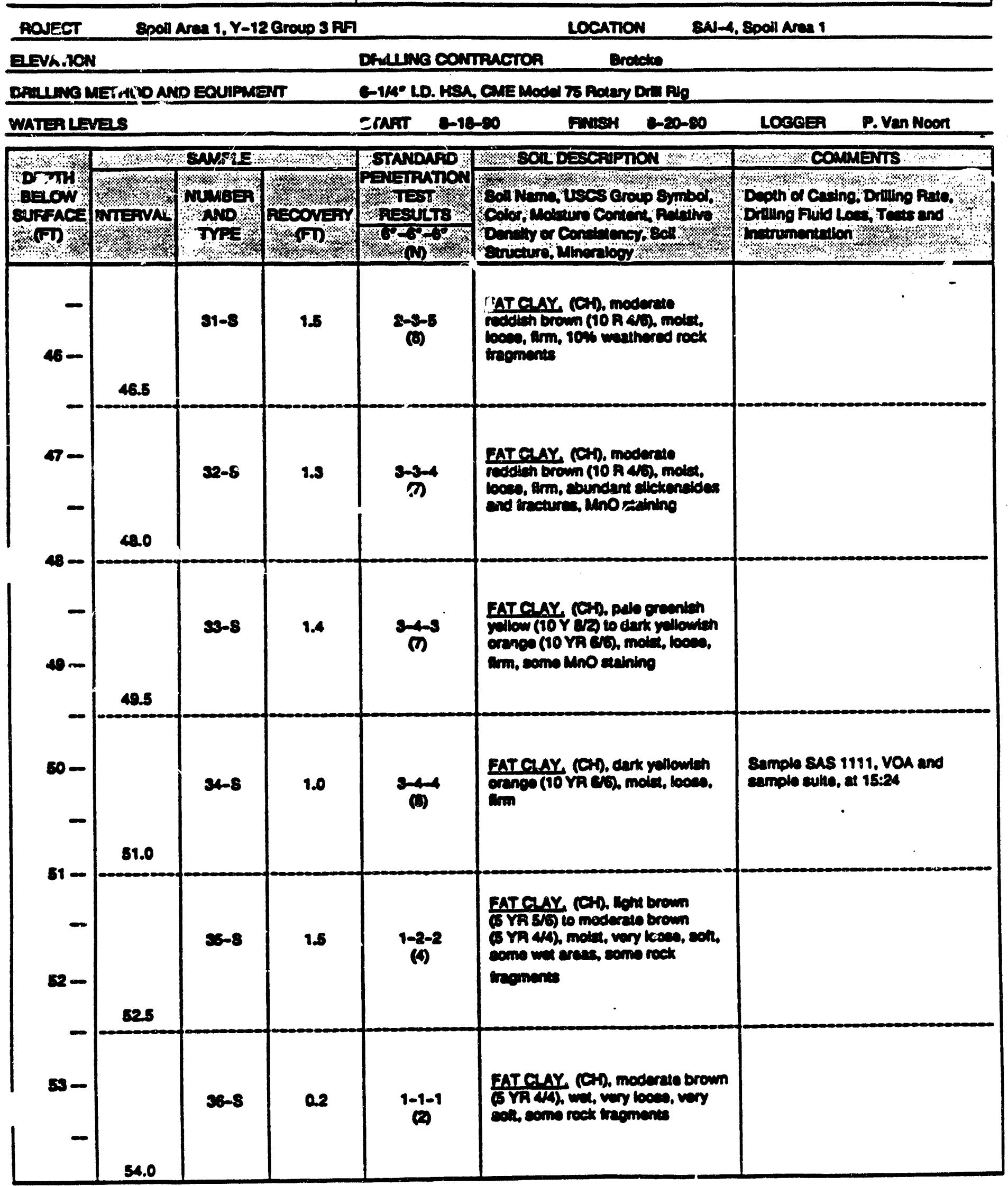


C-23

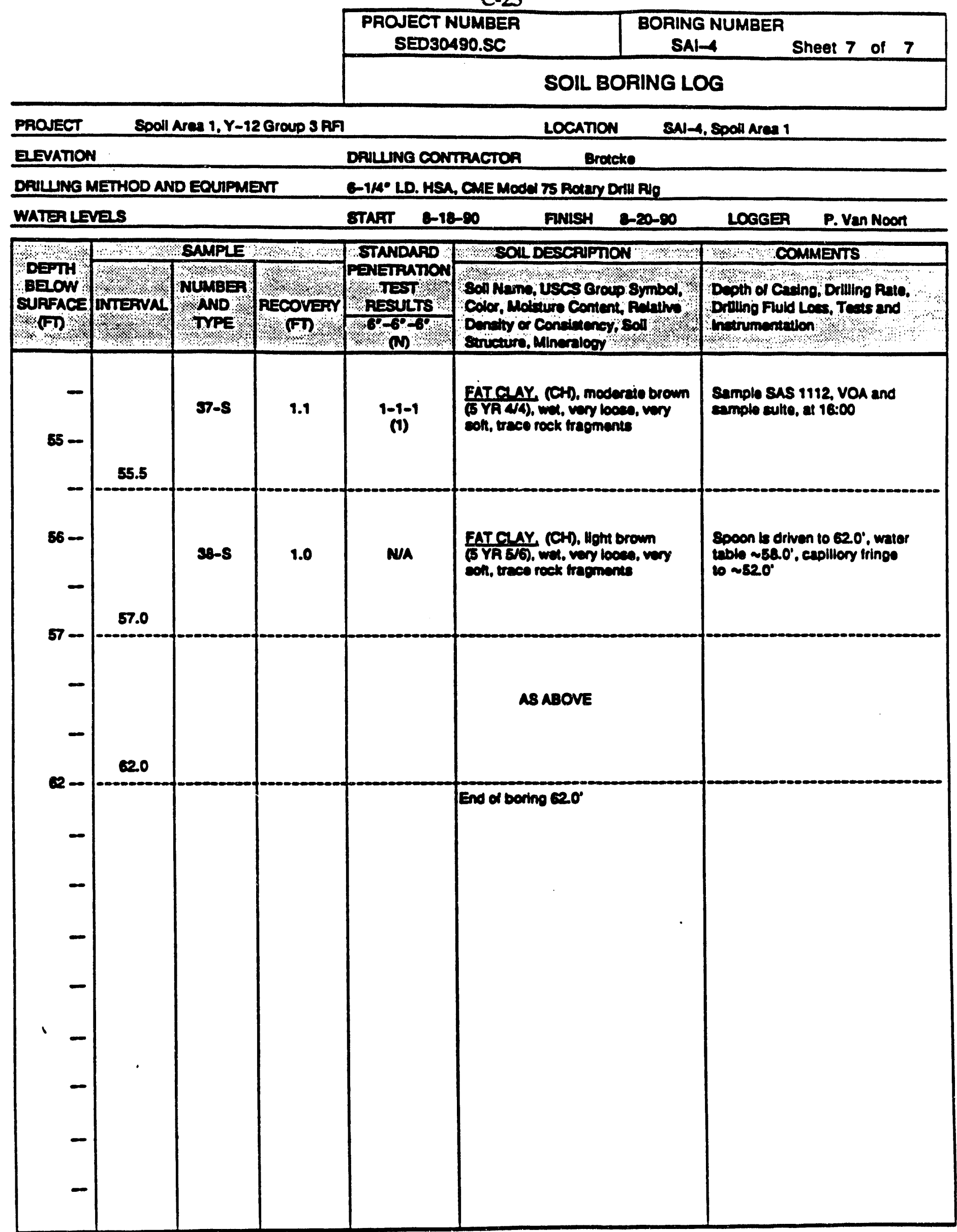


C. 24

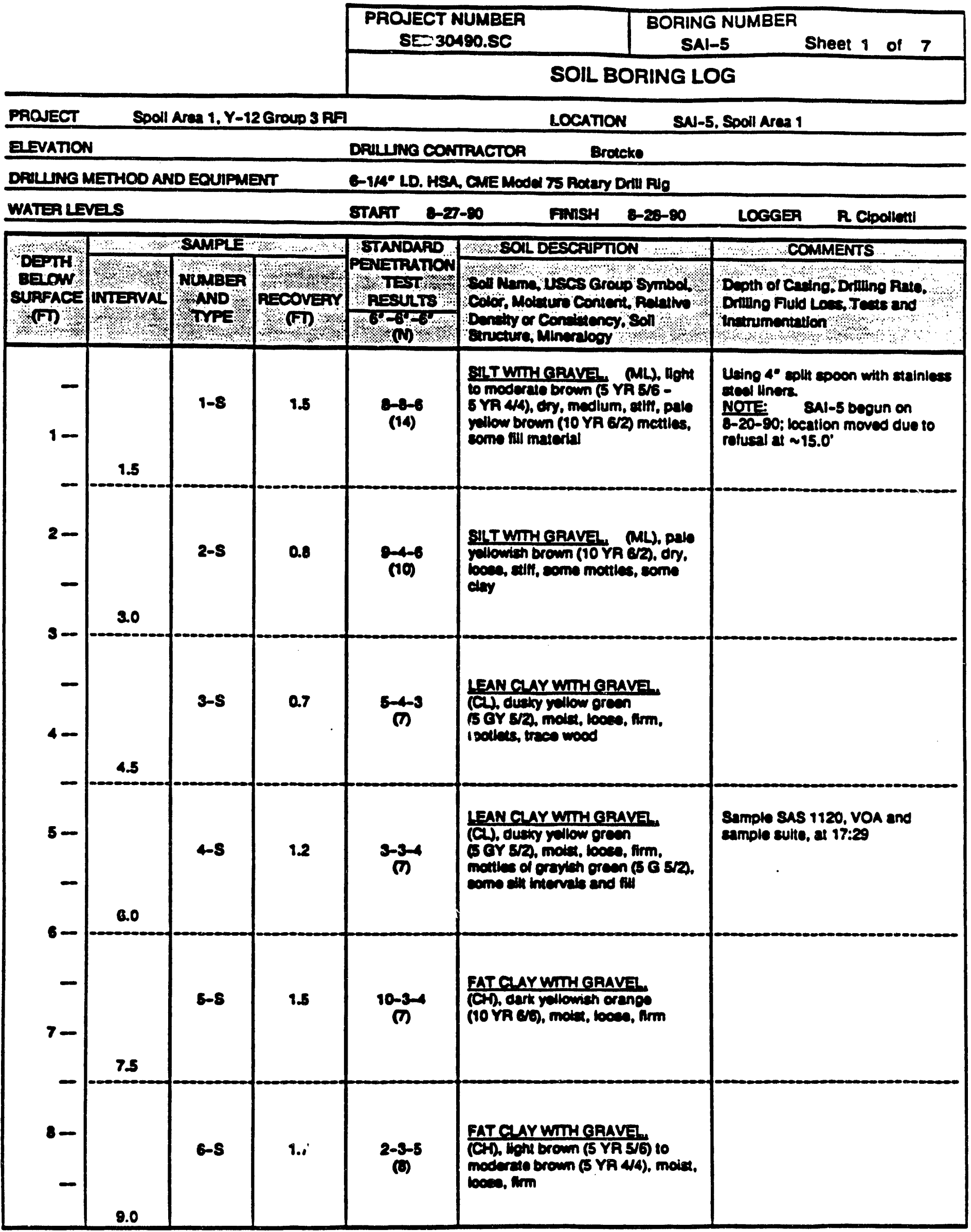


C. -25

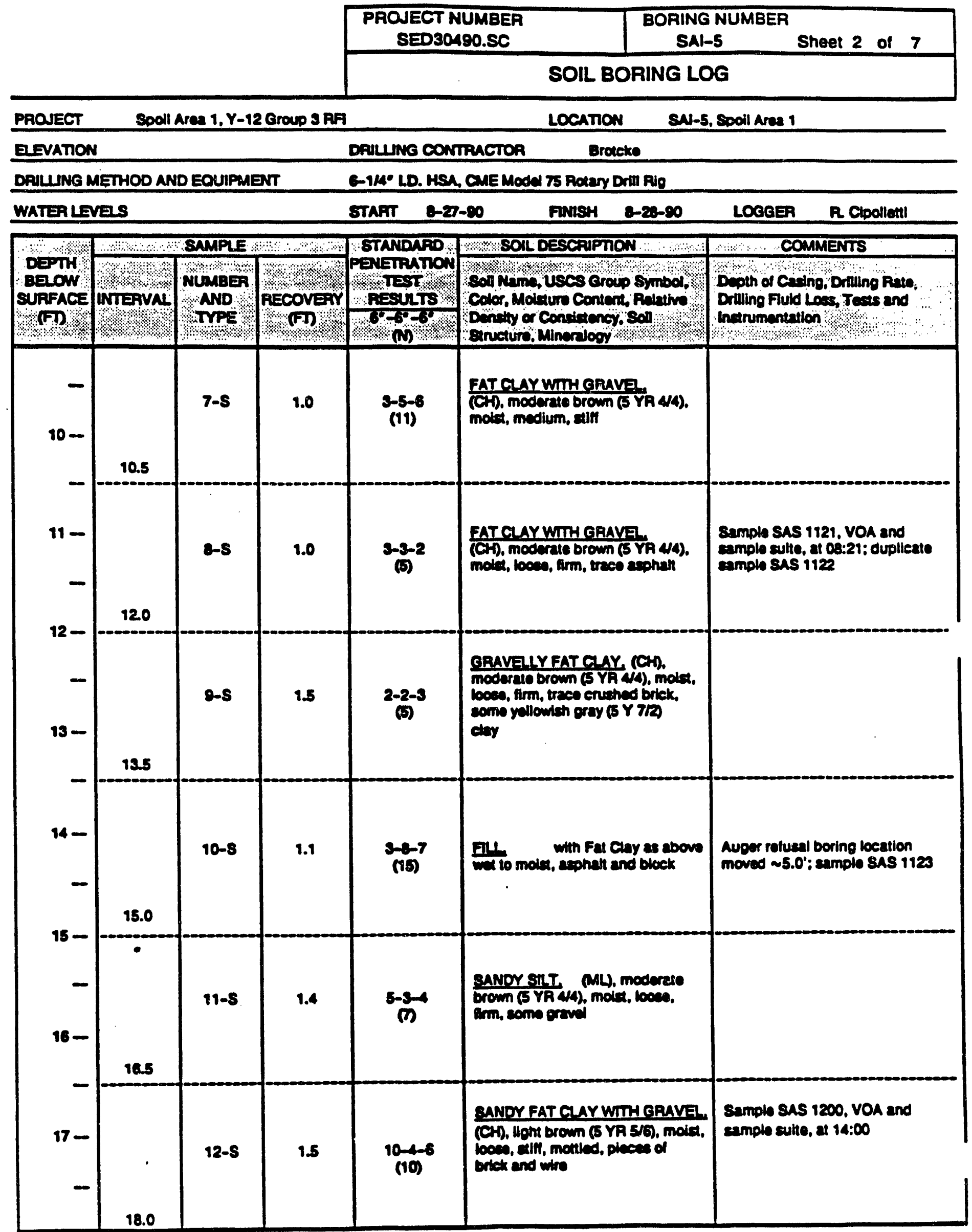


C-26

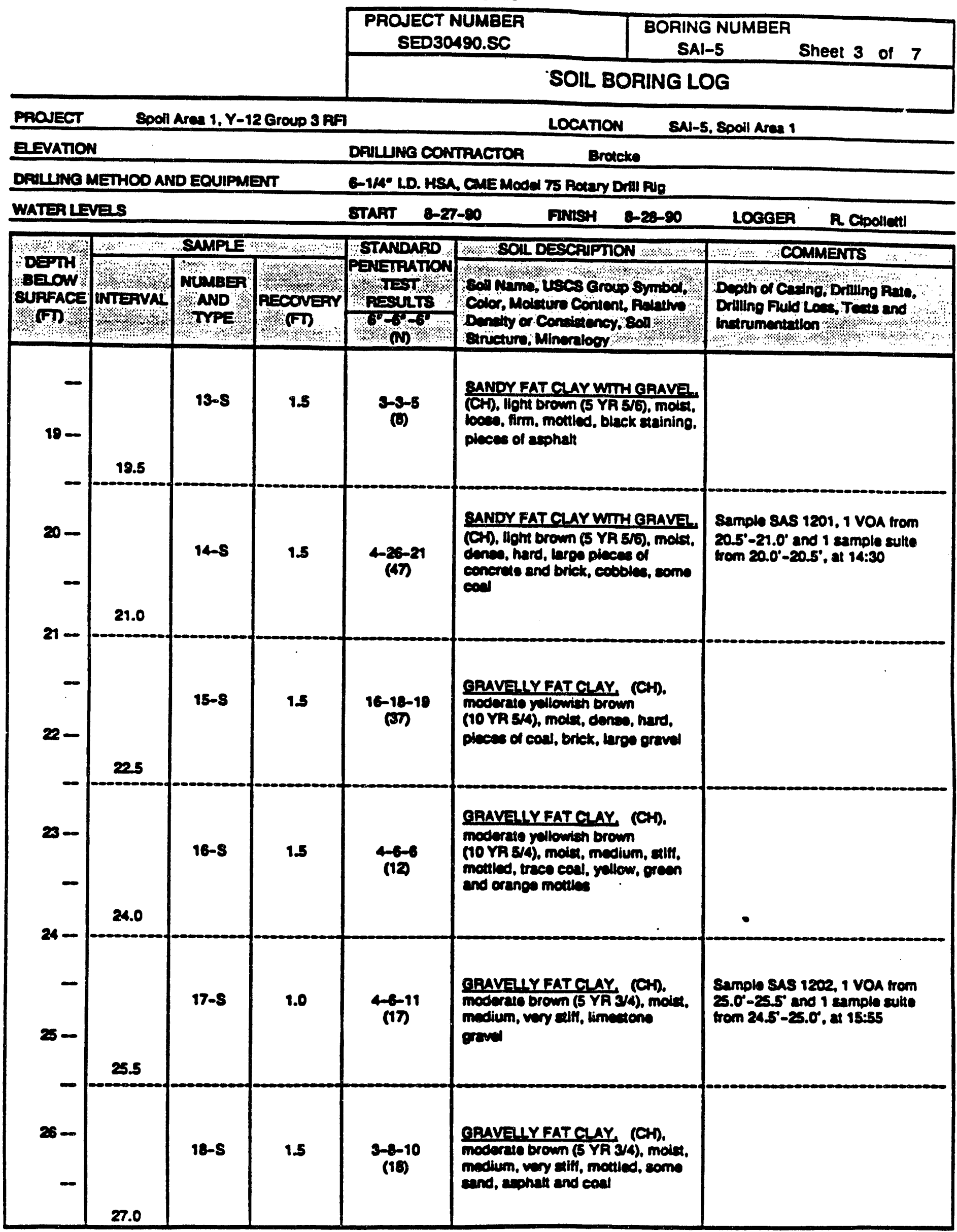




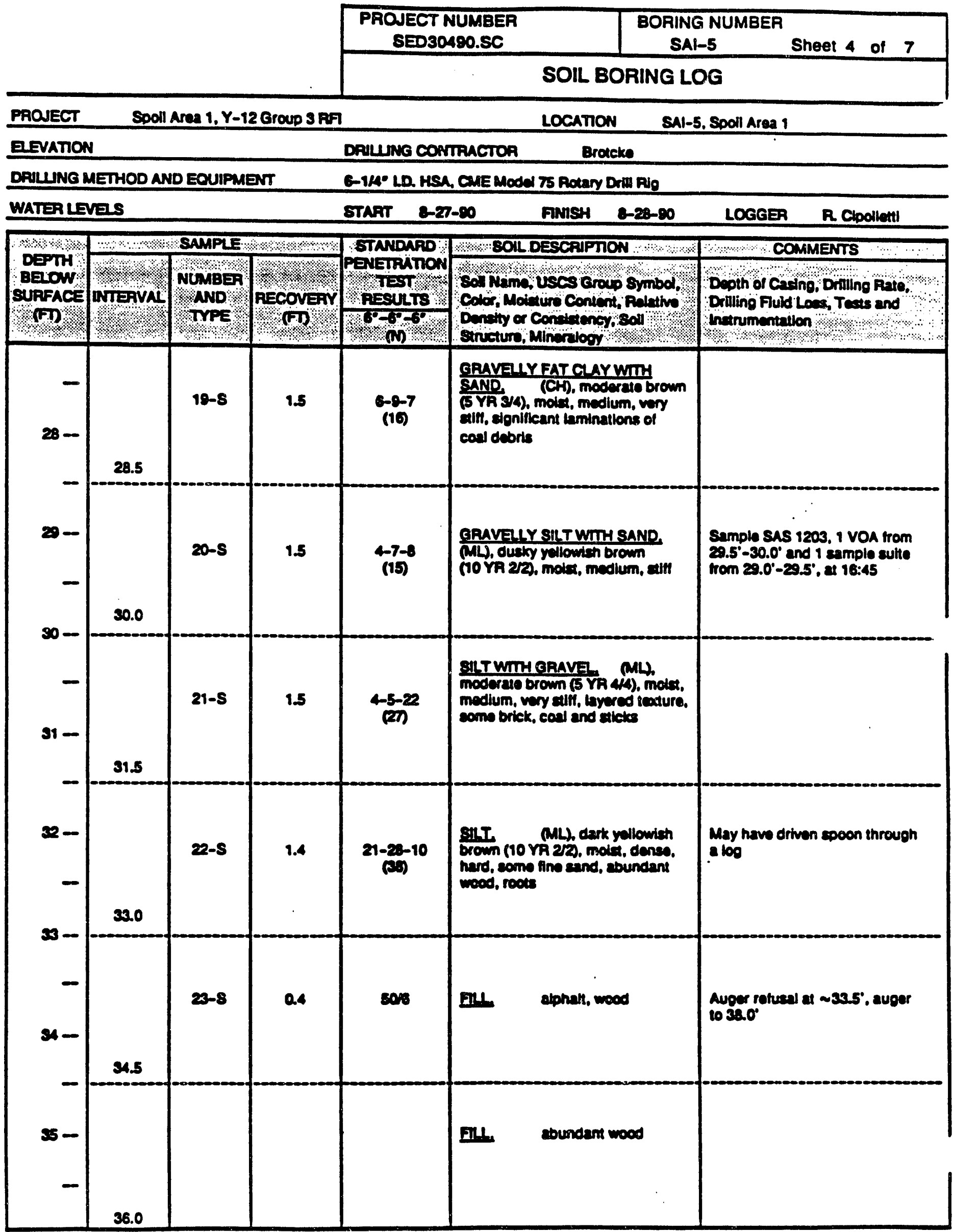


C-28

PROECT NUMBER SED30490.SC BORING NUMBER

SAI-5

Sheet 5 of 7

SOIL BORING LOG

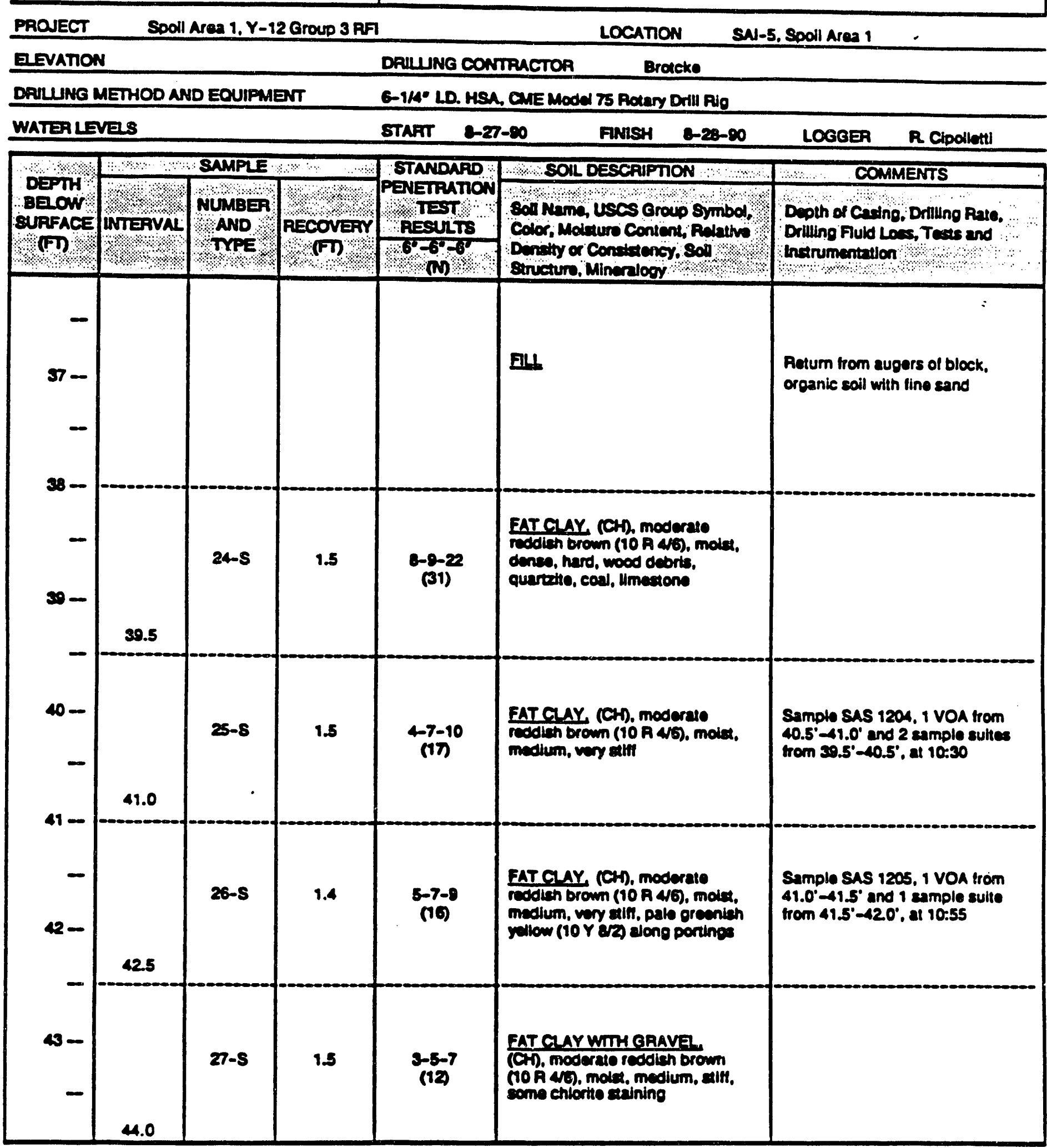




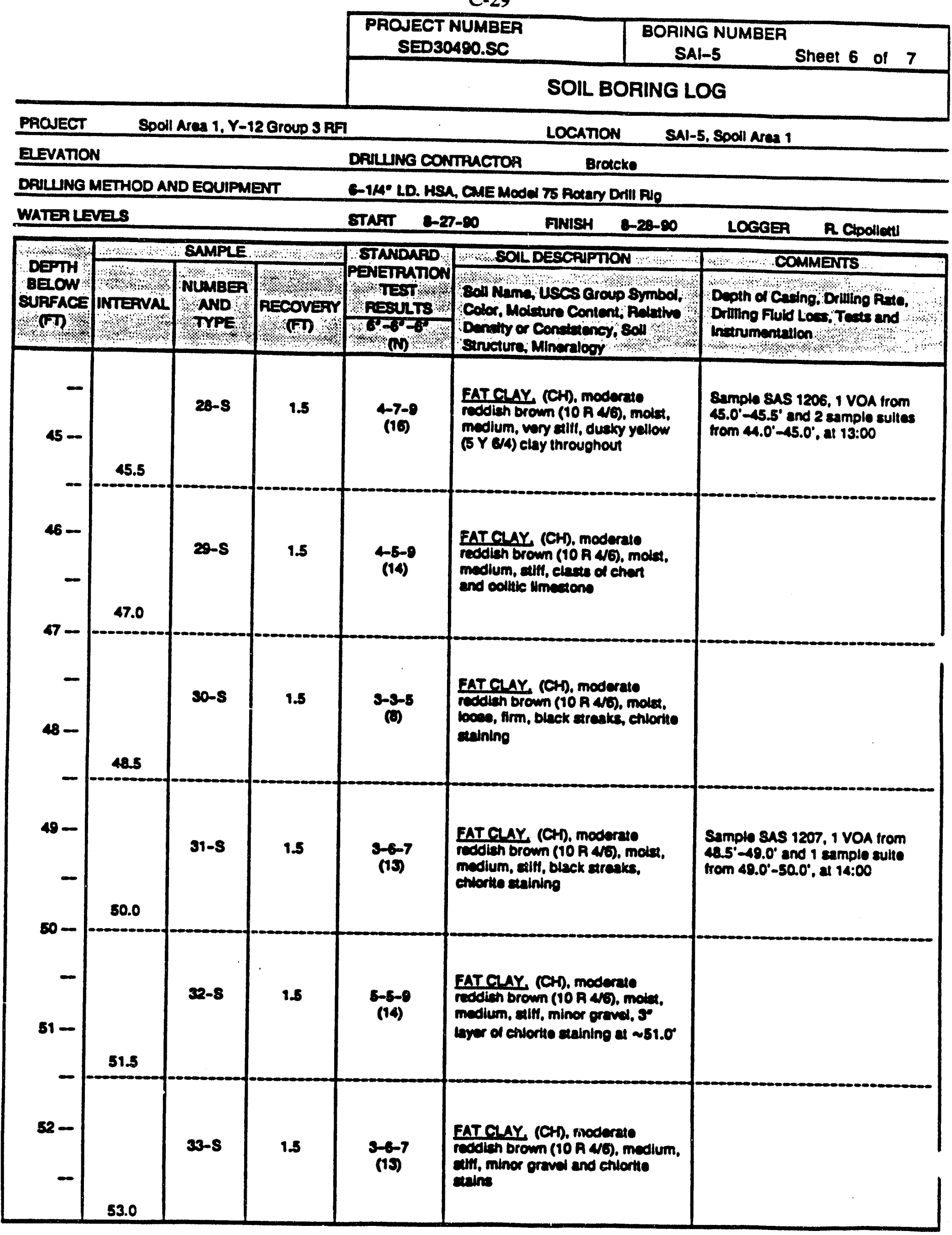


C-30

PROJECT NUMBER

SED30490.SC

BORING NUMBER

SAT-5

Sheet 7 of 7

SOIL BORING LOG

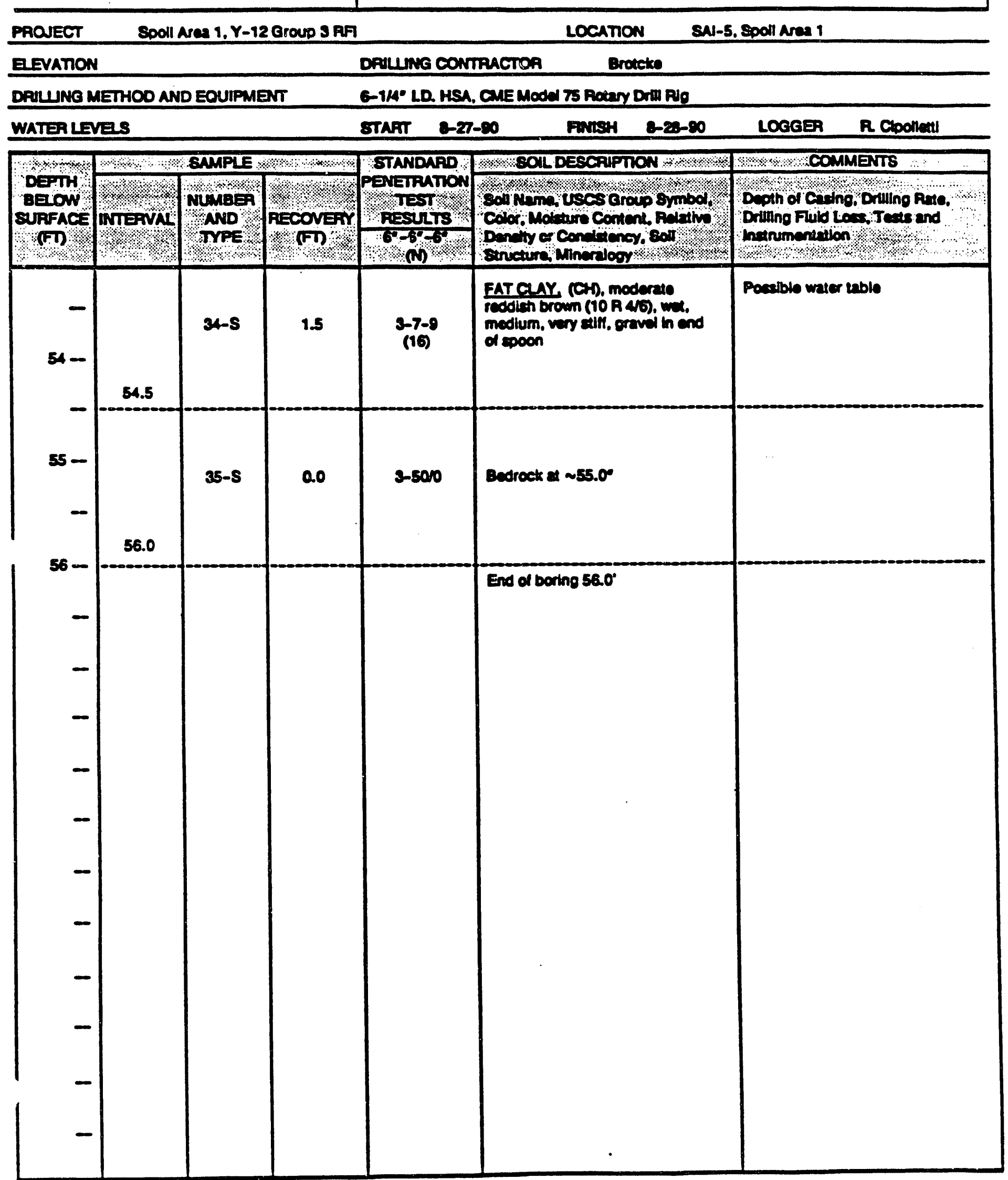




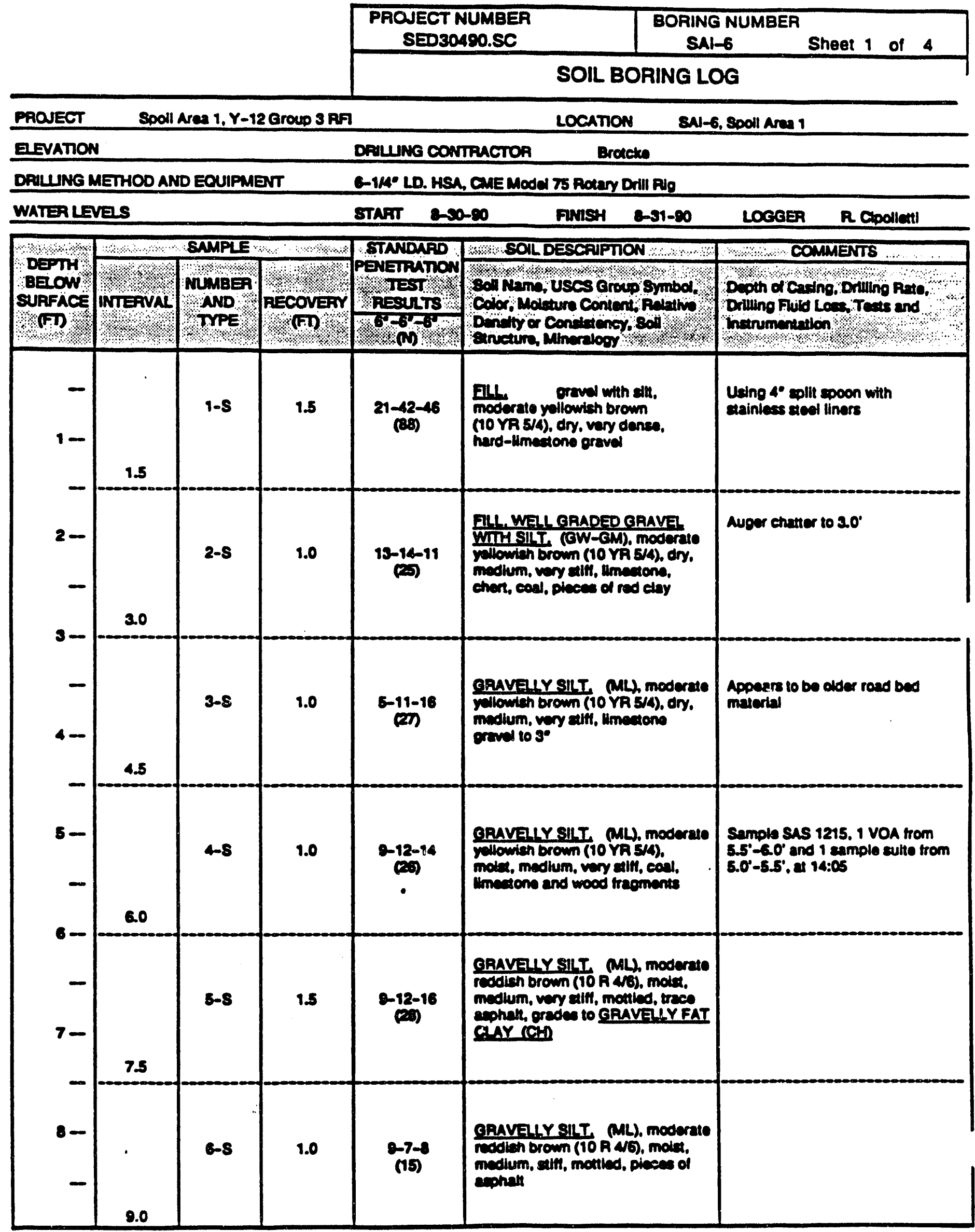




\section{C-32}

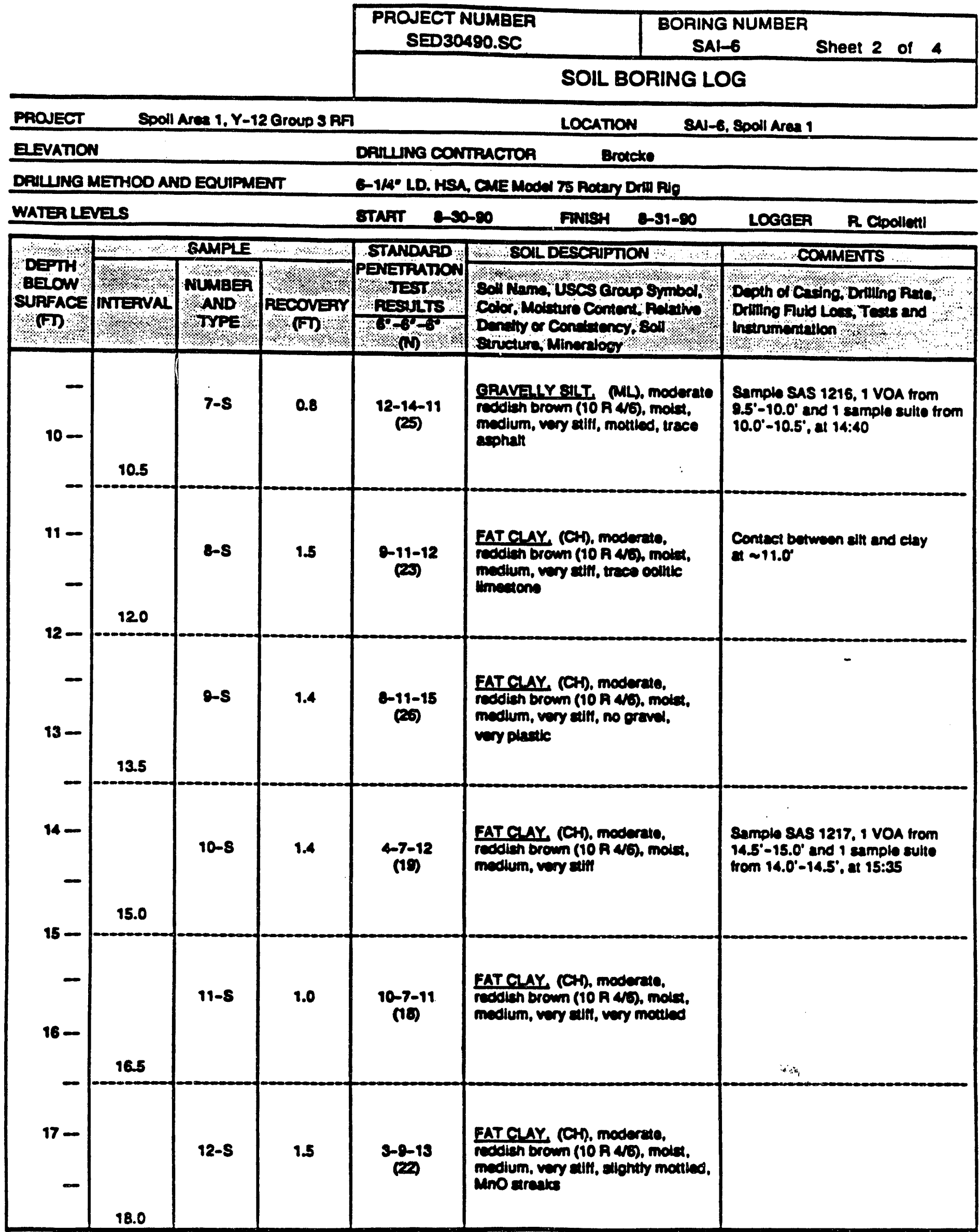




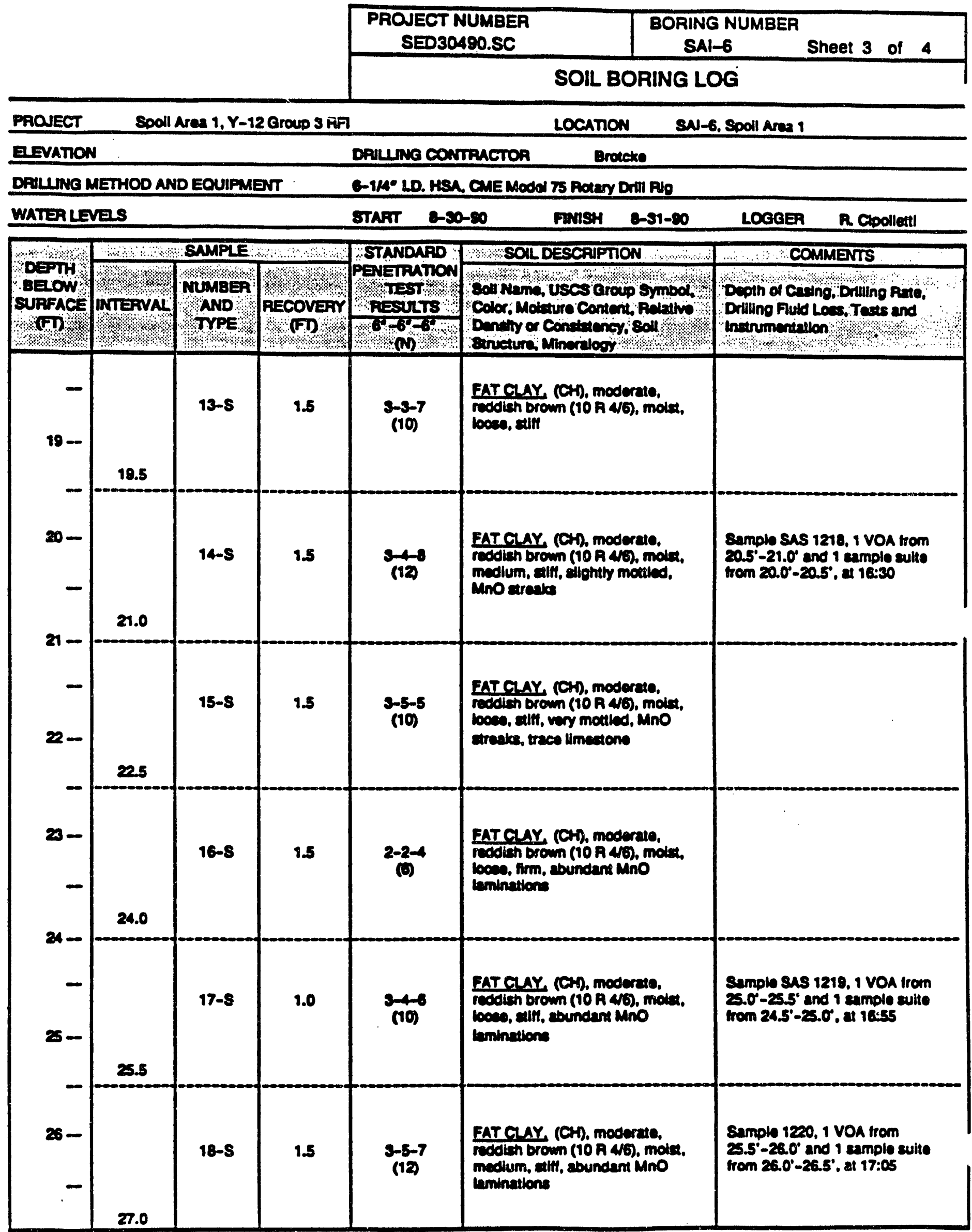




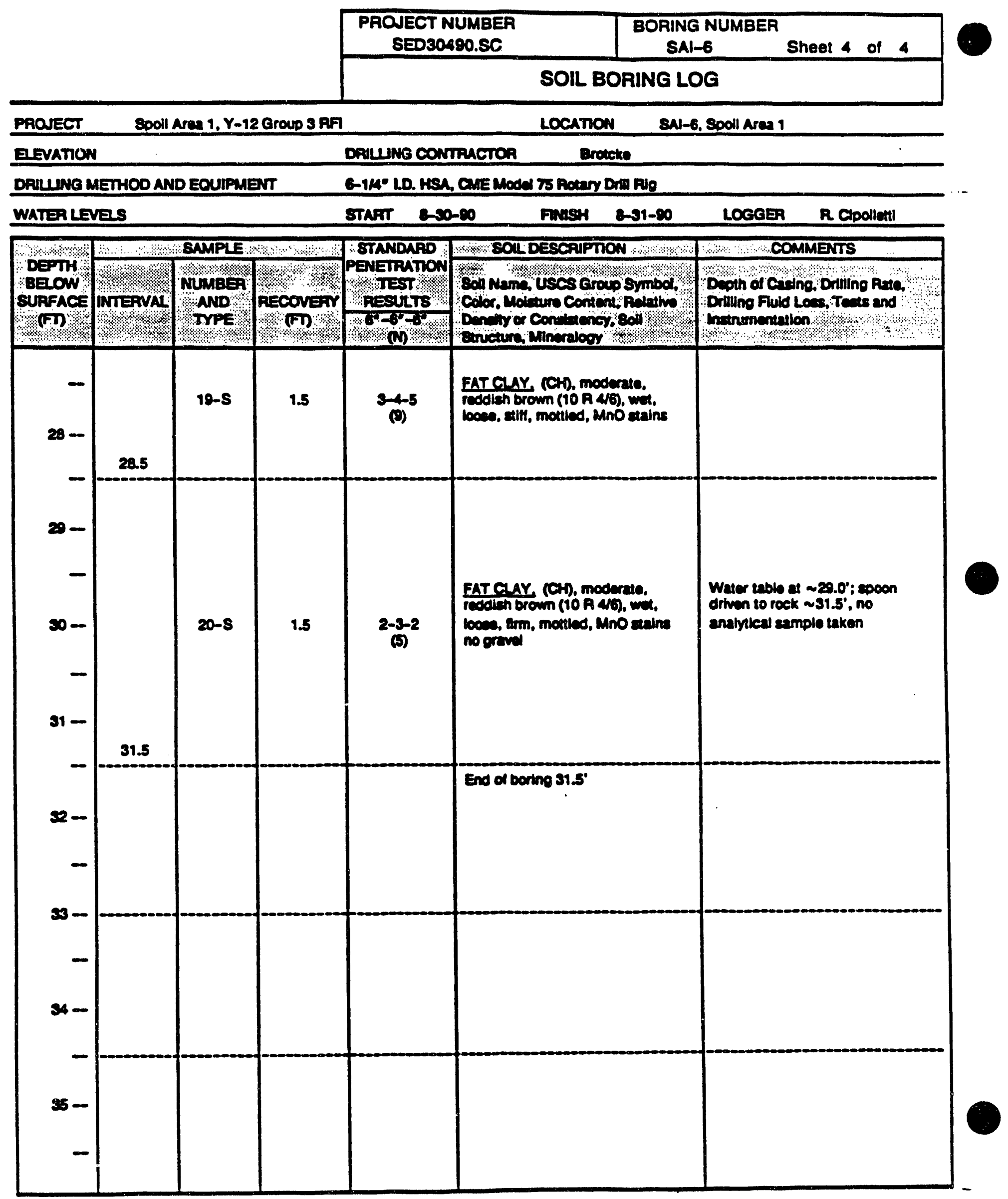




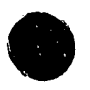

-

SPOIL AREA 1 ANALYTICAL DATA 


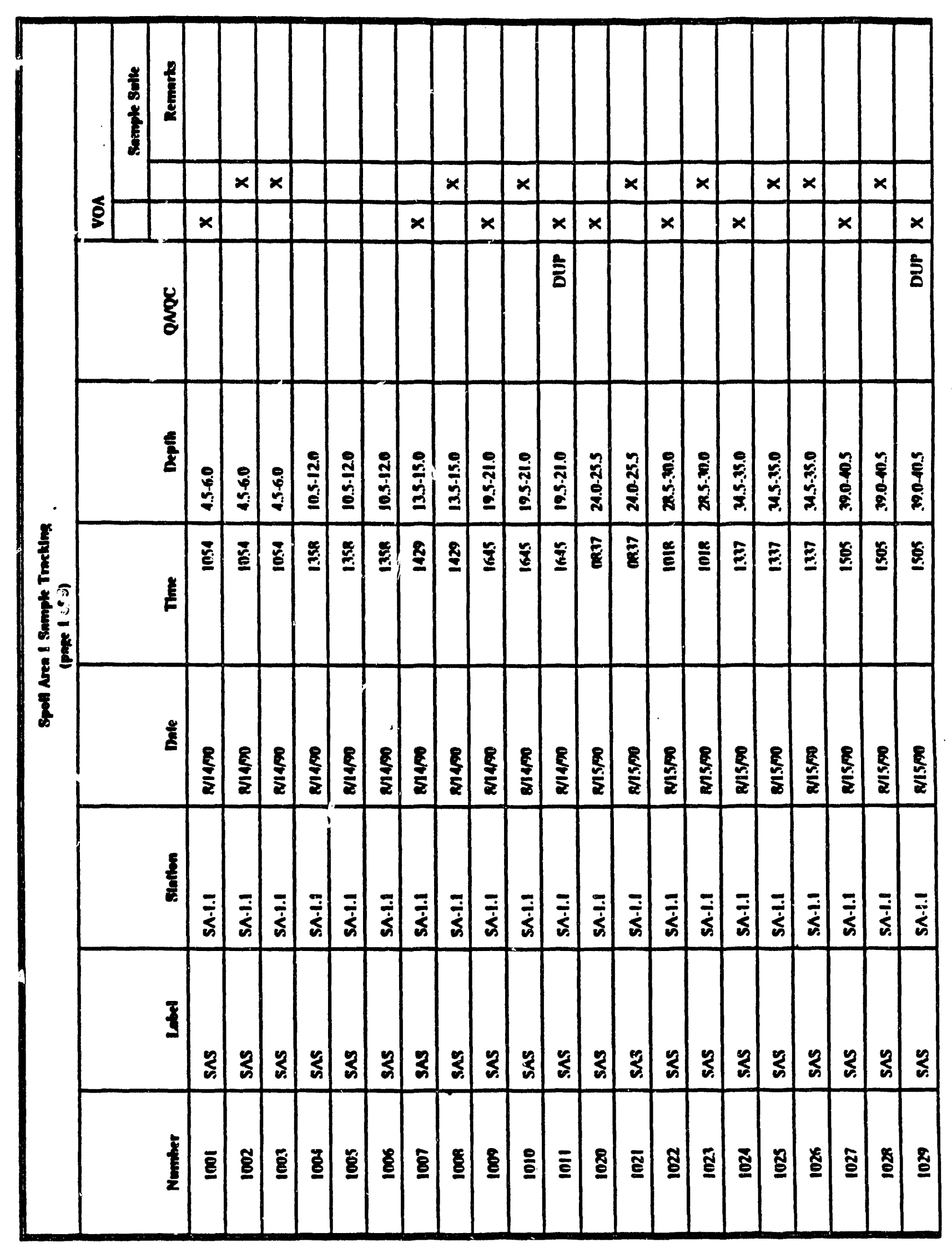




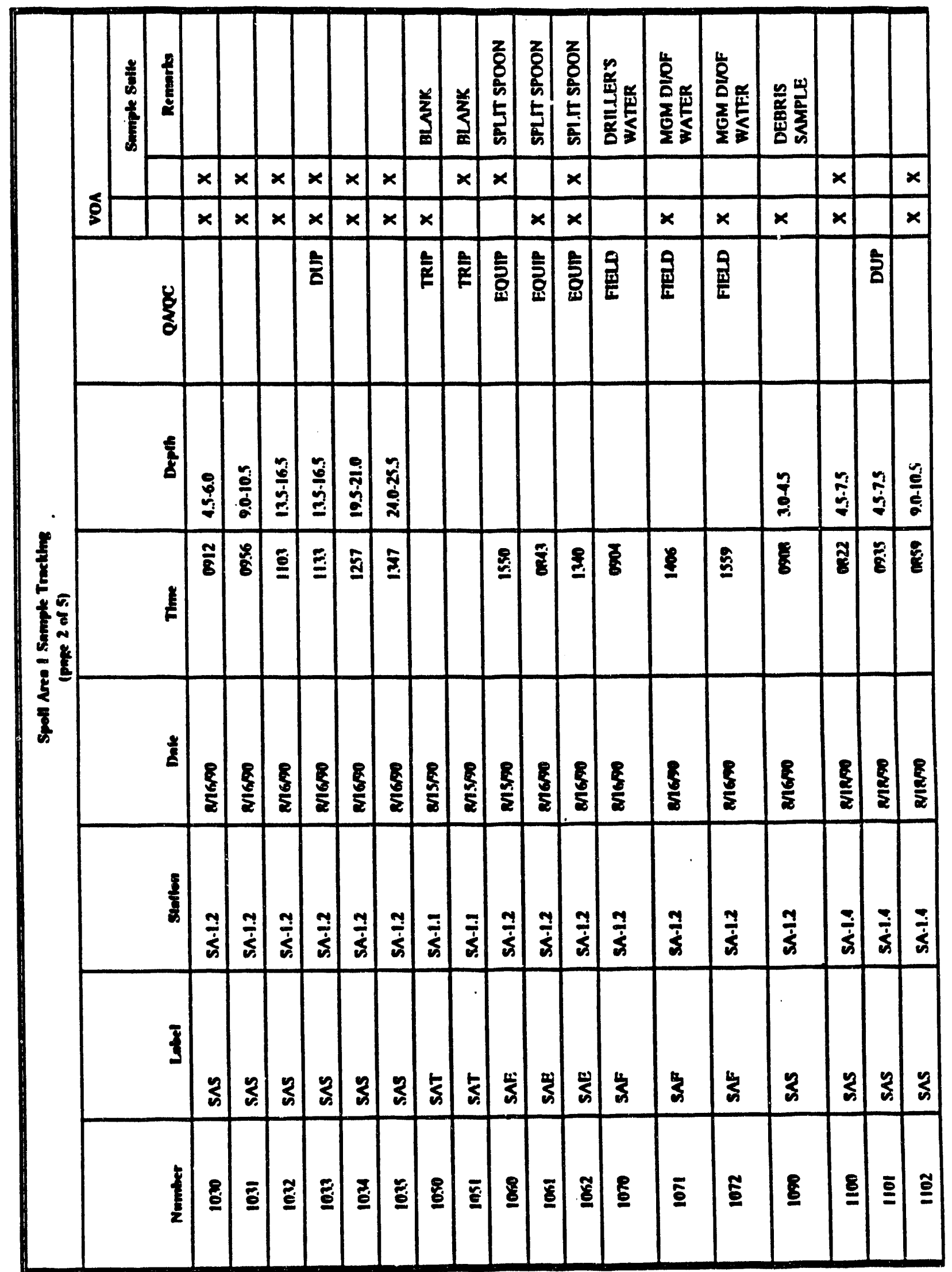




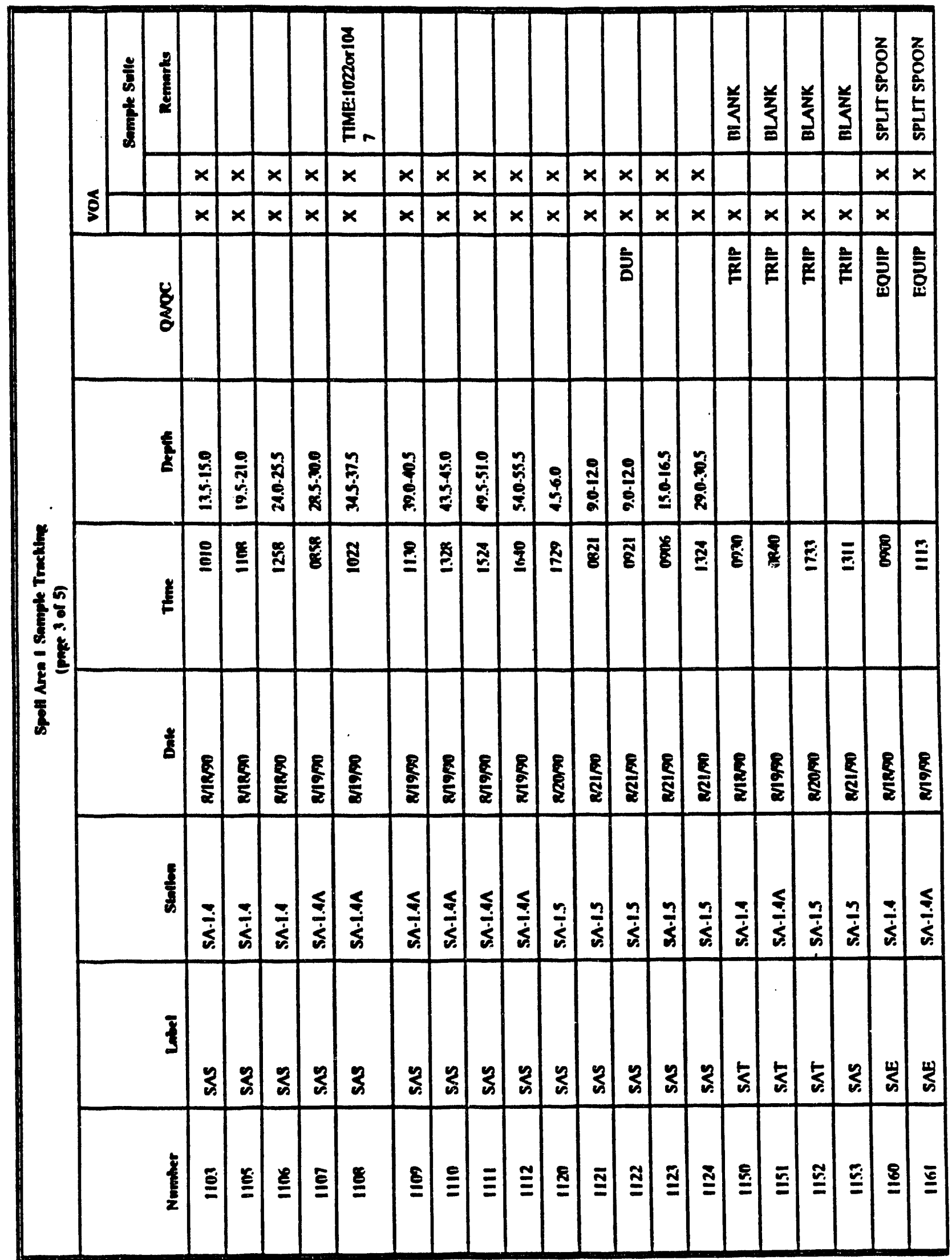




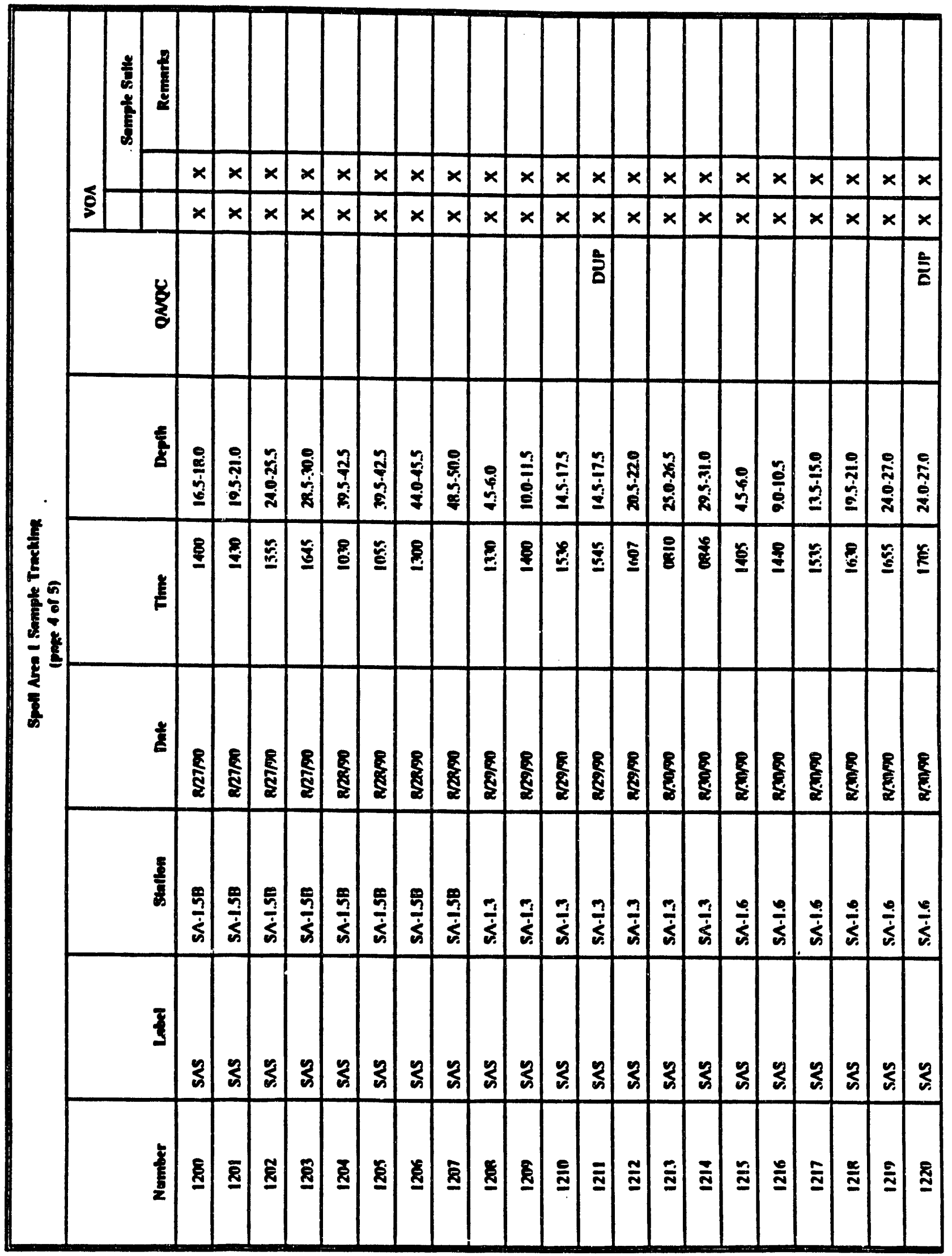




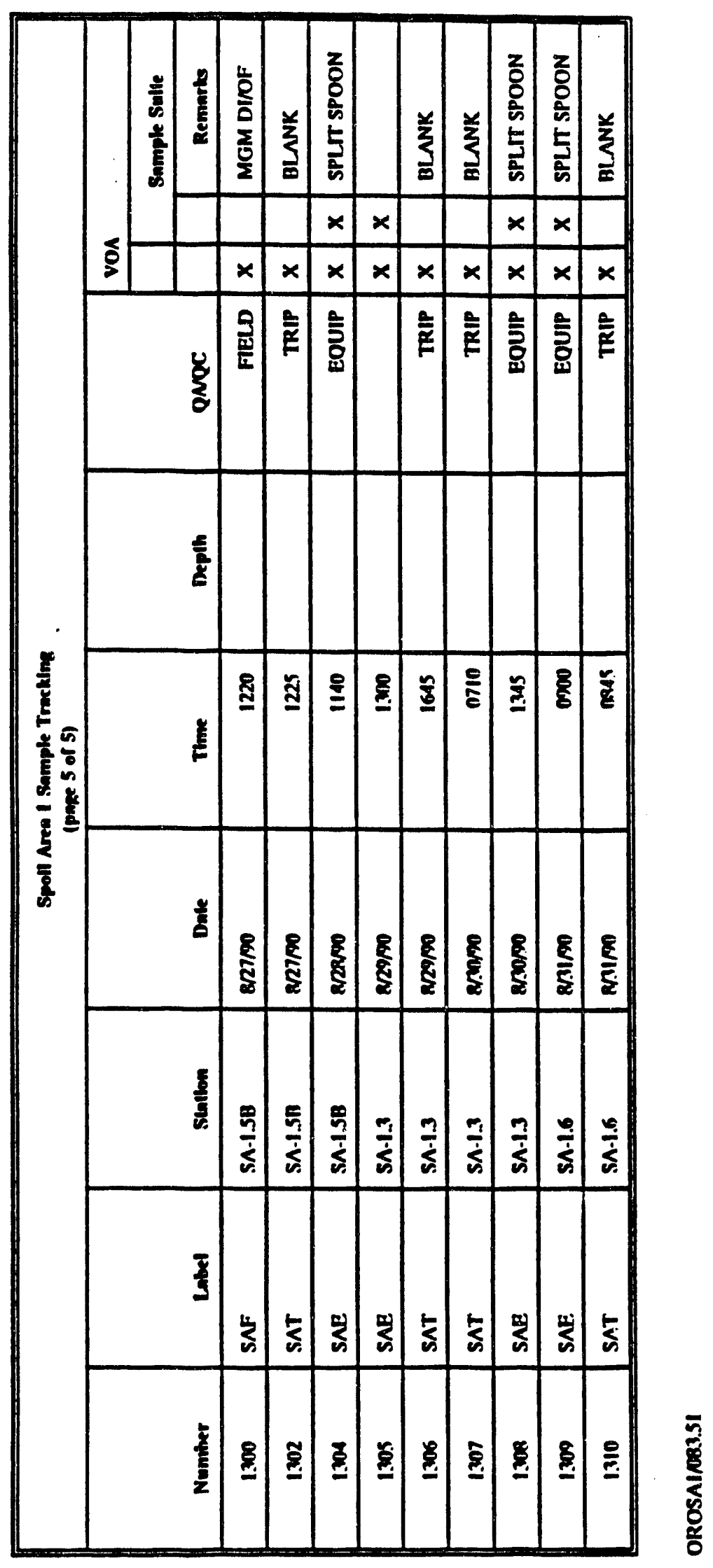


ANALYTICAL DATA

OROSA2.010.51 


\section{Key to Analysis Qualifier Fields}

\begin{tabular}{lrr|c|c|c} 
Analyte & Concentration units & Concentration & A & B & C \\
\hline Acetone & $\mathrm{mg} / \mathrm{kg}$ & 0.014 & $\mathrm{U}$ & $\mathrm{Y}$ & $\mathrm{UJ}$
\end{tabular}

Qualifier fields are fields A, B, and C following the numeric concentration value. Values that can appear in each field include:

- $\quad \mathbf{A}=$ Detection Field

$\mathrm{U}=$ less than detection limit

$\mathrm{D}=$ detected

$\mathbf{R}=$ rejected

- $\quad B=$ Validation Field

$\mathbf{Y}=$ yes, validated

$\mathbf{N}=$ No, not validated

- $\quad \mathrm{C}=$ Flag Field

$\mathrm{UJ}=$ not detected and detection limit is estimated

$\mathrm{JN}=$ tentatively identified and estimated

$\mathrm{J}=$ estimated 


\section{C. -45}

\section{-}

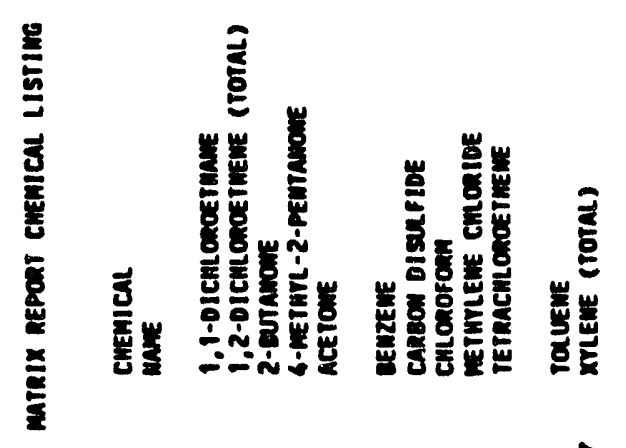

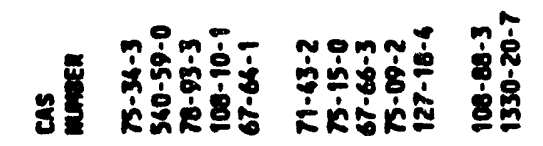

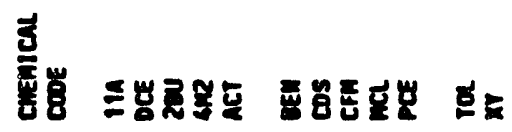

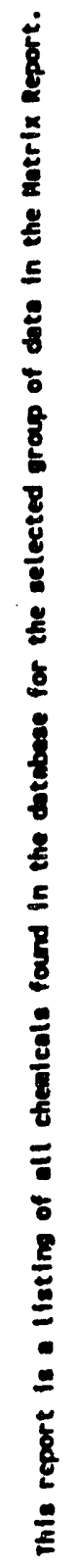


额-

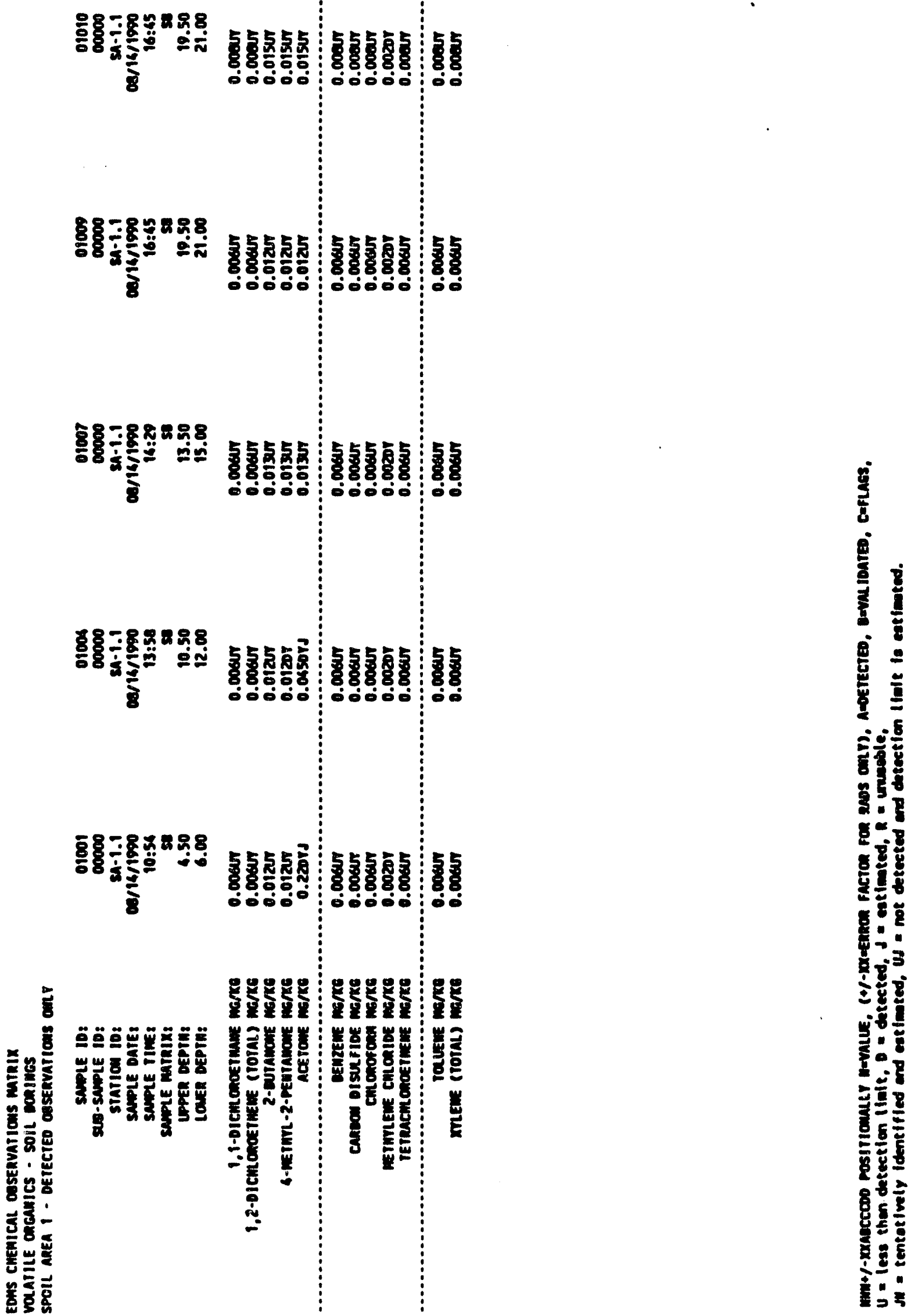




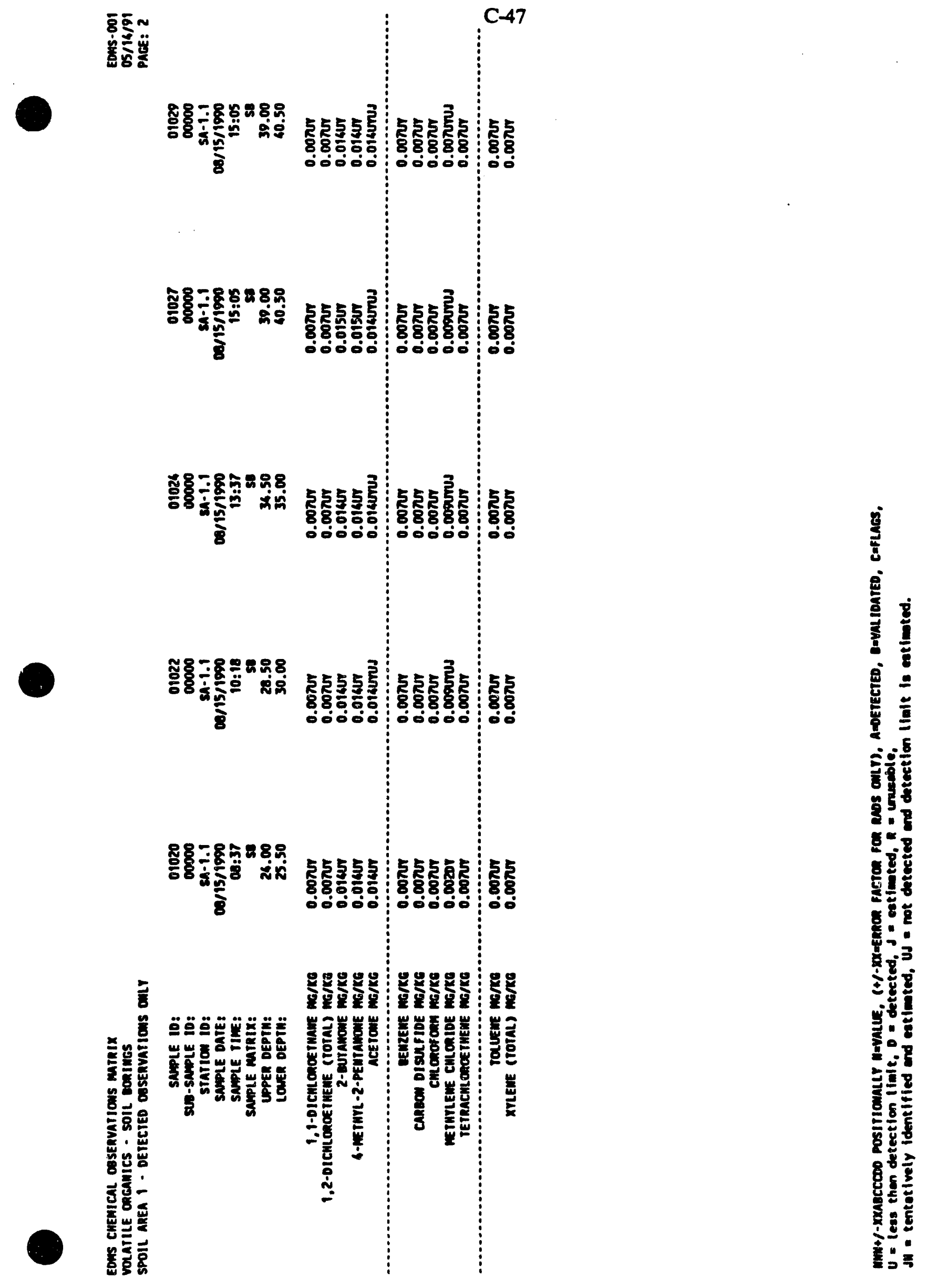




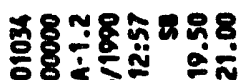

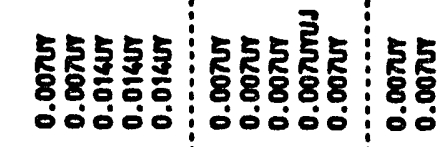

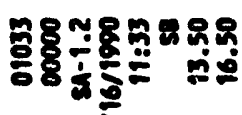
5555
8
8

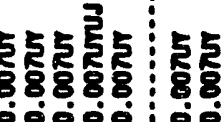

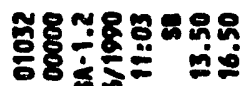

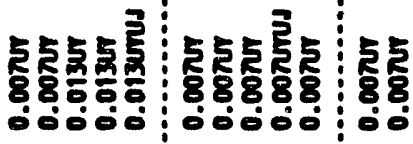

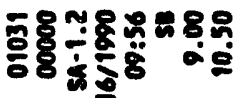

555550
85050
00000

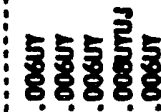

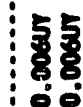

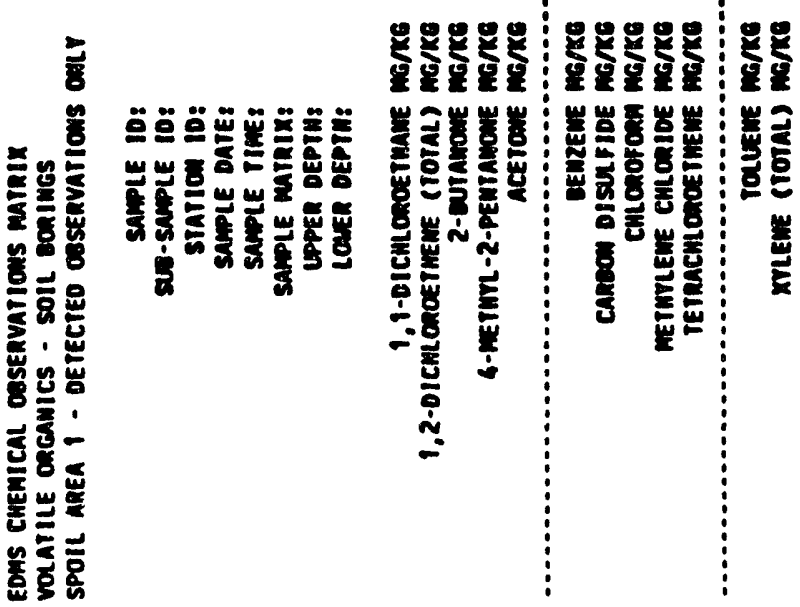


$\overline{8} \overline{0}$

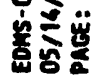
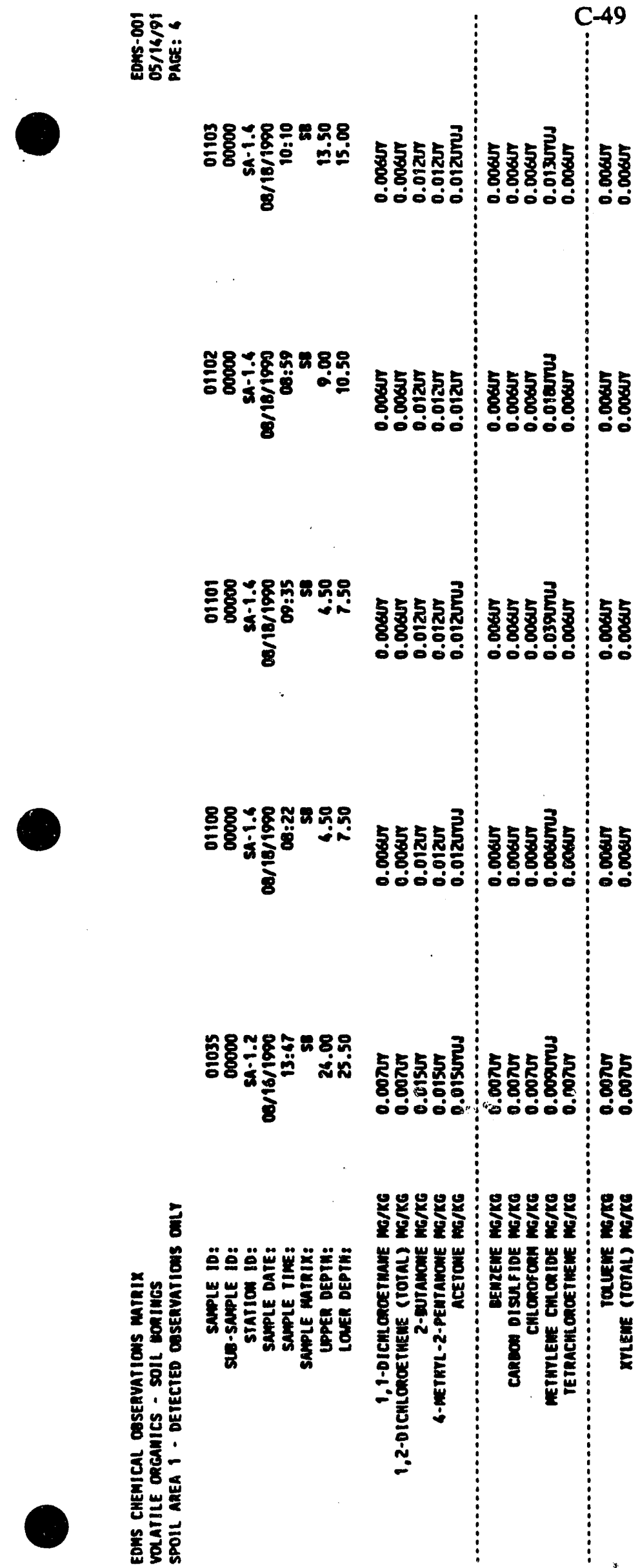

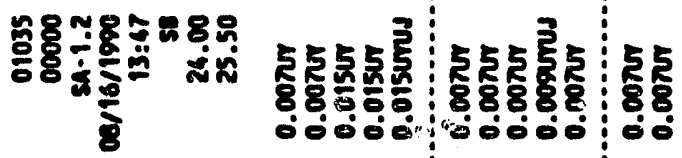




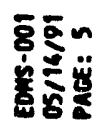

C-50

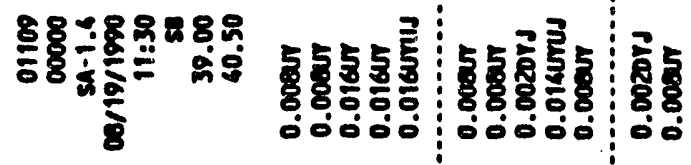

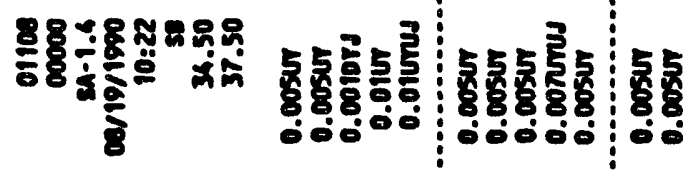

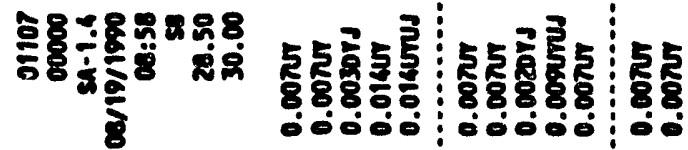

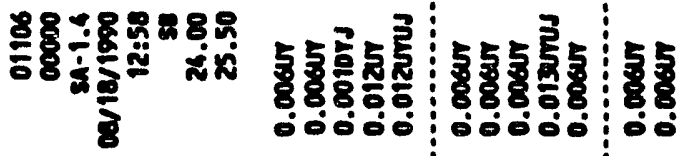

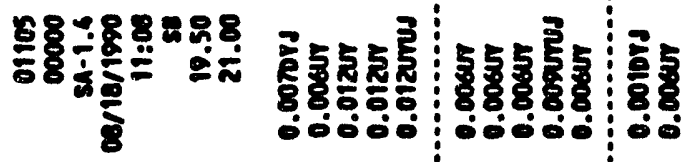

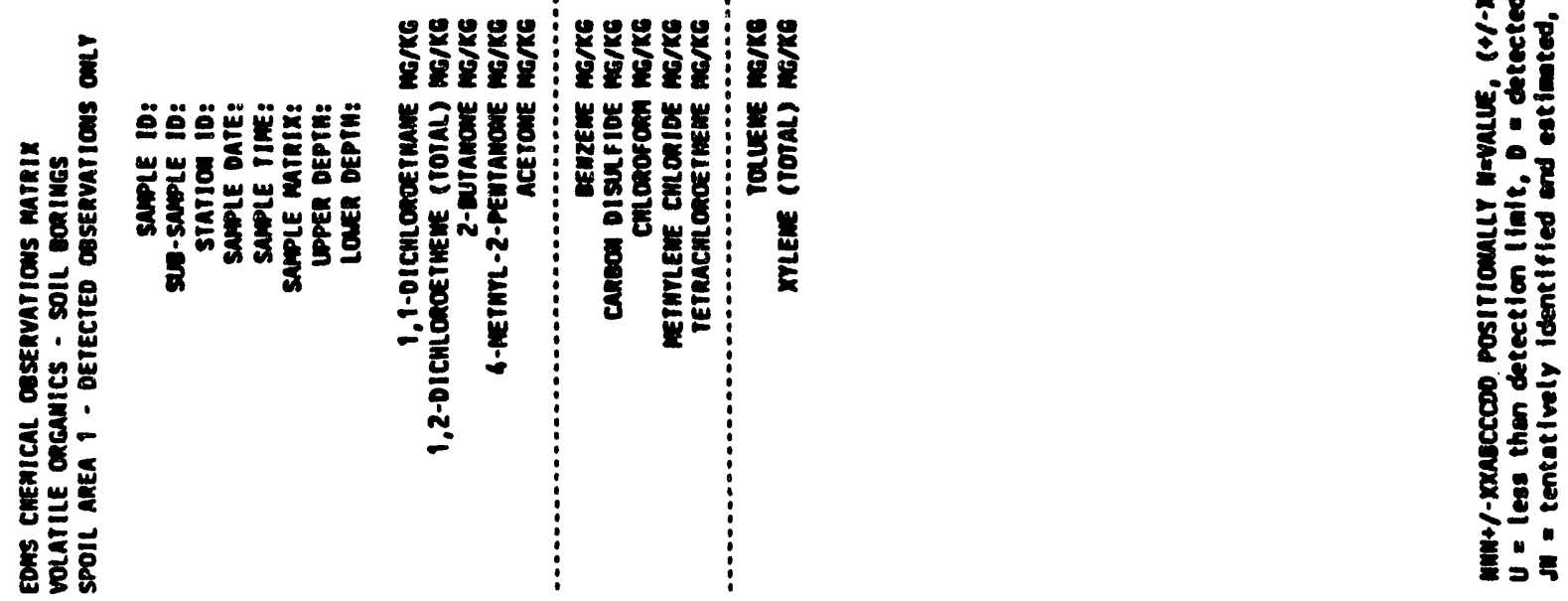




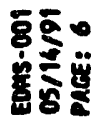
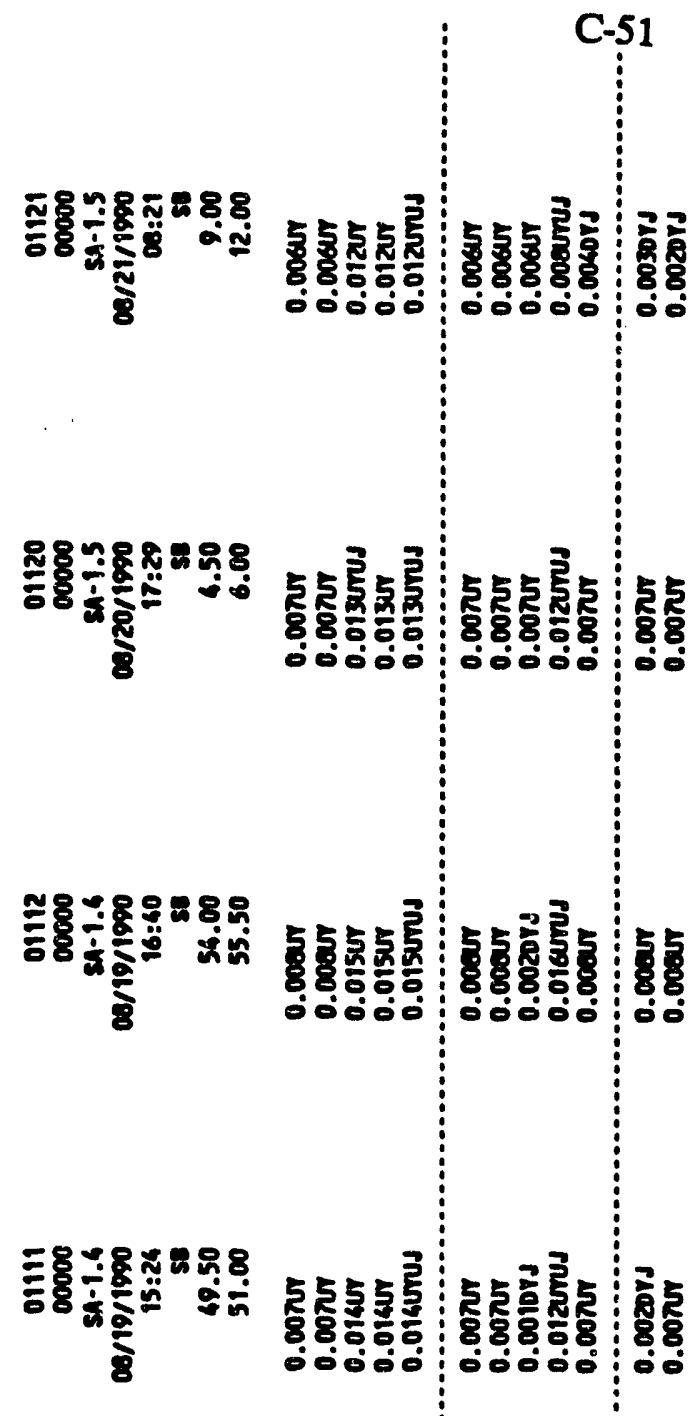

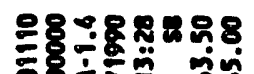
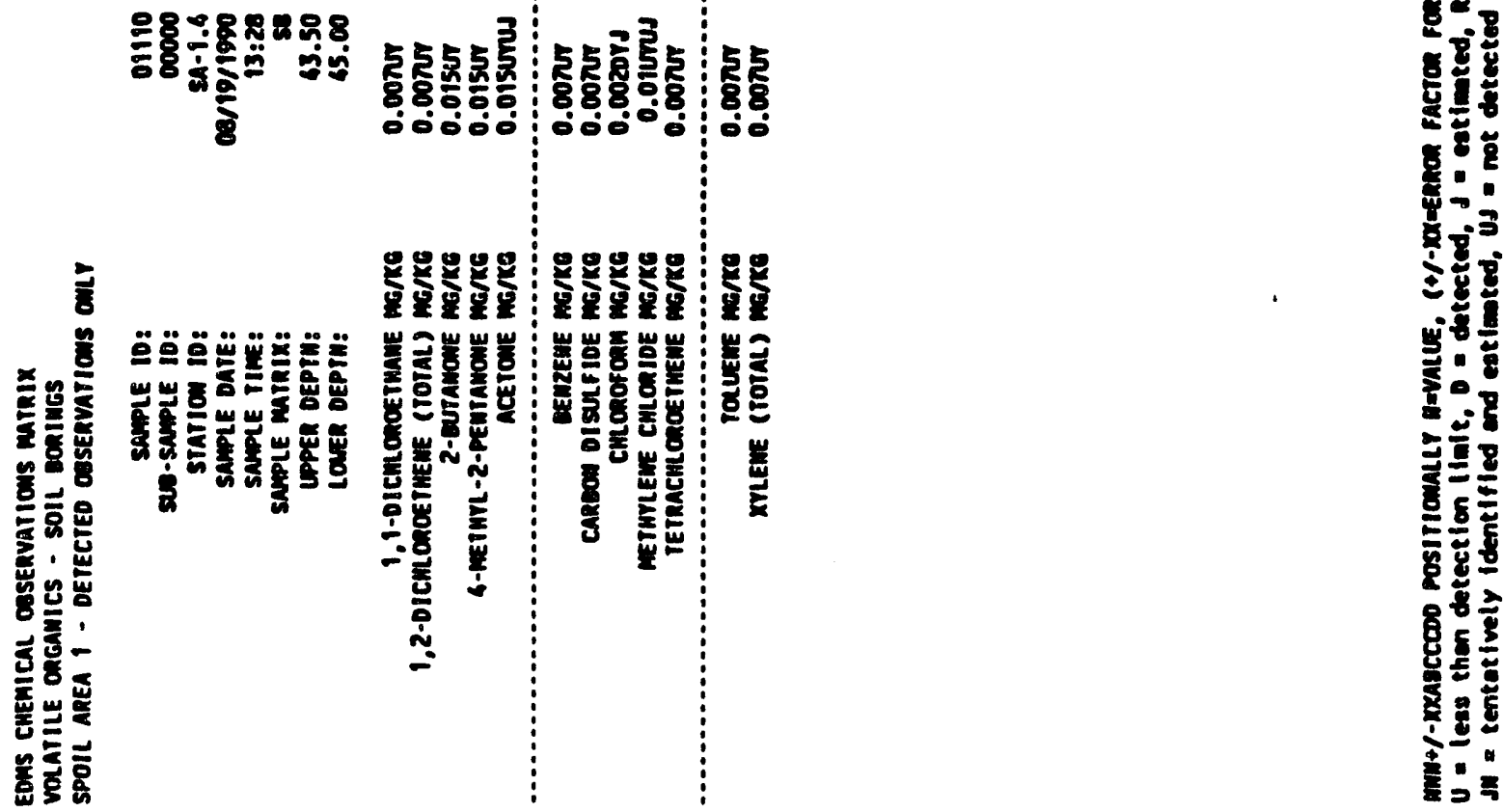


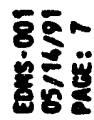

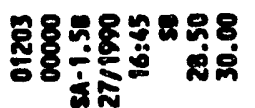

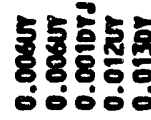

505

5
50
8
0
0

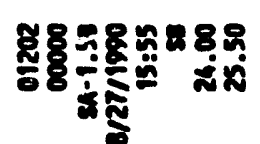

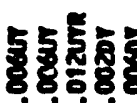

men

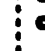

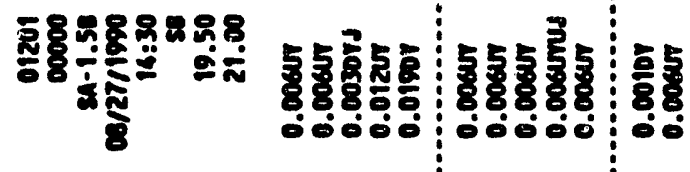

88

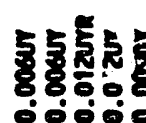
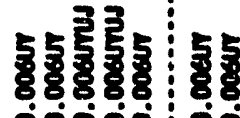

ó

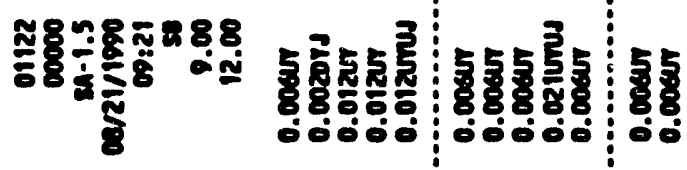

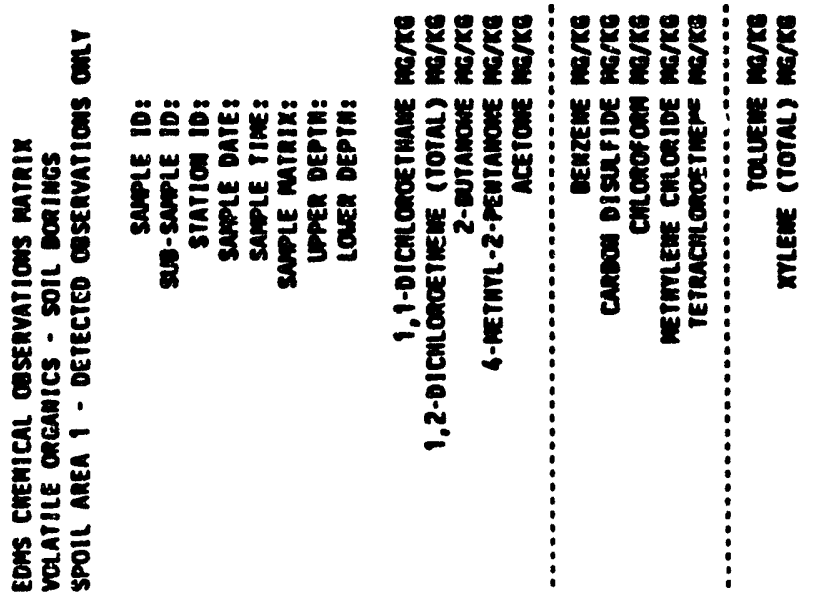




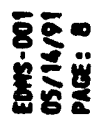
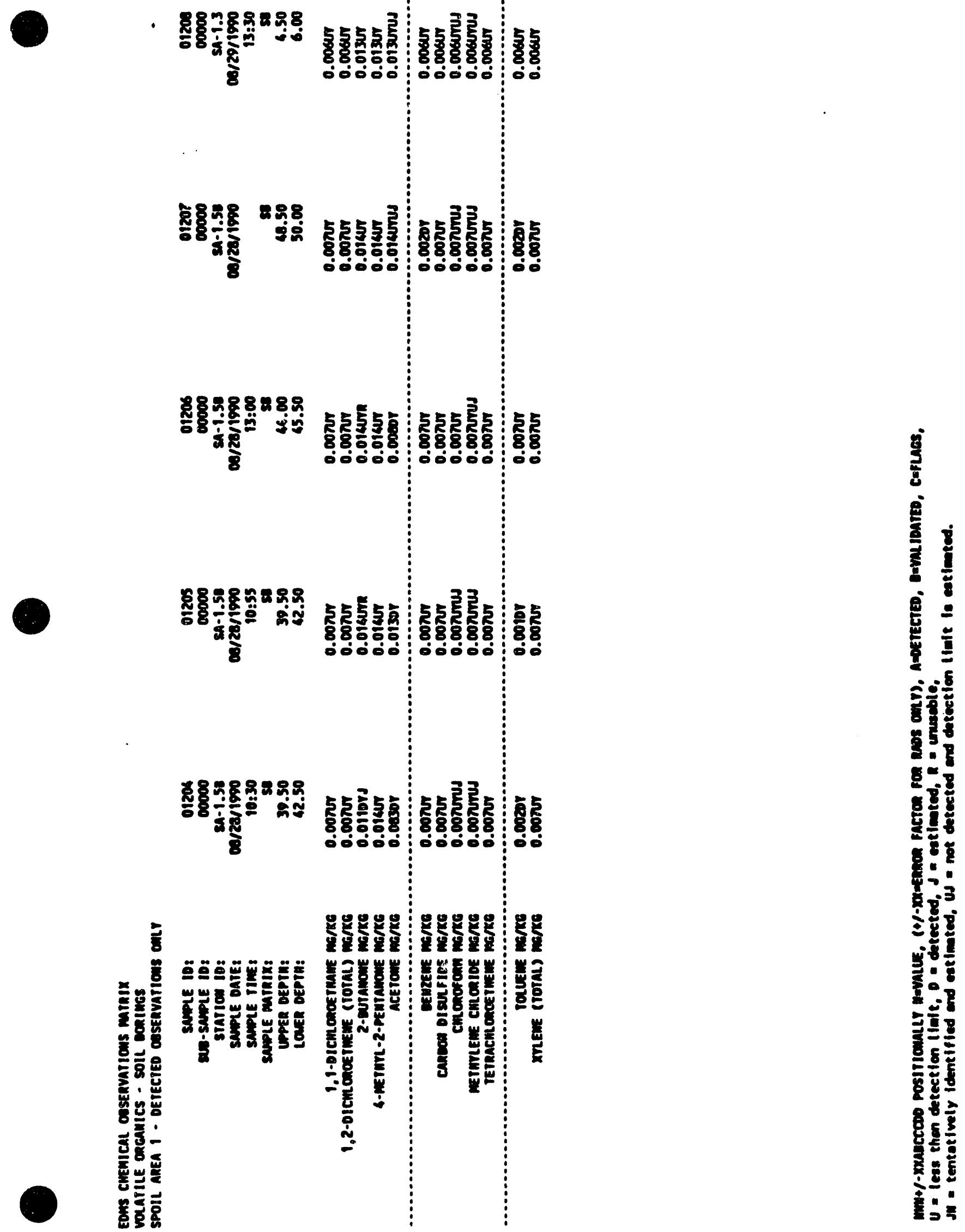


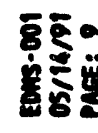

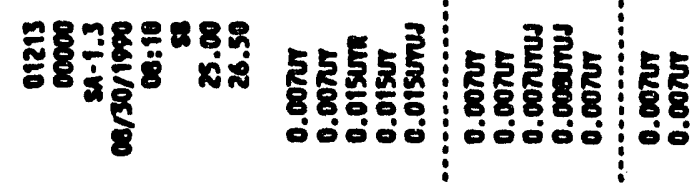

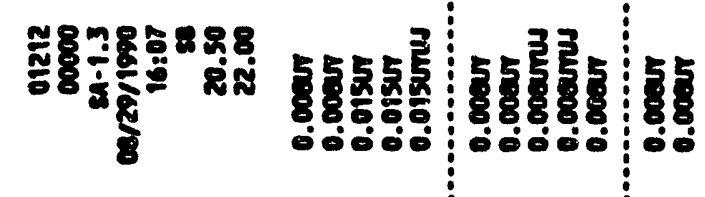

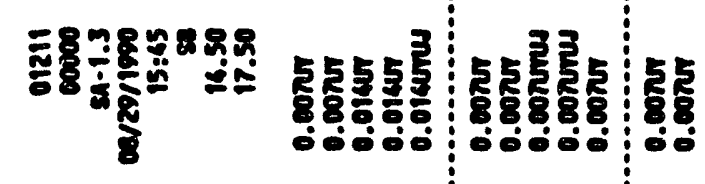

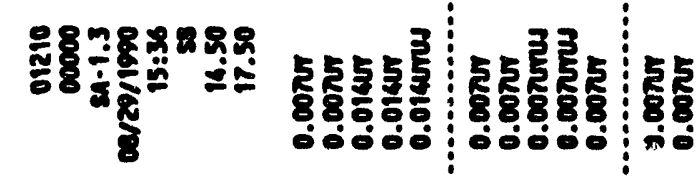
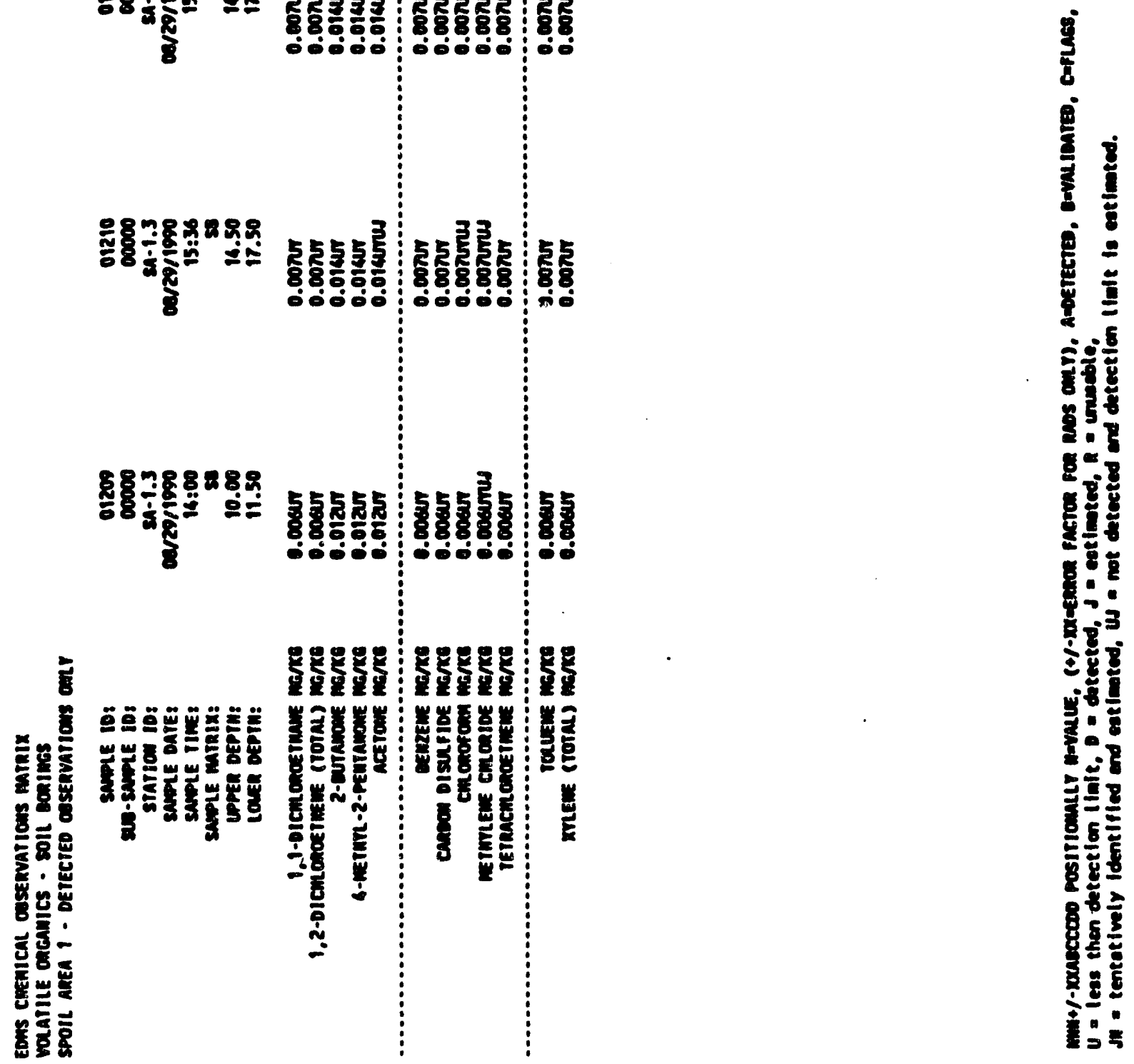


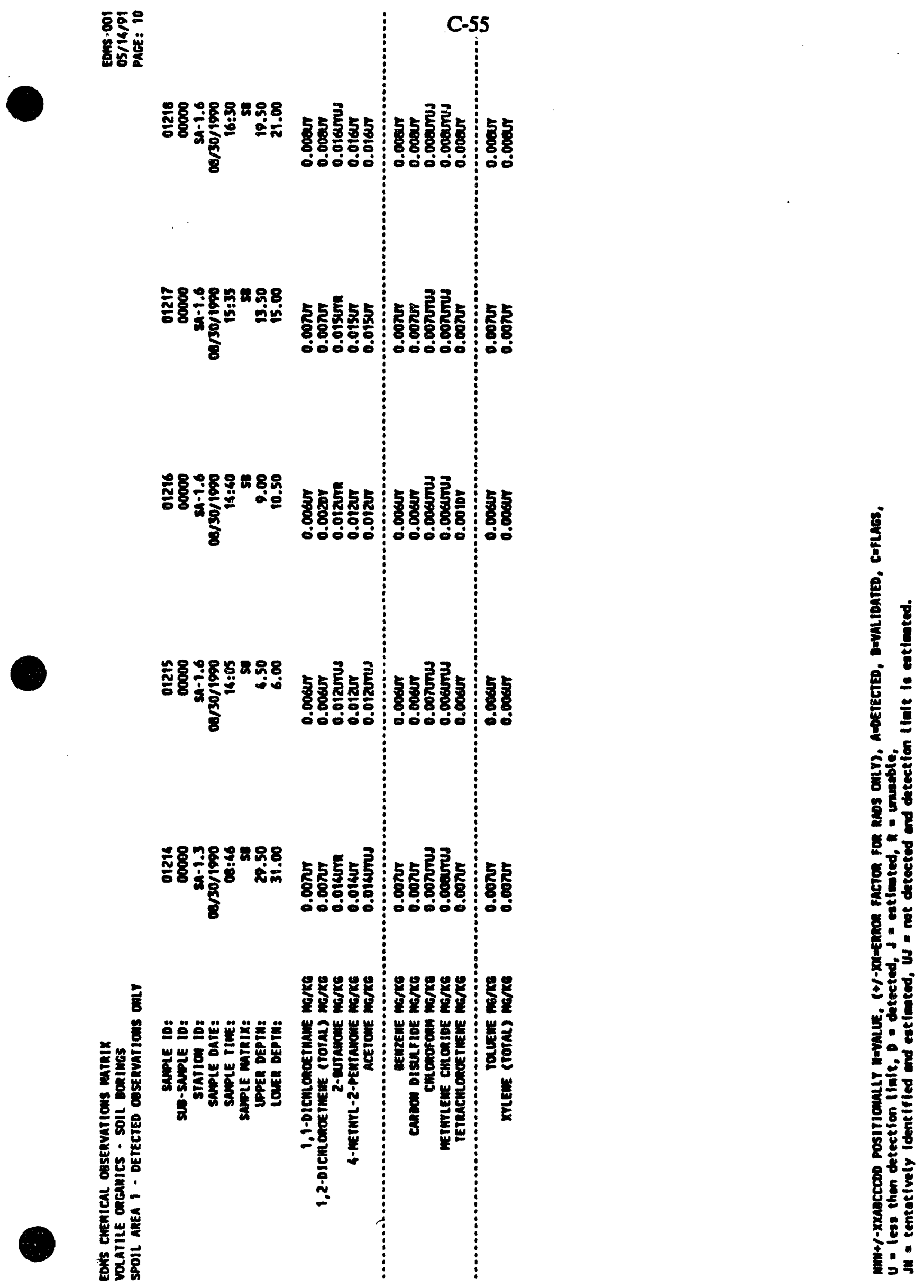




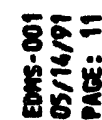
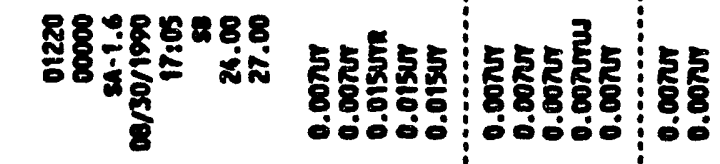

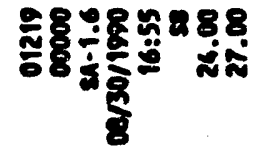

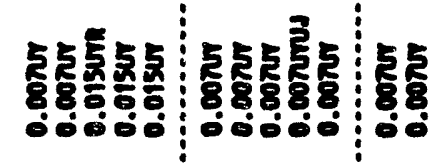

ํㅛㅁ

홀

홍

总

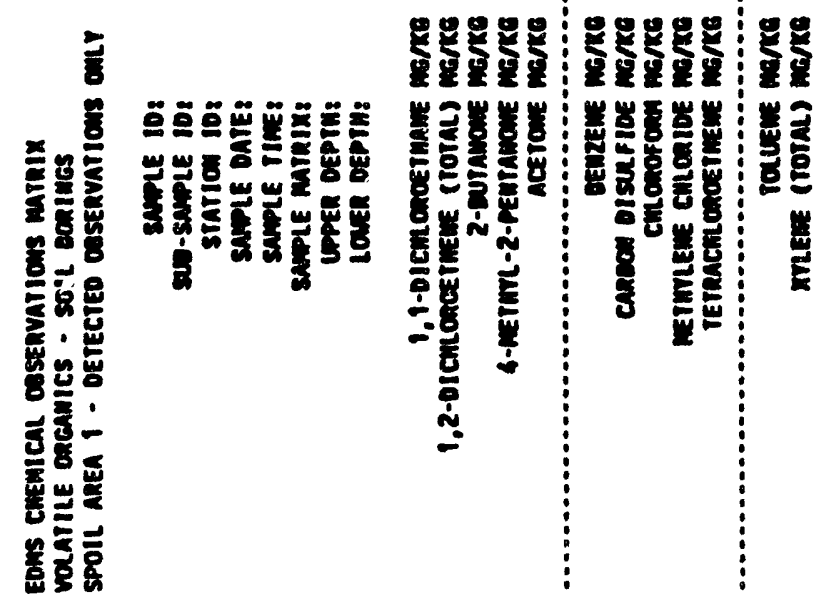


C-57

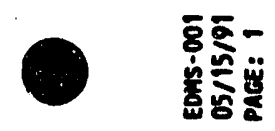

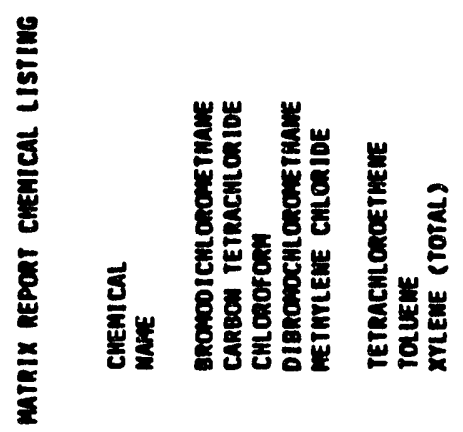

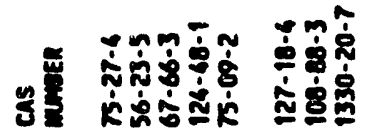

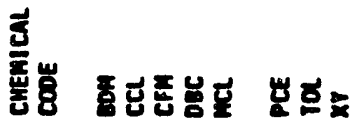

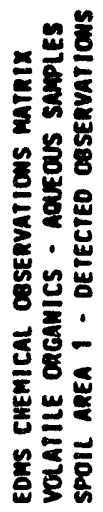

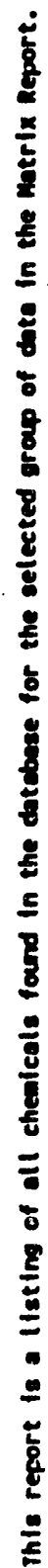




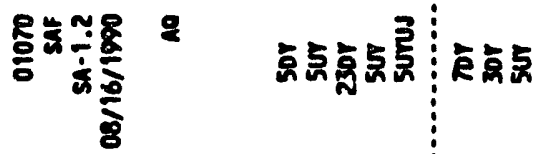

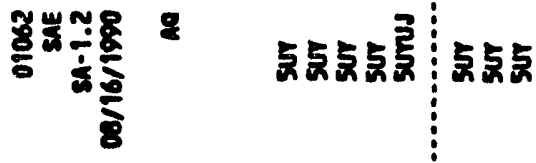

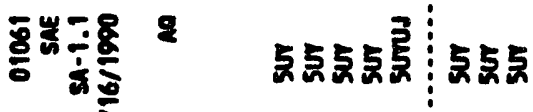

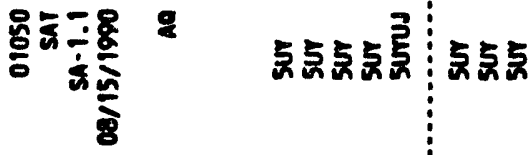

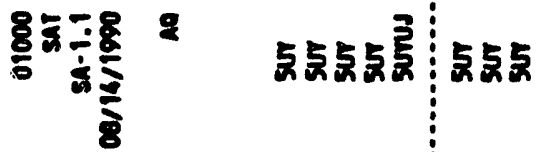

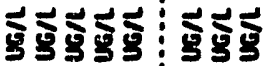
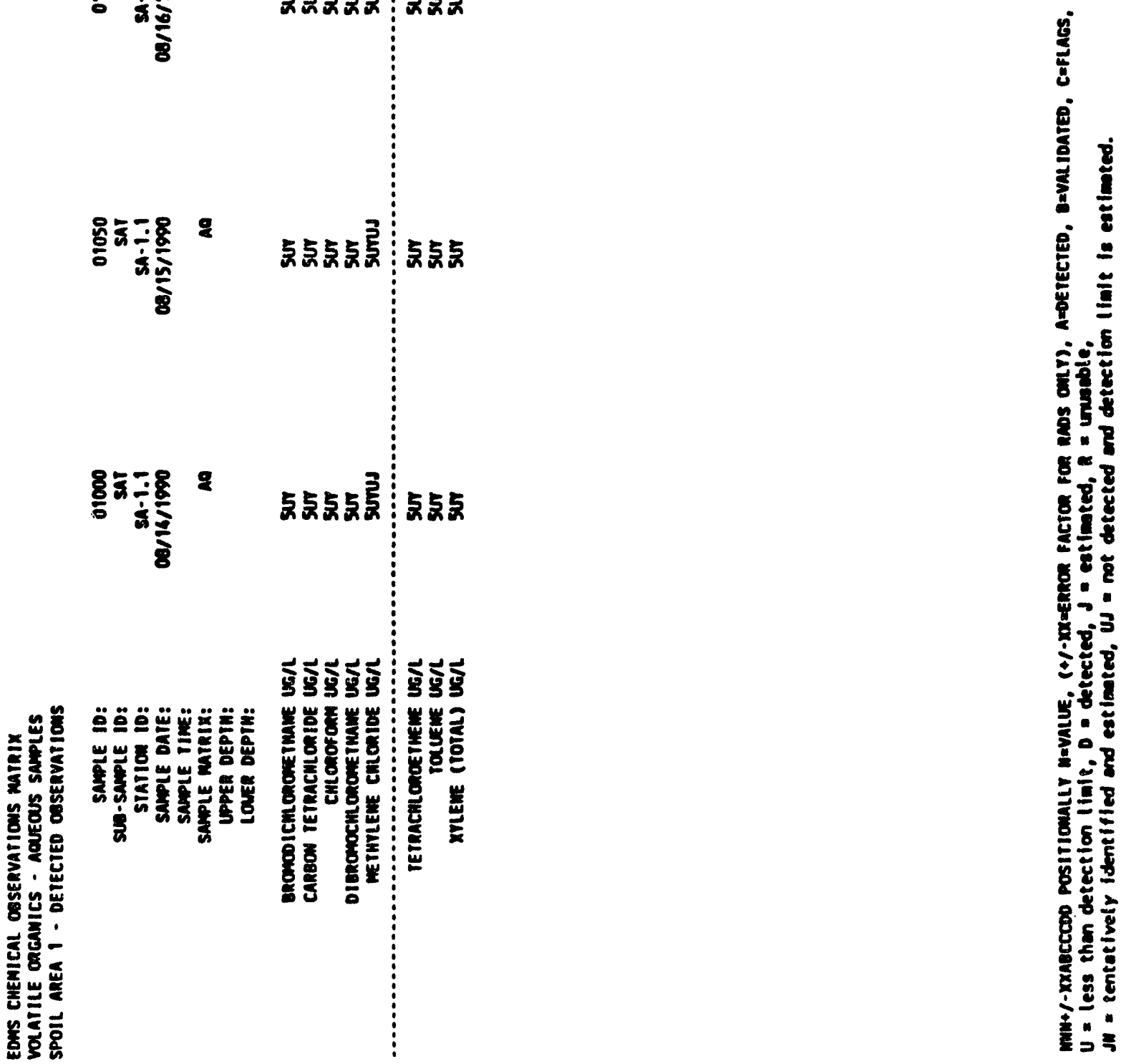


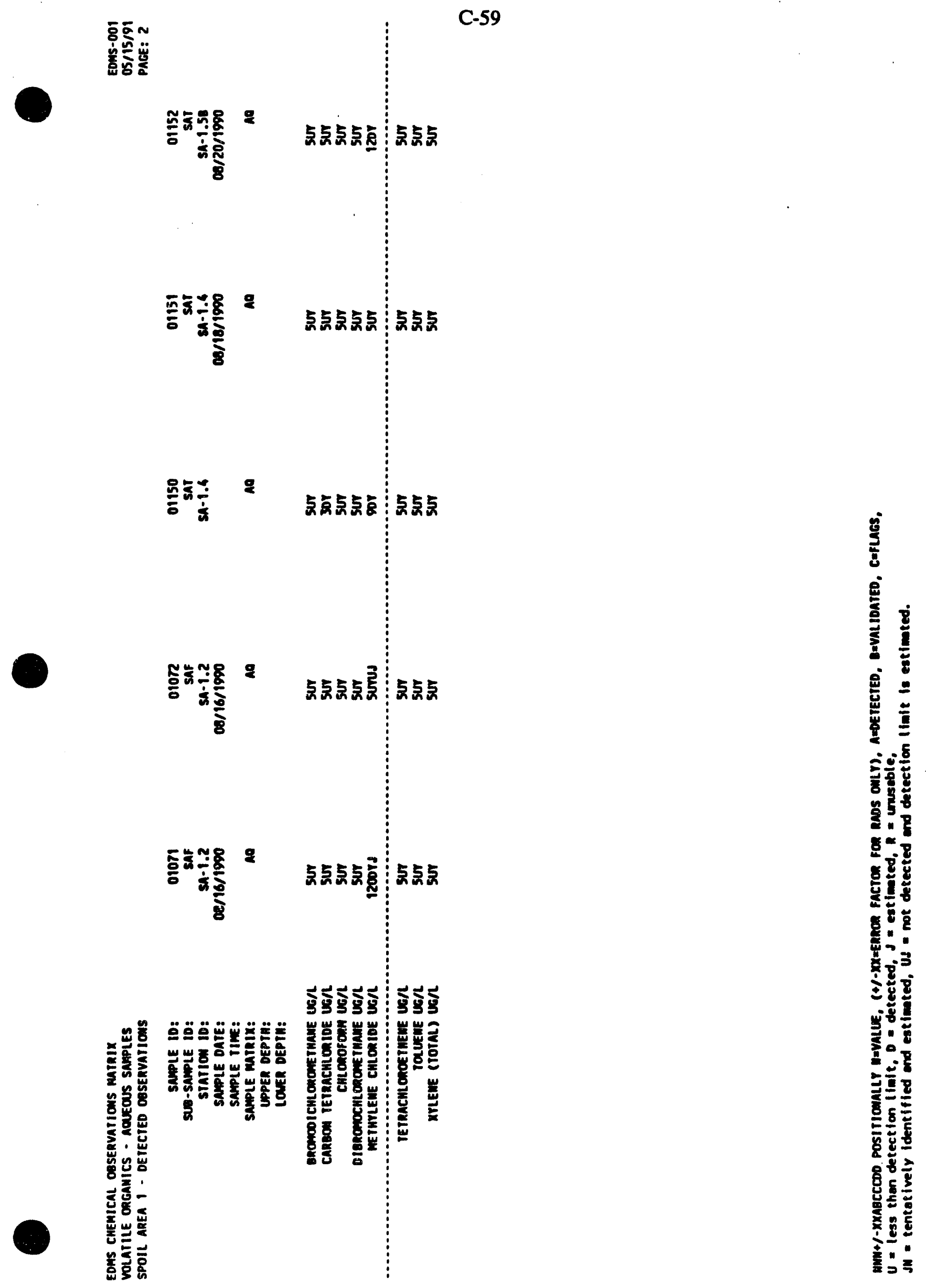




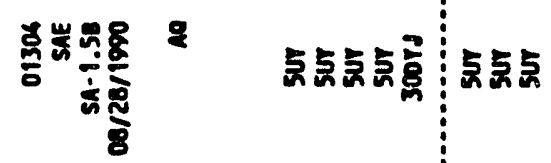

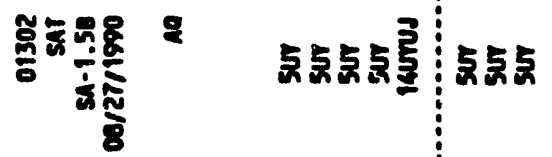

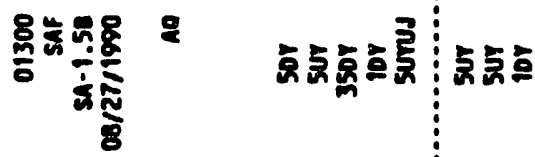

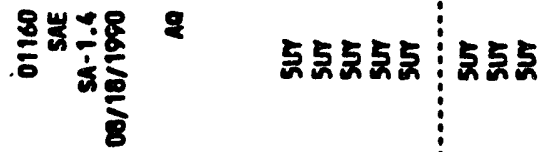

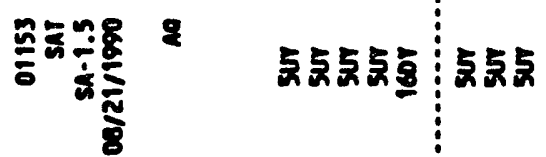
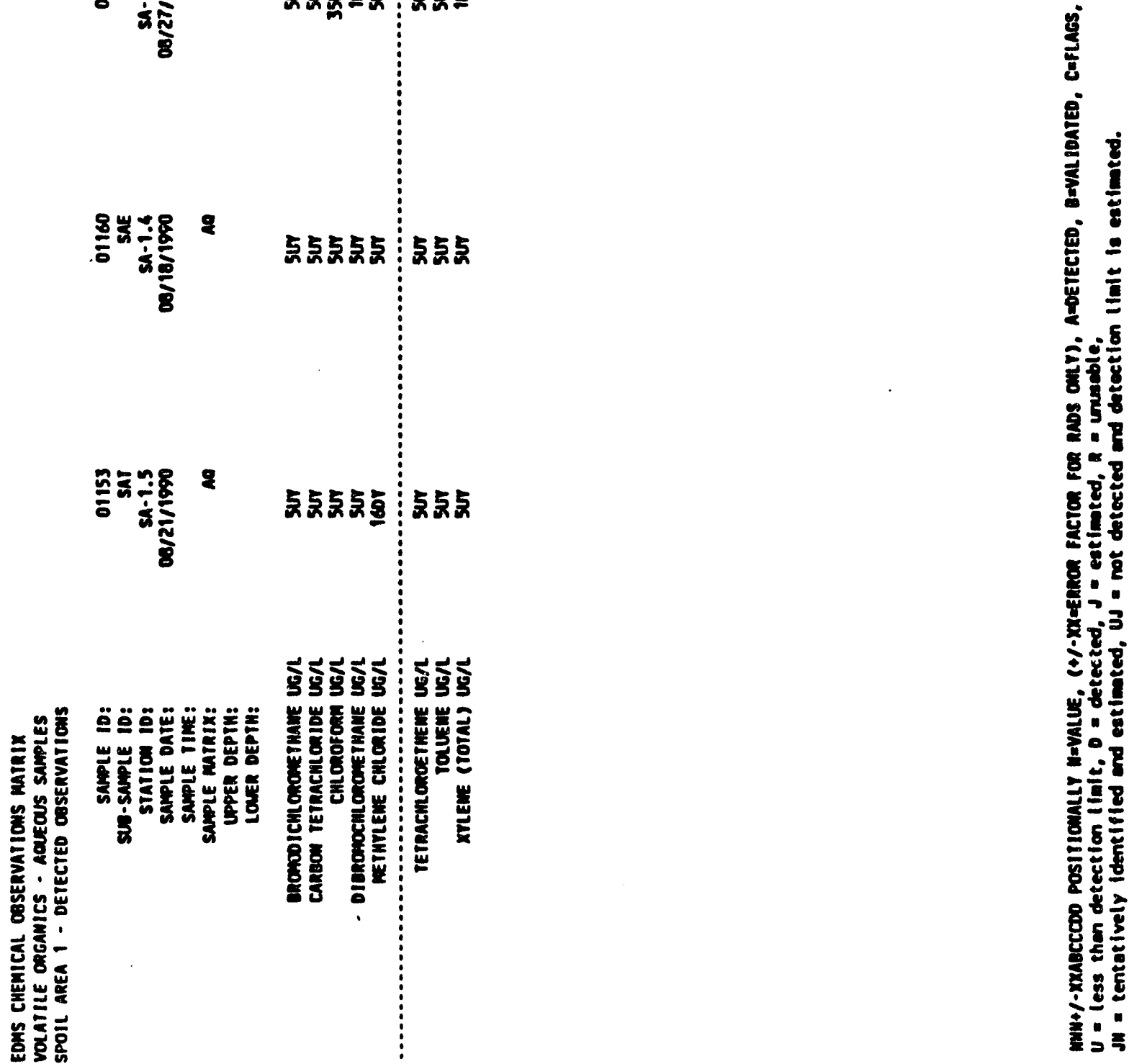


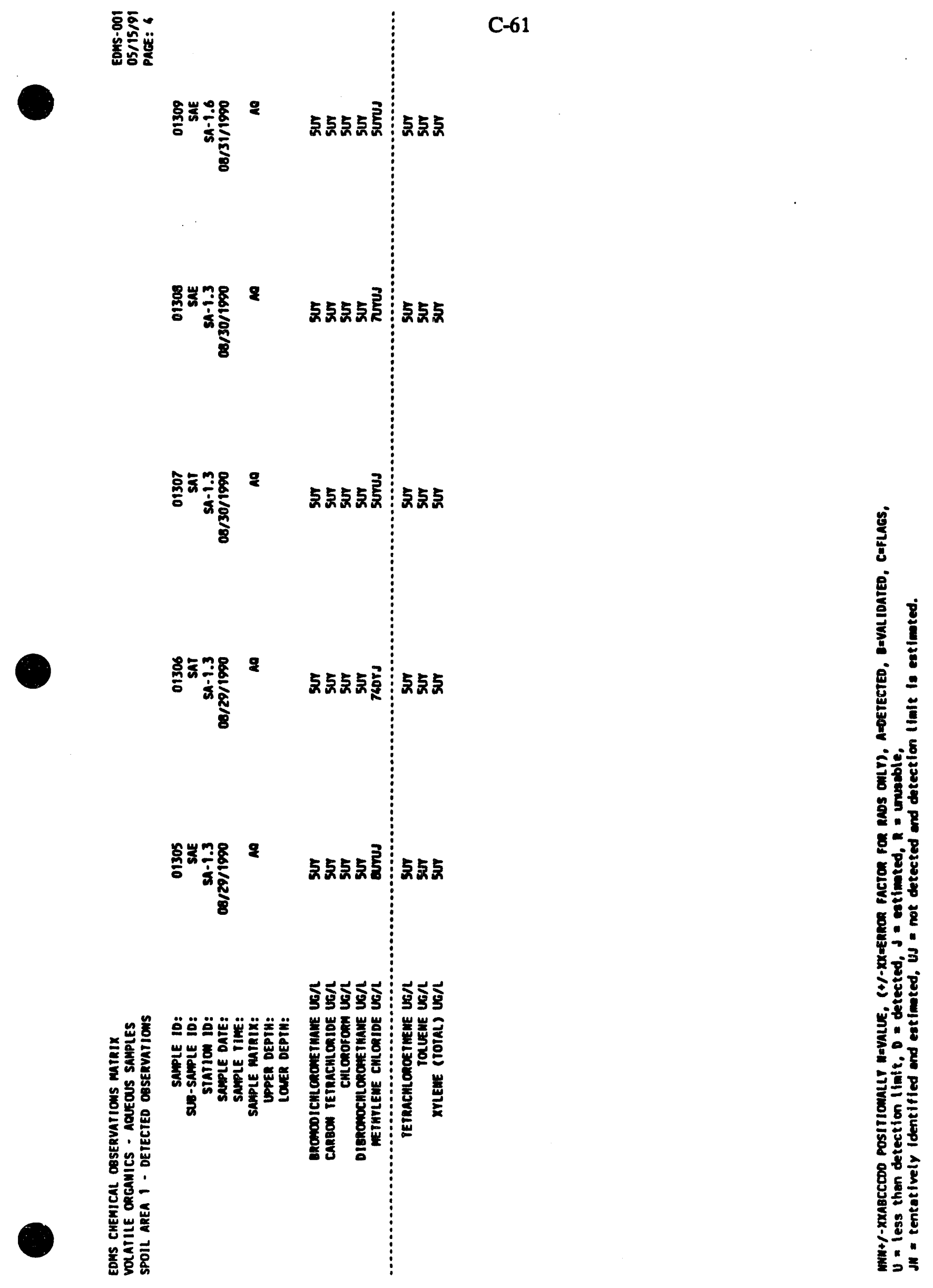




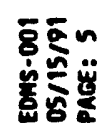

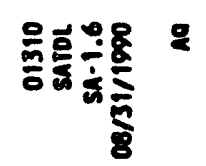

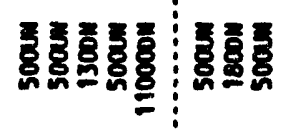

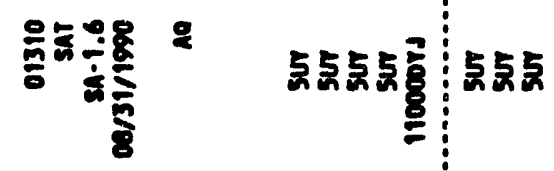

$\frac{8}{8}$

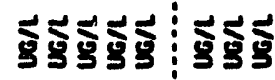
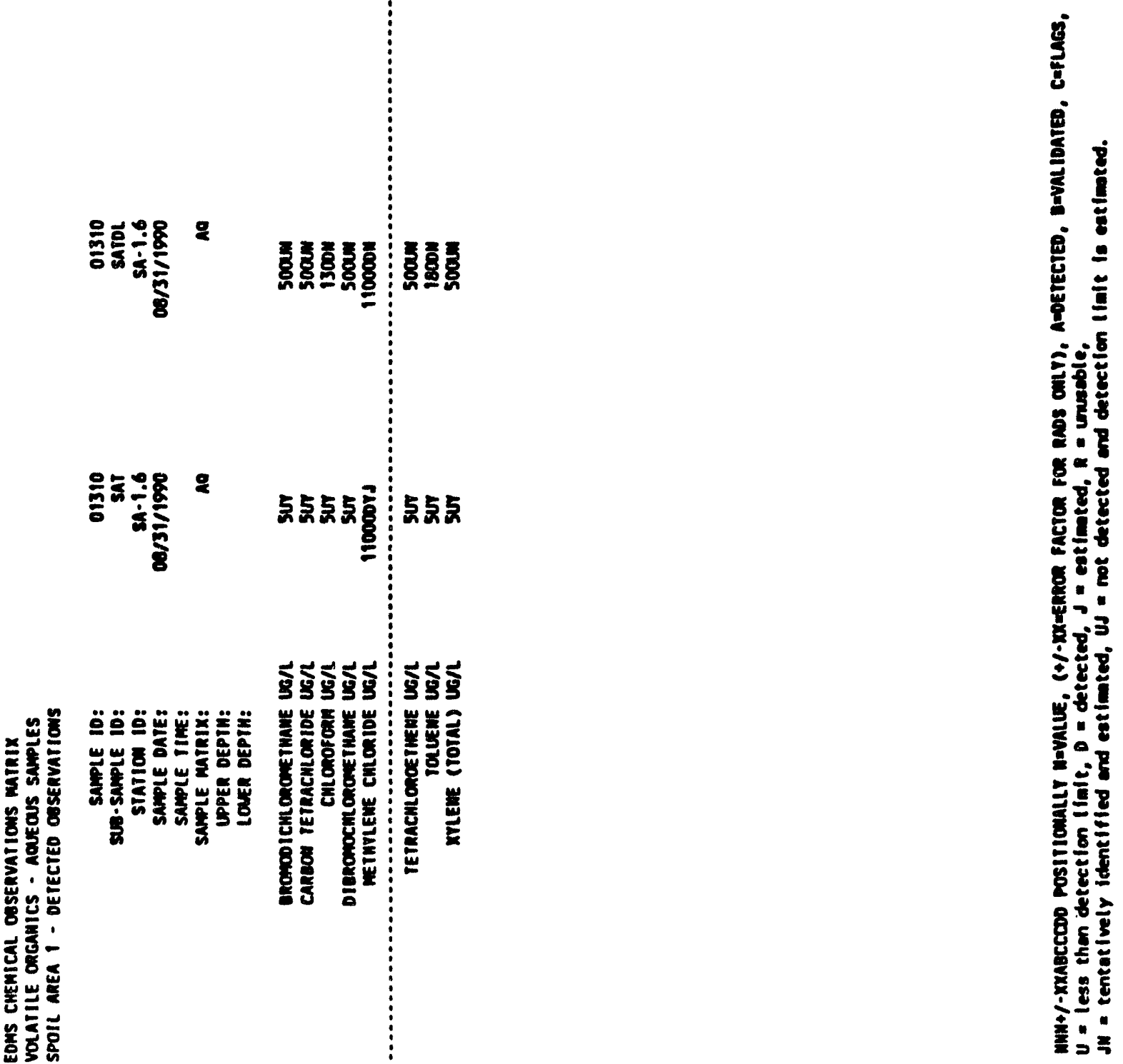


\section{C-63}

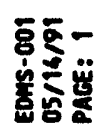

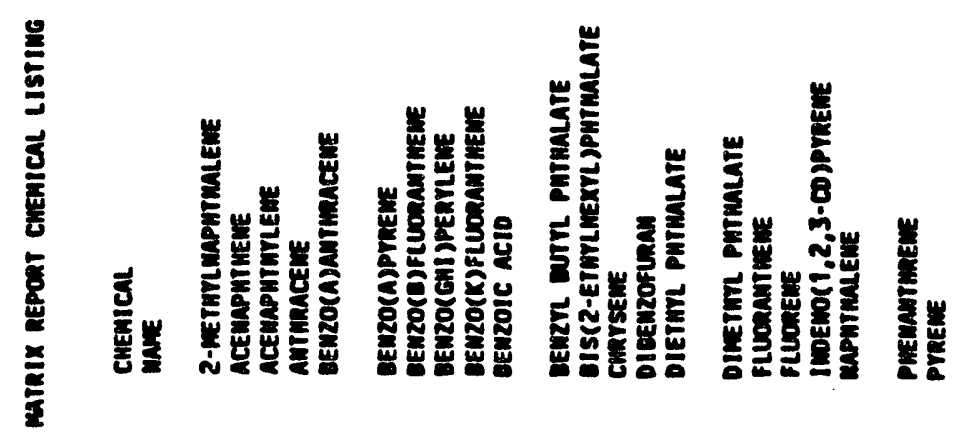

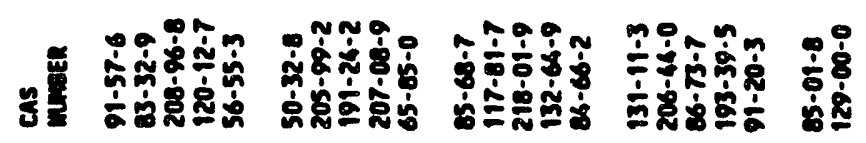
है

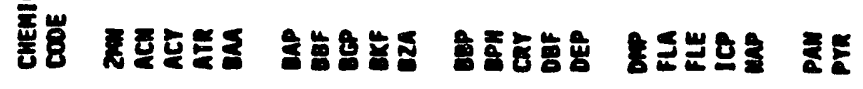


可-

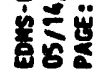
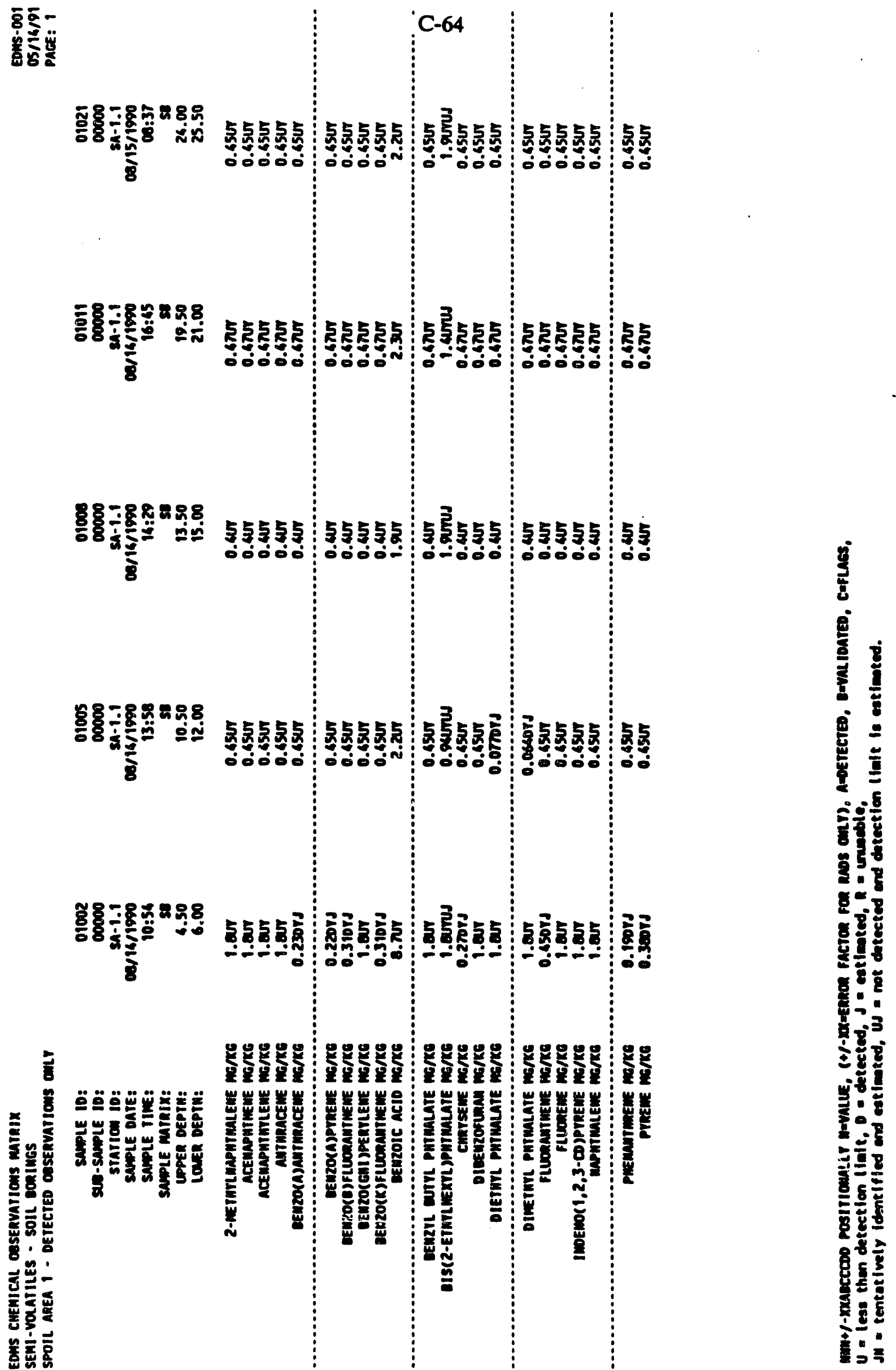


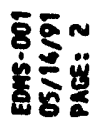

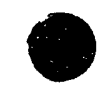

.

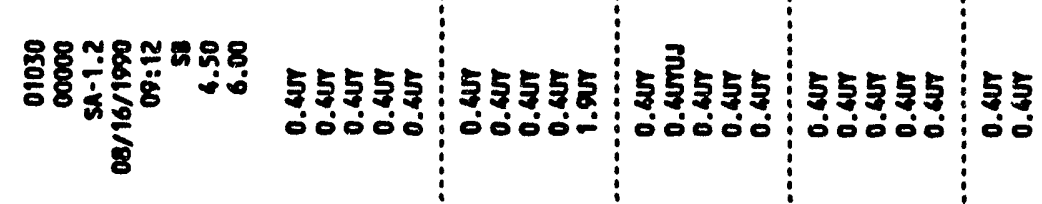

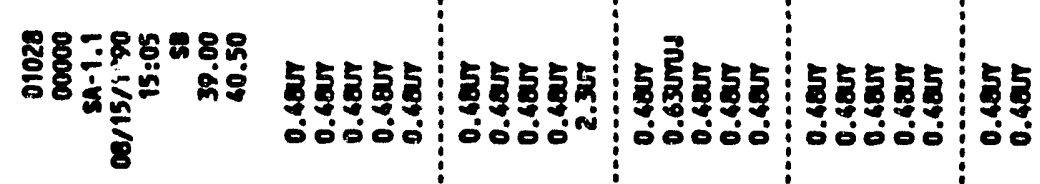

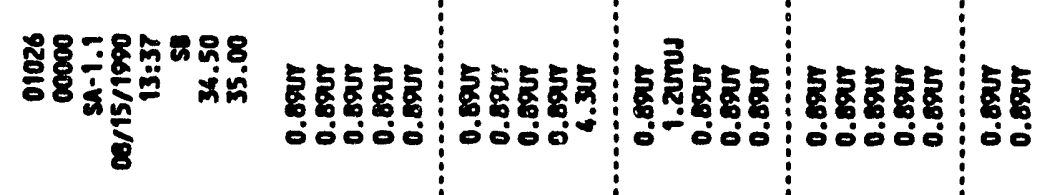

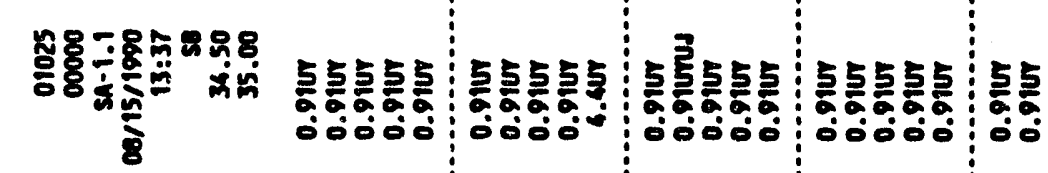

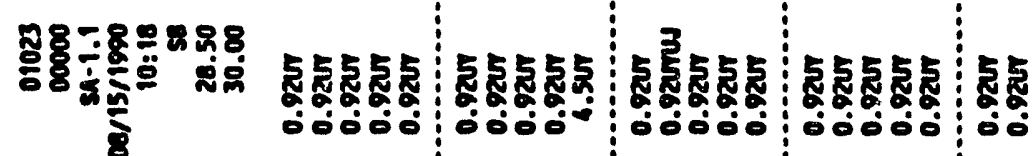

क्ष

든

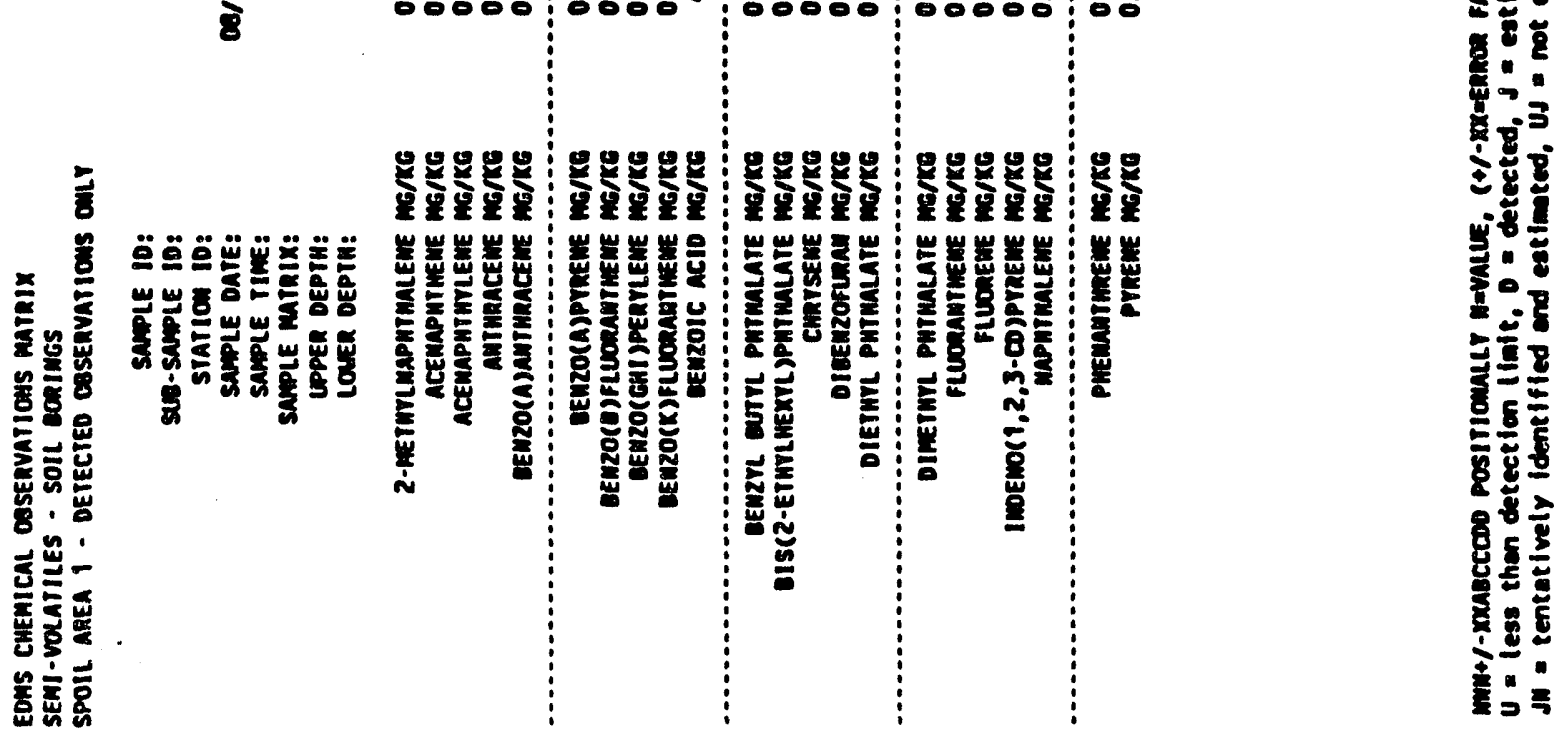




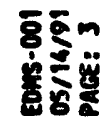

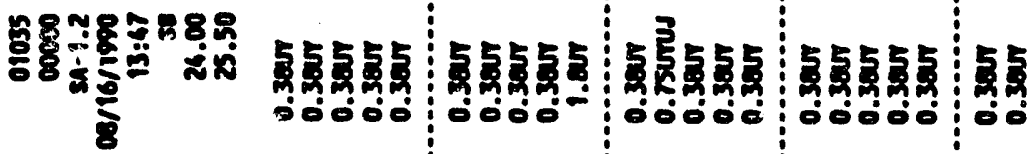

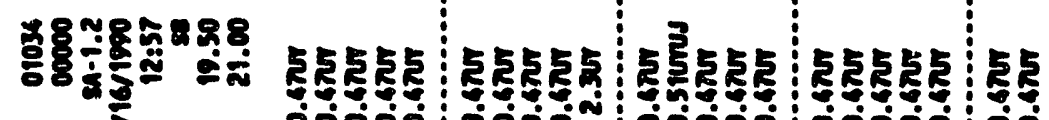

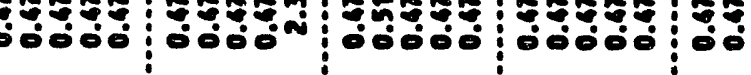

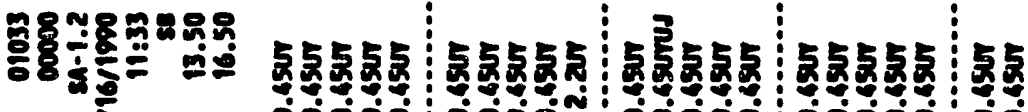

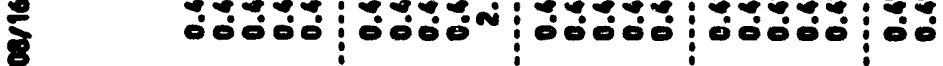

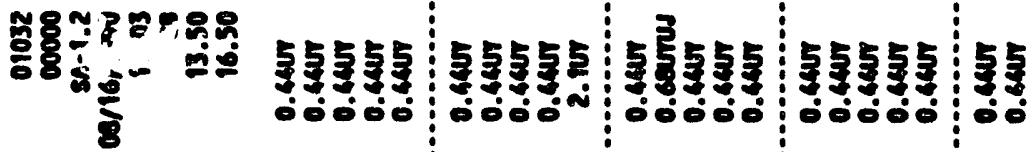

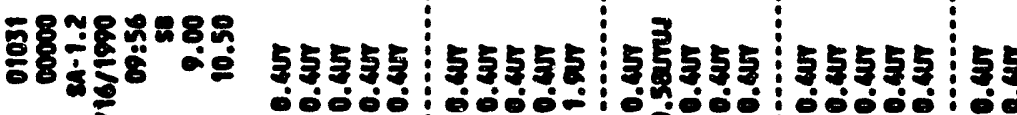

8

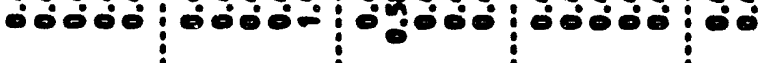

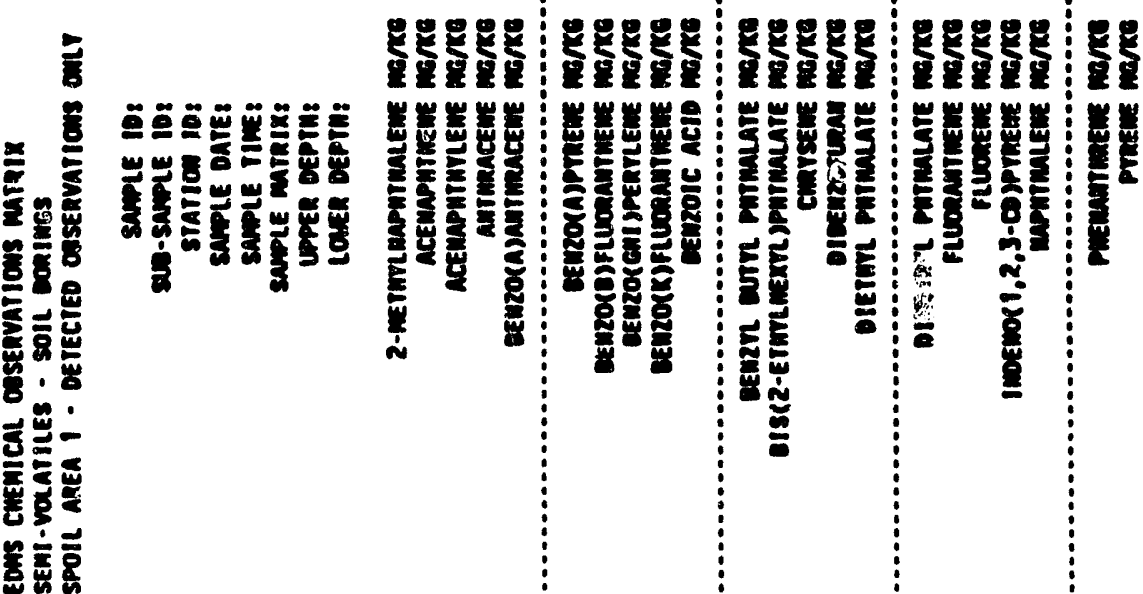




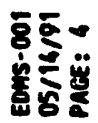

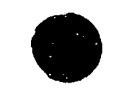

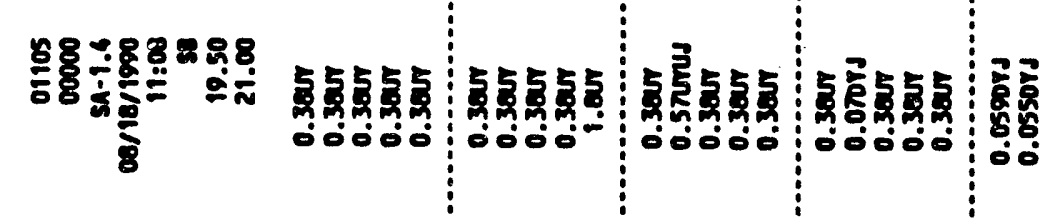

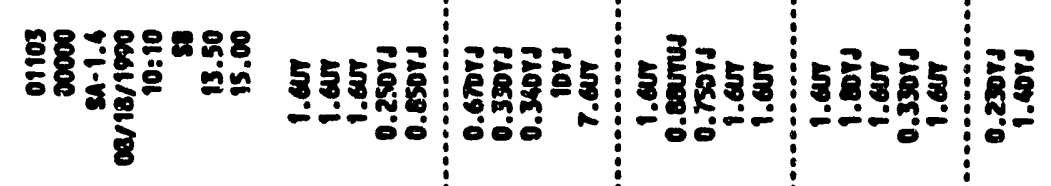

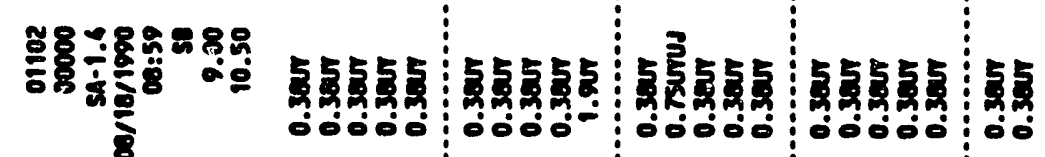

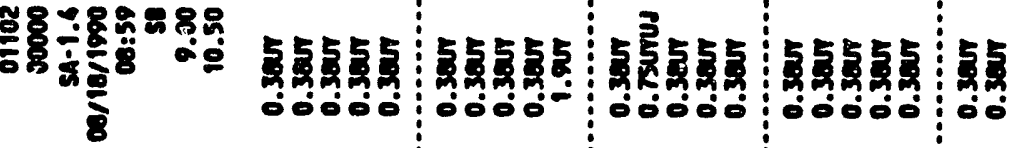

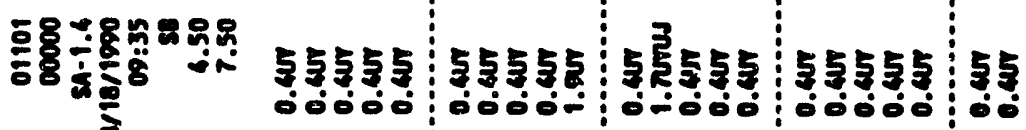

宽

8

눌

$\therefore \div$

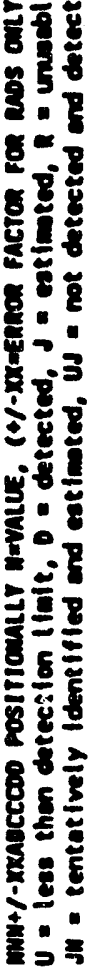

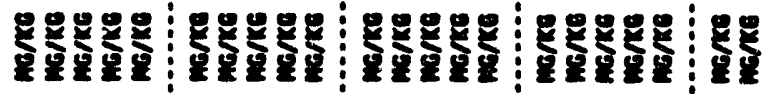

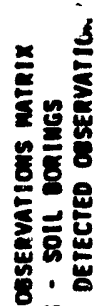

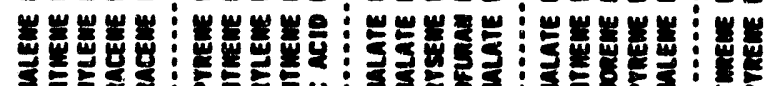

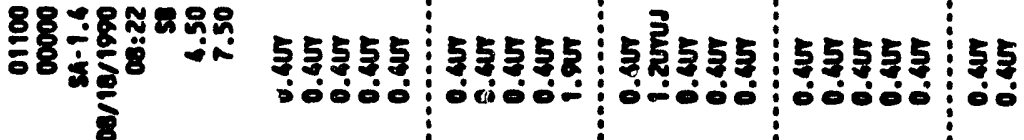

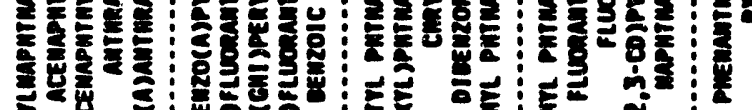

空

尊

:

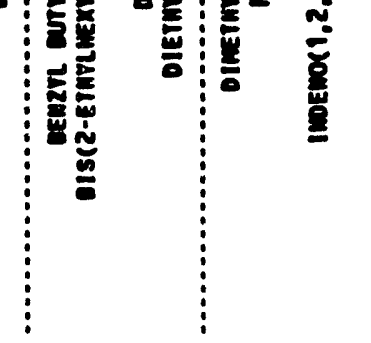




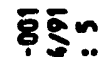

密安部

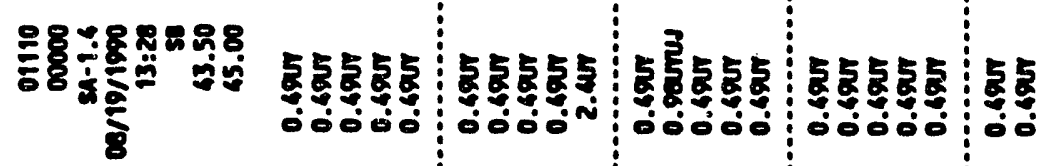

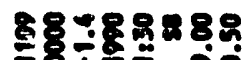

$685=$ is

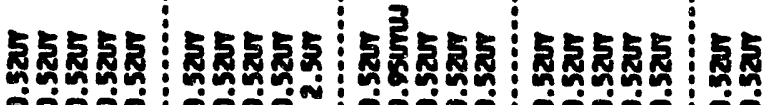
880

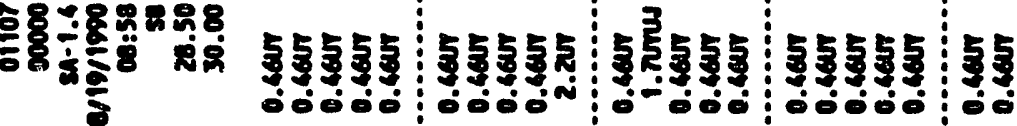

है

훙

을

亏뽈

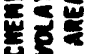

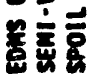

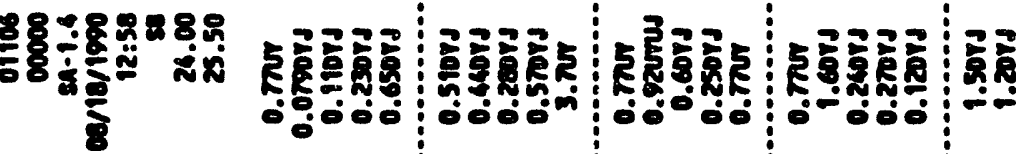

mmm mm mm mm

HEX

(u)

둥

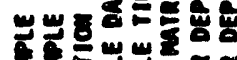

家

i

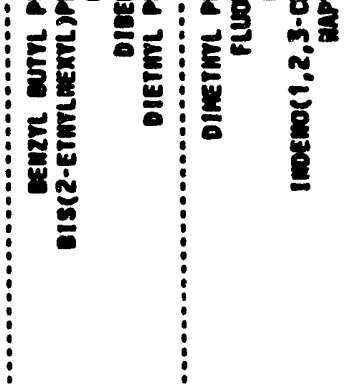

을 


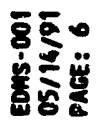

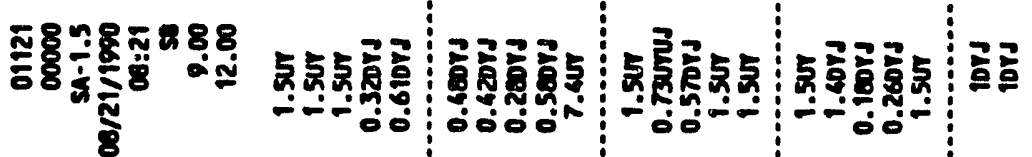

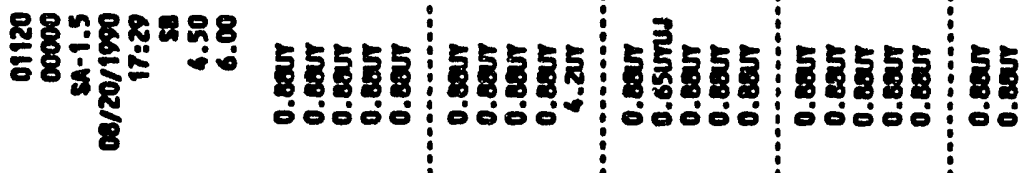

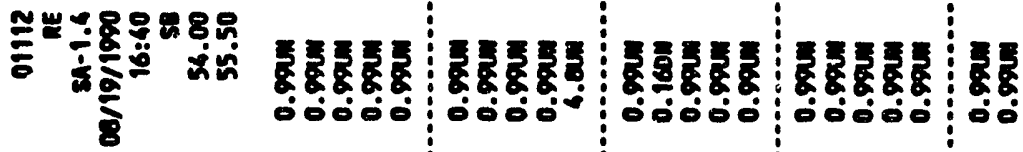

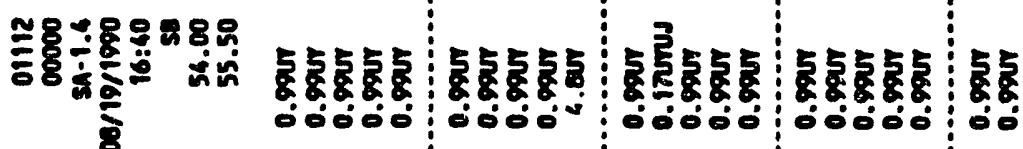

$\frac{4}{8}$

8.

홀

8.

蒫

$\therefore=$

훙

दे

8

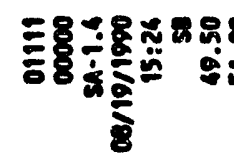

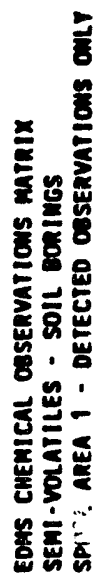

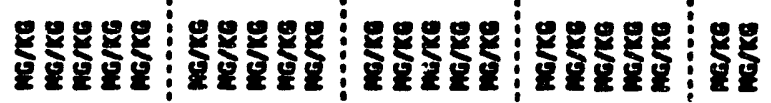

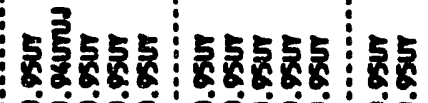

늘

है

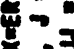

胥安

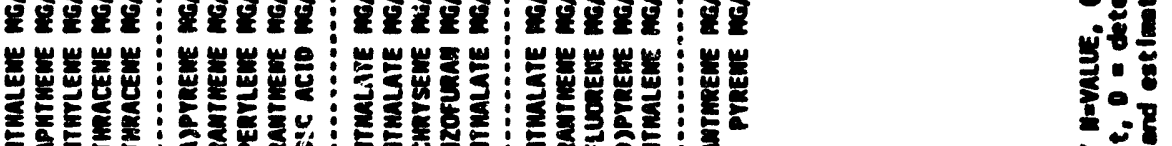

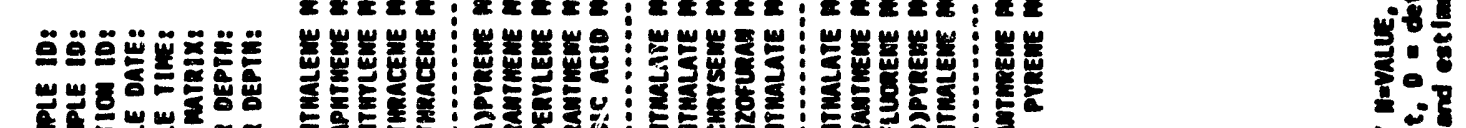

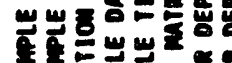

竞

递密

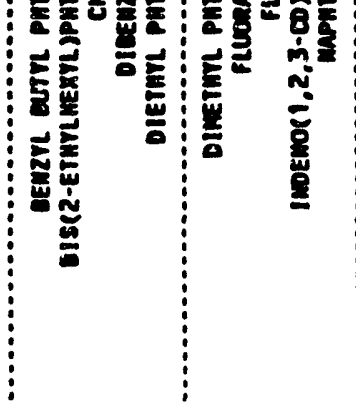

폴 


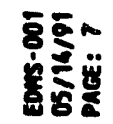

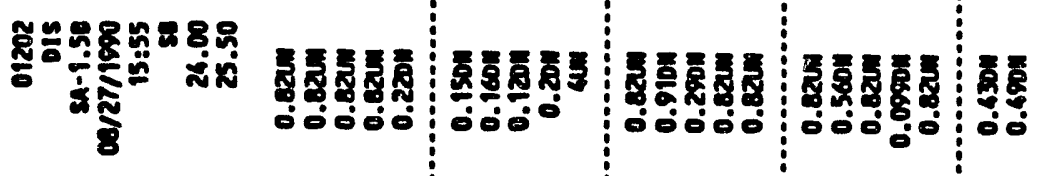

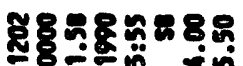

这

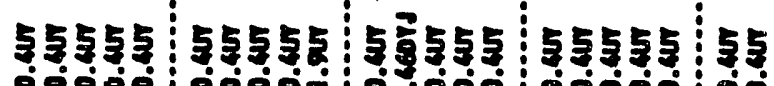

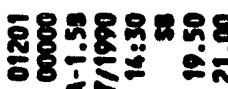

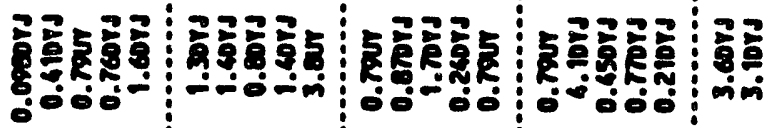
कर

$88 \div 8 \% 8208$

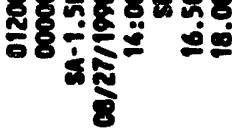

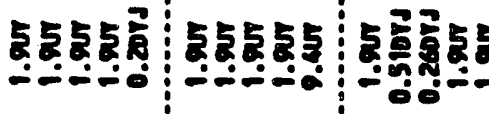

5 훙현.5

象

흘

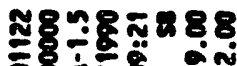

soido

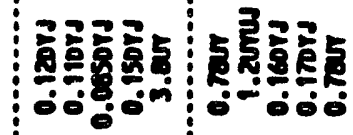

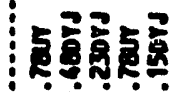

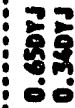

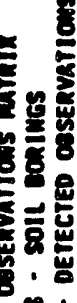

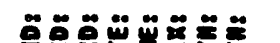

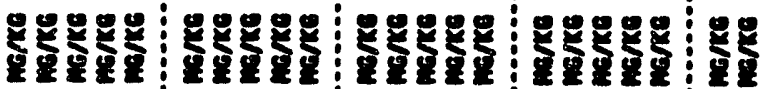

눙
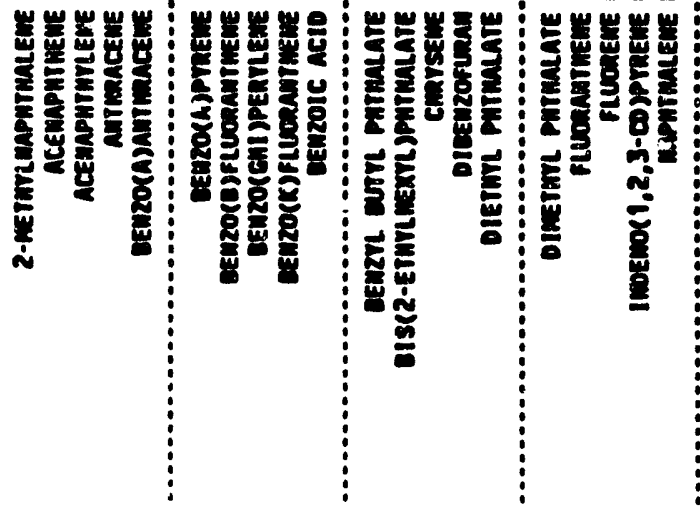

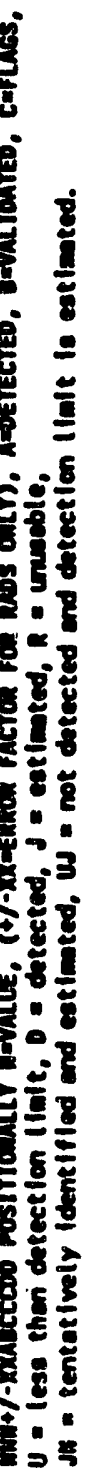




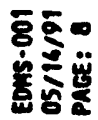
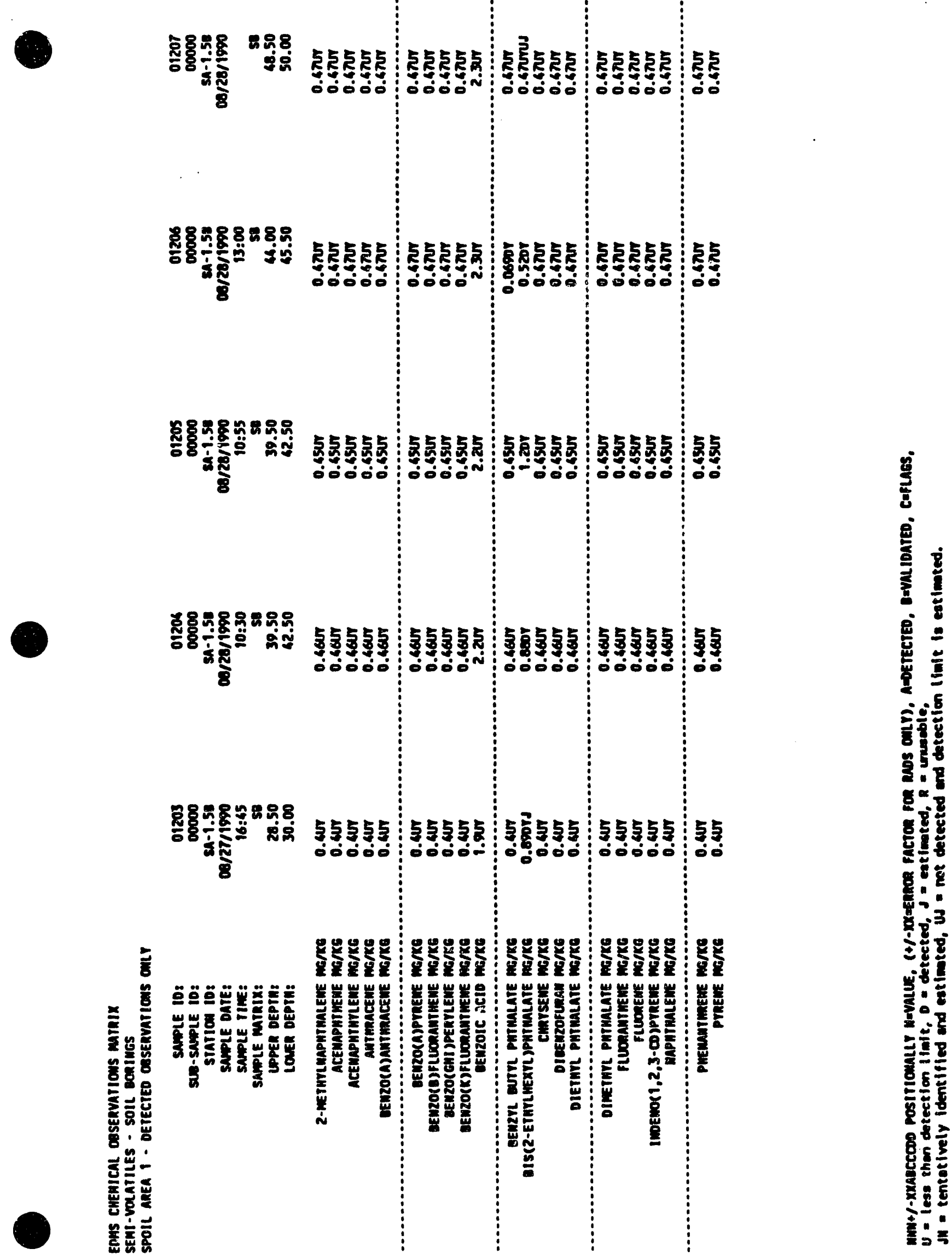


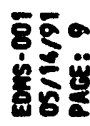

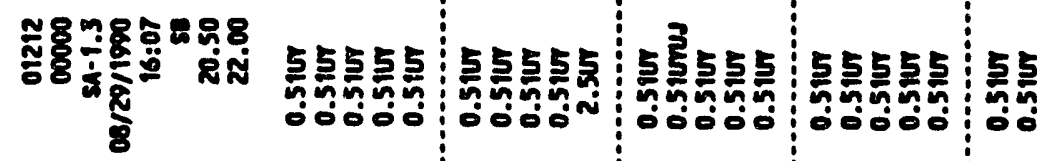

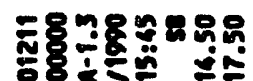

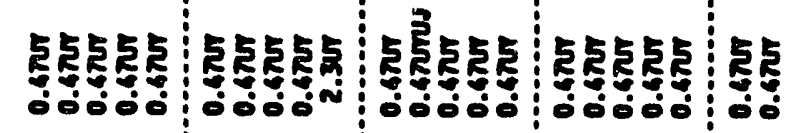

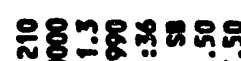

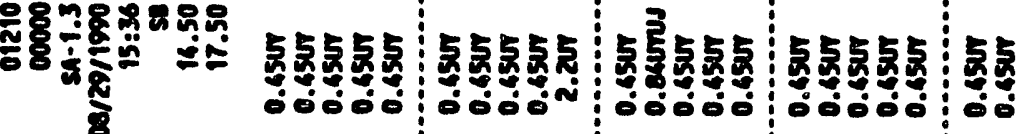

$\sum^{8}$

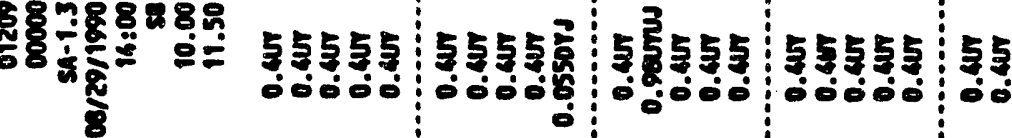

흔

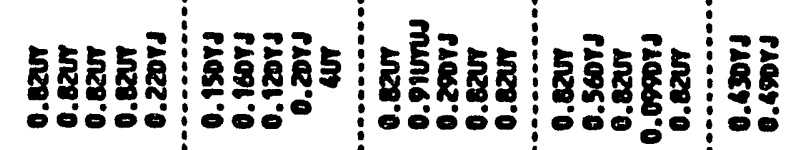

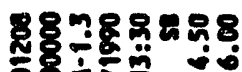

密

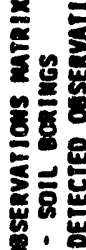

等

尊 


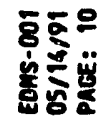

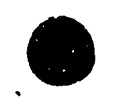

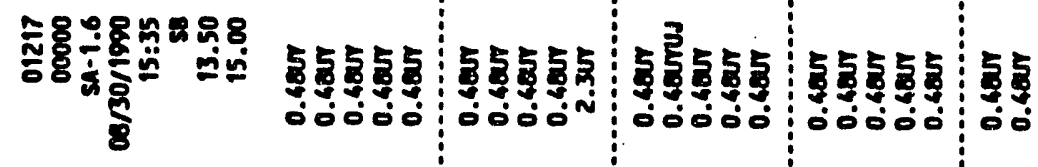

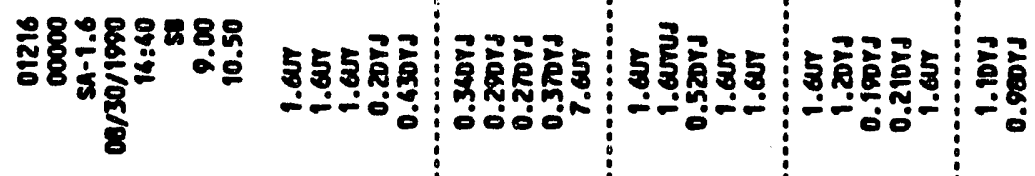

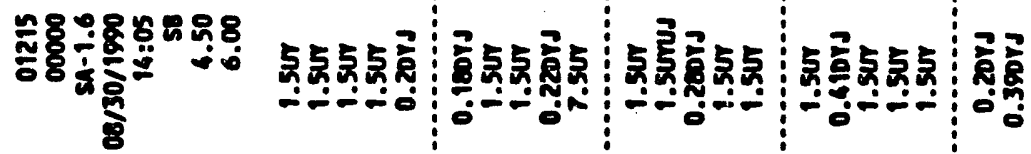

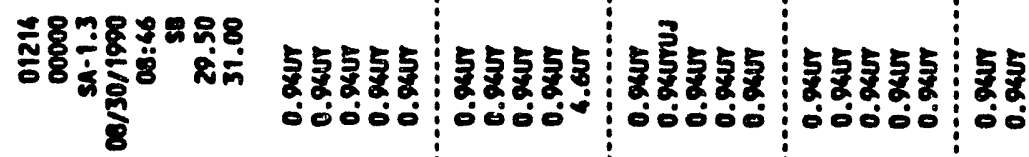

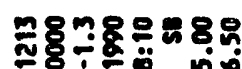

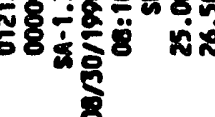

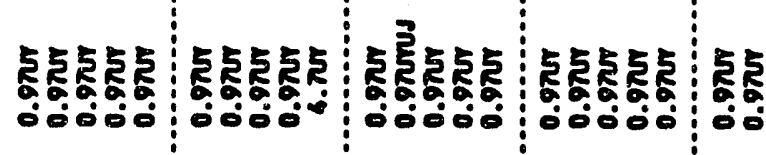

言

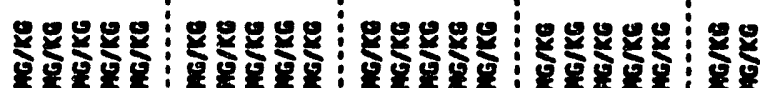

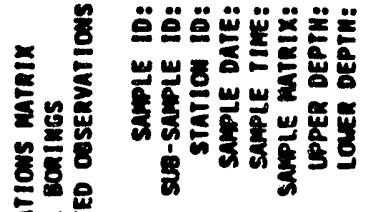

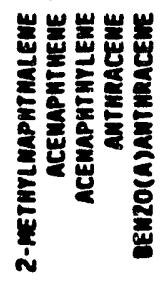

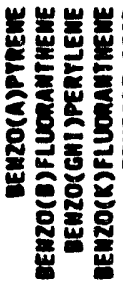

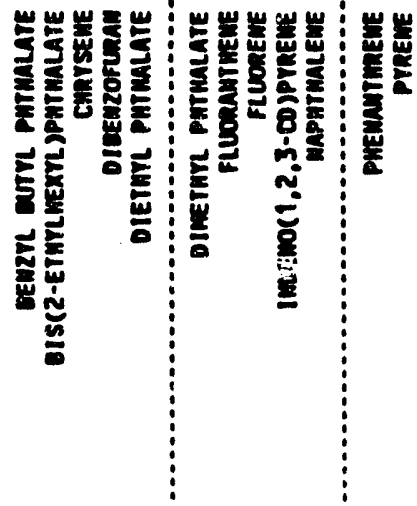

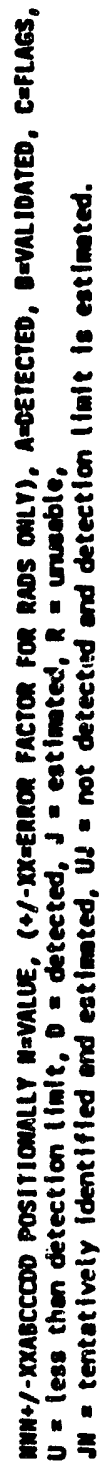




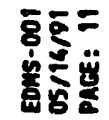

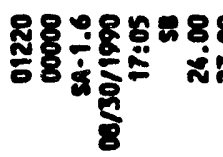

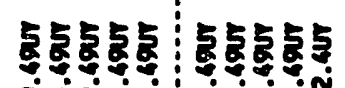

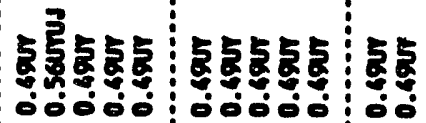

ㅇํㅇำ: क्षे

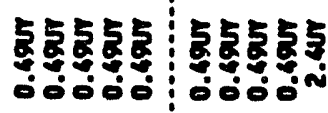

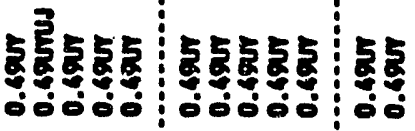

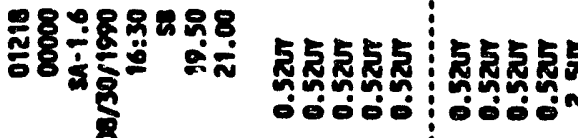

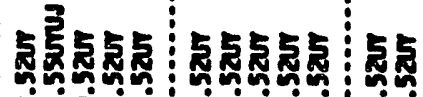

홍

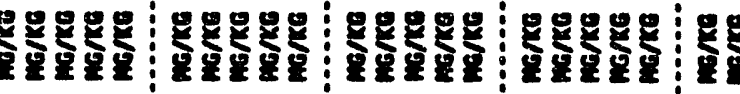

8ु.

这

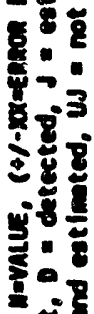

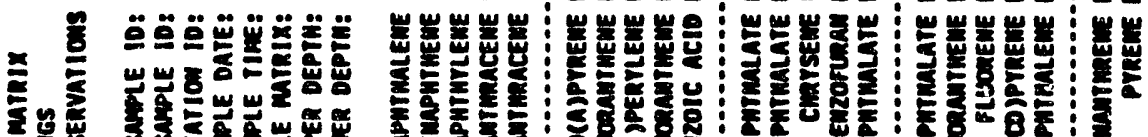

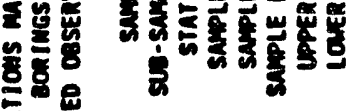

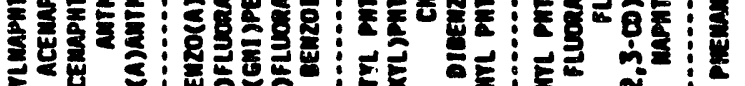

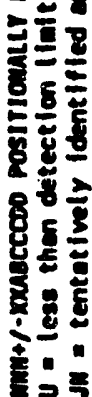

言竞要 


\section{C-75}

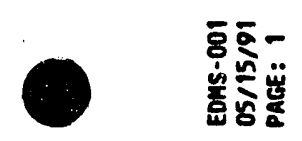

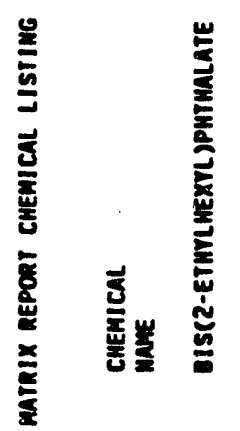

$\overline{5}$

密岩

岇营 


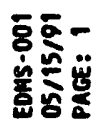

\section{C-76}

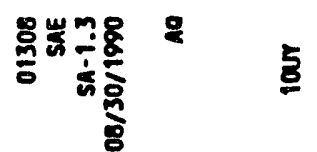

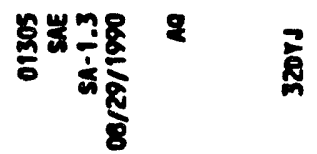

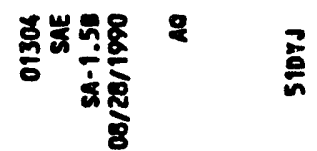

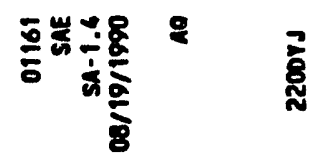

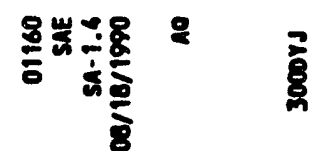
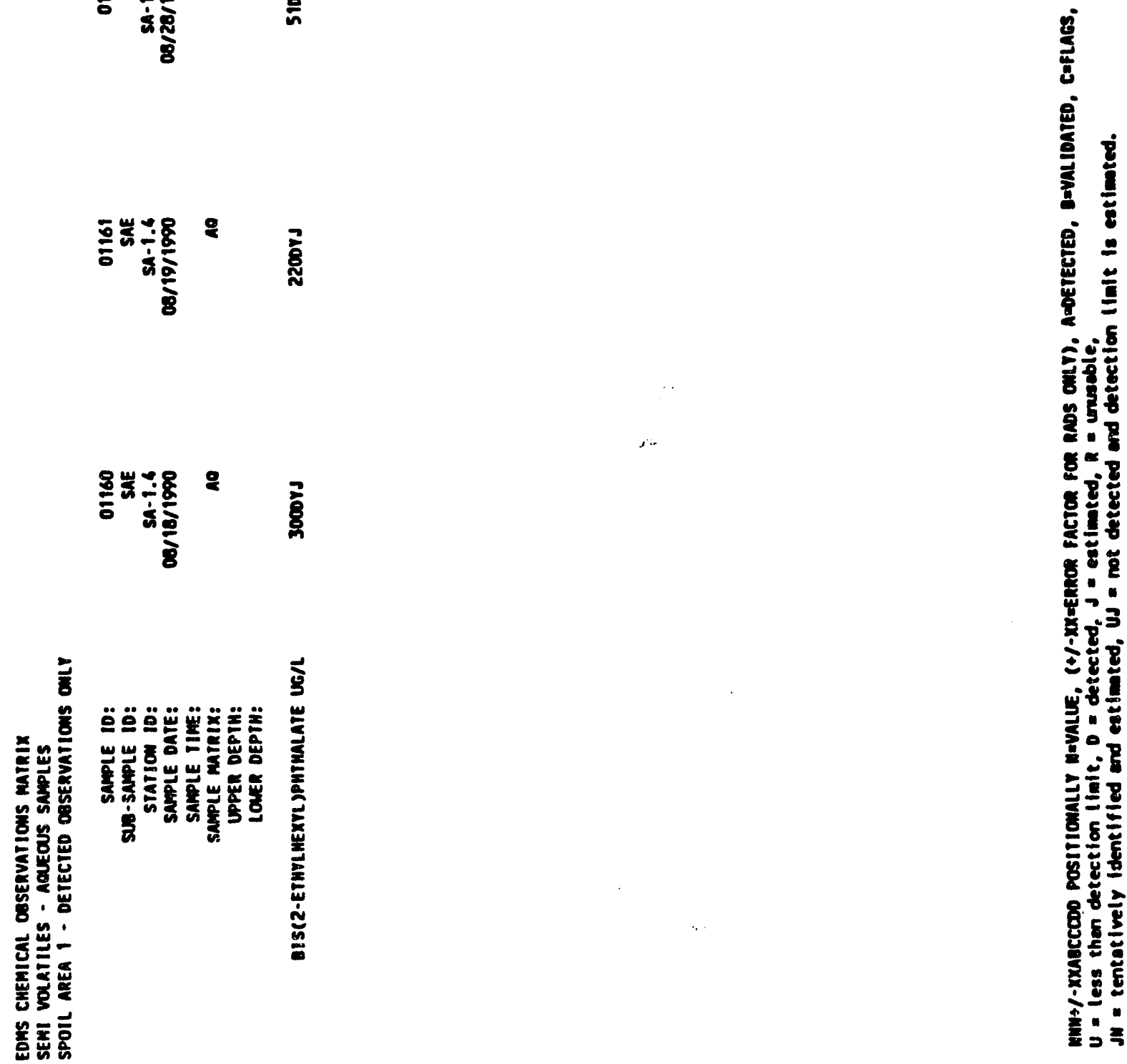


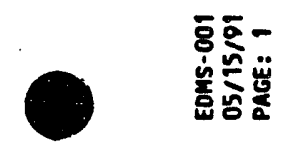
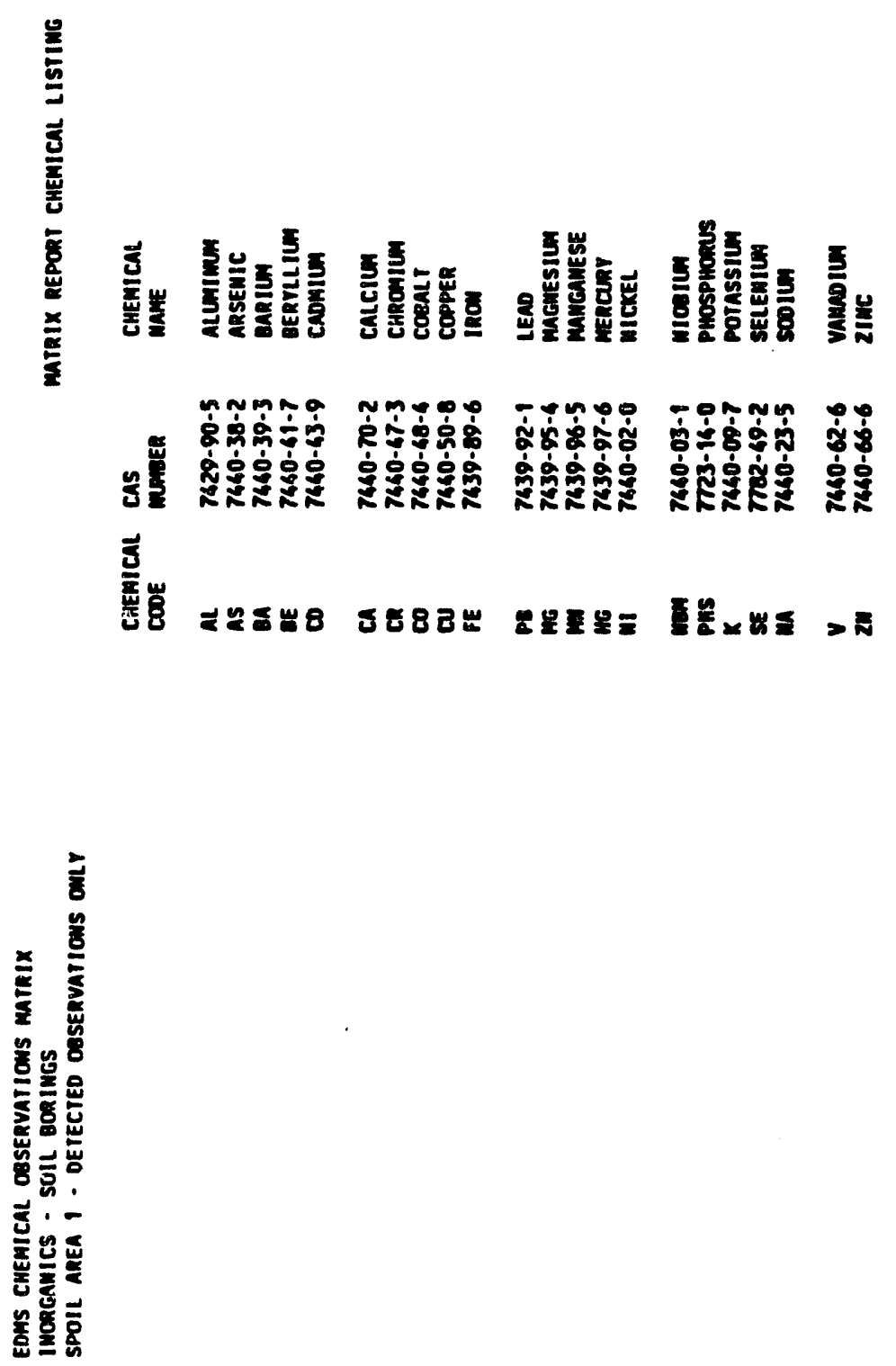


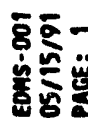

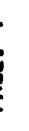

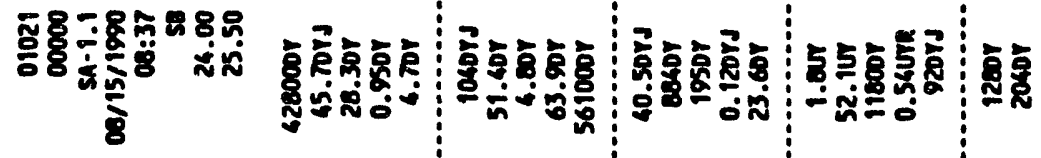

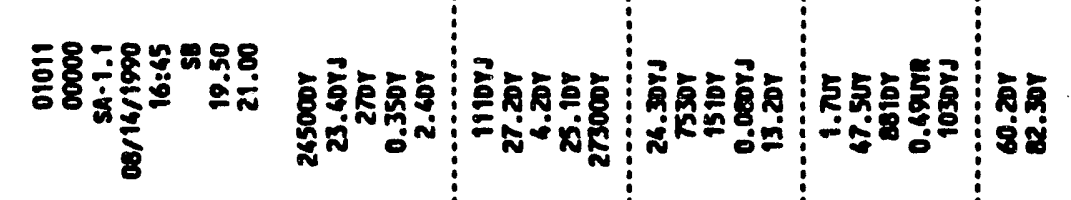

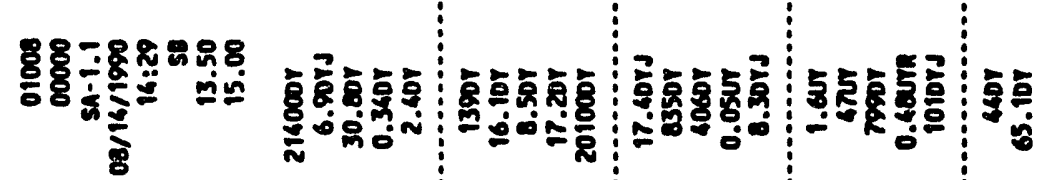

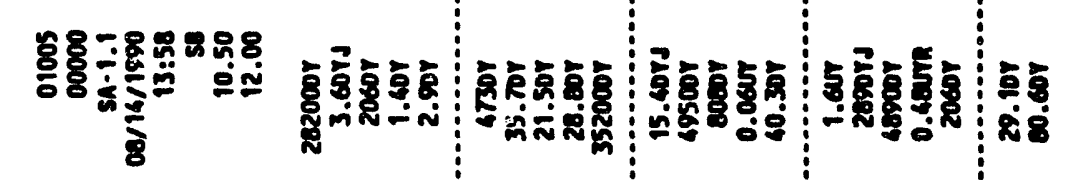

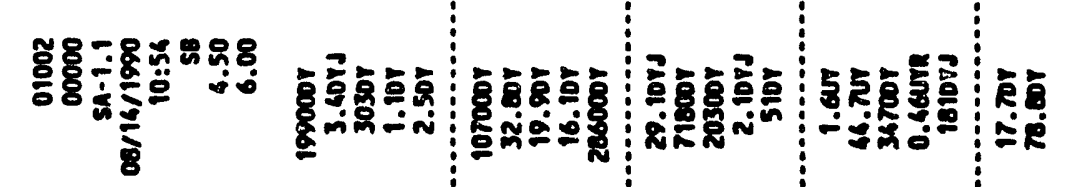

है

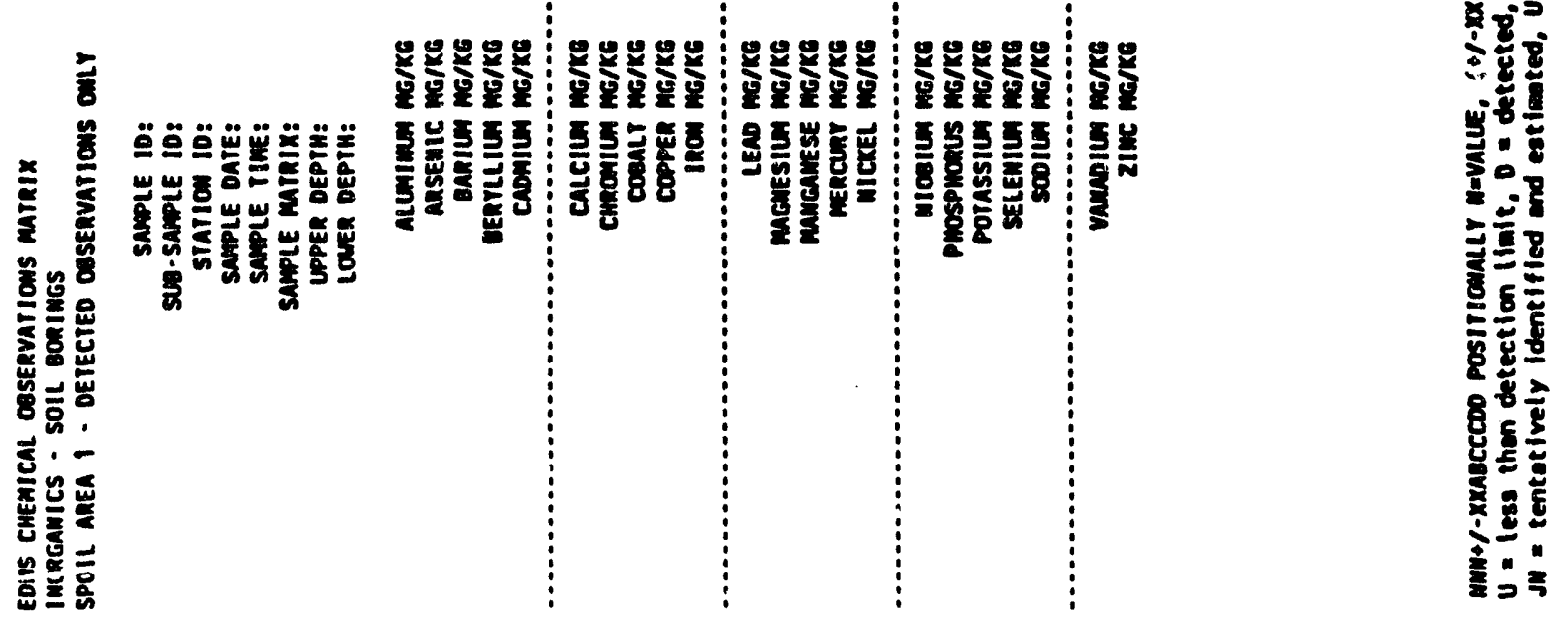




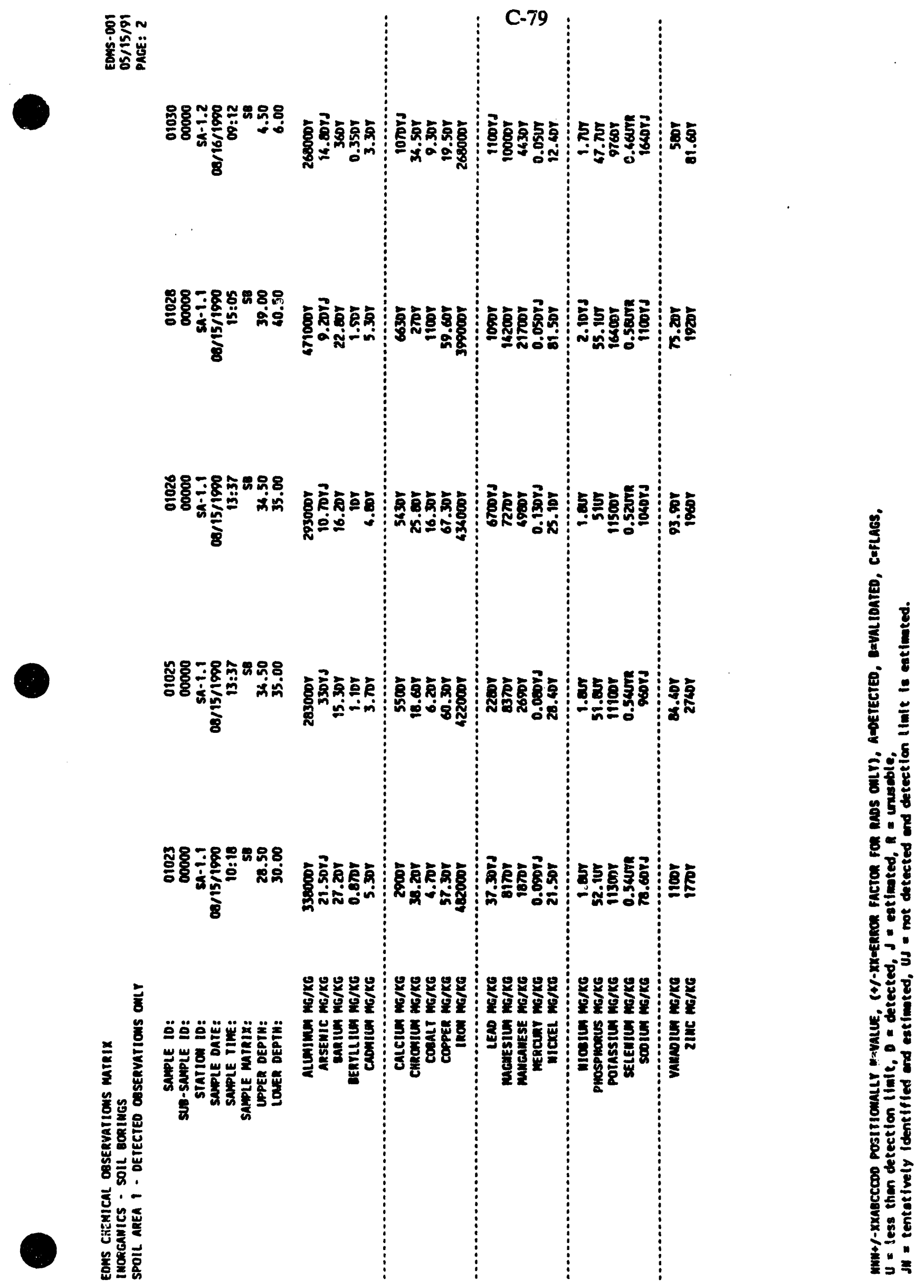




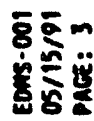

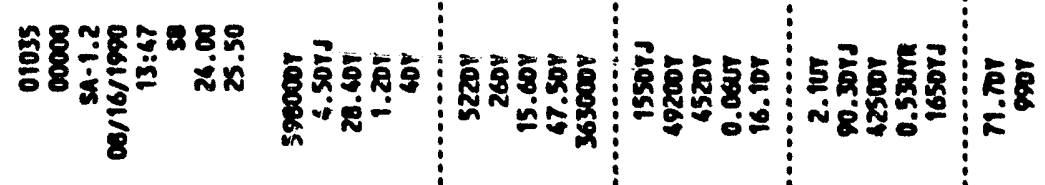

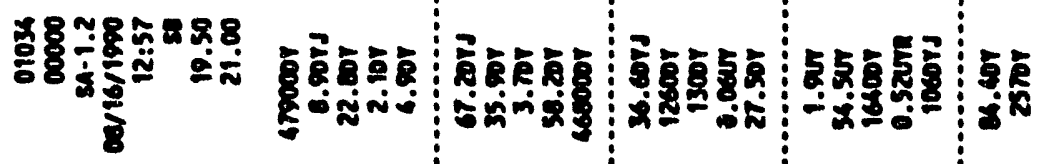

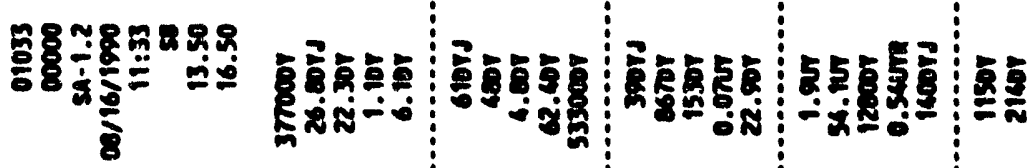

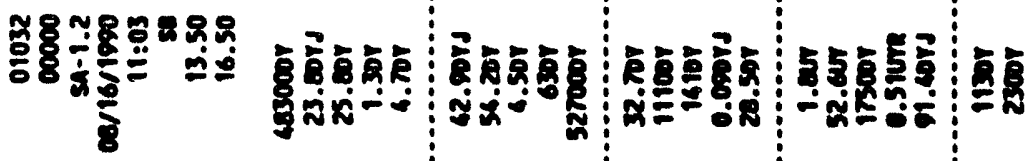

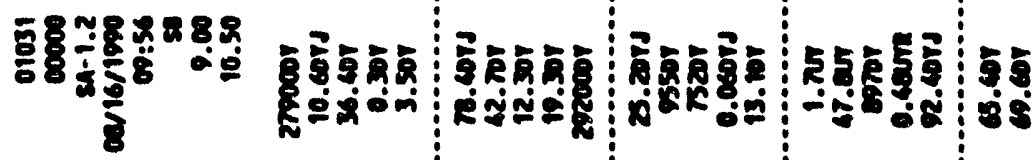




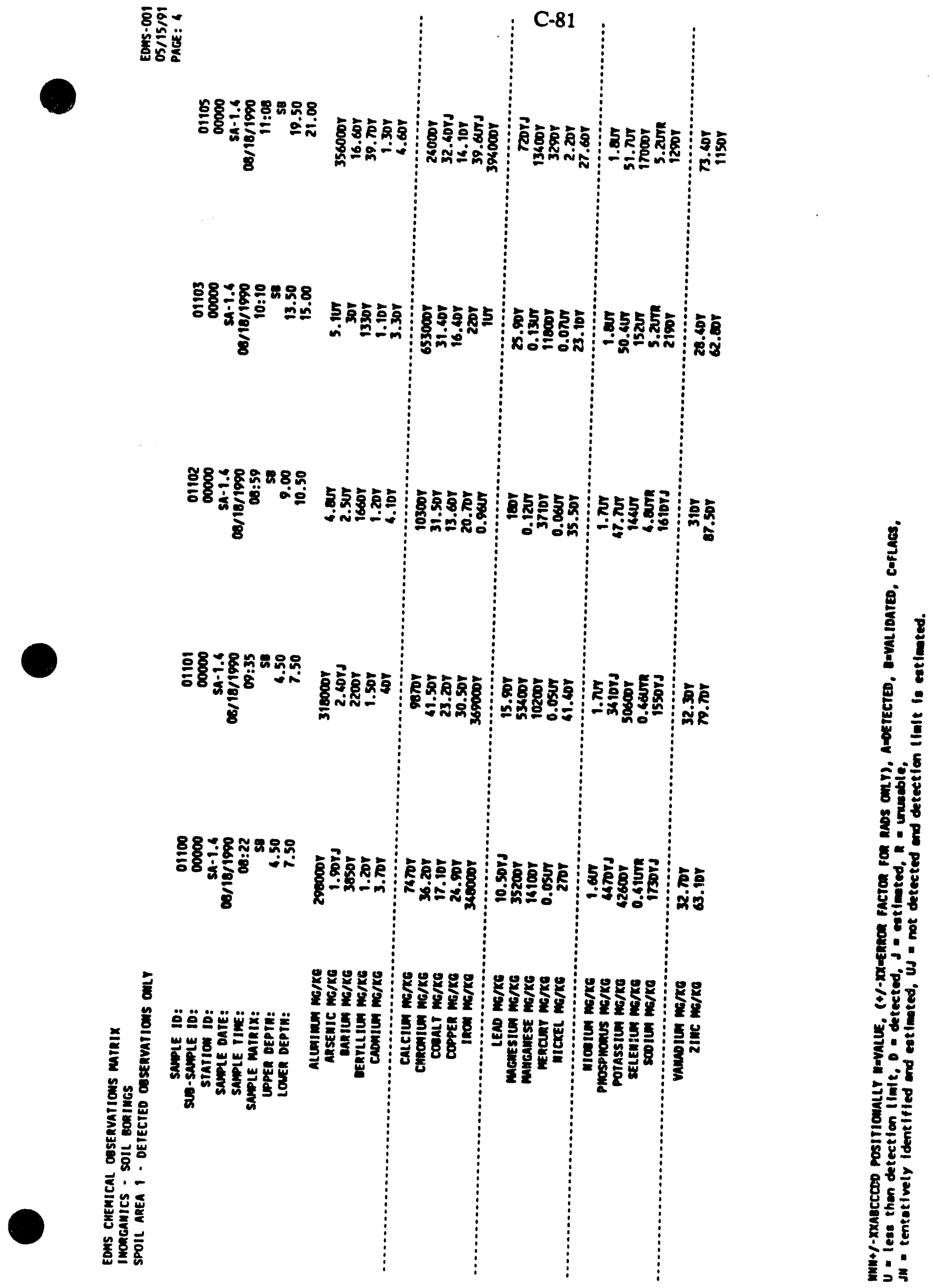




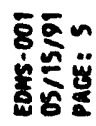

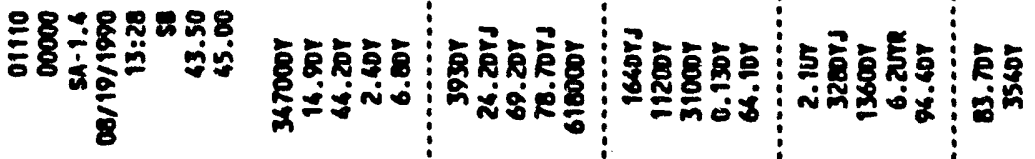

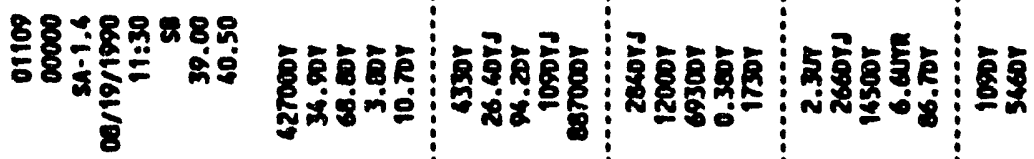

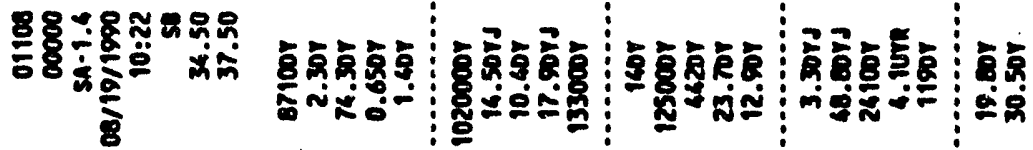

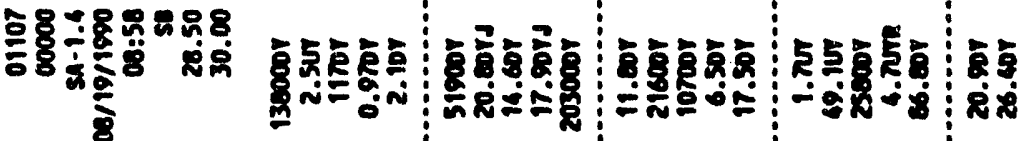

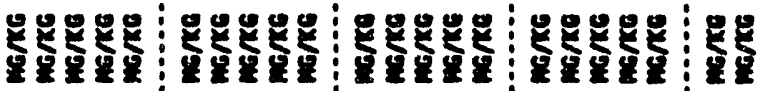

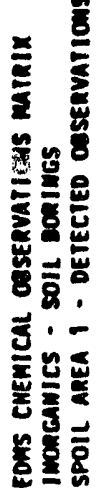

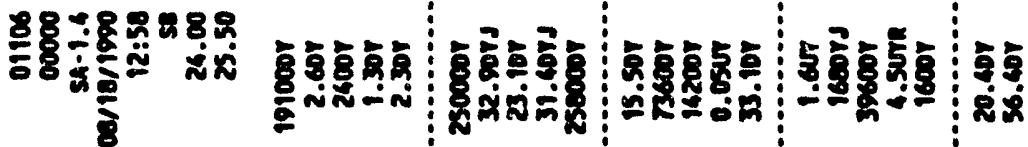

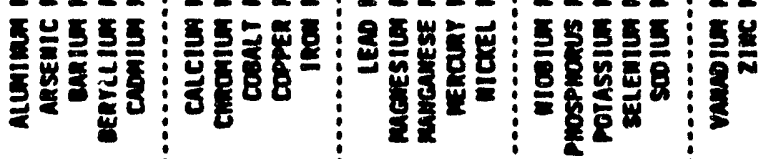

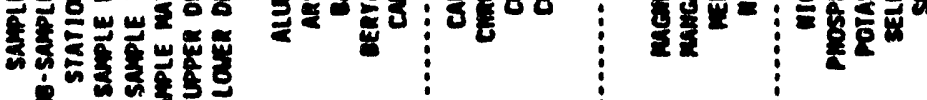




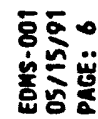

0

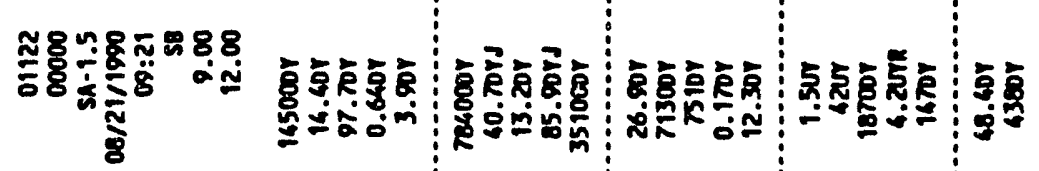

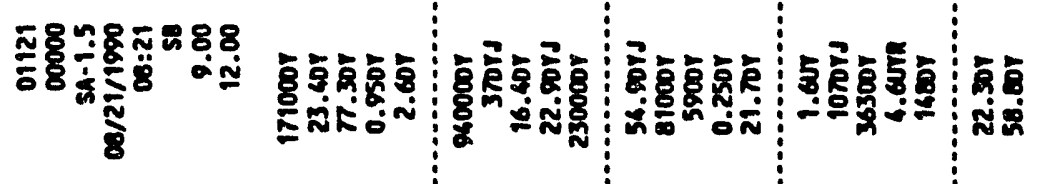

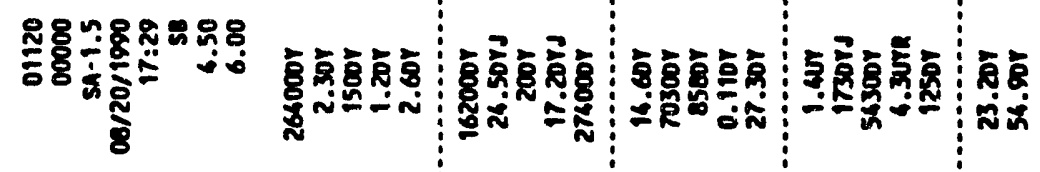

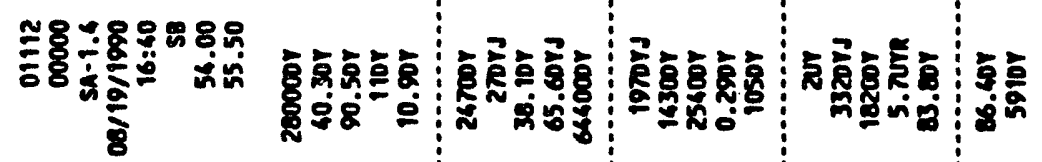

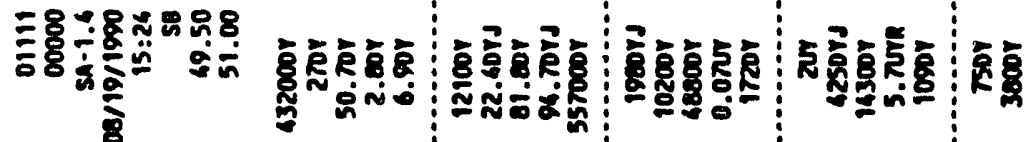

咅

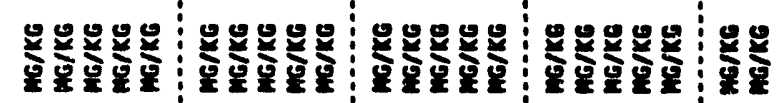

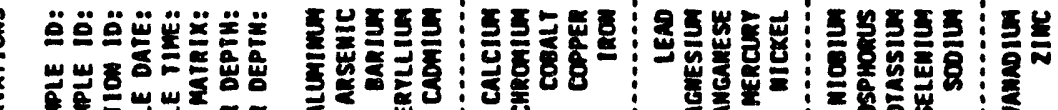

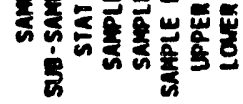

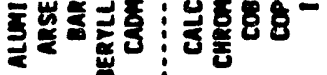

宸整:

政

若

Sí⿺

焉记

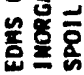




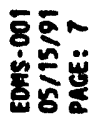

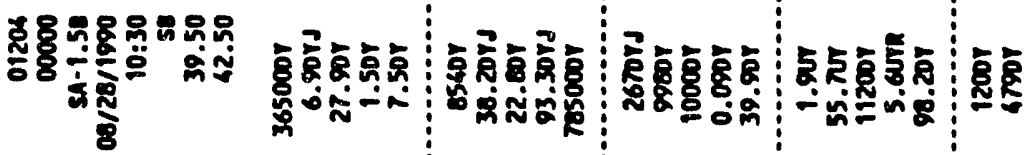

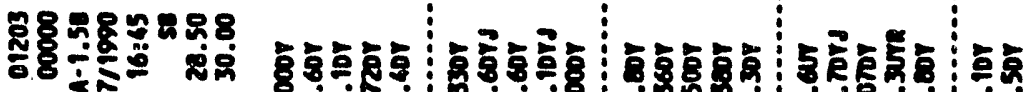
요

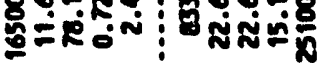

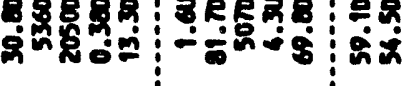

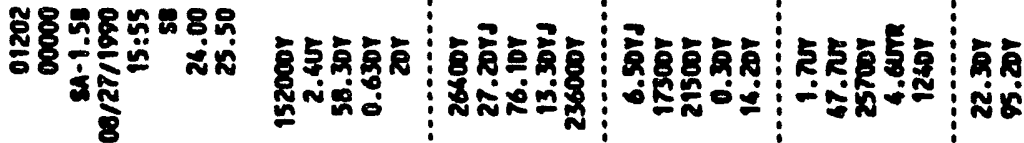

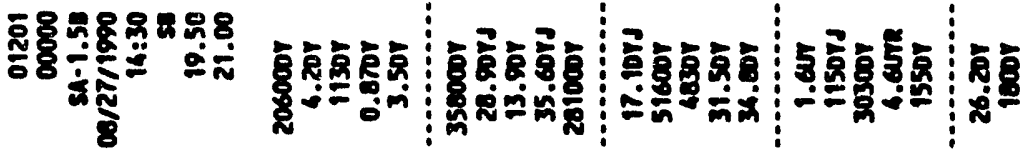

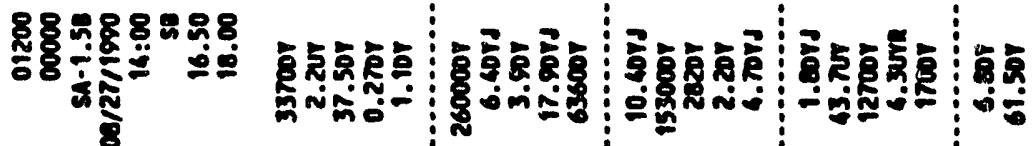

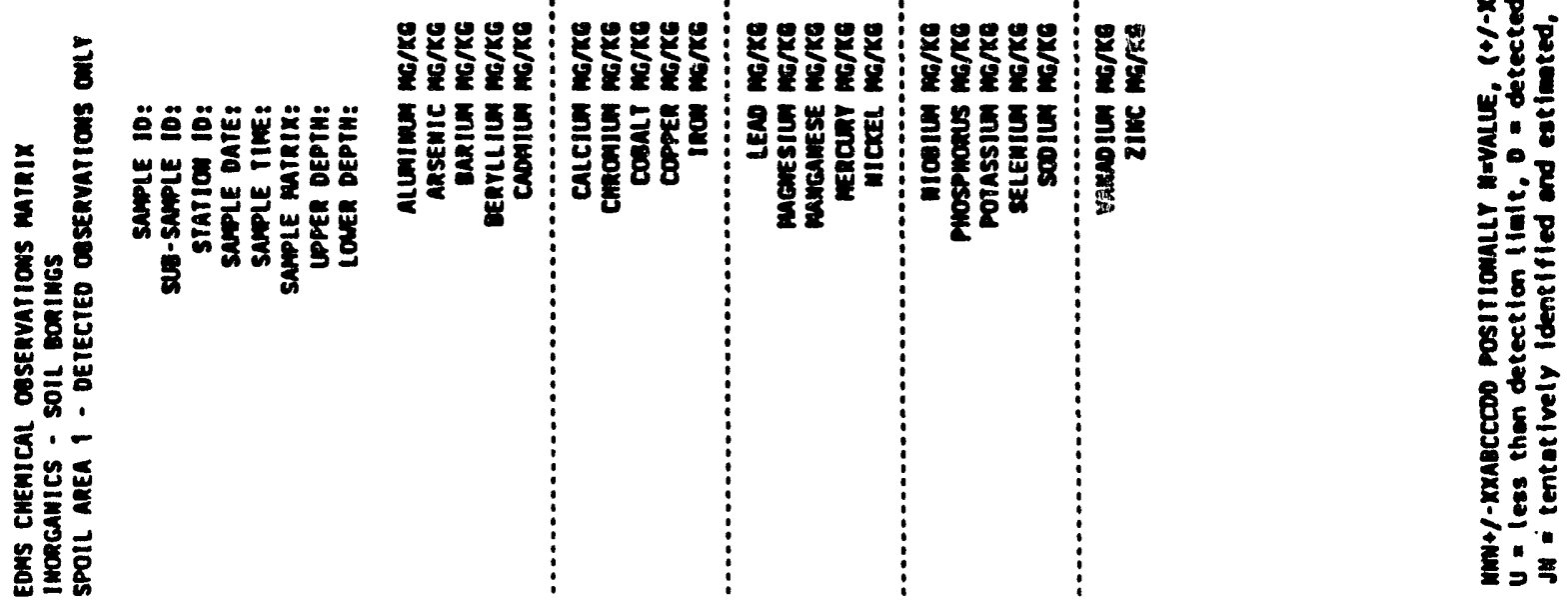




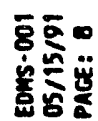

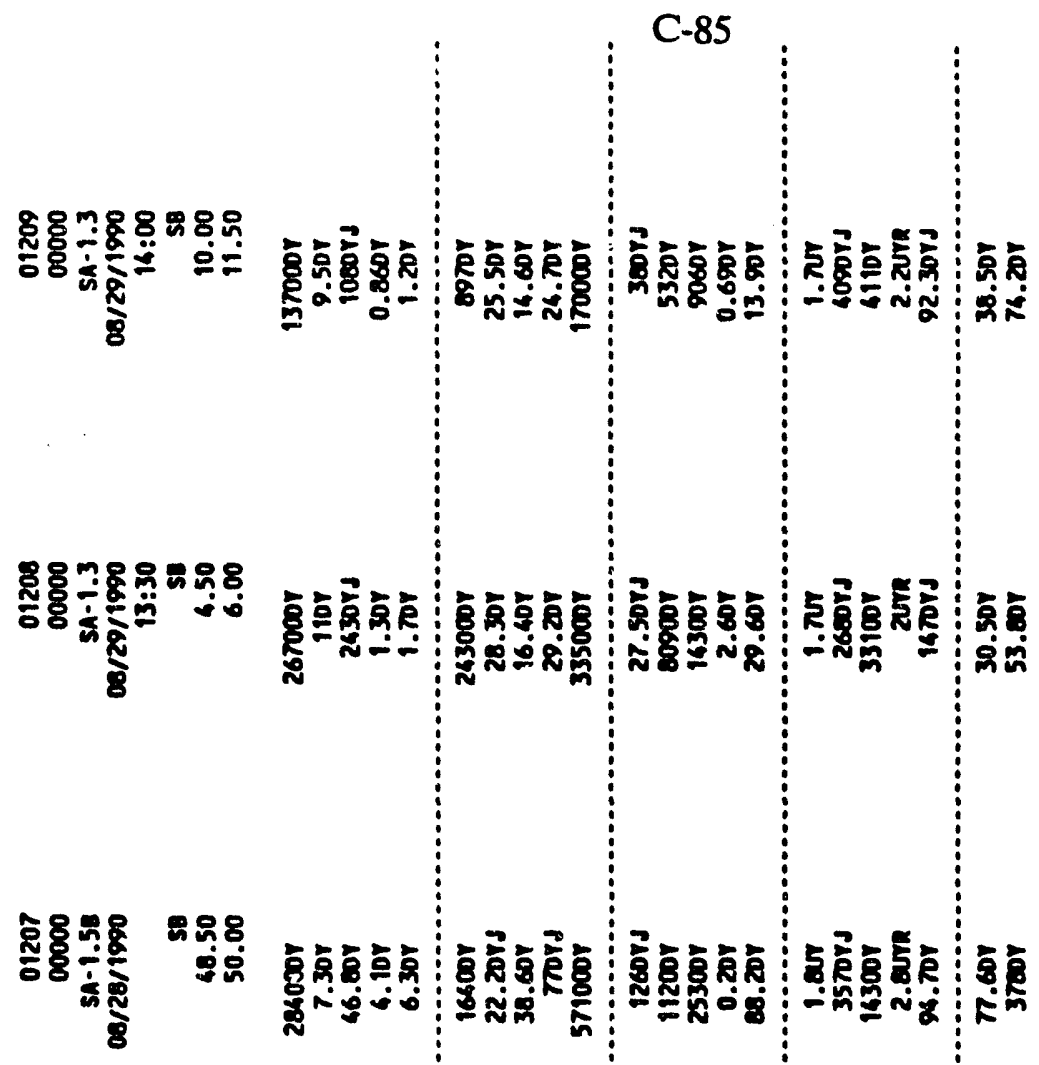

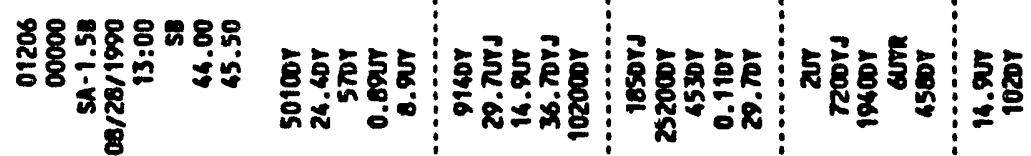

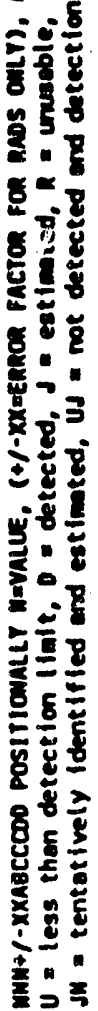

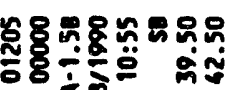

8

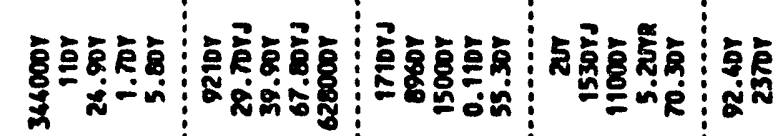

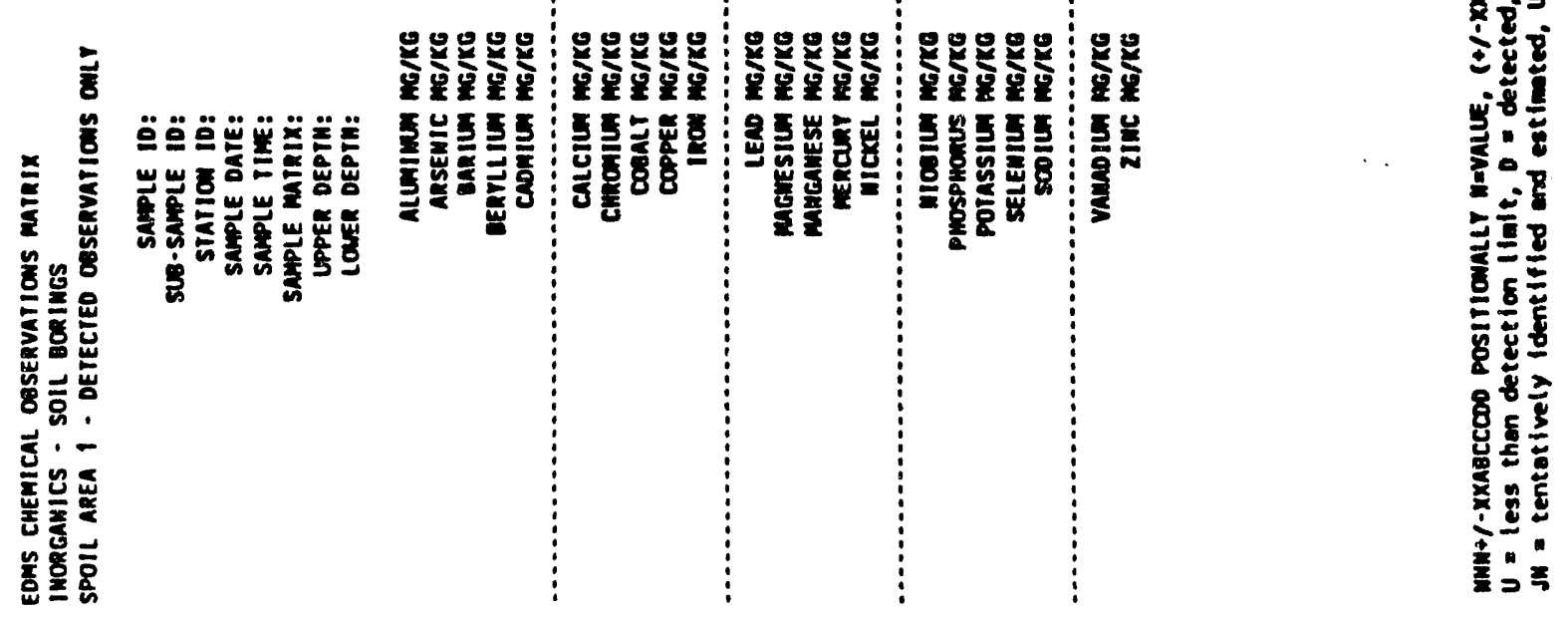




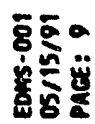

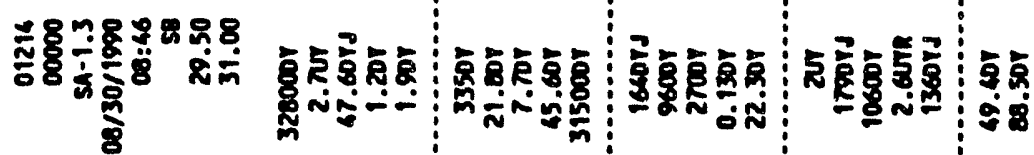

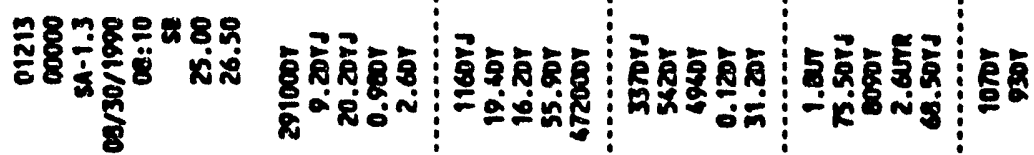

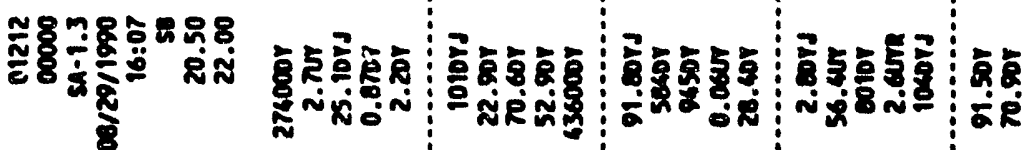

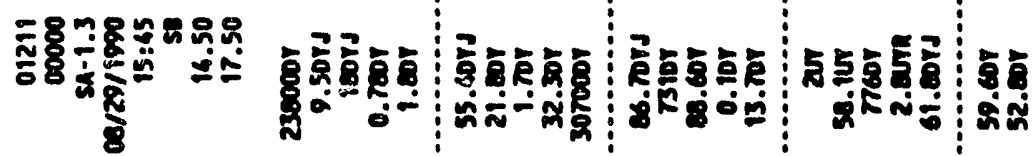

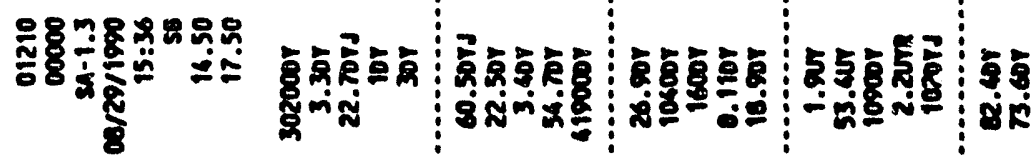

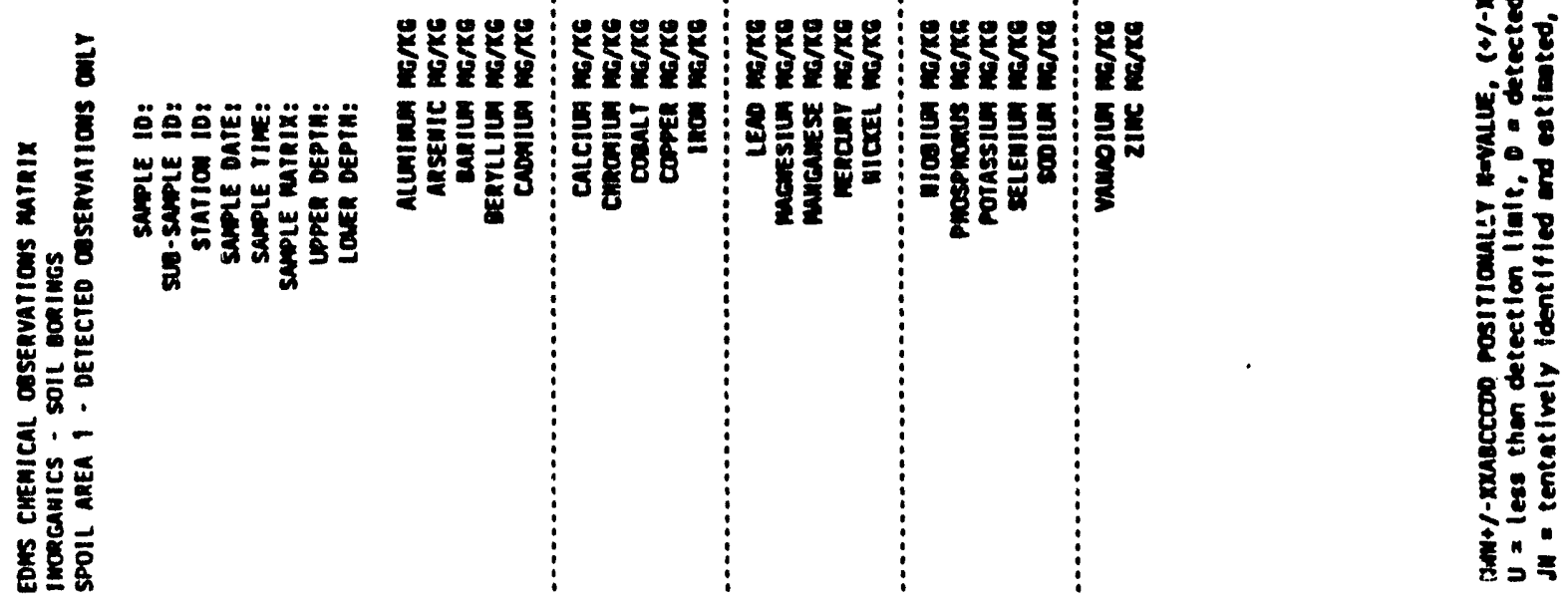

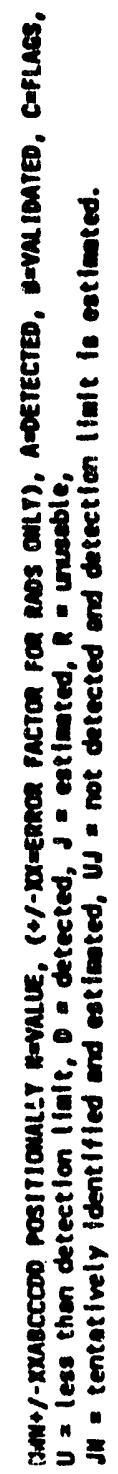




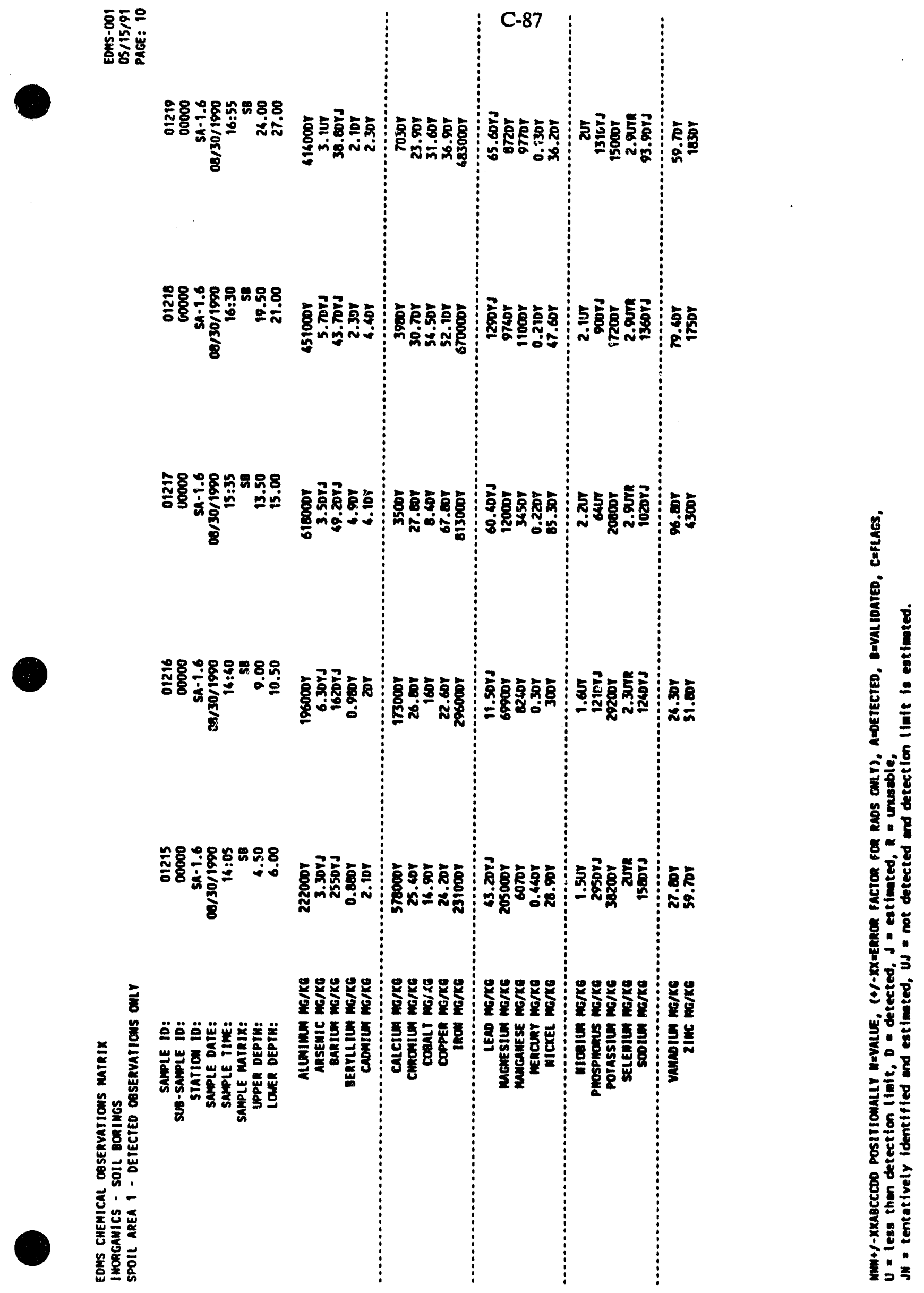




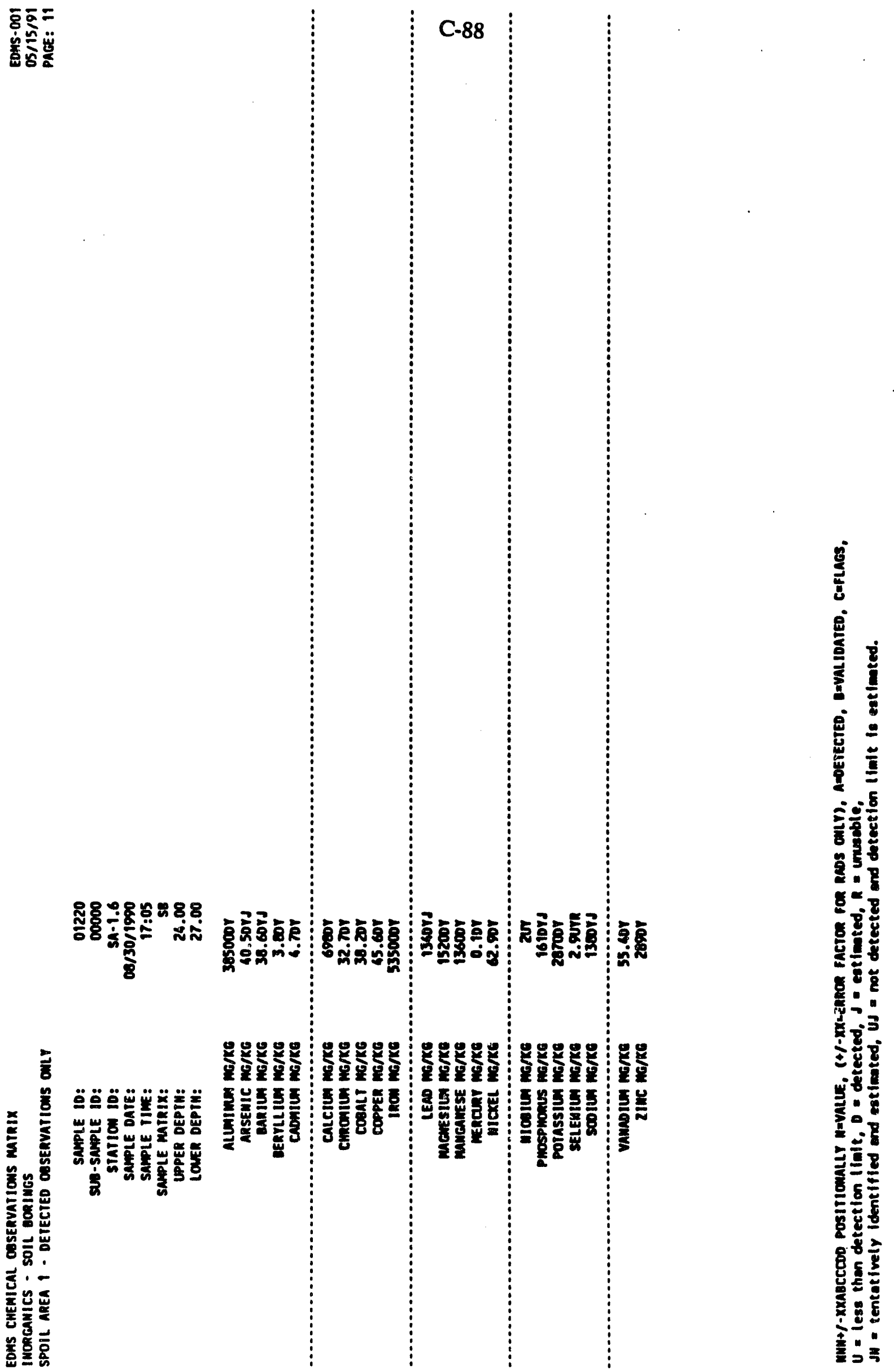




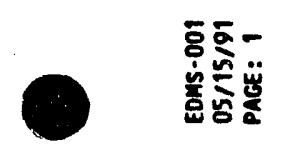
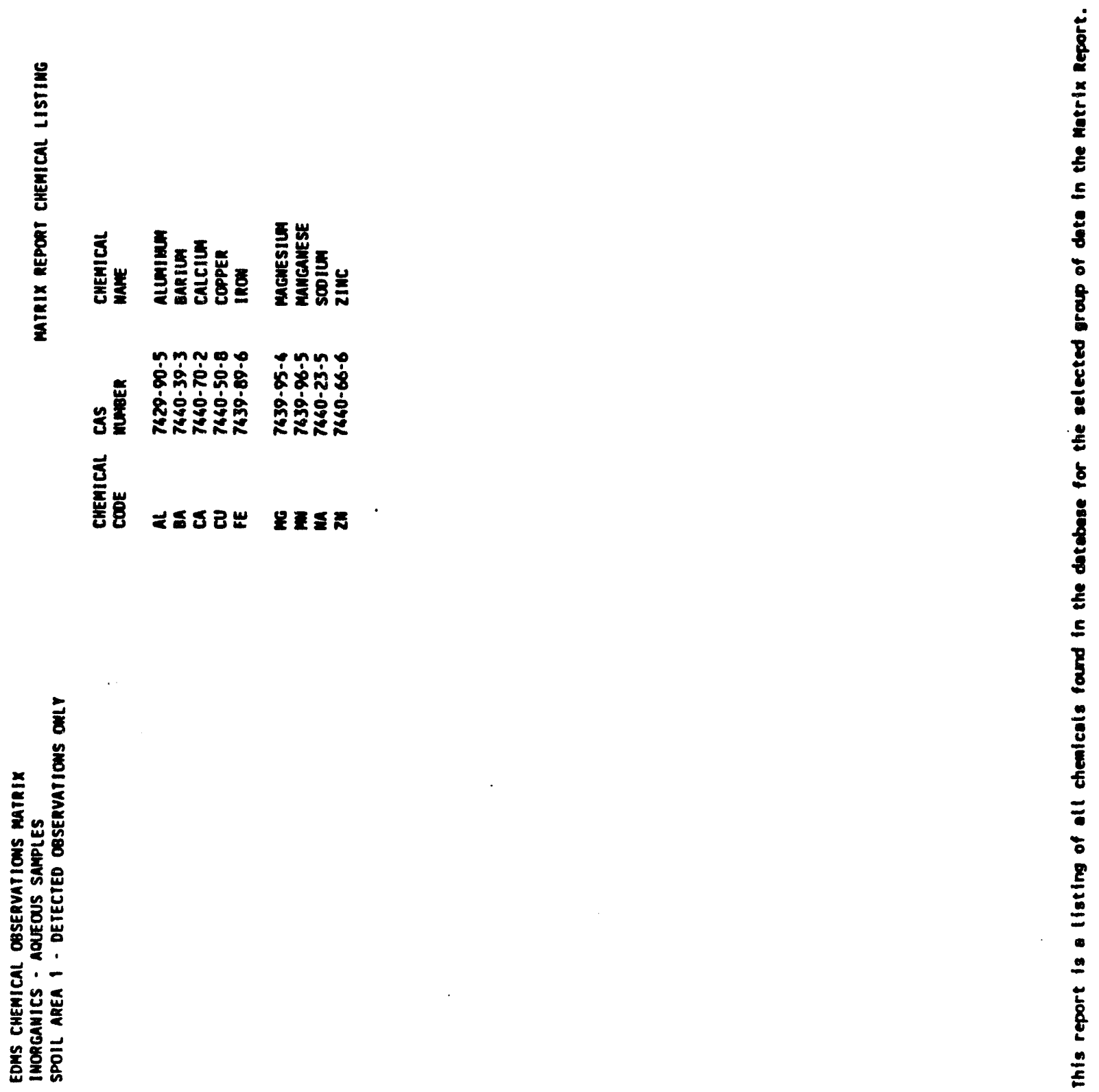


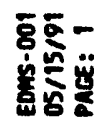

C-90

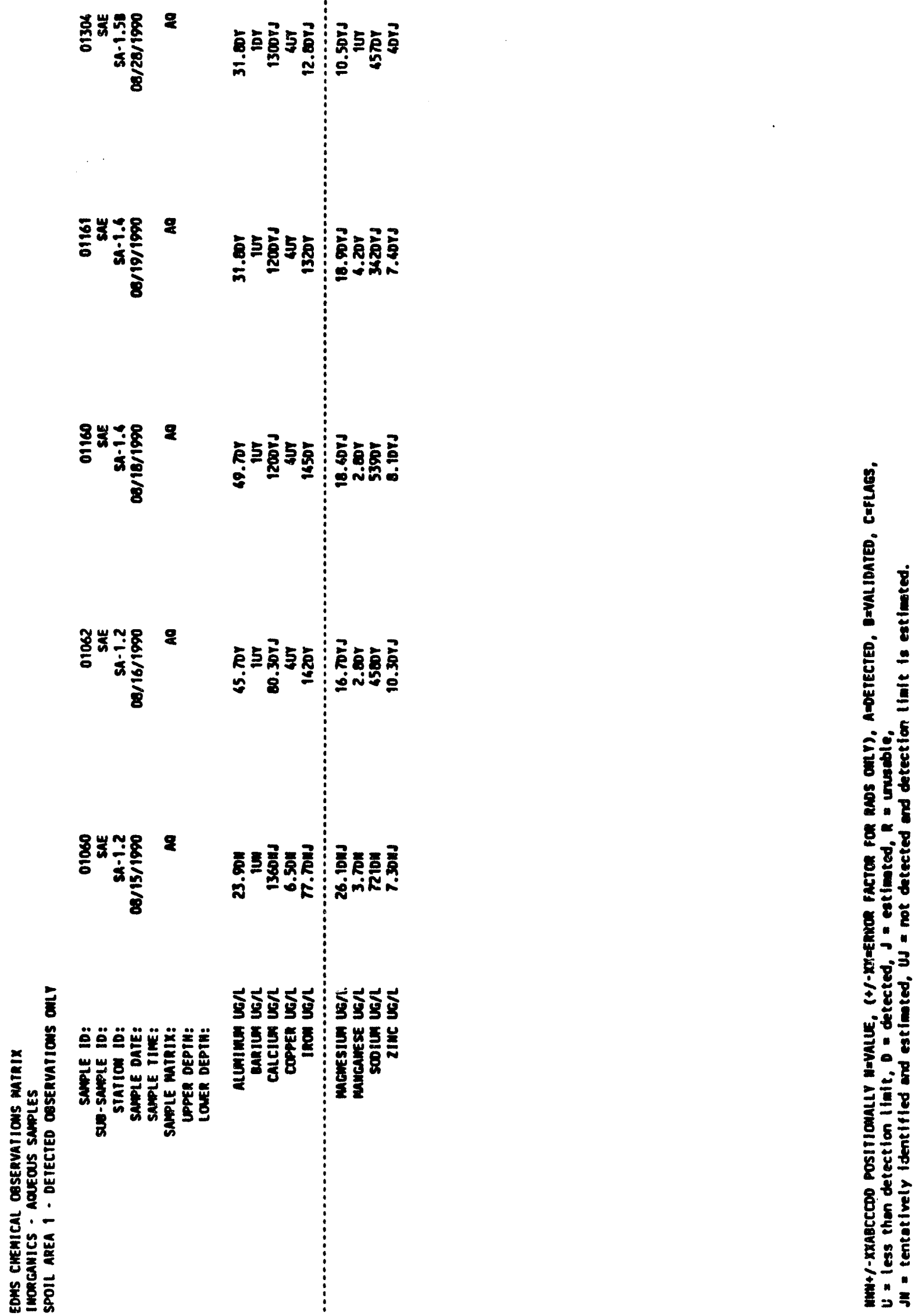




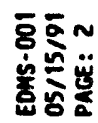

C-91
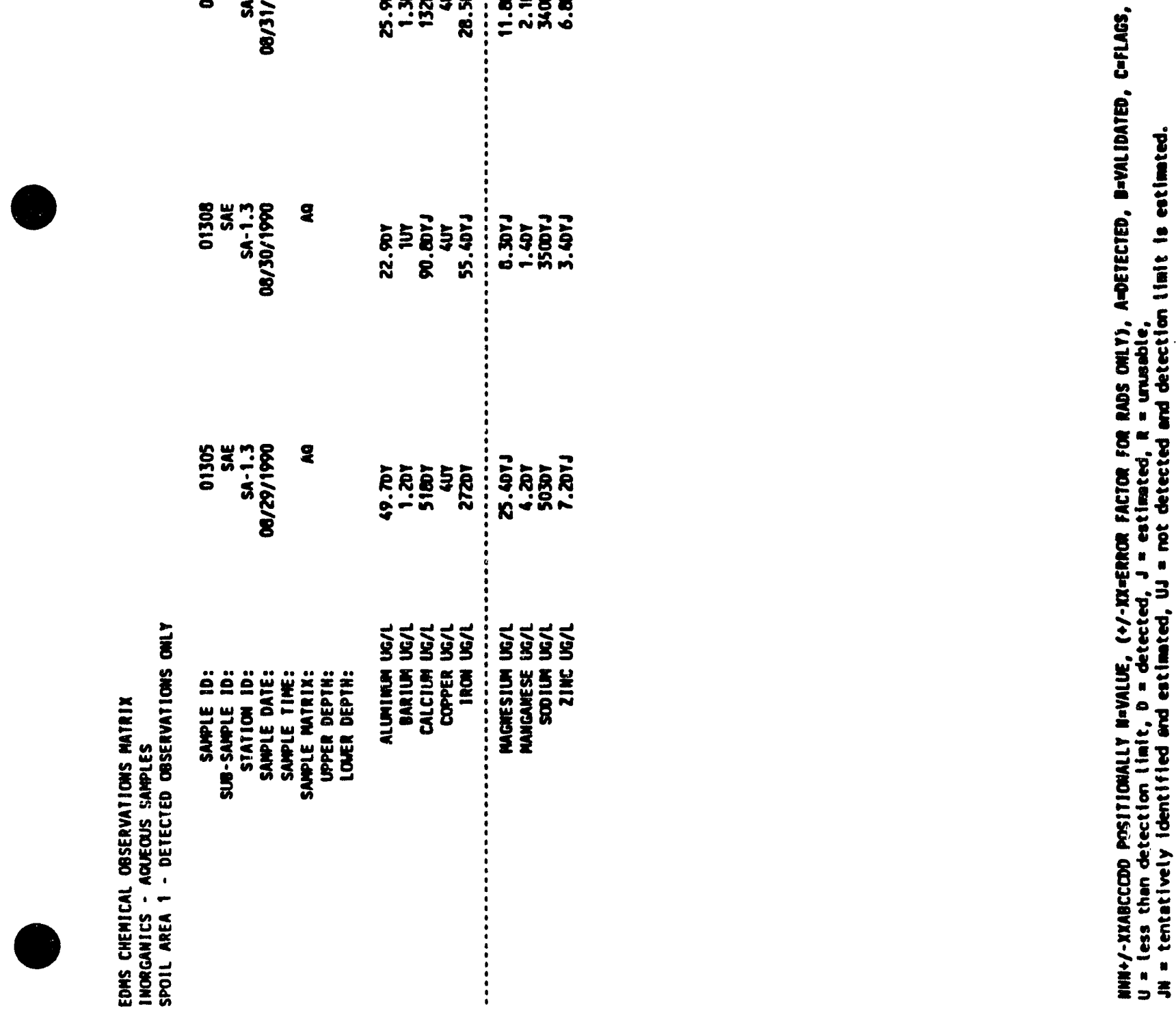
ธิ์

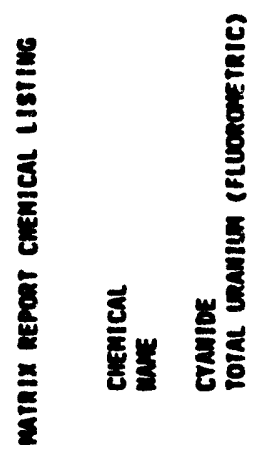

苛葛

害落

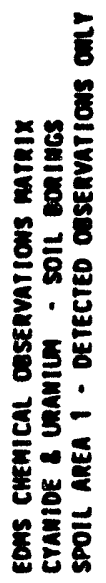




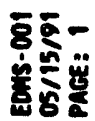

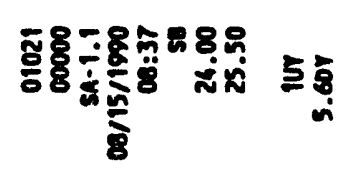

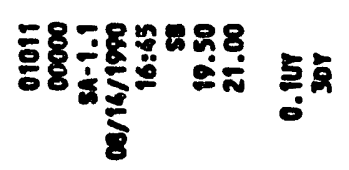

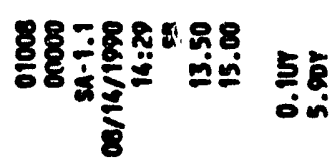

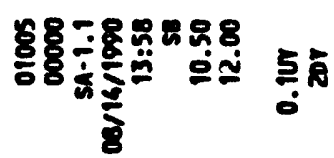

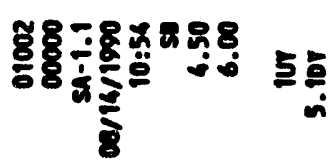
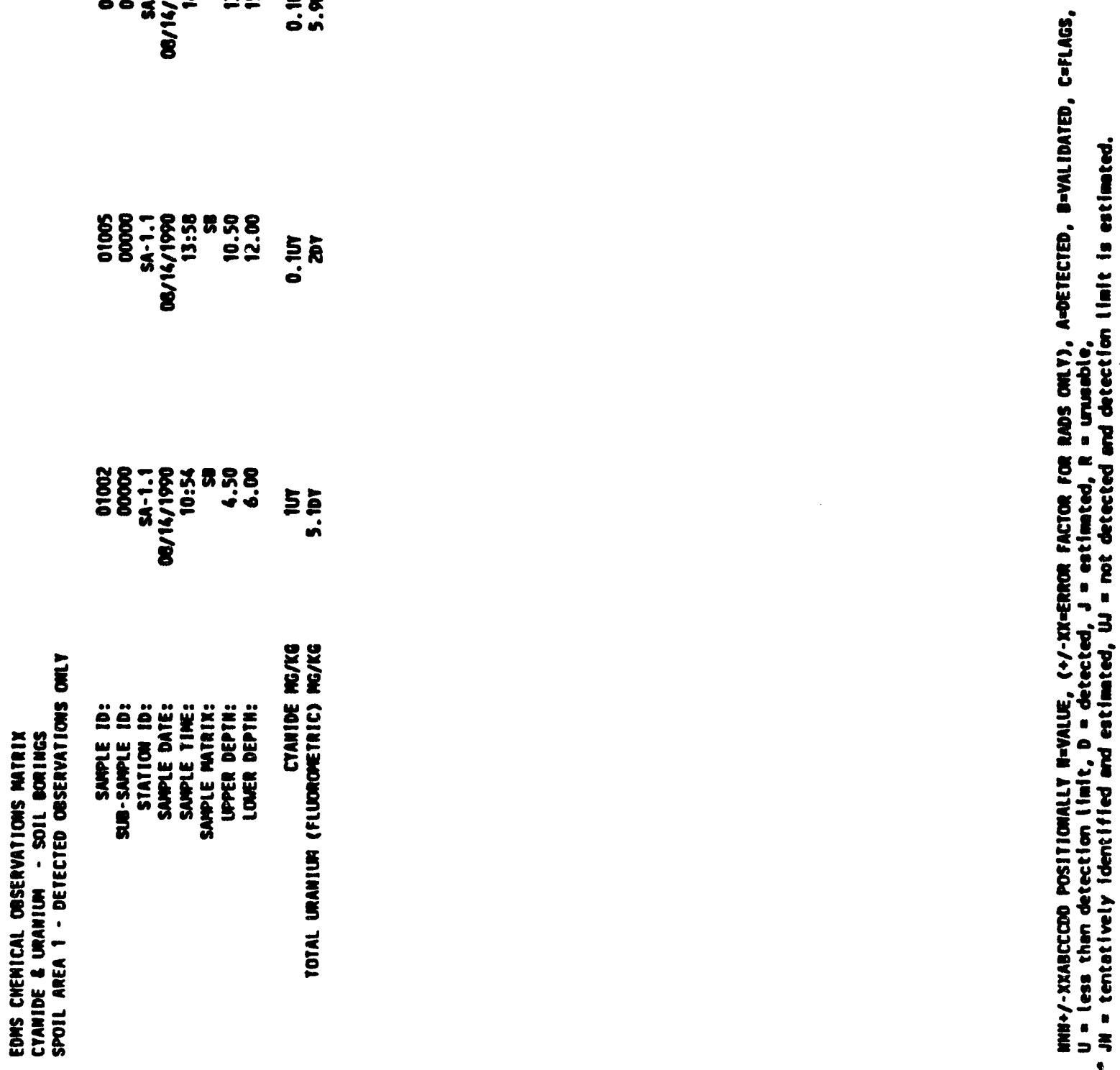
영영

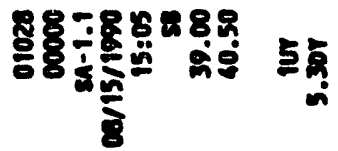

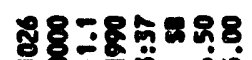

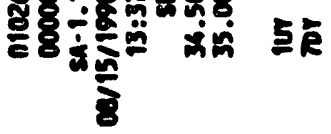

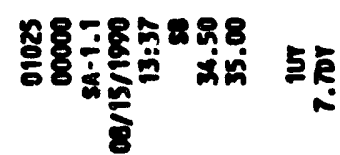

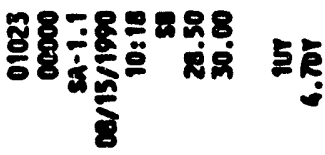

$\frac{8}{8}$

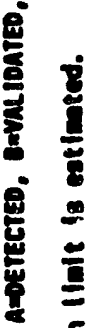

$\div \frac{8}{8}$

se

욜

8.

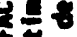

है

†:

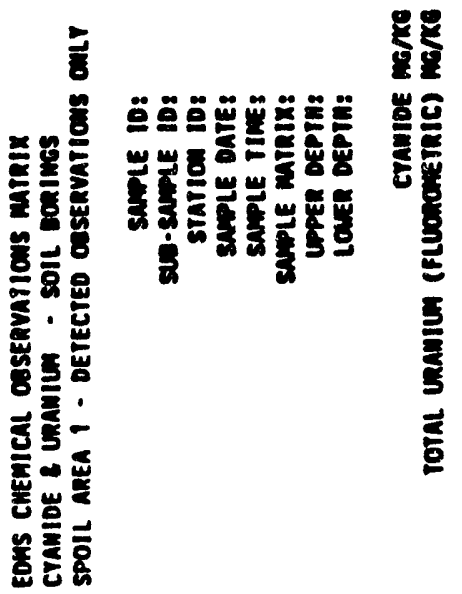

8 


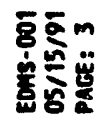

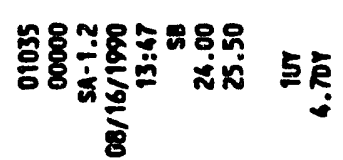

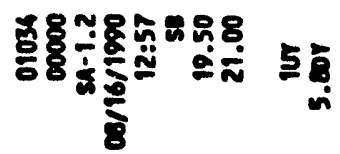

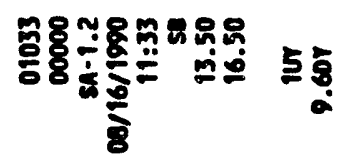

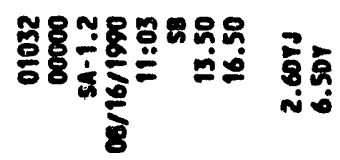

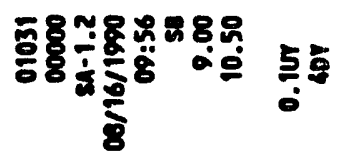
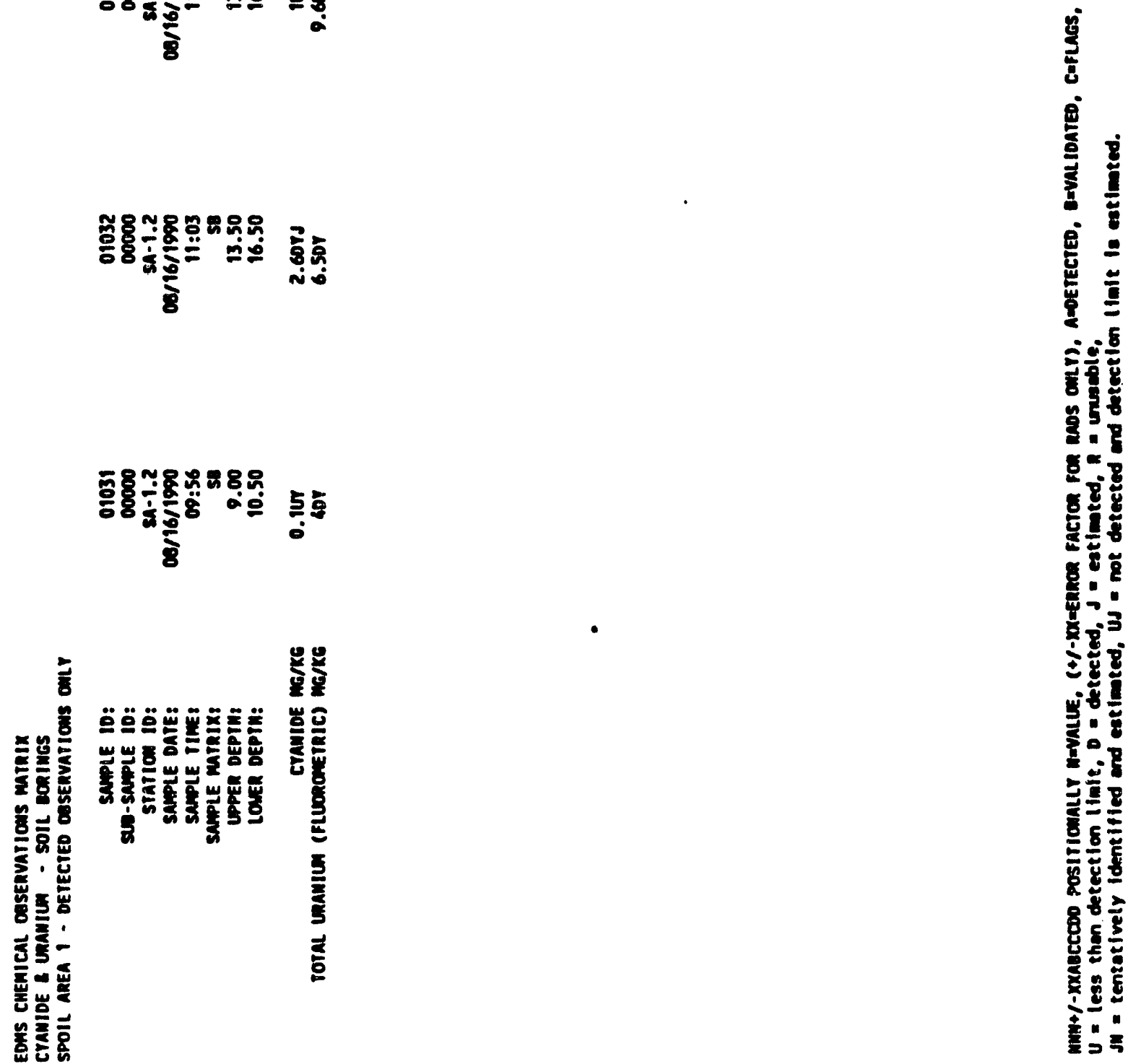
ธ̄ं

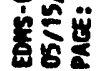

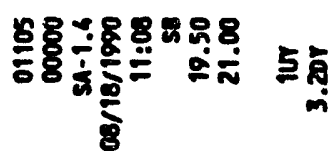

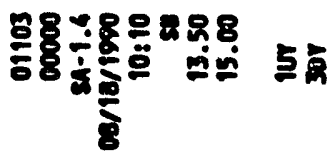

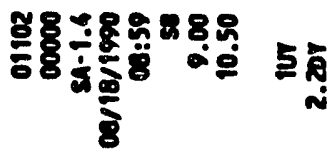

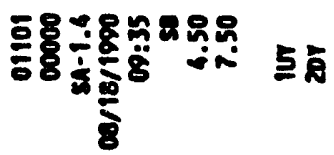

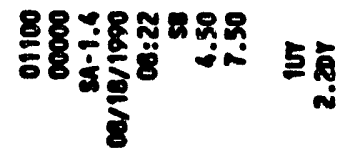

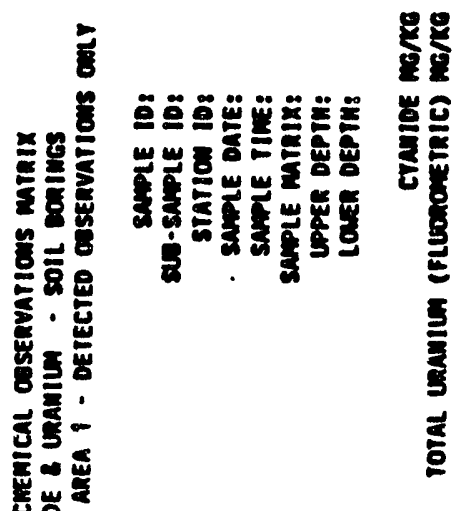

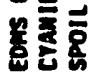

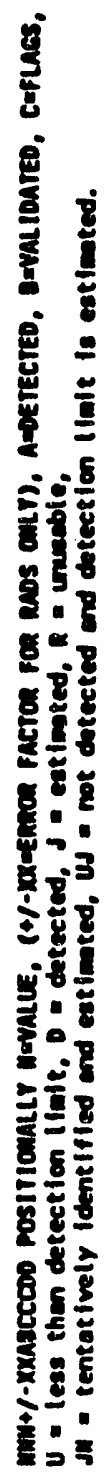


敢n

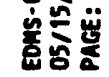

-

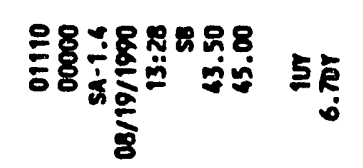

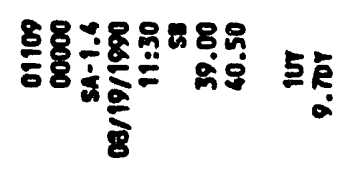

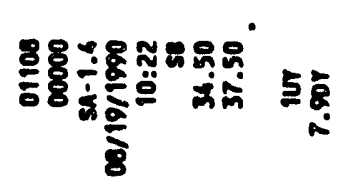

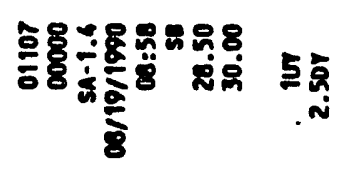

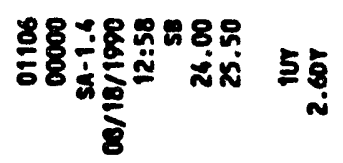
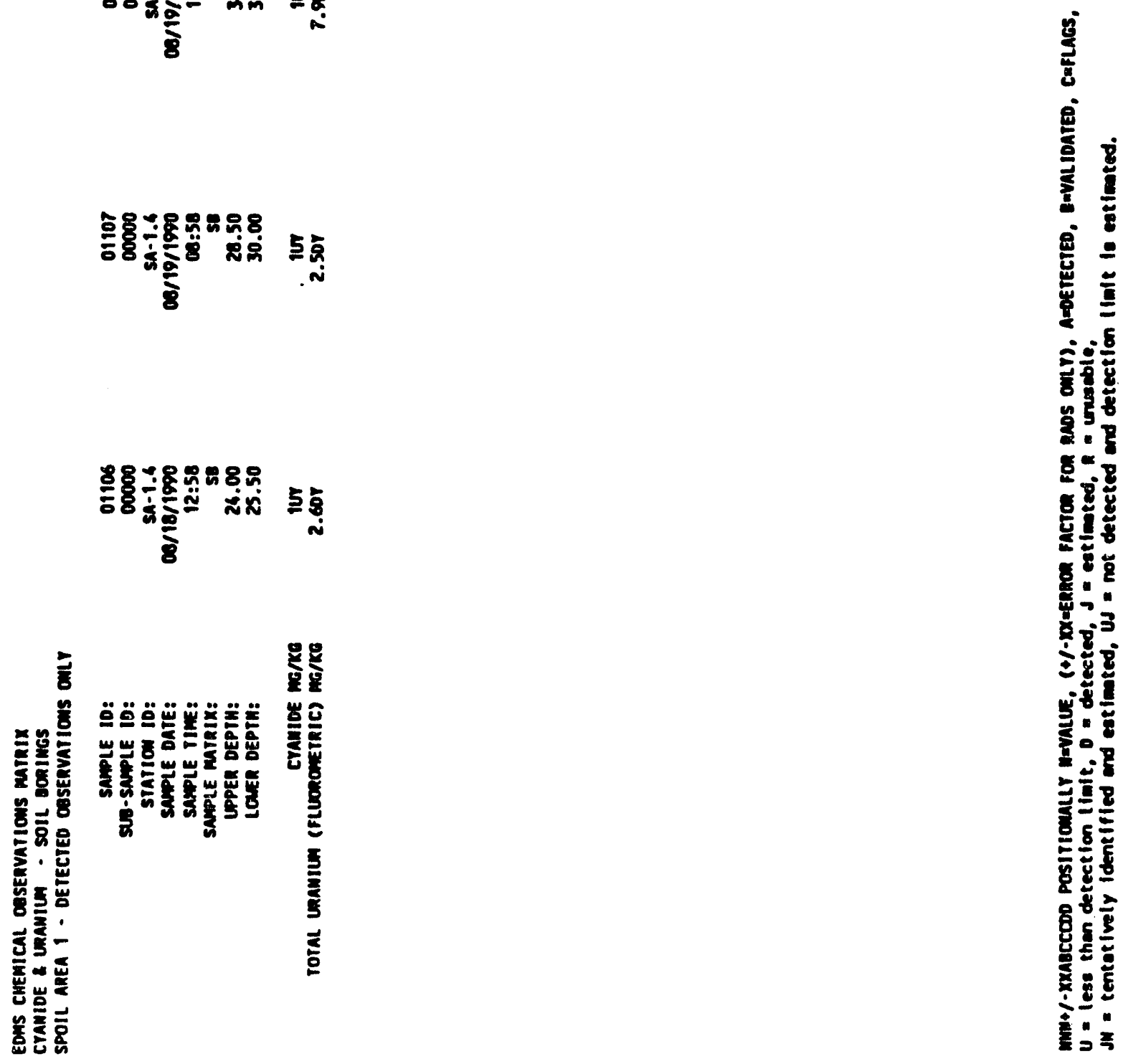


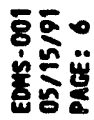

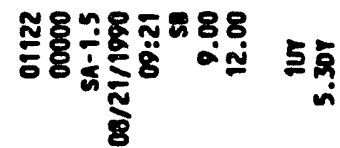

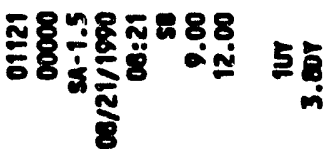

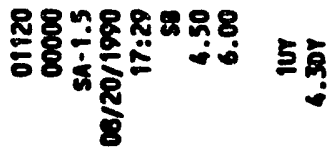

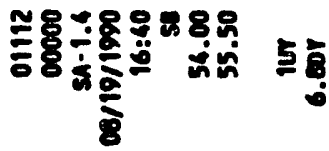

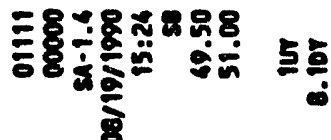

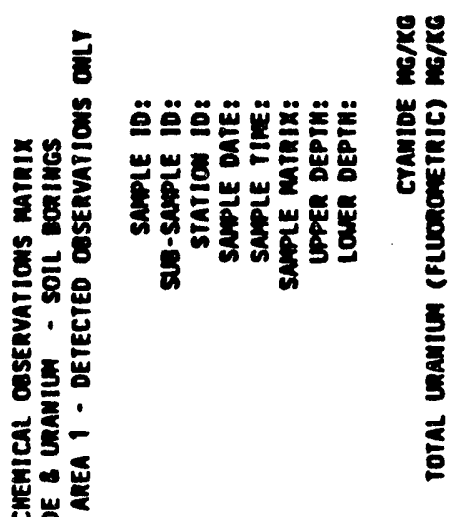

翣

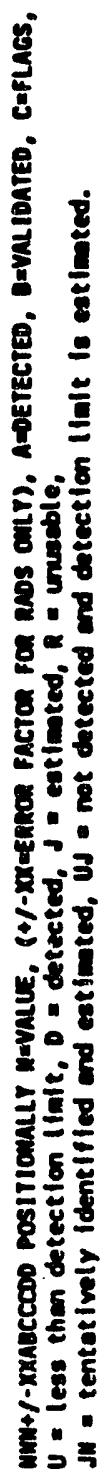




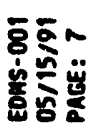

C-99

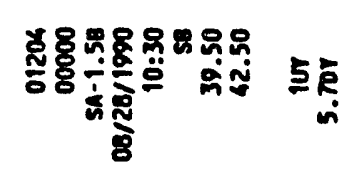

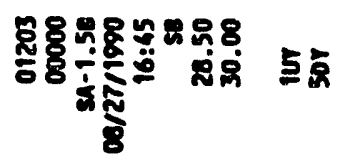

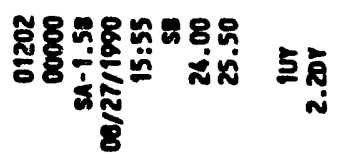

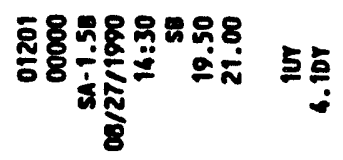

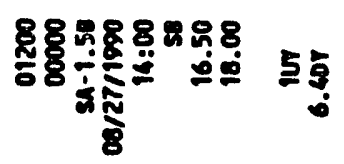
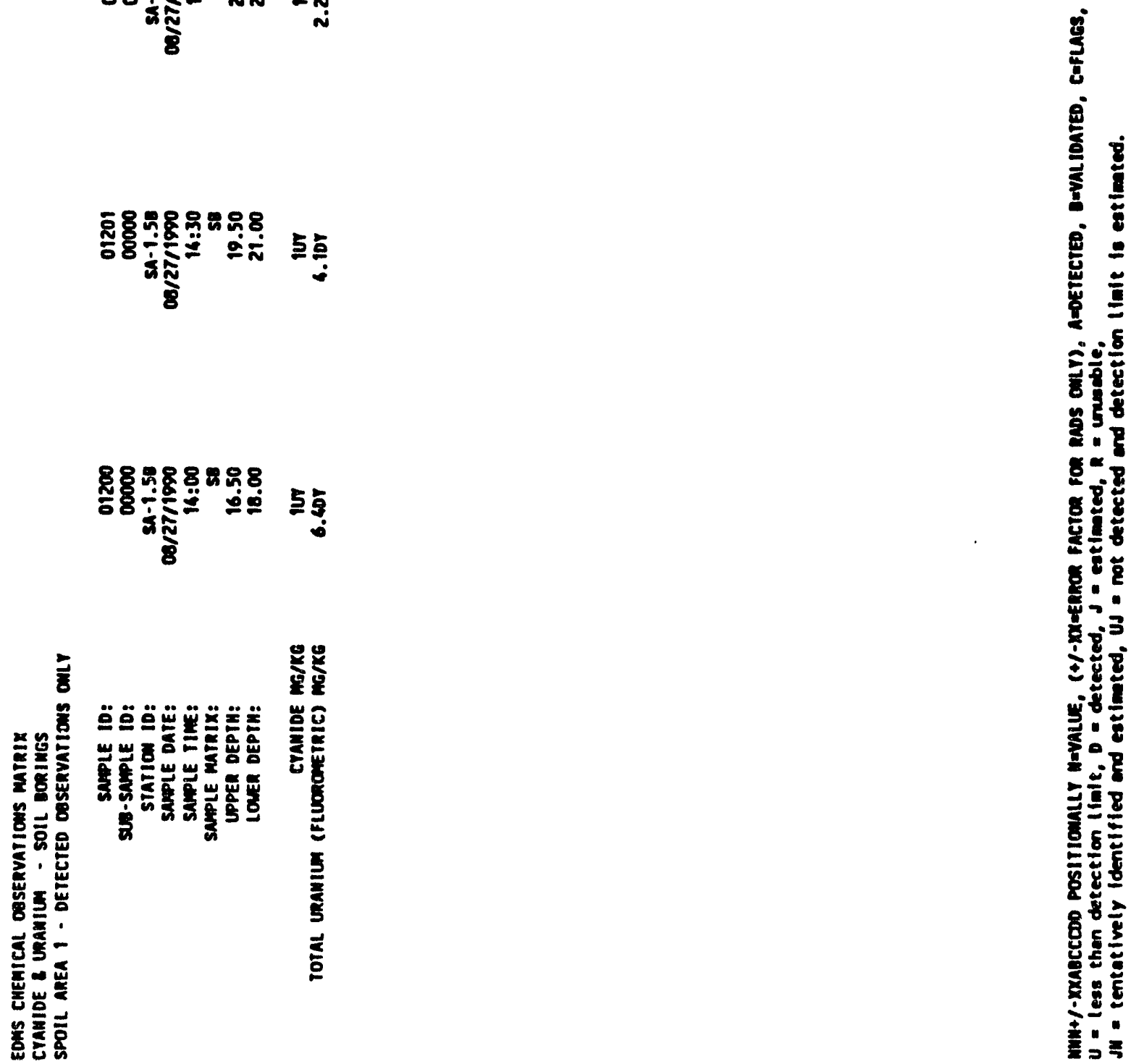


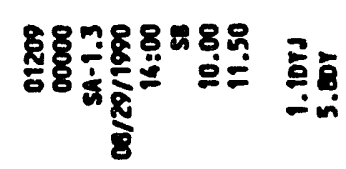

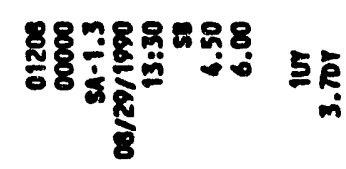

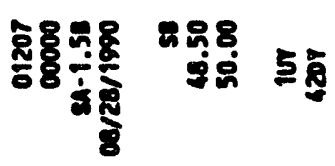

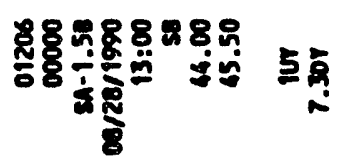

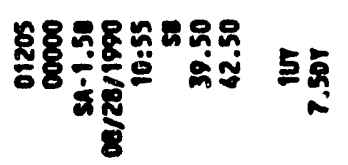
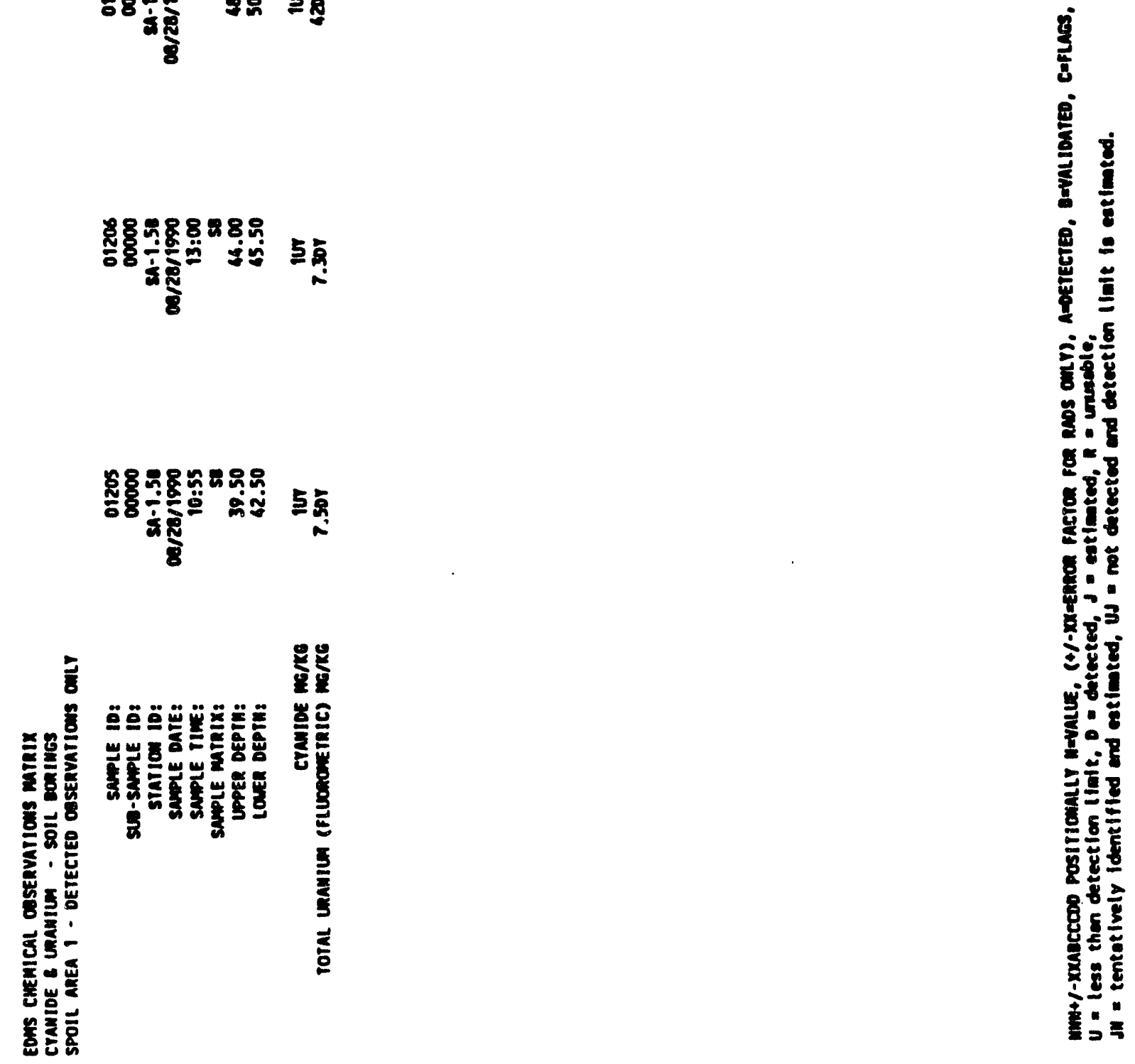


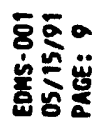

C-101

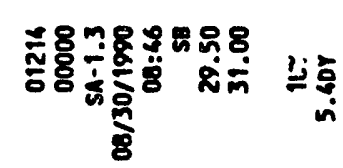

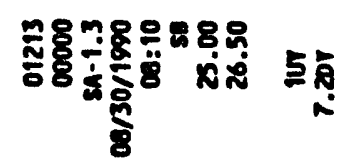

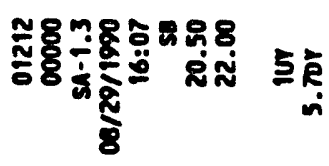

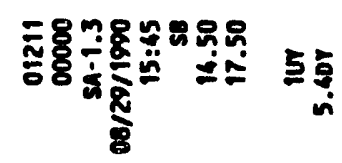

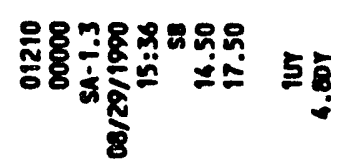

这

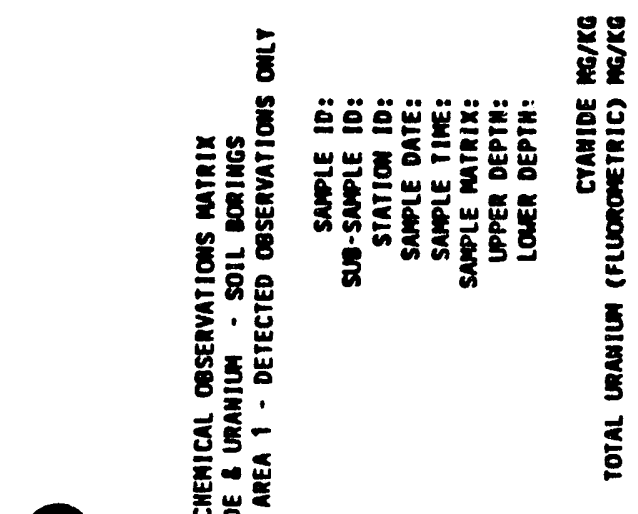

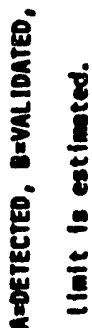

$\therefore 8$

8

है

8

을 


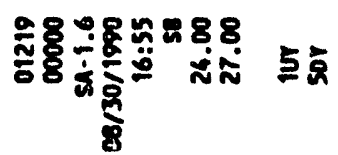

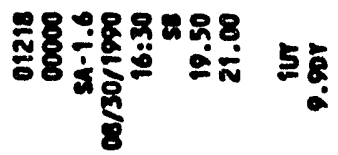

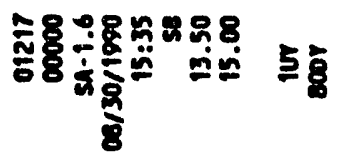

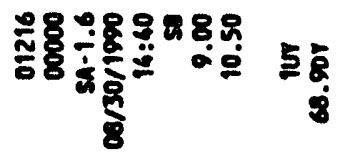

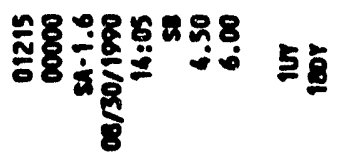
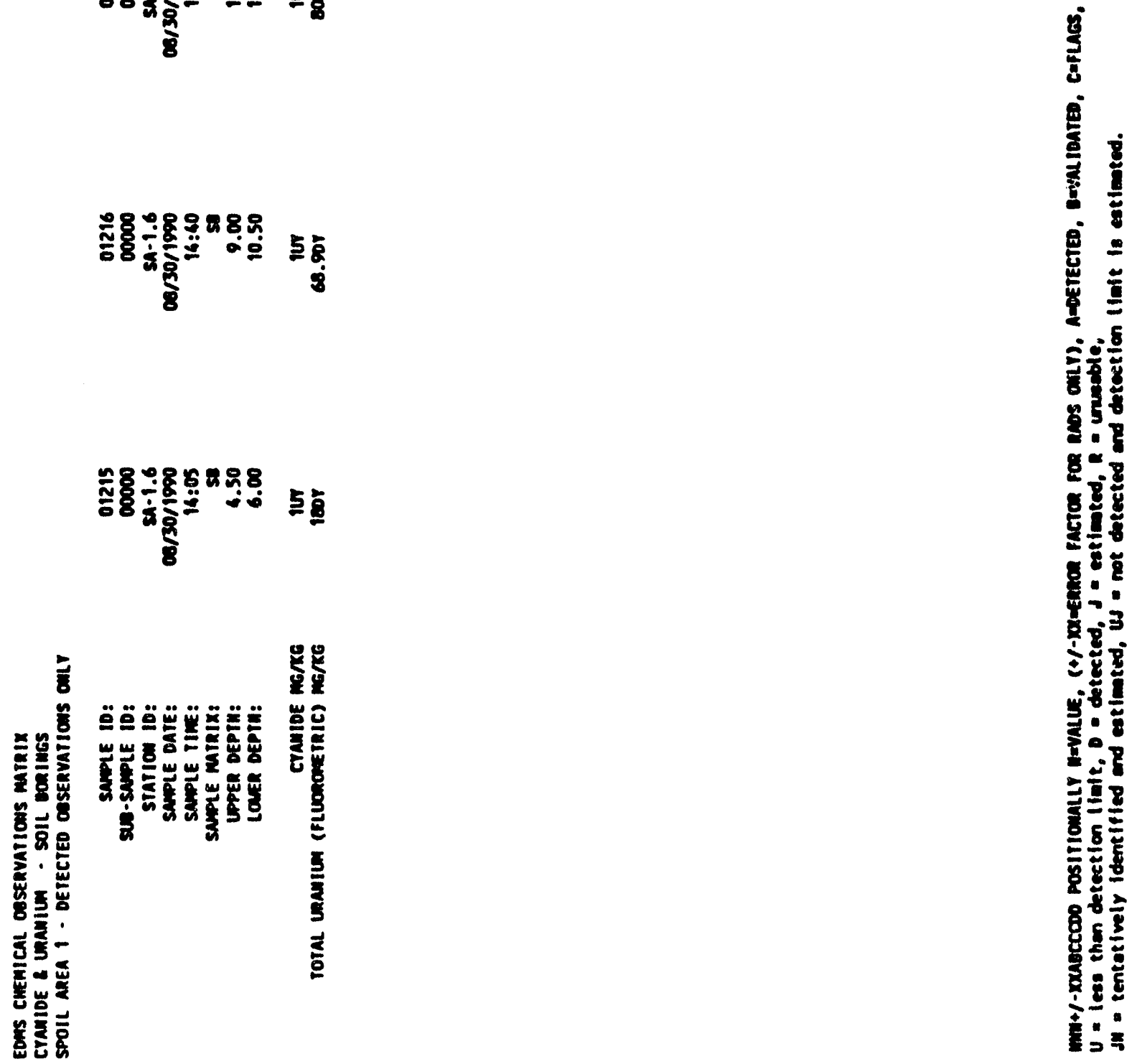
审交=

C-103

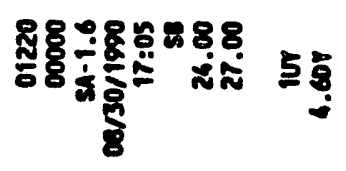
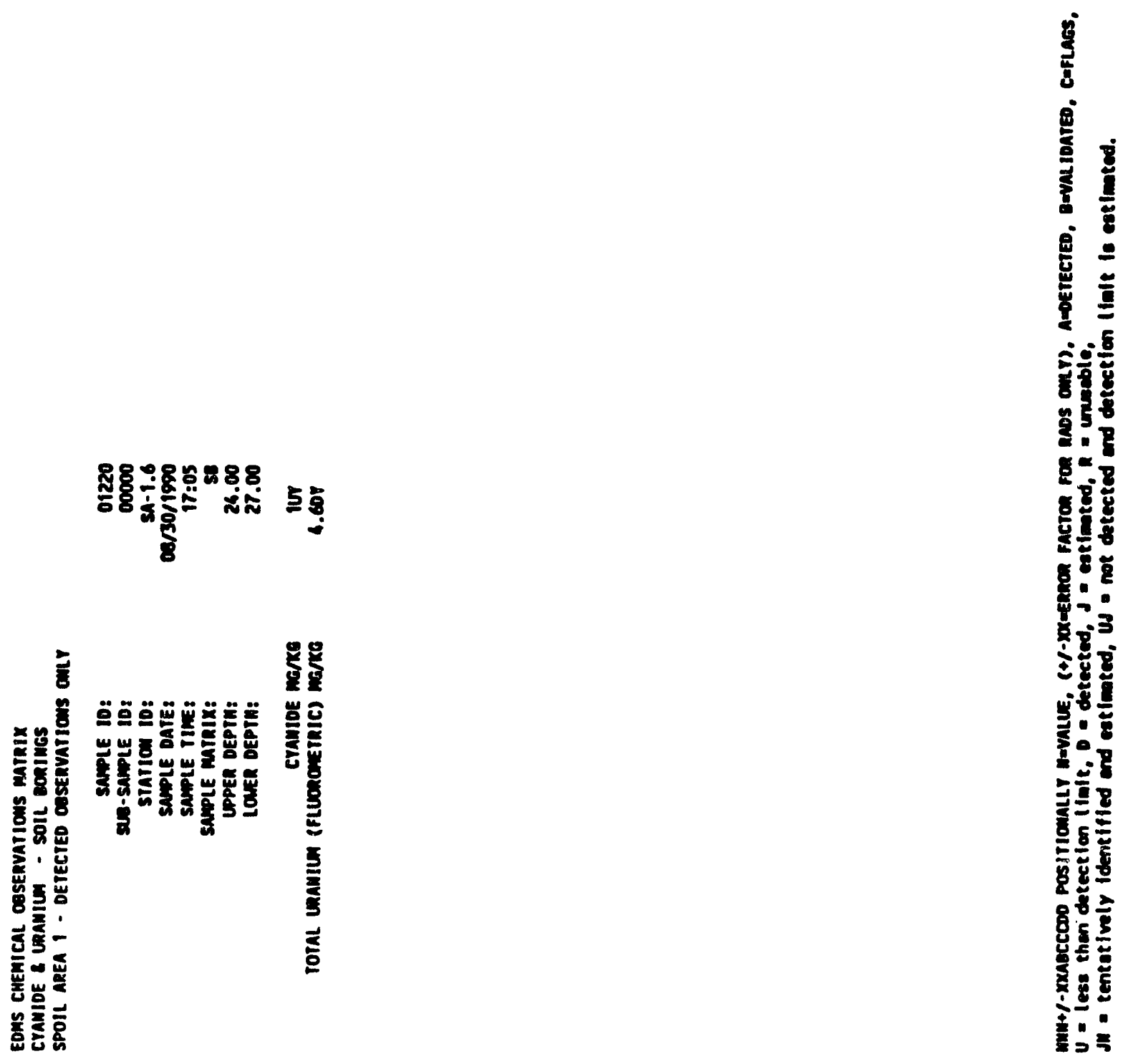


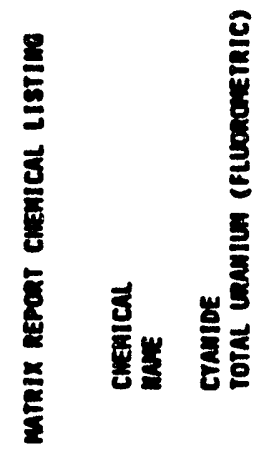

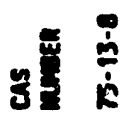
尊岁

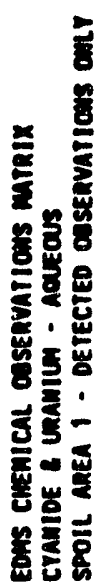


容哥-

\section{C-105}

总哭高紊

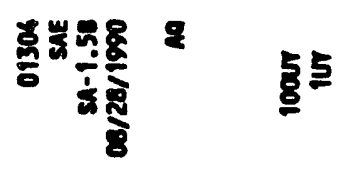

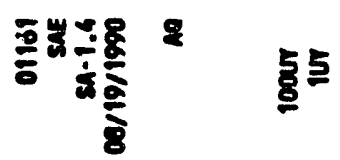

응

ชัตั้
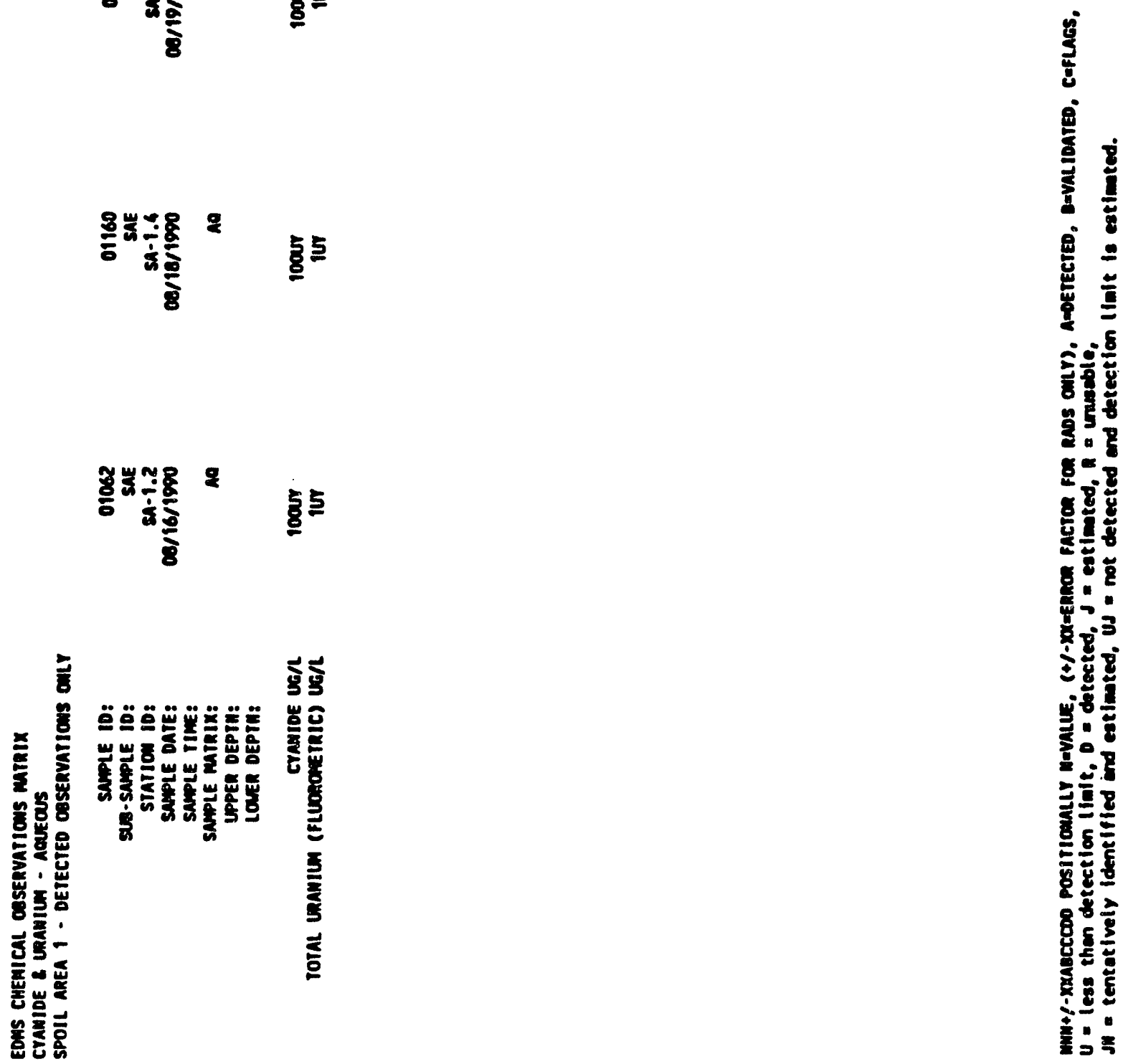

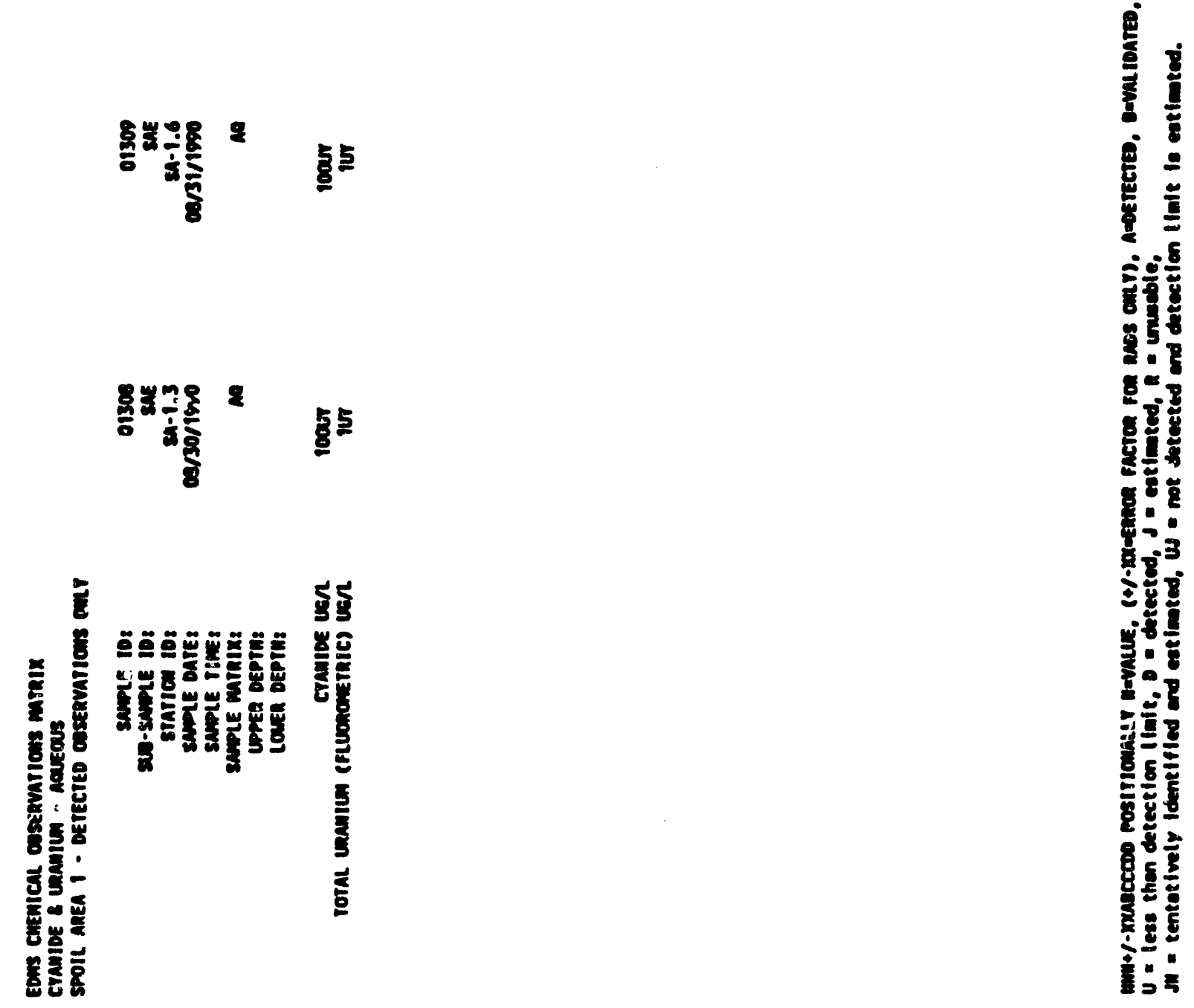


\section{C-107}

\section{-}
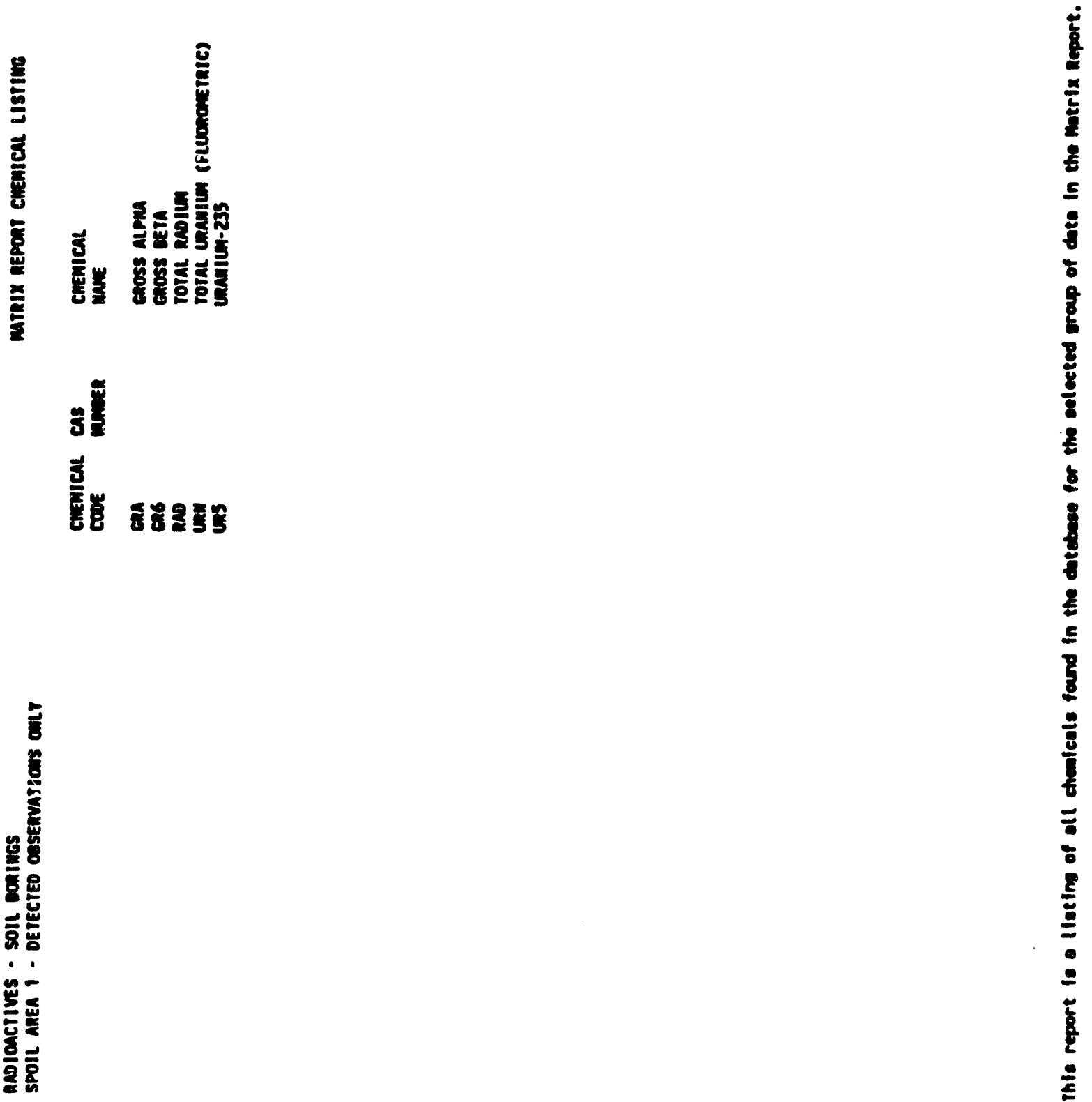
C-108

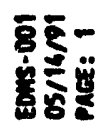

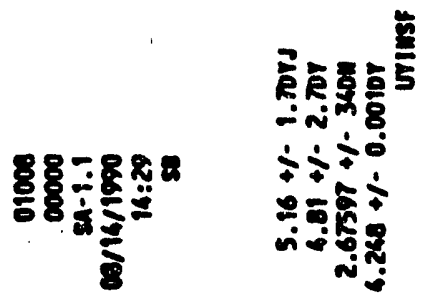

1

$\frac{8}{8}$

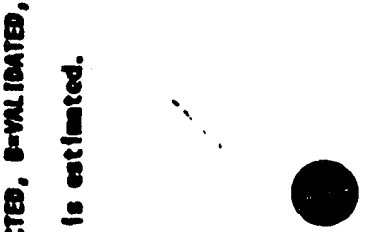

8

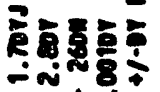

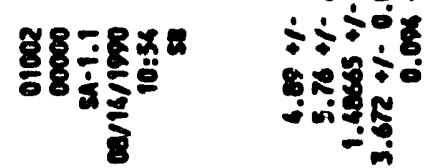

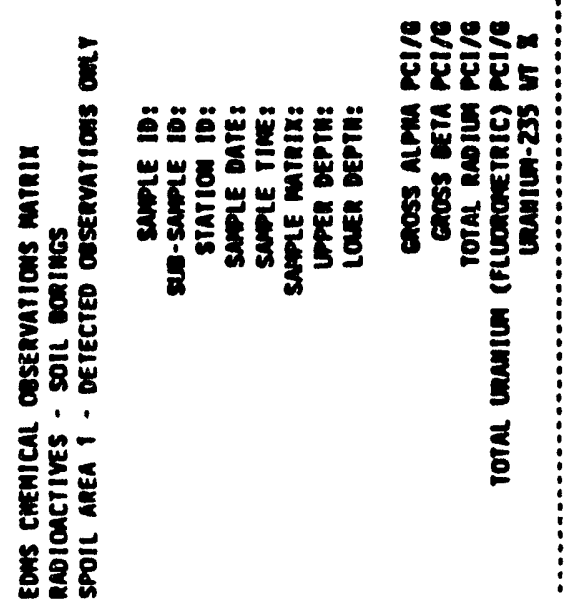




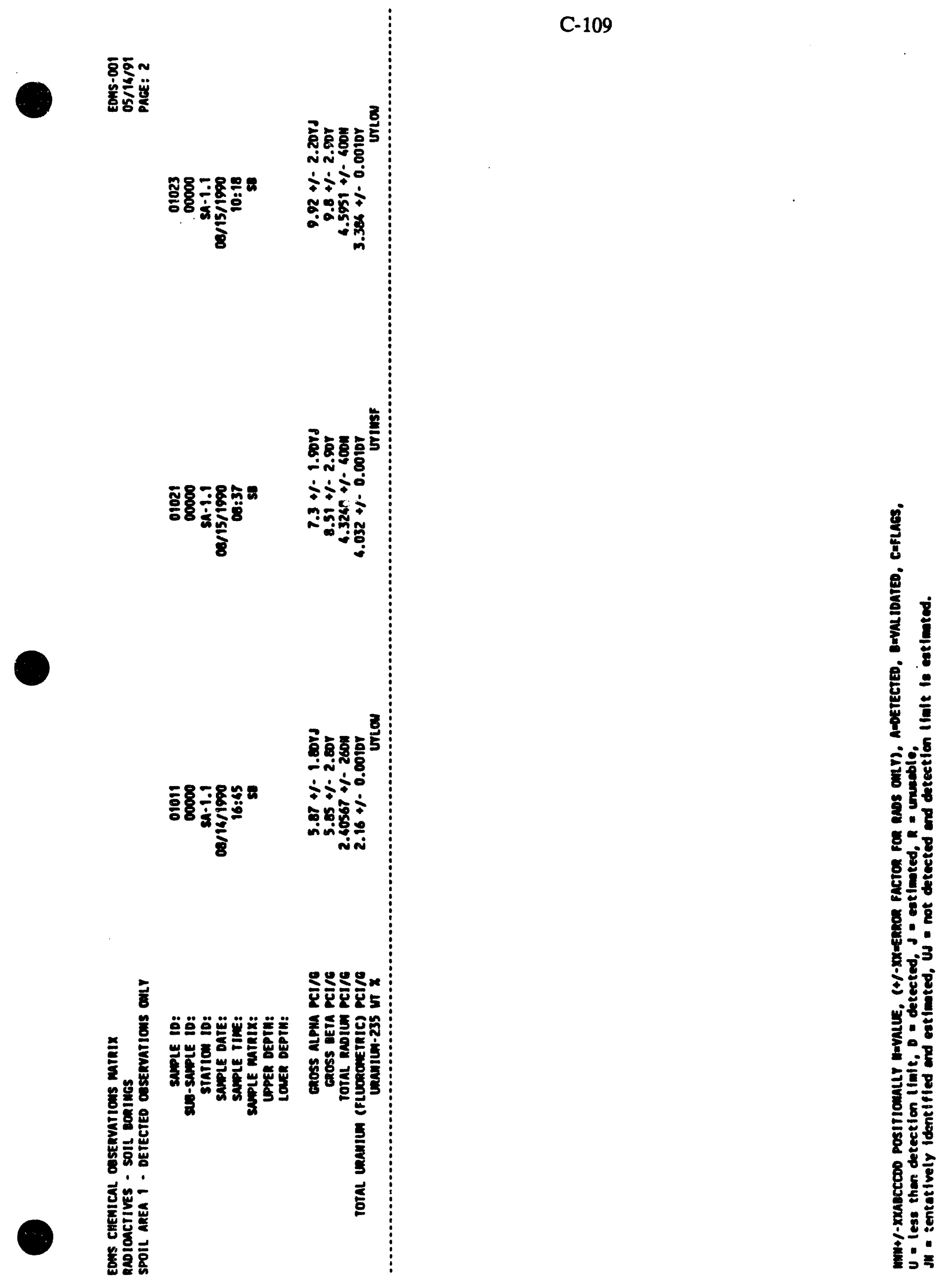




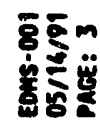

C-110
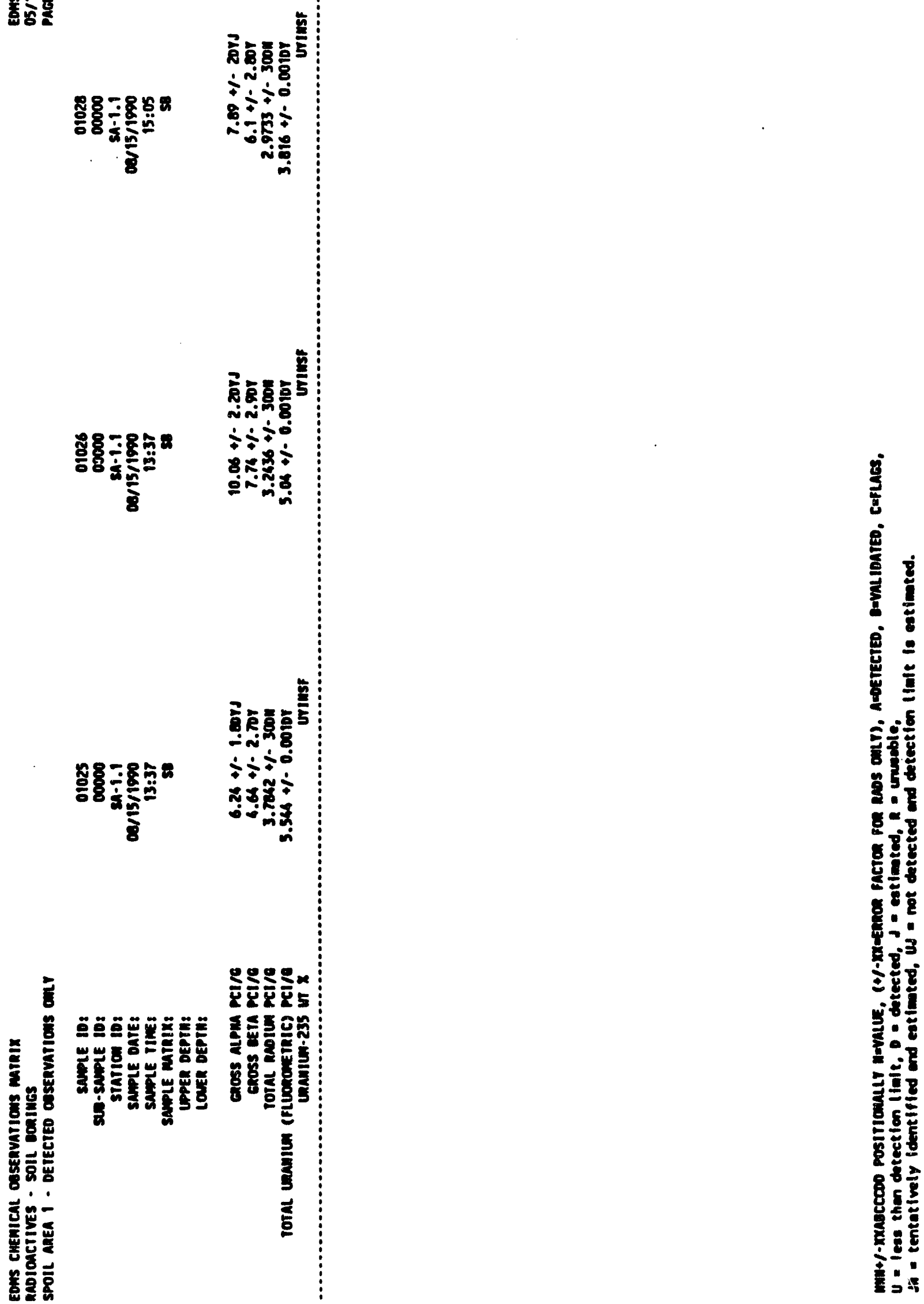


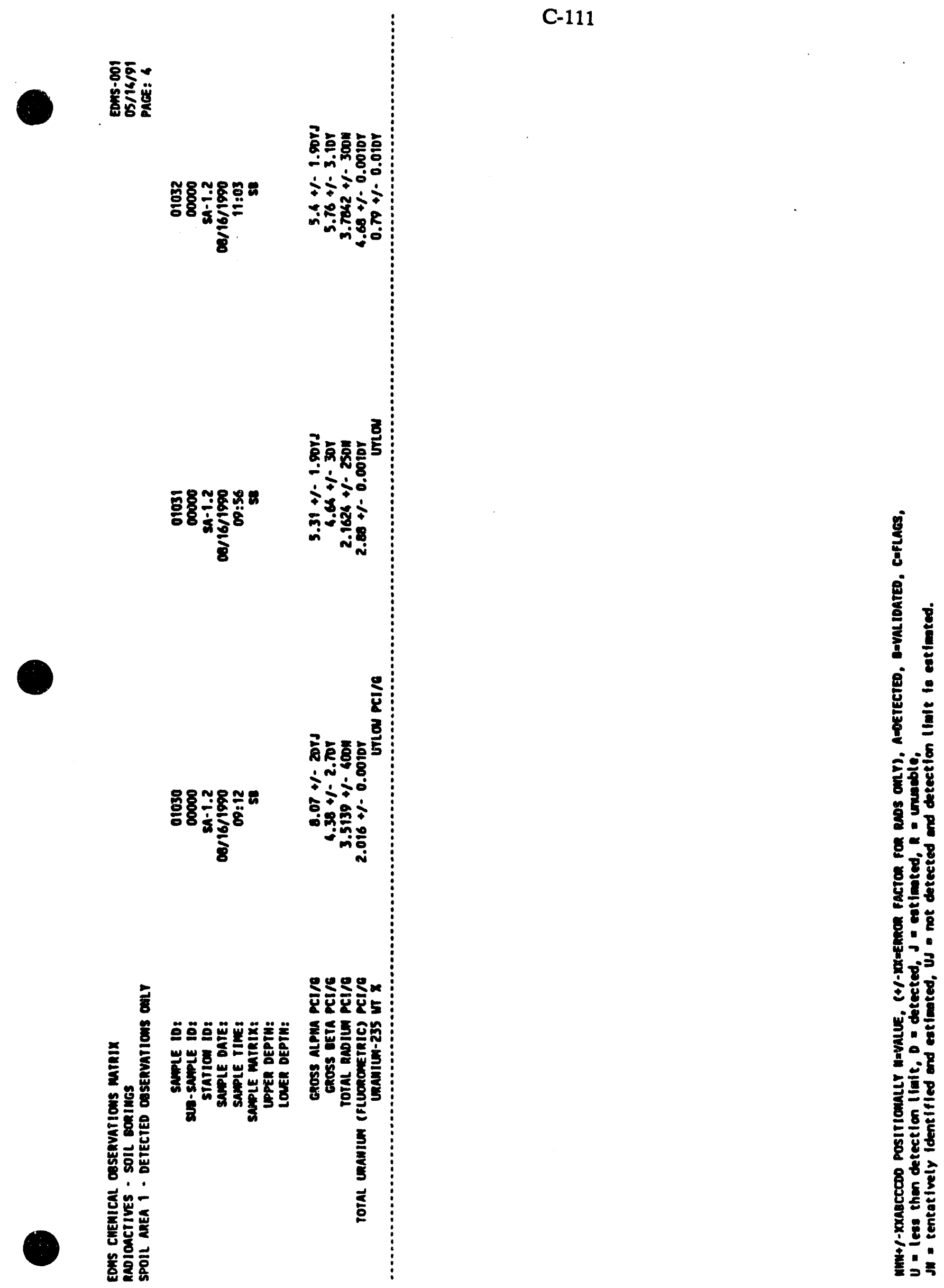




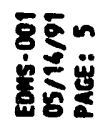

C-112

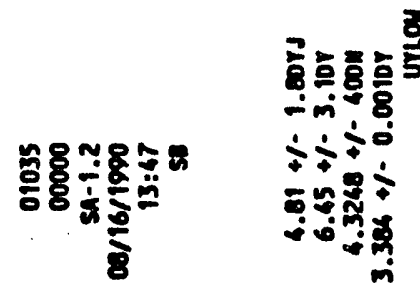

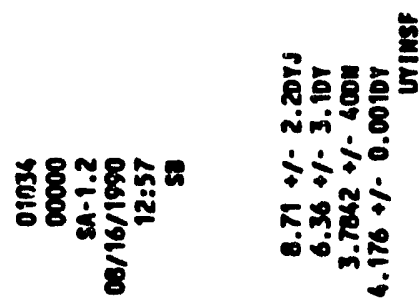

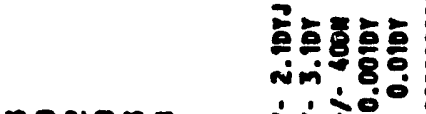

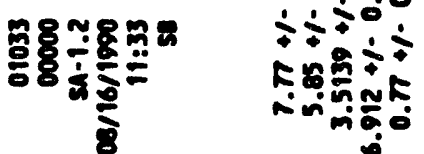
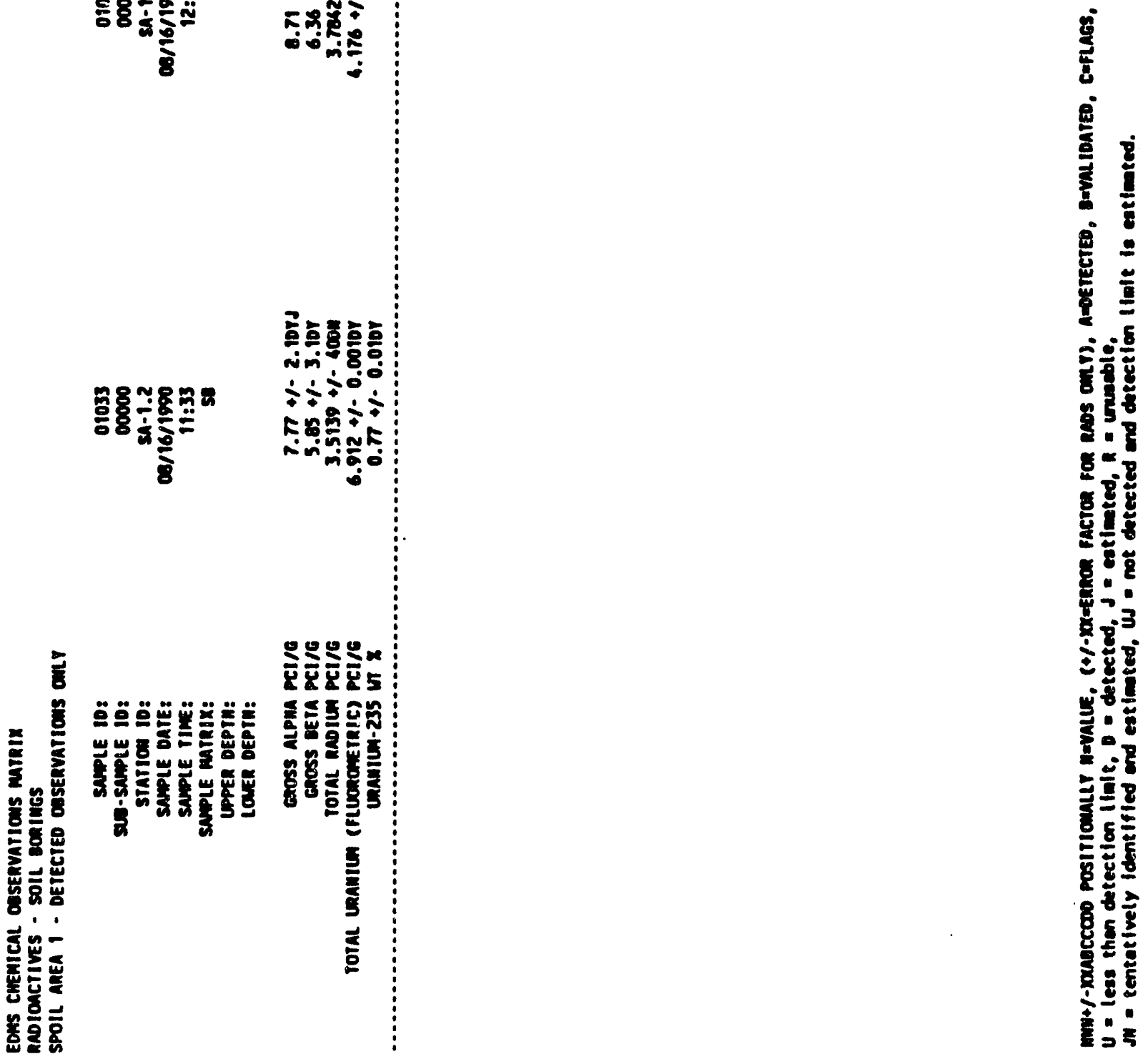


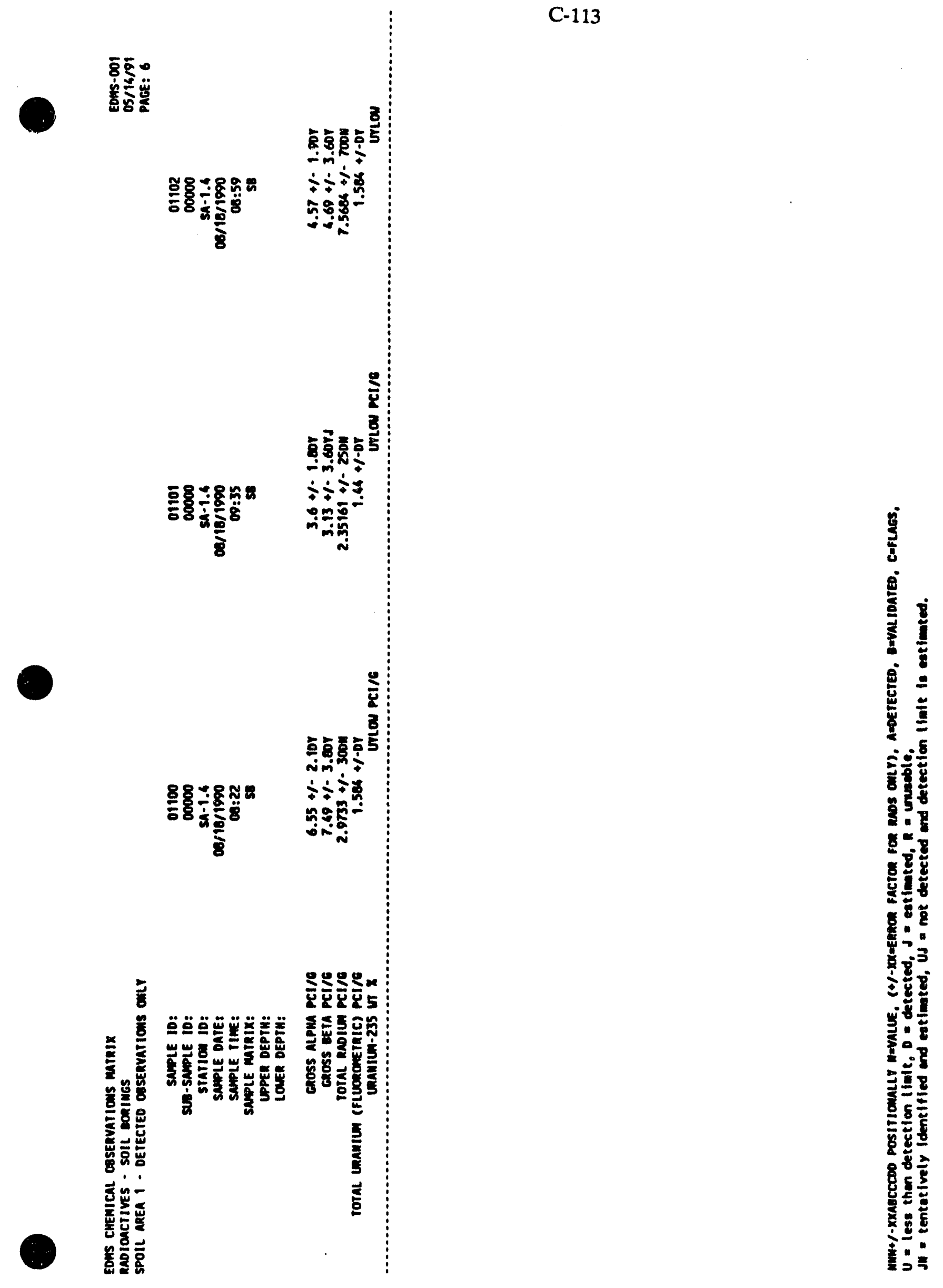




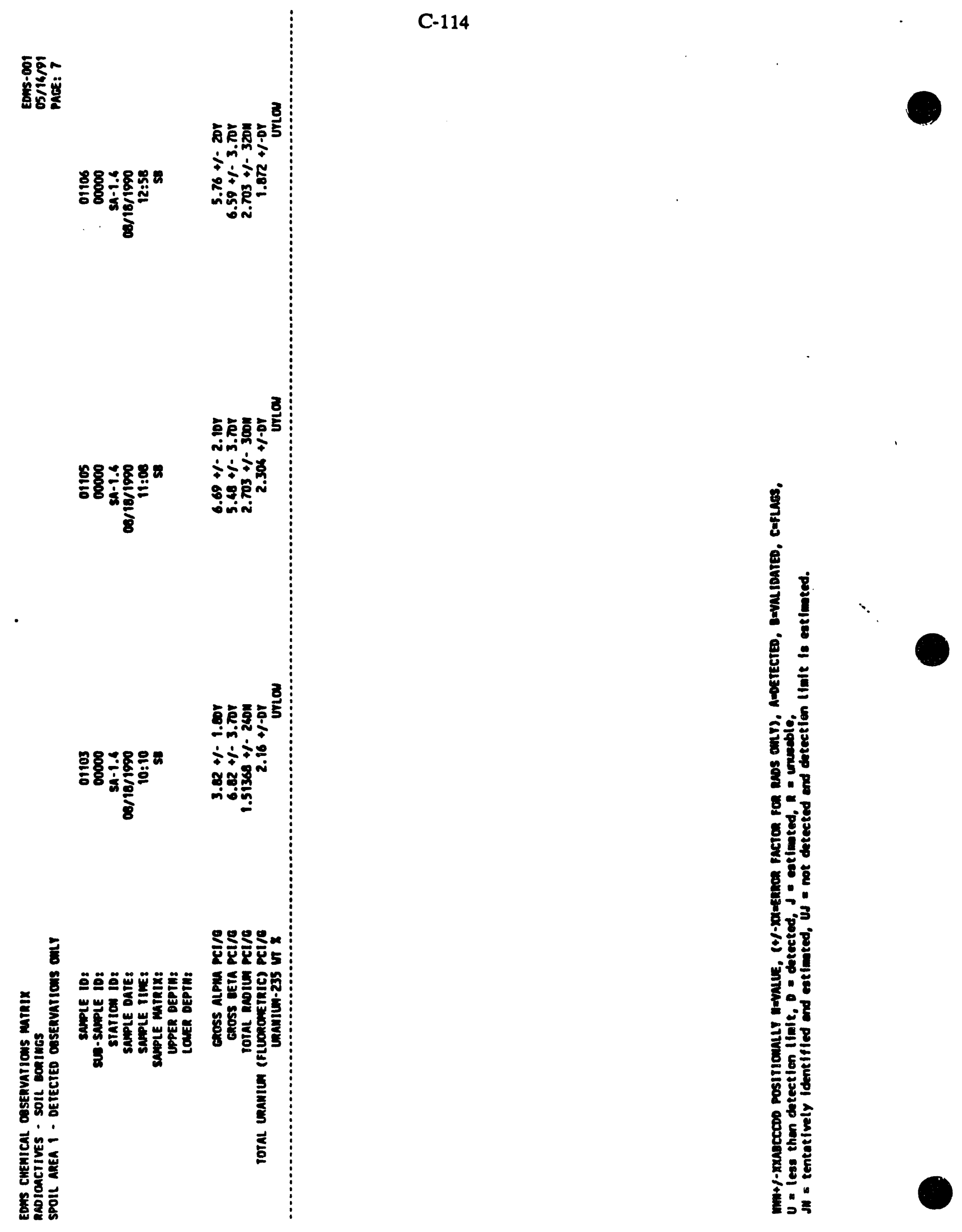




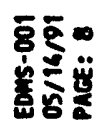

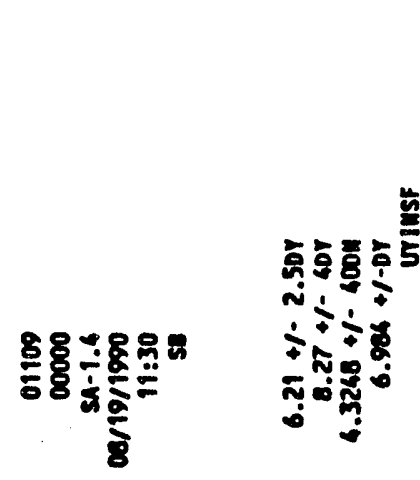

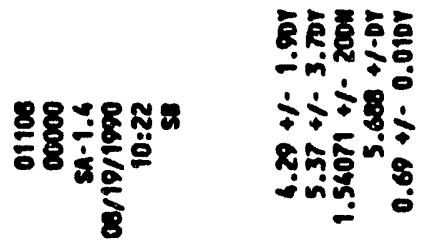

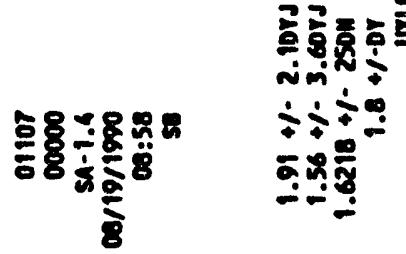
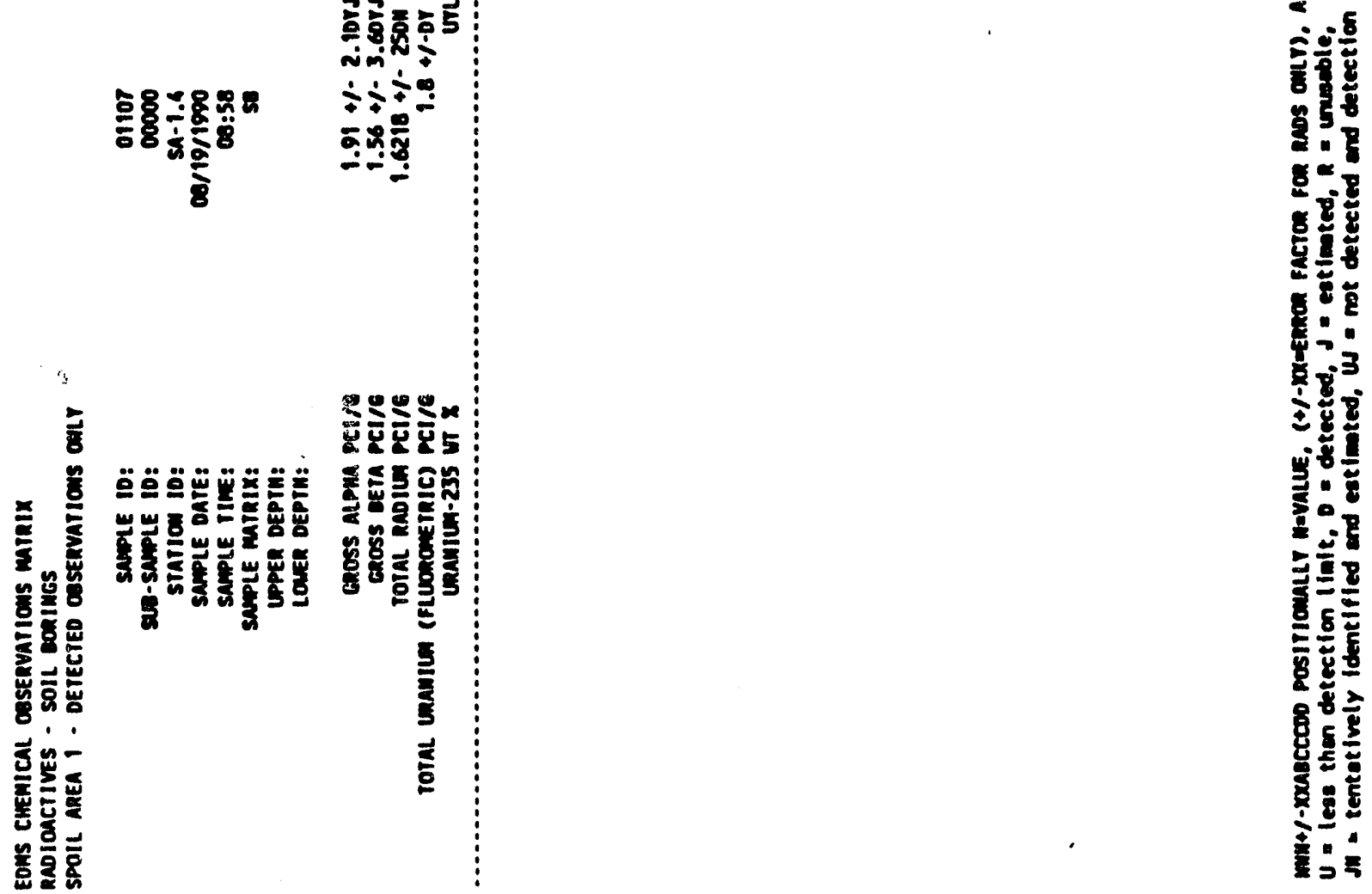


\section{C-116}

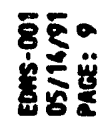

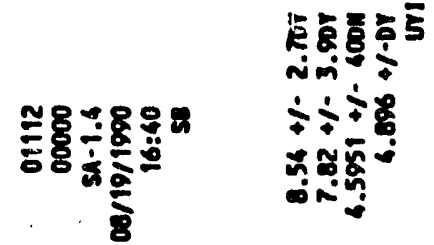

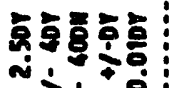

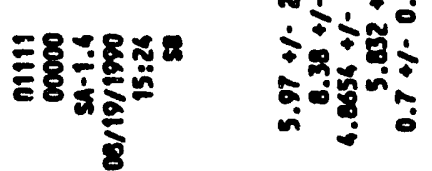

छे

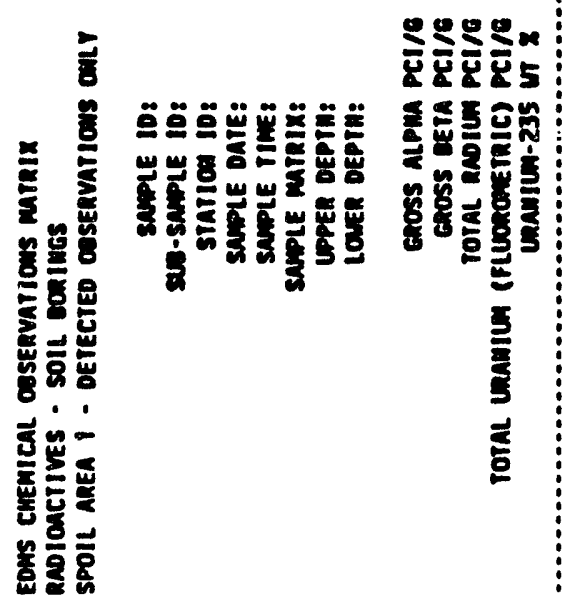

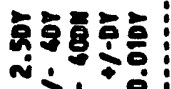

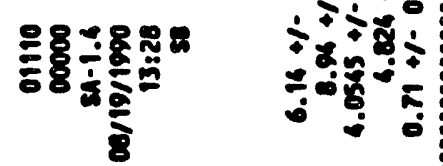

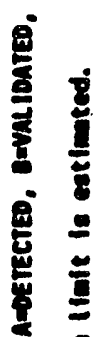

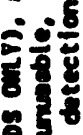

․ 5

8

है

: :

8

过

है 


\section{C-117}

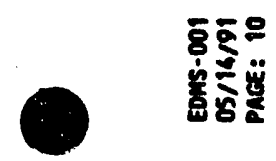

min

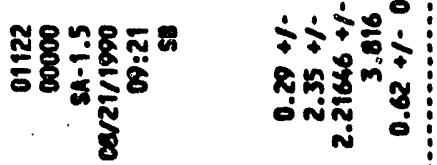

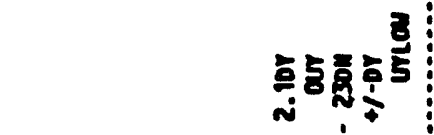

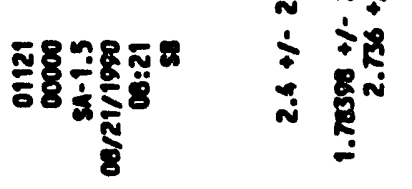

$\frac{8}{8}$

兽

案

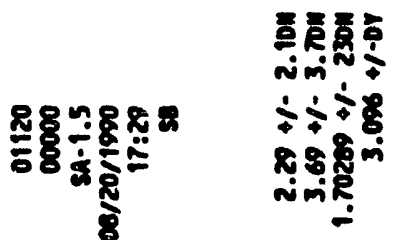

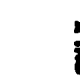

2925

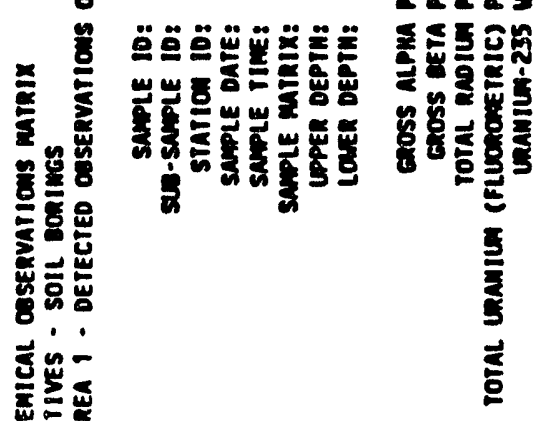

!

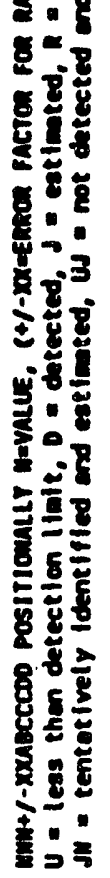


C-118

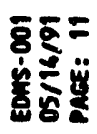

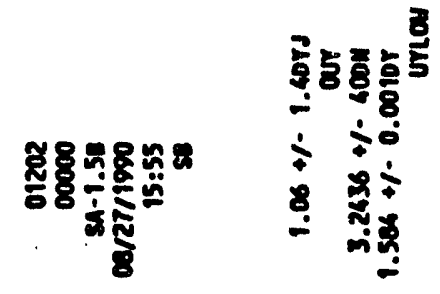

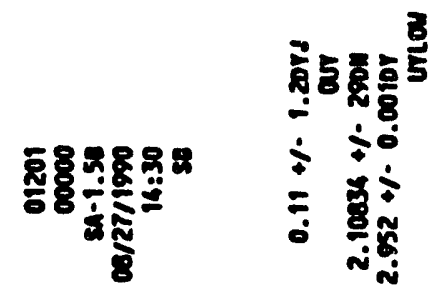

t)

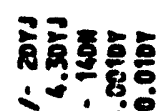

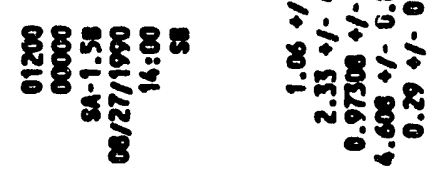
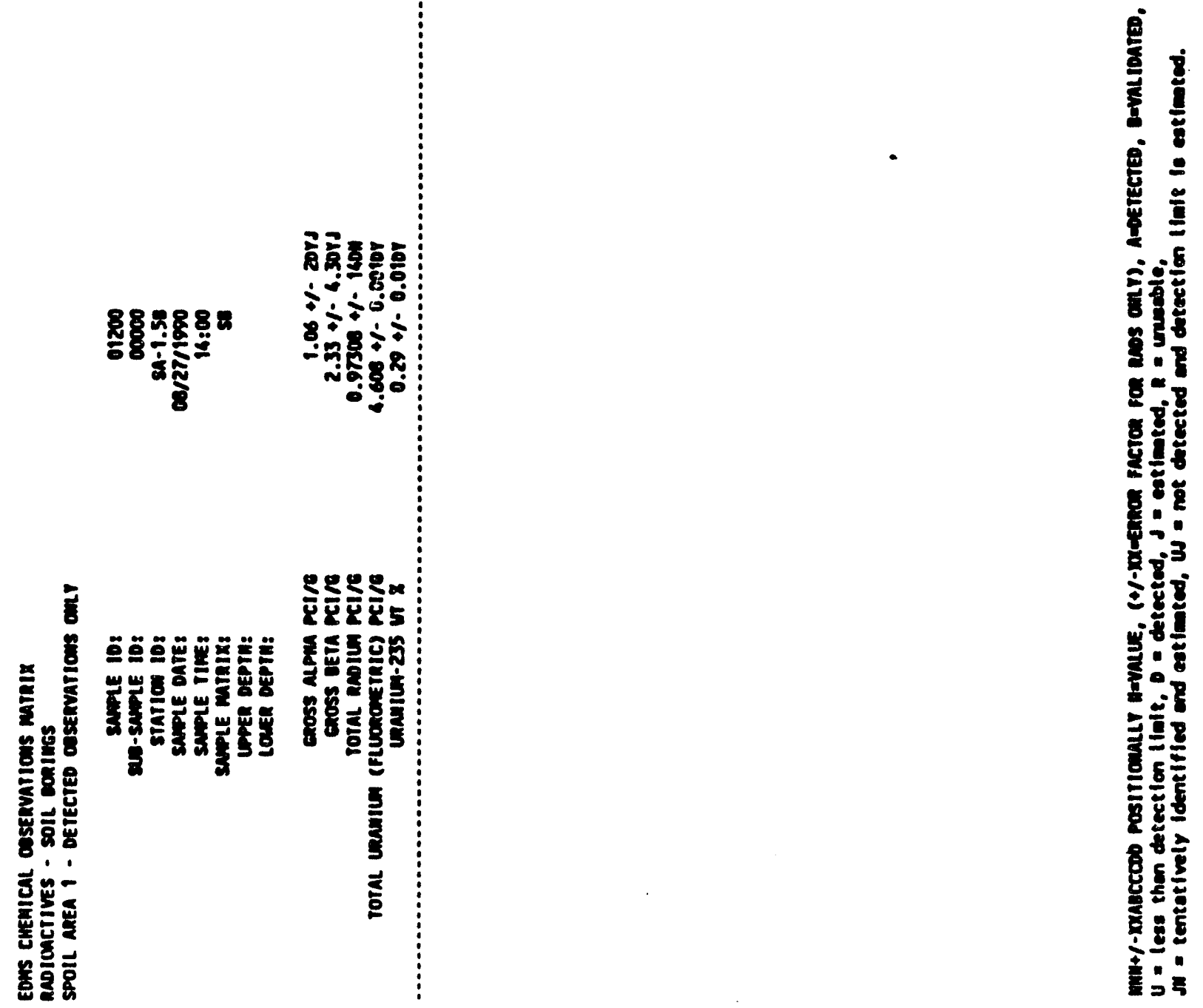


\section{C-119}

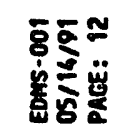

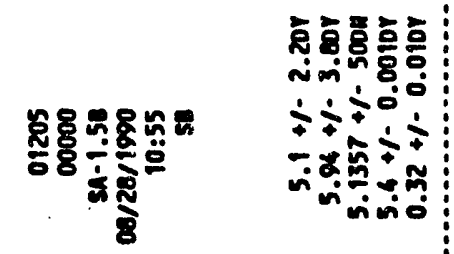

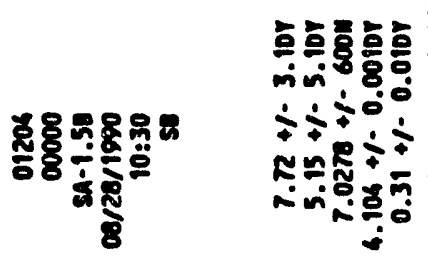

ํㅡㄹ

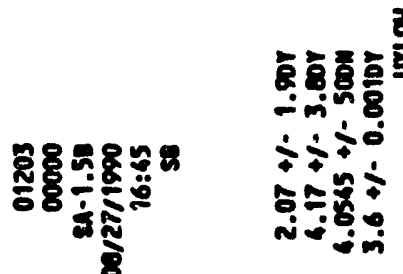

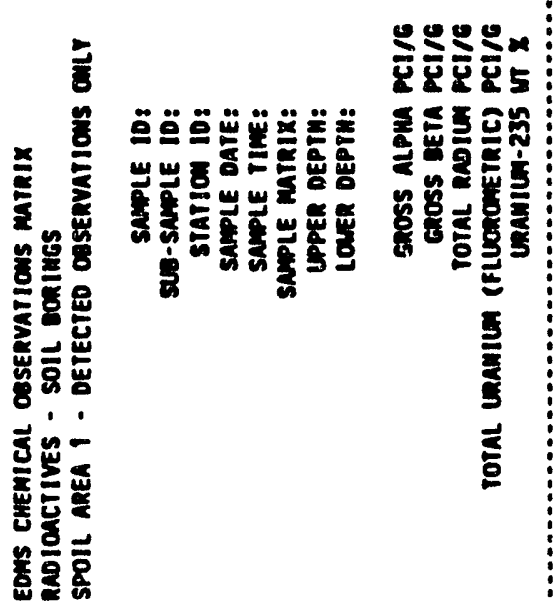

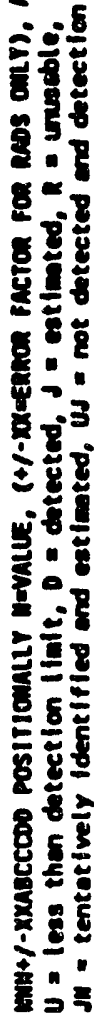




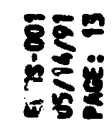

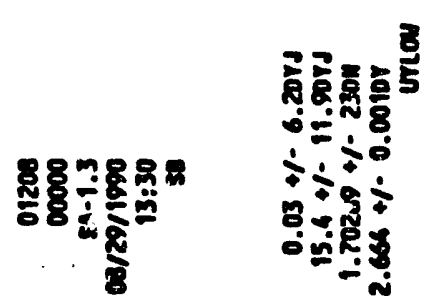

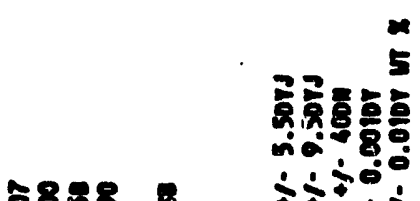

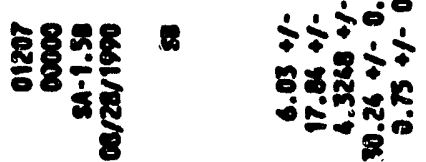

$\frac{5}{8}$

逭

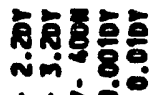

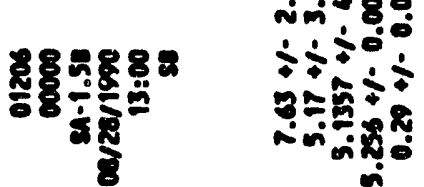

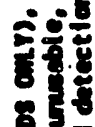

3

8

는

8

7

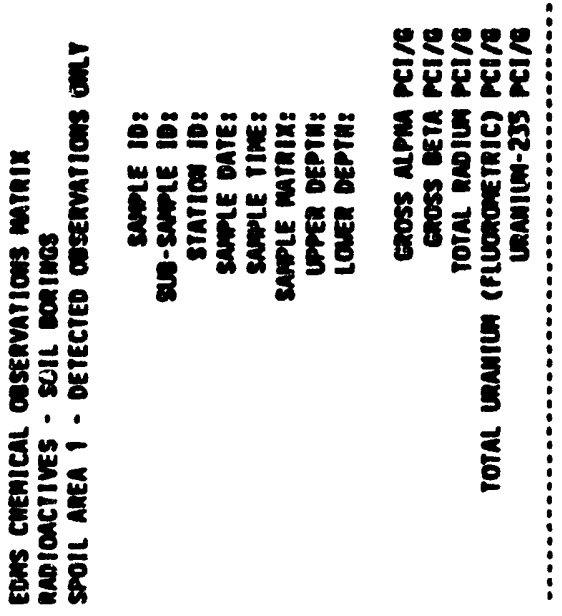

年 
- 䁦

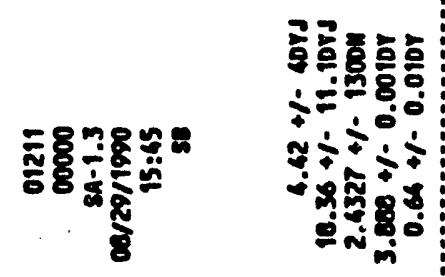

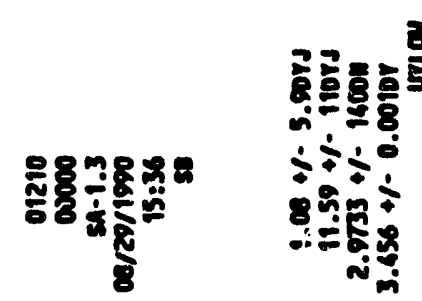

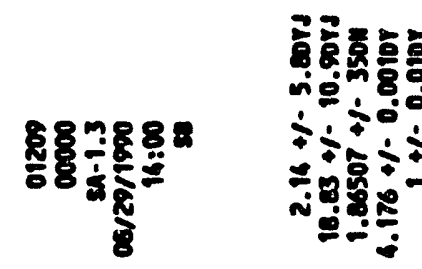
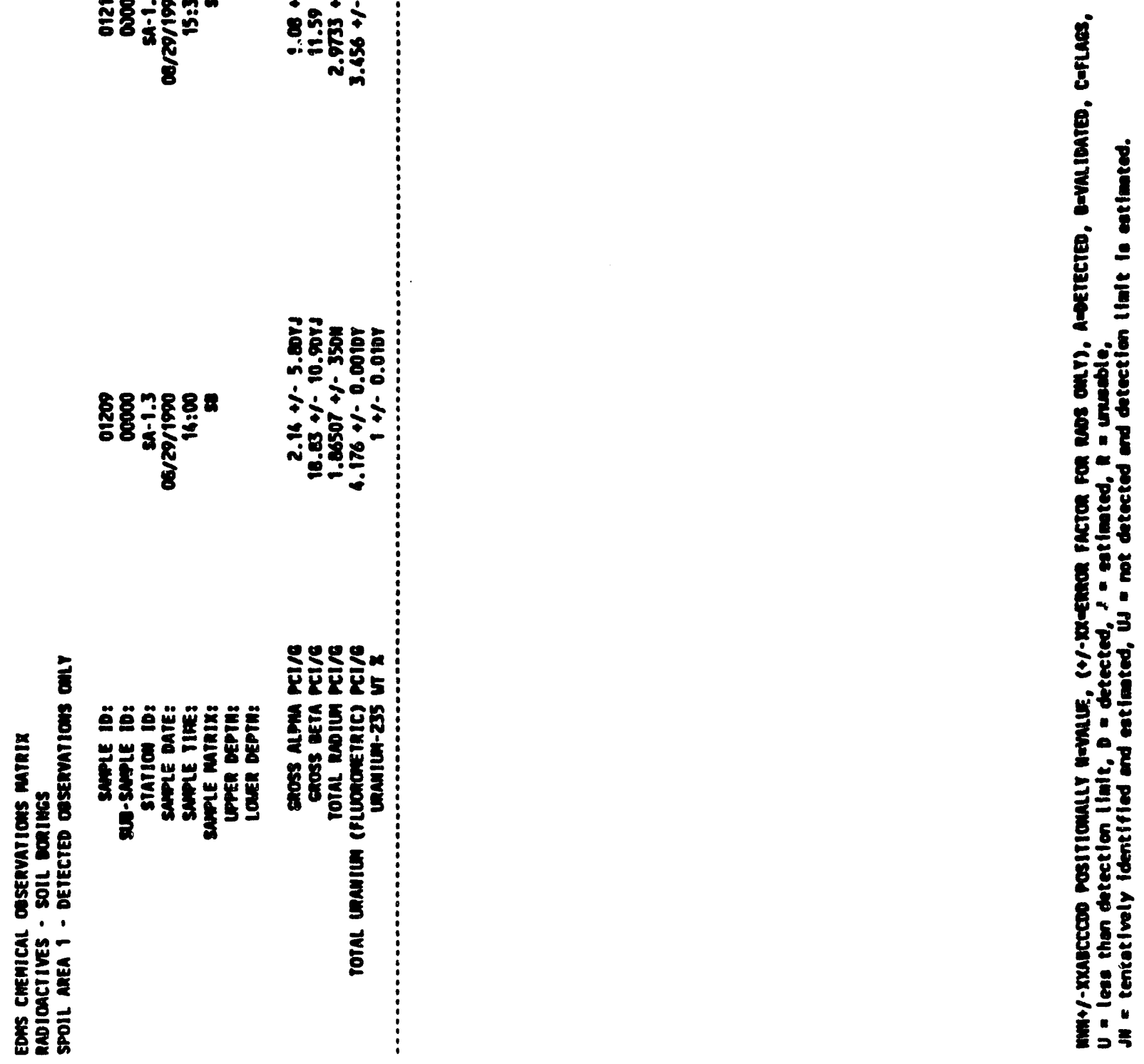


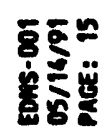

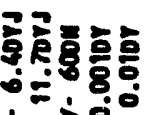

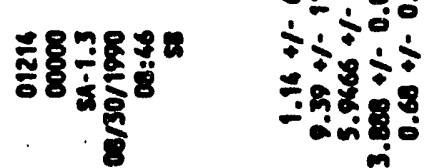

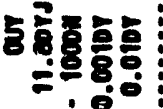

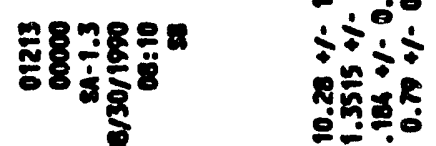

$\frac{8}{8}$

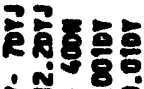

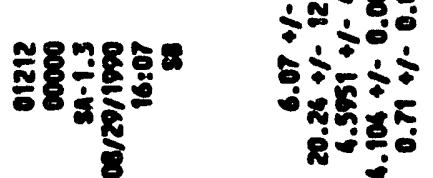

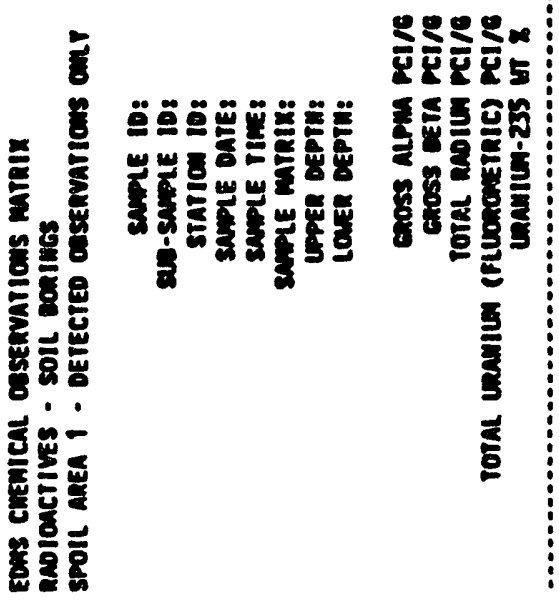

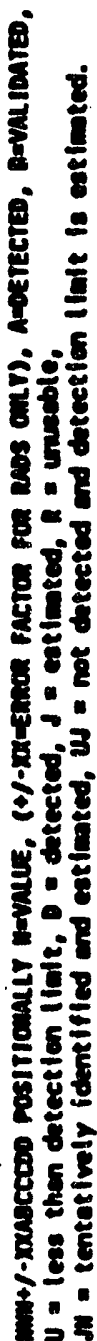


- 琵㩆

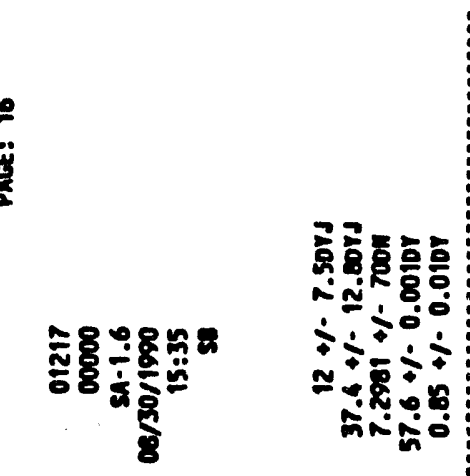

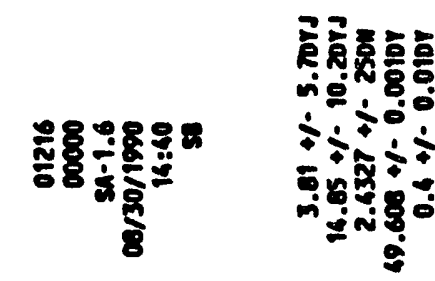

$\frac{8}{8}$

送

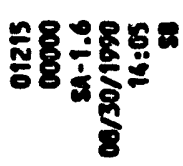

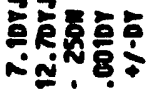

每

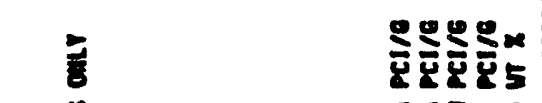

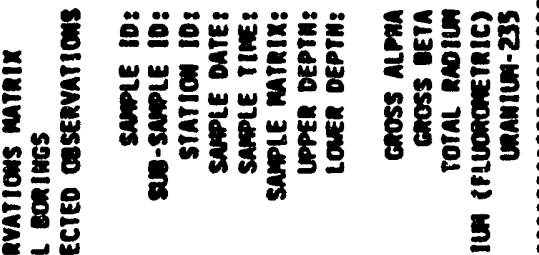

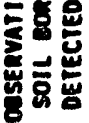

产 


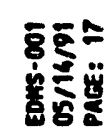

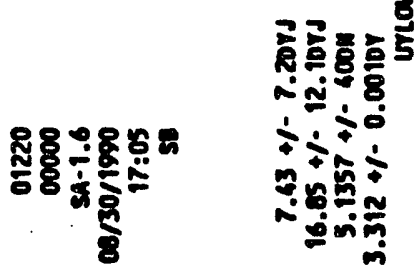

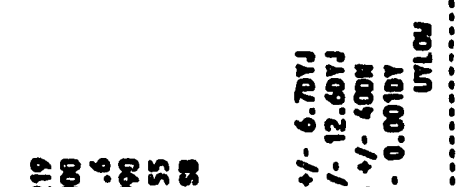

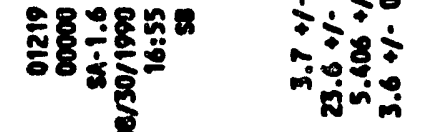

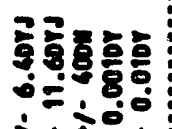

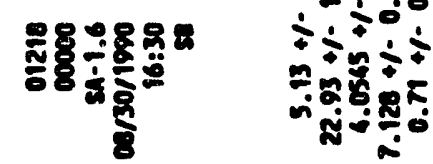

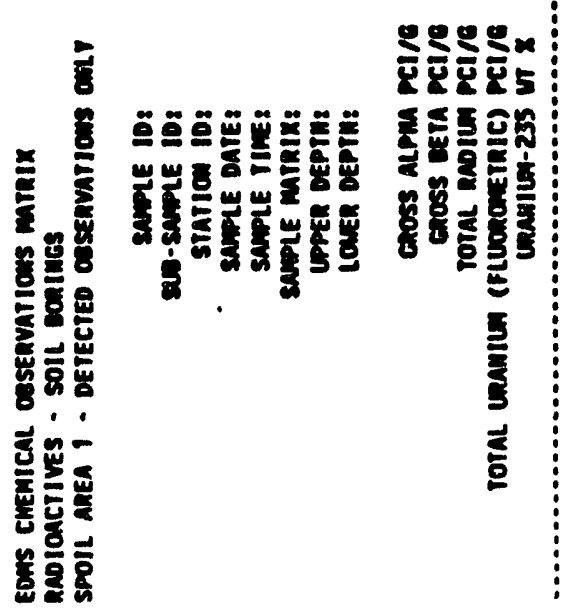

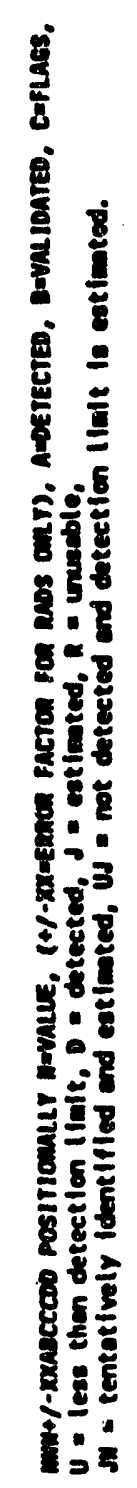


C-125

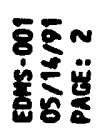

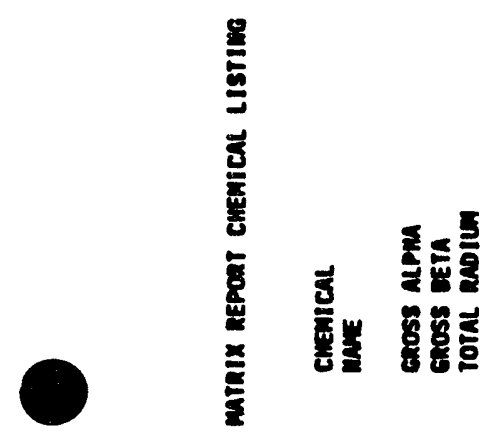

II

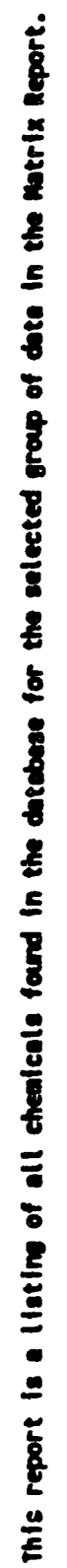


C-126

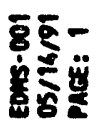

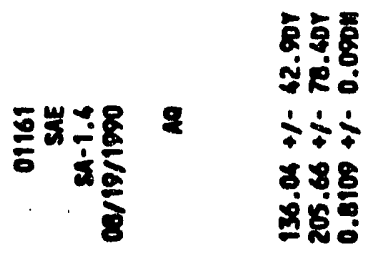

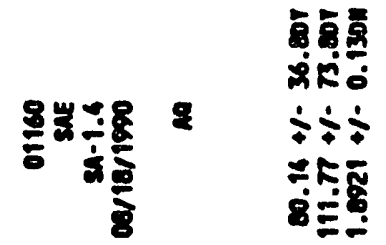

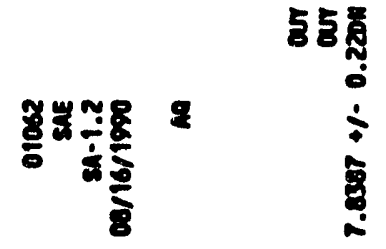
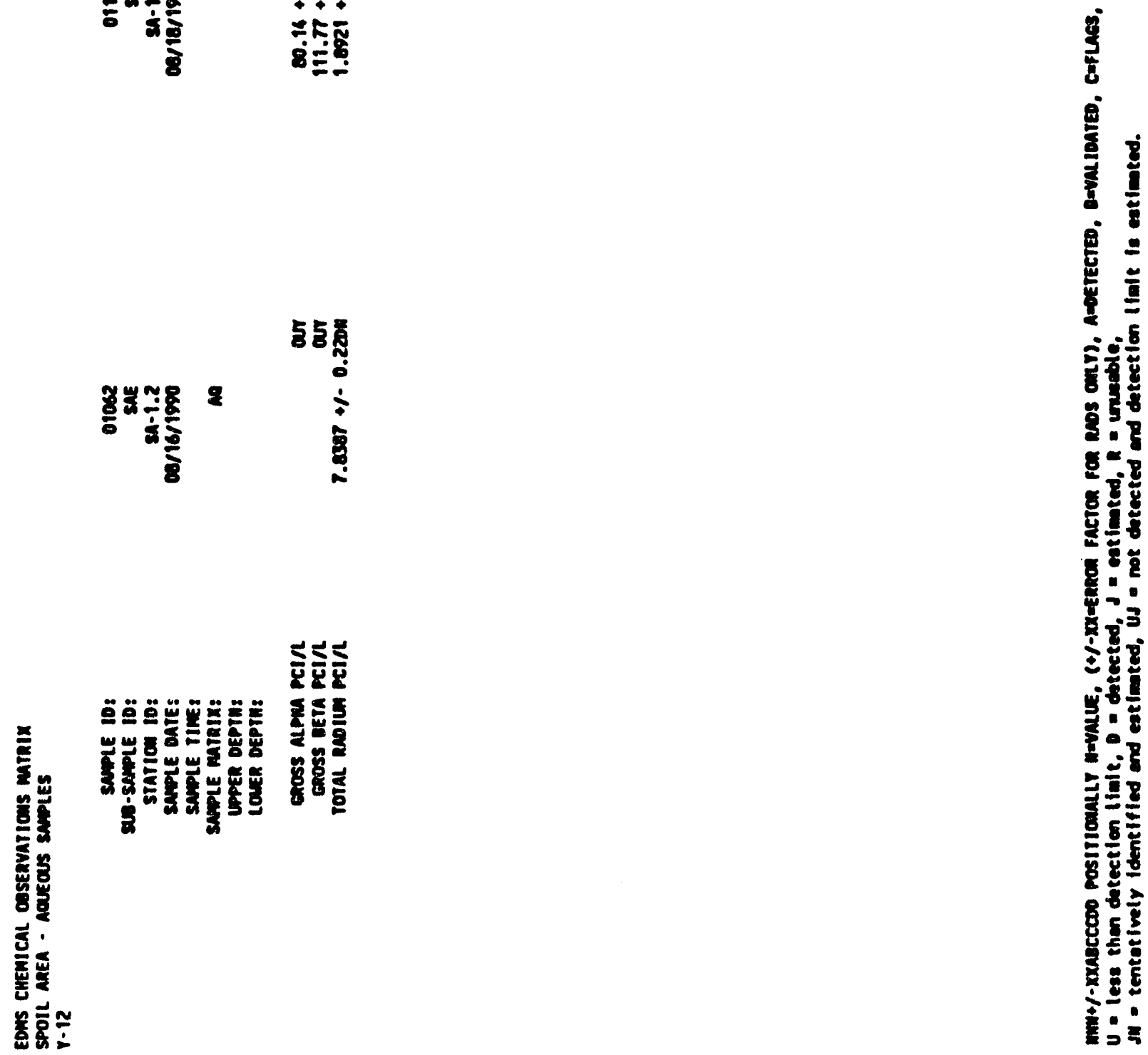
O

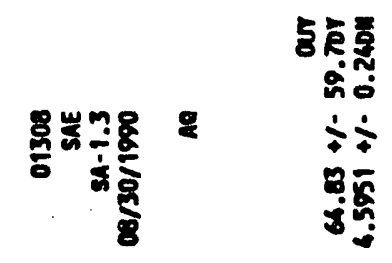

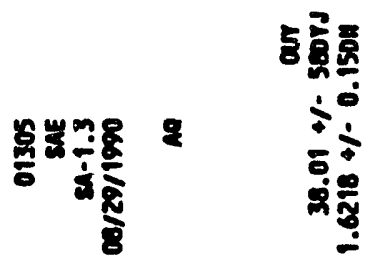

$\frac{8}{8}$

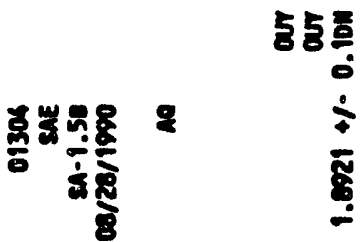

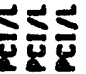

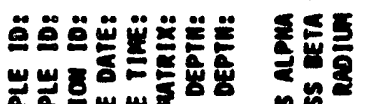

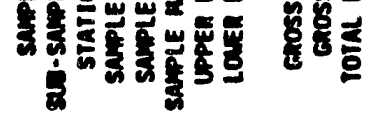

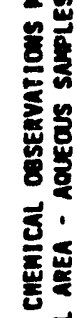

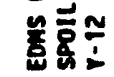

ह

$\therefore-\frac{5}{5}$

8

ㅇ․ㄹ

8

8

$8^{3}$ 


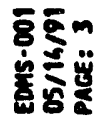

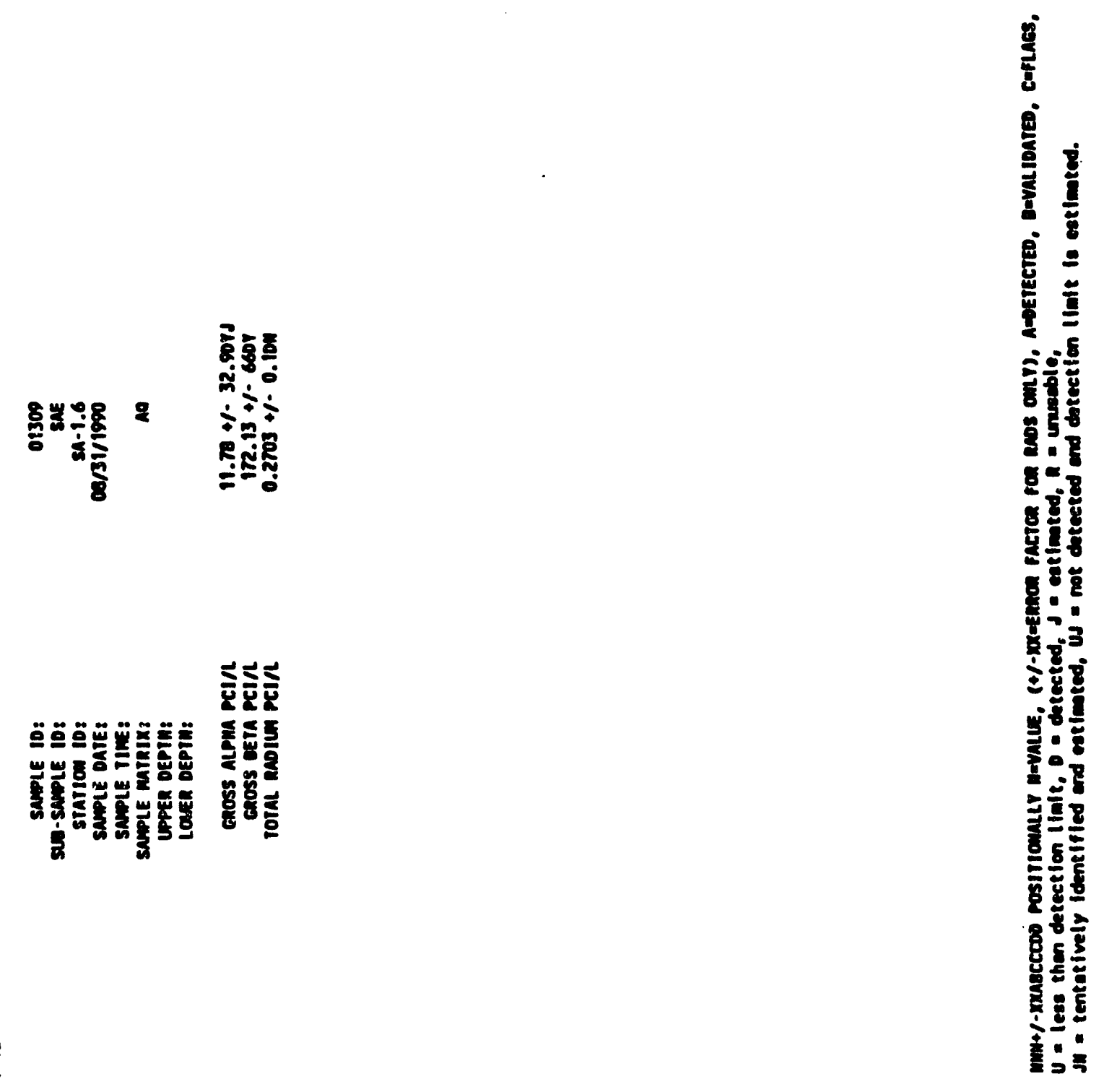


RUST SPOIL AREA ANALYTICAL DATA 
C-131

Location: 106-001

1,1,1-Tricbloroethane (MG/KG)

1,1,1-Trichloroetbane $(M G / L) \cdot O C$

1,1,2,2-Tetrachloroethane (MG/KG)

1,1,2,2-Tetrachloroethane $(M G /) \cdot O C$

1,1,2-Trictloroethane (MG/KG)

1,1,2-Trichloroethase $(M G /) \cdot O C$

11-Dichloroethune (MG/KG)

1.1-Dichloroethane $(M G /)$ - OC

1,1-Dichloroetbene (MG/KG)

11. Dichloroethene $(M G /) \cdot O C$

1,2-Dictloroethune (MG/KG)

1,2-Dictloroethane $(M G /) \cdot O C$

1,2-Dictioroetbene (Will) (MG/KG)

1,2-Dichlorotbene (Lota) (MG $\Omega$ ) - OC

1,2-Dictiocopropase (MG/KG)

1,2-Dichloropropane (MG/L) - OC

2-Butenose (MG/KG)

2-Butanone (MOR) - OC

2.Heanone (MO/KG)

2. Heanone (MG/L) - OC

4Metbyt-2-pentanone (MG/KG)

4-Methyl-2-pencanone $(M G / L) \cdot O C$

Acetone (MG/KG)

Acetone (MG/) - OC

Apba Activity (PCVG)

Alpts Acivity (PCL) $\cdot$ QC

Aluminum (MG/KG)

Alueninum (MG/) · OC

Arsenic (MG/KG)

Arsenic (MGR) - OC

Alebertos (\%)

Asbestos (\%) $\cdot O C$

Barium (MG/KG)

Barium (MG/) - OC

Benzene (MG/KG)

Benzene (MG/L) - OC

Beryltium (MG/KG)

Beryllium (MG/) - OC

Beta Aativity (PCIG)

Beta Activity (PCLL) - OC

Browodictlorowethane (MG/KG)

Bromodictioromethane (MG $\Omega) \cdot O C$

Bromoform (MG/KG)

Bromolorm (MG/) · OC

Bromonethane (MG/KG)

Bromonethane (MG/L) · OC

Cadmium (MG/KG)

Cadmium (MG/L) - OC

Calcium (MG/KG)

Calcium $(M G / 2) \cdot O C$

Carton Disulinde (MG/KG)

Carton Dieulfide (MG/) - OC

Carbon Tetractloride (MG/KG)

Carbon Tetractionide (MG/) - OC

Cblorobenzene (MG/KG)

Chlocobenzene (MG/L) - OC

Cbloroethane (MG/KG)

Chloroethene (MG/) $\cdot$ OC

Chlorolorm (MG/KG)

Chlorolorm (MG/L) - OC

Chiorowethase (MG/KG)

Cbloromethane (MG/L) $\cdot O C$

Chromium (MG/KG)

Chromium (MG/) - OC

Cobalt (MG/KG)

Cobalt $(M G / L) \cdot O C$

Copper (MG/KG)

Copper $(M G /) \cdot O C$

Cyanide (MG/KG)

Cyanide $(M G \Omega) \cdot O C$

Dibromoctloromethane (MG/KG)

Dibromoctboromethane (MG/) $\cdot O C$

Elbyl benzene (MG/KG)

Elbyt benzene (MG/) - QC

$03 / 26190$

$03 / 2690$

$03 / 26 / 90$

$03 / 26 / 90$

$03 / 26190$

$03 / 26 / 90$

$03 / 26 / 90$

$03 / 26190$

$03 / 26190$

032690

$03 / 26190$

$03 / 26190$

$03 / 26190$

$03 / 26 / 90$

$03 / 26 / 90$

$03 / 26950$

0326190

$03 / 26 / 90$

$03 / 26 / 90$

$03 / 26 / 90$

$03 / 26 / 90$

$03 / 26 / 90$

$03,26,90$

032690

$03 / 26 / 90$

$03 / 26 \times 90$

0326490

$03 / 26 / 90$

$03 / 26190$

$03 / 26 / 90$

$03 / 26 / 90$

032650

$03 / 26190$

$03 / 26 / 90$

$03 / 26 / 90$

0326190

$03 / 26190$

$00326 / 90$

$03 / 26950$

$03 / 2690$

$03 / 26 / 90$

032490

$03 / 2690$

$03 / 26 / 90$

$0326 \times 90$

$03 / 2690$

$03 / 26 / 90$

03/2690

$03 / 2690$

$03 / 26190$

$03 / 26 / 90$

0326990

03260

$03 / 26 / 50$

0326980

$03 / 26 / 90$

0326490

0326050

$03 / 26 / 90$

$03 / 2690$

$0326 / 90$

$3 / 260$

0326rso

$03 / 2690$

(2)

032400

$03 / 26 / 90$

$03 / 2690$

a3naso

$03 / 2690$

$03 / 26 / 90$

$03 / 26 / 90$

$03 / 26 / 90$

\begin{tabular}{|c|c|c|c|c|}
\hline $\begin{array}{l}00-05 \\
\text { ND }\end{array}$ & $\begin{array}{l}05.10 \\
\text { ND }\end{array}$ & Blank & Rin-1 & Rin-2 \\
\hline ND & ND & $0.005 U$ & $0.005 \mathrm{U}$ & $0.005 \mathrm{U}$ \\
\hline ND & ND & $0.005 U$ & $0.005 U$ & $0.005 U$ \\
\hline ND & ND & $0,005 U$ & $0.005 U$ & $0,000 \mathrm{U}$ \\
\hline ND & ND & $0.005 U$ & $0.005 U$ & $0.005 \mathrm{U}$ \\
\hline ND & ND & $0.005 U$ & $0.005 U$ & $a \cos U$ \\
\hline ND & ND & $\cos 0$ & 0.0000 & $0.005 U$ \\
\hline ND & ND & $0.005 U$ & $a, 005 U$ & $0.000 U$ \\
\hline ND & ND & acuse & 0.0050 & $a, 005 U$ \\
\hline ND & ND & ND & a.o6s & 0.01 \\
\hline ND & ND & ND & 0.017 & Q.01 \\
\hline 0.16 & 0.23 & ND & ND & ND \\
\hline 225 & 4.35 & 0.009 & 0.058 & 0.013 \\
\hline 220000 & 19000 & & -3604 & $\$ 268$ \\
\hline 5.1 & 6.5 & & $<0,02$ & 0.044 \\
\hline$<0$ & $<0$ & & $<0.005$ & $<0.000$ \\
\hline 94 & 140 & & $<0$ & $<0$ \\
\hline ND & ND & & 0.0012 & $<0,001$ \\
\hline 0.93 & 26 & $0.005 U$ & $0.005 U$ & a.005U \\
\hline 3.33 & 4.03 & & $<0,0003$ & $<0,0003$ \\
\hline ND & ND & & .346 .19 & .23473 \\
\hline ND & ND & 0.0006 & $0.005 U$ & $a \cos U$ \\
\hline ND & ND & $0.005 U$ & $0.005 U$ & 0.0000 \\
\hline 5.7 & 5.6 & ND & ND & ND \\
\hline 14000 & 20000 & & $<0,003$ & $<0,000$ \\
\hline ND & ND & & $<0,004$ & 0.14 \\
\hline ND & ND & $0.005 U$ & $0.005 U$ & $0.005 U$ \\
\hline ND & ND & $0000 \mathrm{U}$ & $2000 \mathrm{U}$ & $0.005 U$ \\
\hline ND & ND & $\operatorname{acos} U$ & $0.005 \mathrm{U}$ & $0 . \cos U$ \\
\hline ND & ND & ND & ND & ND \\
\hline ND & ND & 0.0006 & $0.005 U$ & $0.000 \mathrm{U}$ \\
\hline 27 & 28 & ND & ND & ND \\
\hline 18 & 20 & & $<0.01$ & $<0.01$ \\
\hline 24 & 24 & & $<0.005$ & $<0.005$ \\
\hline$<1$ & $<1$ & & $<0.004$ & 0.0045 \\
\hline ND & ND & & $<0.1$ & $<a_{1}$ \\
\hline ND & ND & $0.005 U$ & $0,005 U$ & $a, 005 U$ \\
\hline 33000 & & $0.005 U$ & $0.005 U$ & 0.0050 \\
\hline
\end{tabular}




\section{C-132}

Iron (MG/L) - OC

Lead (MG/KG)

Land (MG/KG)

Lead $(M G / L) \cdot O C$

Lead (MG/) - OC

Magnesum (MG/KG)

Magnesium $(M G /) \cdot O C$

Manganese (MG/KG)

Manganeac $(M G / L) \cdot O C$

Meraury (MG/KO)

Mercury (MG 2 ) - OC

Methylene Cbloride (MO/KG)

Metbylene Chloride (MG $/$ ) - QC

Moisture Content (\%)

Nictel (MG/KG)

Nictel (MG/L) - OC

Niobium (MG/KG)

Niobium (MGR) - OC

Pbouphoroun (MG/KG)

Pboupborow $(M G \Omega) \cdot$ OC

Potauium (MG/KG)

Potasium (MOR) - OC

Selenium (MG/KG)

Selenium $(M G /) \cdot O C$

Siver (MG/KG)

Siver $(M G \Omega) \cdot Q C$

Sodium (MG/RG)

Sodium (MG/) - OC

Styrene (MG/KG)

Seyreace (MG/) - OC

Tetractiorothene (MG/KG)

Tetrectloroethene $(M G /) \cdot O C$

Thorium (MG/KG)

Thorium (MG/L) - $\propto C$

Tolvene (MG/KG)

Toluene (MG/) - OC

Trichloroethene (MG/KG)

Trictloroetbene $(M G \Omega) \cdot O C$

Uranium Fluorometric (MG/KG)

Uranium Fluorometric (MG/L) · OC

Vanndium (MG/KG)

Vasedium (MG/L) - OC

Vinyl Acetale (MG/KG)

Vinyt Acetale (MG/L) - CC

Vinyt Chloride (MG/KG)

Vinyl Culoride (MG/L) - OC

Xyleoe (lotd) (MG/KG)

Xylepe (Low) (MG/L) - OC

Zinc (MG/KG)

Zinc (MG/) $) \cdot 0 \mathrm{C}$

cit-1,3-Dictloropropene (MG/KG)

cis-1,3-Dictloropropene $(M G /) \cdot O C$

unna-1,3-Dichloropropene (MG/KG)

trans-1,3-Dictloropropene (MGR) - OC

$03 / 26 / 90$

$03 / 26190$

$03 / 26 \sqrt{90}$

$03 / 2690$

032690

$03 / 26190$

$03 / 26190$

$03 / 26190$

$03 / 26190$

$03 / 26490$

$00 / 26190$

$03 / 26190$

0032690

$03 / 26 / 90$

$03 / 26190$

$03 / 26190$

0032650

0326190

$03 / 26 / 90$

$0326 \times 190$

$03 / 26 / 90$

$03 / 2690$

$03 / 26190$

a3/26/90

$03 / 26190$

0326150

032600

03126190

0326190

$03 / 26190$

$03 / 26 / 90$

$03 / 26 / 90$

$03 \sqrt{26950}$

$03 / 26 / 90$

$03 \sqrt{26 / 90}$

$03 / 26 / 90$

0326190

032650

$03 / 26190$

$03 / 26 / 90$

0326490

0326190

032640

032690

0026190

0326400

0026190

0326190

0

o3/26ro

$03 / 26 / 90$

0326590

$0326 / 90$

\begin{tabular}{|c|c|}
\hline 38 & 21 \\
\hline 15 & 24 \\
\hline 2800 & 4600 \\
\hline 1000 & 12000 \\
\hline$<1$ & $<1$ \\
\hline ND & ND \\
\hline 21.9 & 13.4 \\
\hline 23 & 31 \\
\hline$<0.85$ & $<0.86$ \\
\hline 290 & 410 \\
\hline 2700 & 3400 \\
\hline$<0.5$ & $<0.5$ \\
\hline$<0.73$ & $<0.74$ \\
\hline 51 & 39 \\
\hline ND & ND \\
\hline $0.03 \pi$ & $0.013 \mathrm{U}$ \\
\hline$<24$ & $<25$ \\
\hline ND & ND \\
\hline ND & ND \\
\hline 43 & 3.9 \\
\hline 37 & 23 \\
\hline ND & ND \\
\hline ND & ND \\
\hline ND & ND \\
\hline$\infty 0$ & 46 \\
\hline ND & ND \\
\hline ND & ND \\
\hline
\end{tabular}

$<0,044$

$<0,004$

0.05

$<0,004$

$<0.05$

$<0.004$

$0.00072 \quad 0.0093$

a.001

00017

$<0,0002<0,000$

0.000

a.cosu

$<0.01<0.01$

$<0.007<0.00$

$<0.2<02$

$<06$

$<0.6$

$<0.005<0.005$

$<0.006$

$<0.006$

630

6

0.0050

$0.005 U$

a.cosu

a.cosu

a.00su

a.cosu

$<0.2$

$<0.2$

0.0006

00008

a.cosu

$\cos U$

$0.005 U$

$\operatorname{acosu}$

<0.01

<ac01

$<0.005$

$<0,000$

ND

ND

ND

ND

ND

ND

$0,005 \mathrm{U}$

0.0000

acosu

$<0.001$

$<0001$

$0.005 \mathrm{U}$

$0.005 \mathrm{U}$

a.cosu

0.0050

0.0050

$0.000 \mathrm{U}$ 


\section{C-133}

Laction: $106-002$

14,1-Tricbloroethane (MG/KG)

$03 / 27 / 90$

$03 / 27 / 90$

1,1-Trichloroethane (MG/) - OC

1,1,2,2-Tetractloroethane $(M G /) \cdot O C$

1.1.2-Tricbloroethane (MG/KG)

1.1,2-Trictloroethane $(M G /) \cdot O C$

11-Dichloroetheive (MG/KG)

1,1. Dichloroethane (MG/L) $\cdot O C$

1,1-Dichloroethene (MG/KG)

11.Dichloroethese $(M G / 2) \cdot O C$

1,2.Dichloroethane ( $M G / K G)$

1,2-Dictioroethane (MG/L) - OC

1,2-Dichloroethene (lotal) (MG/KG)

1.2-Dicbloroetbene (LUL) (MG/) - OC

4,2-Dicbloropropane (MG/KG)

1.2-Dictloropropane (MG/L) - OC

2-Butunone (MG/KG)

2-Butanone $(M G \Omega) \cdot O C$

2. Heronone (MG/KG)

2-Herenose $(M G / L) \cdot O C$

4Metbyl-2-pentunone (MG/KG)

4Methyt-2-pentasone (MG/R) $\cdot O C$

Acetone (MG/KG)

Acetone $(M G / L) \cdot O C$

Aptos Activity (PCVG)

Apha Activity (PCL) - OC

Aluminum (MG/KG)

Aluminum (MG/) - OC

Amenic (MGRKG)

Anenic (MG/) - OC

Arbestan (\%)

Barium (MG/KG)

Barium $(M G / L) \cdot O C$

Benzene (MG/KG)

Benzene (MG/L) - OC

Benyllium (MG/KG)

Benytlium (MG/L) - OC

Bet Aativity (PCVG)

Bets Activity (PCL) · OC

Browodictlorowethane (MG/KG)

Bromodictionomethane (MG/) - OC

Bromolorm (MG/KG)

Bromolorm (MG/) - OC

Bromowethane (MG/KG)

Bromonethane (MG/L) · OC

Cadaium (MG/KG)

Cadmium (MG $/$ ) - OC

Calcium (MG/KG)

Calcium (MG/) $\cdot$ OC

Carton Disulinde (MG/KG)

Carton Dieutride $(M G / L) \cdot O C$

Carbon Teuractloride (MG/KG)

Curbon Tetractibride (MG/L) - OC

Colorobenzene (MG/KG)

Chlorobenzene (MG/L) $\cdot O C$

Cbloroethane (MG/KG)

Cbloroethane $(M G /) \cdot Q C$

Chloroform (MGKG)

Cblorolorm (MG/L) . OC

Culorowethune (MG/KG)

Chlorosechane (MG/) - OC

Chromium (MG/KG)

Chromium (MG/) - QC

Cobalt (MG/KG)

Cobalt $(M G /) \cdot Q C$

Copper (MG/KG)

Copper $(M G \Omega) \cdot O C$

Cyanide (MG/KG)

Cyanide $(M G /) \cdot O C$

Dibromocbloromethane (MG/KG)

Dibromochloromethane (MG/L) - OC

Elbyl benzene (MG/KG)

Elbyl benzene (MG/) - OC

Iron (MG/KG)

$\operatorname{Iron}(M G \Omega) \cdot O C$

$03 / 27190$

$03 / 27 / 90$

$03 / 27 / 90$

$03 / 27 / 90$

$03 / 27 / 90$

$03 / 27 / 90$

$03 / 27 / 5$

$03 / 27 / 90$

$03 / 27 / 90$

$0327 / 90$

$03 / 27 / 90$

0327/90

$03 / 27 / 90$

$0327 / 90$

$03 / 27 / 90$

03/27/90

$03 / 27 / 90$

$03 / 27 / 90$

$03 / 27 / 90$

$03 / 27 / 90$

$03 / 27 / 90$

$03 / 27 / 90$

$03 / 27 / 90$

$0327 / 90$

0327/90

$00 / 27 / 90$

$03 / 27 / 90$

0327190

03/27\%

$03 / 27190$

$03 / 27 \% 0$

032790

13/27/90

$03 / 27 / 90$

$03 / 27 / 90$

$00127 / 90$

0327190

$03 / 27 / 90$

$03 / 27 / 90$

$03 / 27 \times 0$

$03 / 2790$

03/27/50

$00327 / 90$

$03 \sqrt{27} \times 1 \times 0$

$03 / 27 \times 0$

$03 / 27 / 90$

$03 \sqrt{27} 190$

0327190

002780

$03 \sqrt{27} 190$

$03 / 27 / 90$

$03 / 27 / 90$

00272790

$03 / 27 / 90$

$00 / 27 \times 0$

$03 / 27 / 90$

$03 / 2790$

$03 / 27 / 90$

$0327 / 90$

$03 / 2790$

$03 / 2790$

032790

$03 / 27 / 90$

0312790

$03 \sqrt{27 / 90}$

032740

$0327 \% 0$

$03 / 2790$

$0327 \%$

(1927)

$03 / 27 / 90$

$03 / 27 / 50$

$03 / 27 \times 0$

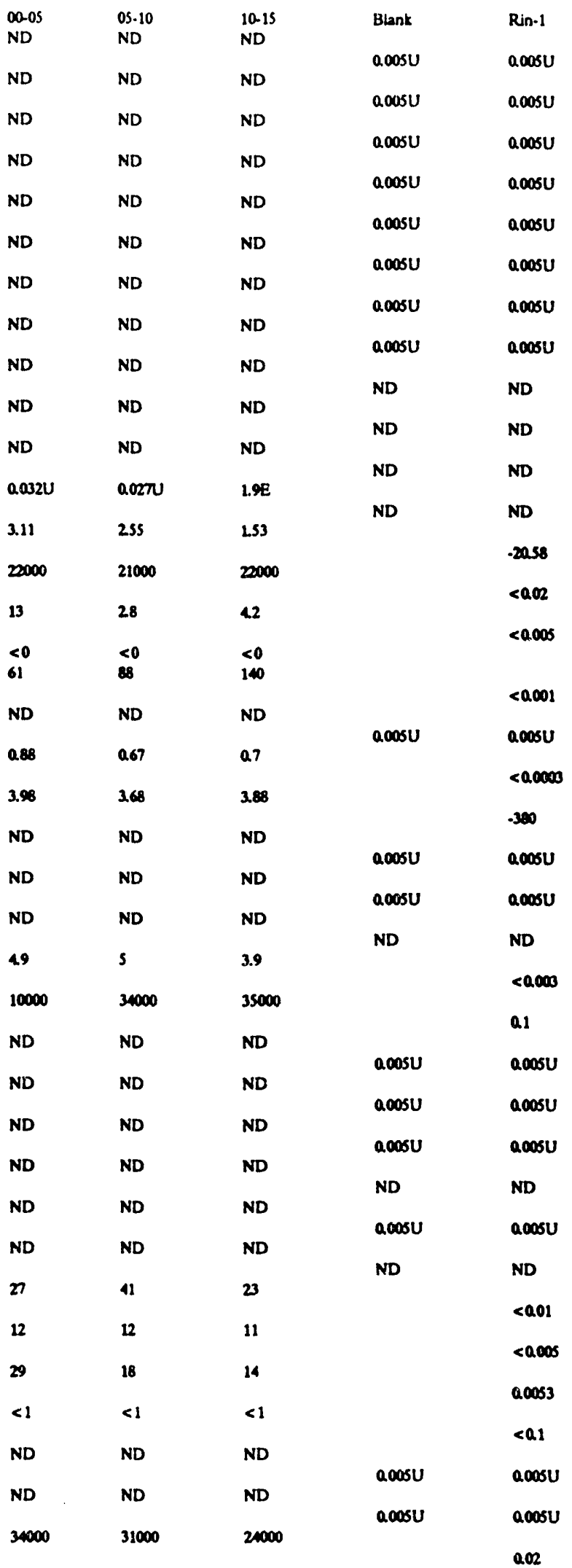




\section{C-134}

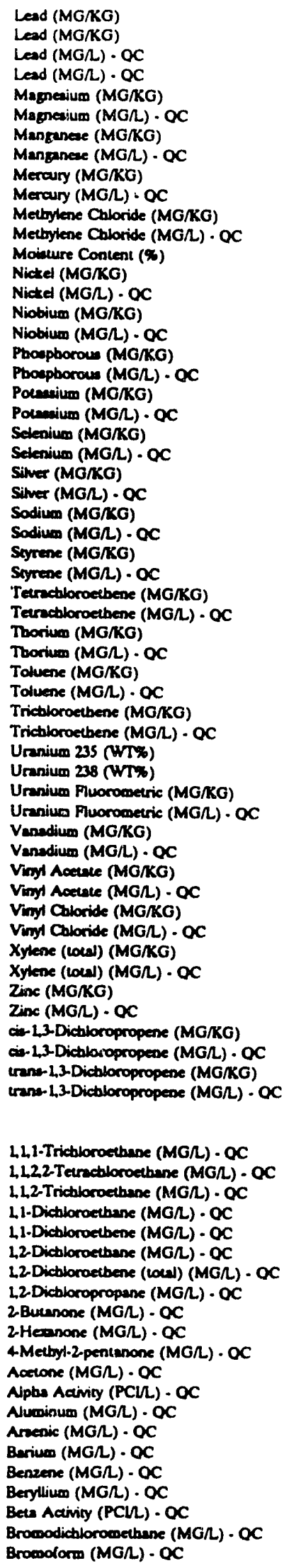

acosu

acosu 
C-135

Bromodethane (in $J \Lambda) \cdot O C$

Cadmium (MG/L) $\cdot O C$

Calcium $(M G / L) \cdot O C$

Carbon Disulfide $(M G /) \cdot O C$

Carbon Tetractloride (MG $/) \cdot Q C$

Culombenzene (MG $L) \cdot O C$

Cbloroethane (MG/L) - OC

Chlorolorm (MG/L) - OC

Chloromethene (MG/L) - OC

Cbromium (MG $/$ ) - QC

Cobalk (MGR) - OC

Copper (MGR) - OC

Cyanide (MGR) $\cdot$ OC

Dibroancichloromethane (MGL) - OC

Bebyl benzene (MGL) - OC

Iron (MG/) - QC

Leal $(M G \Omega) \cdot O C$

Lead (MGR) - OC

Magresium (MG/L) - OC

Manganece (MG/) - OC

Merainy (MG/) - OC

Metbylene Chlocide (MG/L) - OC

Nickel $(M G /) \cdot O C$

Niobium (MG/) - OC

Prospborous (MG/L) - OC

Potanium $(M G \Lambda) \cdot O C$

Sedeniue (MGR) . OC

Siner (MGR) $\cdot$ OC

Sodium (MOR) - OC

Styrese $(M O /) \cdot$ OC

Tetrectionoetbene (MO/) - OC

Thoriven (MG/) - OC

Tolvese (MGR) - OC

Trictilonoethene (MG/) · OC

Uraniven Fluorometric (MGL) - OC

Vanediven (MG/) · QC

Vingt incetale (MGR) $\cdot O C$

Vinyl Daloride (MG $\Omega$ ) . OC

Xylene (Lot:1) $(M G / L) \cdot O C$

Zinc $(M G /)$ ) O OC

-1.3-Dichloropropene (MG/L) - OC

uran-1,3-Dichloropropene (MG/L) · $Q C$

\begin{tabular}{|c|c|}
\hline $03 / 27 / 90$ & ND \\
\hline $03 / 27 / 90$ & $<0,003$ \\
\hline $03 / 27 / 90$ & 0.15 \\
\hline $03 / 27 / 90$ & agosu \\
\hline $03 / 27 / 90$ & $0.005 U$ \\
\hline $03 / 27 / 90$ & $0.005 \mathrm{U}$ \\
\hline$n 3 / 27 / x_{0} 0$ & ND \\
\hline $03 / 27 / 90$ & $0.005 U$ \\
\hline $03 / 27 / 90$ & ND \\
\hline $03 / 27 / 90$ & $<0.01$ \\
\hline $03 / 27 / 90$ & $<0,005$ \\
\hline $03 / 27 / 90$ & 0.007 \\
\hline $03 / 27 / 90$ & $<0.1$ \\
\hline $03 / 27 / 90$ & 0.0050 \\
\hline $03 / 27 / 90$ & $0.005 U$ \\
\hline $03 / 27 / 90$ & 0.043 \\
\hline $03 / 27 / 90$ & $<0.05$ \\
\hline $03 / 27 / 90$ & $<0,004$ \\
\hline $03 / 27 / 90$ & Q.041 \\
\hline $03 / 27 / \times 0$ & $<0.001$ \\
\hline $03 / 27 / 90$ & $<0,000$ \\
\hline $03 / 27 / 90$ & $0.000 \mathrm{U}$ \\
\hline $03 / 27 / 90$ & $<0.01$ \\
\hline $03 / 27 / 90$ & $<0,007$ \\
\hline $03 / 27 / 90$ & $<0.2$ \\
\hline $10 / 27 / 90$ & $<0.6$ \\
\hline $03 / 27 / 90$ & $<0,005$ \\
\hline $03 / 27 / 90$ & $<0,006$ \\
\hline $03 / 27 / 90$ & 0.43 \\
\hline $3 / 27 / 80$ & $0.005 U$ \\
\hline $03 / 27 / 90$ & $\cos u$ \\
\hline$a, 27 / 90$ & $<0.2$ \\
\hline $03 / 27 / 90$ & $\operatorname{acos} v$ \\
\hline $0 / 27 / 90$ & $0.005 U$ \\
\hline $03 / 27 / 90$ & 0.001 \\
\hline $03 / 27 / 90$ & $<0,005$ \\
\hline $03 / 27 / 90$ & ND \\
\hline $23 / 27 / 90$ & ND \\
\hline $3 / 27 / 90$ & $a \cos u$ \\
\hline $3 / 27 / 90$ & 0,0062 \\
\hline $\begin{array}{l}33 / 27 / 90 \\
23 / 27 / 90\end{array}$ & $\begin{array}{l}\operatorname{coc} s u \\
\cos U\end{array}$ \\
\hline
\end{tabular}




\section{C-136}

Location: 106-000

14,1-Trictloroethane (MG/KG)

\begin{tabular}{|c|c|c|c|c|}
\hline cosos & 05.10 & 10.15 & 15.20 & $20-25$ \\
\hline ND & ND & $\begin{array}{l}\text { ND } \\
\text { ND }\end{array}$ & ND & ND \\
\hline ND & ND & $\begin{array}{l}\text { ND } \\
\text { ND }\end{array}$ & ND & ND \\
\hline NL & ND & $\begin{array}{l}\text { ND } \\
\text { ND }\end{array}$ & ND & ND \\
\hline ND & ND & $\begin{array}{l}\text { ND } \\
\text { ND }\end{array}$ & ND & ND \\
\hline ND & ND & $\begin{array}{l}\text { ND } \\
\text { ND }\end{array}$ & ND & ND \\
\hline ND & ND & $\begin{array}{l}\text { ND } \\
\text { ND }\end{array}$ & ND & ND \\
\hline ND & ND & $\begin{array}{l}\text { ND } \\
\text { ND }\end{array}$ & ND & ND \\
\hline ND & ND & $\begin{array}{l}\text { ND } \\
\text { ND }\end{array}$ & ND & ND \\
\hline ND & ND & $\begin{array}{l}\text { ND } \\
\text { ND }\end{array}$ & ND & ND \\
\hline ND & ND & $\begin{array}{l}\text { ND } \\
\text { ND }\end{array}$ & ND & ND \\
\hline ND & ND & $\begin{array}{l}\text { ND } \\
\text { ND }\end{array}$ & ND & ND \\
\hline a.6E & 0.3 & $\begin{array}{l}1.3 \mathrm{E} \\
\text { a.71E }\end{array}$ & 0.26 & 0.2 \\
\hline 167 & 279 & $\begin{array}{l}208 \\
2200\end{array}$ & 183 & 167 \\
\hline 17000 & 18000 & 23000 & 19000 & 23000 \\
\hline
\end{tabular}

L1.1-Trictoroethane (MG/KG) - Dup

21,22-Tetractiloroethane (MGKG)

11,22. Tetrachloroethase (MG/KG) - Dup

1,1,2 Trichloroethane (MG/KG)

4,2-Trictloroethane (MG/KG) • Dup

4,1-Dichloroethane (MG/KG)

L1.Dictilorocthase (MG/KG) - Dup

41-Dichloroctbene (MG/KG)

1,1-Dictloroetbene (MG/KG) - Dup

12-Dichloroethene (MO/KO)

1,2-Dictloroethene (MG/KG) - Dup

1.2-Dicbiorocthene (Lot) (MORO)

12.Dicbloroethese (Lot) (MG/KG) - Dup

12-Dichloropropape (MO/RO)

L2-Dictionopropase (MO/KG) - Dup

2. Buremone (MGRK)

2 burenose (MG/KG) - Dup

2.Hesenose (MGRKO)

2Hemonone (MG/KG) - Dup

4 Methyt-2-pentanone (MG/KG)

$4 \cdot$ Metbyt-2 pentansone (MG/KO) - Dup

Acelone (MORKG)

Acetose (MOKKG) - Dup

Appen Adiviny (PCLG)

Apten Aativiny (PCVG) - Dup

Aluminum (MO/KO)

Ausinum (MO/KG) - Dup

Anseaic (MG/KG)

Anenic (MG/KG) - Dup

Alberesces (\%)

Albertos (\%) - Dup

Bariven (MG/KG)

Bariue (MG/KG) - Dup

Benrene (MG/KG)

Benzene (MG/KO) - Dup

Beryllium (MGRK)

Bentivine (MG/KG) - Dup

Bets Aaivity (PCVG)

Bet Activity (PCVO) - Dup

Bromodictbloromethese (MG/KG)

Bromodictloromethene (MG/KG) - Dup

Browolorm (MORKG)

Browolorm (MG/KO) - Dup

Browowethenc (MG/KG)

Bromosethese (MG/KG) - Dup

Cadeium (MGRK)

Cadaiven (MORKG) - Dup

Culeiven (MOKKO)

Calcium (MG/rG) - Dup

Carton Dimuride (MOKKG)

Carton Diauride (MO/KO) - Dup

Carton Teurnctionide (MG/KG)

Carton Tetractionide (MG/KG) - Dup

Calorobennene (MG/KG)

Culorobecisene (MG/KG) - Dup

Chloroethene (MG/KG)

Cbloroethane (MG/RG) - Dup

Cbloroform (MG/KG)

Cilorolorm (MG/KG) - Dup

Chloromethene (MG/KG)

Cibromettane (MG/KG) - Dup

Chromiun (MG/KG)

Oromium (MG/KG) - Dup

Cobalt (MG/KO)

Cobalt (MG/KG) - Du

Copper (MG/KG)

Copper (MG/KG) - Dup

Cyanide (MG/KG)

Cynnide (MG/KG) - Dup

Dibrowoctionosethane (MG/KG)

Dibroenoctioroenethene (MG/KG) - Dup

Elbyl benzene (MG/KG)

Eiby benzene (MG/KG) - Dup

Iron (MG/KO)

$03 / 27 / 90$

032790

032700

$03 / 27 / 90$

$03 / 2790$

$03 / 27 / 50$

$03 / 27 / 90$

mancos

$03 / 2790$

0327190

$03 / 27 \times 5$

$0327 \% 0$

$03 / 27 / 90$

$03 / 27 / 50$

$03 / 27 / 90$

$03 / 27 / 90$

$03 / 27 / 90$

$03 / 27 / x$

$03 / 27 / 50$

$03 / 27 / 90$

$03 / 27 \times 0$

$03 / 27190$

$03 / 27 / 90$

$03 / 27 \%$

$03 / 27 / 90$

a3r2tos

$0327 / 50$

$0327 / 90$

$0327 \times 0$

$0327 / 90$

03/27/90

$0327 \times 5$

$03 / 27 / 90$

c12700

032790

$0327 \times 0$

$03 / 27 / 90$

$0327 \times 0$

03278

03/27/90

$0327 \times 0$

$03 / 27 / 50$

$03 / 2790$

$03 / 27 / 90$

$03 / 27 / 50$

$327 \%$

armen

cosstisio

0.27\%

m27\%

$0327 \times$

$0327 / 80$

$0327 \times$

$0327 \times$

0032750

a3p7x

$03 \sqrt{27} 790$

$0327 \times 0$

03/27\%

asm

$03 \sqrt{27} 7 \times$

os 2790

1327\%

032740

032780

$03 \sqrt{27} 90$

1327\%

$1327 \%$

1327\%

$03 / 2790$

032790

$0327 \times$

0327\%

$0327 \times 5$

$03 / 27 / 90$
67

ND

as

24

ND

ND ND

ND ND

35

17000

ND

ND

ND

ND

ND

ND

ND

14

20

$<1$

ND

ND

24000

48

$<0$

100

ND

0.71

3.7

3.9

ND

ND

ND

ND

10000

3.1

$<0$

150

ND

a.8

3.3

ND

ND

ND

3.6

4000

ND

ND

ND

ND

ND

ND

20

10

18

$<0.1$

<a.

ND

ND

ND

ND

20000

10000 


\section{C-137}

Iron (MG/KG) - Dup

Lead (MG/KG)

Lead (MG/KG)

Lead (MG/KG) - Dup

Lead (MG/KG) - Dup

Magneaium (MG/KG)

Mappesium (MG/KG) - Dup

Manganeac (MG/KG)

Manganese (MG/KG) - Dup

Meroury (MG/KG)

Meraury (MG/KG) - Dup

Metbylene Chloride (MG/KO)

Metbylene Cularide (MG/KG) - Dup

Mointure Content (\%)

Moisure Content (\%) - Dup

Nided (MGRKG)

Nicted (MG/KG) - Dup

Niobienon (MG/KG)

Niobiuno (MG/KG) - Dup

Ptoospborou (MG/KG)

Ptociptoroun (MG/RG) - Dup

Pocmenium (MOKKG)

Potmeive (MG/KG) - Dup

Selenien (MG/KG)

Selentum (MG/KG) - Dup

Siver (MG/KG)

Silver (MG/KG) - Dup

Sodinm (MGKKG)

Sodiver (MO/KG) - Dup

Syrone (MG/KG)

Syrese (MG/KG) - Dup

Tetrectlorostbene (MG/KG)

Tetrectioroethene (MG/KG) - Dup

Thorium (MG/KG)

Thorius (MG/KG) - Dup

Tolvene (MG/KG)

Toluene (MO/KG) - Dup

Trictioroetbene (MG/KG)

Trictloroetbene (MG/KG) - Dup

Uraniven 235 (WTX) - Dup

Urasiuen 238 (WT) - Dup

Uraniven Plworometric (MG/KG)

Uranium Phorometric (MG/KG) - Dup

Urantum-234 (WT\%) - Dup

Uranium-236 (WT\%) - Dup

Vandium (MG/KG)

Vanadium (MG/KG) - Dup

Vinyl Aartale (MG/KG)

Vinyl Acetale (MG/KG) - Dup

Viayl Culoride (MG/KG)

Vinyl Coloride (MG/KG) - Dup

Xylene (Lote) (MGRKG)

Xylene (locel) (MG/KG) - Dup

Zinc (MG/KG)

Zinc (MG/KG) - Dup

ci-12-Dichioropropene (MO/KG)

ci-1,3-Dictioropropene (MG/KG) - Dup

crane-13-Dictloropropene (MG/KG)

crane-13-Dichloropropene (MG/KG) - Dup

$03 / 27 / 90$

$03 / 27 / 90$

$03 / 27 / 90$

$03 / 27,90$

$03 / 27190$

$03 / 27 / 90$

$03 / 27 / 90$

$03 / 27 / 90$

$03 / 27 \times 9$

$03 / 27 / 90$

$03 / 27190$

$03 / 27 / 90$

$03 / 27 / 90$

$00 / 27 / 90$

$03 / 27 \times 0$

$03 / 2790$

$03 / 27 / 50$

or/27/s0

032780

$0327 / 90$

$\infty 2790$

$03 / 27 / 90$

$03 / 27 / 50$

$03 / 27 / 90$

$03 / 27 / 90$

$03 / 27 / 90$

$00327 / 90$

$03 / 27 \times 90$

0327950

032790

$0327 / 90$

$0327 / 90$

$00327 / 90$

cos2790

$0027 / 90$

os/27s

$02 / 27 / 90$

$0327 \times$

$03 / 27 / 30$

002779

$0327 \times 10$

(1)27\%90

$03 / 27 / 90$

$0227 / 90$

$0027 \%$

032700

$03 / 27 / 50$

$03 / 27 / 90$

$03 / 27 / 90$

c2727\%0

03/27/90

$0327 \times$

mame

$03 / 27 \times 0$

$03 / 27 \times 0$

0327190

032790

1032790

$03 / 27 / 90$

1.4.1-Trictloroethene (MG/L) - OC

1, L.2.2. Tetractloroethane (MGR) · OC

1.1.2-Trictloroetbane $(M G / L) \cdot O C$

1. Dicbloroethene (MGR) - OC

1.1-Dichloroethene (MGI) - OC

1.2-Dichloroethane $(M G \Omega) \cdot O C$

L2. Dictloroetbene (Loll) (MGR) - OC

2.2-Dictloropropane $(M G /) \cdot O C$

2. Bursosose (MG/) $\cdot$ OC

2 Heanone (MG/L) - OC

4 Mebyt-2-peninnone $(M G /) \cdot O C$

Aetione (MGR) . OC

Nptes Adivity (PCL) · OC

Aluminum $(M G /) \cdot O C$

Arsenic (MG/) $\cdot$ OC

Barium (MGR) $\cdot$ OC

Benzere $(M G /) \cdot O C$

$03 / 27 / 90$

$00327 \times 0$

$03 / 27 / 90$

$02327 \times 9$

$0327 \%$

$00327 / 90$

00327190

002790

ares27s0

$\infty 2780$

032790

$03 / 27 / 90$

$0327 \times 0$

mamen

0327190

or27s0

03/27/90

\begin{tabular}{|c|c|}
\hline 22 & 28 \\
\hline 26 & 56 \\
\hline 3300 & 6000 \\
\hline 740 & 690 \\
\hline 7.5 & 2.3 \\
\hline ND & ND \\
\hline 13.6 & 13.9 \\
\hline 21 & 16 \\
\hline
\end{tabular}

(2907.

30

$<560$

31

103

7600

21000

360

440

$<1$

62

ND

ND

65

186

16

$<110$

$<0.78$

$<7$

370

310

320

$<200$

$1700 \quad 2300$

$<0.52<0.42$

$<0.67<0.67$

39

84

ND

ND

Q.014U $0.014 \mathrm{U}$

$<2$

$<2$

ND

ND

ND

ND

12

2000

$<6000$

$<0.43$

$<053$

$<0.67$

$<68$

$n$

1100

ND

ND

a012U

20140

$<2$

$<2300$

ND

ND

ND

ND

49

20

$<56$

ND

ND

ND

ND

ND

ND

47

190

ND

ND

ND

ND

ND

ND

ND

2725

$<0.02 \quad 02$

$<0.005<0.005$

$<0.001<0.001$

$0 . \cos U \quad 0.005 \mathrm{U}$ 


\section{C-138}

Beryllium (MG/L) - OC

Bets Aativity (PCL) - OC

Browodictloroesethane (MG/L) - OC

Brocolorm (MG/) - QC

Browomethane (MG/) $\cdot Q C$

Cadmium (MG/L) - QC

Calcium (MGL) - OC

Carton Diaulfide (MOL) - OC

Carton Tetractloride $(M O / L) \cdot O C$

Chlorobenzene (MOL) $\cdot$ OC

Chlorocthane $(M G /) \cdot O C$

Coloroform (MG/) - QC

Cbloromethane (MGR) - OC
Cbronium (MGR) - OC

Cobalt (MOL) - OC

Copper $(M O /) \cdot \mathrm{OC}$

Cyanide $(M O N) \cdot O C$

Dibroenoctiloromethens (MGR) - OC

Elbyt berasene (MOL) - OC

Iron $(M G / L) \cdot \mathbf{O C}$

Lad $(M O \Omega) \cdot$ OC

Lad (MGR) - OC

Mappoives (MOR) · OC

Menpance (MG/L) $\cdot$ OC

Merany (MGR) - OC

Metbytene Chloride (MGR) - OC

Nictel (MOR) - OC

Niobiven $(M O / L) \cdot O C$

Promptorou (MGL) · OC

Pouminom (MOR) - OC

Selonium $(M O /) \cdot O C$

Sinve (MOR) - OC

Sodiven $(M G \Omega) \cdot O C$

Sonnese $(M G / L) \cdot O C$

Tetrictionoethens $(M G \Omega) \cdot O C$

Thoriuen (MG/) - QC

Tolvese $(M O / L)$ - OC

Trictlonoctbene (MG $/$ ) · QC

Uraniver Pluorowetric (MG/L) - OC

Veasediue (MGR) - OC

Viny Acetale (MOL) - OC

Vinst Culoride (MGN) $\cdot O C$

Xylowe (cota) (MGL) - OC

Zine (MOR) - OC

in-L3-Dichloropropene (MOR) $\cdot O C$

$03 / 27 / 90$

$03 / 27 / 90$

$03 / 27 / 90$

$03 / 27 / 90$

$03 / 27 / 90$

$03 / 27 / 90$

$03 / 27 / 90$

$03 / 27 / 90$

$03 / 27 / 90$

$03 / 27 / 90$

03/27/90

$03 / 27 / 90$

$0327 / 50$

03270

$003 / 27 / 90$

$03 / 27 / 90$

$03 / 27 / 90$

$00 / 27 / 50$

03/27/50

$0327 / 90$

$03 / 27 / \% 0$

$03 / 27 / 90$

03/27/90

$03 / 27 / 90$

$03 / 27 / 90$

032780

a3r27/90

$03 / 27 / 90$

$03 / 27 / 90$

$0327 \times 0$

$03 / 27 / 90$

co2/27\%

$02 / 27 / 90$

$03 / 27 / 90$

cor27so

10327\%0

03/27/s0

$00 / 27 / 10$

$03 / 27 / 90$

$0327 \times 0$

$03 / 27 / 90$

$0327 / 90$

$03 / 27 / 90$

$02727 \times$

una-13-Dictioropropene (MG/L) · OC

$03 / 27 / 50$

\begin{tabular}{|c|c|}
\hline$<0,0000$ & $<0.00003$ \\
\hline .368 .86 & .391 .21 \\
\hline $0.005 \mathrm{U}$ & $0,005 U$ \\
\hline $0.005 U$ & $0.005 U$ \\
\hline ND & ND \\
\hline$<0,003$ & $<0.003$ \\
\hline 0.039 & 0.078 \\
\hline $0.005 U$ & $0.005 U$ \\
\hline $\operatorname{acos} U$ & $\operatorname{acos} u$ \\
\hline $0.005 \mathrm{U}$ & $a \cos U$ \\
\hline ND & ND \\
\hline $0.005 \mathrm{~s}$ & $\operatorname{acos} U$ \\
\hline ND & ND \\
\hline$<0.01$ & $<0.01$ \\
\hline$<0,00 s$ & $<0,005$ \\
\hline$<0.004$ & 0.0065 \\
\hline$<0.1$ & $<a_{1}$ \\
\hline a.cosu & $0.005 U$ \\
\hline $0.005 v$ & $0,005 U$ \\
\hline 00068 & $\operatorname{acos}$ \\
\hline$<0.05$ & $<0.0 s$ \\
\hline$<0,04$ & $<0,004$ \\
\hline a.cos & 0.015 \\
\hline 0.0013 & 0.0027 \\
\hline$<0,0002$ & $<0,0002$ \\
\hline $0.005 U$ & $a . \cos U$ \\
\hline$<0.01$ & $<0.01$ \\
\hline$<0.007$ & <a.00n \\
\hline$<0.2$ & $<a_{2}$ \\
\hline$<0.6$ & $<0.6$ \\
\hline caces & cacos \\
\hline$<0,000$ & $<0000$ \\
\hline Q.13 & a.23 \\
\hline $\operatorname{acos} U$ & $a 005 U$ \\
\hline a.cosu & acosu \\
\hline$<0.2$ & $<0_{2}$ \\
\hline $\operatorname{acos} v$ & $\operatorname{acos} U$ \\
\hline a.cosu & acosu \\
\hline$<0.001$ & $<0001$ \\
\hline$<000 s$ & <acos \\
\hline ND & ND \\
\hline ND & ND \\
\hline a.cosu & $\operatorname{acoss}$ \\
\hline 0.0 .027 & $\operatorname{acos} 7$ \\
\hline acosu & acosu \\
\hline $\operatorname{acos} v$ & $\operatorname{acos} u$ \\
\hline
\end{tabular}


Location: 106-004

41,1-Trictlonoethase (MG/KG)

1, 1.1-Trictloroethane (MG/KG) - Dup

1, 1,2,2. Tetractoroethane (MG/KG)

1,1,2,2-Tetractionoethane (MG/KG) - Dup

4,L2-Trictloroethane (MG/KG)

1,L,2-Trictoroethane (MG/KG) - Dup

1,1-Dichloroethane (MG/KG)

11.Dictionoethane (MG/KG) - Dup

1.1.Dichlorotibene (MGRG)

1,1-Dichloroctbene (MG/KG) - Dup

1.2-Dichloroethene (MG/KG)

1,2-Dichloroethese (MG/KG) - Dup

12-Dictionoetbene (LOW) (MG/KG)

1,2-Dictloroctbese (Lot) (MG/KG) - Dup

1.2-Dictiloropropase (MG/KG)

42-Dichloropropane (MGRKG) - Dup

2-Butanoce (MG/KG)

2-Butanone (MG/KG) - Dup

2.Hernone (MG/KG)

2.Hemano (MG/KG) - Dup

4-Metbyt-2-pentanose (MG/KG)

4 Metby-2-pentanose (MG/KG) - Dup

Acetone (MG/KG)

Aoctone (MG/KG) - Dup

Alphs Acivisy (PCVO)

Apto Aativiny (PCVG) - Dup

Alumioum (MG/KG)

Aleminuos (MG/KG) - Dup

Ansenic (MG/KG)

Aneaic (MGRKG) - Dup

Anbealon (\%)

Albeelos (\%) - Dup

Bariuan (MG/KG)

Bariuen (MG/KG) - Dup

Benzene (MG/KG)

Benwene (MG/KG) - Dup

Bayllium (MG/KG)

Beryllium (MG/KG) - Dup

Bets Activiny (PCUG)

Beta Activity (PCVG) - Dup

Browodictiorowethene (MG/KG)

Bromodichlorometbane (MG/RG) - Dup

Browoform (MG/KG)

Bromolorm (MG/KG) - Dup

Browometbane (MG/KG)

Browoenetbase (MG/KG) - Dup

Codenium (MG/KG)

Cadminus (MG/KG) - Dup

Caldium (MG/KG)

Calcium (MG/KG) - Dup

Carton Divulide (MGRKG)

Cartoon Dinulicide (MG/KG) - Dup

Cartion Tetractioride (MG/KG)

Curbon Tetrictiboride (MG/KG) - Dup

Cblorobenzene (MG/KG)

Chlorobenzene (MG/KG) - Dup

Caloroctiane (MOKKG)

Clonethene (MG/KG) - Dup

Culorotorm (MG/KG)

Culorolorm (MG/KG) - Dup

Cbloroesecthene (MG/KG)

Chorowethene (MG/KG) - Dup

Cuncosium (MG/KG)

Chromium (MG/KG) - Dup

Cobatk (MG/KG)

Cobnk (MG/KG) - Dup

Copper (MGKKG)

Copper (MG/KG) - Dup

Cyanide (MG/KO)

Cyanide (MG/KG) - Dup

Ditroenochloromethase (MG/KG)

Dibromoctioromethane (MG/KG) - Dup

Elbyl benzene (MG/KG)

Eubyt benrene (MG/KG) - Dup

Iron (MG/KG)

\begin{tabular}{|c|c|c|c|c|c|}
\hline & $00-05$ & 05.10 & 10.15 & 15.20 & \\
\hline $\begin{array}{l}03 / 28 / 90 \\
03 / 28 / 90\end{array}$ & ND & ND & ND & $\begin{array}{l}\text { ND } \\
\text { ND }\end{array}$ & ND \\
\hline $\begin{array}{l}03 / 28 / 90 \\
03 / 28990\end{array}$ & ND & ND & ND & ND & ND \\
\hline $03 / 28 / 90$ & ND & ND & ND & $\begin{array}{l}\text { ND } \\
\text { ND }\end{array}$ & ND \\
\hline $03 / 28 \times 90$ & & & & ND & \\
\hline 03/2890 & ND & ND & ND & ND & ND \\
\hline 0328190 & & & & ND & \\
\hline $\begin{array}{l}0328890 \\
03 / 2899\end{array}$ & ND & ND & ND & ND & ND \\
\hline $\begin{array}{l}03 / 2890 \\
03 / 2890\end{array}$ & & & & ND & \\
\hline $\begin{array}{l}03 / 2890 \\
03 / 28 / 90\end{array}$ & ND & ND & ND & ND & ND \\
\hline $\begin{array}{l}03 / 28 / 90 \\
03 / 28 / 90\end{array}$ & ND & & & ND & \\
\hline $\begin{array}{l}03 / 28 / 90 \\
03 / 28 / 90\end{array}$ & & ND & ND & $\begin{array}{l}\text { ND } \\
\text { ND }\end{array}$ & ND \\
\hline $03 / 28 / 90$ & ND & ND & ND & $\begin{array}{l}\text { ND } \\
\text { ND }\end{array}$ & ND \\
\hline $03 / 28 / 90$ & & & & ND & \\
\hline $03 / 28 / 90$ & ND & ND & ND & ND & ND \\
\hline $03 / 28980$ & & & & ND & \\
\hline 032890 & ND & ND & ND & ND & ND \\
\hline $03 / 28 / 90$ & & & & ND & \\
\hline $03 / 28 / 90$ & ND & ND & ND & ND & ND \\
\hline $03 / 28950$ & & & & ND & \\
\hline $03 / 2890$ & a.02su & Q.95E & L.1E & $26 E$ & Q.3 \\
\hline 0328990 & & & & L.3E & \\
\hline $03 / 2850$ & $2 \pi$ & 3.81 & 243 & 1.45 & 281 \\
\hline $03 / 28 / 90$ & & & & 291 & \\
\hline $03 / 2890$ & 26000 & 21000 & 21000 & 20000 & 21000 \\
\hline conseso & & & & 18000 & \\
\hline $00 \sqrt{2} 2 x=$ & 14 & 11 & 7 & 17 & 10 \\
\hline carseso & & & & 11 & \\
\hline 032890 & $<0$ & $<0$ & $<0$ & $<0$ & $<0$ \\
\hline 032890 & & & & $<0$ & \\
\hline $03 / 28 / 90$ & 52 & 140 & 120 & 130 & 200 \\
\hline orraso & & & & 120 & \\
\hline 03/28490 & ND & ND & ND & ND & ND \\
\hline cr2s:so & & & & ND & \\
\hline 032890 & $a 9$ & a.r & Q.79 & 1.2 & 26 \\
\hline 032850 & & & & 0.85 & \\
\hline corranso & 3.32 & 5.07 & 5.07 & 447 & 3.32 \\
\hline 032890 & & & & 401 & \\
\hline 032840 & ND & ND & ND & ND & ND \\
\hline $03 / 2890$ & & & & ND & \\
\hline 032890 & ND & ND & ND & ND & ND \\
\hline 0028290 & & & & ND & \\
\hline 032890 & ND & ND & ND & ND & ND \\
\hline $03 / 28 / 90$ & & & & ND & \\
\hline 03raso & 5.4 & 49 & 3.8 & 5.3 & 7.3 \\
\hline 032890 & & & & 3.2 & \\
\hline 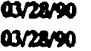 & 4000 & 24000 & 21000 & 4000 & 1500 \\
\hline $\begin{array}{l}0328190 \\
0325190\end{array}$ & & & & 2000 & \\
\hline $\begin{array}{l}0325490 \\
0328 / 90\end{array}$ & ND & ND & ND & ND & ND \\
\hline $\begin{array}{l}1328 / 90 \\
128290\end{array}$ & & & & ND & \\
\hline 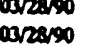 & ND & ND & ND & ND & ND \\
\hline orase & ND & ND & ND & ND & \\
\hline BR2ano & & 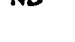 & ND & $\begin{array}{l}\text { ND } \\
\text { ND }\end{array}$ & ND \\
\hline 12840 & ND & ND & ND & ND & ND \\
\hline B28so & & & & ND & \\
\hline $\begin{array}{l}32890 \\
32800\end{array}$ & ND & ND & ND & ND & ND \\
\hline $\begin{array}{l}132890 \\
\text { 325950 }\end{array}$ & & & & ND & \\
\hline 12890 & ND & ND & ND & ND & ND \\
\hline 3r28450 & & & & ND & \\
\hline 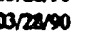 & 26 & 28 & 25 & $\infty$ & 36 \\
\hline araso & & & & 26 & \\
\hline 3/284so & 11 & 13 & 11 & 20 & 35 \\
\hline 328:50 & 33 & & & 13 & \\
\hline 3rasso & 33 & 27 & 20 & $\begin{array}{l}26 \\
18\end{array}$ & 22 \\
\hline 3rass0 & $<1$ & $<1$ & $<1$ & $<1$ & $<1$ \\
\hline 32890 & & & & $<1$ & \\
\hline $328 \times 90$ & ND & ND & ND & ND & ND \\
\hline $3 / 2890$ & & & & ND & \\
\hline $3 / 28 / 90$ & ND & ND & ND & ND & ND \\
\hline 32890 & & & & ND & \\
\hline $3 / 28190$ & 35000 & 31000 & 26000 & 16000 & 67000 \\
\hline
\end{tabular}


C-140

Iron (MG/KG) - Dup

Lead (MG/KG)

Lead (MG/KG)

Lead (MG/KG) - Dup

Lead (MG/KG) - Dup

Magnesium (MG/KG)

Magnesium (MG/KG) - Dup

Manganese (MG/KG)

Manpanene (MG/KG) - Dup

Meraury (MG/KG)

Merainy (MG/KG) - Dup

Metbylene Chloride (MG/KG)

Metbylene Coloride (MORKG) - Dup

Moinure Costeas (\%)

Moimure Content (\%) - Dup

Nictel (MG/KG)

Nictel (MGRKO) - Dup

Niobium (MGRG)

Niobiuen (MG/KO) - Dup

Proceporoun (MG/KG)

Prospboroun (MG/KG) - Dup

Poumituon (MG/KG)

Pounenivos (MG/KG) - Dup

Codenivom (MG/KG)

Seleniue (MO/KG) - Dup

Siver (MG/KG)

Siver (MORKG) - Dup

Sodiven (MG/KO)

Sodium (MO/KG) - Dup

Syrome (MG/KG)

Styrease (MO/KG) - Dup

Tetrectloroetbese (MO/KG)

Tetrectiloroctbene (MG/KG) - Dup

Tborivon (MG/KG)

Trorium (MG/KG) - Dup

Toluese (MGRG)

Toluene (MG/KG) - Dup

Trictloroctbene (MG/KG)

Trictibrotbese (MG/KG) - Dup

Unanium Pluorometric (MG/KG)

Unnium Fuorometric (MORKG) - Dup

Vanadium (MG/KG)

Vasadiun (MORKG) - Dup

Vins Acetive (MG/RG)

Vingl Aotede (MG/KG) - Dup

Vint Culoride (MG/RG)

Viryt Chloride (MG/KG) - Dup

Xytene (lold) (MG/KG)

Xylese (Low) (MG/KG) - Dup

Zioc (MGRKG)

Zine (MG/KG) - Dup

in-1,3-Dictloropropene (MG/sG)

cir-13-Dictionopropene (MG/KG) - Dup

tran-1,2-Dichionopropene (MG/KKG)

trane-13-Dictioropropene (MG/KG) - Dup

$03 / 28 / 90$

$03 / 289$

$03 / 28 / 90$

$03 / 28950$

032890

032890

$03 / 2890$

$03 / 2890$

$0328 \%$

$03 / 2890$

032890

$03 / 2890$

032850

032890

032890

03/28sp

a328450

002895

002890

co3/28950

0328950

comeros

0325890

032890

03r2aso

0328490

0328950

0з32890

0328450

$03 / 2890$

0322450

capare

c) 2840

osparso

c3ren

01289

cospese

0322890

032890

$0328 \times$

03/2890

$03 / 289$

0032840

cas28so

cor2aso

aszerso

corrarso

032890

arpars

032850

1325\%

opreso

corzaso

032840

cor2sy

0012890

cor2aso

cos?2aso

crass.

(1)

$02 \sqrt{28 \times 0}$

032840

corzese

crass

crzaro

coresso

cor2aso

mpars

coserso

arzaso

$0328 \times 0$

arperos

cosseso

arpero

0322890

cornesso

$\begin{array}{llll}39 & 36 & 20 & 2500 \\ 20 & 32 & 36 & 91 \\ 1500 & 5400 & 5000 & 2000 \\ 480 & 740 & 590 & 1 \\ 1.1 & <1 & <1 & 1 \\ \text { ND } & \text { ND } & \text { ND } & \\ 18 & 13.2 & 125 & 2900 \\ 22 & 24 & 20 & 25 \\ <0.85 & <0.85 & <0.82 & 17\end{array}$

25000
100
97

21

1700

5300

$<1$

ND

25

39

cas

1000

200

<Qus

<an

32

ND

a.015U

$<26$

ND

ND

2

36

ND

ND

ND

55

ND

ND

\begin{tabular}{|c|c|c|}
\hline Blank & Rin-1 & $\begin{array}{l}R \sin -2 \\
\operatorname{acos} U\end{array}$ \\
\hline $\begin{array}{l}a \cos U \\
a \cos U\end{array}$ & $\begin{array}{l}a \cos U \\
a \cos U\end{array}$ & $\begin{array}{l}a, 000 \mathrm{U} \\
a, 005 \mathrm{U}\end{array}$ \\
\hline 0.0000 & a.cosu & acosu \\
\hline acosu & consu & $\operatorname{acos} u$ \\
\hline $\operatorname{acos} U$ & $a \cos U$ & 0.0050 \\
\hline $\operatorname{cocos} U$ & $\operatorname{acosu}$ & a.000U \\
\hline $\operatorname{acos} U$ & acosu & $\operatorname{acos} v$ \\
\hline acosu & $2.000 \mathrm{U}$ & $\operatorname{acos} U$ \\
\hline ND & ND & ND \\
\hline ND & ND & ND \\
\hline ND & ND & ND \\
\hline \multirow[t]{5}{*}{ ND } & 0.037 & a.034 \\
\hline & +268 & $-2 n$ \\
\hline & a.071 & $<0,02$ \\
\hline & $<0.000$ & $<0.00 s$ \\
\hline & $<0,001$ & 0.0011 \\
\hline \multirow[t]{3}{*}{$0.005 U$} & $\operatorname{acos} U$ & $a \cos U$ \\
\hline & $<0,0000$ & $<00000$ \\
\hline & -212.37 & -12295 \\
\hline 0.0006 & $\operatorname{acos} U$ & $0 . \cos U$ \\
\hline 0.0000 & $a \cos U$ & $0.005 U$ \\
\hline
\end{tabular}




\section{C-141}

Branomethane (MG/L) $\cdot \propto C$

Cademium $(M G / L) \cdot O C$

Calcium (MG $\Omega$ ) - $Q C$

Carbon Disulfide (MG/) - QC

Carbon Tetractloride (MGR) - QC

Chlorobenzere (MG $\Omega) \cdot O C$

Chloroetbene (MG/L) - OC

Chlorolorm (MGR) - OC

Chloromethane (MG $/) \cdot \alpha C$

Chromium $(M G \Omega) \cdot O C$

Cobalt $(M G \Omega) \cdot O C$

Copper $(M G /) \cdot Q C$

Cyanide (MG/) $\cdot$ OC

Dibromochloromethane (MG/) - OC

Ectoyl benzene (MG/) - OC

Iron $(M G \Omega) \cdot O C$

Lead (MGR) - OC

Lead (MG $L) \cdot O C$

Maquecium (MG/L) - OC

Manganese (MG/) $\cdot$ OC

Merany (MG/L) - OC

Metbylene Obloride $(M G /) \cdot O C$

Nictel $(M G /)$ - $Q C$

Niobium $(M G /$ ) $\cdot$ OC

Pbompboroul (MG/) - $\propto C$

Potmaium (MG/L) - QC

Selenium $(M G /) \cdot O C$

Silver $(M G /) \cdot O C$

Sodium $(M G \Omega) \cdot O C$

Soyrene (MG/L) - OC

Tetrachloroutbene $(M G /) \cdot O C$

Thorium $(M G /) \cdot O C$

Tolvene (MGR) - OC

Trichloroetbeos (MG/L) - OC

Uranium Fluorometric (MGR) $\cdot$ OC

Vanadium (MG/) - OC

Viryl Aoetute (MG/L) - OC

Vinyl Chloride (MG/L) - OC

Xylene (lolal) (MG/) - OC

Zinc $(M G /)$ - OC

cir-1,3-Dictloropropene (MG/) - OC

tran-1,3-Dichloropropene (MGL) $\cdot$ OC

$03 / 28 / 90$

$03 / 2890$

$03 / 28950$

$03 / 28 / 90$

$03 / 28 / 90$

$03 / 28490$

$03 / 28 / 90$

$03 / 28490$

$03 / 28 / 90$

$03 / 28 / 90$

$03 / 2890$

$03 / 2890$

$03 \sqrt{28} 390$

$03 / 28 \times 90$

$03 / 2890$

$03 / 28 / 90$

$03 / 2890$

0328190

002890

a328/90

032899

032890

03/28/90

$0328 \times 9$

$03 / 28 / 90$

$03 / 28950$

$03 / 2890$

032895

032890

03/28950

0325950

$03 / 28990$

c3:2890

$03 / 2890$

0328990

$03 / 28 / 90$

corsesso

o3rsso

03/28950

035290

cospaso

cosesso
ND

a.005

$0.005 \mathrm{U}$

Q. $005 \mathrm{U}$

ND

0.0008

ND

$<0.01$

$<0.005$

0.0056

$<0.1$

a.cosu $0.005 \mathrm{a} \quad 0.005 \mathrm{U}$

a.cosu $\quad 0.005 U \quad 0.005 U$

0.00440 .04

$<0.05$

$<0.004<0.004$

0.0068 0.01

$0.0013 \quad 0.0026$

$<0,0002$

$0.005 U \quad 0.005 U$

$<0.01<0.01$

$<0.007 \quad 0.007$

$<0.005<0.005$

$<0006 \quad<0.006$

Q.045 a.04

$0.005 U \quad 0,005 U \quad 0.005 U$

$0.005 U \quad 0.005 U \quad 0.005 U$

a.cosu $\quad<0.2 \quad<0.2$

a.cosu a.cosu

$<0.001 \quad<0.001$

$<0,005<0.005$

ND ND $\quad$ ND

ND ND ND

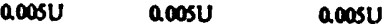

$0.0035 \quad 0.0052$

a.0⿰丿) acosu a a cosu

a.cosu a.0osu a.cosu 


\section{C-142}

Location: 106-00s

1,1,1-Tricbloroetbane (MG/KG)

1,11. Tricbloroethane $(M G /) \cdot O C$

1,1,2,2-Teurscbloroethane (MG/KG)

1, 2,22-Tetracbloroethane (MG/L) - OC

1,1,2-Trictioroethane (MG/KG)

4, 1,2-Trichloroetiane $(M G / L) \cdot O C$

1.1-Dichloroethane (MG/KG)

1.1-Dictloroethare $(M G / 2) \cdot O C$

11-Dichloroethene (MG/KG)

1,1-Dichloroethese $(M G /) \cdot O C$

1.2-Dichloroethane (MG/KG)

1,2-Dictibroethane $(M G \Omega) \cdot O C$

1.2-Dichioroetbene (lota) (MG/KG)

1,2-Dichloroetbese (Lotal) (MG/L) - OC

12-Dictioropropane (MG/KG)

1,2-Dictionopropane (MG/L) - OC

2-Butanone (MG/KG)

2-Butsance $(M G /)$ - OC

2.Hexnone (MG/KG)

2. Hexanose (MG $/$ ) - OC

4Metbyl-2-pentanone (MG/KG)

4-Metbyl-2-pentanose $(M G \Omega) \cdot O C$

Acetone (MG/KG)

Acetone (MG/L) - OC

Aptu Aativity (PCVG)

Apten Acivity (PCL) - OC

Aluminum (MG/KG)

Aluminum (MG/L) - OC

Anenic (MG/KG)

Anenic (MG/) $\cdot$ QC

Asbealon (\%)

Barium (MG/KG)

Barium (MG/L) - OC

Benzene (MG/KG)

Benrene (MG/) $\cdot$ OC

Berytium (MGRG)

Benyllium $(M G /) \cdot O C$

Bets Activity (PCI/G)

Bess Activity (PCL) - OC

Bromodictloromethane (MG/KG)

Browodictiloromechane (MG/L) . OC

Bromoform (MG/KG)

Bromolorm (MG/) - OC

Bromomethane (MG/KG)

Bromomethane (MG/L) * OC

Cadmivim (MG/KG)

Cudmium (MG/) $\cdot$ OC

Calcium (MGRSG)

Cabium (MG/) - OC

Carton Diwutide (MG/KG)

Carton Divulide (MGR) - OC

Carbon Tetrectloride (MG/KG)

Carton Tetrectloride (MGR) - OC

Calorobensene (MG/KG)

Chlorobenzespe (MG/) - OC

Cloroethane (MG/KG)

Choroethane (MG/) - OC

Colorolorm (MG/KG)

Culorolorw (MG/) - OC

Cbloromethane (MG/KG)

Culoromethane (MG/L) - OC

Coromium (MG/KG)

Chromiven (MGR) + OC

Cobalk (MG/KG)

Cobalk $(M G /) \cdot$ OC

Copper (MG/KG)

Copper $(M G /) \cdot O C$

Cyanide (MG/KG)

Cyanide (MG/) - OC

Dibromoctloromethane (MG/XG)

Dibromoctbloromethase (MG/) $\cdot{ }^{\circ} \mathrm{OC}$

Eltyl benzene (MG/KG)

Elbyl benzenc (MG/) - OC

Iron (MG/KG)

Iron $(M G /) \cdot O C$

\begin{tabular}{|c|c|c|c|}
\hline & co-os & Rin-1 & Rin-2 \\
\hline $03 / 28 / 90$ & ND & & \\
\hline $03 / 28 / 90$ & & $0.005 U$ & $0.005 U$ \\
\hline $03 / 28 / 90$ & ND & & \\
\hline $03 / 28 / 90$ & & $0.005 \mathrm{U}$ & $0.005 U$ \\
\hline $03 / 28 / 90$ & ND & & \\
\hline $03 / 28990$ & & $0.005 U$ & $0.005 \mathrm{U}$ \\
\hline $03 / 28 / 90$ & ND & & \\
\hline $03 / 28 / 90$ & & $0.005 U$ & $0.005 U$ \\
\hline $03 / 28490$ & ND & & \\
\hline $03 / 2890$ & & $0.005 \mathrm{U}$ & $0,005 U$ \\
\hline $03 / 28 / 90$ & ND & & \\
\hline $03 / 2890$ & & $0.005 U$ & $a .005 U$ \\
\hline $03 / 2890$ & ND & & \\
\hline $03 / 2890$ & & $\operatorname{acos} U$ & $0,005 U$ \\
\hline 032890 & ND & & \\
\hline $03 / 2890$ & & $0.005 U$ & $0.005 \mathrm{U}$ \\
\hline 032890 & ND & & \\
\hline 03/28so & & ND & ND \\
\hline $\begin{array}{l}03 / 2890 \\
03 / 28 / 90\end{array}$ & ND & ND & ND \\
\hline $03 / 2890$ & ND & . & \\
\hline 032890 & & ND & ND \\
\hline 032890 & $0.93 E$ & & \\
\hline praseso & & 2026 & 0.01 \\
\hline $03 / 2890$ & 2.97 & & \\
\hline 032890 & & -5.05 & -51.71 \\
\hline 032890 & 23000 & & \\
\hline 032899 & & $<0.02$ & $<0.02$ \\
\hline $03 / 2890$ & 6 & & \\
\hline 032899 & & $<0.000$ & $<a, 00 s$ \\
\hline $0328 / 90$ & $<0$ & & \\
\hline $03 / 2890$ & 25 & & \\
\hline $0328 \times 90$ & & $<a, 001$ & $<0.001$ \\
\hline 032890 & ND & & \\
\hline $03 / 2890$ & & $0.005 U$ & $0.005 U$ \\
\hline 032899 & 11 & & \\
\hline 032890 & & $<0,0003$ & $<0,0000$ \\
\hline $\begin{array}{l}03 / 28490 \\
03 / 28 / 90\end{array}$ & 4.8 & & -245.9 \\
\hline 0328990 & ND & - wet is & \\
\hline 032890 & & $0.005 U$ & $0.005 v$ \\
\hline $0328 \times$ & ND & & \\
\hline 032890 & & $0.005 U$ & Q.005U \\
\hline 0328990 & ND & & \\
\hline 03r28sy & & ND & ND \\
\hline 0282890 & 5.3 & & \\
\hline 032890 & & $<0,003$ & $<0.003$ \\
\hline 032890 & 1900 & & \\
\hline c3r2490 & & a.075 & 0.0067 \\
\hline 0328940 & ND & & \\
\hline 032890 & & $\operatorname{acos} U$ & $\cos U$ \\
\hline $03 / 2890$ & ND & & \\
\hline $03 / 2890$ & & $\operatorname{acos} U$ & $0.005 U$ \\
\hline 032850 & ND & & \\
\hline 032890 & & $0.005 U$ & $a \cos U$ \\
\hline 032899 & ND & & \\
\hline 032890 & & ND & ND \\
\hline $\begin{array}{l}032890 \\
032890\end{array}$ & ND & & $a \cos U$ \\
\hline $03 / 2890$ & ND & 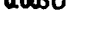 & \\
\hline cosesso & & ND & ND \\
\hline $\cos 28 / 90$ & 25 & & \\
\hline 032890 & & $<201$ & $<0.01$ \\
\hline 032890 & 9.6 & & \\
\hline 032890 & & $<0,005$ & $<0,000$ \\
\hline 032840 & 43 & & \\
\hline 032890 & & $<0,004$ & $<0,000$ \\
\hline 032890 & $<1$ & & \\
\hline 032890 & & $<0.1$ & $<a_{1}$ \\
\hline $03 / 28 / 90$ & ND & & \\
\hline $03 / 2890$ & & $0.005 U$ & 0.0050 \\
\hline 032890 & ND & & \\
\hline $03 / 28 \times 90$ & & $\operatorname{acos} U$ & $0.005 U$ \\
\hline 032890 & 45000 & & \\
\hline 032890 & & 0.0071 & $<0,004$ \\
\hline
\end{tabular}




\section{C-143}

Lead (MG/KG)

Lead (MG/KG)

Lead $(M G /) \cdot O C$

Lead (MG/) - OC

Magnesium (MG/KG)

Magnexium $(M G /) \cdot O C$

Manganese (MG/KG)

Manganeac $(M G / L) \cdot O C$

Merairy (MG/KG)

Mercury (MG/L) : OC

Methylene Chloride (MG/KG)

Metbylese Chloride (MG/L) - OC

Moimture Content (\%)

Nictel (MG/KG)

Nictel $(M G \Omega) \cdot O C$

Niobium (MG/KG)

Niobius $(M G / L) \cdot \propto C$

Phoupboroun (MG/KG)

Prospborous (MG/L) - OC

Potmium (MG/KG)

Pocmaium (MG/L) - OC

Sedenium (MGKKG)

Setenium $(M G /) \cdot \alpha$

Silver (MG/KG)

Siver $(M G /) \cdot O C$

Sodium (MG/KG)

Sodium $(M G /) \cdot O C$

Styreme (MG/RG)

Syrene (MG/) - OC

Tetracbloroetbene (MG/KG)

Tetractioroethene (MG/) - OC

Thorium (MG/KG)

Thorium (MG/L) - OC

Tolvene (MG/KG)

Toluene $(M G /) \cdot O C$

Trichloroetbene (MG/KG)

Trictlonoethese $(M G /) \cdot O C$

Uranium Fluocometric (MG/KG)

Uranium Fluorometric (MGR) $\cdot \propto C$

Vanadium (MG/KG)

Vanadium $(M G /) \cdot O C$

Vinyl Acetale (MG/KG)

Vinyt Acetale (MG/),$O C$

Vinyl Chloride (MG/KG)

Viryt Culoride (MGR) $\cdot O C$

Xylene (low) (MG/KG)

Xylene (Lot) (MGR) - OC

Zinc (MG/KG)

Zinc $(M G /) \cdot O C$

ci-1,3-Dichloropropene (MG/KG)

cir-1,3-Dichloropropene (MGR) $\cdot O C$

trane-1,3-Dictloropropene (MG/KG)

tran-1,3-Dictlonopropene (MG/L) - OC
$03 / 2890$

$03 / 2890$

$03 / 2890$

$03 / 28940$

$03 / 2899$

$03 / 2890$

$03 / 2890$

$03 / 29 \times 0$

$03 / 2890$

$03 / 2890$

$03 / 28 / 90$

$03 / 28 / 40$

0328390

0028980

$03 / 2890$

$03 / 28 \times 190$

0012890

$03 / 2890$

032890

$03 / 2890$

$03 / 289$

032850

$03 / 2890$

$03 / 28490$

$03 / 2890$

032890

$03 / 2890$

corsesco

032890

$03 / 2890$

$03 / 2890$

$03 / 289$

032890

$03 \sqrt{28} 90$

$03 / 2890$

$03 / 2890$

$03 / 2849$

032850

032895

$03 / 2895$

032890

032890

032890

ansaso

032890

032850

asr2840

canser

aspen

$3 / 28 / 50$

032850

032899

13/28490

cor2aso
30
19

$<0.05<0.05$

870

500

$<0.004<0.004$

$<1$

ND

23.6

20

$<09$

1500

1000

$<0.61$

$<0.79$

27

ND

$0.014 U$

29

ND

ND

ND

5.8

$\infty$

ND

ND

ND

130

ND

ND
$<0.000$

$<0.001$

$<0.0002$

$0.005 \mathrm{U}$

$<00$

$<0.007$

$<0.2$

$<0.6$

$<0.005$

$<0.006$

0.027

0.0050

$0 . \cos U$

$<0.2$

0.0008

a.cosu

0.001

$<0,005$

ND

ND

$0.005 \mathrm{U}$

0.0035

$\operatorname{acos} U \quad \cos U$

$a \cos U$ 


\section{C-144}

Locution: 106-006

11.1-Trichloroethane (MG/KG)

1,11.Trichloroechane (MG/KG) - Dup

1.1.1-Tricbloroethane $(M G /) \cdot O C$

1,1,22. Tetractlorocthase (MG/KG)

1,12,2-Tetractloroethane (MG/KG) - Dup

1,1.2.2-Tetrachlorioethane (MG/) - OC

1,1,2-Trictloroethine (MG/KG)

1,1,2-Trictiloroethane (MG/KG) - Dup

1, L,2-Trictionethene (MG/) $)$ OC

1.1-Dichloroethane (MG/KG)

11-Dichloroethane (MG/KG) - Dup

1.1-Dichloroethase $(M G / L) \cdot O C$

L1-Dichloroethene (MG/KG)

41-Dichloroetbene (MG/KG) - Dup

1,1-Dictloroetbene $(M G /) \cdot$ OC

1.2.Dictiorocthane (MG/KG)

1,2-Dichloroethane (MG/KG) - Dup

1.2-Dictioroethene $(M G /)$. OC

1.2-Dichionoethene (Lold) (MG/KG)

1.2-Dichloroetbene (Loll) (MG/KG) - Dup

1.2.Dicbloroctbene (lold) (MG/L) - OC

1.2-Dichloropropane (MG/KG)

12-Dictloropropane (MG/KG) - Dup

1,2-Dichloropropene (MG/L) - OC

2-Butanone (MG/KG)

2-Butanone (MG/KG) - Dup

2Butanose (MGL) - OC

2Hesonone (MG/KG)

2.Heranone (MG/KG) - Dup

2-Hexnone (MG/L) $\cdot Q C$

4-Methyl-2-pentanone (MG/KG)

4Metbyl-2-pentanone (MG/KG) - Dup

4Methyl-2-pentanone (MG/) - OC

Acetone (MG/KG)

Acetone (MG/KG) - Dup

Actione (MG/) - OC

Npts Acivity (PCUG)

Alphe Activity (PCI/G) - Dup

Alphe Activity (PCL) - OC

Aluminum (MG/KG)

Aluminum (MG/KG) - Dup

Numinum $(M G /) \cdot O C$

Amenic (MG/KG)

Anenic (MG/KG) - Dup

Ansenic (MG/L) - OC

Asberlos (\%)

Asbestos (\%) - Dup

Barium (MG/KG)

Barium (MG/KG) - Dup

Barium (MG/L) + OC

Benzene (MG/KG)

Benzene (MG/KG) - Dup

Bernzene $(M G /) \cdot O C$

Beryllium (MG/KG)

Berylliuon (MG/KG) - Dup

Beryllium (MG/) - $\alpha$

Bets Aaivity (PCLG)

Bets Aativity (PCVG) - Dup

Bes Aaivity (PCL) . OC

Brosodichloromethine (MG/KG)

Bromodictionomethane (MG/KG) - Dup

Bromodictiloromethane $(M G /) \cdot O C$

Bromolorm (MG/KG)

Browoform (MG/KG) - Dup

Bromolorm (MG/) . OC

Bromosethane (MG/KG)

Bromoonethase (MG/KG) - Dup

Bromosethane (MG/L) $\cdot$ QC

Cedmium (MG/KG)

Cadmium (MG/KG) - Dup

Cudmium (MGR) - OC

Calcium (MG/KG)

Calcium (MG/KG) - Dup

Celcium (MG/) - OC

Carbon Divulfide (MG/KG)
$03 / 29 / 90$

$03 / 29 / 90$

$03 / 29 / 90$

$03 / 29 / 90$

$03 / 29 / 90$

$03 / 29 / 90$

$03 / 29 / 90$

$03 / 29 / 90$

$03 / 29190$

$03 / 29 / 90$

$03 / 29190$

$03 / 29 / 90$

032990

0329190

$03 / 29 / 90$

$03 / 29190$

$03 / 29 / 90$

$03 / 29 / 90$

$03 / 2940$

$03 / 29190$

$03 / 29 / 90$

$03 / 29 / 90$

$03 / 29490$

032940

$03 / 2990$

$03 / 29 / 90$

0329940

032900

$03 / 2990$

$03 / 29 / 90$

$03 / 29190$

$03 / 29 / 90$

0329190

$03 / 2990$

0329190

comors

032940

corseso

$03 / 2990$

0329190

032990

$03 / 29 / 90$

$03 / 2990$

$03 / 29190$

$03 / 2990$

$03 / 29190$

120290

$03 / 2940$

03/29190

$03 / 2990$

032990

$03 / 2990$

a329190

0329490

$03 / 29 / 90$

$03 / 29 / 90$

$03 / 29$

$03 / 29 / 90$

03/29190

$03 / 29 / 90$

03329190

032990

mpars

0129\%0

$03 / 2990$

$03 / 2990$

032990

$03 / 2950$

0129190

$03 / 2990$

032000

03/2990

$03 / 29190$

$03 / 29 \% 0$

0329190

\begin{tabular}{|c|c|c|c|c|}
\hline \multirow{2}{*}{$\begin{array}{l}00-05 \\
\text { ND }\end{array}$} & 05.10 & 10.15 & Blank & Rin-1 \\
\hline & $\begin{array}{l}\text { ND } \\
\text { ND }\end{array}$ & ND & & \\
\hline ND & $\begin{array}{l}\text { ND } \\
\text { ND }\end{array}$ & ND & $0.005 U$ & $a \cos U$ \\
\hline ND & $\begin{array}{l}\text { ND } \\
\text { ND }\end{array}$ & ND & $0.005 U$ & $0,005 U$ \\
\hline ND & $\begin{array}{l}\text { ND } \\
\text { ND }\end{array}$ & ND & $0,005 \mathrm{U}$ & $\operatorname{acos} U$ \\
\hline ND & $\begin{array}{l}\text { ND } \\
\text { ND }\end{array}$ & ND & $0 . \cos U$ & $\operatorname{acos} U$ \\
\hline ND & $\begin{array}{l}\text { ND } \\
\text { ND }\end{array}$ & ND & $\operatorname{acos} U$ & 0,0000 \\
\hline ND & $\begin{array}{l}\text { ND } \\
\text { ND }\end{array}$ & ND & $0.005 \mathrm{U}$ & $0.005 U$ \\
\hline ND & $\begin{array}{l}\text { ND } \\
\text { ND }\end{array}$ & ND & $a, \cos U$ & $0,005 U$ \\
\hline ND & $\begin{array}{l}\text { ND } \\
\text { ND }\end{array}$ & ND & $0,005 \mathrm{U}$ & $\operatorname{acos} u$ \\
\hline ND & $\begin{array}{l}\text { ND } \\
\text { ND }\end{array}$ & ND & ND & ND \\
\hline ND & $\begin{array}{l}\text { ND } \\
\text { ND }\end{array}$ & ND & ND & ND \\
\hline $0.02 \%$ & $\begin{array}{l}\text { Q.7TE } \\
\text { a.49 }\end{array}$ & 0.25 & ND & ND \\
\hline 275 & $\begin{array}{l}275 \\
3.96\end{array}$ & 437 & 0.007 & a.011 \\
\hline 19000 & $\begin{array}{l}300000 \\
27000\end{array}$ & 33000 & & 10.49 \\
\hline 16 & 22 & 26 & & $<0,2$ \\
\hline$<0$ & $\begin{array}{l}<0 \\
<0\end{array}$ & $<0$ & & $<0,000$ \\
\hline 100 & $\begin{array}{l}32 \\
24\end{array}$ & 25 & & \\
\hline ND & $\begin{array}{l}\text { ND } \\
\text { ND }\end{array}$ & ND & & $<0001$ \\
\hline 0.95 & $\begin{array}{l}1 \\
1.2\end{array}$ & L.S & $2005 U$ & $\operatorname{acos} U$ \\
\hline 3.15 & $\begin{array}{l}3.16 \\
3.83\end{array}$ & 4.16 & & $<0,0000$ \\
\hline ND & $\begin{array}{l}\text { ND } \\
\text { ND }\end{array}$ & ND & & -55.80 \\
\hline ND & $\begin{array}{l}\text { ND } \\
\text { ND }\end{array}$ & ND & 0,0006 & $a, 0000$ \\
\hline ND & $\begin{array}{l}\text { ND } \\
\text { ND }\end{array}$ & ND & $0.005 U$ & a.00su \\
\hline 2.4 & 4.5 & 5.3 & ND & ND \\
\hline & 5.1 & & & \\
\hline 2000 & $\begin{array}{l}320 \\
190\end{array}$ & $n$ & & $<0,000$ \\
\hline & 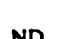 & . & & 002 \\
\hline
\end{tabular}


Carbon Disullide (MG/KG) - Dup

Carton Disulnide $(M G /) \cdot O C$

Carton Teluachloride (MG/KG)

Carbon Tetracbloride (MG/KG) - Dup

Carbon Teuractstoride (MG/L) . OC

Chlorobenzene (MG/KG)

Chlorobenzene (MG/KG) - Dup

Chiorobenzene (MG/L) - OC

Chloroethase (MG/KG)

Chlorcethane (MG/KG) - Dup

Chioroethane (MG/) - OC

Chlorolorm (MG/KG)

Caloroform (MG/KG) - Dup

Chloroform (MG/) - OC

Cbloromethane (MG/KG)

Chloromethane (MG/KG) - Dup

Chloromethane (MG/) - QC

Chromium (MG/KG)

Chroenium (MG/KG) - Dup

Chromium (MG/) - OC

Cobalt (MG/KG)

Cobalt (MG/KG) - Dup

Cobalt (MG/L) - OC

Copper (MG/KG)

Copper (MG/KG) - Dup

Copper $(M G /) \cdot Q C$

Cyanide (MG/RG)

Cyanide (MG/KG) - Dup

Cyanide $(M G /) \cdot O C$

Dibrowoctboromethane (MG/KG)

Dibromoctloromethane (MG/KG) - Dup

Dibromochloromethane (MG/) - OC

Eltyl benzene (MG/KG)

Eubyl benzene (MG/KG) - Dup

Echyl benzene (MGR) - OC

Iron (MG/KG)

Iron (MG/KG) - Dup

Iron $(M G / L) \cdot O C$

Lead (MG/KG)

Lead (MG/KG)

Lead (MG/KG) - Dup

Lead (MGKKG) - Dup

Lead (MGR) $\cdot$ OC

Lead (MG $L)$ - OC

Magnerium (MG/KG)

Magnesium (MG/KG) - Dup

Magnesileo $(M G / L) \cdot O C$

Manganese (MG/KG)

Manganese (MG/KG) - Dup

Manganese $(M G \Omega) \cdot O C$

Meraury (MG/KG)

Meraury (MG/KG) - Dup

Metoury (MG/L) - OC

Metbylene Coloride (MG/KG)

Metbylene Cbloride (MG/KG) - Dup

Metbylene Chloride (MG/) - OC

Moisture Content (\%)

Moisture Content (\%) - Dup

Nictel (MG/KG)

Nickel (MG/KG) - Dup

Nictel $(M G / L) \cdot O C$

Niobium (MG/KG)

Niobium (MG/KG) • Dup

Niobiuos $(M G /) \cdot O C$

Pboaptoroul (MG/KG)

Pboaptoroul (MG/KG) - Dup

Pboupborous (MG/) - OC

Pocancium (MG/KG)

Polnsuium (MG/KG) - Dup

Pocsusium (MG/) $\cdot$ OC

Setenium (MG/KG)

Setenium (MG/KG) - Dup

Setenium (MG/L) . OC

Silver (MG/KG)

Siner (MG/KG) - Dup

Siver $(M G \Omega) \cdot O C$

Sodium (MG/KG)

Sodium (MG/KG) - Dup

$03 / 29 / 90$

$03 / 29 / 90$

$03 / 29 / 90$

$03 / 29 / 90$

$03 / 29 / 90$

$03 / 2900$

$03 / 29 / 90$

$03 / 29 / 90$

$03 / 29 / 90$

$03 / 29 / 90$

$03 / 29190$

$03 / 29190$

$03 / 29 / 90$

$03 / 29190$

$03 / 29 / 90$

$03 / 29 / 90$

$03 / 29 / 40$

$03 / 29 / 90$

03299190

$03 / 29190$

$03 / 29 / 90$

0329190

a3/2910

$03 / 29 / 90$

$03 / 29190$

$03 / 29 / 90$

032900

$03 / 29190$

$03 / 29190$

$03 / 29 / 90$

$03 / 29190$

$03 / 29 / 90$

$03 / 29 / 90$

$03 / 29 / 90$

0329100

$03 / 29 / 90$

$03 / 29 / 90$

$03 / 29 / 90$

$03 / 29 / 90$

$03 / 29 / 90$

$03 / 29190$

$03 / 2940$

$03 / 29 / 90$

$03 / 29190$

0329190

$03 / 29 / 90$

$03 / 29190$

$03 / 2900$

$03 / 2990$

$03 / 2990$

$03 / 29190$

$03 / 29190$

$03 / 29 / 90$

$03 / 2940$

$03 / 29190$

$03 \sqrt{29} 40$

$03 \sqrt{29} 90$

$03 / 29190$

$03 / 2940$

$03 / 29100$

$03 \sqrt{2940}$

03290

$03 \sqrt{29} 90$

$03 / 2940$

$03 / 29190$

0372900

$03 \sqrt{29} \times$

$03 / 29 / 90$

032910

037so

$03 / 29 / 90$

$03 / 29190$

$03 / 2990$

037940

$03 / 29 / 20$

$03 / 29 / 90$

$03 / 29 / 90$

032900

\begin{tabular}{|c|c|c|c|c|}
\hline \multirow[b]{2}{*}{ ND } & \multicolumn{2}{|l|}{ ND } & \multirow[b]{2}{*}{$0.005 U$} & \multirow[b]{2}{*}{$0,005 U$} \\
\hline & $\begin{array}{l}\text { ND } \\
\text { ND }\end{array}$ & ND & & \\
\hline ND & $\begin{array}{l}\text { ND } \\
\text { ND }\end{array}$ & ND & $0.005 \mathrm{U}$ & $0,005 U$ \\
\hline ND & $\begin{array}{l}\text { ND } \\
\text { ND }\end{array}$ & ND & $0.005 U$ & $0.005 U$ \\
\hline ND & $\begin{array}{l}\text { ND } \\
\text { ND }\end{array}$ & ND & ND & ND \\
\hline ND & $\begin{array}{l}\text { ND } \\
\text { ND }\end{array}$ & ND & 0.0006 & a.cosu \\
\hline 31 & $\begin{array}{l}27 \\
26\end{array}$ & 27 & ND & ND \\
\hline 40 & $\begin{array}{l}14 \\
13\end{array}$ & 66 & & $<0.01$ \\
\hline 15 & $\begin{array}{l}43 \\
51\end{array}$ & 74 & & $<0.005$ \\
\hline$<1$ & $\begin{array}{l}<1 \\
<1\end{array}$ & $<1$ & & ra,om \\
\hline ND & $\begin{array}{l}\text { ND } \\
\text { ND }\end{array}$ & ND & & $<a_{1}$ \\
\hline ND & $\begin{array}{l}\text { ND } \\
\text { ND }\end{array}$ & ND & $0.005 U$ & $a \cos U$ \\
\hline & & & $0.005 U$ & $\operatorname{acos} U$ \\
\hline
\end{tabular}

0.018

53

58

$47 \quad 150$

136

$<0.05$

900

930

coom

a.0035

2000

1100

$<0.001$

$<1<$

$<1$

$<0,0002$

ND

ND

24.2

$0.005 U$

a.00se

128

27

52

$<0.01$

$<0.83$

$<094$

$<0.007$

780

1600

680

1300

$<0.6$

$<0.56$

$<0.55$

$<0,005$

$<0.71<0.78<0.81$

$<0.78$
$<0.79$

47

47
26

41 
C-146

Sodium (MGR) $\cdot$ OC

Styrese (MG/KG)

Styrese (MG/KG) - Dup

Sirrene (MG/) - OC

Teuracbloroethene (MG/KG)

Teractioroetbene (MG/KG) - Dup

Tetrachloroetbene (MG/L) - OC

Tborivo (MG/KG)

Thoriuos (MG/KG) - Dup

Thorium (MG/) - OC

Tolwene (MG/KG)

Tolvene (MG/KG) - Dup

Tolvene $(M G /) \cdot O C$

Trictloroetbene (MG/KG)

Trictloroethene (MG/KG) - Dup

Trictionoethene (MGL) - OC

Unanium Fluorometric (MGRKG)

Uranium Fuorodetric (MORKG) - Dup

Uranium Fluorowetric (MG/L) - OC

Vanedium (MG/KG)

Vanedium (MGRKG) - Dup

Vanadium (MGR) - OC

Viryt Acetale (MG/KG)

Viryl Acetste (MG/KG) - Dup

Virsyl Acetsle (MG/L) - OC

Viant Culoride (MG/KG)

Virst Cutoride (MG/RG) - Dup

Vinyl Chloride (MGR) - OC

Xylese (lotal) (MG/KG)

Xylese (Lotd) (MGRKG) - Dup

Xylene (loLl) (MG/L) - OC

Zinc (MG/KG)

Zine (MG/KG) - Dup

Zinc (MG/) - OC

cir-13-Dichloropropene (MG/KG)

cir-1,3-Dichloropropene (MG/KG) - Dup

in-13-Dictloropropene (MG/L) - OC

trane-1,3-Dictuloropropene (MG/KG)

trane-1,3-Dictloropropene (MG/KG) - Dup

trans-1,3-Dichloropropene (MG/L) - OC

$03 / 29 / 90$

$03 / 29 / 90$

$03 / 29 / 90$

$03 / 29 / 90$

$03 / 29 / 40$

$03 / 29 / 90$

$03 / 29 / 90$

$03 / 29 / 90$

$03 / 29190$

0329990

$03 / 29190$

$03 / 29 / 90$

0329190

$03 / 29 / 90$

$03 / 29190$

$03 / 2990$

032940

0329190

0329190

$0329 / 90$

$03 / 29 / 90$

0329190

$03 / 29 / 90$

$03 / 29 / 90$

$03 / 29190$

$03 / 29 / 50$

$03 / 2990$

ar2950

$03 / 29 \times 10$

$03 / 29450$

032990

032940

0329190

032900

$03 / 29 / 90$

$03 / 29190$

$03 / 29 \% 0$

$03 / 2990$

$03 \sqrt{29} 90$

032900

$$
\text { ND }
$$

$0.014 \mathrm{U}$

ND
ND

0.0150

$<24$

29

ND

ND

3.8

3.8

39

ND

ND

ND

62

ND

ND

0)20\%o

LL1-Trictloroethane $(M G /) \cdot O C$

1.1,2,2-Tetrectiloroethane (MG/) - $Q C$

4, 2, Trichloroethane $(M G /) \cdot O C$

1.1-Dictioroethase (MGR) - OC

L.1-Dichloroetbene $(M G /)$ - OC

12.-Dichloroethese (MG/) - OC

12-Dictiloroethese (Lot) (MG $L$ ) - OC

1,2-Dictloropropane (MGR) - OC

2Butanone (MGR) - OC

2 Hempone (MG/L) - OC

4Metbyt-2-pentapose (MGL) - OC

Acetone (MGR) - QC

Alpts Activity (PCLL) · OC

Aluminum (MG 2 ) - OC

Arsenic (MG/L) - OC

Bariuon (MGR) $\cdot \mathrm{OC}$

Benuene $(M G \Lambda) \cdot O C$

Berytium (MG/) - $\mathrm{OC}$

Bet Activity (PCL) - OC

Bromodictionometbane $(M G / L) \cdot Q C$

Broenolorm (MGL) - QC

Browosethane (MG/) - OC

Cadmium $(M G \Omega) \cdot O C$

Celcium $(M G /) \cdot O C$

Carton Dieulfide (MG/) - OC

Carbon Teuractlonide $(M G / L) \cdot O C$

Chlorobenzene $(M G / L) \cdot O C$

Chlorothane (MG/) $\cdot$ OC

Chloroform (MG/L) - OC

Chlorowethane (MG/) - OC

Chromium (MG/L) - OC

Cobalt (MG/) $\cdot$ OC

Copper $(M G \Omega) \cdot O C$

Cyanide $(M G \Omega) \cdot O C$

Dibrowoctbloromethane (MGI) $\cdot O C$

Elbyl benzene (MG/L) - QC
032990

0329450

03/2990

032990

0329950

$03 / 29 / 90$

$03 / 29190$

$\cos 200$

032950

arzerso

032siso

$03 / 29190$

032990

032950

wrass

032900

032950

0329190

$.03 / 290$

c329/90

032990

0329190

$00 / 29 / 90$

m2990

032990

$03 / 29 / 90$

0329190

0012990

cos/29rso

$03 \sqrt{29} 9 x^{2}$

$03 / 29 \times 190$

$03 / 29190$

032940

$03 / 2990$

$03 / 29 / 90$
Rin-2

acosu

$0, \cos U$

a.cosu

acosu

acosu

$\operatorname{acos} U$

$0.005 \mathrm{U}$

a.cosu

ND

ND

ND

Q.013

1522

$<0.02$

$<0.005$

$<0.01$

acosu

$<0,0000$

$-1788$

$0 . \cos U$

a.cosu

ND

$<0.003$

0.0056

$0.005 U$

$0 . \cos U$

a.cosu

ND

a.cosu

ND

$<0.01$

$<0.005$

ca.004

$<0.1$

$0 . \cos U$

$0.005 \mathrm{U}$
ND

0.0050

$a .005 \mathrm{U}$

$0.016 \mathrm{U}$

$0.005 \mathrm{U}$

a.cosu

$<02$

a. $005 \mathrm{U}$

0.0007

0.0000

acosu

$<0001$

copos

ND

ND

ND

ND

$\operatorname{acos} U$

a.cosu

20041

a.cosu

$0.000 \mathrm{U}$

$0 . \cos U$

$a \cos U$ 


\section{C-147}

$\operatorname{Iron}(M G /)$ - OC

Lad $(M G / L) \cdot O C$

Lead (MG $/$ ) - QC

Magneaium (MG/L) $\cdot$ OC

Manganese (MG/L) - OC

Mercury (MG/) - QC

Metbylene Cbloride (MG/) · OC

Nictel $(M G /) \cdot O C$

Niobium (MG/) . OC

Pboupborous (MG $/) \cdot Q C$

Polseaium (MOR) - OC

Setenium $(M G \Omega) \cdot O C$

Sitver $(M G / L) \cdot Q C$

Sodium $(M G /) \cdot O C$

Styrese $(M G /) \cdot \mathbf{Q C}$

Tetrachloroetbene (MGR) - OC

Thorium (MG $\Omega$ ) - QC

Toluene (MG $/$ ) - OC

Trictiloroetbene (MGR) - OC

Uranius Pluorometric (MG/) • OC

Vandium (MGI) - OC

Viant Acetale (MGR) · OC

Vinyl Caloride (MG/L) $\cdot$ OC

Xylene (loul) (MGN) - OC

Zine (MGN) - OC

cis-1,3-Dichloropropepe (MGL) - OC

trana-1,3-Dictloropropene (MG/) $\cdot \mathrm{OC}$

$03 / 2990 \quad 0.014$

$03 / 2990<<0.05$

$03 / 29 / 90 \quad<0.004$

$03 / 29 / 90 \quad 0.001$

$03 / 29 / 90 \quad 0.0013$

$03 / 29190<\quad<0.0002$

$03 / 29 / 90 \quad 0.005 \mathrm{U}$

$03 / 29 / 90 \quad<0.01$

$03 / 29 / 90<<0.007$

$03 / 29 / 90<<0.2$

$03 / 29190<<0.6$

$03 / 29 / 90<<0.005$

$03 / 29 / 90 \quad<0.006$

$03 / 29190 \quad 0.027$

$03 / 29 / 90 \quad 0.005 \mathrm{U}$

$03 / 29 \% 000000$

Carse $\quad<02$

$00 / 29190 \quad 0.002$

$03 / 29900 \quad 0.005 \mathrm{U}$

$03 / 29 / 90<<0.001$

$03 / 29 / 90<<0.005$

$03 / 29190 \quad$ ND

$03 / 29190$ ND

$03 / 29190 \quad a .005 U$

$03 / 29 / 90 \quad 0.0047$

$03 / 29 / 90 \quad 0.0050$

$03 \sqrt{29 / 90} \quad 0.005 \mathrm{U}$ 
Location: 106-007

1,1.1-Tricbloroethane (MG/KG)

1,1,1-Tricbloroethane (MG/KG) - Dup

1,1,1.Tricbloroethane (MGR) - OC

1.1.22. Tetracbloroethane (MG/KG)

1,1,22. Tetractioroethane (MG/KG) - Dup

4,1,2,2-Tetrachloroethane (MG/L) - OC

1,1.2. Trichloroethine (MG/KG)

1,1,2-Tricbloroetbuse (MOKKG) - Dup

1.12-Trichloroethane (MGR) - OC

1.1. Dichloroethane (MG/KG)

1,1-Dichloroethane (MG/KG) - Dup

11. Dicbloroethine (MGL) - QC

11-Dichloroetbene (MO/KG)

1.1-Dictiloroethene (MG/KG) - Dup

1,1-Dictionoethene $(M G /)$ - QC

1,2-Dichloroethene (MO/KG)

1,2-Dichloroethane (MO/KG) - Dup

1,2-Dictionoethane $(M G /) \cdot O C$

1.2-Dictloroetbene (Lot) (MG/KG)

1.2-Dicbloroetbene (Lota) (MG/KG) - Dup

1.2-Dictionoctbene (Lotal) (MO/L) - OC

1.2. Dichloropropane (MG/KG)

1.2.Dicbloropropene (MG/KG) - Dup

1.2-Dichloropropene $(M G / L) \cdot O C$

2-Butunone (MG/KG)

2-Butanone (MG/KG) - Dup

2. Butanone $(M G /) \cdot O C$

2. Hexanone (MGRG)

2-Heranone (MG/KG) - Dup

2-Hexnone (MGR) - OC

4Metbyl-2.pentanone (MG/KG)

4-Metbyl-2-pentanone (MG/KG) - Dup

4 Metbyt-2-pentanone (MG/L) $\cdot O C$

Acelone (MO/KG)

Acetone (MGKKG) - Dup

Actone (MG/) - OC

Alptas Activity (PCNG)

Aptes Activity (PCVG) - Dup

Nptes Aativity (PCLL) - OC

Aluminum (MG/RG)

Numinum (MGKG) - Dup

Aluminum (MG/L) - OC

Anenic (MG/KG)

Anenic (MG/KG) - Dup

Anenic (MG/) - OC

Albectos (\%)

Albewion (\%) - Dup

Barium (MG/KG)

Barium (MG/KG) - Dup

Barium (MGR) - OC

Benzenc (MG/KG)

Benzene (MG/KG) - Dup

Benzene $(M G /)$ ) OC

Beryllium (MG/KG)

Bentlium (MG/KG) - Dup

Beryllium (MG/) $\cdot O C$

Bets Aaivity (PCVG)

Bets Aaviry (PCVG) - Dup

Bets Activity (PCLL) - OC

Bromodictiloromethine (MO/KG)

Bromodicthloromethane (MG/KG) - Dup

Bromodictioromethane (MG/) $\cdot O C$

Bromulorm (MGKG)

Browolon (MG/KG) - Dup

Bromolorm (MG/ ) - OC

Bromonethare (MG/KG)

Browomethane (MG/KG) - Dup

Bromomethane $(M G \Omega) \cdot O C$

Cadmium (MG/KG)

Cadmium (MG/KG) - Dup

Cadmium $(M G \Omega) \cdot O C$

Culcium (MG/KG)

Calcium (MG/KG) - Dup

Caloium (MG/L) - OC

Carbon Dimulinde (MG/KG)
$04 / 0290$

$04 / 02 / 90$

04/02/90

$04 / 02 / 90$

$04 / 02 / 90$

$04 / 02 / 90$

0402190

04/02/90

$0402 / 90$

0402190

040290

averso

040250

040290

0402/90

$0402 / 90$

ostorso

040290

$0402 / 90$

0.0250

$04 / 02 / 90$

040290

040295

$0402 / 90$

$0402 / 90$

$002 \pi$

04000

040290

040250

040250

aross

040295

040250

$0402 / 90$

curess

בroper

040290

0402190

0402190

arrose

0.10250

acos/so

0.10290

040250

actorso

anosso

ONo2s0

across

$0402 \times$

caross

curos

040290

4000

040250

040290

040250

curoso

cuross

040250

0.0290

04029

cerosen

cerse

040290

avers

$0402 / 90$

curesso

0arerso

040290

$0402 / 90$

arinesso

curosso

arosso

040250

040250

\begin{tabular}{|c|c|c|c|}
\hline \multirow{3}{*}{$\begin{array}{l}00-05 \\
\text { ND } \\
\text { ND }\end{array}$} & \multirow[t]{2}{*}{ Blank } & \multirow[t]{2}{*}{$\operatorname{Rin}-1$} & \multirow[t]{2}{*}{ Rin-2 } \\
\hline & & & \\
\hline & & & \\
\hline \multicolumn{4}{|l|}{ ND } \\
\hline \multicolumn{4}{|l|}{ ND } \\
\hline & $0.005 U$ & $0.005 U$ & $0.005 U$ \\
\hline \multicolumn{4}{|l|}{ ND } \\
\hline \multicolumn{4}{|l|}{ ND } \\
\hline \multirow{2}{*}{\multicolumn{4}{|c|}{$\begin{array}{l}\text { ND } \\
N D\end{array}$}} \\
\hline & & & \\
\hline \multicolumn{4}{|l|}{ ND } \\
\hline \multicolumn{4}{|l|}{ ND } \\
\hline \multicolumn{4}{|l|}{ ND } \\
\hline & $0.005 U$ & $0.005 U$ & $a \cos U$ \\
\hline \multicolumn{4}{|l|}{ ND } \\
\hline \multicolumn{4}{|l|}{ ND } \\
\hline & $0.005 U$ & $a \cos U$ & $a \cdot \cos U$ \\
\hline ND & & & \\
\hline ND & & & \\
\hline & $0 . \cos U$ & $0.005 U$ & $\operatorname{acosu}$ \\
\hline ND & & & \\
\hline ND & $0 . \cos U$ & $a \cos U$ & $\operatorname{acos} U$ \\
\hline ND & & & \\
\hline & ND & 0.02 & 0.02 \\
\hline ND & & & \\
\hline ND & & & \\
\hline & ND & 0.005 & 0.006 \\
\hline ND & & & \\
\hline ND & & & \\
\hline & ND & ND & ND \\
\hline $\begin{array}{l}2.1 E \\
0.24\end{array}$ & & & \\
\hline & ND & 0.03 & 0.057 \\
\hline 214 & & & \\
\hline 273 & & & \\
\hline & & .53 .47 & 133.66 \\
\hline 21000 & & & \\
\hline 29000 & & & \\
\hline 85 & & $<0,2$ & $<0,02$ \\
\hline 13 & & & \\
\hline & & $<0,000$ & $<0,000$ \\
\hline$<0$ & & & \\
\hline$<0$ & & & \\
\hline 230 & & & \\
\hline 110 & & & \\
\hline & & $<0, \infty 01$ & 0.002 \\
\hline $\begin{array}{l}\text { ND } \\
\text { ND }\end{array}$ & & & \\
\hline ND & $\operatorname{acos} U$ & $0.005 \mathrm{U}$ & $a \cos U$ \\
\hline 19 & & & \\
\hline 21 & & & \\
\hline & & $<0,0000$ & $<0.0000$ \\
\hline 265 & & & \\
\hline 3.43 & & & \\
\hline & & .245 .9 & 1218 \\
\hline ND & & & \\
\hline ND & & & \\
\hline & $0 \cdot \cos U$ & $a \cos U$ & $0,005 \mathrm{U}$ \\
\hline ND & & & \\
\hline ND & & & n masu \\
\hline ND & $\operatorname{acos} U$ & $a \cos U$ & 0.0000 \\
\hline ND & & & \\
\hline & ND & ND & ND \\
\hline 3.9 & & & \\
\hline 19 & & $<0,003$ & $<0,000$ \\
\hline 7000 & & & \\
\hline 3700 & & & \\
\hline & & 0,023 & 0.021 \\
\hline
\end{tabular}




\section{C-149}

Carton Disulitide (MG/KG) - Dup

Carton Dieulinide $(M G /) \cdot O C$

Carton Tetractioride (MG/KG)

Carton Tetracbloride (MG/KG) - Dup

Carton Tetrachloride $(M G / L) \cdot O C$

Chimobenzene (MG/KG)

Cularobenzene (MG/KG) - Dup

Chlorobenzene (MGR) - OC

Chloroethane (MG/KG)

Clonoethase (MG/KG) - Dup

Chlorocthane (MG/L) $\cdot O C$

Cabrolorm (MGKG)

Culorotorm (MGRK) - Dup

Chloroform (MG/) - OC

Otomercinese (MG/KG)

Culoromethene (MG/KG) - Dup

Cblorosethane (MG/) $\cdot$ QC

Crromium (MG/RG)

Coroeniun (MG/KG) - Dup

Corominon (MG/L) - QC

Cobelt (MG/KG)

Cobalk (MG/KG) - Dip

Cobalt $(M G /)$ - OC

Copper (MG/KG)

iopper (MG/KG) - Dup

Copper (MGL) $\cdot$ OC

Cyaide (MG/KG)

Cyanide (MG/KG) - Dup

Cyanide (MG/L) - OC

Dibneochloromethane (MG/KG)

Dibroisoctioromethane (MG/KG) - Dup

Dibrowoctibromethane (MG/) - OC

Elbyl benzene (MG/KG)

Elayl betwene (MG/KG) - hup

Eubyl benzene (MGN) $\cdot O C$

Inon (MG/KG)

Iron (MG/KG) - Dup

If $=(M G \Omega) \cdot Q C$

La: (AGNKG)

Lead (MGKKG)

Leed (MG/KG) - Dup

Lead (MGRKG) - Dup

Lead $(M G / L) \cdot O C$

Lead (MGL) - OC

Marneaium (MG/KG)

Mayneinus (MGRK) - Dup

Mapreaium (MG/L) - OC

Mangancas (MG/KG)

Mangar ac (MG/KG) - Dup

Manga e $(M G /$ ) $-O C$

Metary (MG/KG)

Merany (MGRKG) - Dup

Merenry (MG/L) - OC

Metbriene Caloride (MGRKG)

Metbylene Culoride (MG/KG) - Dup

Metbyleose Chloride (MG/L) - OC

Mointure Content (\%)

Moimature Costede (\%) - Dup

Nietet (MG/KG)

Nicted (MG/KG) - Dup

Nictel $(M G \Omega) \cdot O C$

Niobiven (MG/KG)

Niobium (MG/KG) - Dup

Niobium (MG/L) - OC

Pboupborous (MGRG)

Phoupboroun (MGKG) - Dup

Pbospboroms $(M G /) \cdot O C$

Pocmanos (MGRG)

Poumanim (MGKK) - Du

Porming (MG/) - OC

Selenium (MG/KG)

Selesines (MG/KG) - Dup

- Sedenium (MG/L) $\mathrm{OC}$

siver (MG/KG)

Siver (MG/KG) - Dup

Siner $(M G /) \cdot C C$

Sodiven (MG/KG)

Sodive (MGKS) - Dup

$0402 / 90$

040250

040290

$0402 / 90$

$04 / 02 / 90$

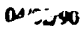

04/02/90

$04 / 02 / 90$

$0402 / 30$

0400200

0402so

$0402 \times 0$

040250

arperso

040250

040250

acterso

040290

040200

040290

0,0250

040250

averso

040250

$0402 / 90$

c40250

ovoseso

croesso

0.40250

0

040290

$0402 / 90$

c402/90

040290

averso

orrexpo

c102/s0

ocosso

cropero

0.102/so

averso

$0402 / 90$

curpese

arpos

c10250

040250

040250

$0402 \% 0$

cursess

04029

curess

aspose

curesso

cures:

040250

carose

arorso

caresso

coros

040250

(1)

0402s:

cures

14000

$002 \%$

cusers

040290

04000

040200

040290

$0402 \times 10$

curos

040290

04000

$0402 \times 5$

040250

coresso
ND

ND

ND

ND

ND

ND

ND

ND

ND

ND

ND

33

36

17

25

$<1$

$<1$

ND

ND

ND

34000

41000

27

39

83

48

300

3700

990

810

$<1$

$<1$

ND

ND

246

246

31

ss

$<0.85$

$<Q 84$

1300

1600

3200

3300

$<$ as2

<ass

$<073$

$<0.7$

530

rio

$\begin{array}{lll}0.005 U & 0.005 U & 0.005 U \\ 0.005 U & 0.005 U & 0.005 U \\ 0.005 U & 0.005 U & 0.005 U\end{array}$

ND ND ND

$0.005 U \quad 0.005 U \quad 0.005 U$

ND ND ND

$<0.01<0.01$

$<0.005 \quad<0.000$

<0.004 <acos

$<a_{1}<a_{1}$

$0.005 U \quad 0.005 U \quad 0.0000$

a.cose a.0osu a.00su

$0.012 \quad 0.15$

$<0.05<0.05$

sacos cacos

a.0031 a.0041

$0.0013<0.001$

$<0,0002 \quad<a 000$

$0.005 U \quad 0.005 U$

$<001<0.01$

cocor sacos

$<02<02$

$<06 \quad<06$

$<0000 \quad<0005$

$<0,000<0000$ 
C-150

Sodium $(M G /) \cdot O C$

$04102 / 90$

$0402 / 90$

Sryrene (MG/KG)

Styrene (MG/KG) - Dup

Syrene (MGR) $\cdot O C$

Tetrachloroetbene (MG/KG)

Tetractiloroetbene (MG/KG) - Dup

Tetrocbloroetbene (MG/) $\cdot$ OC

Thorium (MG/KG)

Thorium (MG/KG) - Lup

Thoriue $(M G /) \cdot O C$

Toluene (MG/KG)

Tolvene (MG/KG) - Dup

Toluene $(M G /) \cdot O C$

Tricbloroubene (MG/KG)

Trictionoetbese (MGRG) - Dup

Trictioroethene (MG/L) - OC

Uraniver 20S (WTX) - Dup

Unaium 238 (WT\%) - Dup

Uraning Pluorometric (MG/KG)

Unaium Pluorosetric (MG/KG) - Dup

Unaium Pluorometric (MG/) - OC

Urminem-234 (WT\%) - Dup

Urasium-236 (WT\%) - Dup

Vanadium (MG/KG)

Vanediven (MG/KO) - Dup

Veandium (MOR) - OC

"ivist Acetece (MO/RG)

Vioy Aceute (MORKG) - Dup

Viont Aoetule (MO/L) - OC

Vingt Culoride (MGKRO)

Vianl Coloride (MO/KG) - Dup

Viayl Cibride (MG/L) - OC

Xylowe (Lowl) (MGKKG)

Xylune (Lodd) (MG/KG) - Dup

Xylene (Lotd) (MGL) - OC

Zinc (MG/KG)

$\operatorname{Zinc}(M G K K G)$ - Dup

Zixe (MG/) - OC

in-1,3-Dictioropropene (MGRKG)

in-1,3-Dictloropropene (MGKKG) - Dup

in-1,3-Dichloropropese (MG/) - OC

uno-1,3-Dichioropropene (MG/KG)

una-13-Dictioropropene (MG/KG) - Dup

uran-1.3-Dictloropropene (MG/) - OC

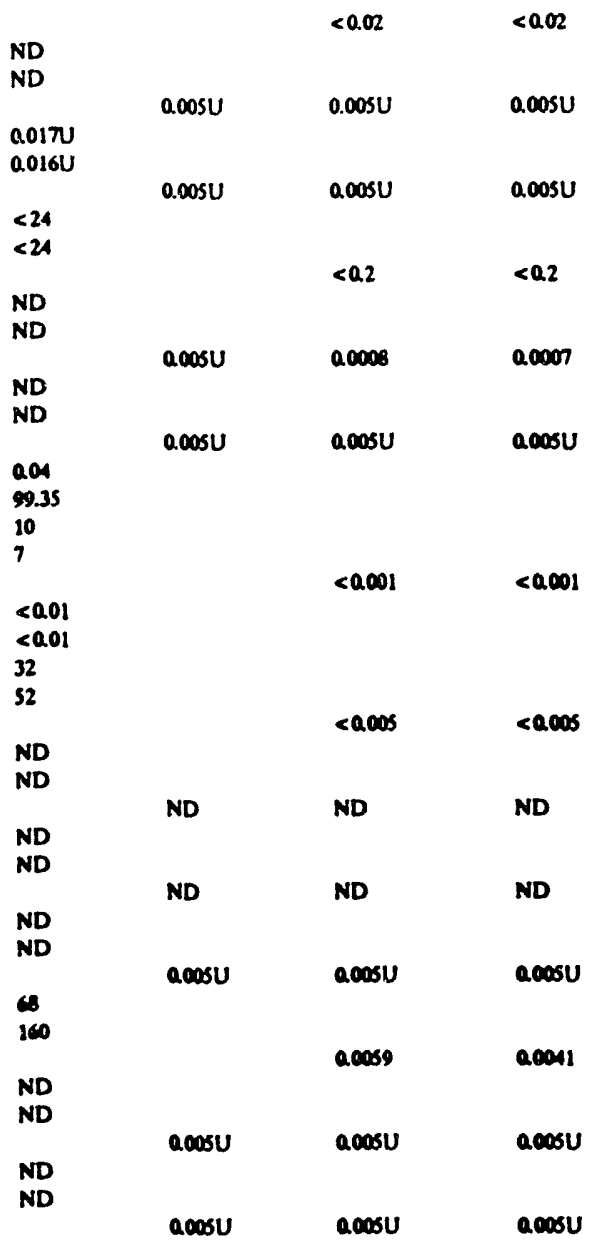


Appendix D

\section{ENVIRONMENTAL RESTORATION PROGRAM SITE-SPECIFIC HEALTH AND SAFETY PLAN}

The following checklist should be used in its entirety for hazardous waste operations and emergency response activities temporarily (i.e., until checklists that specifically address the unique features of those two functions are completed). 
D-3 Page 1

Revision No.:

Revision Date:

\section{SITE-SPECIFIC HEALTH AND SAFETY PLAN FOR}

Site Name: Bear Creek Valley Operable Unit 2

Prepared by:

$\overline{\text { (Signature) }}$ (Date)

Reviewed by:

\begin{tabular}{lll}
\hline Environmental Restoration & (Signature)
\end{tabular}

Reviewed by:

\begin{tabular}{lll}
\hline Health Physics & (Signature)
\end{tabular}

Reviewed by:

\begin{tabular}{lll}
\hline Industrial Hygiene & (Signature)
\end{tabular}

Reviewed by:

\begin{tabular}{lll}
\hline Industrial Safety & (Signature)
\end{tabular}

Approved by:

$\overline{\text { HAZWOPER Coordinator (Signature) (Date) }}$




\section{SITE DESCRIPTION}

The Bear Creek Valley (BCV) Operable Unit 2 (OU 2) Site is located within the U. S. Department of Energy Oak Ridge Reservation in Anderson County, Tennessee. (See Site Map).

The BCV OU 2 Site is near the headwaters of Bear Creek, just west of the Y-12 Plant main facilities.

The BCV OU 2 Site is comprised of two construction spoil areas, Rust Spoil Area and Spoil Area 1, and an equipment storage yard, SY-200 Yard. The area is bounded to the north and south by Pine Ridge and Chestnut Ridge, respectively, and has an elevation of $975 \pm 50 \mathrm{ft}$ above MSL. It is underlain by the Maynardville Limestone and Nolichucky Shale formations. Environs surrounding the BCV OU 2 include hickory forest, grasslands, devegetated areas, and developed locations, with the forests serving as habitat for many species. Weather patterns in the area are temperate, with warm, humid summers and cool winters. Average annual temperature is approximately $58^{\circ}$.

\section{SITE HISTORY}

The Rust Spoil Area operated as a dump and received spoil materials from the Y-12 Plant. The bulk of the waste deposited consisted of demolition debris, with minor amounts of solvent contaminated material, and materials containing asbestos, mercury, and uranium.

The Spoil Area 1 Site operated as a landfill for rubble and noncombustible, nonputrescible solid waste. Estimates indicate that approximately $100,000 \mathrm{yd}^{3}$ of nonuranium contaminated construction debris have been disposed of at the site. According to the RFI Plan, construction materials disposed here may have contained minor amounts of asbestos, mercury, beryllium, uranium, thorium, and other contaminants.

The SY-200 Yard was used as a "holding yard" for materials stored by various operations divisions at Y-12. By September 1986, all items were removed and the site excavated in preparation for construction of the Y-12 Environmental Support Facility. Storage of materials at the site may have resulted in minor releases of mercury, lead, and PCBs to surface soils. 
Revision Date:

\section{SITE MAP}
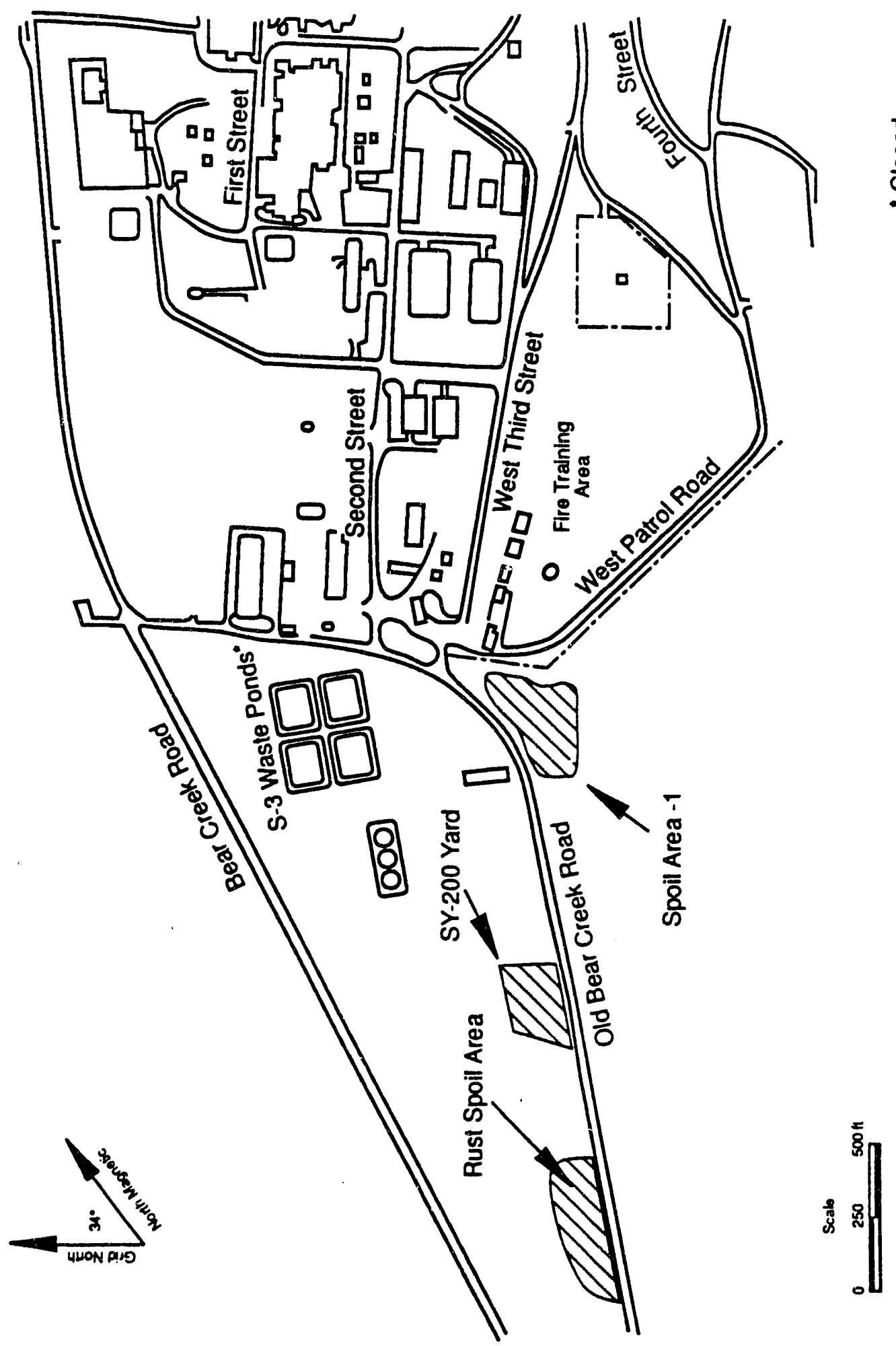


\section{D-6}

\section{HEALTH AND SAFETY HAZARD EVALUATION}

[Place an $\mathrm{X}$ in each ( ) to indicate presence of hazard]

4.1 Physical hazards

(X) Heat stress

( ) Confined space

(X) Tripping/Falling

( ) Oxygen deficient
Page 4

Revision No.:

Revision Date:

4.2 Construction hazards

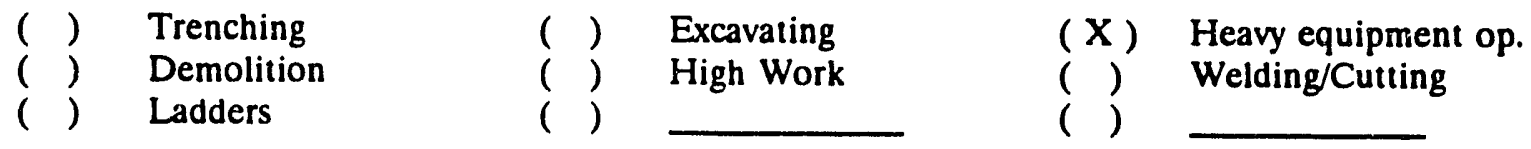

4.3 Chemical hazards
(X) Organic chemical
(X) Inorganic chemical
(X) Carcinogen
( ) Corrosive
( ) Mutagen
( ) Reactive
( ) Teratogen
( $X)$ OSHA specific substances
(X) Noise
( ) Heavy lifting
( ) High pressure water
) Vibration

4.4 Ionizing radiological hazards
( ) Internal exposure
(X) External exposure

4.5 Nonionizing radiological hazards
( ) UV
( ) Laser
( ) RF

4.6 Biological/Vector hazards

$\begin{array}{lllll}\text { ( ) } & \text { Wildlife } & \text { ( ) } & \text { Plants } & \text { ( ) } \\ \text { ( ) } & \text { Bacterial } & \text { ( ) } & \text { Parasites } & \end{array}$

( ) Microwave 
D-7

5. PREVIOUS SAMPLING RESULTS

Source (Water, Sediment,

Contaminant

Sludge, Soil, Air, etc.)
Page 5

Revision No.:

Revision Date:

\section{Quantity or Concentration}

See Attached Tables D.1 through D.8 


\section{D-8 Page 6}

Revision No.:

Revision Date:

Table D.1. 1990 summary of surface water concentrations from sampling stations BCK-12.4 and $11.97^{\circ}$

$$
(\mu \mathrm{g} / \mathrm{L})
$$

\begin{tabular}{lrrr}
\hline \multicolumn{1}{c}{ Analyte } & BCK-12.4 & BCK-11.97 & $\begin{array}{r}\text { Maximum Contaminant } \\
\text { Level }\end{array}$ \\
\hline Barium & 76.4 & 481 & 1,000 \\
Boron & 63 & 50 & \\
Cadmium & 6 & & 10 \\
Chromium & & & 50 \\
Copper & & & $1,300^{\circ}$ \\
Lead & & 44 & 50 \\
Mercury & & 714 & 2 \\
Nickel & 422 & 211 & $100^{\circ}$ \\
Strontium & 512 & & \\
Uranium & & 150,100 & $5,000^{\circ}$ \\
Zinc & 31,400 & & 10,000 \\
Nitrate & & & \\
\hline
\end{tabular}

Source: Energy Systems 1991.

- Average values for analytes found in OU 2 groundwater samples.

b Average concentration was below the detection limit.

- Proposed.

- Secondary level. 


\section{D-9}

Page 7

Revision No.:

Revision Date:

Table D.2. RSA - 1990 average groundwater concentrations

(Total analyses - $\mu \mathrm{g} / \mathrm{L}$, except where noted)

\begin{tabular}{|c|c|c|c|c|c|c|c|}
\hline Analyte & $G W-306^{b}$ & GW-307 & GW-308 & GW-309 & GW-310 & GW-311 & GW-312 \\
\hline Barium & 46 & 87 & 95 & 46 & 96 & 18 & 41 \\
\hline Boron & 300 & 260 & 38 & 370 & 160 & 260 & 250 \\
\hline Cadmium & c & 2 & & & & & \\
\hline Chromium & & & 62 & & 34 & & 34 \\
\hline Copper & 11 & 30 & 38 & 3.6 & 8.6 & 7.8 & 9.3 \\
\hline Lead & & 30 & 50 & & 22 & & 50 \\
\hline Mercury & & & 0.2 & & 0.2 & & \\
\hline Nickel & 13 & 19 & 16 & & & & 15 \\
\hline Strontium & 180 & 270 & 320 & 420 & 330 & 70 & 580 \\
\hline Uranium & 1 & 1 & 2 & 2 & 0.9 & 0.8 & \\
\hline Zinc & 18 & 40 & 44 & 9 & 12 & 15 & 34 \\
\hline Chloride & 17,800 & 35,500 & 31,200 & 34,000 & 32,500 & 3,750 & 1,000 \\
\hline Nitrate & 11,000 & 17,800 & 15,000 & 17,800 & 23,000 & 750 & 280 \\
\hline Sulfate & 36,000 & 91,500 & 13,100 & 64,700 & 68,000 & 4,250 & 2,750 \\
\hline 1,2-DCE & 12.6 & 20.2 & 16.8 & 16.8 & 19.2 & & \\
\hline PCE & & 1.75 & 1.5 & 1.8 & 2.4 & & \\
\hline TCA & 2.4 & 2.5 & 2.2 & & & & \\
\hline TCE & 75 & 55.5 & 37 & 19.7 & 27.2 & 33.5 & 57.5 \\
\hline $\begin{array}{l}\text { Gross alpha, } \\
\text { pCi/L }\end{array}$ & 2.64 & 5.33 & 5.57 & 2.38 & 3.50 & 1.25 & 1.36 \\
\hline $\begin{array}{l}\text { Gross beta, } \\
\mathrm{pCi} / \mathrm{L}\end{array}$ & 26.7 & 49.0 & 40.5 & 49.9 & 61.9 & 2.36 & 21.4 \\
\hline
\end{tabular}

- Average values for quarterly samples with a minimum of two analyses above detection limit. Values below detection limit were treated as one-half the detection limit.

- Groundwater well designation.

c Analyte not detected above background more than once during the year.

Source: HSW 1991. 
D-10 Page 8

Revision No.:

Revision Date:

Table D.3. 1990 average groundwater concentrations

(Total Analyses - $\mu \mathrm{g} / \mathrm{L}$, except where noted)

\begin{tabular}{|c|c|c|c|c|c|c|}
\hline Analyte & GW-313 & GW.314 & GW.315 & GW-316 & GW-317 & GW-323 \\
\hline Barium & 23 & 39 & 47 & 37 & 16 & 34 \\
\hline Boron & 10 & 30 & 22 & 13 & 23 & 16 \\
\hline Cadmium & $c$ & & & & & 3 \\
\hline Copper & 9 & 6 & 5 & 7 & 8 & \\
\hline Lead & 28 & 3 & & 6 & & \\
\hline Strontium & 78 & 93 & 141 & 39 & 45 & 21 \\
\hline Uranium & . & & 1 & 0.7 & & \\
\hline Zinc & 8 & 9 & 10 & 32 & 12 & 13 \\
\hline Chloride & 2,000 & 4,600 & 6,800 & 2,000 & 880 & 1,000 \\
\hline Nitrate & 900 & 10,800 & 16,000 & 400 & 180 & \\
\hline Sulfate & 2,600 & 6,200 & 11,200 & 2,600 & 7,000 & 2,000 \\
\hline 1,2-DCE & 7.5 & 11.7 & 26.6 & & & \\
\hline PCE & 8.6 & 13.3 & 33.3 & & & \\
\hline TCE & 4.7 & 5.7 & 13.5 & & & \\
\hline Gross alpha, pCi/L & 0.30 & 1.00 & 1.30 & 1.01 & 0.38 & 1.14 \\
\hline Gross beta, $\mathrm{pCi} / \mathrm{L}$ & 3.12 & 32.3 & 54.9 & 2.54 & 3.01 & 1.80 \\
\hline
\end{tabular}

- Average values for quarterly samples with a minimum of two analyses above detection limit. Values below detection limit were treated as one-half the detection limit.

b Groundwater well designation.

c Anabyte not detected above background more than once during the year.

Source: HSW 1991. 
Table D.4. Summary of soil chemical data, RSA soil borings

\begin{tabular}{|c|c|c|c|c|}
\hline Chemical/element & $\begin{array}{c}\text { Number of } \\
\text { detects/analyses }\end{array}$ & $\begin{array}{c}\text { Detected } \\
\text { minimuma } \\
\text { (mg/kg) } \\
\end{array}$ & $\begin{array}{c}\text { Detected } \\
\text { maximum } \\
(\mathrm{mg} / \mathrm{kg}) \\
\end{array}$ & $\begin{array}{c}\text { BCV soil } \\
\text { background levels } \\
\text { (ppm) }^{b}\end{array}$ \\
\hline \multicolumn{5}{|c|}{ Volatile Organic Compounds } \\
\hline Acetone & $9 / 24$ & 0.16 & 0.49 & \\
\hline Tetrachloroethene (PCE) & $1 / 24$ & & 0.072 & \\
\hline \multicolumn{5}{|c|}{ Metals } \\
\hline Arsenic & $24 / 24$ & 2.8 & 26 & 6.758 \\
\hline Barium & $24 / 24$ & 24 & 820 & 149.5 \\
\hline Beryllium & $23 / 24$ & 0.67 & 2.1 & $1.34^{c}$ \\
\hline Cadmium & $23 / 24$ & 2.4 & 7.3 & 0.2453 \\
\hline Chromium & $23 / 24$ & 17 & 41 & 14.70 \\
\hline Cobalt & $23 / 24$ & 9.4 & 66 & 34.81 \\
\hline Copper & $24 / 24$ & 14 & 740 & 21.22 \\
\hline Lead & $24 / 24$ & 13 & 150 & 42.28 \\
\hline Mercury & $5 / 24$ & 1.1 & 7.5 & 0.1639 \\
\hline Nickel & $23 / 24$ & 15 & 55 & $54.86^{c}$ \\
\hline Uranium & $24 / 24$ & 2 & 14.5 & 2.30 \\
\hline Vanadium & $23 / 24$ & 20 & 70 & 49.18 \\
\hline Zinc & $24 / 24$ & 44 & 230 & 46.35 \\
\hline \multicolumn{5}{|c|}{ Radiological } \\
\hline Gross alpha, pCi/g & $24 / 24$ & 1.45 & 4.37 & $15 \mathrm{pCi} / \mathrm{g}^{d}$ \\
\hline Gross beta, pCi/g & $24 / 24$ & 1.87 & 5.07 & $50 \mathrm{pCi} / \mathrm{g}^{d}$ \\
\hline Uranium-235, wt \% & $3 / 3$ & 0.04 & 1.18 & \\
\hline
\end{tabular}

- Concentration units are mg/kg unless otherwise indicated.

'From Turner et al. 1988.

Represents mean background for East Tennessee.

${ }^{d}$ Represents DOE-established action limits. 

D-12

Page 10

Revision No.:

Revision Date:

Table D.5. SY-200 Yard soil sample analytical results, July 1986

\begin{tabular}{lcccc}
\hline \multicolumn{1}{c}{ Sample name } & Interval & $\begin{array}{c}\text { Mercury } \\
(\mu \mathrm{g} / \mathrm{g})\end{array}$ & $\begin{array}{c}\text { PCB } \\
(\mu \mathrm{g} / \mathrm{g})\end{array}$ & EP tox \\
\hline P-1 & Surface & 20 & & Pass \\
EP-2 & Surface & 42 & & Pass \\
EP-3 & Surface & 17,000 & & Pass \\
Surface composite & Surface & 3.80 & 32 & \\
transformer area & & & & \\
Deep sample 1 & $2-4$ in. & 29 & 2.8 & \\
Deep sample 2 & $2-4$ in. & 19 & 7.7 & \\
\hline
\end{tabular}


Page 11

Revision No.:

Revision Date:

Table D.6. Summary of SY-200 Yard soil sample analytical results, January 1988

\begin{tabular}{lccccc} 
& & \multicolumn{2}{c}{ Range } & & \\
\cline { 3 - 4 } \multicolumn{1}{c}{ Parameter } & Units & Upper & Lower & Average & Comments \\
\hline Alpha activity & $\mathrm{pCi} / \mathrm{g}$ & 170 & 8.6 & 38 & \\
Beta activity & $\mathrm{pCi} / \mathrm{g}$ & 250 & 15 & 71 & \\
Gamma activity & $\mathrm{pCi} / \mathrm{g}$ & 420 & $<300$ & & Detected in 1 of 15 samples. \\
Arsenic & $\mathrm{mg} / \mathrm{kg}$ & & $<40$ & & Not detected in any sample. \\
Barium & $\mathrm{mg} / \mathrm{kg}$ & 340 & 182 & 239 & \\
Cadmium & $\mathrm{mg} / \mathrm{kg}$ & & & & Not detected in any sample. \\
Chromium & $\mathrm{mg} / \mathrm{kg}$ & 80 & 29 & 51 & \\
Lead & $\mathrm{mg} / \mathrm{kg}$ & 370 & $<20$ & 93 & Detected in 11 of 15 samples. \\
Mercury & $\mu \mathrm{g} / \mathrm{g}$ & 200 & 0.18 & 28 & Detected in 14 of 15 samples. \\
Selenium & $\mathrm{mg} / \mathrm{kg}$ & & $<0.1$ & & Not detected in any sample. \\
Silver & $\mathrm{mg} / \mathrm{kg}$ & & $<4$ & & Not detected in any sample. \\
PCB & $\mu \mathrm{g} / \mathrm{g}$ & 0.3 & $<0.1$ & & Detected in 3 of 15 samples. \\
EP tox Leach Test & & & & & All samples passed. \\
\hline
\end{tabular}


D-14

Page 12

Revision No.:

Revision Date:

Table D.7. Summary of soil sample analytical results, January 1989

$(\mu \mathrm{g} / \mathrm{g})$

\begin{tabular}{lccc}
\hline & \multicolumn{3}{c}{ Range } \\
\cline { 2 - 3 } Parameter & Upper & Lower & Average \\
\hline Thorium & 15.3 & 3.71 & 7.34 \\
Uranium & 8.06 & 0.52 & 2.56 \\
Mercury & 2100 & 3.4 & 244 \\
\hline
\end{tabular}


Table D.8. Chemical summary, SA-1 soil borings

\begin{tabular}{|c|c|c|c|}
\hline Chemical/element & $\begin{array}{c}\text { Number of } \\
\text { detects/analyses }\end{array}$ & $\begin{array}{c}\text { Detected minimum } \\
(\mathrm{mg} / \mathrm{kg})\end{array}$ & $\begin{array}{c}\text { Detected maximum" } \\
(\mathrm{mg} / \mathbf{k g})\end{array}$ \\
\hline \multicolumn{4}{|c|}{ Semivolatile Organic Compounds } \\
\hline Acenaphthene & $4 / 53$ & 0.079 & 0.41 \\
\hline Acenaphthylene & 1/53 & 0.11 & 0.11 \\
\hline Anthracene & $7 / 53$ & 0.14 & 0.85 \\
\hline Benzo(a)anthracene & $12 / 53$ & 0.14 & 1.7 \\
\hline Benzo(a)pyrene & $11 / 53$ & 0.12 & 1.3 \\
\hline Benzo(a)fluoranthene & $10 / 53$ & 0.11 & 1.4 \\
\hline Benzo(ghi)perylene & $9 / 53$ & 0.085 & 0.8 \\
\hline Benzo(k)fluoranthene & $11 / 53$ & 0.15 & 1.4 \\
\hline Chrysene & $12 / 53$ & 0.16 & 1.7 \\
\hline Dibenzofuran & $3 / 53$ & 0.17 & 0.25 \\
\hline Fluoranthene & $13 / 53$ & 0.07 & 4.1 \\
\hline Fluorene & $6 / 53$ & 0.18 & 0.45 \\
\hline Indeno(1,2,3-cd)pyrene & $8 / 53$ & 0.099 & 0.77 \\
\hline Naphthalene & $3 / 53$ & 0.12 & 0.21 \\
\hline Phenanthrene & $13 / 53$ & 0.059 & 3.6 \\
\hline Pyrene & $13 / 53$ & 0.055 & 3.1 \\
\hline \multicolumn{4}{|c|}{ Metals } \\
\hline Arsenic & $44 / 51$ & 1.9 & 45.7 \\
\hline Barium & $51 / 51$ & 15.3 & 385 \\
\hline Beryllium & $50 / 51$ & 0.27 & 11 \\
\hline Cadmium & $50 / 51$ & 1.1 & 10.9 \\
\hline Chromium & $50 / 51$ & 6.4 & 54.2 \\
\hline Cobalt & $50 / 51$ & 1.7 & 110 \\
\hline Copper & $50 / 51$ & 13.3 & 109 \\
\hline Lead & $51 / 51$ & 0.5 & 670 \\
\hline Mercury & $38 / 51$ & 0.55 & 31.5 \\
\hline Nickel & $51 / 51$ & 4.7 & 173 \\
\hline Uranium & $51 / 51$ & 2 & 80 \\
\hline Vanadiuin & $50 / 51$ & 6.8 & 128 \\
\hline Zinc & $51 / 51$ & 26.4 & 591 \\
\hline
\end{tabular}


D-16

Page 14

Revision No.:

Revision Date:

Table $\mathbf{D . 8}$ continued

\begin{tabular}{lccc} 
Chemical/element & $\begin{array}{c}\text { Number of } \\
\text { detects/analyses }\end{array}$ & $\begin{array}{c}\text { Detected minimum* } \\
(\mathbf{m g} / \mathbf{k g})\end{array}$ & $\begin{array}{c}\text { Detected maximum* } \\
(\mathbf{m g} / \mathbf{k g})\end{array}$ \\
\hline Gross alpha, pCi/g & $50 / 51$ & Radiological \\
Gross beta, pCi/g & $48 / 51$ & 0.03 & 12 \\
Total radium, pCi/g & $51 / 51$ & 1.56 & 37.4 \\
Uranium-235, wt\% & $21 / 57$ & 0.973 & 7.568 \\
\hline
\end{tabular}

- Concentration units are mg/kg unless othenwise noted. 


\section{CONTAMINANTS}

\subsection{Chemical: ARSENIC}

PEL/TLV : $.002 \mathrm{mg} / \mathrm{m}^{3}$

STEL: NG

Action level: $.002 \mathrm{mg} / \mathrm{m}^{3}$

IDLH: $100 \mathrm{mg} / \mathrm{m}^{3}$

LEL: Not Applicable (NA)

Route of exposure: Inhalation, absorption, contact, ingestion

Monitoring equipment: Sampling pump and filter

Symptoms/effects of exposure: Respiratory irritation

Spe ial medical monitoring: Bioassay

6.2 Chemical: BERYLLIUM

PEL/TLV : .0005 mg/m3

STEL: $0.025 \mathrm{mg} / \mathrm{m}^{3}$

IDLH: $10 \mathrm{mg} / \mathrm{m}^{3}$

Action level: $.005 \mathrm{mg} / \mathrm{m}^{3}$

LEL: NA

Route of exposure: Inhalation

Monitoring equipment: Sampling pump and filter

Symptoms/effects of exposure: Fatigue, respiratory symptoms, weak

Special medical monitoring: Bioassay

6.3 Chemical: LEAD

PEL/TLV : $0.05 \mathrm{mg} / \mathrm{m}^{3}$

STEL: Not Given in research literature (NG)

IDLH: $700 \mathrm{mg} / \mathrm{m}^{3}$

Action level: NG

LEL: NA

Route of exposure: Inhalation, ingestion, skin or eye contact

Monitoring equipment: Sampling pump and filter

Symptoms/effects of exposure: Weakness, insomnia, low weight

Special medical monitoring: Bioassay

6.4 Chemical: MERCURY

PEL/TLV : $.01 \mathrm{mg} / \mathrm{m}^{3}$

STEL: $.03 \mathrm{mg} / \mathrm{m}^{3}$ (skin)

IDLH: $10 \mathrm{mg} / \mathrm{m}^{3}$

Action level: NG

LEL: NA

Route of exposure: Inhalation, absorption, skin or eye contact

Monitoring equipment: Jerome Mercury Analyzer

Symptoms/Effects of exposure: Cough, chest pain, indecision, irritability, weak, headache

Special medical monitoring: Urinalysis

65 Chemical: TETRACHLOROETHENE

PEL/TLV : $25 \mathrm{ppm}\left(170 \mathrm{mg} / \mathrm{m}^{3}\right)$

STEL: 200 ppm

IDLH: 500 ppm

Action level: NG

LEL: NA

Route of exposure: Inhalation, ingestion, skin or eye contact

Monitoring equipment: PID/OVM

Symptoms/Effects of exposure: Irritated eyes, nose or throat; nausea, flushed, dizzy, headache Special Medical monitoring: Bioassay

* nSHA, NIOSH, or ACGIH Standard, whichever is most restrictive 
Chemical: URANIUM

PEL/TLV : $0.05 \mathrm{mg} / \mathrm{m}^{3}$

IDLH: $20 \mathrm{mg} / \mathrm{m}^{3}$

STEL: NG

LEL: Unknown

Action level: NG

Route of exposure: Inhalation, absorption, contact, ingestion

Monitoring equipment: Alpha particle detection meter

Symptoms/Effects of exposure: Irritation of skin, eyes, nose, and throat; headache, irritability, sensitization

Special medical monitoring: Whole-body dosimetry

Chemical: VANADIUM

PEL/TLV : $.05 \mathrm{mg} / \mathrm{m}^{3}$

STEL: $0.5 \mathrm{mg} / \mathrm{m}^{3}$

IDLH: $70 \mathrm{mg} / \mathrm{m}^{3}$

Action level: $.05 \mathrm{mg} / \mathrm{m}^{3}$

LEL: NA

Route of exposure: Inhalation, ingestion, contact

Monitoring Equipment: Sampling pump and filter

Symptoms/Effects of exposure: Irritated eyes and throat; green tongue, metallic taste, cough

Special medical monitoring: Bioassay

6.8 Chemical: SELENIUM

PEL/TLV : . $2 \mathrm{mg} / \mathrm{m}^{3}$

IDLH: Unknown

STEL: NA

LEL: Unknown

Action level: NG

Route of exposure: Inhalation, absorption, ingestion, contact

Monitoring equipment: Sampling pump and filter

Symptoms/Effects of exposure: Irritated eyes, nose, throat; visual disturbance, headache, chills, metallic taste

Special medical monitoring: Bioassay

6.9 Chemical: THORIUM

PELTLV : NA

IDLH: NA

STEL: NA

LEL: NA

Action level: NA

Route of exposure: GI tract, skin

Monitoring equipment: Alpha particle detection meter

Symptoms/Effects of exposure: Radioactivity, dermatitis

Special medical monitoring: Whole body dosimetry

- OSHA, NIOSH, or ACGIH Standard, whichever is most restrictive 
6.10 Chemical: ASBESTOS

PEL/TLV : 0.2 fibers/cc

STEL: Excursion limit: 1 fiber/cc (30 min)

IDLH:

Action level: 0.1 fiber/cc

LEL: NA

Route of exposure: Inhalation, ingestion

Monitoring equipment: Sampling pump and filter

Symptoms/Effects of exposure: Irritation of eyes and nose

Special medical monitoring: Chest x-ray

\subsection{Chemical: BARIUM}

PEL/TLV : $.5 \mathrm{mg} / \mathrm{m}^{3}$

STEL: NG

IDLH: $1100 \mathrm{mg} / \mathrm{m}^{3}$

Action level: NG

LEL: Unknown

Route of exposure: Inhalation, ingestion, contact

Monitoring equipment: Sampling pump and filter

Symptons/Effects of exposure: Irritated eyes, skin, throat; skin burns

Special medical monitoring: Bioassay

6.12 Chemical: CHROMIUM

PEL/TLV : $.5 \mathrm{mg} / \mathrm{m}^{3}$

STEL: NG

IDLH: NG

Action level: NG

LEL: NA

Route of exposure: Ingestion

Monitoring equipment: Sampling pump and filter

Symptoms/Effects of exposure: Sensitization, dermatitis

Special medical monitoring: Bioassay

6.13 Chemical: PCBs

PELTLV : $.001 \mathrm{mg} / \mathrm{m}^{3}$

STEL: NG

Action level: NG

IDLH: $5 \mathrm{mg} / \mathrm{m}^{3}$

Route of exposure: Inhalation, absorption

Monitoring equipment: Sampling pump and filter

Symptoms/Effects of exposure: Eye irritation, chloracne

Special medical monitoring: Bioassay

* OSHA, NIOSH, or ACGIH Standard, whichever is most restrictive 
6.14 Chemical: FLUORANTHENE

PEL/TLV : NA

IDLH: NA

STEL: NA

LEL: NA

Action level: NA

Route of exposure: GI tract, skin

Monitoring equipment: Sampling pump and filter

Symptoms/Effects of exposure: Toxic by ingestion

Special medical monitoring: Bioassay

6.15 Chemical: PHENANTHRENE

PEL/TLV : NA

STEL: NA

IDLH: NA

Action level: NA

LEL: NA

Route of exposure: Respiratory tract, intravenous (iv)

Monitoring equipment: Sampling pump and filter

Symptoms/Effects of exposure: Toxic by ingestion, iv poison

Special medical monitoring: Bioassay

6.16 Chemical: PYRENE (as coal tar pitch volatiles)

PEL/TLV : $0.1 \mathrm{mg} / \mathrm{m}^{3}$

STEL: NA

IDLH: $700 \mathrm{mg} / \mathrm{m}^{3}$

Action level: NA

LEL: NA

Route of exposure: Respiratory tract, GI tract, skin

Monitoring Equipment: Sampling pump and filter

Symptoms/Effects of exposure: Inhalation: poison; ingestion, intraperitoneal: moderate toxicity; skin: irritant

Special medical monitoring: Bioassay

6.17 Chemical: RADIUM

PEL/TLV : NA

STEL: NA

IDLH: NA

Action level: NA

Route of exposure: Respiratory tract, GI tract, skin

Monitoring equipment: Alpha particle detection meter

Symptoms/Effects of exposure: Possible lung cancer, bone cancer, osteitis, skin damage, blood dyscrasias

Special medical monitoring: Whole-body dosimetry

* OSHA, NIOSH, or ACGIH Standard, whichever is most restrictive 


\section{TASK BREAKDOWN}

7.1 Description: drilling

Level of Personal

Protective Equipment:

Primary C

Contingency

Upgrade or downgrade as needed

Type of work:

Intrusive ( $X$ )

Nonintrusive ( )

Engineering controls:

None required

Administrative controls:

Occupational Safety and Health Administration $40-\mathrm{hr}$ health and safety training, as specified in 29 CFR 1910.120 , shall be required for all employees engaged in hazardous waste operations.

Personnel will be required to have annual 8-hr refresher training courses. Managers and supervisors shall receive an additional 8 hours of instruction. All classroom training shall be supplemented with 24-hr on-site orientation and instruction under an experienced and qualified individual.

Personal Protective Equipment:

1. Respiratory protection: fullface, organic, \& HEPA filter

Primary

Contingency

2. Protective clothing: plain tyvek

3. Head protection: hardhat

4. Eye protection: safety glasses with side shields

5. Foot protection: steel-toed butyl rubber boots

6. Hand Protection: gloves - rubber outer, latex inner

7. Hearing protection: earplugs

8. Tape-up required:

$\mathbf{Y}(\mathrm{x}) \mathbf{N}() \quad \mathrm{Y}(\mathrm{)}) \mathbf{N}()$

$Y(X) N() \quad Y() N()$

$Y(X) N() \quad Y() N($ )

$\mathrm{Y}(\mathrm{X}) \mathrm{N}(\mathrm{)} \quad \mathrm{Y}(\mathrm{)}) \mathrm{N}($ )

$\mathrm{Y}(\mathrm{X}) \mathbf{N}() \quad \mathrm{Y}(\mathrm{)}) \mathbf{N}(\mathrm{)}$

$\mathrm{Y}(\mathrm{X}) \mathrm{N}() \quad \mathrm{Y}(\mathrm{)}) \mathrm{N}()$

$Y(X) N() \quad Y() \quad N()$

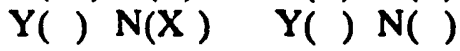

7.2 Description: soil sampling

Level of Personal

Protective Equipment:

$\begin{array}{lll}\text { Primary Contingency } & \text { C }\end{array}$

Type of work:

Intrusive ( $X$ )

Nonintrusive ( )

Engineering controls:

None required 
D-22 Page 20

Revision No.:

Revision Date:

Administrative controls:

Occupational Safety and Health Administration 40-hr health and safety training, as specified in 29 CFR 1910.120 , shall be required for all employees engaged in hazardous waste operations.

Personnel will be required to have annual 8-hr refresher training courses. Managers and supervisors shall receive an additional 8 hours of instruction. All classroom training shall be supplemented with 24-hr on-site orientation and instruction under an experienced and qualified individual.

Personal Protective Equipment:

1. Respiratory protection:fullface, organic, \& HEPA filter

2. Protective clothing: plain tyvek

3. Head protection: hardhat

4. Eye protection: safely glasses with side shields

5. Foot protection: steel-toed rubber boots

6. Hand protection: gloves-butyl rubber outer, latex inner

7. Hearing protection: earplugs

8. Tapc-up required:

Primary Contingency

$\mathbf{Y}(\mathrm{x}) \mathbf{N}() \quad \mathrm{Y}(\mathrm{)}) \mathbf{N}($ )

$Y(x) N() \quad Y() N($ )

$Y(x) N() \quad Y() N()$

$\mathrm{Y}(\mathrm{x}) \mathrm{N}() \quad \mathrm{Y}(\mathrm{)}) \mathrm{N}($ )

$Y(x) N() \quad Y() N()$

$Y(x) N() \quad Y($ ) $N($ )

$Y(x) N() \quad Y() \quad N()$

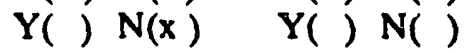

7.3 Description: surface water/sediment sampling

Level of Personal

Protective Equipment:

Primary C Contingency

Upgrade or downgrade as necessary

Type of work:

Intrusive $(x)$

Nonintrusive ( )

Engineering controls:

None required

Administrative controls:

Occupational Safety and Health Administration 40-hr health and safety training, as specified in 29 CFR 1910.120 , shall be required for all employees engaged in hazardous waste operations.

Personnel will be required to have annual 8-hr refresher training courses. Managers and supervisors shall receive an additional 8 hours of instruction. All classroom training shall be supplemented with 24 -hr on-site orientation and instruction under an experienced and qualified individuai. 
Personal Protective Equipment:

1. Respiratory protection: fullface, organic, \& HEPA filter

Primary

$\mathrm{Y}(\mathrm{x}) \mathrm{N}()^{-}$
$\mathrm{Y}(\mathrm{x}) \mathrm{N}(\mathrm{)}$ $\mathrm{Y}(\mathrm{x}) \mathrm{N}(\mathrm{)}$ $\mathrm{Y}(\mathrm{x}) \mathrm{N}($ ) $\mathrm{Y}(\mathrm{x}) \mathrm{N}($ ) $Y(x) N()$ $\mathrm{Y}(\mathrm{x}) \mathrm{N}()$ $\mathrm{Y}(\mathrm{N}) \mathrm{N}(\mathrm{x})$
Contingency

$\mathrm{Y}($ ) $\mathrm{N}($ )

$\mathrm{Y}(\mathrm{)} \mathbf{N}()$

$Y($ ) $N($ )

$\mathrm{Y}($ ) $\mathbf{N}()$

$\mathrm{Y}($ ) $\mathrm{N}()$

$\mathrm{Y}($ ) $\mathbf{N}($ )

$\mathrm{Y}($ ) $\mathrm{N}($ )

$\mathrm{Y}($ ) $\mathbf{N}()$

7.4 Description: monitoring well installation

Level of Personal

Protective Equipment:

Primary C Contingency

Upgrade or downgrade as needed

Type of work:

Intrusive $(x)$

Nonintrusive ( )

Engineering controls:

Administrative controls:
None required

Occupational Safety and Health Administration 40-hr health and safety training, as specified in 29 CFR 1910.120, shall be required for all employees engaged in hazardous waste operations. Personnel will be required to have annual 8-hr refresher training courses. Managers and supervisors shall receive an additional 8 hours of instruction. All classroom training shall be supplemented with 24-hr on-site orientation and instruction under an experienced and qualified individual.

Personal Protective Equipment:

1. Respiratory protection: fullface, organic, \& HEPA filter

Primary

2. Protective clothing: plain tyvek

3. Head protection: hardhat

4. Eye protection: safety glasses with side shields

5. Foot protection: steel-toed rubber boois

6. Hand protection: gloves-butyl rubber outer, latex inner

7. Hearing protection: earplugs

8. Tape-up required:

$\mathrm{Y}(\mathrm{x}) \mathrm{N}(\mathrm{)}$

$\mathrm{Y}(\mathrm{x}) \mathrm{N}(\mathrm{)}$

$\mathrm{Y}(\mathrm{x}) \mathrm{N}(\mathrm{)}$

$\mathrm{Y}(\mathrm{x}) \mathrm{N}($ )

$\mathrm{Y}(\mathrm{x}) \mathrm{N}($ )

$Y(x) N()$

$Y(x) N()$

$\mathrm{Y}(\mathrm{)}) \mathrm{N}(\mathrm{X})$
Contingency

$\mathrm{Y}($ ) $\mathrm{N}($ )

$Y() N()$

$Y() N($ )

$\mathrm{Y}($ ) $\mathrm{N}($ )

$Y() N($ )

$\mathrm{Y}($ ) $\mathrm{N}($ )

$\mathrm{Y}($ ) $\mathrm{N}($ )

$\mathrm{Y}(\mathrm{N}) \mathrm{N}()$ 
7.5 Description: monitoring well sampling

Level of Personal

Protective Equipment:

Primary C Contingency

Upgrade or downgrade as necessary

Type of work:

Intrusive $(x)$

Nonintrusive ( )

Engineering controls:

Administrative controls:
None required

Occupational Safety and Health Administration 40-hr health and safety training, as specified in 29 CFR 1910.120, shall be required for all employees engaged in hazardous waste operations. Personnel will be required to have annual 8-hr refresher training courses. Managers and supervisors shall receive an additional 8 hours of instruction. All classroom training shall be supplemented with 24-hr on-site orientation and instruction under an experienced and qualified individual.

Personal Protective Equipment:

1. Respiratory protection: fullface, organic, \& HEPA filter

2. Protective clothing: plain tyvek

3. Head protection: hardhat

4. Eye protection: safety glasses

5. Foot protection: steel-toed rubber boots

6. Hand protection: gloves-butyl rubber outer, latex inner

7. Hearing protection: earplugs

8. Tape-up required:

Primary

$\mathbf{Y}(\mathbf{)} \mathbf{N}(\mathbf{x})$

$\mathrm{Y}(\mathrm{x}) \mathrm{N}(\mathrm{)})$

$\mathbf{Y}(\mathrm{x}) \mathbf{N}($ )

$Y(x) N()$

$Y(x) N()$

$\mathrm{Y}(\mathrm{X}) \mathrm{N}($ )

$\mathrm{Y}(\mathrm{x}) \mathrm{N}(\mathrm{)}$

$\mathrm{Y}(\mathrm{)}) \mathrm{N}(\mathrm{X})$
Contingency

$\mathbf{Y}($ ) $\mathbf{N}()$

$\mathrm{Y}($ ) $\mathrm{N}($ )

$\mathrm{Y}($ ) $\mathbf{N}()$

$\mathrm{Y}($ ) $\mathbf{N}()$

$\mathbf{Y}($ ) $\mathbf{N}()$

$\mathrm{Y}($ ) $\mathbf{N}()$

$Y() N()$

$\mathrm{Y}($ ) $\mathrm{N}()$

7.6 Description: site survey

Level of Personal

Protective Equipment:

Primary

D

Intrusive ( )
Contingency

Nonintrusive ( $\mathrm{x}$ )

Type of work: 
Engineering controls:

Administrative controls:
None required

Occupational Safety and Health Administration 40-hr health and safety training, as specified in 29 CFR 1910.120 , shall be required for all employees engaged in hazardous waste operations.

Personnel will be required to have annual 8-hr refresher training courses. Managers and supervisors shall receive an additional 8 hours of instruction. All classroom training shall be supplemented with 24-hr on-site orientation and instruction under an experienced and qualified individual.

Personal Protective Equipment:

1. Respiratory protection:

2. Protective clothing:

3. Head protection: hardhat

4. Eye protection: safety glasses

5. Foot protection: steel-toed boots

6. Hand protection:

7. Hearing protection:

8. Tape-up required:

\section{Primary}

$\mathrm{Y}(\mathrm{)}) \mathrm{N}(\mathrm{x})$

$Y($ ) $N(x)$

$Y(x) N($ )

$\mathrm{Y}(\mathrm{x}) \mathbf{N}($ )

$\mathrm{Y}(\mathrm{x}) \mathrm{N}($ )

$\mathrm{Y}(\mathrm{)} \mathbf{N}(\mathrm{x})$

$\mathrm{Y}($ ) $\mathbf{N}(\mathrm{x})$

$Y($ ) $N(x)$
Contingency

$\mathrm{Y}($ ) $\mathbf{N}($ )

$\mathrm{Y}($ ) $\mathrm{N}($ )

$\mathrm{Y}($ ) $\mathrm{N}($ )

$\mathrm{Y}($ ) $\mathrm{N}($ )

$\mathrm{Y}($ ) $\mathrm{N}($ )

$\mathrm{Y}($ ) $\mathrm{N}($ )

$\mathrm{Y}() \mathbf{N}()$

$\mathrm{Y}(\mathrm{N}()$ 


\section{MONITORING REQUIREMENTS}

Instrument

\subsection{Direct Reading Instruments}

LEL meter

$\mathrm{O}_{2}$ meter

Colorimetric indicator tubes

Photoionization Detector (PID)

Flame Ionization Detector (FID)

Alpha meter

Beta/Gamma meter

Area radiation monitors

Perimeter radiation monitors

Noise meter

Jerome mercury analyzer

\subsection{Personnel Monitoring}

Whole-body dosimetry

Extremity dosimetry

Whole-body count

Urinalysis/Bioassay

Chemical air sampling

Asbestos

Beryllium

Dust (total)

Radiation air sampling
Task(s)

Monitoring

frequency

Action guidelines

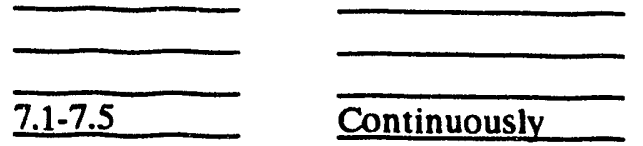

Continuously

7.1-7.5

$7.1-7.5$

$7.1-7.5$

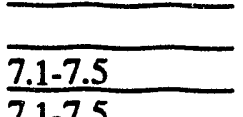

$7.1-7.5$

7.1-7.5

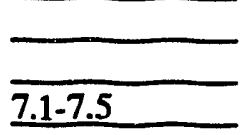

$7.1-7.5$

$7.1-7.5$

7.1-7.5
On job site

As deemed

As deemed

Start/as needed

Continuously
7.1-7.5

Start/Stop of job Baseline/Annual

Continuously

Continuously

Continuously

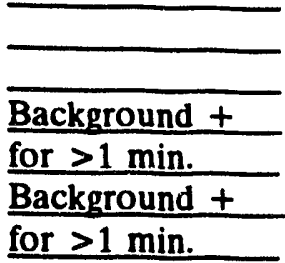

for $>1 \mathrm{~min}$

ALARA

ALARA

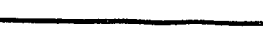

$0.01 \mathrm{mg} / \mathrm{m}^{3}$

\section{$2 \mathrm{mR} / \mathrm{h}$}

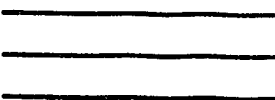

0.2 fiber/cc

$0.002 \mathrm{mg} / \mathrm{m}^{3}$ $>10 \mathrm{mg} / \mathrm{m}^{3}$ 


\section{HAZARD ANALYSIS}

\subsection{Chemicals}

\section{Tasks 7.1-7.5}

Specific labeling requirements of site-generated waste: Soil boring cuttings, investigation-derived wastes, and decon water will be generated, labeled, handled, and temporarily stored according to $\mathrm{Y}-12$ requirements.

Chemical-specific disposal requirements: Soil cuttings will either remain at the site or be put in drums for appropriate disposal; personnel and equipment decontamination water and investigation-derived groundwater shall be drummed and sent to the Y-12 West End Treatment Plant for treatment and disposal; protective clothing shall be drummed for disposal by the $\mathrm{Y}-12$ waste management personnel. Final disposition of the wastes will be based on analytical results.

\subsection{Fire/Explosion}

Tasks: N/A

Are flammable liquids present?

Description

Location

Quantity

Containment/Storage method

For welding, cutting, or brazing is a welding permit required?

N/A

\subsection{Confined/Enclosed Spaces}

Tasks: N/A

Confined/enclosed space entry required (low/high risk)?

Operations safety work permit required?

No

Standard operating procedure required?

No

\subsection{Ionizing Radiation}

Tasks: 7.1-7.5

Applicable detailed checklist? 
Primary contaminating isotope(s)

Location on site

Containment/storage method

Radiation type

Dose rate (maximum)

(average)

Worker dose limit

Contamination level (fixed) (removable)

Airborne contamination concentration

Water contamination potential?

Unrestricted airborne contamination release potential?

Radiation work permit required?

Health Physics coverage

Special task operation requirements

\author{
$\underline{\text { Uranium }}{ }^{23} \underline{\mathrm{U}}$ Thorium Radium
}

(Isotopes may be present but expected only at low levels)

Rust Spoil Area, SY-200 Yard, Spoil Area 1

decon water and investigation-derived wastes

Alpha/Beta/Gamma (may be present but expected only at low levels)

$\stackrel{? ?}{?} \mathrm{mR} / \mathrm{mR} @ \mathrm{mR} @ \operatorname{meter}(\mathrm{s})$

$2 \quad \mathrm{mR} / \mathrm{h}$ (SAIC employees limited to $500 \mathrm{mR} / \mathrm{yr}$ )

$5000 \mathrm{dpm} / 100 \mathrm{~cm}^{2}$

$1000 \mathrm{dpm} / 100 \mathrm{~cm}^{2}$

mCi/ml (Airborne concentrations exceeding limits in Table 1, Attach. 1 of DOE Order 5480.11 will require the use of appropriate PPE.)

Yes

Yes

No

Intermittent

Welding/cutting/brazing Grinding/chipping Hydraulic/air hammer operation Dusty conditions (sweeping, vacuuming, etc.) Equipment decontamination/free release

\subsection{Nonionizing Radiation}

Tasks: 7.1

High-Voltage ( $>100 \mathrm{Kv}$ ) electrical transmission lines nearby?

Yes

Location, distance, and voltage: The electrical hazards will be minimized by locating the auger so that no power lines are within a radius of a distance equal to the height of the auger mast. 
Radiofrequency radiation sources (AM and/or FM broadcast towers, $r-f$ sealers) nearby?

Location and distance:

Microwave sources in use on site?

No

Location and description:

Lasers in use nearby?

No

Location and laser class:

Are workers potentially exposed to sunlight (ultraviolet radiation)? Yes

Are ultrasound sources in use on site?

No

Location:

\subsection{Electrical Hazards}

Tasks: 7.1

Electrical shock hazard?

Yes/No

Voltage

Current

Location of hazard: None yet identified; however, the location of above ground and underground utilities will be determined during the Y-12 Excavation and Penetration Permit procedure, Y-12 Plant Procedure EP-D-06. This procedure will be followed during all augering operations.

\subsection{Temperature Extremes}

Tasks: 7.1-7.6

Temperature extremes (hot/cold)? Average daily high temperalure (during work shift) Average daily low temperature (during work shift)

Yes/No Average wind speed MPH

${ }^{\circ} \mathrm{F} / \mathrm{C}$

${ }^{\circ} \mathrm{F} P \mathrm{C}$

Temperature WBGT $^{\circ} \mathrm{C}$

cloudy/sunny 
Work load:

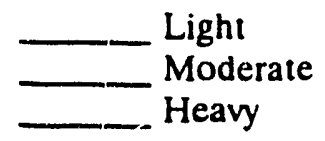

Work/Rest regimen: $\%$ work $\%$ rest

Threshold Limit Value

Precautions (specify): The work schedule has not been determined; therefore, the potential for temperature extremes cannot be evaluated. However, excessive temperature extremes are not anticipated.

Cooling/heating equipment needed: None.

\subsection{Noise}

Tasks: 7.1

Noise extremes?

$$
\text { Yes/No }
$$

Sound level $\mathrm{dB}(\mathrm{A})$

Noise source(s): Hollow stem auger drill utilized to collect split spoon samples. A concrete cutter may be used to remove asphalt or concrete plug before sampling activities if necessary.

Noise above $85 \mathrm{~dB}(\mathrm{~A})$ (hearing protection required)

$$
\text { Yes/No }
$$

Precautions(specify): It is recommended that hearing protection be worn while the hollow stem auger and the concrete cutter are in operation. Occupational noise exposure should be monitored initially.

\subsection{Vibration}

Tasks: None

Vibration extremes? Yes/No

Vibration frequency 1

Precautions (specify):

\subsection{Sanitation}

Tasks: 7.1-7.6

Potable water required?

Nonpotable water used?

No

Eating, drinking, and smoking permitted?

Yes 


\section{D-31 Page 29}

Revision No.:

Revision Date:

\section{Safety Officer.}

Where? Only in an area located outside the exclusion zone as designated by the Site Health and

Toilet facilities required?

Yes

Location and number: Specified by plant personnel at time of check-in.

Washing facilities required?

Yes

Location: Specified by plant personnel at time of check-in.

Change rooms required?

Specify:

No

\subsection{Illumination}

Tasks: None

Additional illumination needed?

NA

\subsection{Safety Hazards}

Site posted information/notification required?

No

Site posting required?

Yes

Site guard required?

No

Access control required?

Yes

Entry/exit logs required?

No

Escape routing/posting required (include site map)?

Yes

Compressed gas cylinders?

No Location:

Storage:

\section{EMERGENCY PREPAREDNESS}

Evacuation route (map attached):

EMERGENCY CONTACTS: All emergency services at the Bear Creek Valley OU 2 Site are to be contacted by first calling the Plant Shift Superintendent (PSS) at Commercial extension, 574-7172; from Y-12, extension 
4-7172. In the event that the PSS is not available, emergency services may be reached at the telephone numbers shown below.

\author{
Facility Personnel \\ PSS \\ Project Engineer \\ Contract Engineer \\ Program Health \& Safety Coordinator \\ Industrial Hygiene \\ Industrial Safety \\ Health Physics \\ Plant Disposal \\ Quality Assurance
}

\section{Emergency Assistance Service}

Police

Ambulance

Fire

Hospital

Doctor

Health Information Services
Phone

574-7172

Steve Walker (615) 576-5364

Larry May (615) 576-4018

Rudy Weigel (615) 241-2487

Wes James (615) 574-3897

Dave Gauss (615) 576-7877

Wayne Rideout (615) 576-5794

Hugh Newsom (615) 576-5810

\section{Phone}

Y-12 extension, 911; commercial extension 574-7272

Y-12 extension, 911; commercial extension 576-1890

Y-12 extension, 911; commercial extension 576-1890

Methodist Medical Center of Oak Ridge, 481-1190 or 911

Methodist Medical Center of Oak Ridge, 481-1190 or 911

Methodist Medical Center of Oak Ridge, 481-1190 or 911

Directions to Oak Ridge Methodist Medical Hospital: from Y-12 Plant, turn left onto Scarboro Road, travel approximately 0.25 mile and turn right onto Lafayette Road. Travel approximately 1.75 miles to the Oak Ridge Turnpike. Turn right. The Methodist Hospital is immediately to the left. See attached hospital location map. 


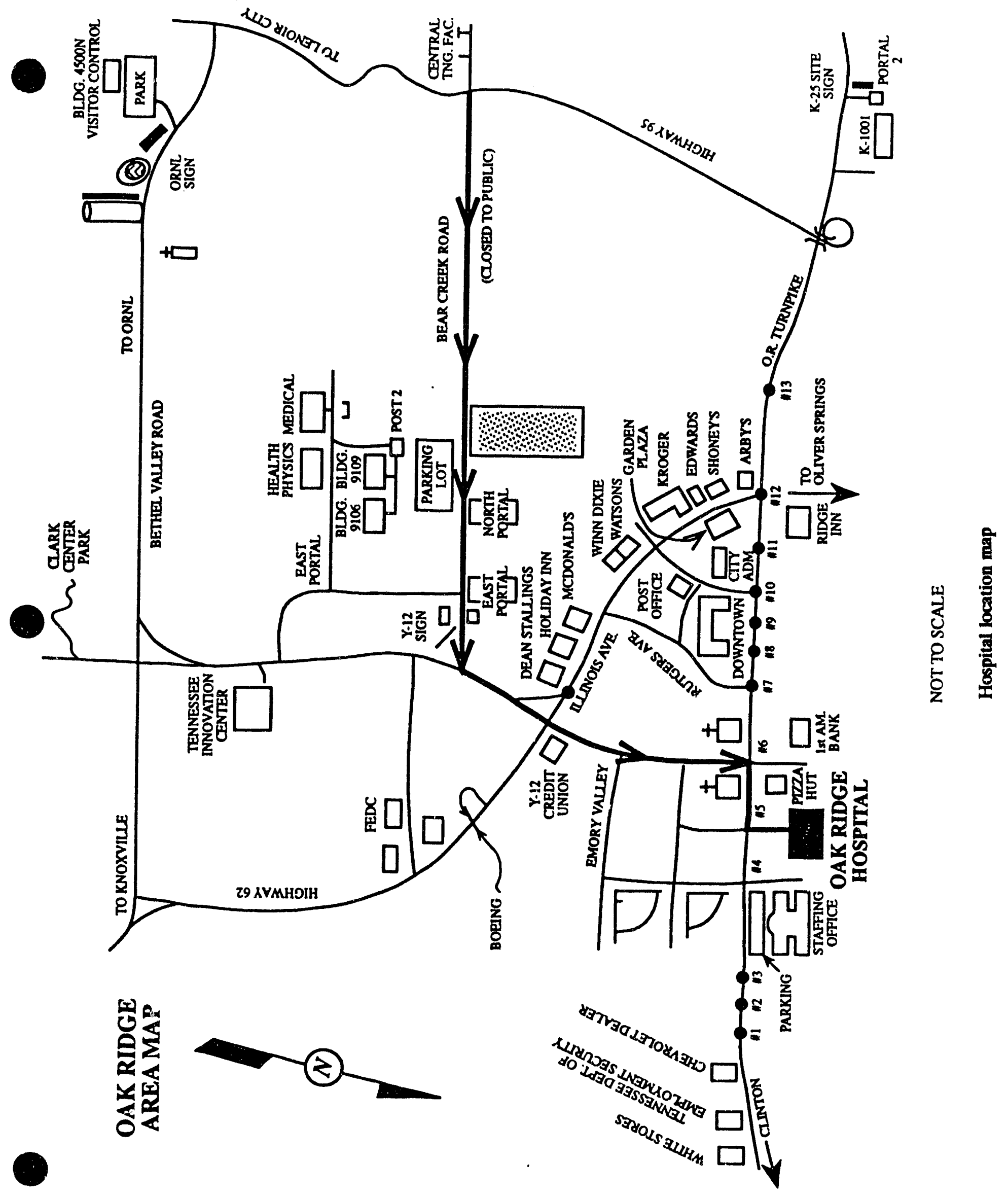




\section{RECORD KEEPING REQUIREMENTS}

(Mark with an $\mathrm{X}$ as appropriate)

Hazardous Chemicals

Area monitoring

Personnel monitoring

Oxygen Level Measurements

Flammability Measurements

Ionizing Radiation

Worker dose

Contamination levels

Airborne contamination level

Radiation work permit

Nonionizing Radiation

UV level measurements

Microwave level measurements

Biological

Laser power level measurements

\section{$\underline{\text { Required }}$}

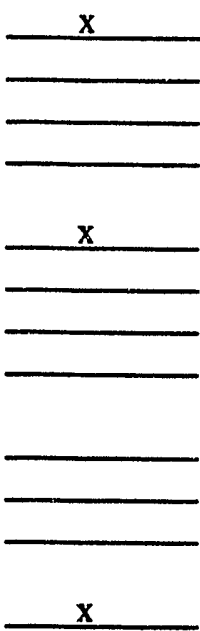

Electrical

Personnel exposure monitoring

Tag-out records

Tamperature extremes

WBGT measurements

Noise

Daily temperature/wind speed

Area monitoring

Personnel monitoring

Vibration

Source measurements

Illumination

Area foot-candle measurements

Personnel Medical Monitoring

Safety/Emergency Response

OSHA accident records

Accident/incident reports

Personal Protective Equipment

Inspection of:

Clothing

Respirators

Gloves

Waste Disposal Manifests

Boots

Spill Incident Reports

Training of Employees
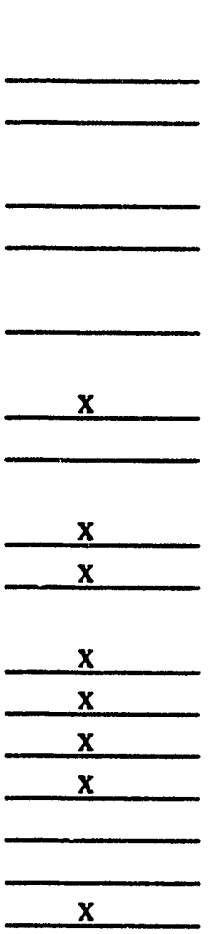

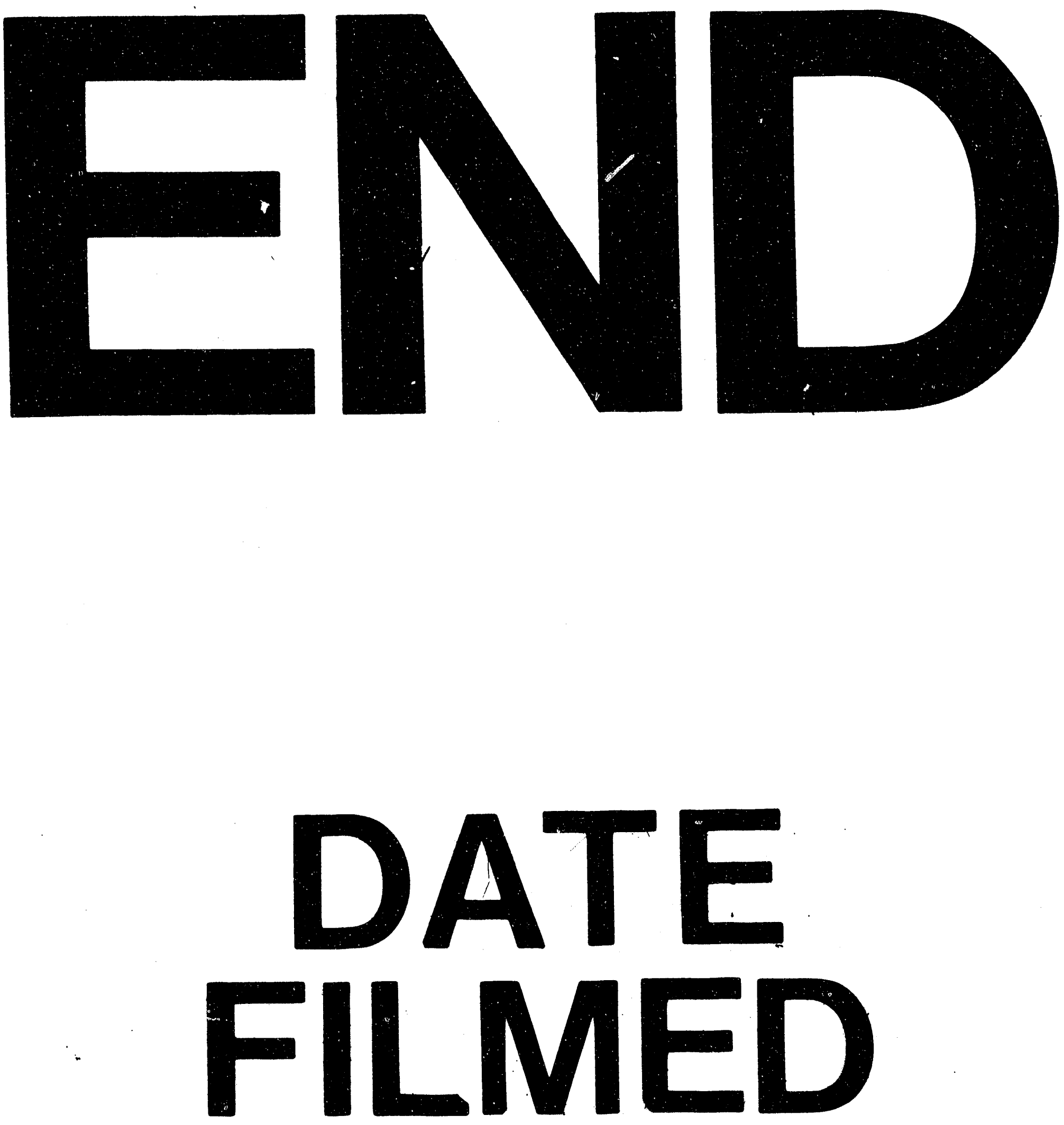

1

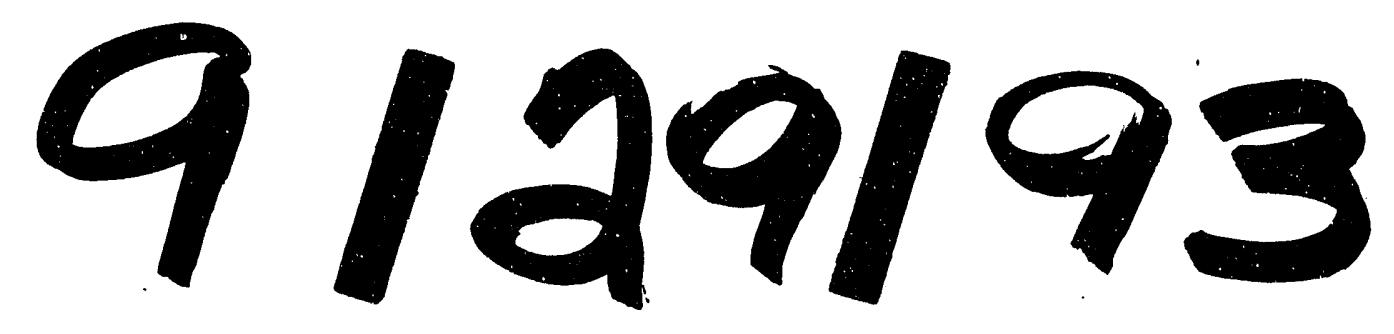


